Fall 1980

\title{
1980 Miracle Yearbook
}

\section{Cedarville College}

Follow this and additional works at: https://digitalcommons.cedarville.edu/yearbooks

Part of the Higher Education Commons, Organizational Communication Commons, and the Public Relations and Advertising Commons

\section{Recommended Citation}

Cedarville College, "1980 Miracle Yearbook" (1980). Yearbooks. 60.

https://digitalcommons.cedarville.edu/yearbooks/60

This Book is brought to you for free and open access by DigitalCommons@Cedarville, a service of the Centennial Library. It has been accepted for inclusion in Yearbooks by an authorized administrator of DigitalCommons@Cedarville. For more information, please contact digitalcommons@cedarville.edu. 


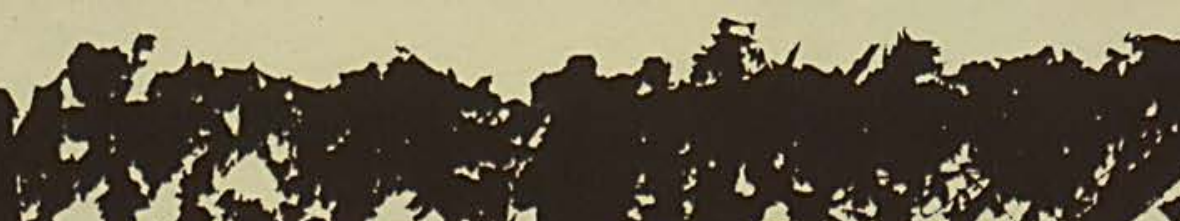

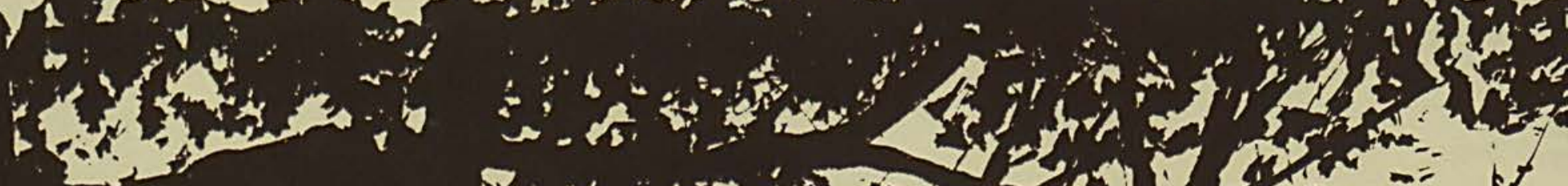

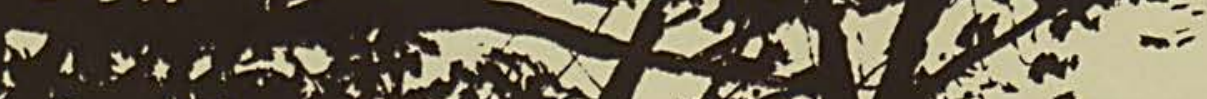
(4)

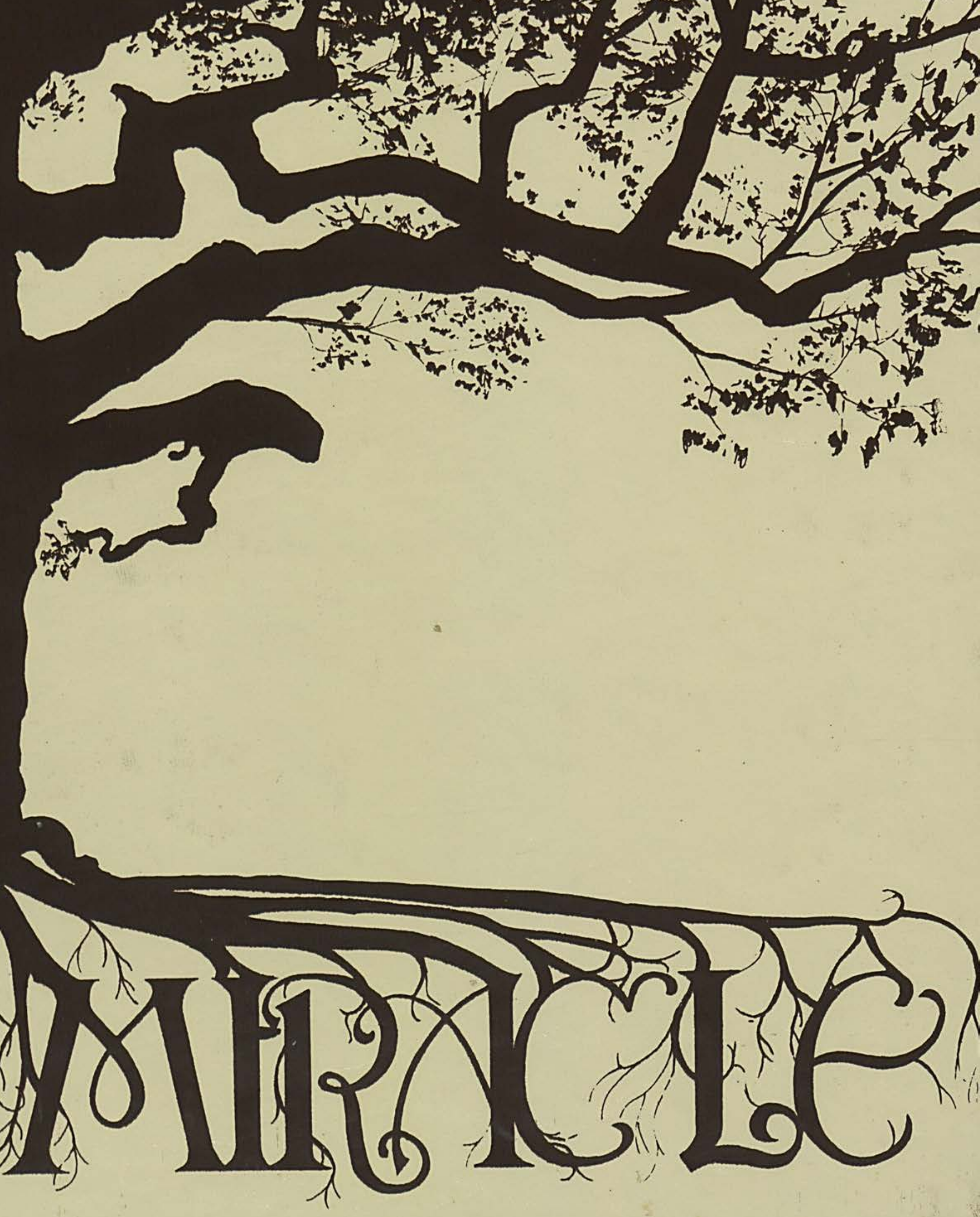




Mr. Ken St. Clair came to Cedarville College in 1958 to look it over at the personal invitation of Dr. Jeremiah. Then in September of 1959 Mr. St. Clair created the Business Department, teaching all classes except shorthand and typing. In its second year, the business department became the second largest department at Cedarville. Two of his early students were Bill Riter, now Chairman of the Department and Barbara Randall, who has completed requirements for her CPA license. In the Fall of 1963, Mr. St. Clair added the responsibility of Business Manager to his teaching duties. It is through his strong influence and excellent financial policies that he has obtained superb reputation for himself and Cedarville College throughout The GARBC.

Ken St. Clair was born on June 1, 1927 in Brighton, Colorado. He has a brother fourteen years older and one two years younger. He was saved at the age of twelve in the Presbyterian Church. As a junior in high school his family moved and he went from a large high school to a small one. The school did not have classes he wanted in Chemistry and Physics so he was forced into bookkeeping. At the end of WWII he joined the Navy and soon after met and married Mrs. St. Clair (1948). Also while in the Navy, he become convinced that the Baptist mode of baptism was correct and thus joined the Baptists. Later, at a Business School in Quincy Illinois, he was asked to join the faculty. Shortly after he did, he was called from the Naval Reserve to active duty and was stationed in California. Finally, in 1956 he was able to finish his B.S. at the University of Illinois and then started his Master's Degree. He accepted a job as an auditor with a CPA

Whe dedicate this book to our' Business 解anager, who has grown with
Cedaruille college for more than twenty years. firm which prepared him for his work at Cedarville College. In 1963, by attending school during the week and returning home on the weekends, he was able to complete his Master's in Church Accounting. In the past Ken St. Clair has served as President of Midwest Association of Business Administrators for Christian Colleges and Treasurer for the town of Cedarville. He currently teaches part time, is treasurer for two churches and serves on the Kyle Medical Center Committee. At the request of many people, he is working on a seminar for financial management for churches and colleges, truly a sign of his expertise and its effect on Cedarville College.

Thank you Mr. Ken St. Clair for your dedication and your part in making Cedarville the leader it is.
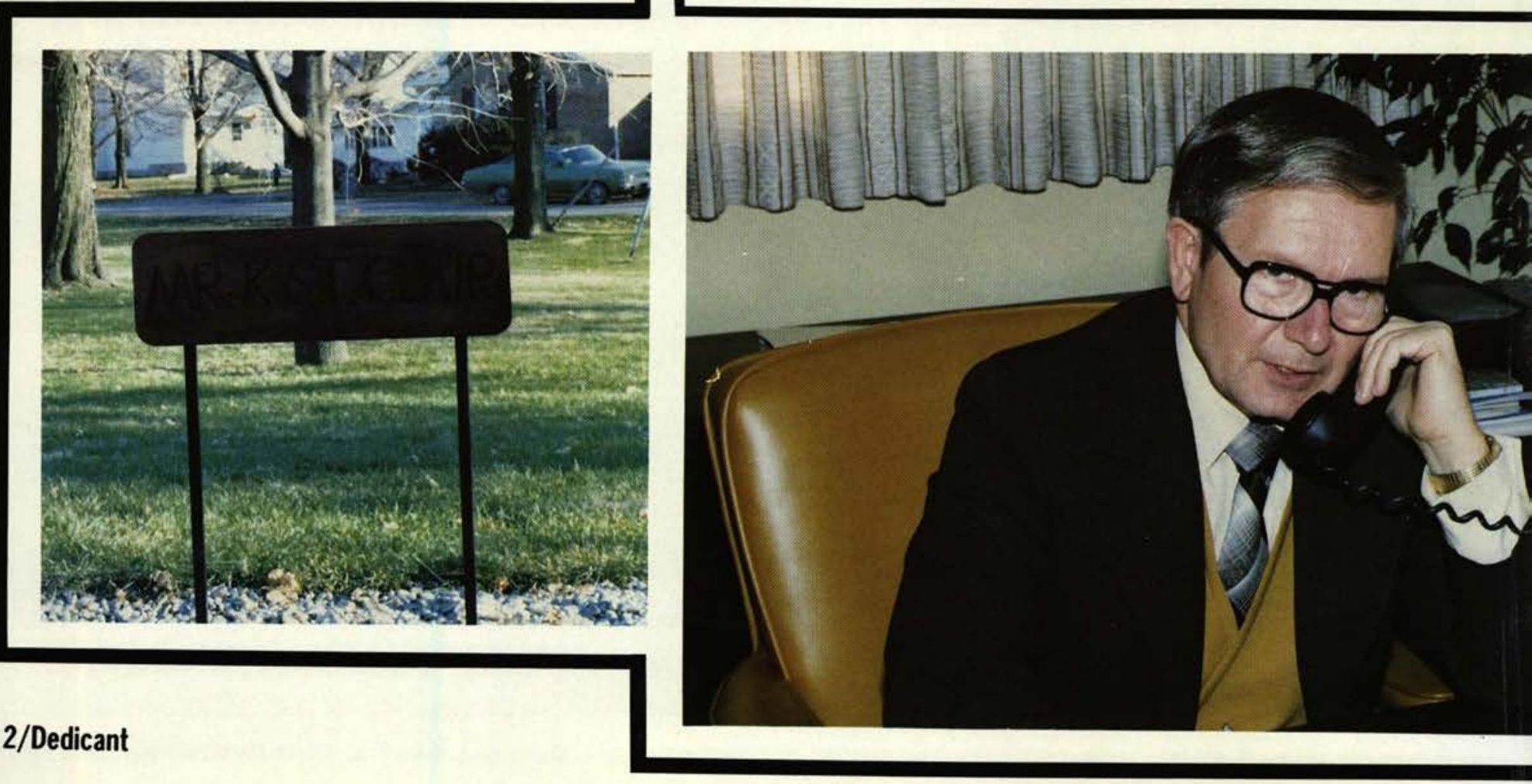

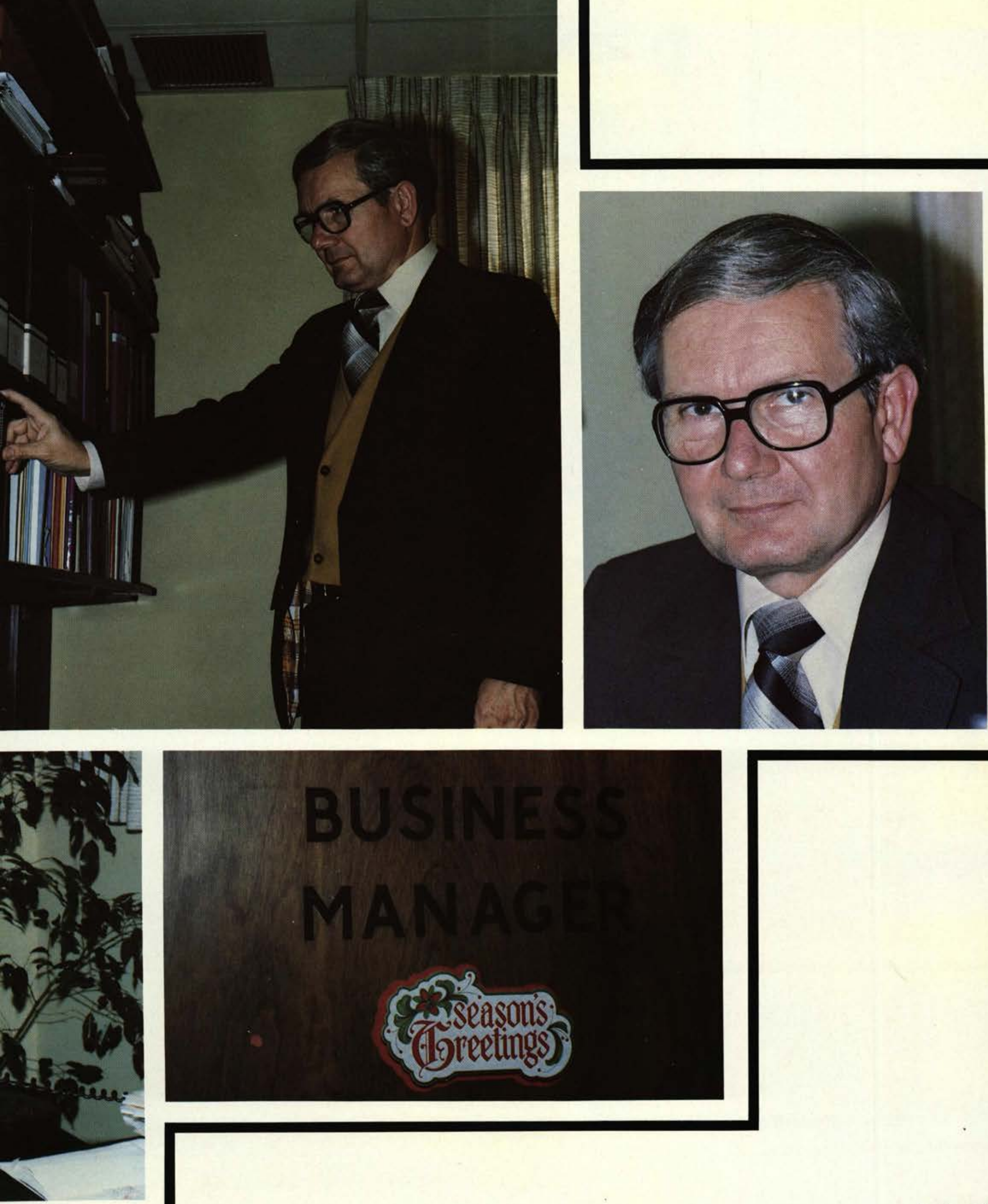

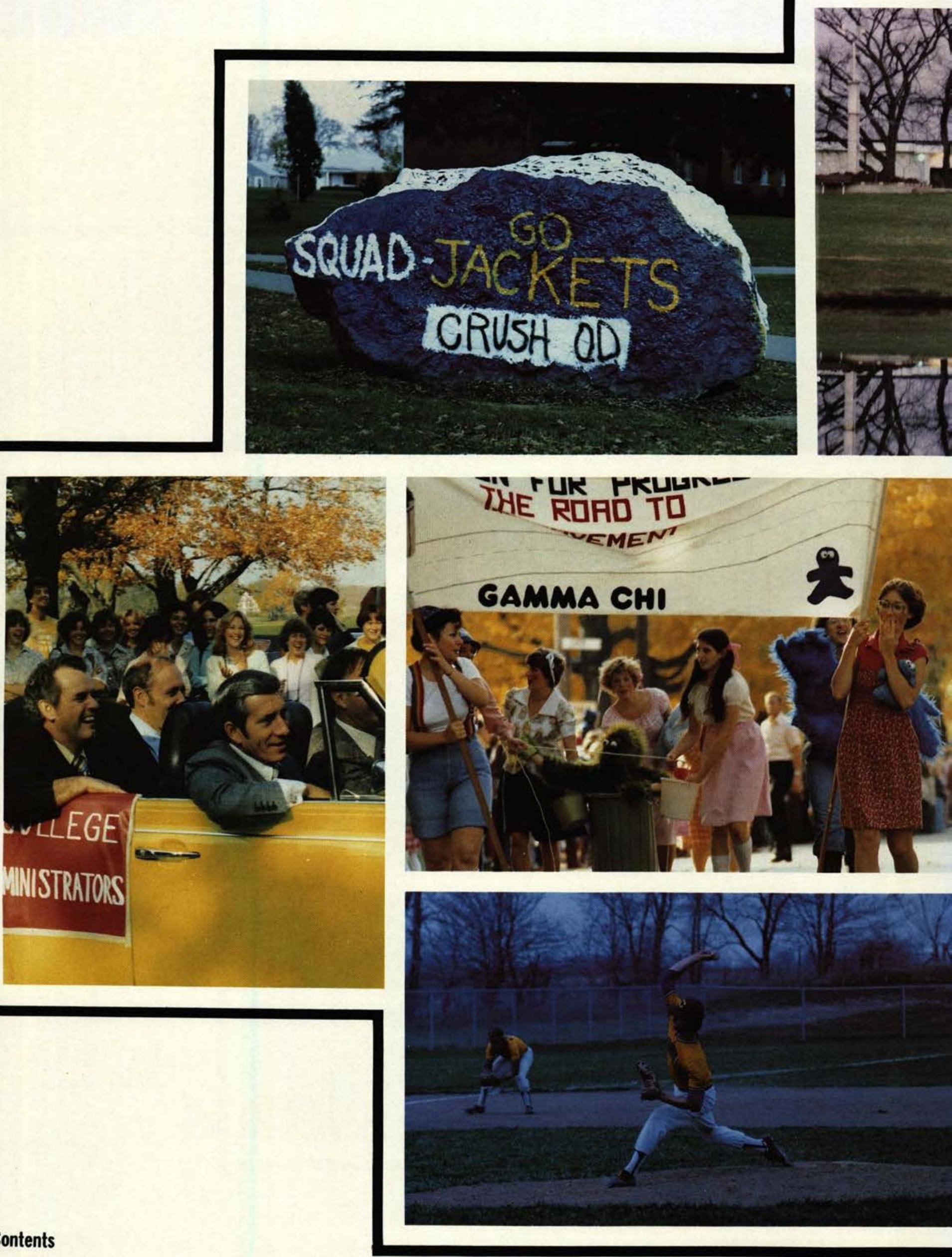

\section{4/Contents}



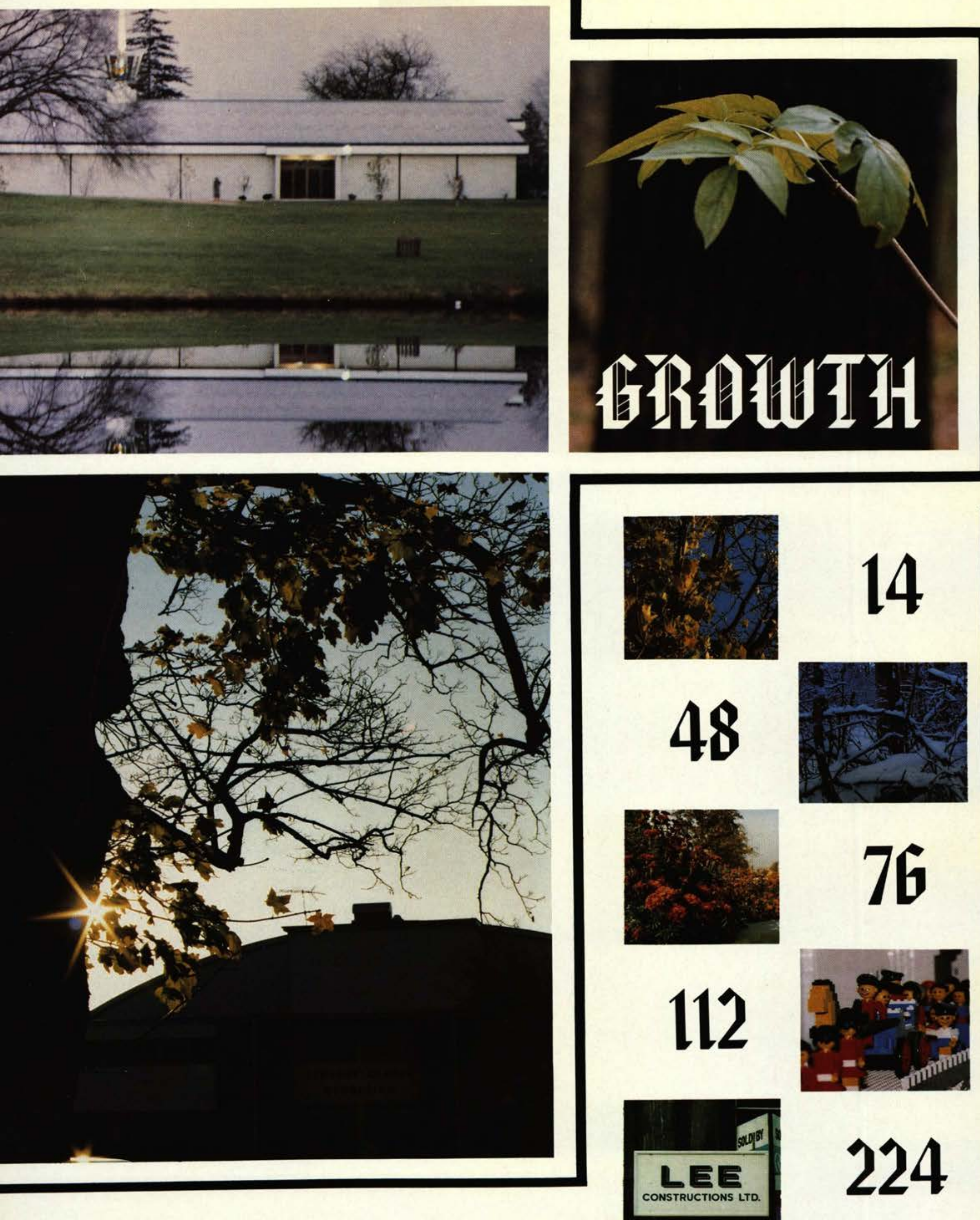

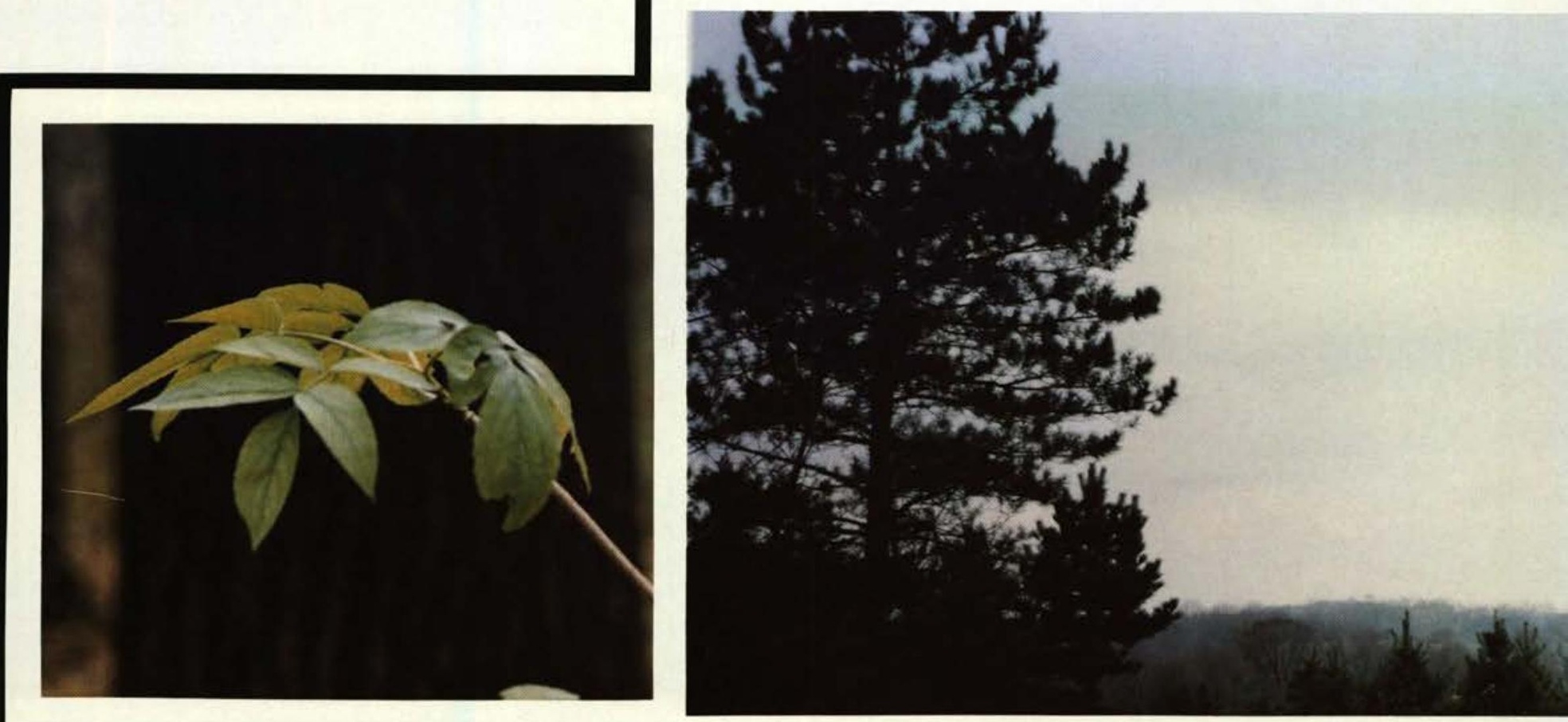

wlye, like trees grow up in many places. Fach one of us starts small and matures into a young adult. But the growing has not stopped ...

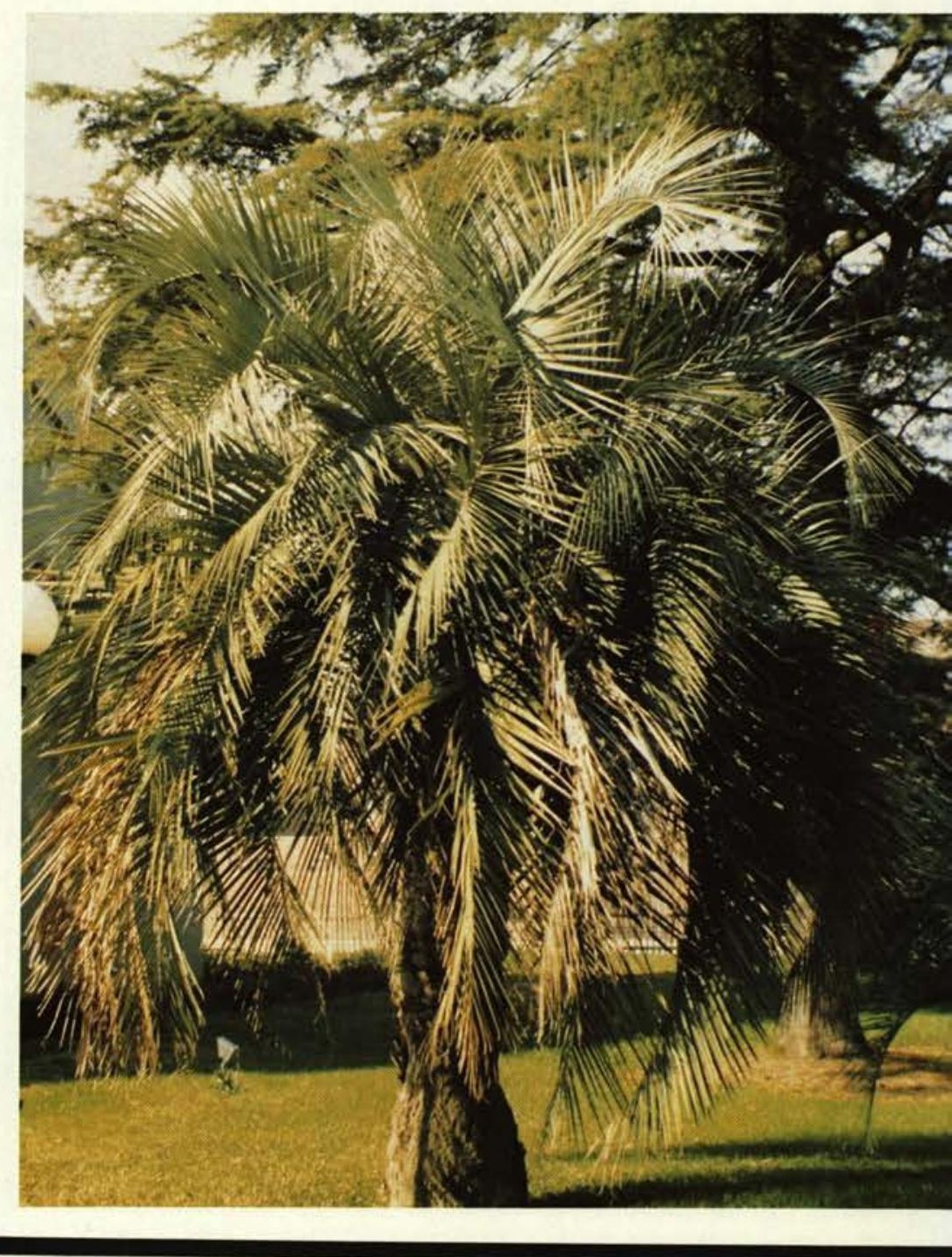


Ats young men and women we move on to college. Former ties are broken and we move into another enuironment ...
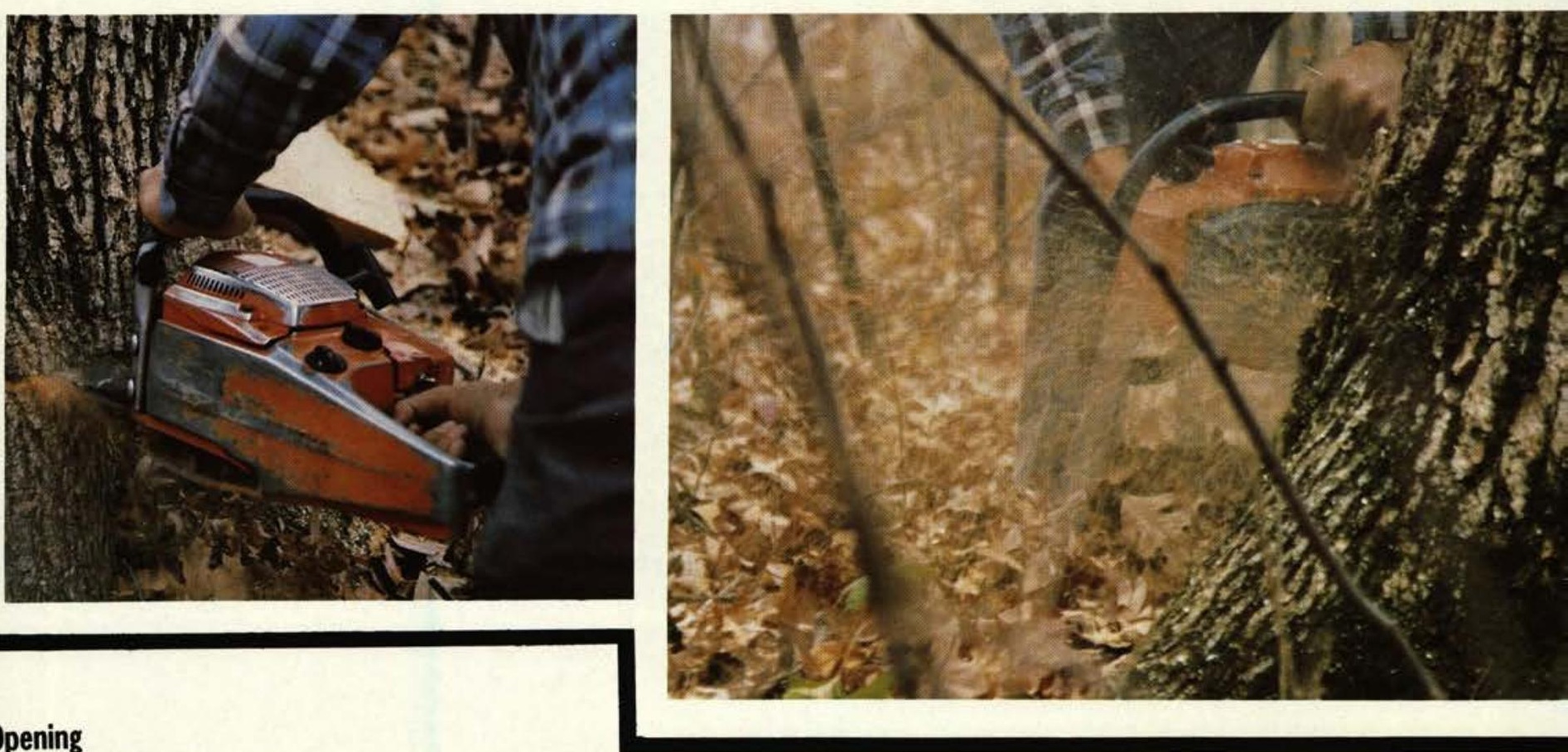

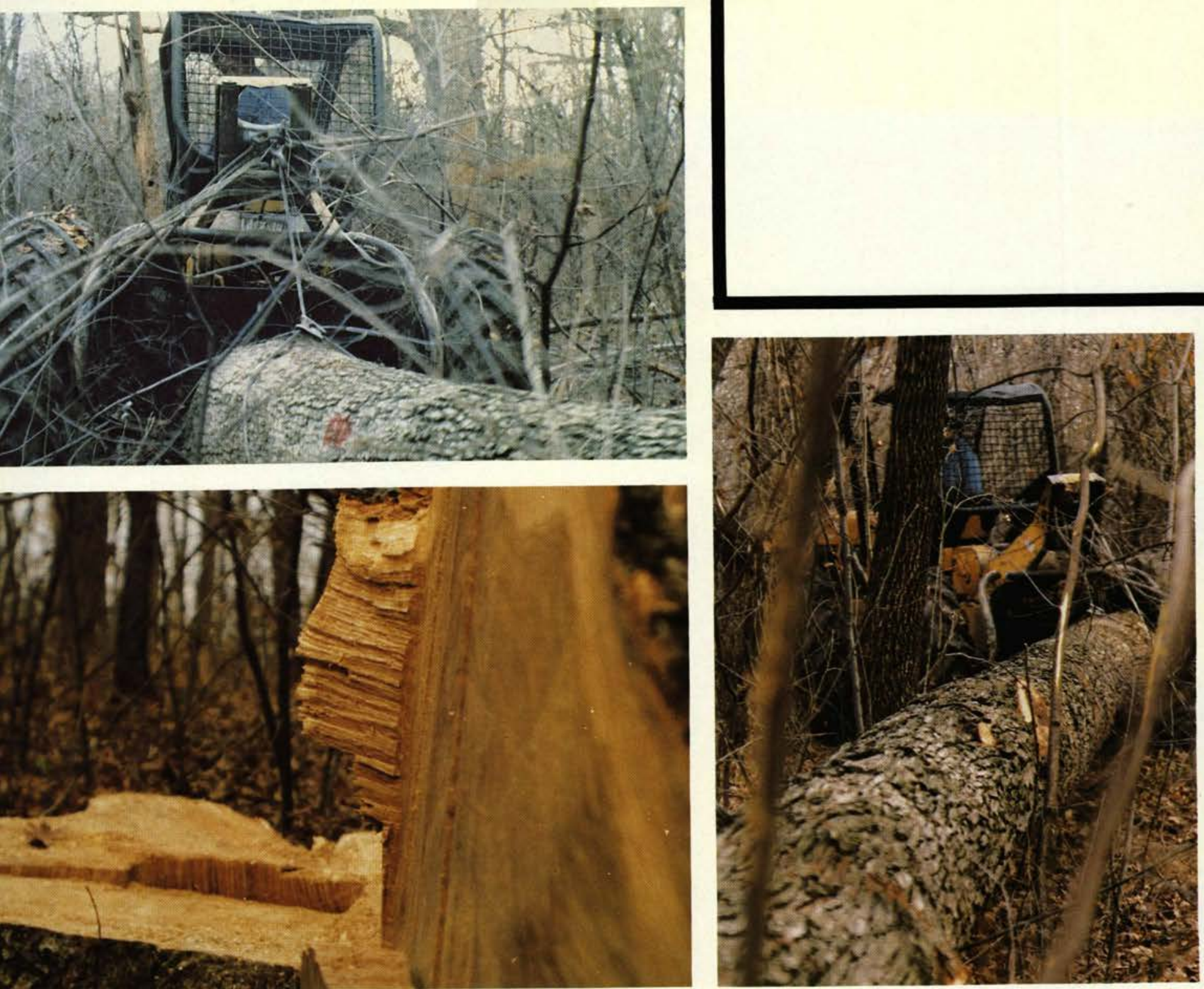

ofreis. ofyes

of 28 o

exinges

425

(1)

1. 3 is

arters

3 in 5

ह

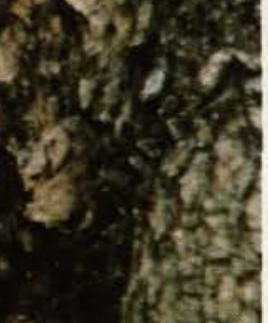

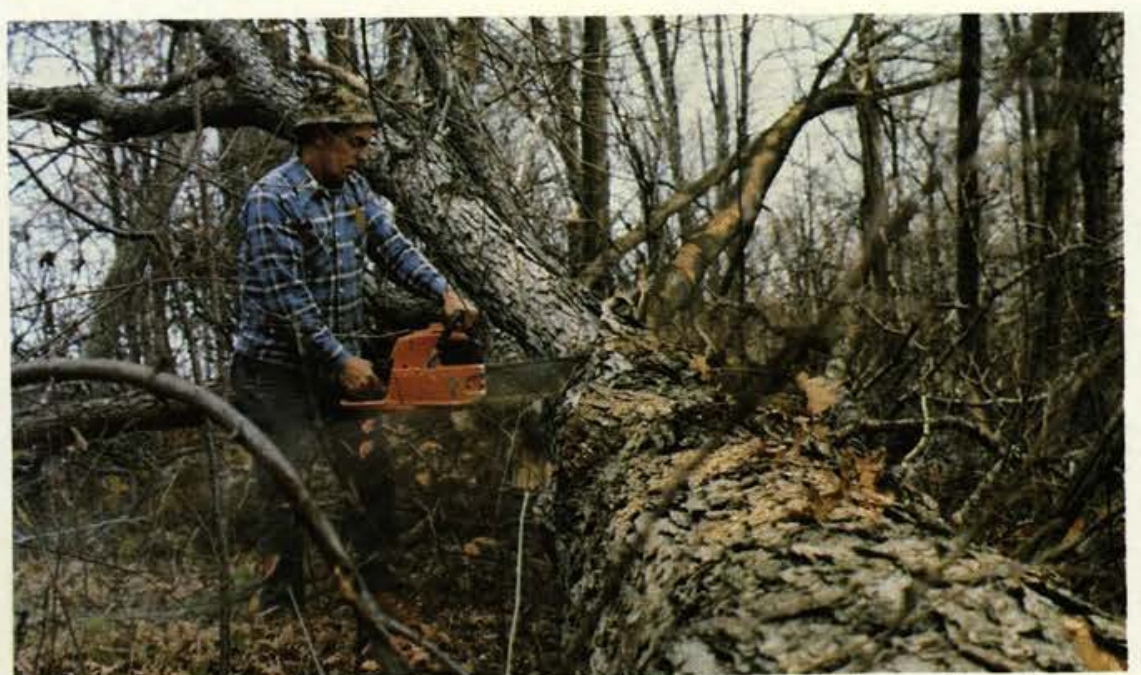



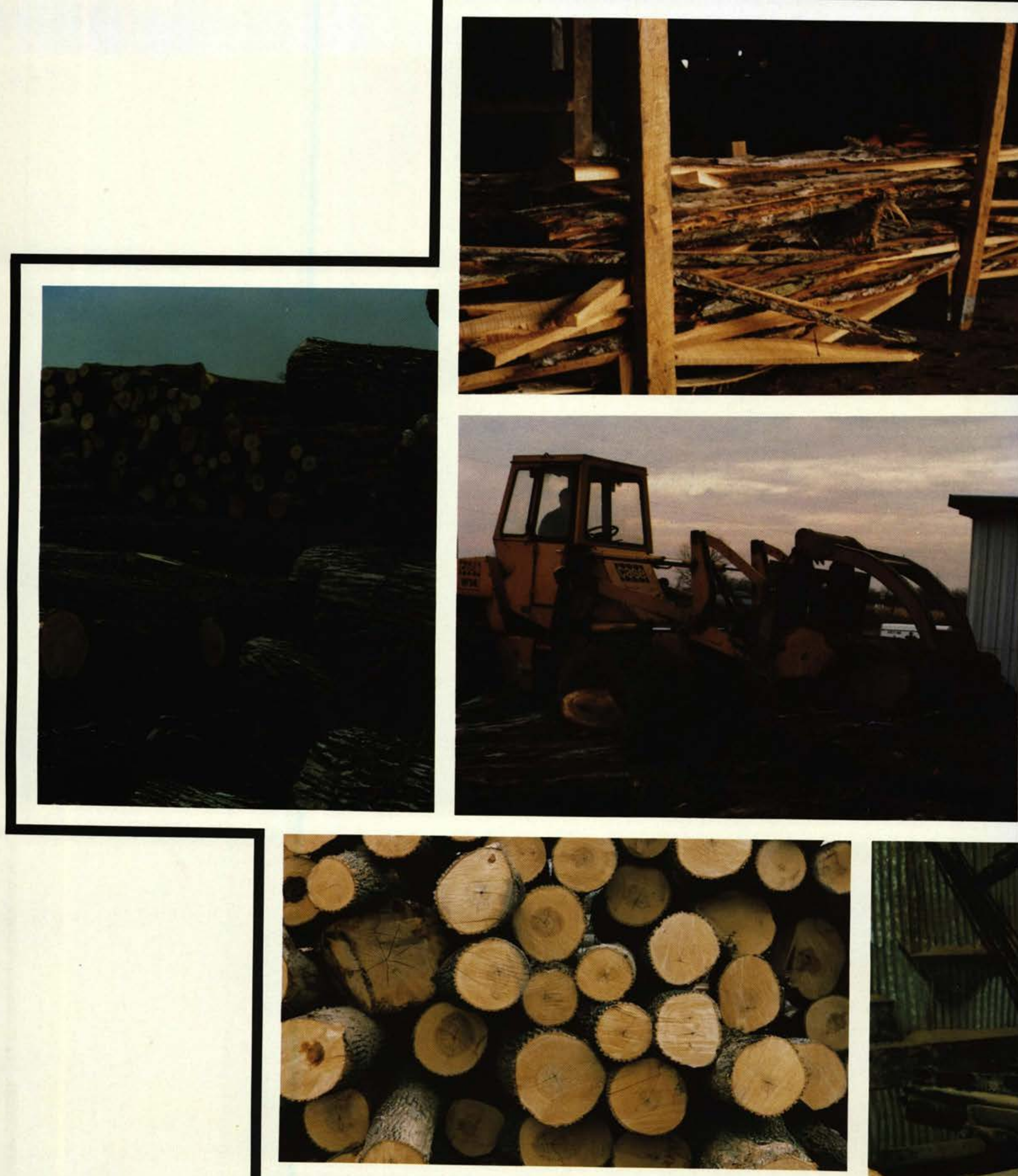

10/0pening 
Here at fedaruille we find many who, like us, persevere through four year's of follege. Wtue learn many things and lose some rough edges ....

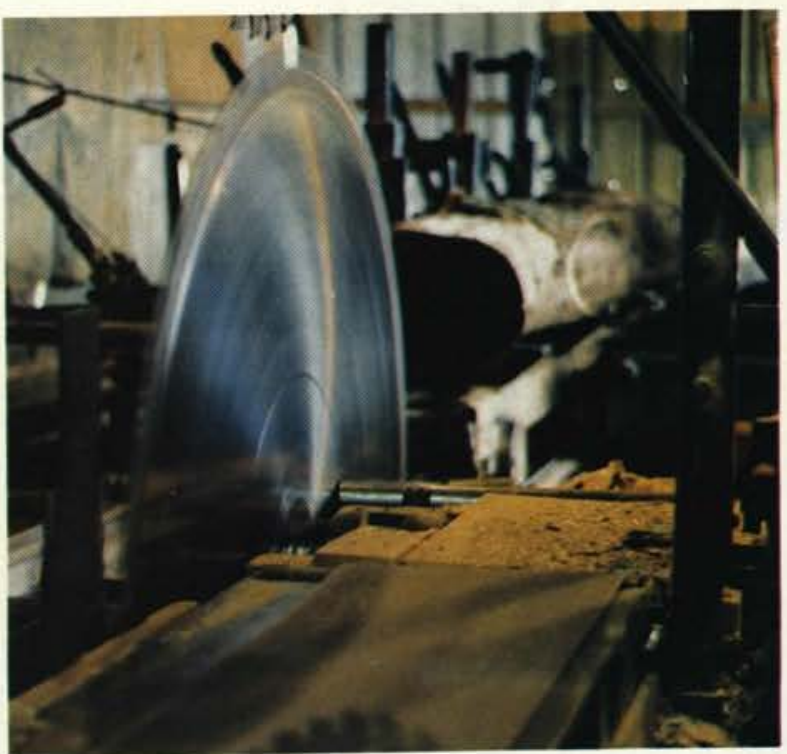




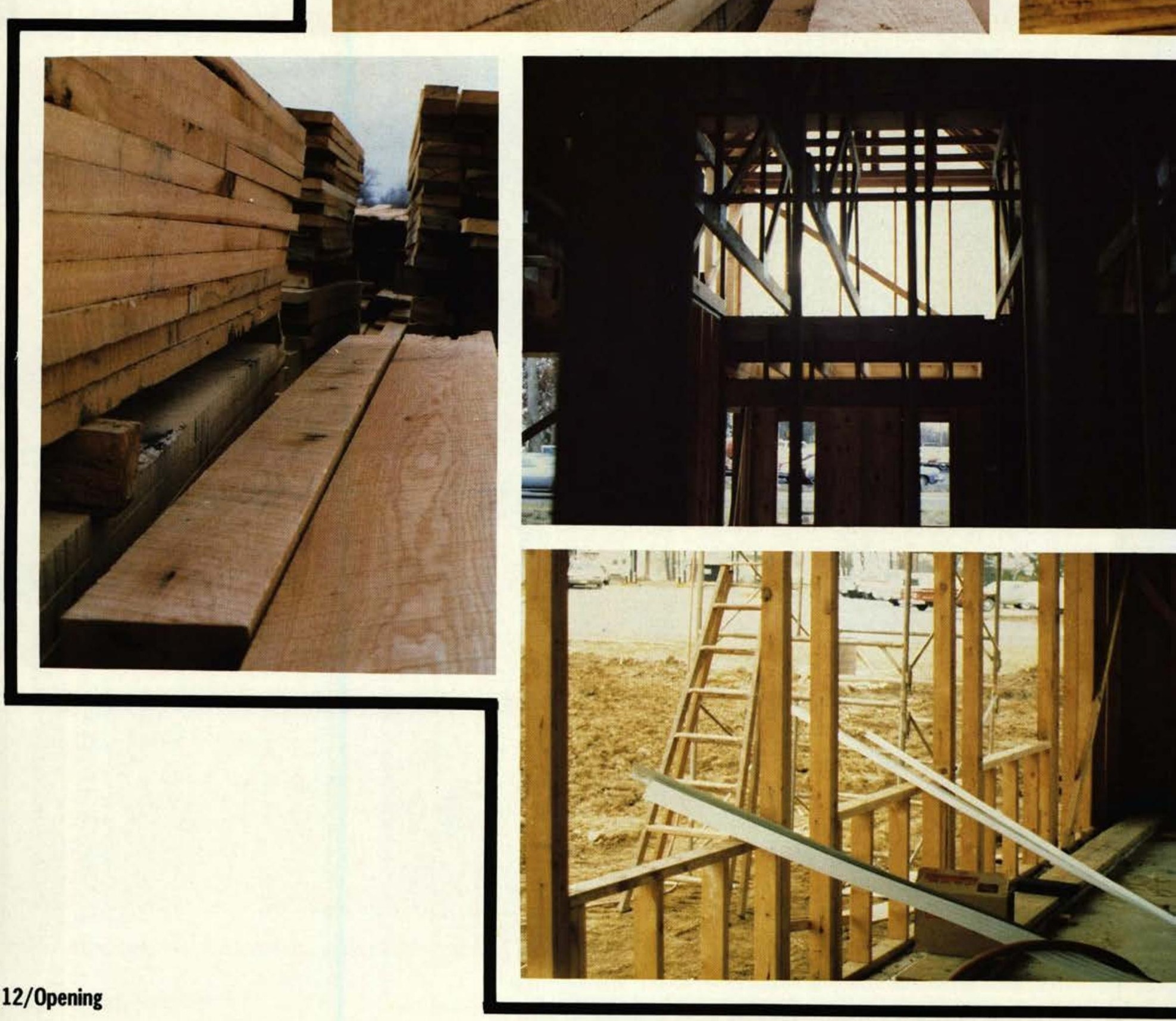



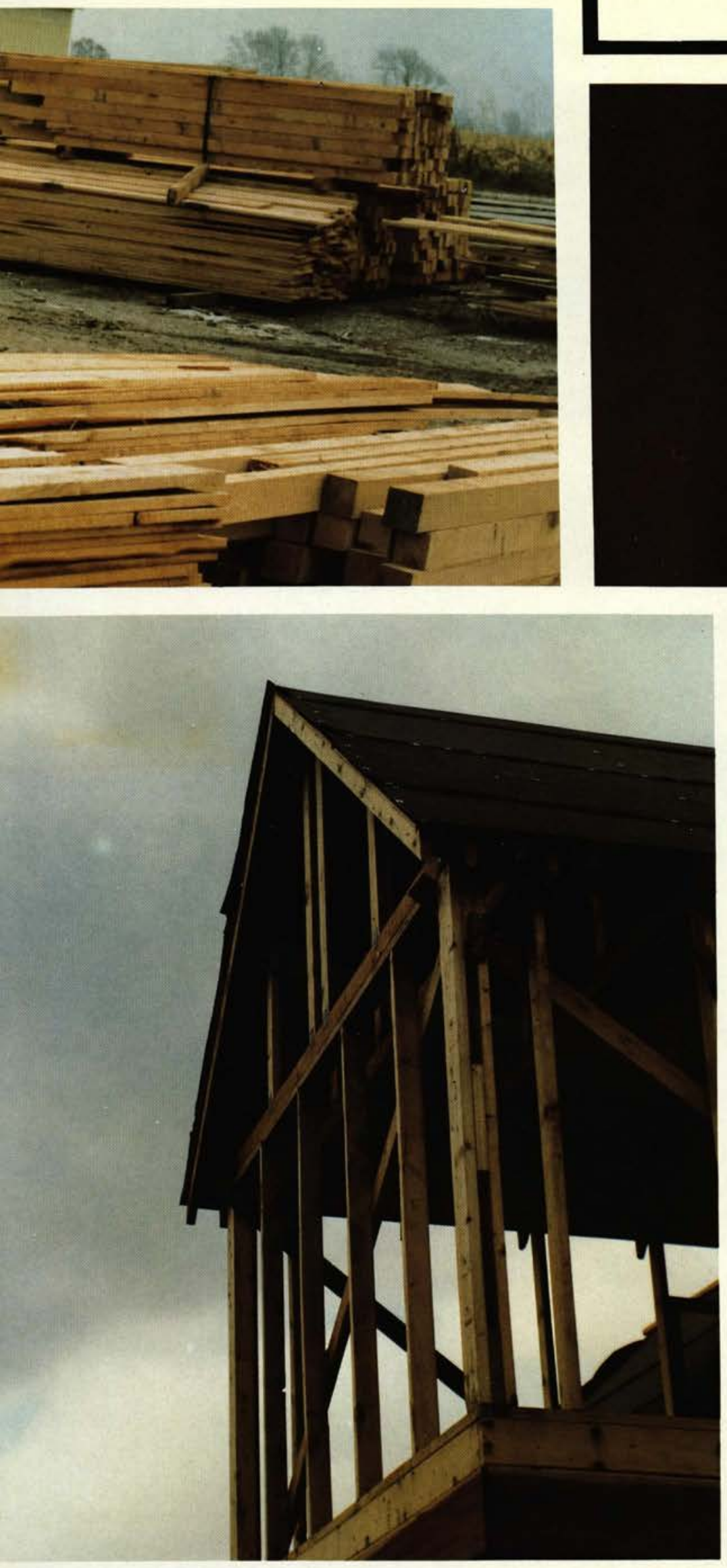

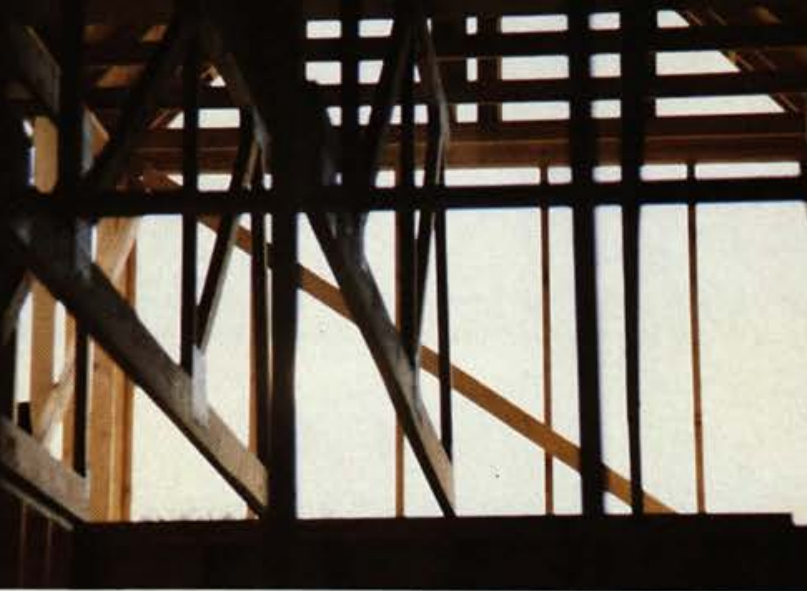

finally we graduate, departing as raw material, readly to initiate another phase of life. 

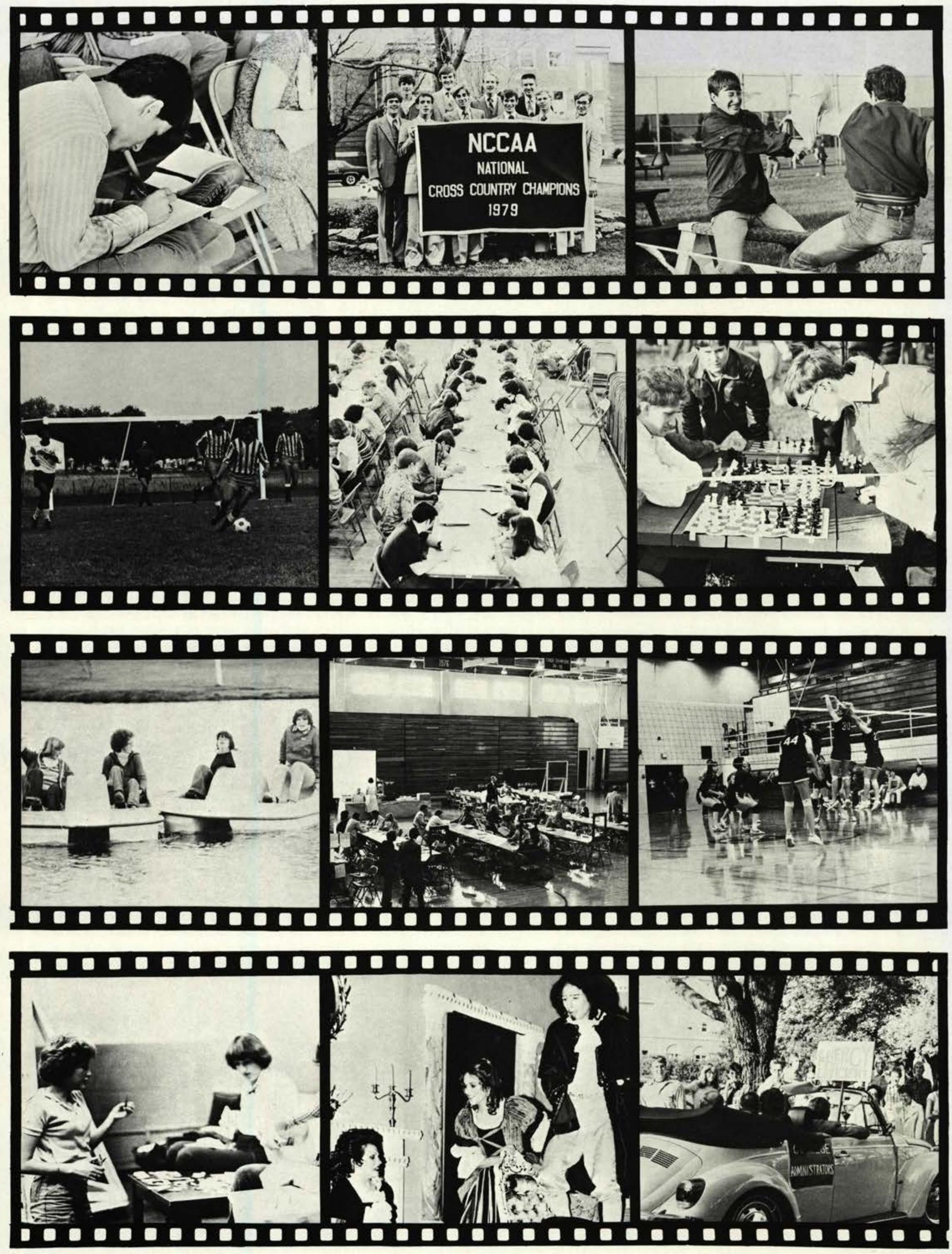


\section{Homecoming}

There was a picnic out by the lake that afternoon followed by the soccer game which Cedarville won over Ohio Dominican.

To end the days activities there was a hayride and bonfire at the Clifton 4-H camp. Marlene Eissens, Jan Anderson, Geoff Walker and Debbie Jackson all ministered in song. The students were served carmel apples and delicious apple cider.

1. The winning float for 1979 , none other than the Freshman Class.

2. The Mayor of Cedarville and his wife.

3. The Cedarville College Marching Band.

4. Homecoming activities in front of the Student Center.

5. Retired Drum Major marching in Cedar. ville Parade.

6. Administrators show their spirit in annual Parade.

7. Varsity and J.V. Cheerleaders show their spirit with the Yellow Jacket.

8. Participants running in pre-parade road race.
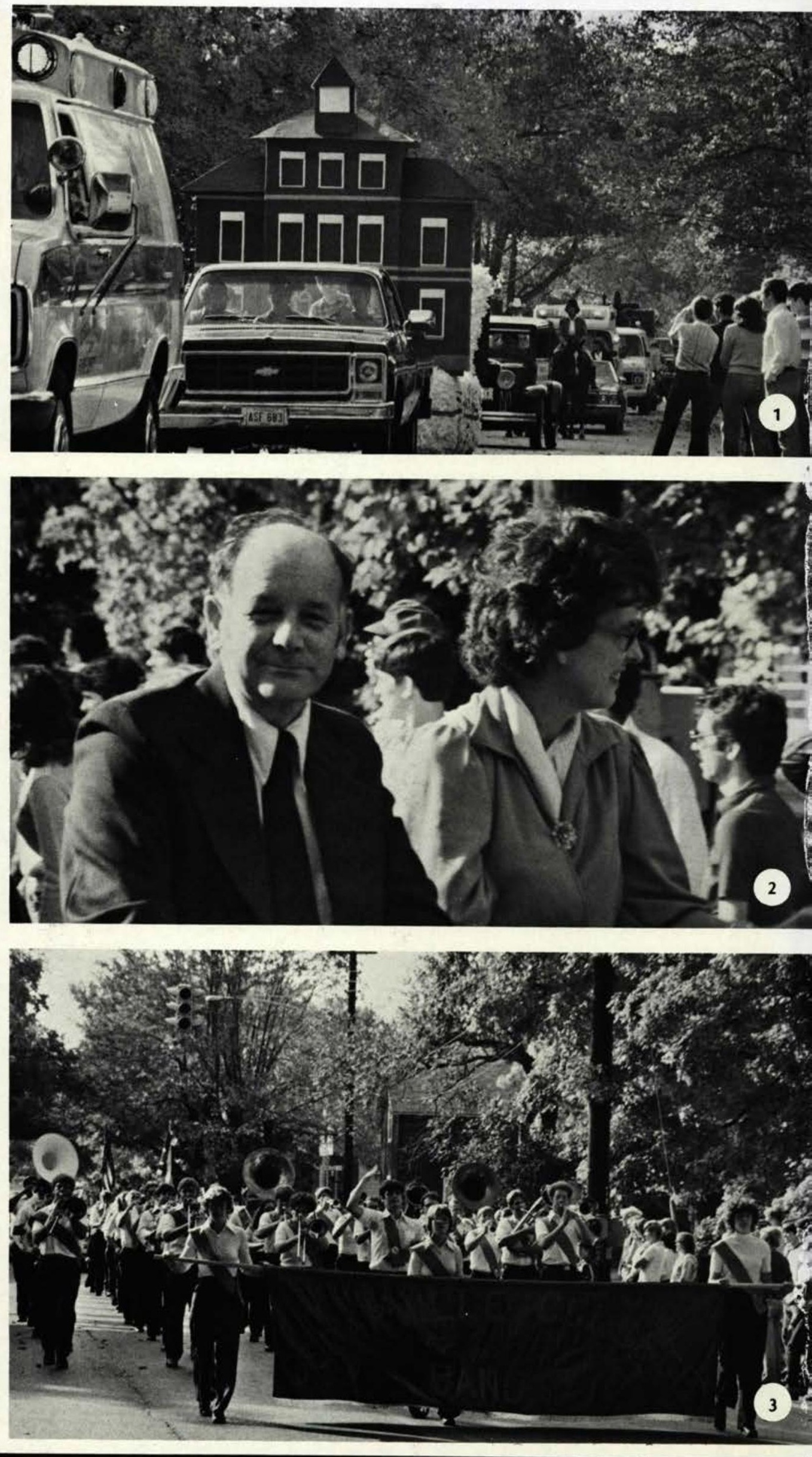


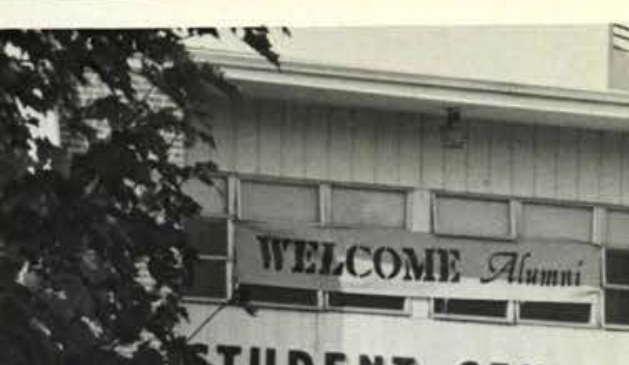

: A NUDENT CENTER

1.

i sand and

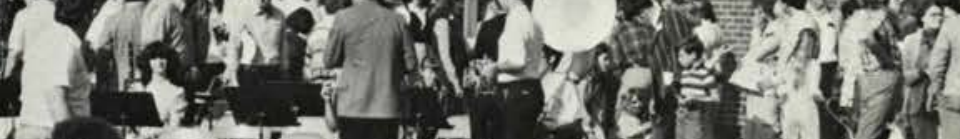
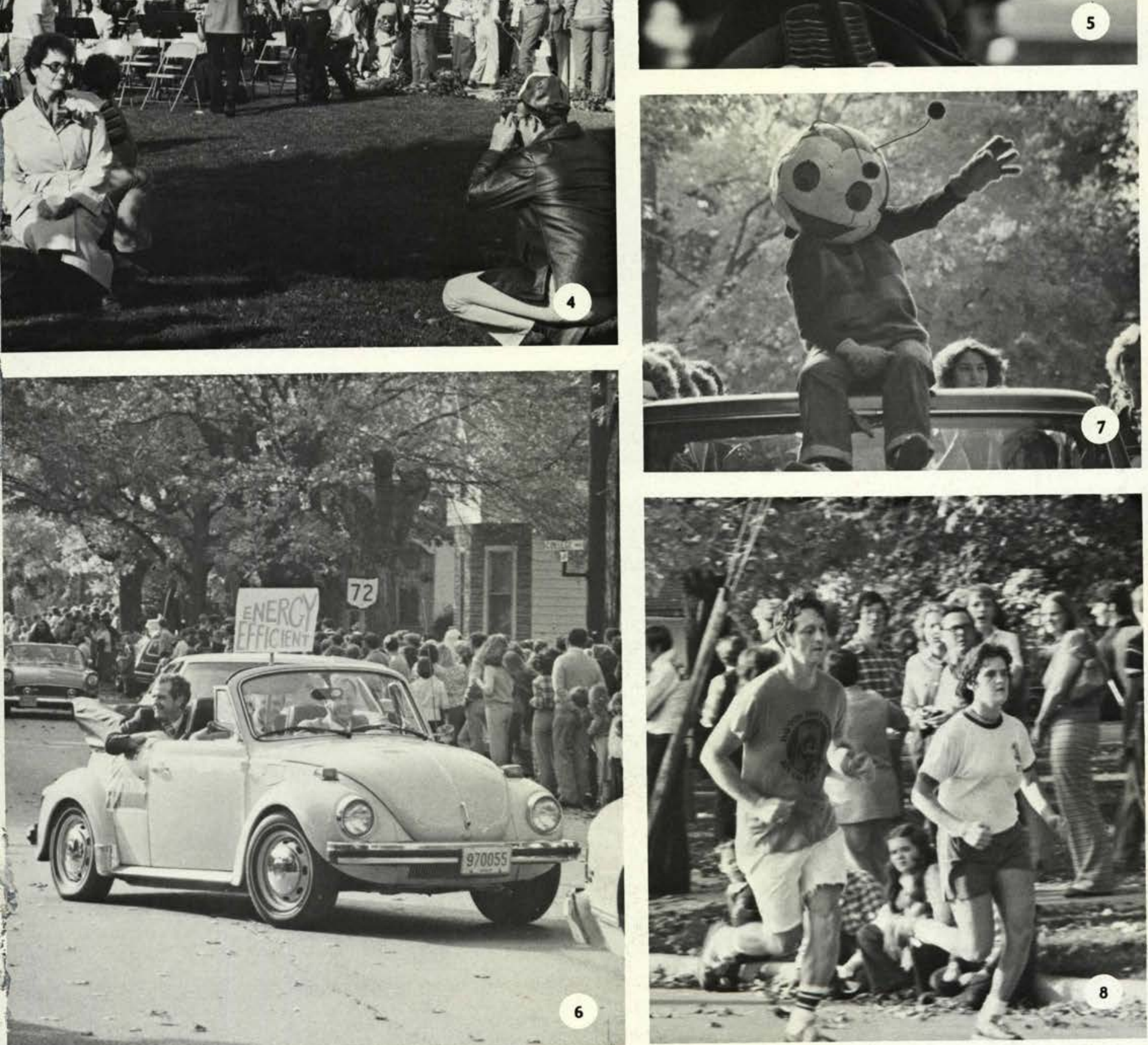


\section{Homecoming}

The morning of October 20 started off a series of activities celebrating Cedarville's annual homecoming. A moving pageant of color and sound drew crowds which lined Main Street from the downtown area to the campus. Floats, made by each class, were brilliant in their color and originality. The Cedarville College Band, Cedar vinie in. scnool Band, Gammi Chi and their Sesame Street characters, the town mayor, trusties of the college, and many cheerleaders all took part in the parade. The queen and her court were also featured in the parade.

1. 1979 Homecoming queen, Sarah Arthur and escort Dale Shaw.

2. Terri Potter, the Sophomore attendant, with escort Dann Green.

3. Freshman attendant Karen Miller and her escort Sheldon Arndt.

4. Senior attendant Danette Wetzel and escort Randy O'Quinn.

5. Junior attendant BethAnn Payne and her escort Randy Harper.

6. The Alpha Chi Sweethearts: Valerie Dell, Amy Young, and Darlene Repp.
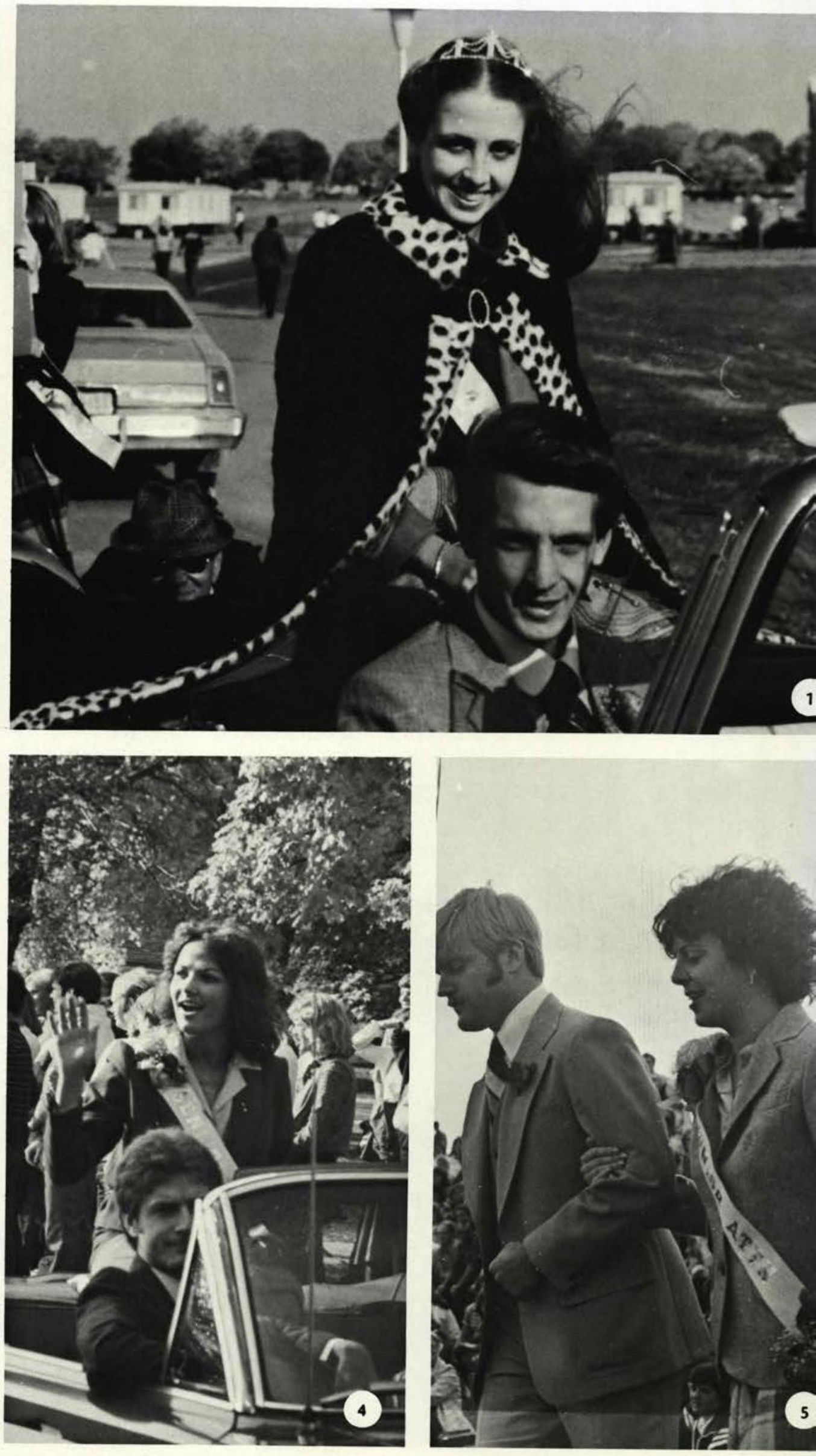


\section{The Imaginary Invalid}

The sarcastic humor of the play and its superb actors made it one of the best in the schools history.

Argon, the main character, was a professing hypochondriac. He trusted completely in his physicians and did whatever they prescribed for him - no matter how ridiculous.

Toinette, Argon's servant, was aware of her masters predicament. She decided through several different plots to help him overcome his dependency on doctors. While she was doing this, Toinette was also helping Angilique, Argons daughter, forgoe an unwanted marriage to Thomas Diaforus. Angeliques real love was Clenante.

During this, Beline, Argons second wife, was trying to talk her husband into sending his daughter to a convent, so that she would be his only heir. Finally, Argon relinquished his dependency on doctors, and became one himself, through a mock ceremony. He then allowed his daughter to marry her true love.

1. Argon informs Toinette that she has been an impudent servant. 2. Toinette looks happy as she reveals her plot to Angelique. 3. Beline, Argon's second wife, cannot hide her contempt for her husband. 4. With glee, Toinette informs Argon of something dreadful. 5. Toinette asks Angelique to trust her and believe everything will work out. 6 . Beline reveals some rather disturbing news to Argon. 7. When Argon thought he had lost his daughter Louison, he bent to find her pretending. 8. Argon and Toinette demonstrate their equal ability to be stubborn.
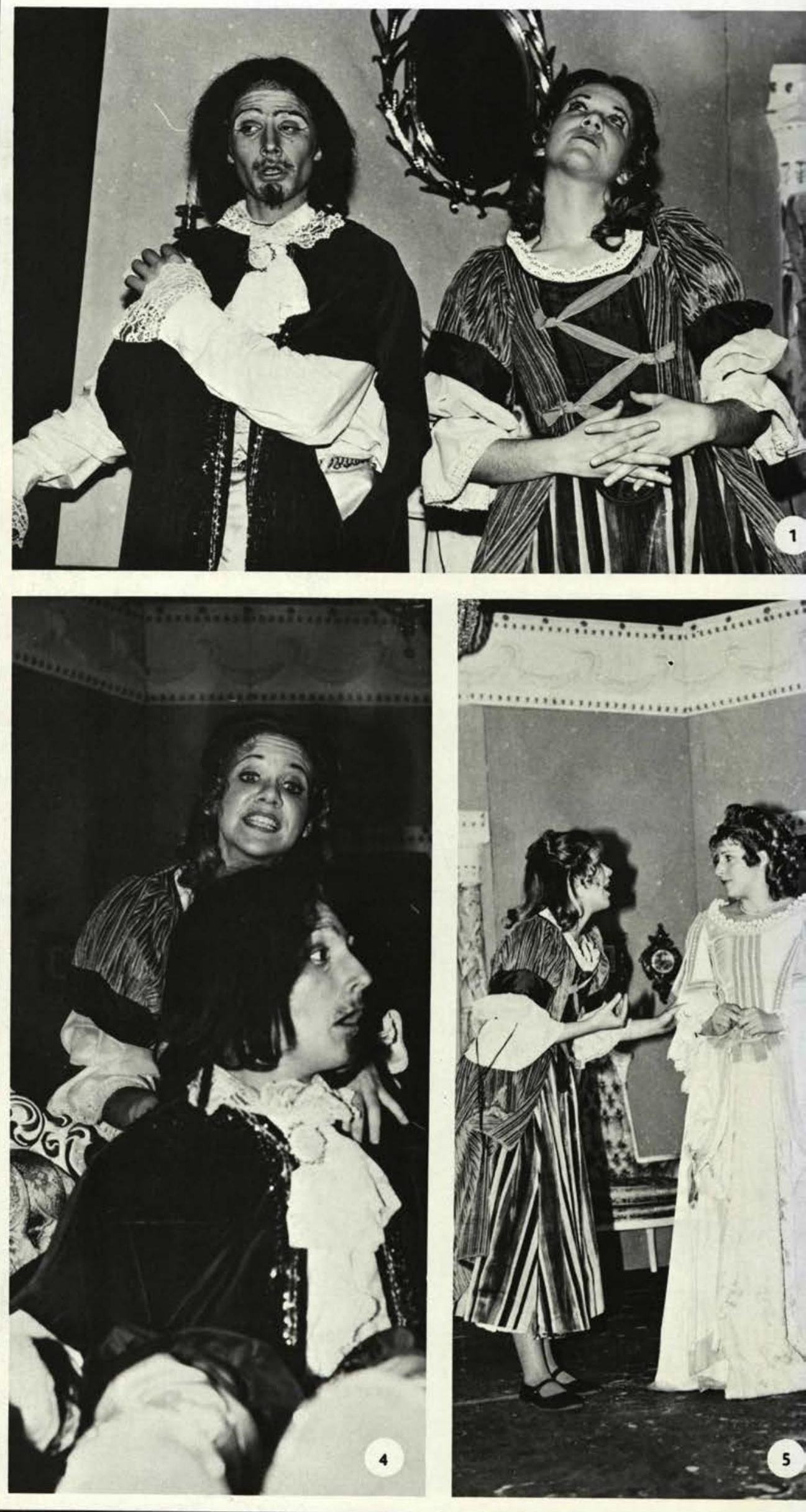

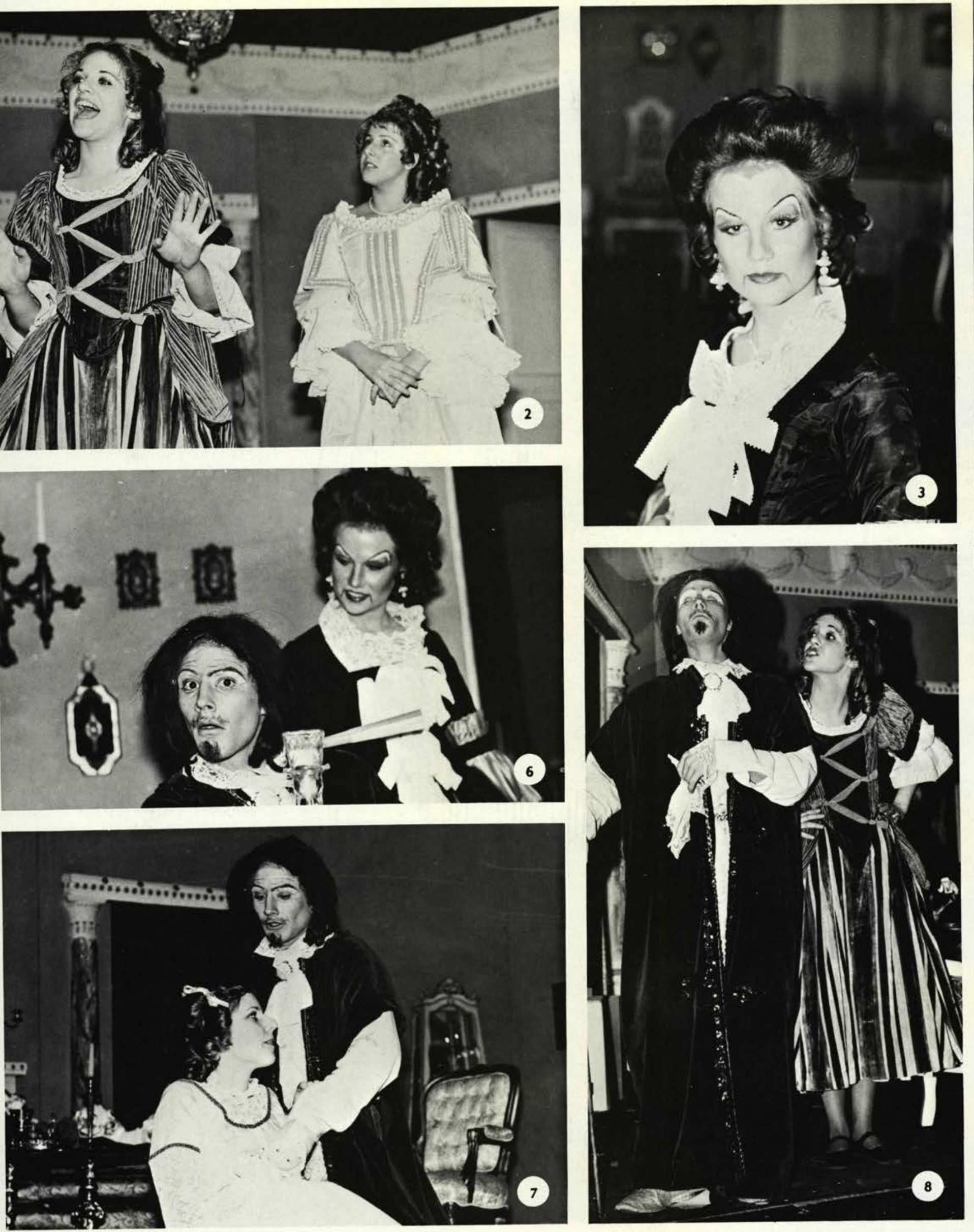

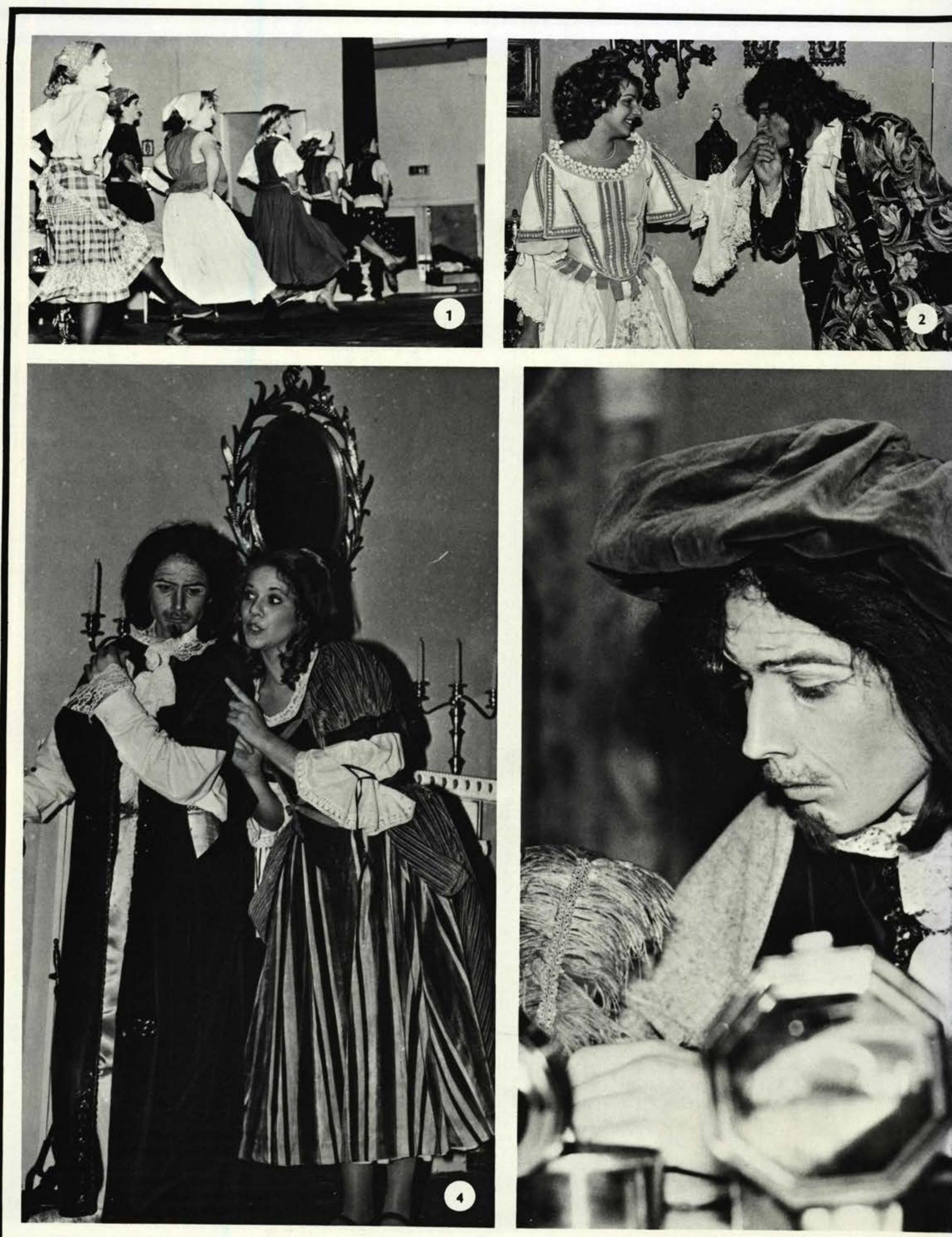

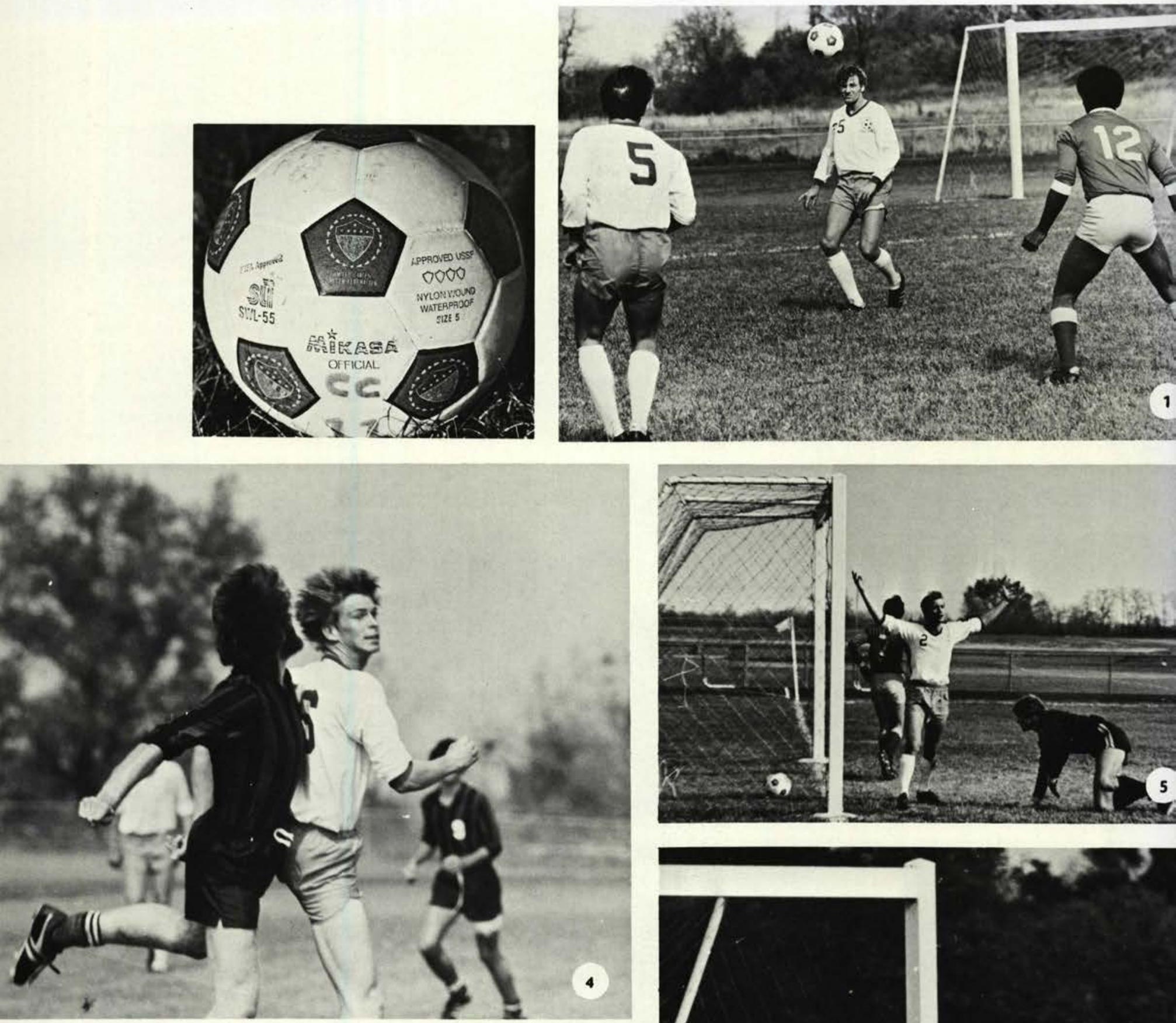

1. Dave Merkh, Al Stewart, and opponent focus on the ball. 2. Chuck Bodey, Coach McGillivray, Stefan Pabst, Josias Lima, Jim Barrett, and Dallas Stewart concentrate on a Junior Varsity soccer game. 3. Bobby Shomo and Al Stewart warm up before the game. 4. An opponent surprises Jeff Bowser. 5. "You're kidding!" protests Jim Barrett after a call of no goal. 6. Tim Graham makes another spectacular save. 7. As opponents wallow in a despair, Jeff Bowser jumps for joy.
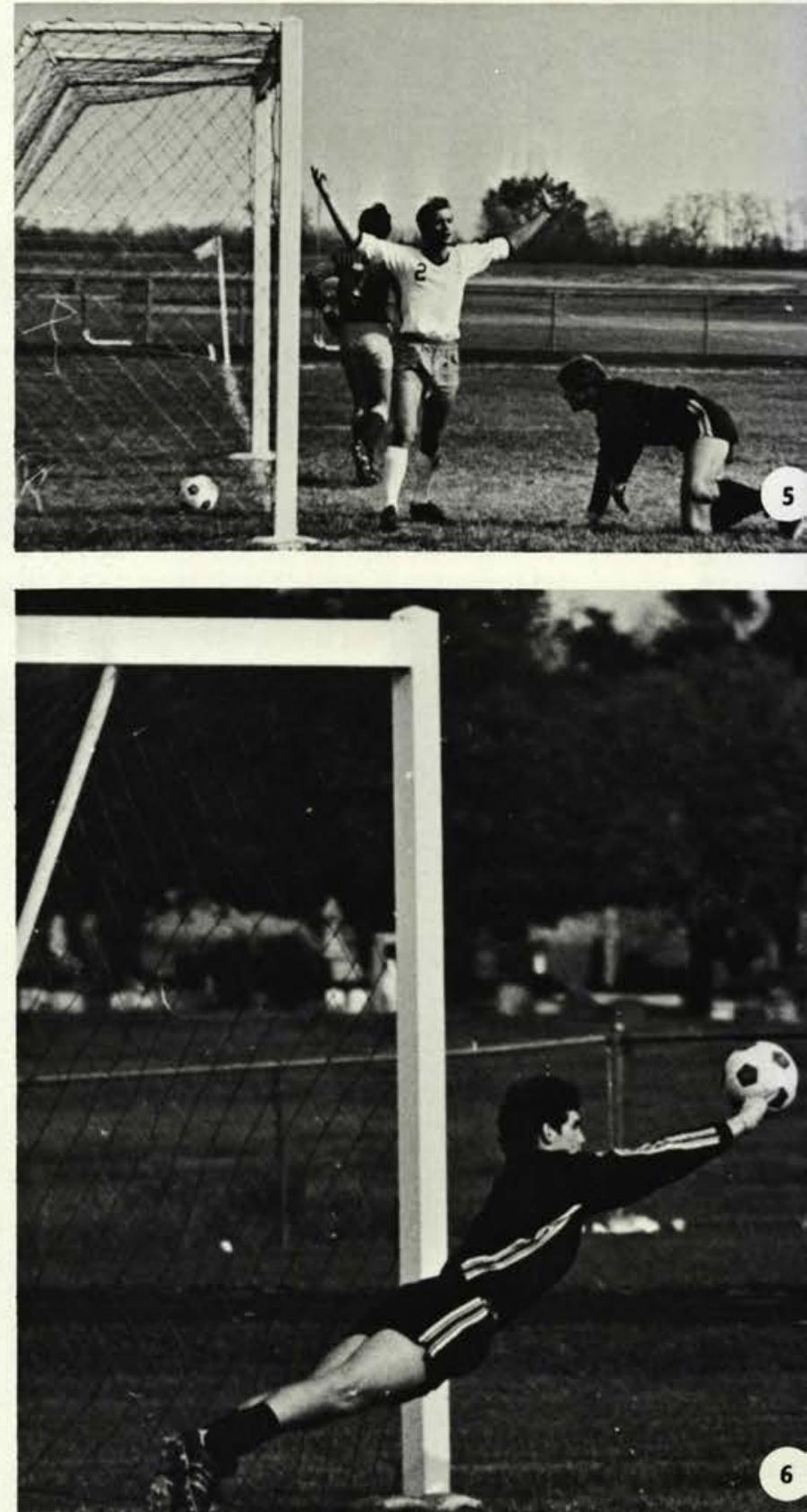


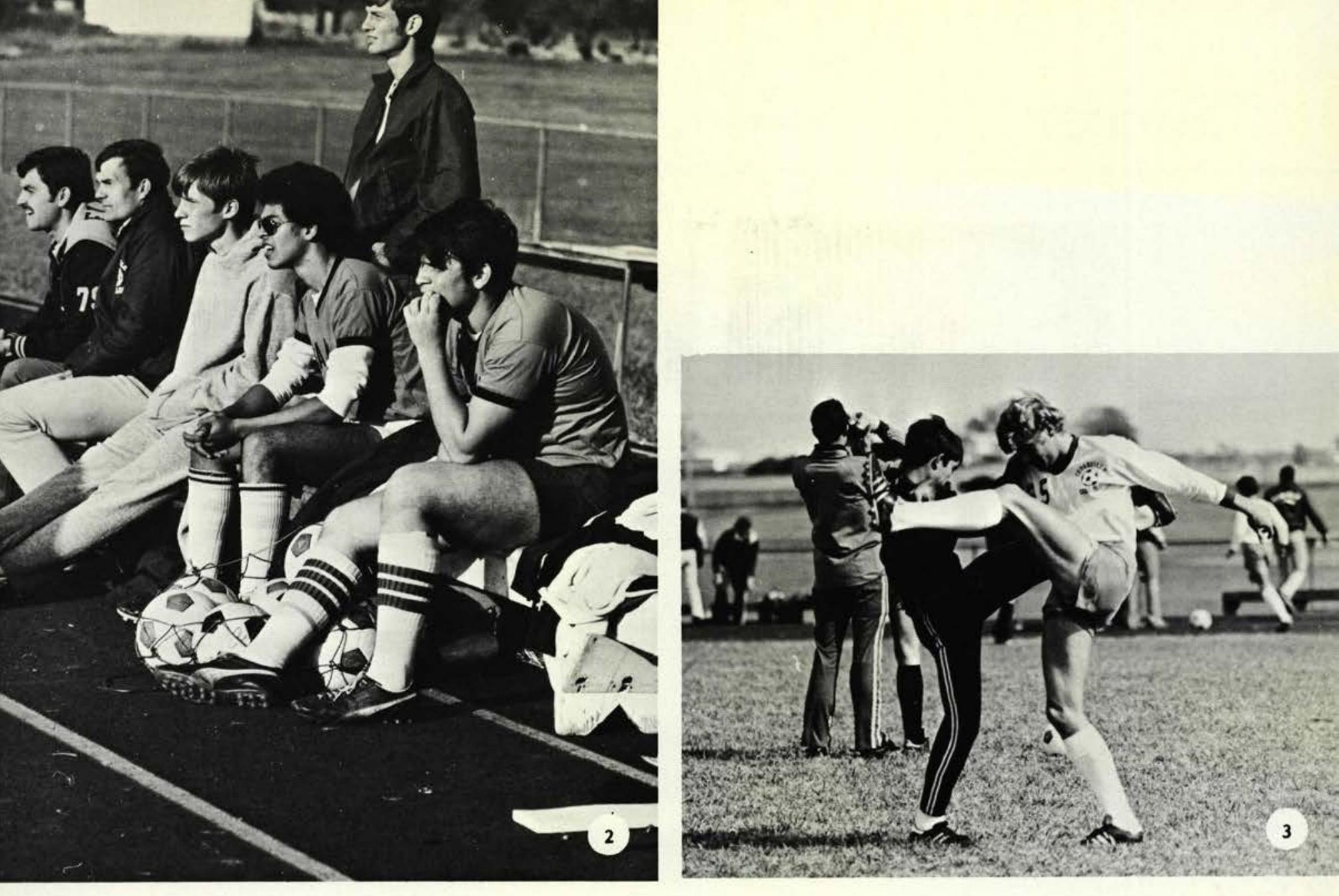




\section{Soccer}

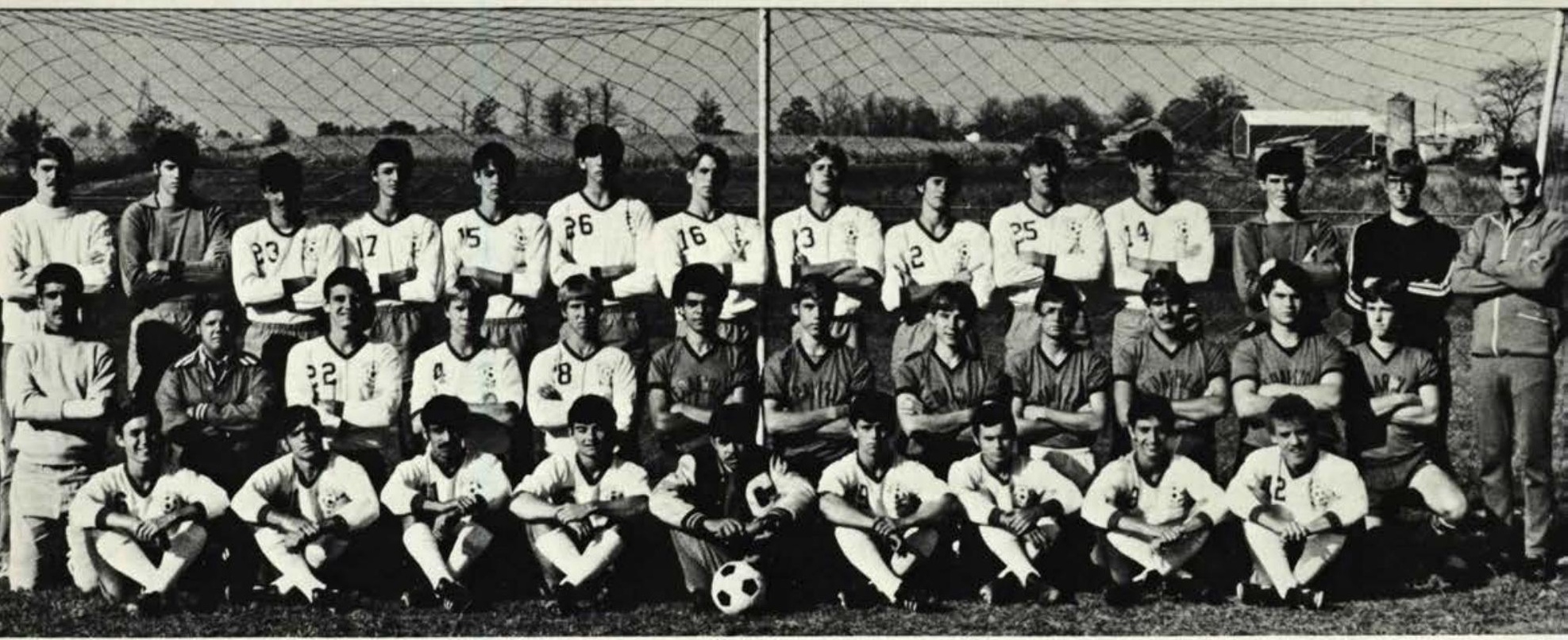

This year's Soccer team, coached by John McGillivray, had another successful year. Their overall record of 8-10-1 came as a result of competing with strong outside competition. The team had a 6-1 record within the NAIA District 22, finishing as runner-up. The teaii captured first place in the MOC $4-0$ record by collecting an exciting come from behind, overtime victory from Walsh. The team had a good season despite injuries to last year's two leading scorers and this year's top two goalkeepers. Next year's team looks promising with 10 starters returning. This year's Junior Varsity team, under the direction of John Ring, had a 1-4-1 record including a 3-1 loss in the annual Alumni game. Several of their starters did not play every game because they were moved up to the Varsity team. Next year Coach McGillivray hopes to have the Varsity and Junior Varsity divided into two separate teams.

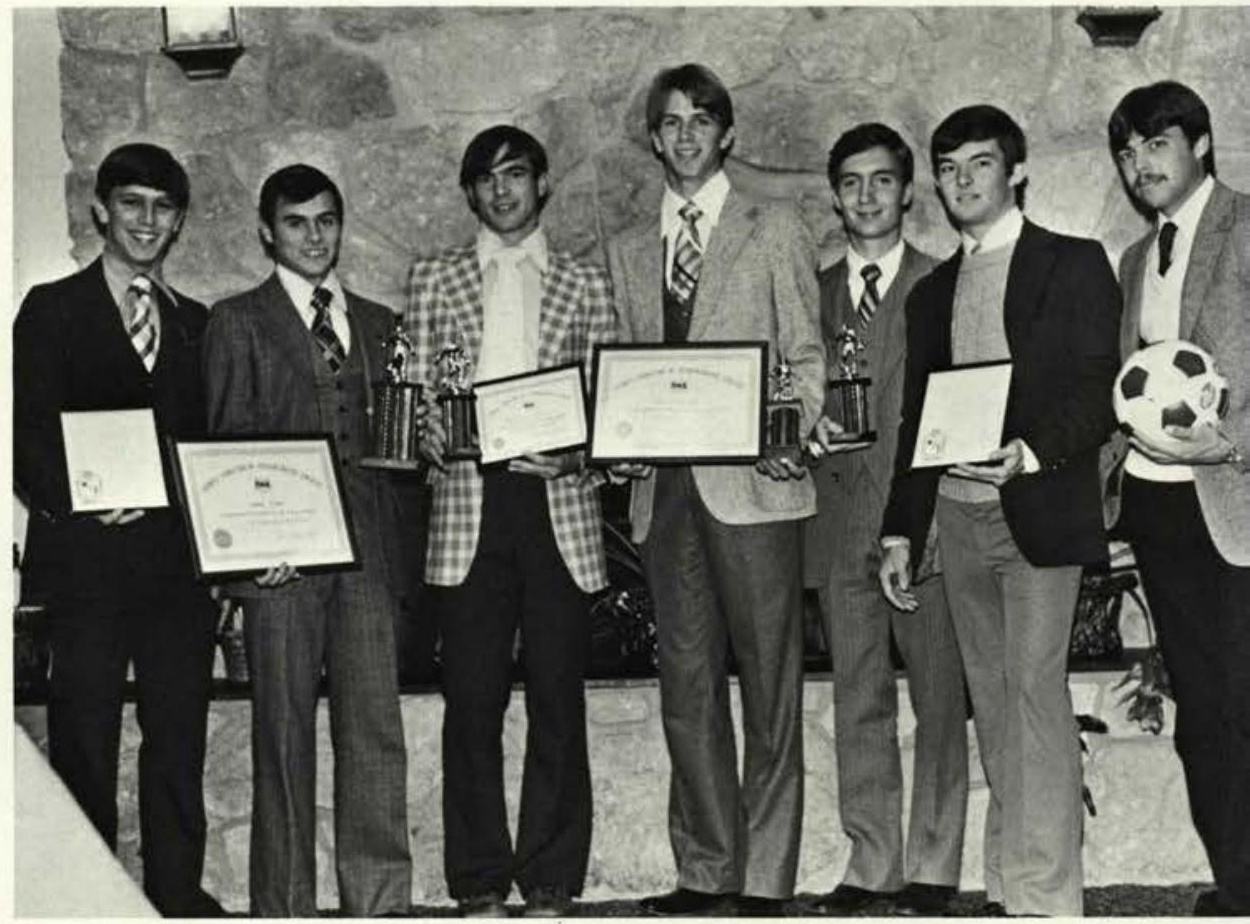

TOP

Front row, left to right: Dan Standridge, Carleton Birch, Bobby Shomo, Dave Merkh, Tom Aitken, Mark Leach, Dave Cox, Dave Standridge, John DeLancey. Second row, left to right: Steve Piazza, Dennis Wates - Manager, Mark Wells, Craig Herl, Phil Miller, Josias Lima, Bob Boynton, Stefan Pabst, Chris Boudreau, Kent Van Kleck, Dallas Stewart, Don Greening. Third row, left to right: Joe O'Neal, Wynn Gifford, Dan DeLancey, Kim Jenerette, James Fischer, Mike Draa, Jeff Bowser, Ed Stewart, Jim Barrett, Al Stewart, Jim Jobson, Tim Graham, Steve Sadowitz, Coach McGillivray. Missing from picture: Michael Bamgbose, Jeff Smith, John Ring - J.V. coach.

BOTrOM: These soccer players received special awards. Left to right: Mark Leach - Captain, NCCAA District. Dave Cox Conference, NAIA Honorable Mention, NAIA District first team, All State Honorable Mention, Most Valuable Player, NAIA Area IV first team. Carleton Birch - Conference, NAIA District Second team, Best Defense, NAIA Area IV second team. Jeff Bowser Conference, NAIA District first team, High Point, NCCAA District, NAIA Area IV first team. Dan Standridge - Most Improved Player. Dave Merkh - Conference, Captain. Tom Aitken - Captain. 


\section{Cross Country}
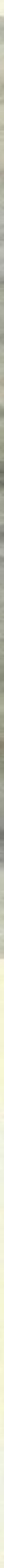

The Cross Country Team enjoyed another rewarding year under the direction of Coach Elvin King. Coach King was pleased at the ease with which they won some of the meets. They missed first place in the Findlay Invitational by only two points. The team's goal was to defend the NCCAA National Championship achieved last year. The Cross Country Team retained their title of Champion by winning the NCCAA Championship at John Bryan and MOC title the previous week.

This year, Coach King organized the first women's cross country team. They ran in the turkey trot and the intramural run. Next year's team is expected to compete against other colleges.

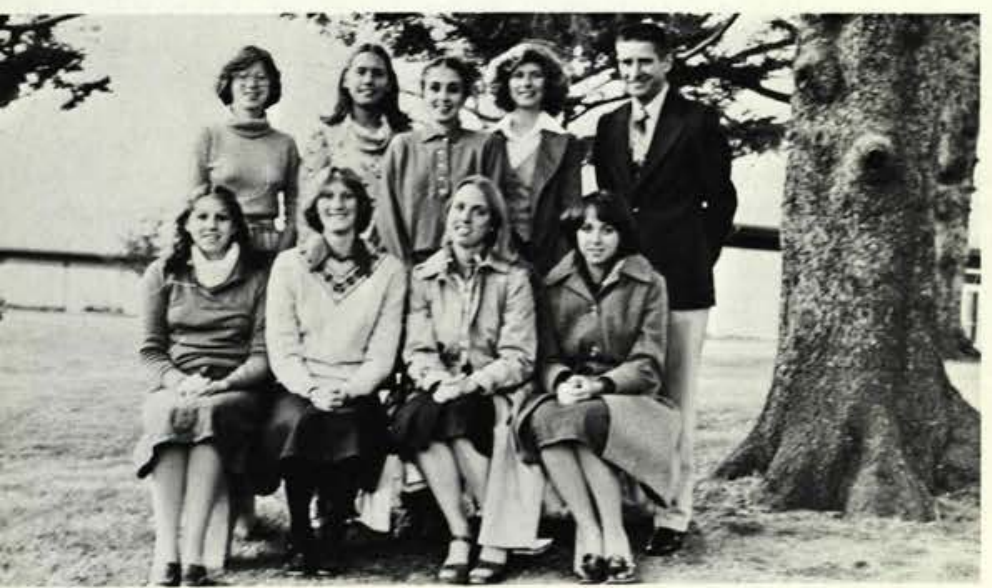

TOP PHOTO

Left to right, front: Kirk Keiler, Sonny Snell, Jon Shelden, Dean Johnson. Middle row: Dave Fogle, Manager, Craig Colas, Dale Shaw, Tom Yater, Chris Yoder, Elvin King Coach. Back Row: Cal Clark, Dave Treese, Ryan Spencer, Roger Michel.

Left to right, front row: Coach Elvin King - NCCAA Coach of the year; Dave Treese Most Improved; Sonny Snell — Outstanding Freshman; Dale Shaw - Most Valuable, All Conference, All American. Back Row: Jon Seldon - letter winner; Craig Colas Captain, All American; Tom Yater - All Conference; Cal Clark - letter winner. Missing - Dean Johnson - letter winner.

\section{BOTTOM PHOTO}

Left to right, front row: Cindy Treese, Peggy Harrell, Julie Hutchins, Mary Wallace. Back now: Laura Clayton, Lynda Patton, Sarah Arthur, Beth Landis, Coach King. 

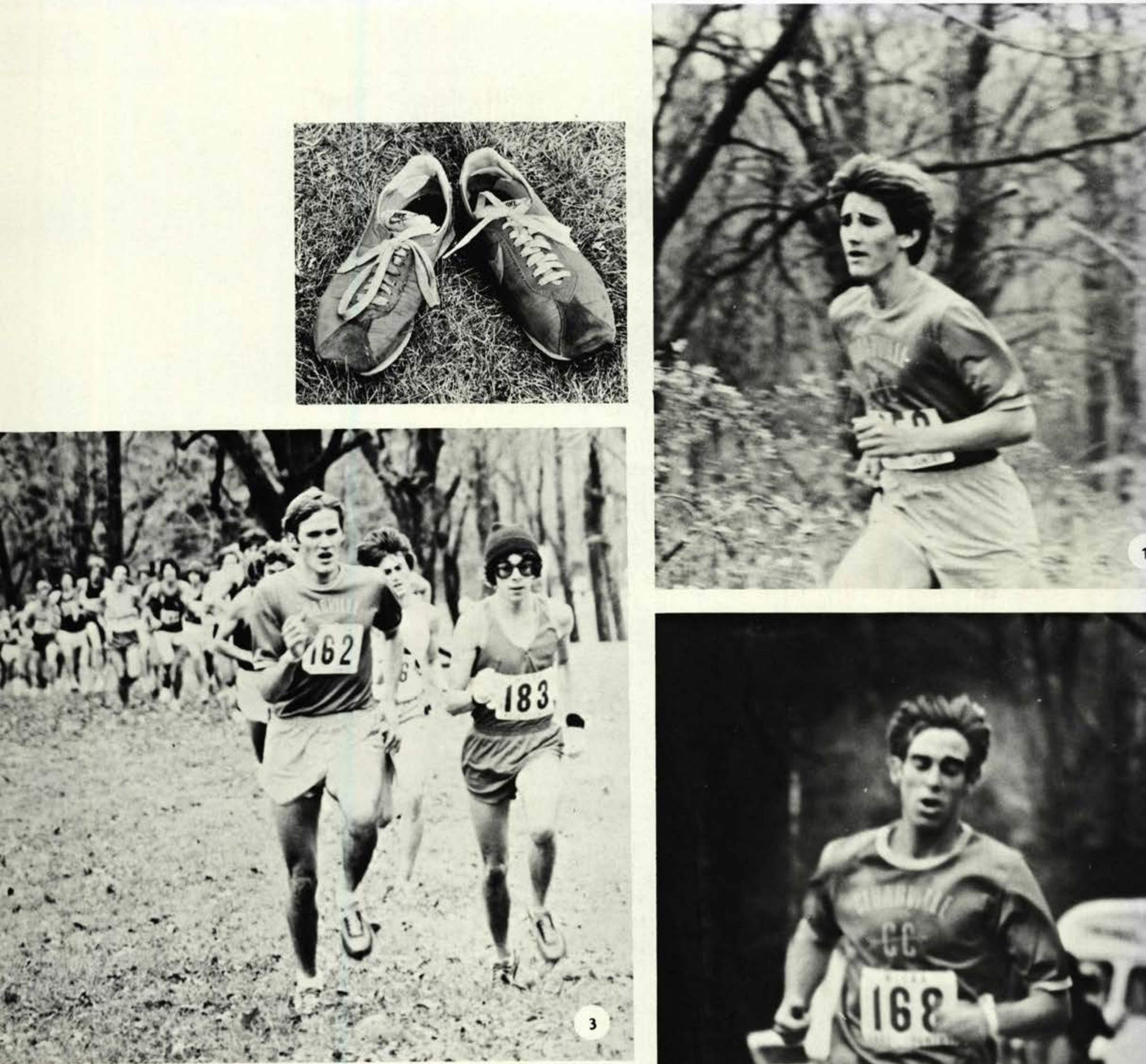

1. Kirk Keller runs in the MOC meet. 2. Cedarville's cross country team prepares to begin the NCCAA National meet. 3. Who's after you, Craig Colas? 4. Dave Treese concentrates as he runs the NCCAA Nationals. 5. Cal Clark makes the turn at John Bryan. 6. After the meet Craig Colas relaxes. 7. Kirk Keller and Cal Clark listen carefully to the instructions of Coach King.

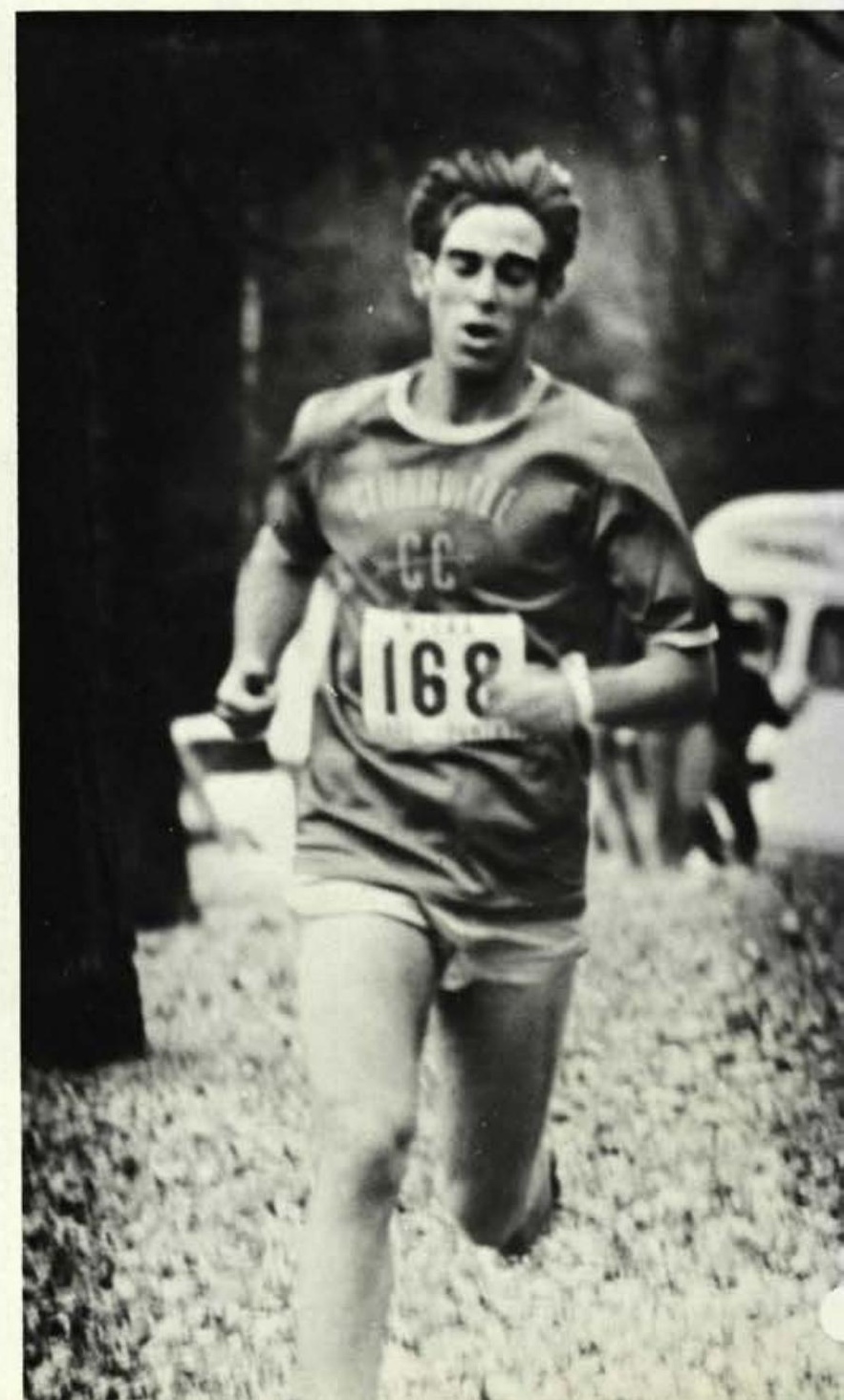



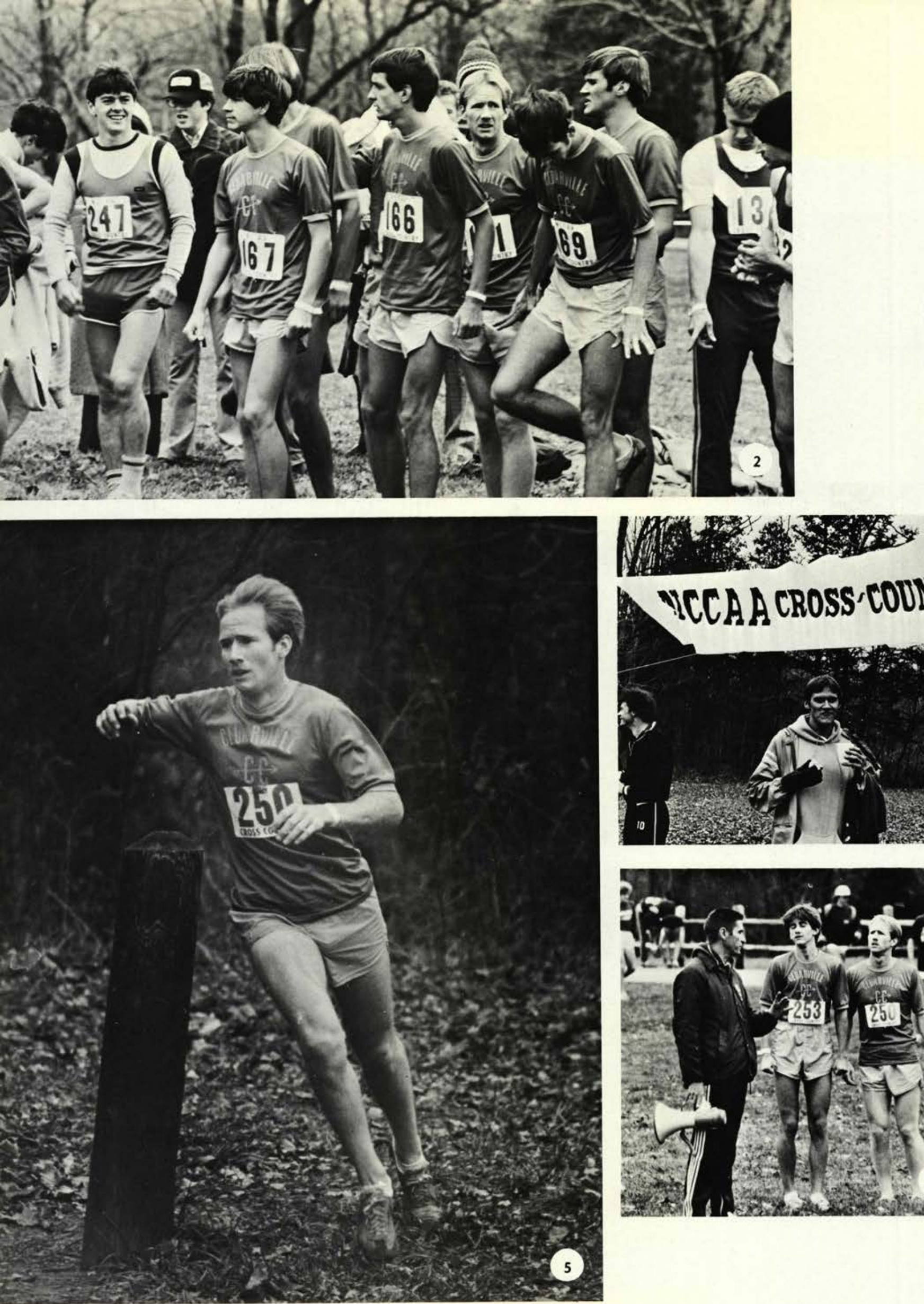

TCCAACROSS' COUNTRY 19

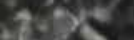

wers
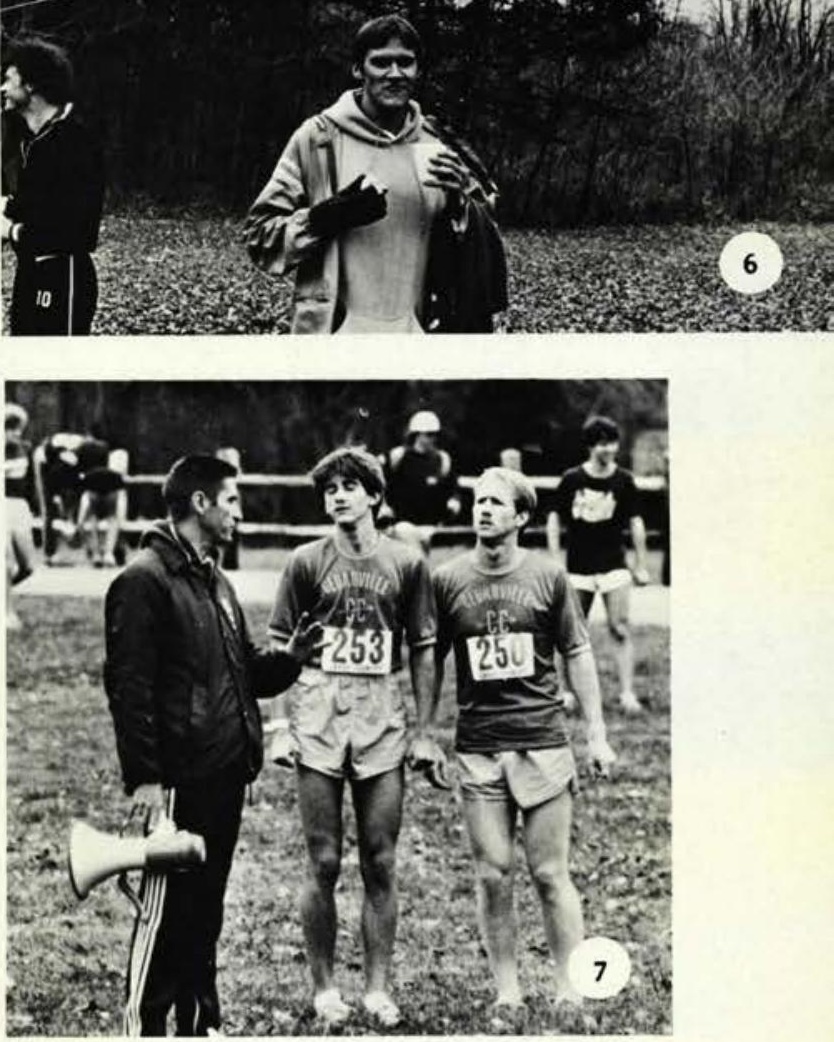

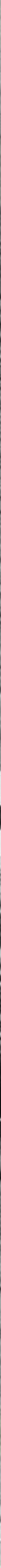

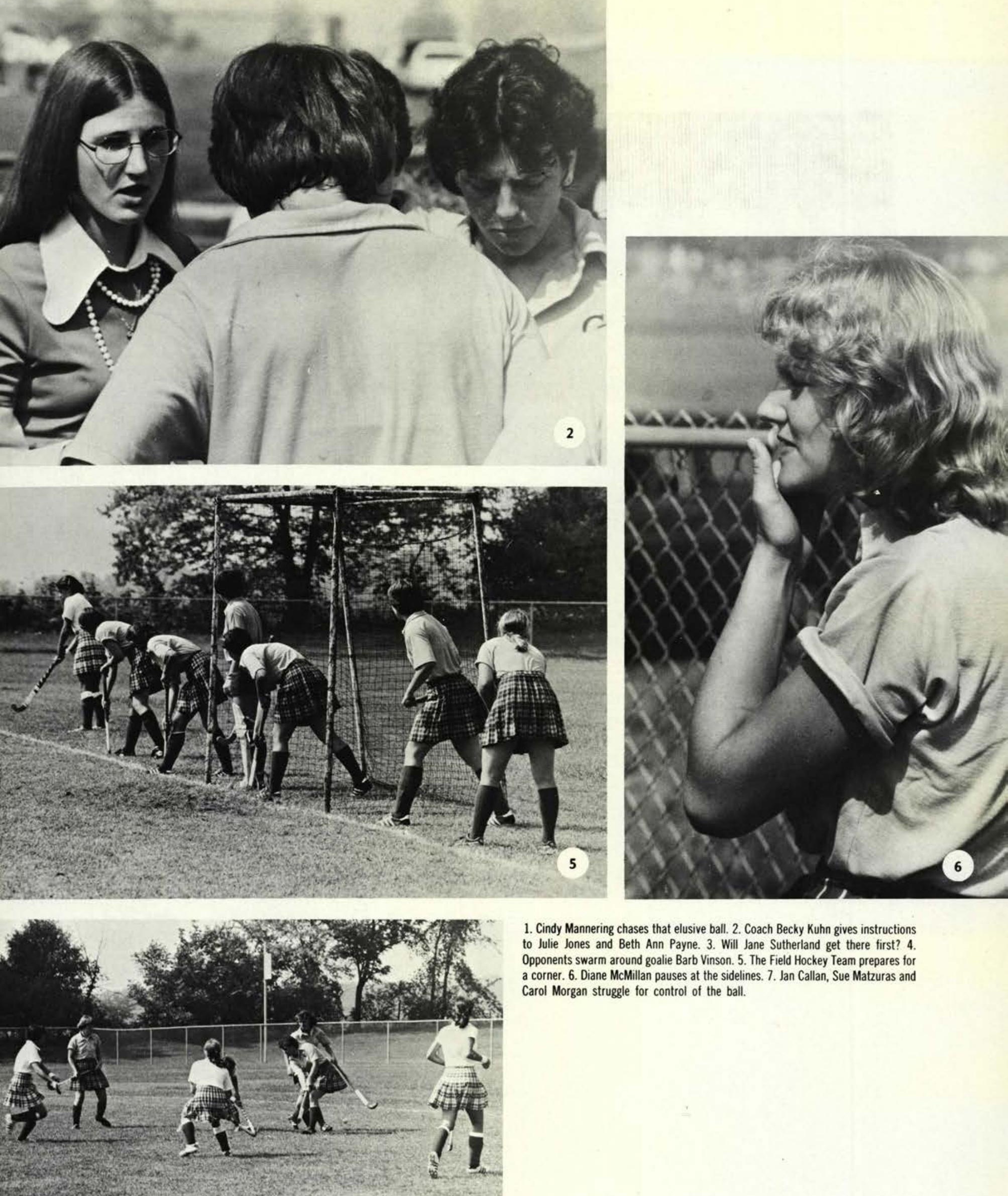

1. Cindy Mannering chases that elusive ball. 2. Coach Becky Kuhn gives instructions to Julie Jones and Beth Ann Payne. 3. Will Jane Sutherland get there first? 4. Opponents swarm around goalie Barb Vinson. 5. The Field Hockey Team prepares for a corner. 6. Diane McMillan pauses at the sidelines. 7. Jan Callan, Sue Matzuras and Carol Morgan struggle for control of the ball. 


\section{Field Hockey}

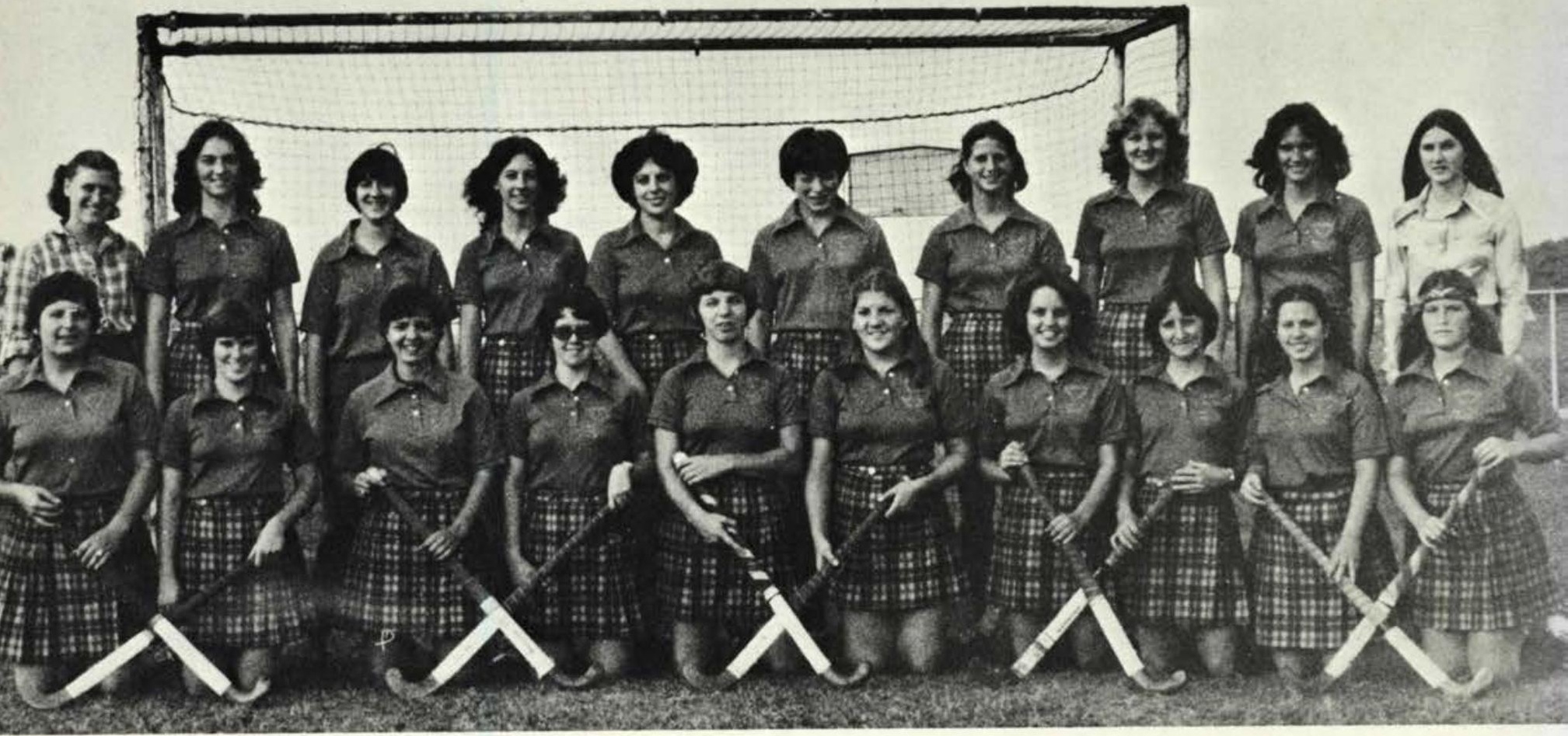

The Field Hockey Team finished with a record of 2-7-1, an improvement over last year's record. According to Coach Becky Kuhn, the team built on the foundation laid last year and improved immensely as a result of their willingness to work hard. The goal of the team was "total release performance." This goal of giving $100 \%$ at all times was demonstrated by the continuous improvement in the team. Their last game was their best performance because they never gave up, even in the 4-1 loss to a strong Ashland College team. If this attitude continues next year, the team will exhibit even greater development.

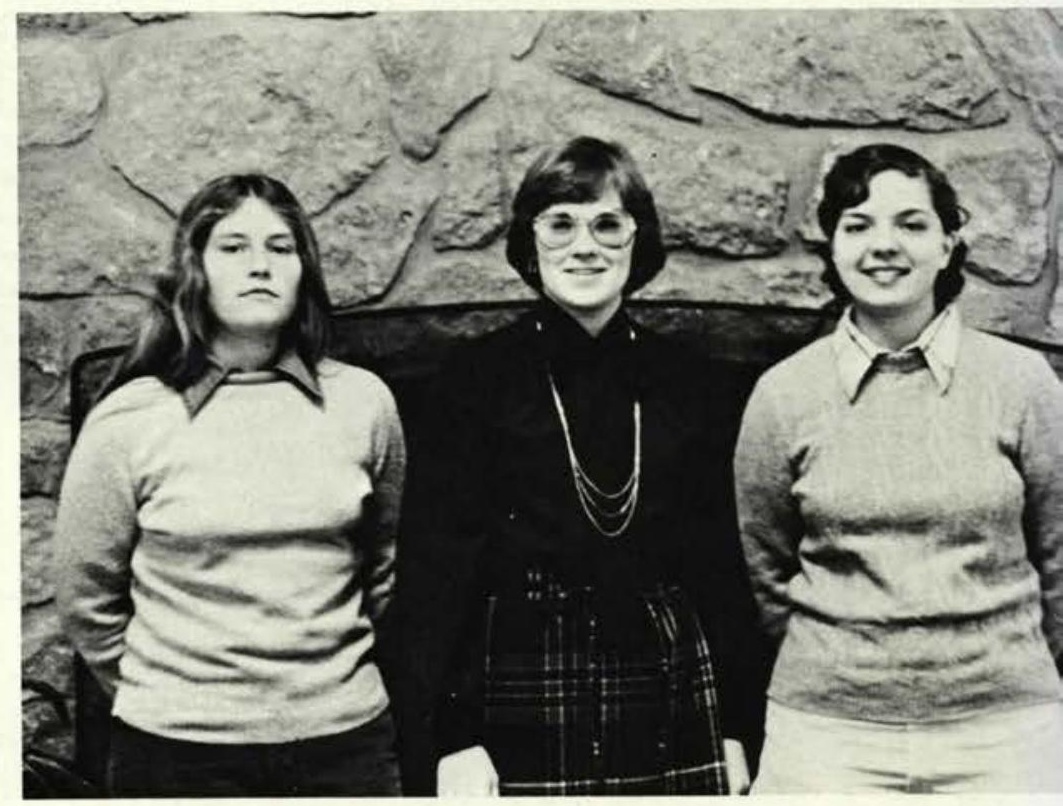

TOP PHOTO

Left to right, front row: Patty Mullican, Jan Callan, Sue Matzuras, Donna McHugh, Sue Howard, Jane Sutherland, Carol Morgan, Carol Stoltzfus, Jennifer Vigueres, Terri Aiken. Second row: Pat Turner Manager/Trainer, Cindy Mannering, Barb Vinson, Diane Reese, Beth Ann Payne, Julie Jones, Debbie Kearsley, Diane McMillan, Judy Basye, Becky Kuhn - Coach.

BOTTOM PHOTO

Left to right: Terri Aiken - Most Improved; Jan Callan - Captain; Sue Matzuras - Best Defense; Missing - Deb Kearsley - Captain, Most Goals Scored; Barb Vinson - Most Valuable. 


\section{Volleyball}

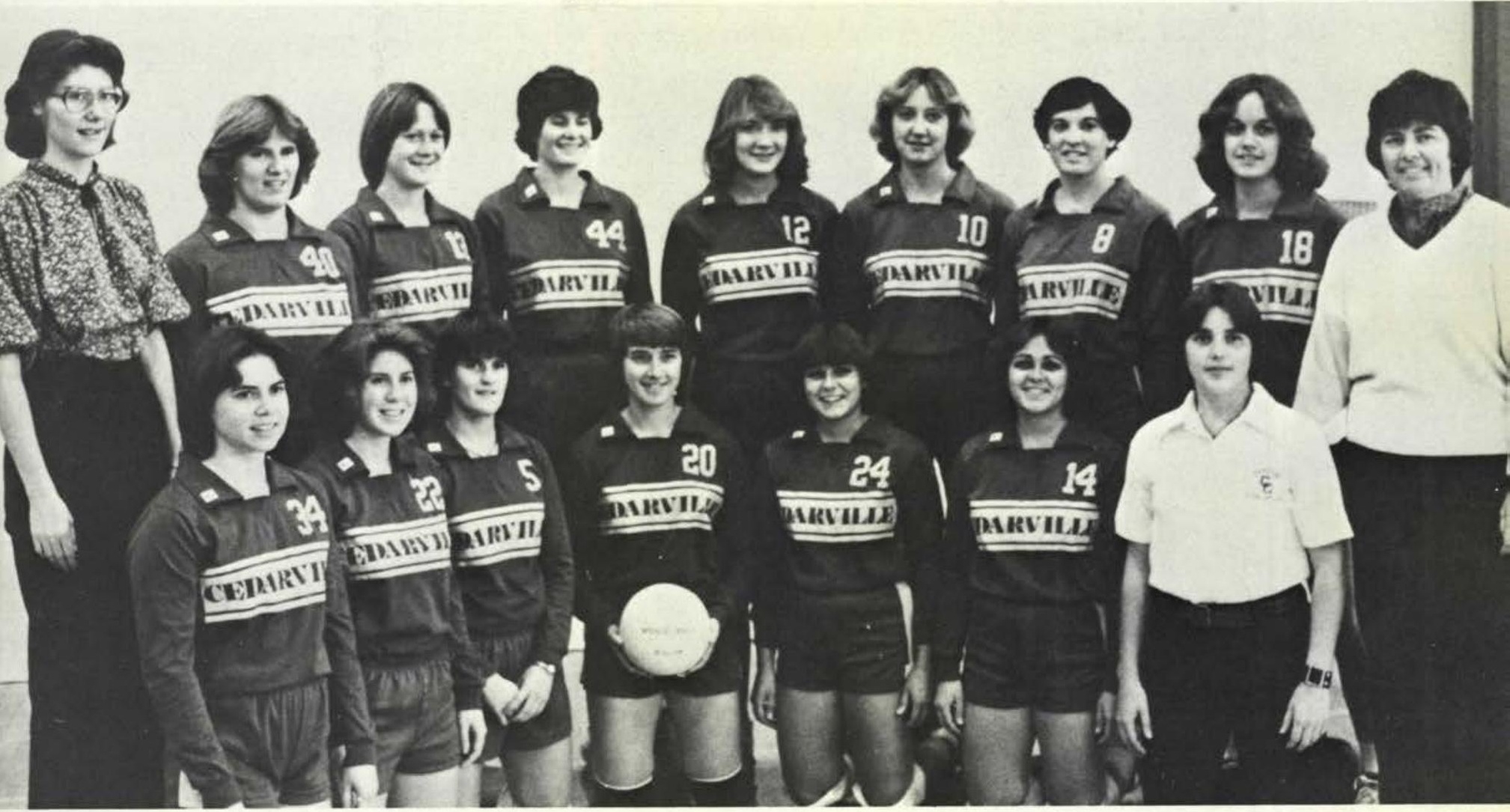

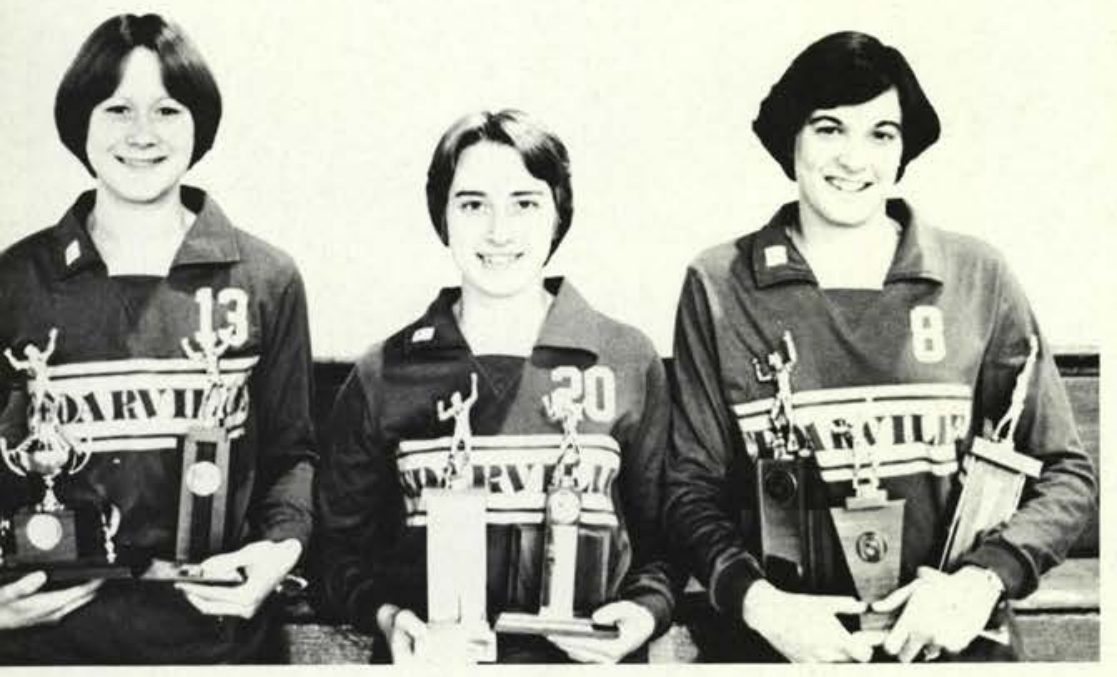

TOP PHOTO

Front row, left to right: Kathy Turner, Jennifer Knecht, Lori Franklin, Susie Riegle, Darcy Morton, Marcy Morton, Sue Kulp (trainer). Standing, left to right: Karen Lapp (manager), Marcy Greening, Sue Palmer, Debbie Fakan, Jill Griswold, Joan Schmitt, Brenda Hobar, Bonnie Beikert, Dr. Kearney (coach). Not pictured: Mary Stuenzi (trainer).

\section{BOTTOM PHOTO}

Sue Palmer, Most Improved Player, Most Valuable Setter; Sue Riegel, Best Serving Percentage; Brenda Hobar, Most Valuable Blocker, Most Valuable Hitter, Most Valuable Player.
The Volleyball Team was once again coached by Dr. June Kearney, finishing the season with an impressive conference record of $14-5$ and a good overall record of 22-15. The team produced exciting play as indicated by spectator enthusiasm. One of the most exciting and rewarding moments was winning the OAISW SatelliteWest Tournament held at Cedarville College. 

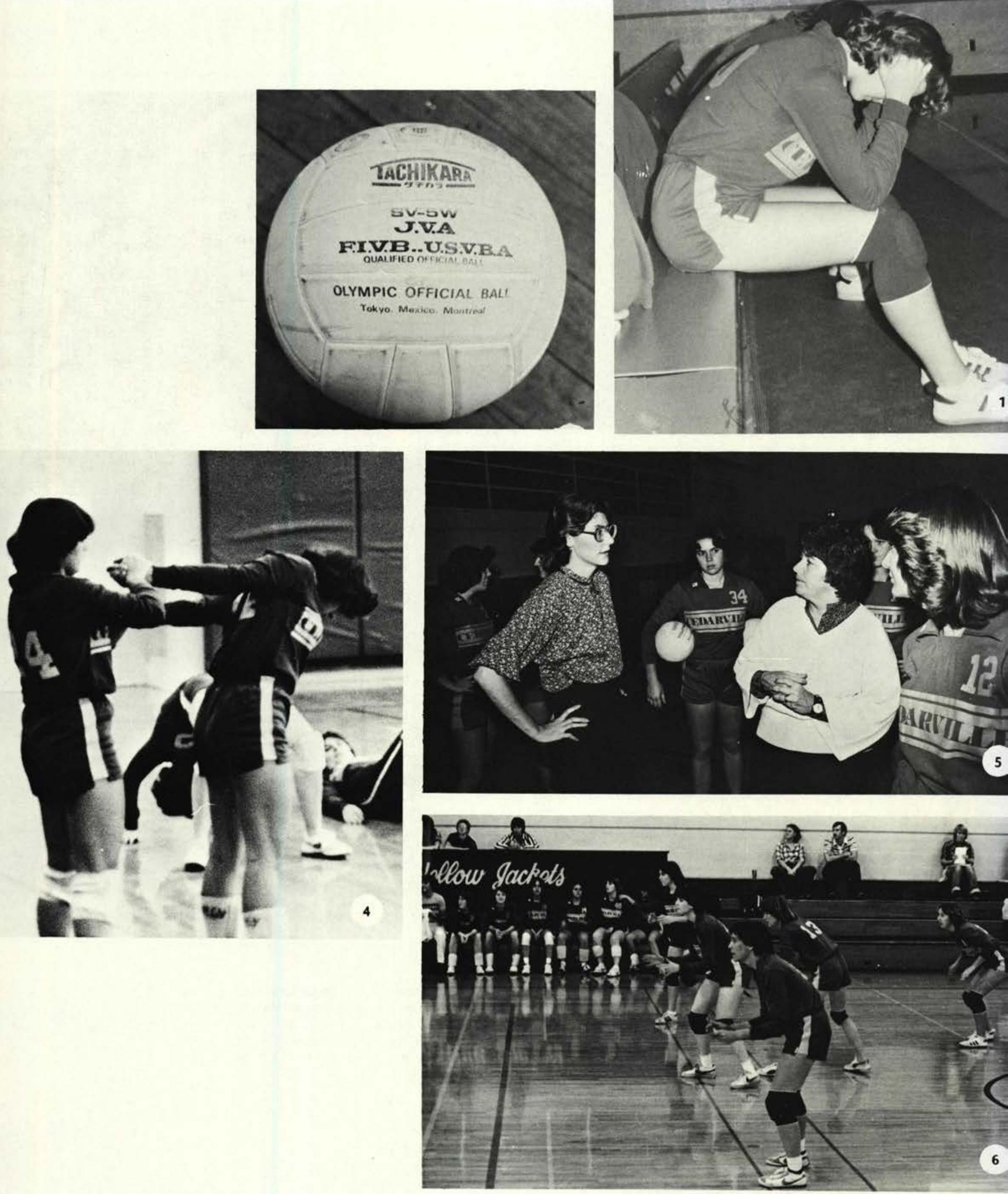


\section{Cedar County Fair}

October 5 was a time to get to know each other better. Student Activities, under the direction of Myron Youngman, sponsored the Cedar County Fair. The fair began with an outdoor barbecue. The different clubs and student organizations ran game booths in an attempt to better acquaint the student body with the activities and purposes of each group. Many professors participated as targets of games or as workers at concession stands. Students competed for points at the different booths. The two P.A.'s and their units who collected the highest number of points by the end of the fair were treated to a dinner at Jed's.

1. The Dean of Men is ready to meet his fate at the dunking game. 2. Mark Skyles and Bob Smith demonstrate their skill at chess. 3. Dean Rickard prepares to take the plunge. 4. Booths begin to go up for the fair. 5 . Everyone enjoys a paddle boat contest unless they get wet. 6 . Students could "settle their differences" at the MENC game. 7. Jan Anderson and Marla Eissens provide musical entertainment at the fair.
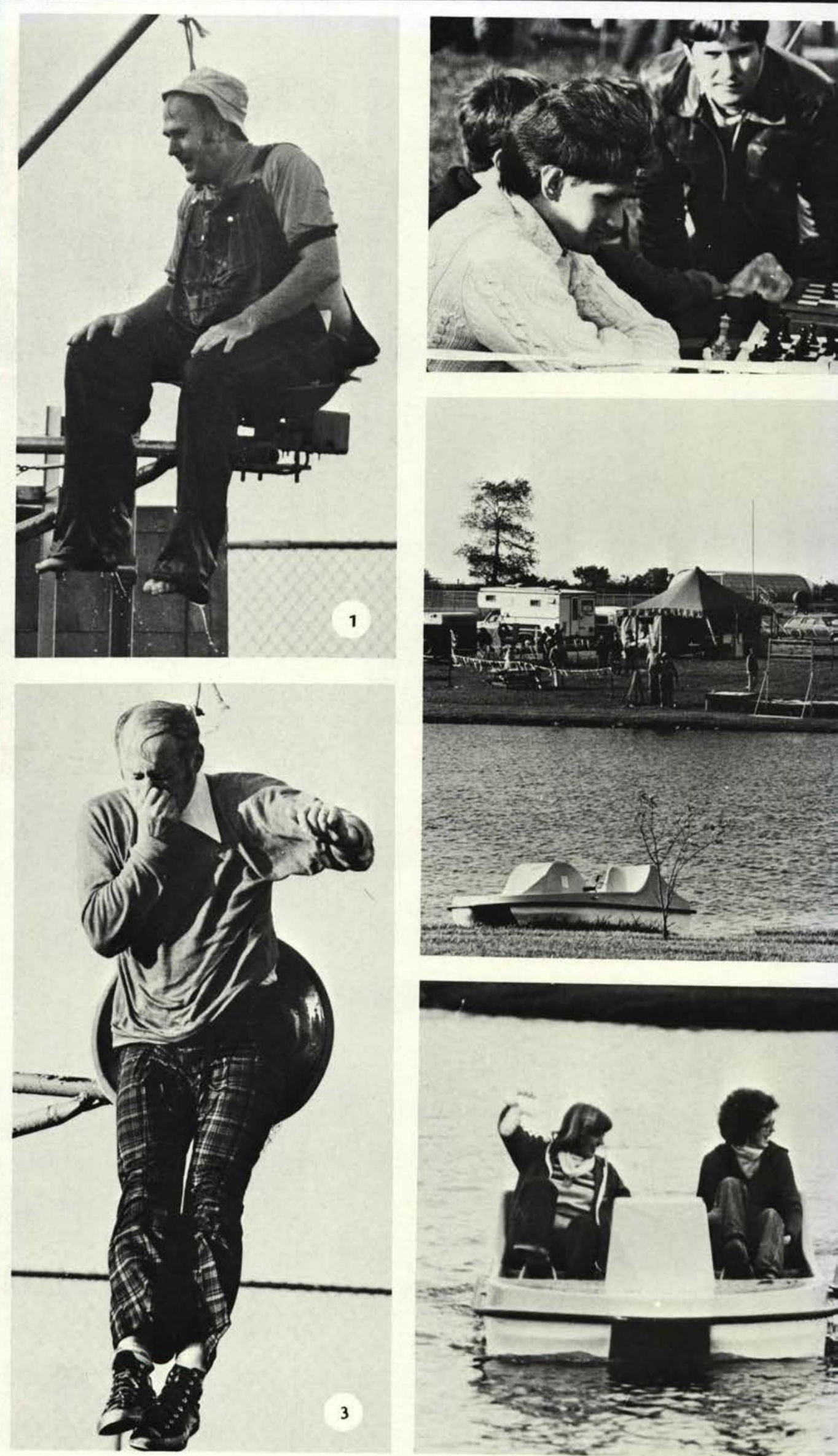


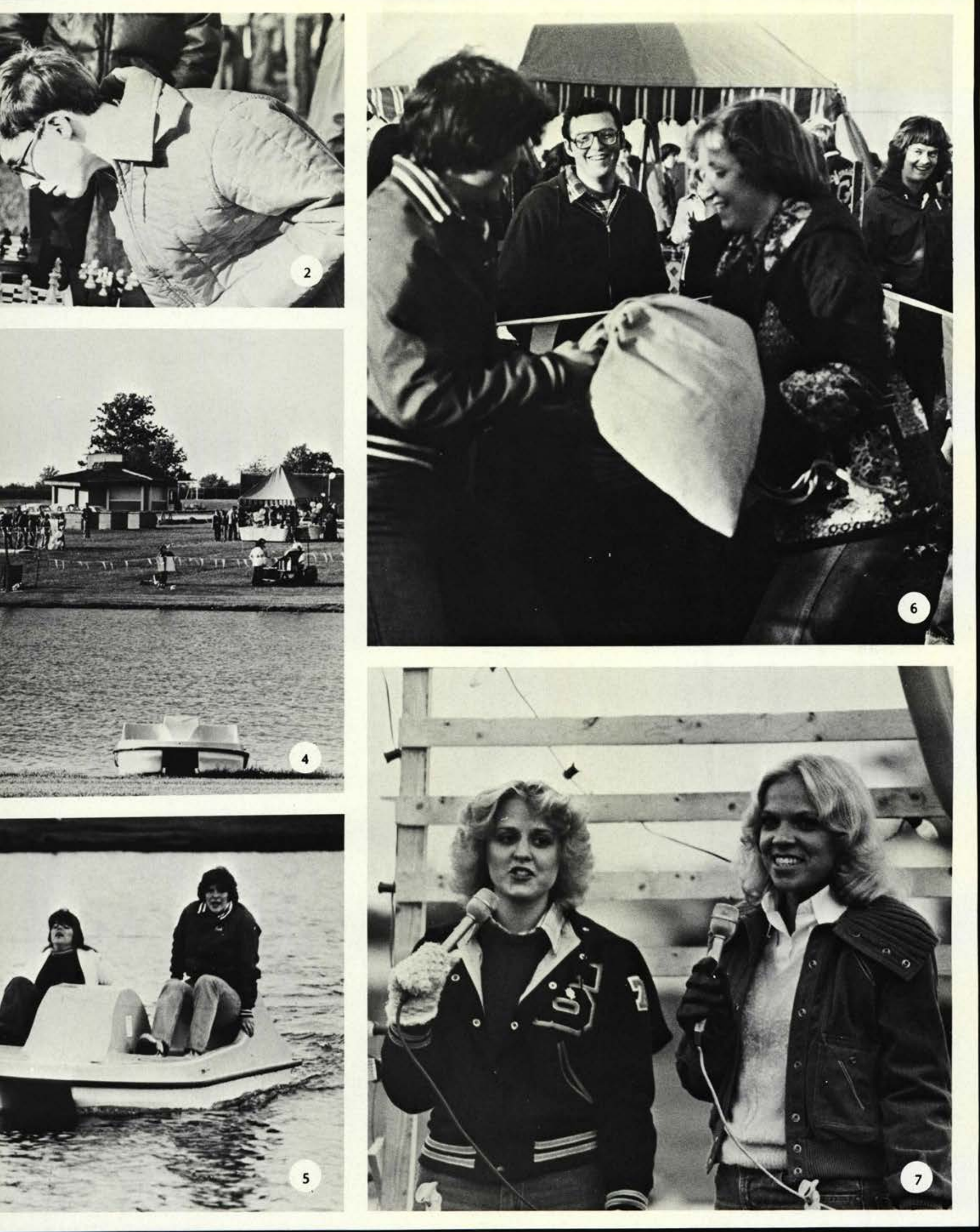



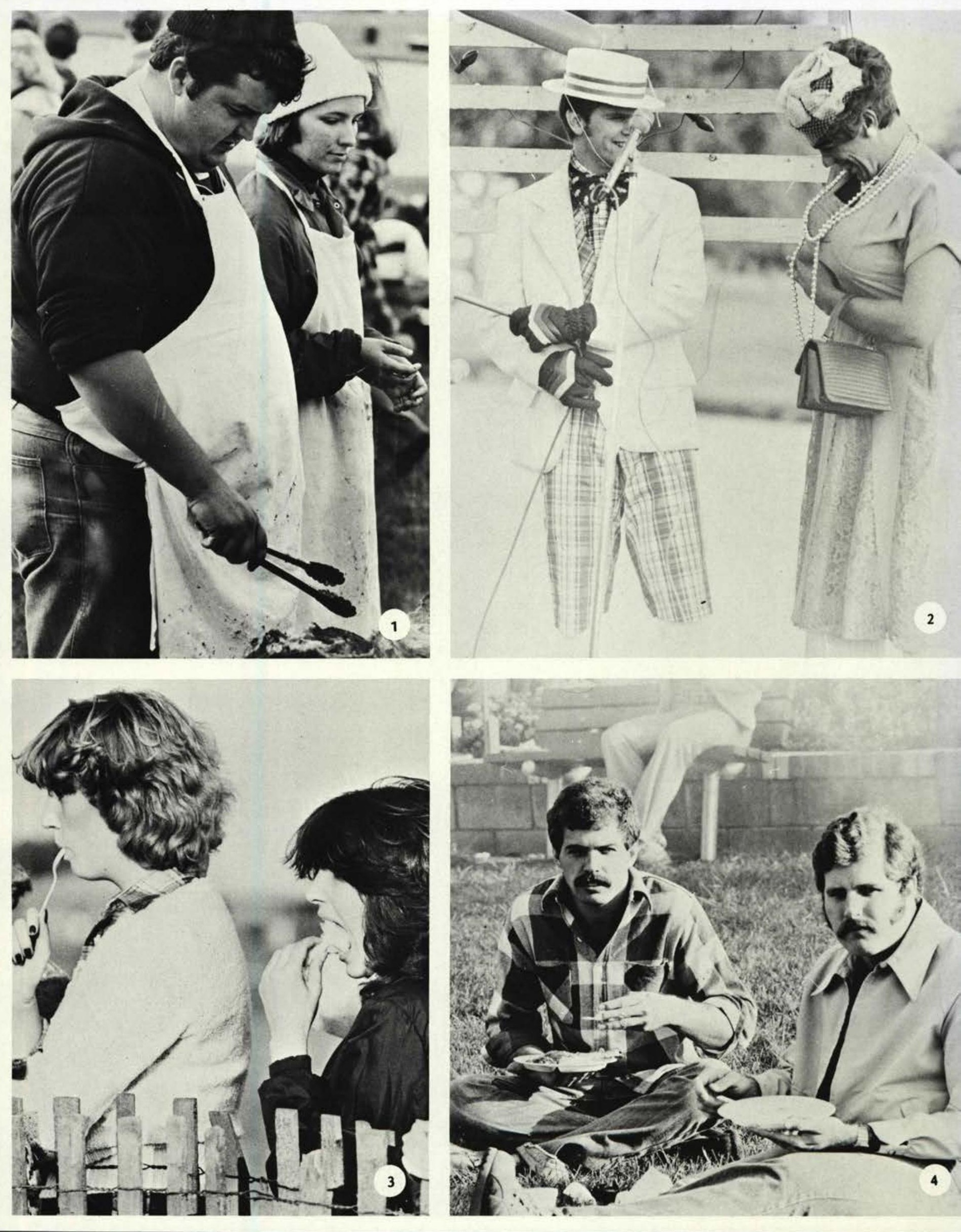


\section{People}

1. An open Gym Night turns out to be a time of fun and relaxation for all. 2. Trudy Tangblade and Lisa Ramsey perform a skit for the Alpha Chi Banquet. 3. Eating dinner outside is an occasional event at Cedarville. 4. Two "living dolls" enjoy the Homecoming Parade. 5. They always do this when girls walk by! 6 . Three loyal fans show their support for their team. 7. The bleachers are packed again for another exciting basketball game.

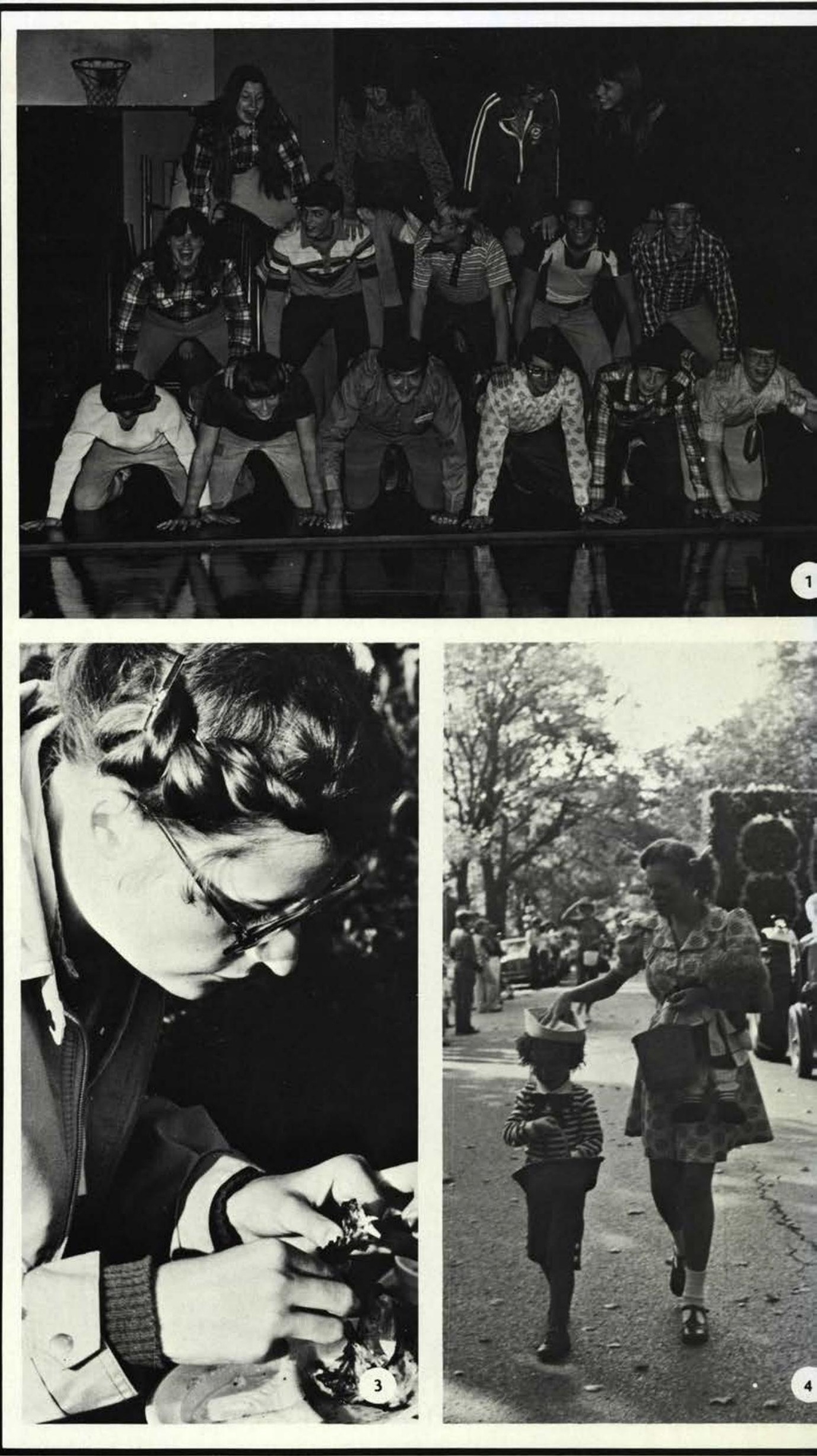




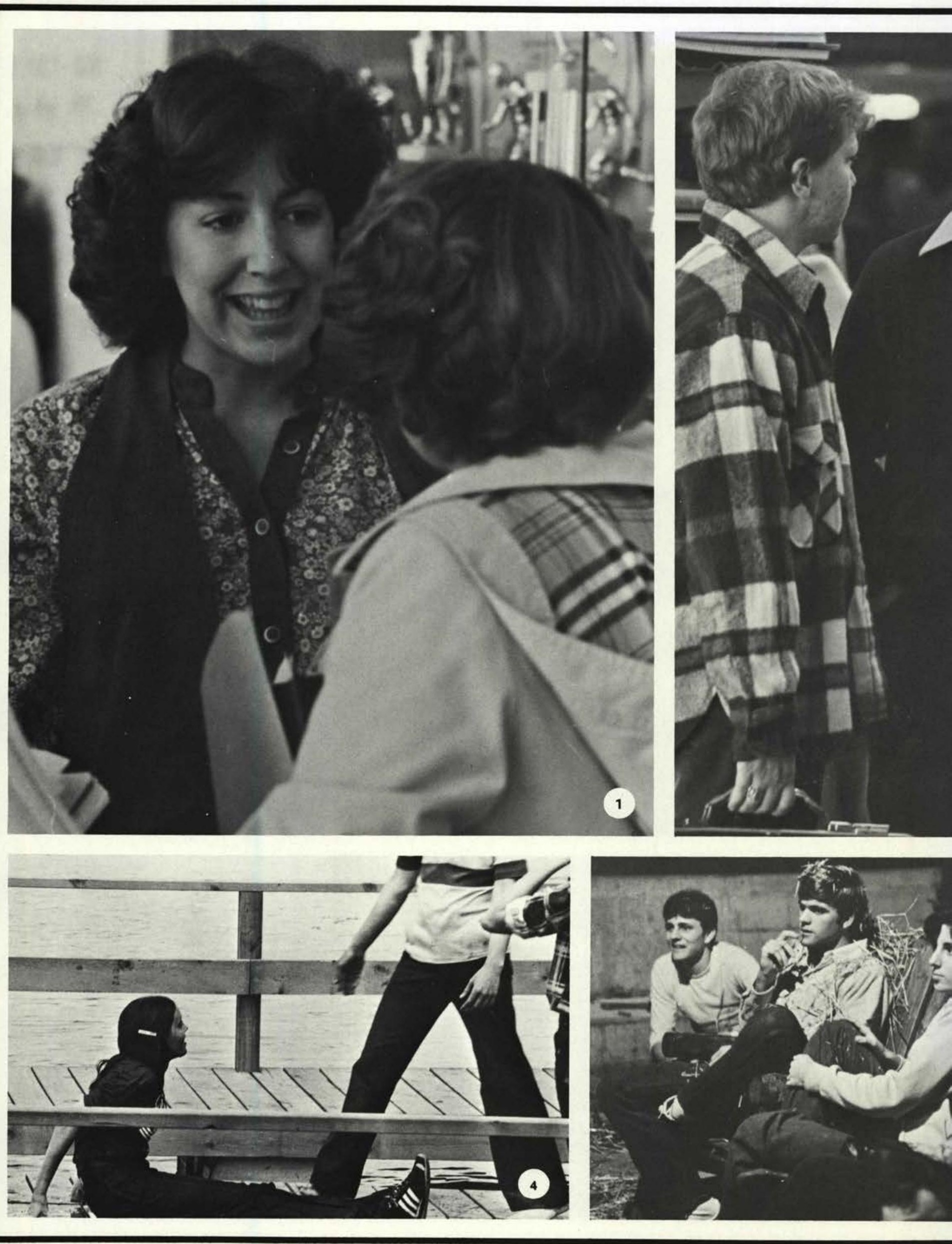




\section{Friends}

When students come to school, they do not have too many friends there; they have left all of their friends at home. During the first weeks there are many names to figure out; but soon names are remembered and friendships become established. For the majority, old acquaintances are renewed and new friends are also accumulated.

1. Betty Lewis and Letty Walker exchange some news while changing classes. 2. A conterence among friends: Tim Hoganson, Fritz Huber, and Ellen Jenson. 3. Of course, some find a special friend. 4. "With friends like you, who needs enemies?" 5 . It seems Roger Michel has some "friends" too. 6. Kim Turner subtly informs

Cindy Jacobs her phone call stinks.

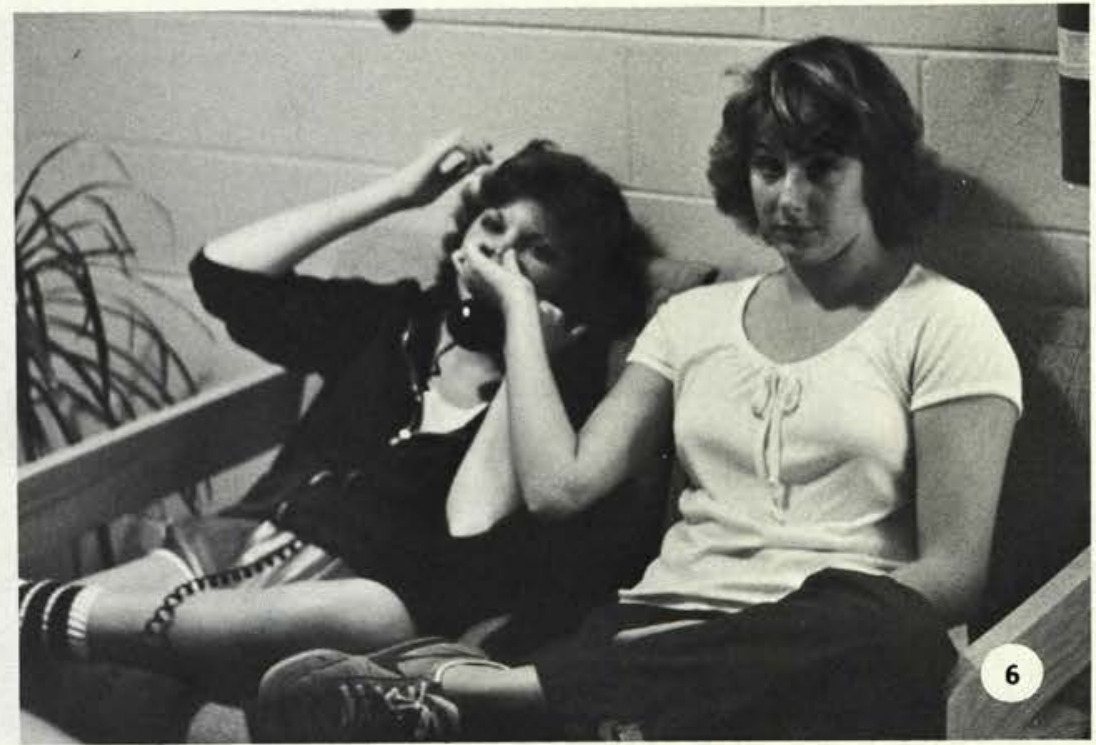




\section{Christmas 1979}

As Fall quarter comes to an end, students prepare for the Christmas Holidays. A scurry of activity takes place as the dorm rooms are polished and decorated for the co-ed open houses. The pressures of finals are lessened as the college considers this joyous event.

1. The sing-along was a special time of fellow ship for those in attendance.

2. During open house, roommates Ruth Hurlburt and Linda Grafton prepare a feast for their guests.

3. Do you suppose Santa is headed for Lawlor?

4. The Printy Hall girls know what to do at their Christmas party.

5. Christal Marihugh and Jeff Bartling enjoy a private joke.

6. Everyone was lined up, waiting for the Christmas visitors.

7. The thought of Christmas brings smiles to the faces of Patterson girls.

8. The thought of being number one brings smiles to the faces of the members of Carr Four.
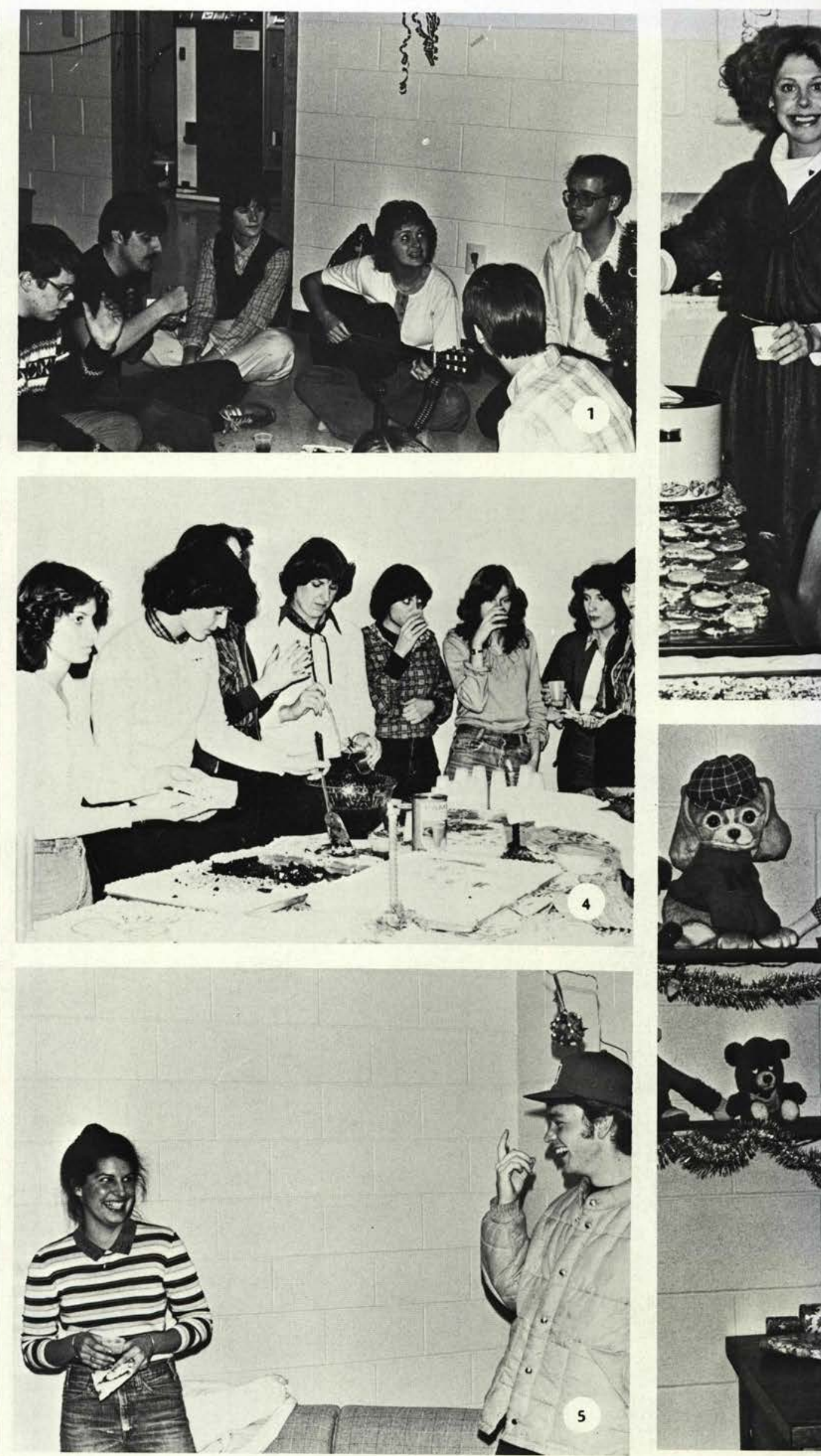


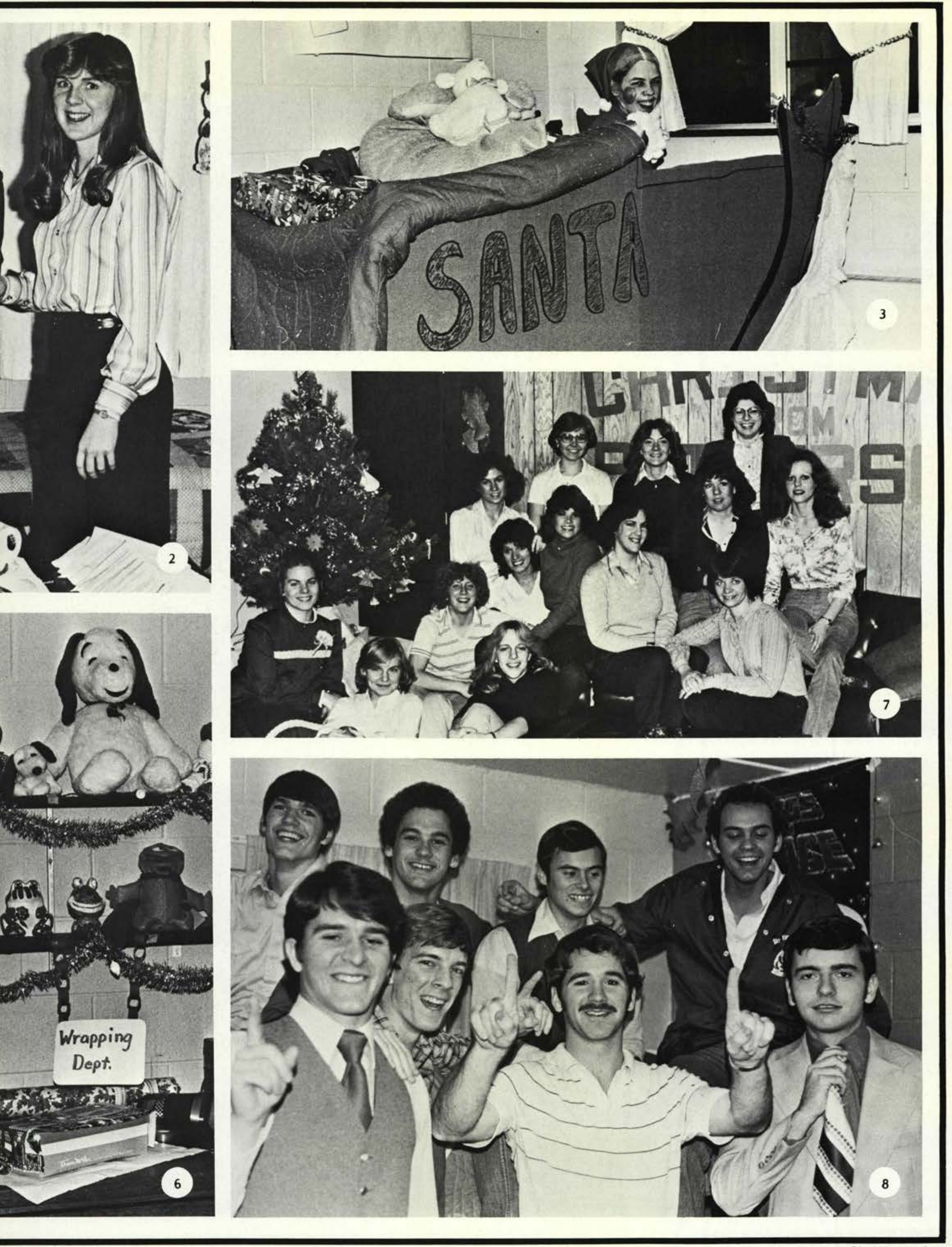

Christmas/45 


\section{Winter Friends}

In the routine of a cold winter's day at Cedarville College the students can look forward to a great lunch. Students enjoy the time of fellowship around the table; many are the hours spent there. Truly it is something for which to be thankful as a break from the studies in order to laugh and have a fun time with those friends with whom we live, laugh and cry. Friends have shared many thoughts and problems around the good old lunch table. Proverbs 17:17 states that "a friend loveth at all times". The Lord has richly blessed the student body with blessed friendships.

1. Tammy King takes student I.D. numbers. 2. Kenny Gaines enjoys his tomato soup. 3 Joni Webber and Ray Miller - "Get every drop!" 4. Carl Ruby is having another cup of coffee, as part of his daily routine. 5. Clay. ton Beck and Angela Bowers are sharing an intense conversation. 6 . Eat every bite, Valerie Dell. 7. Oh those lovely lunch lines! 8. Hey! Don't take my food. 9. Randy Wilcox and Don Pippin get ready to take their seats. 10. Cheryl Coates thinks that was just great. 11. Vinnie Jaquery and Josias enjoy a time of fellowship. 12. Several turn out for an early morning breakfast at the 'ville.
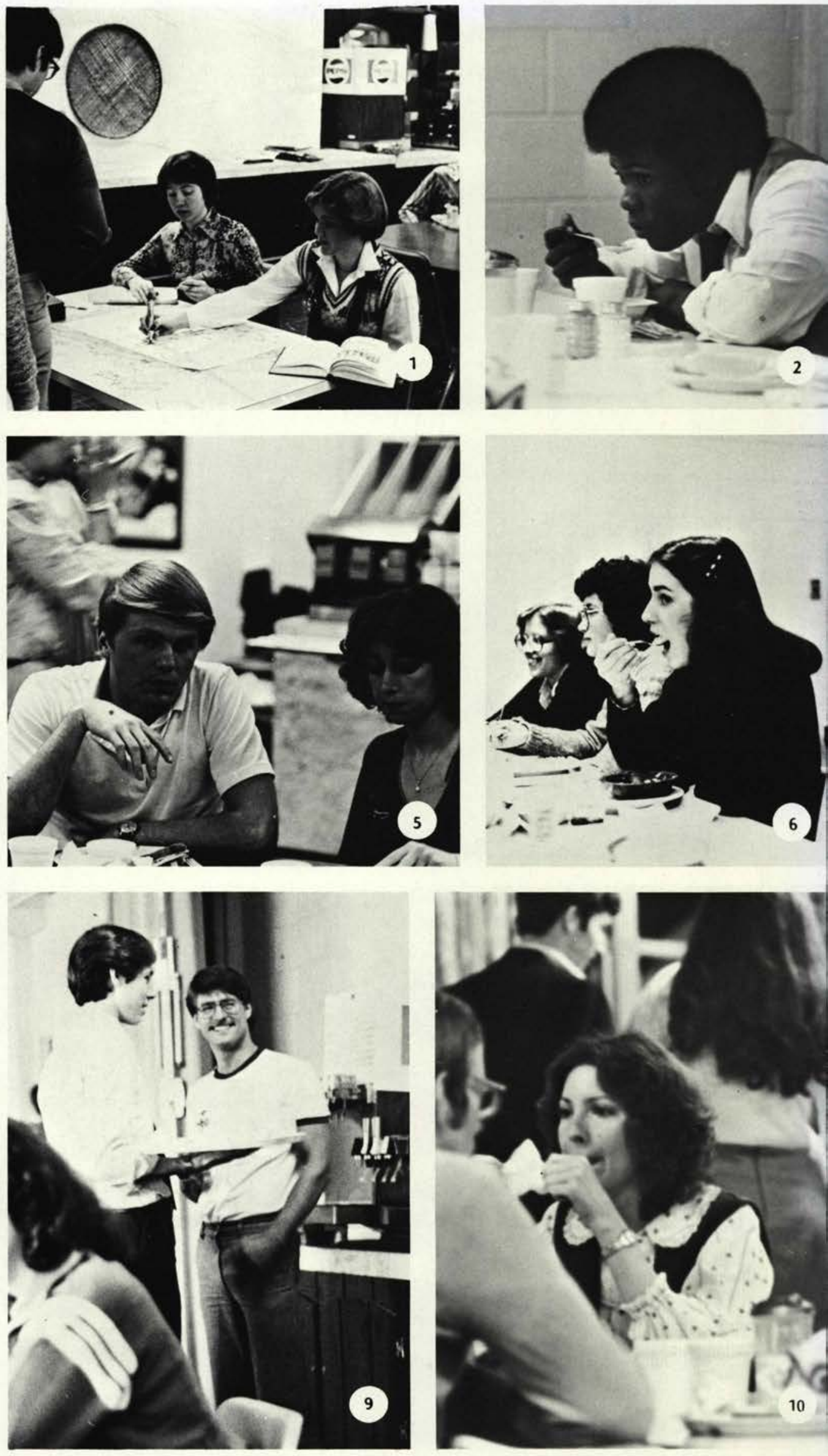


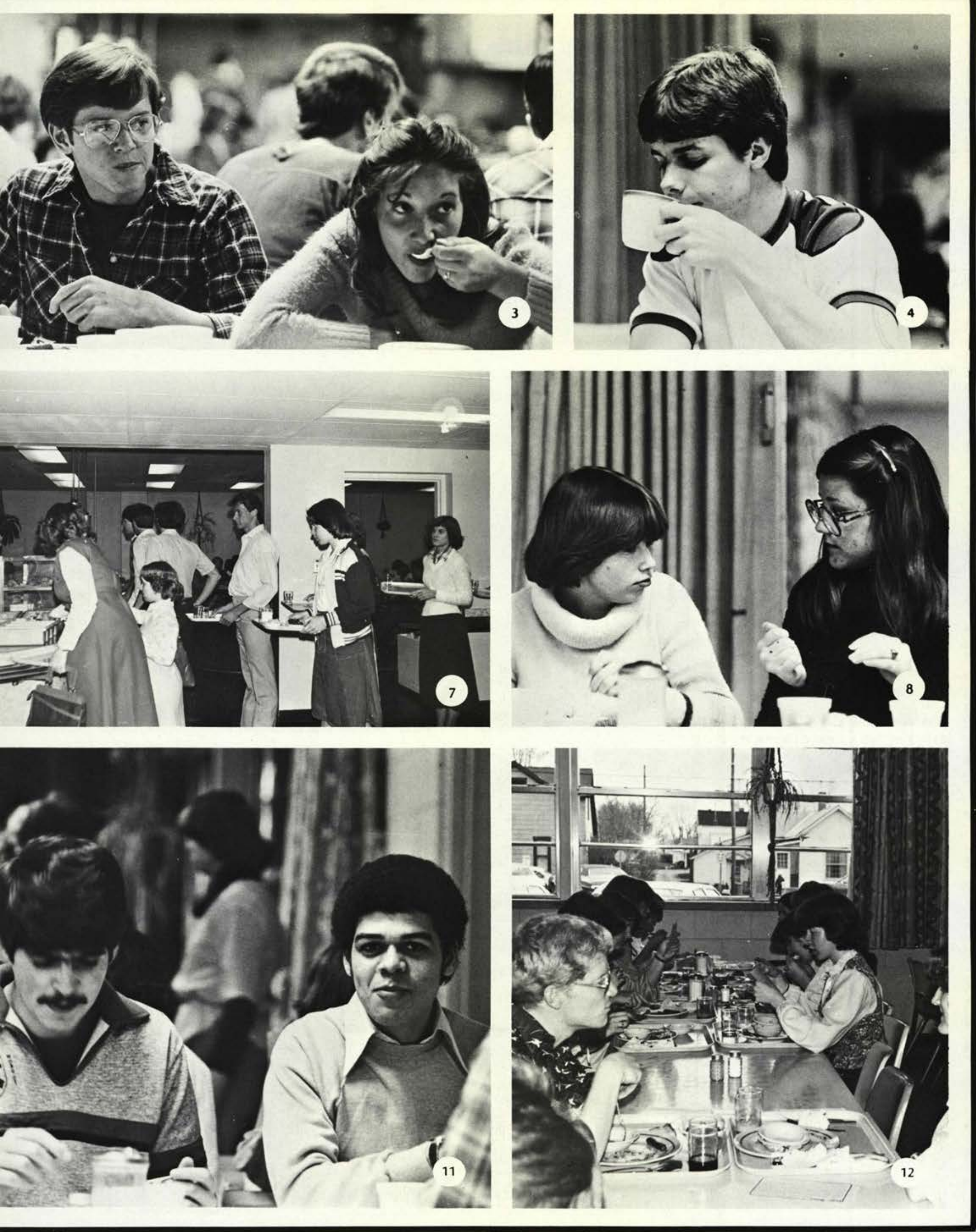



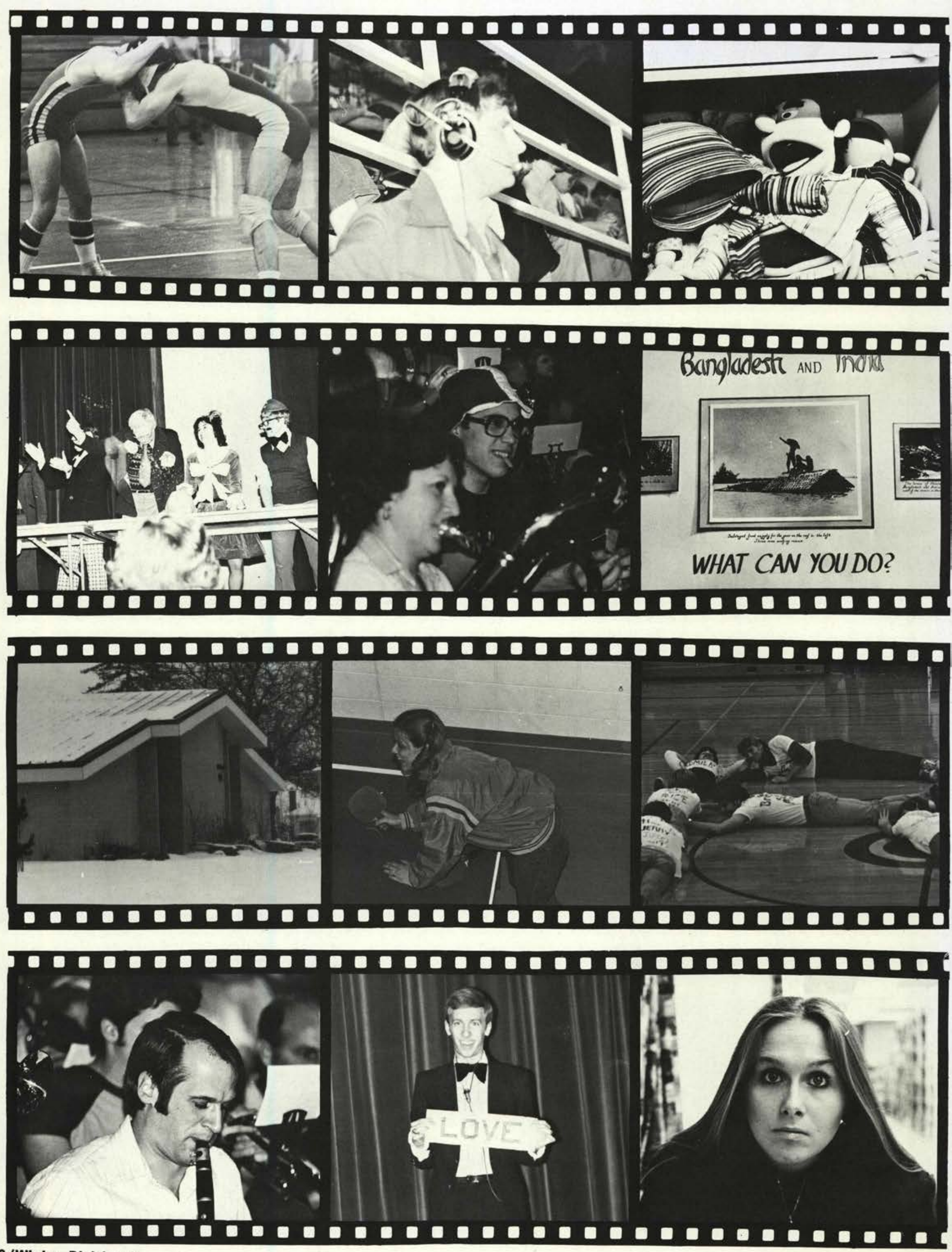


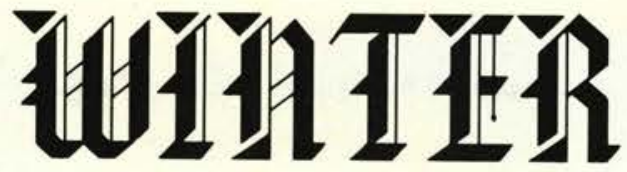

00000000000000000000000000000000000000
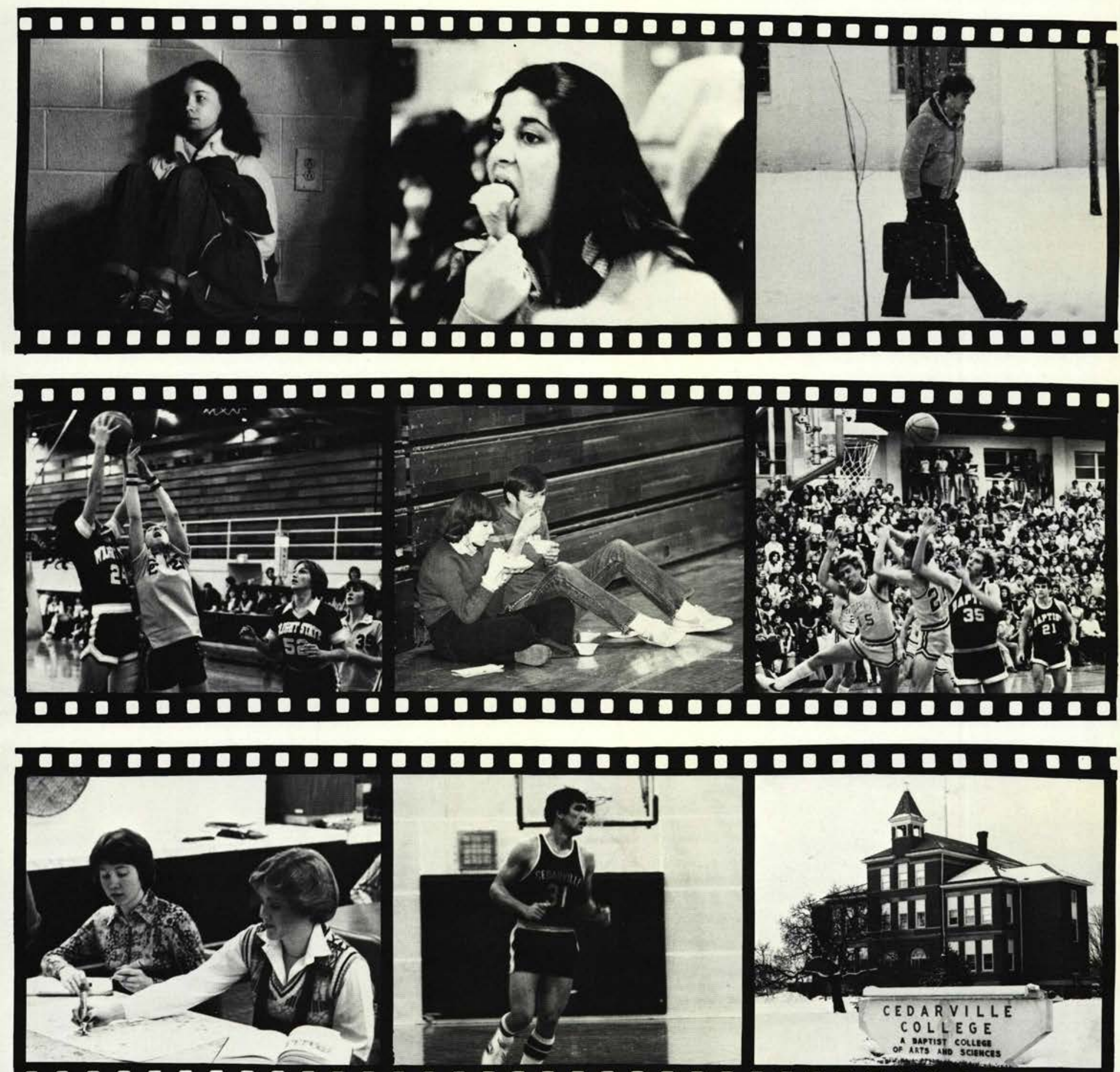

000000000000000000000000000000000001 


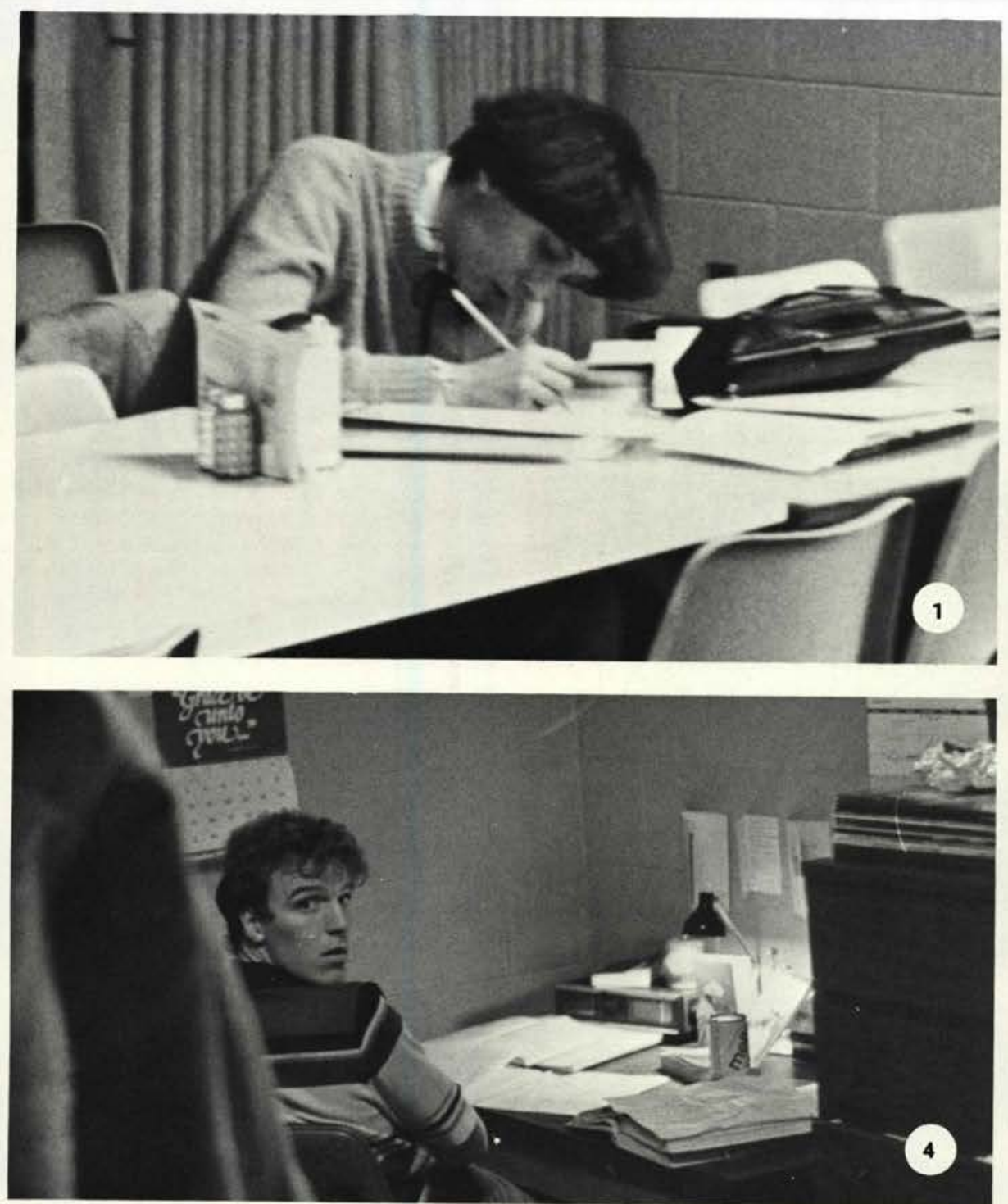

SUBJECT

AUTHOR-TI

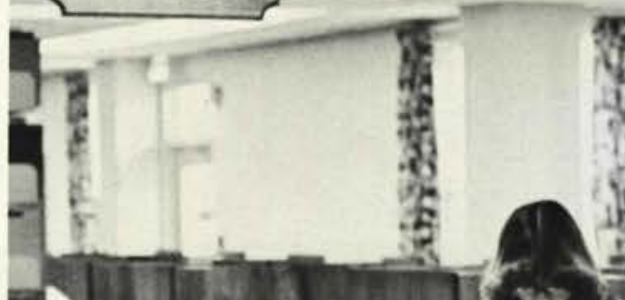

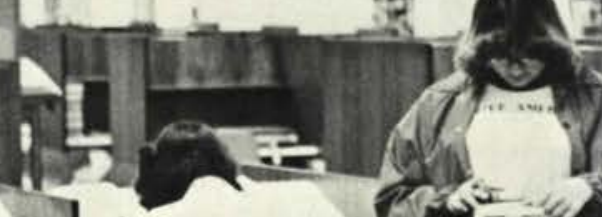

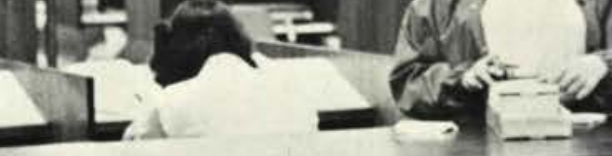

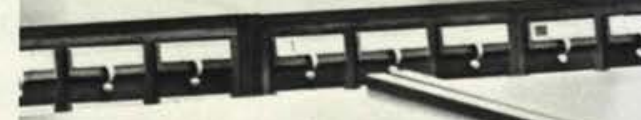

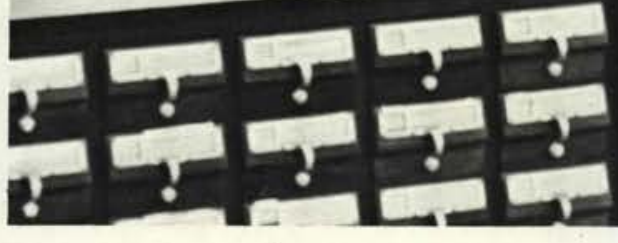

rnt

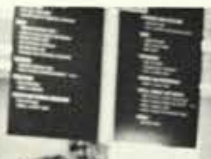

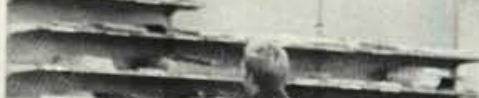

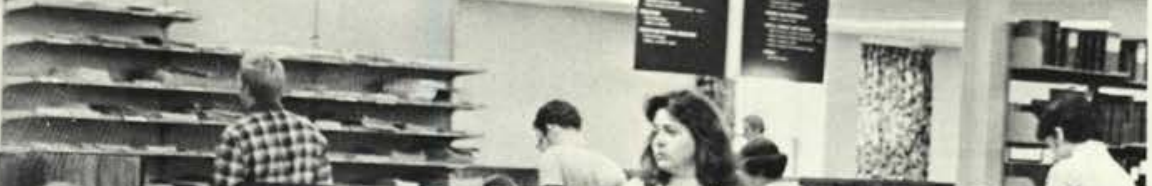

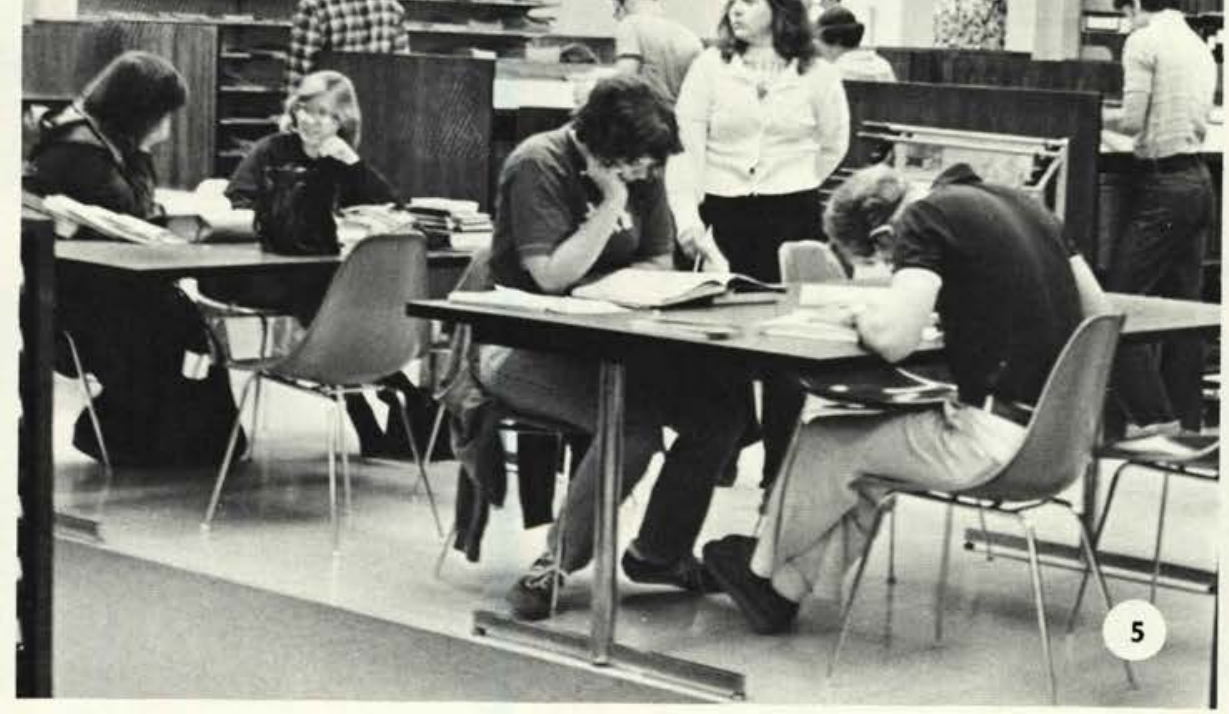

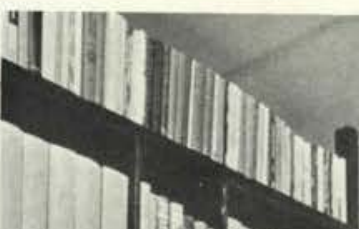

(1)
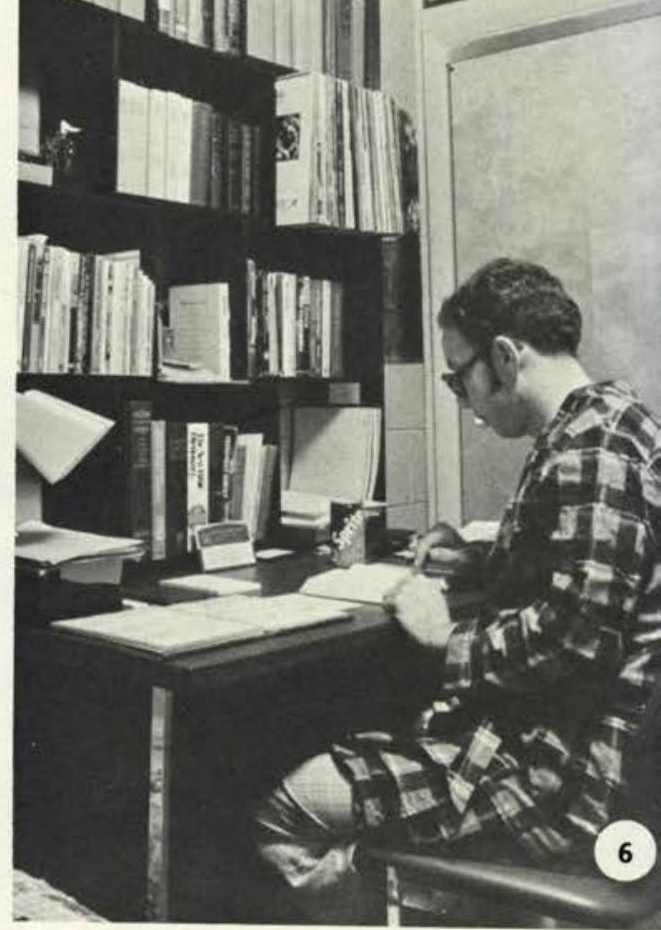

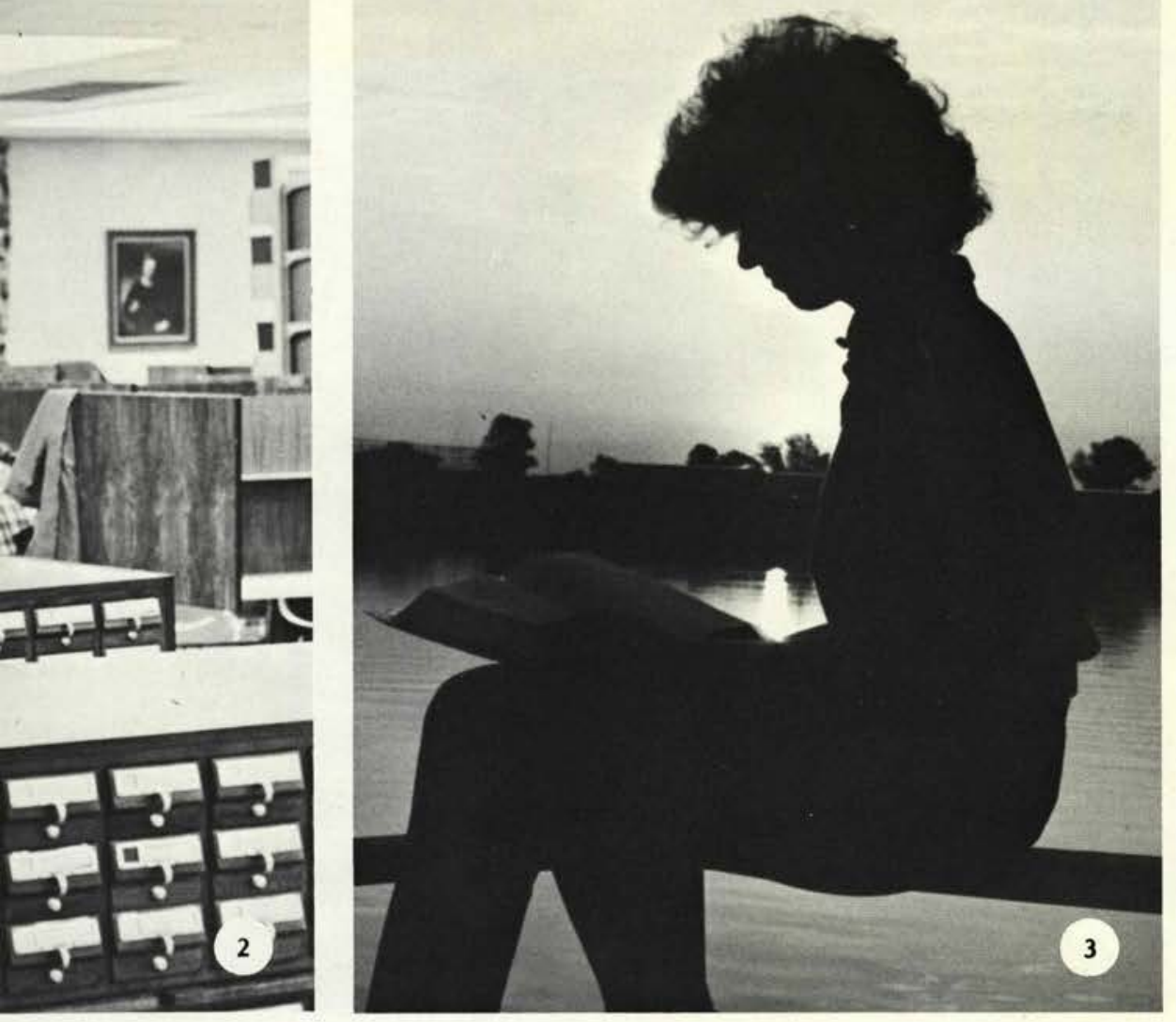

\section{Studying}

The primary purpose of most students in college is to get a degree. Unfortunately for most, that means studying. For some, studying starts with finals, but the majority start at the beginning of each quarter. There are a variety of places and styles of studying, but hopefully, they get the job done.

1. Mary Wallace utilizes the snack shop for her study. 2. Research for term papers takes special knowledge of the library. 3. Studying by the lake attracts this student. 4. Kerry Weaver finds his room the most conducive place for study. 5 . The library gets pretty crowded around finals week. 6. Matt Vincent keeps his study area neat. 7. Dan Cawood puts in an extra five minutes before his final.

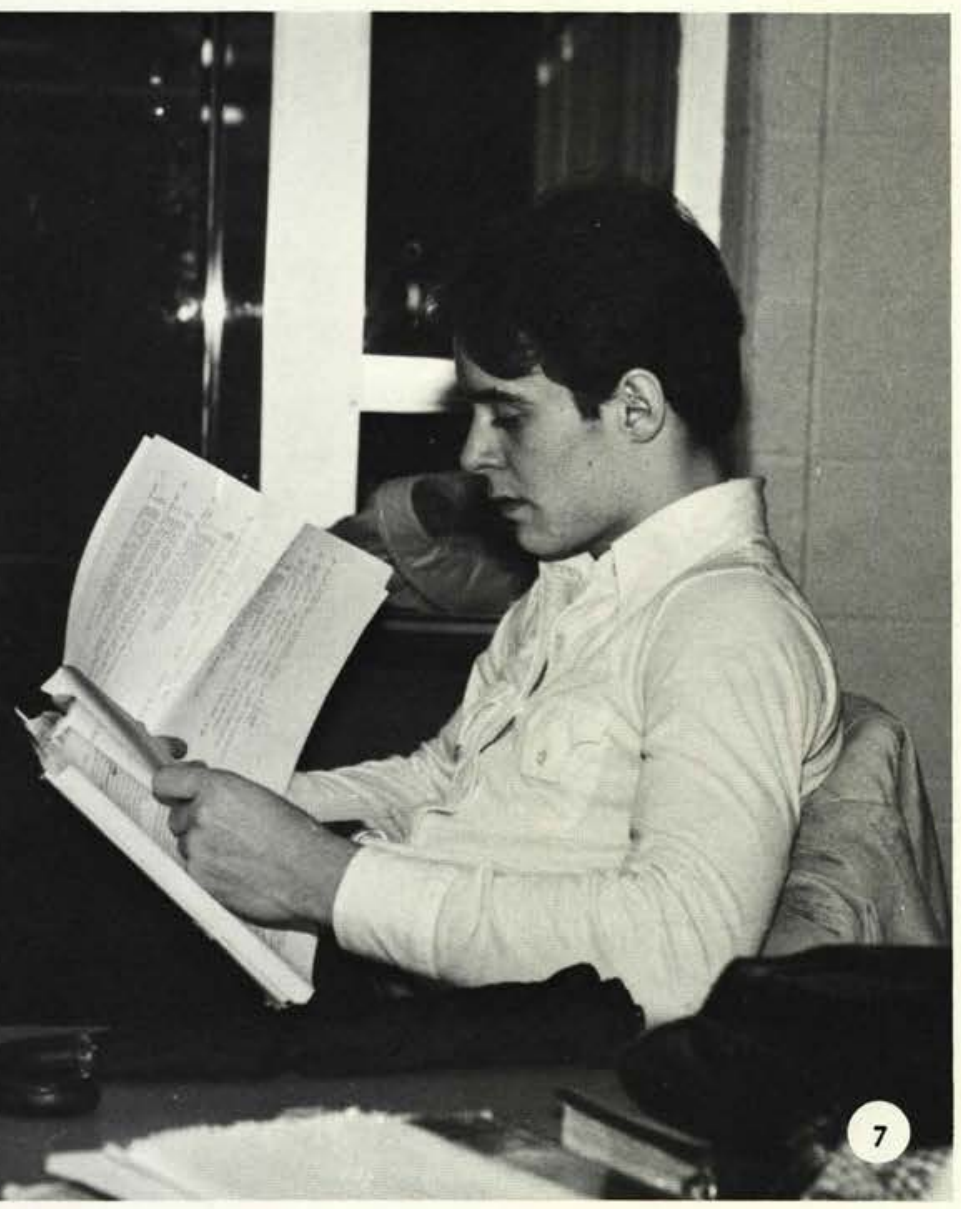




\section{AlI School \\ Birthday Party}

The All School Birthday Party was a time of fun and relaxation for all who attended. The idea of the Party was to celebrate everyone's birthday. Many games and activities were planned by Dana Treese. Among these activities were three legged races, mattress races, and sliding boards. The evening was further heightened by showing $\mathrm{col}$ lege level flicks such as Bugs Bunny, Little Rascals, and Three Stooges.

1. They are enjoying a skateboard built for six. 2. "Mmm, Mmm! Boy this ice cream and cake tastes good." 3. This is not a very comfortable way to sleep! 4. Practice swing. ing thoses legs together.

\section{Family Feud}

The Junior Class organized and directed the Family Feud, a spin off of the T.V. game show by the same name. The show was hosted by John Hart and Randy Harper, with the "Families" consisting of Faculty/Staff, Seniors/Juniors and Sophomores/Freshmen. Two rounds were played in each game, then the winners had a play-off for the grand prize. An all expense paid trip to Kings Island was awarded to the victorious Sophomore/Freshman family.

1. They are taking a Young's commercial break between the rounds. 2. Mrs. Dixon and Dr. Spencer are settling their differences. 3. The Snortenwippers try to cheer one another on. 4. The Faculty really takes this game seriously. 5 . As the tension builds the Staff Family finds it hard to control themselves. 6 . Here is a serious moment (the only one) provided by the underclass. man team.
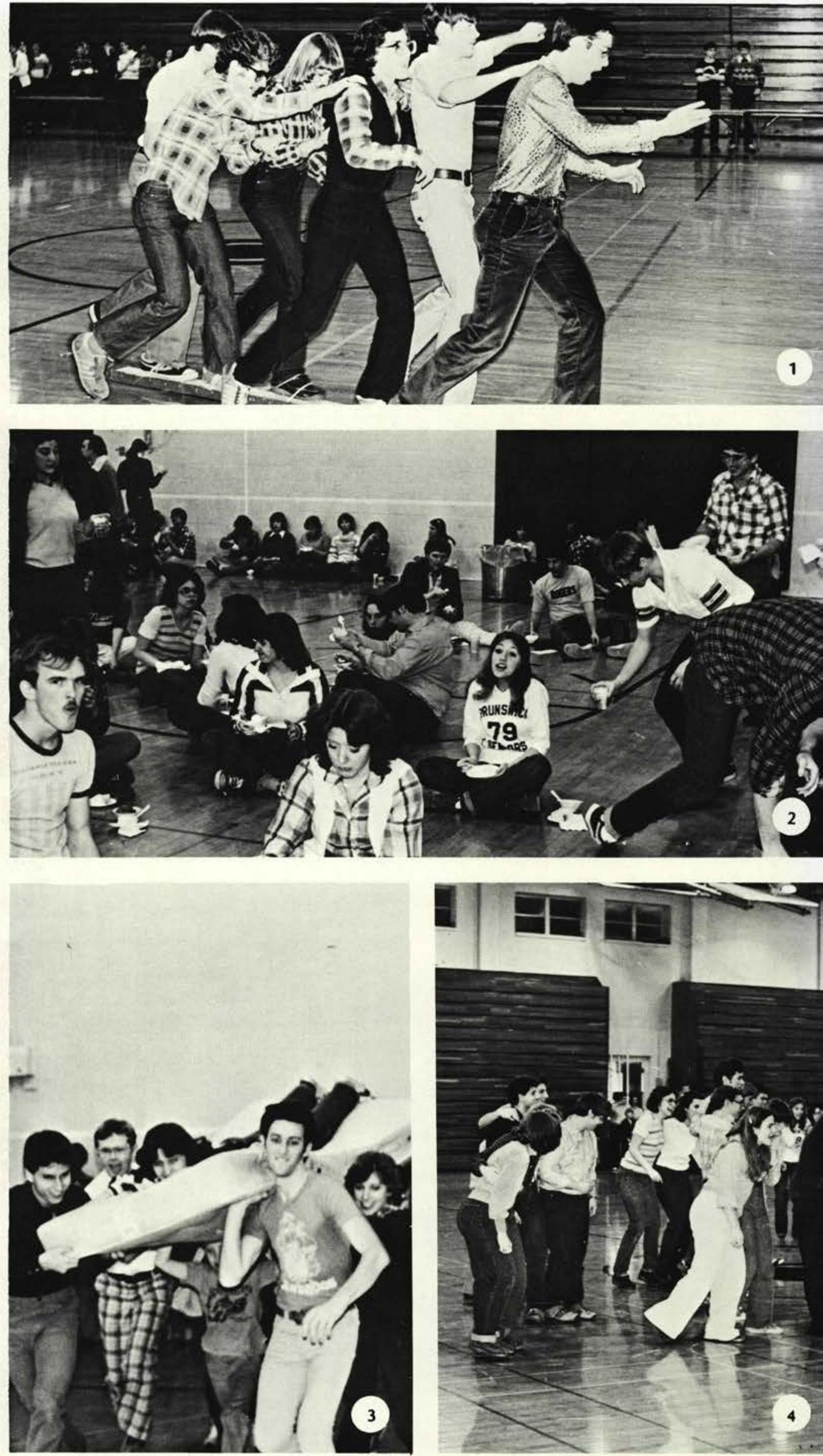

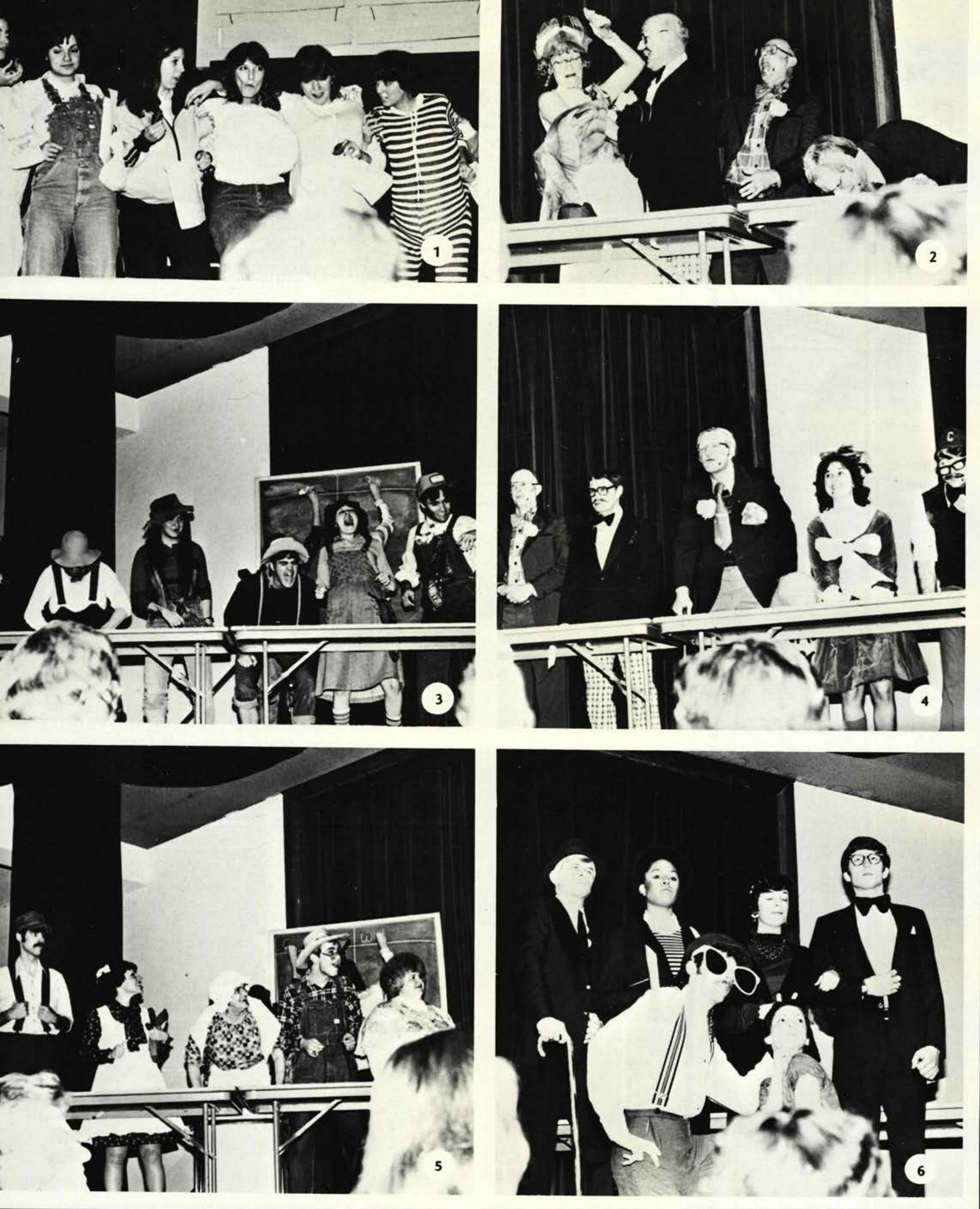

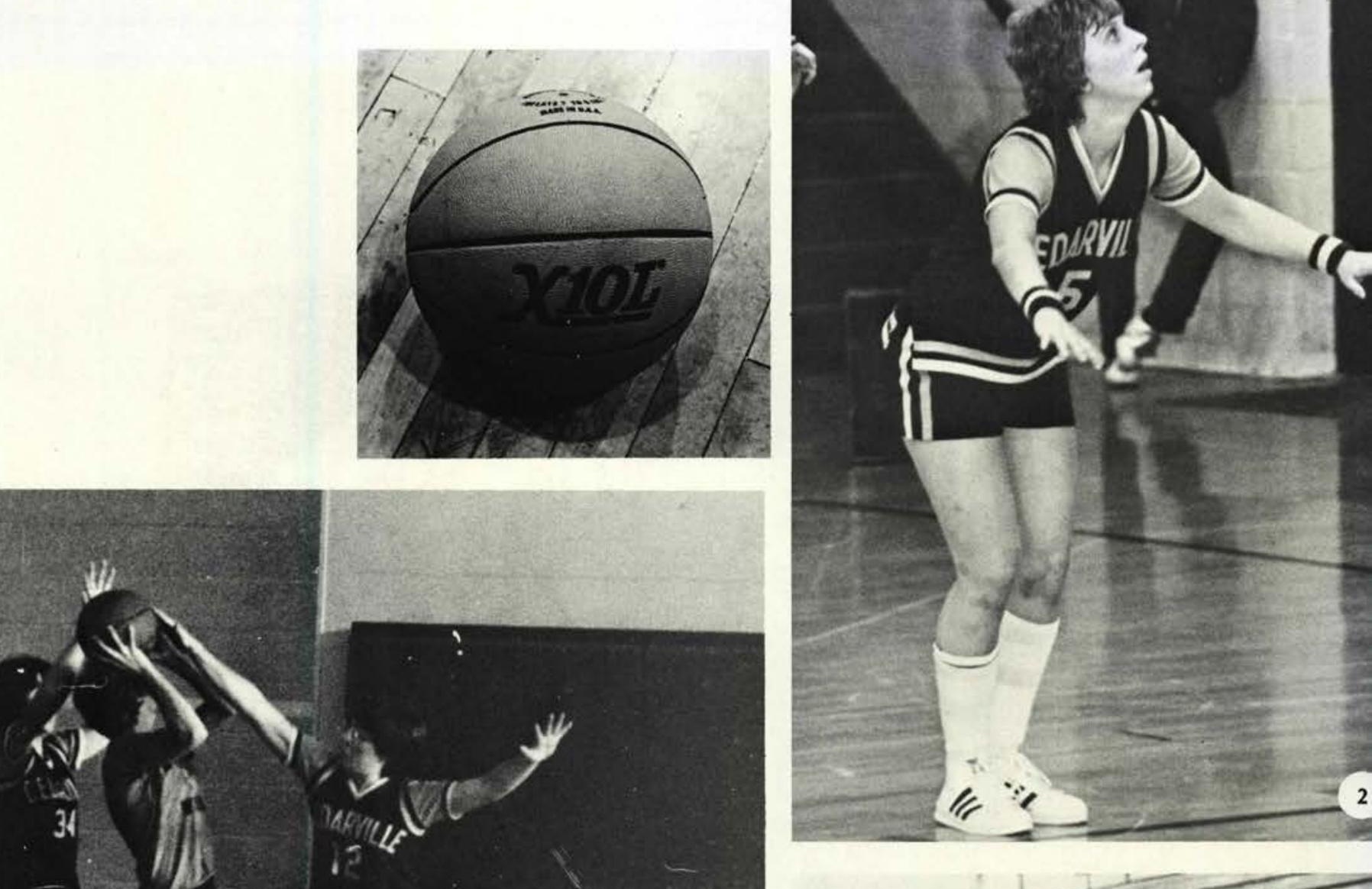

(1)
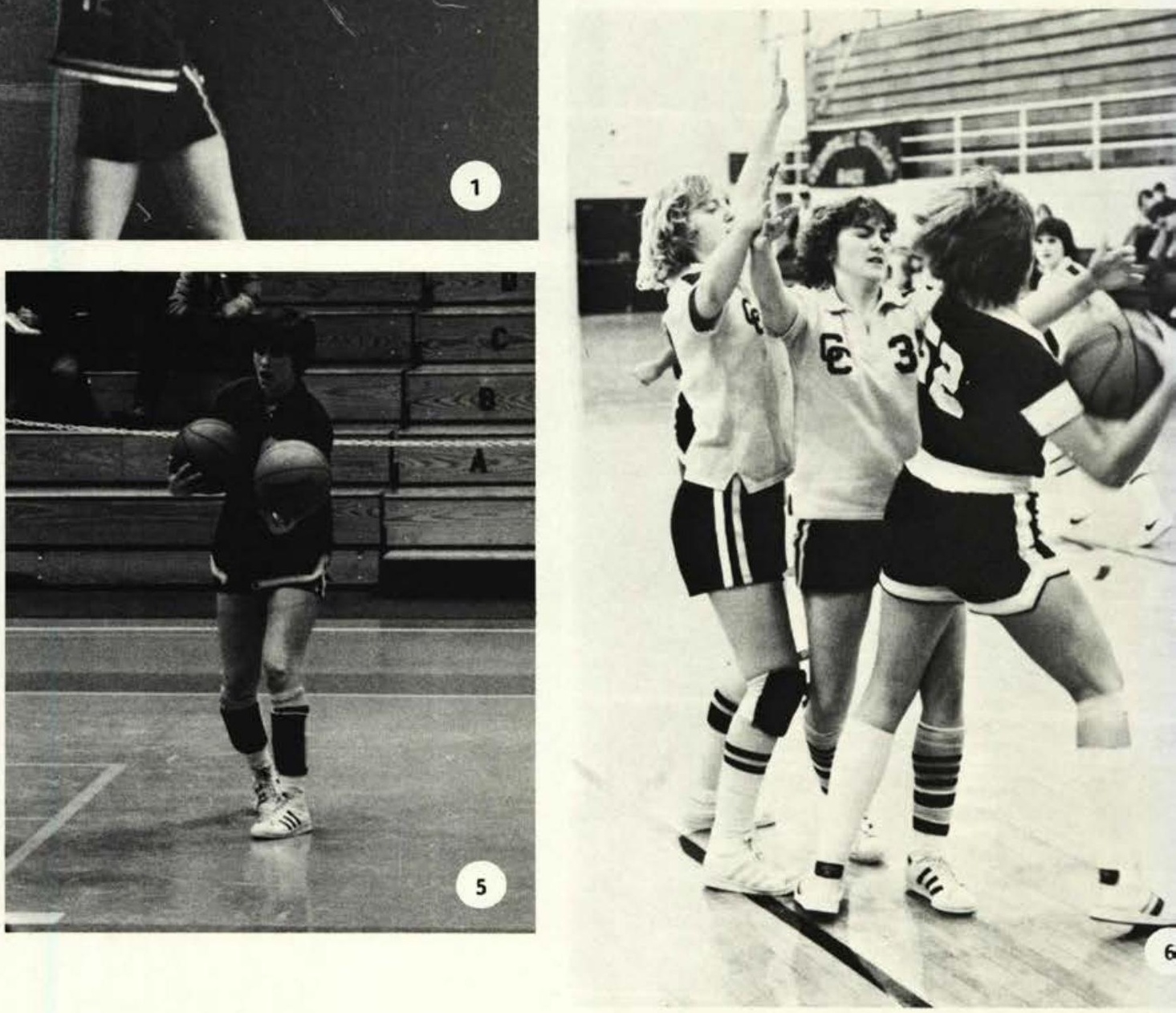

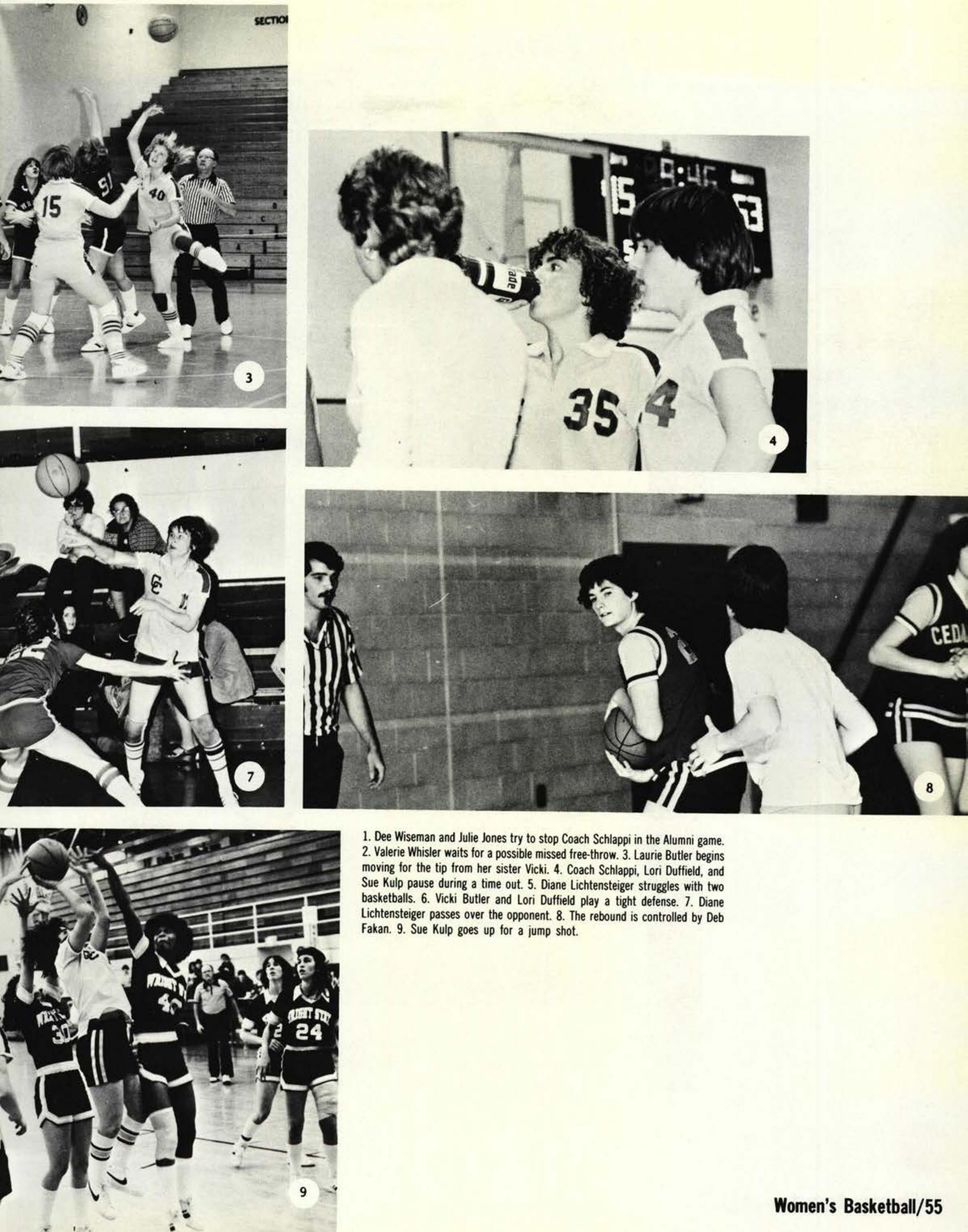

1. Dee Wiseman and Julie Jones try to stop Coach Schlappi in the Alumni game. 2. Valerie Whisler waits for a possible missed free-throw. 3. Laurie Butler begins moving for the tip from her sister Vicki. 4. Coach Schlappi, Lori Duffield, and Sue Kulp pause during a time out. 5. Diane Lichtensteiger struggles with two basketballs. 6 . Vicki Butler and Lori Duffield play a tight defense. 7. Diane Lichtensteiger passes over the opponent. 8. The rebound is controlled by Deb Fakan. 9. Sue Kulp goes up for a jump shot. 


\section{Women's Basketball}

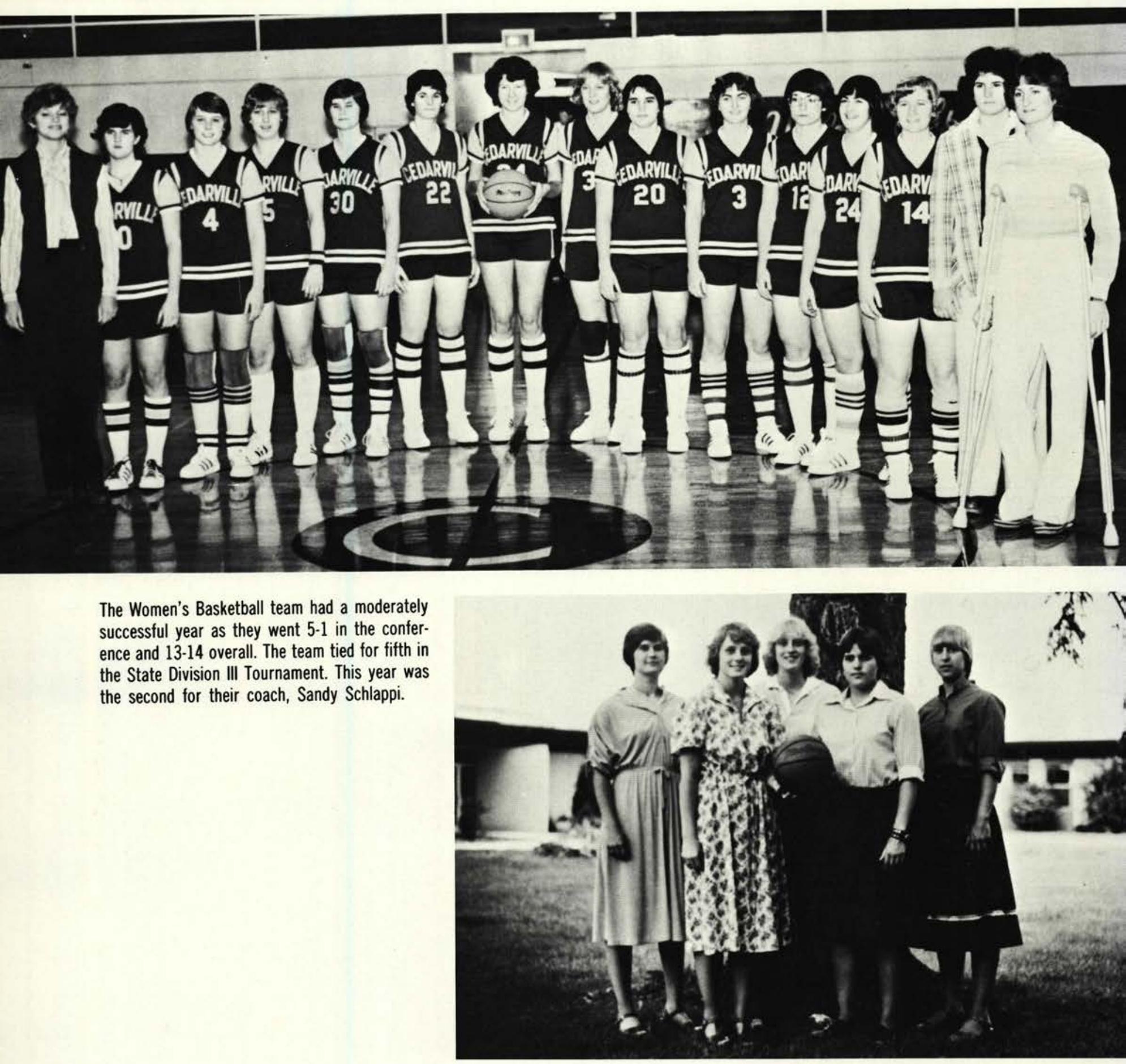

TOP PHOTO

Left to right: Coach Sandy Schlappi, Lori Franklin, Laurie Butler, Valerie Whisler, Diane Lichtensteiger, Deb Fakan, Dee Wiseman, Vicki Butler, Sue Kulp, Lori Duffield, Julie Jones, Barb Vinson, Jean Hatton, Sandy Fakan (Manager), Karen Collins.

\section{BOTTOM PHOTO}

Diane Lichtensteiger, Most Improved Player; Laurie Butler, Best Defense; Vicki Butler, All-District, All-Ohio, Team Captain, Best Field Goal Percentage, Most Rebounds, Most Valuable; Sue Kulp, Team Captain; Valerie Whisler, Best Free Throw Percentage. 


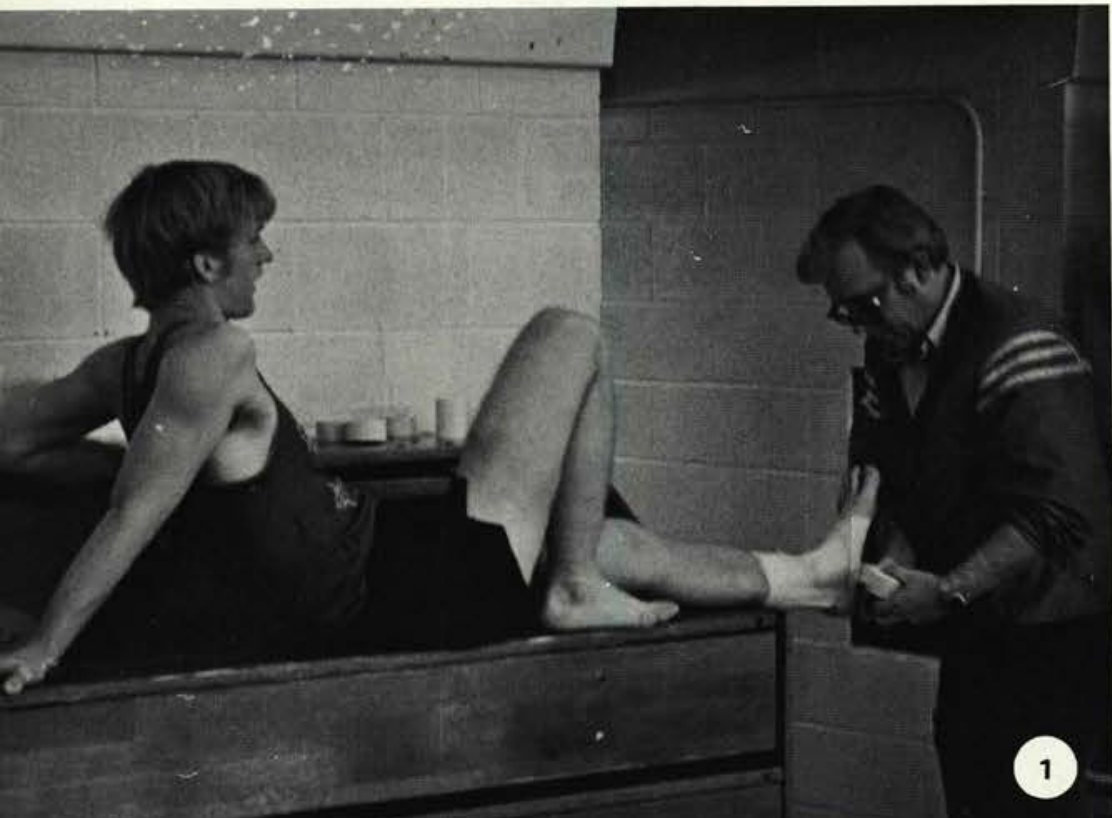

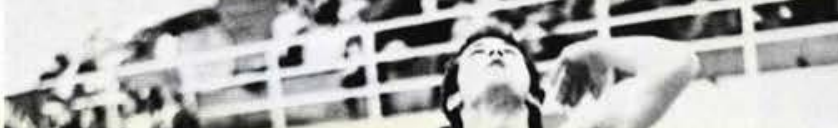
$\Delta+y=-1$

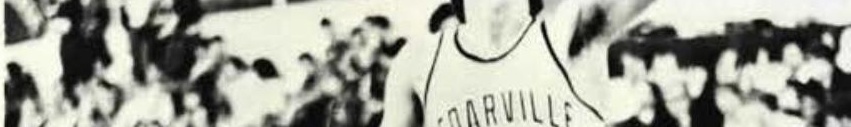
(5)

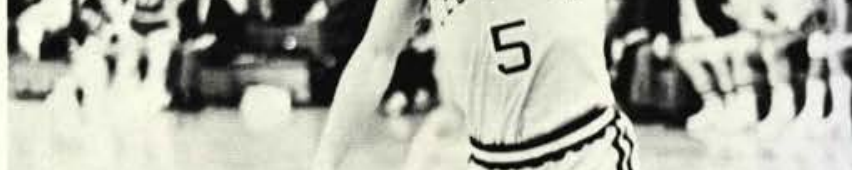
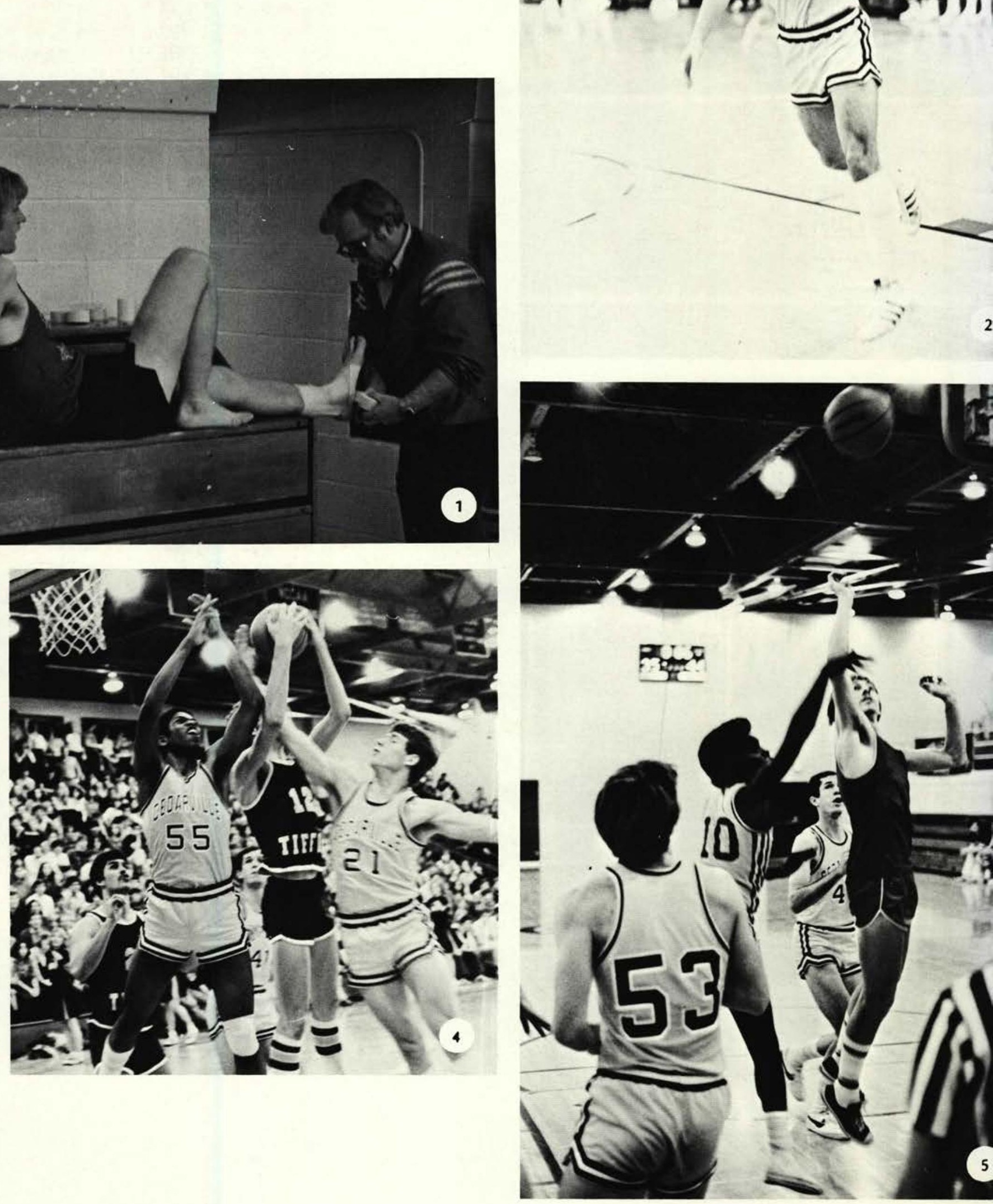

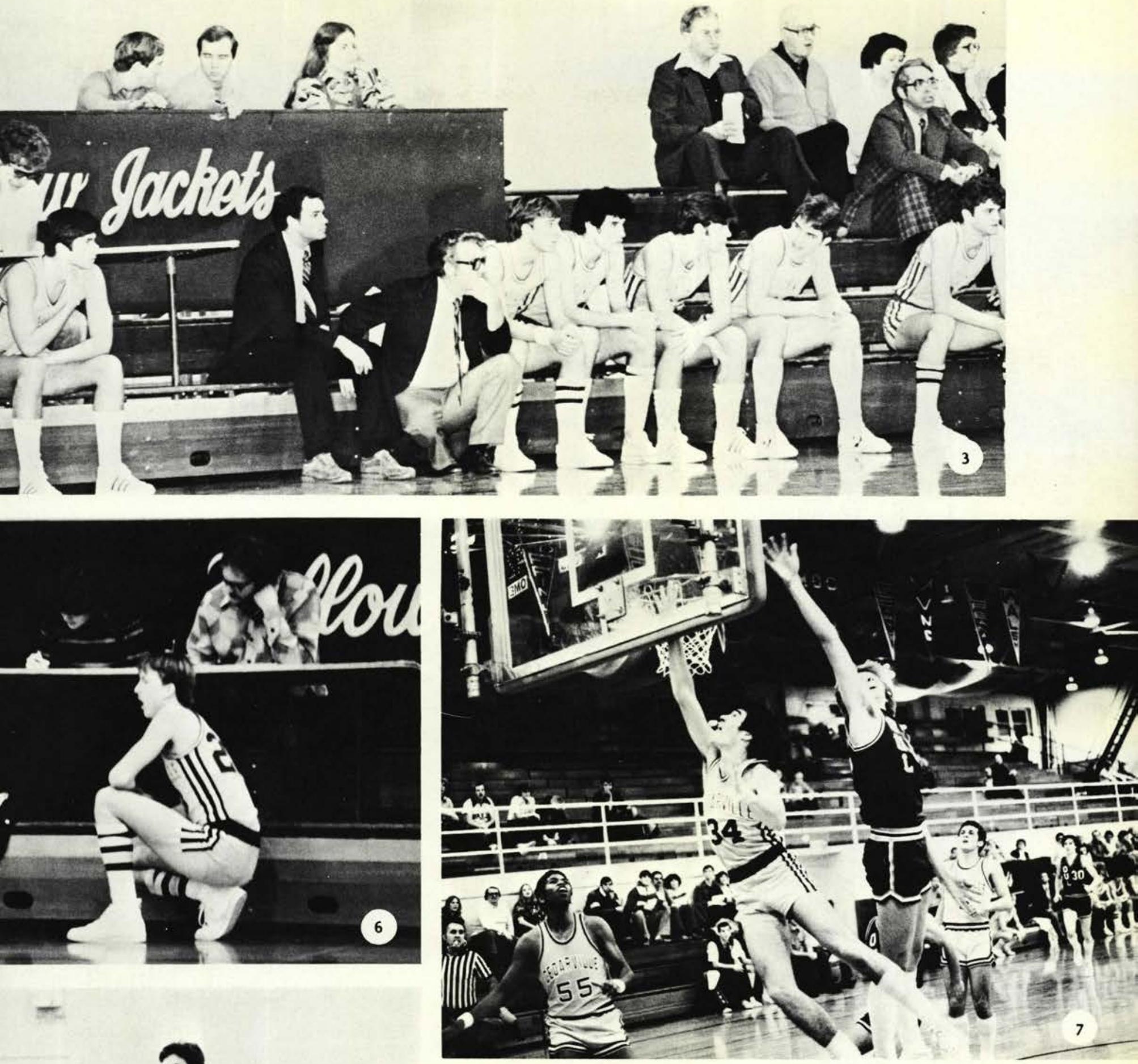

1. Coach Clark tapes Mike Smart's ankle before practice. 2. Larry Green watches the ball on his lay-up. 3. Activity on the bench can be very interesting. 4. Ted DeShields and Greg Greve try for the rebound. 5. As Larry Gibbs attempts a blocked shot, Brian Bentrude and Scott Carr prepare for the rebound. 6. Steve Bontekoe is ready to enter the game. 7. A pass from mid-air is made by Ken Massie. 

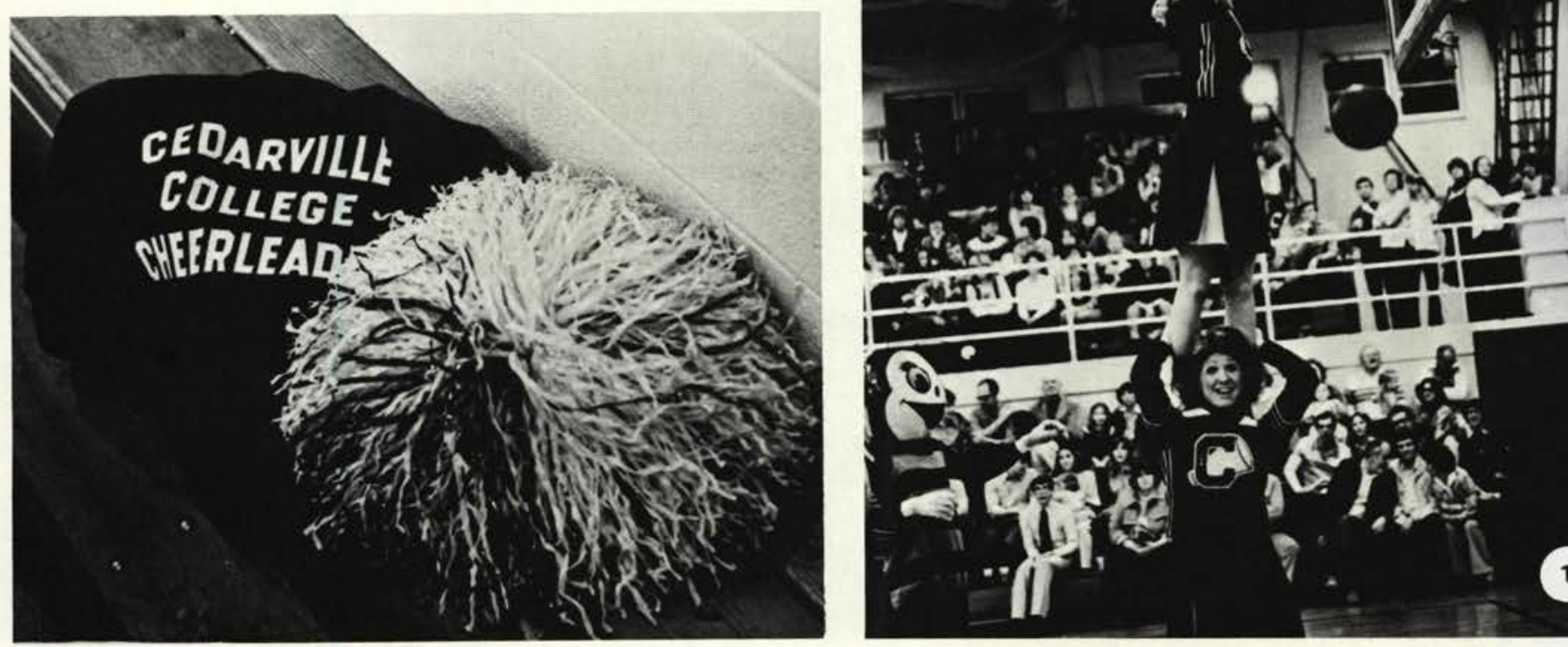
COLLEEE

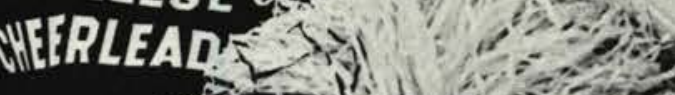
is

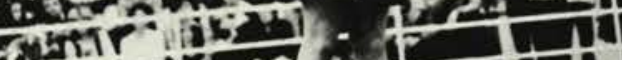

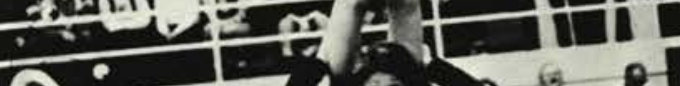

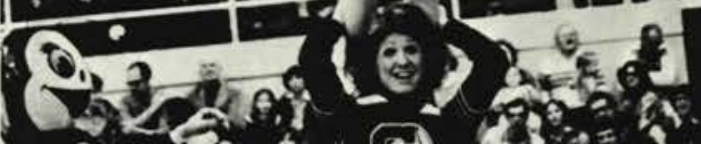

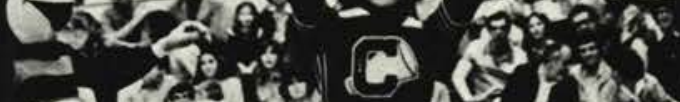

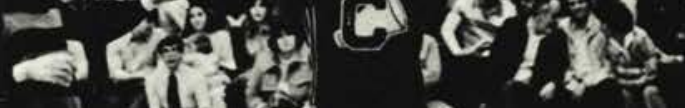

$$
\text { III, }
$$
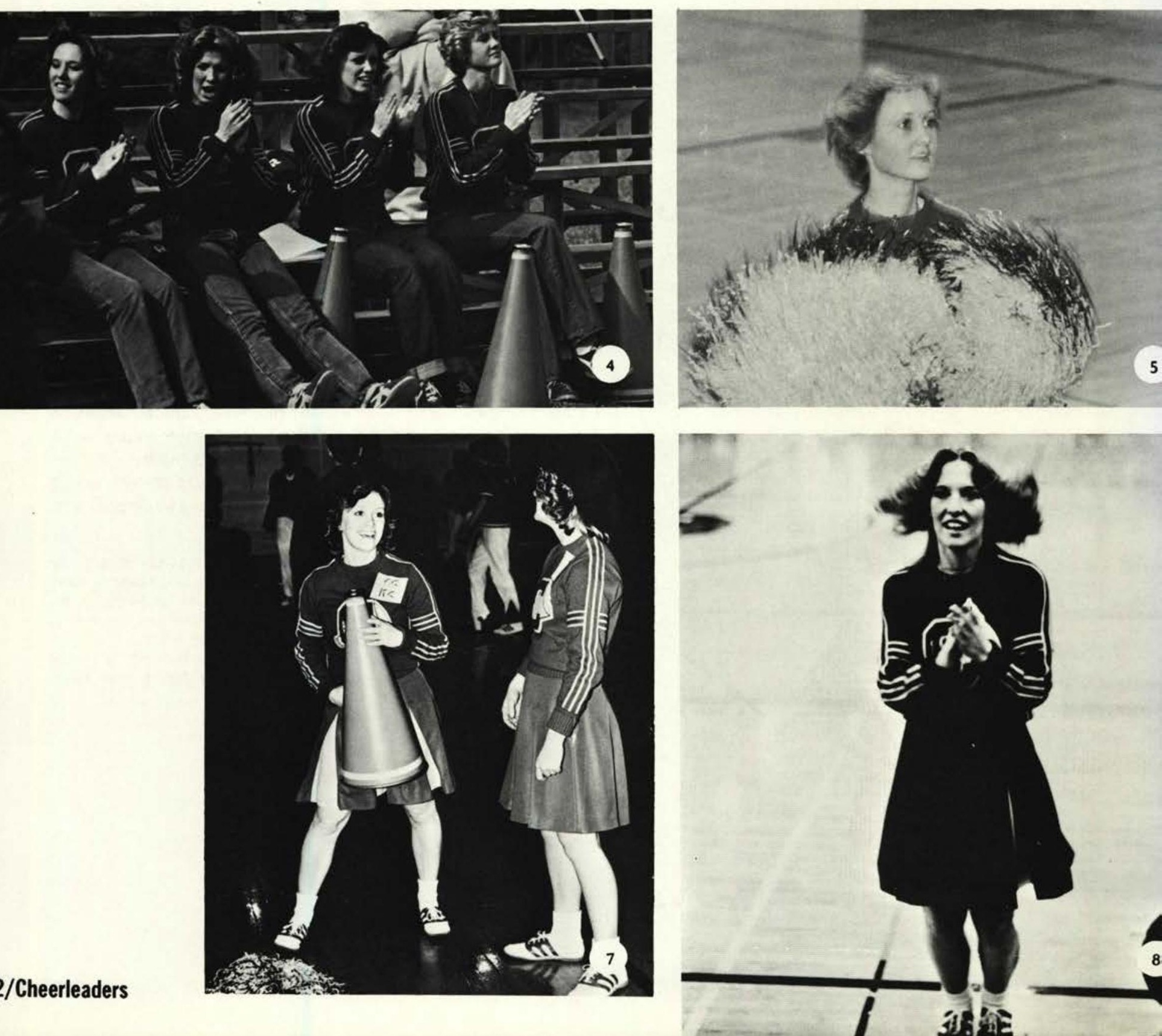

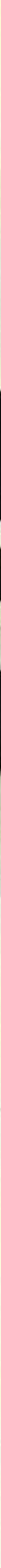

The six varsity and five junior varsity cheerleaders fill an important role in Cedarville College's athletic program. During the season the cheerleaders are responsible for organizing the Teammate program (which provides a secret prayer partner for all school athletes), and for conducting pep rallies and school spirit boosters. Their offcampus activities include presenting cheerleading clinics in area schools, judging cheerleader try-outs and sponsoring a one week cheerleading camp for Christian high schools during the summer.

1. The Yellow Jacket watches Val Friley dunk the ball, with a little help from Jan Ashcraft. 2. Varsity Cheerleaders, left to right: Valerie Friley, Amy Young, (Co-captain), Kim Smith (Co-captain), Lenna Barrand, Jan Ashcraft, Cindy Krewson. 3. Janell Johnson, The Yellow Jacket, and Pam McKay raise fan support. 4. Cindy Krewson, Jan Ashcraft, Amy Young, and Lenna Barrand support the soccer team. 5. Lenna Barrand uses the standard pompons. 6. Junior Varsity Cheerleaders, left to right: Linda Moody, Michelle Feura, Janell Johnson, Pam McKay, Marcia Mallare. 7. Amy Young and Kim Smith share a light moment before the game. 8. Cindy Krewson flips her hair while leading a cheer. 9. Junior Varsity Cheerleaders watch a free throw. 

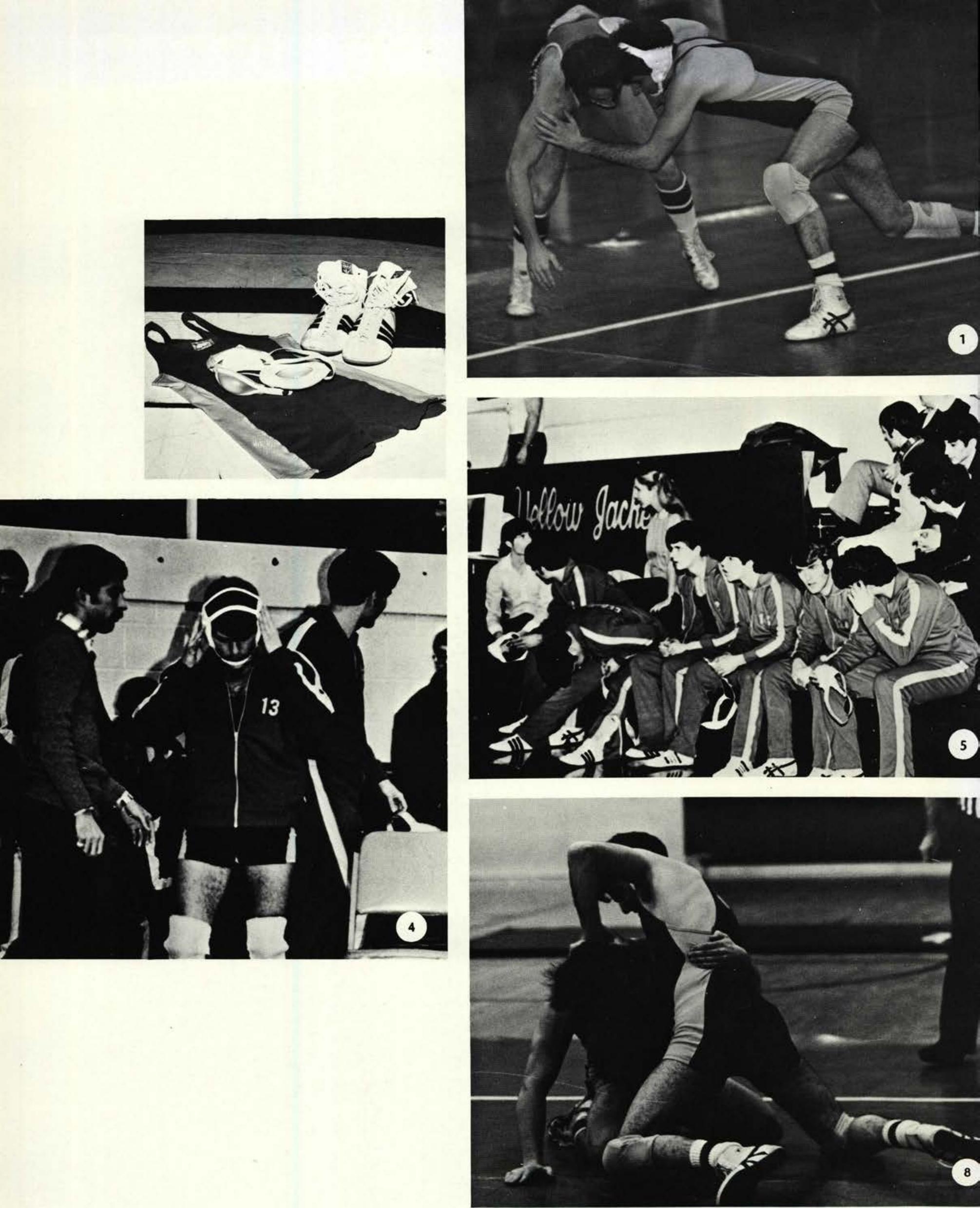

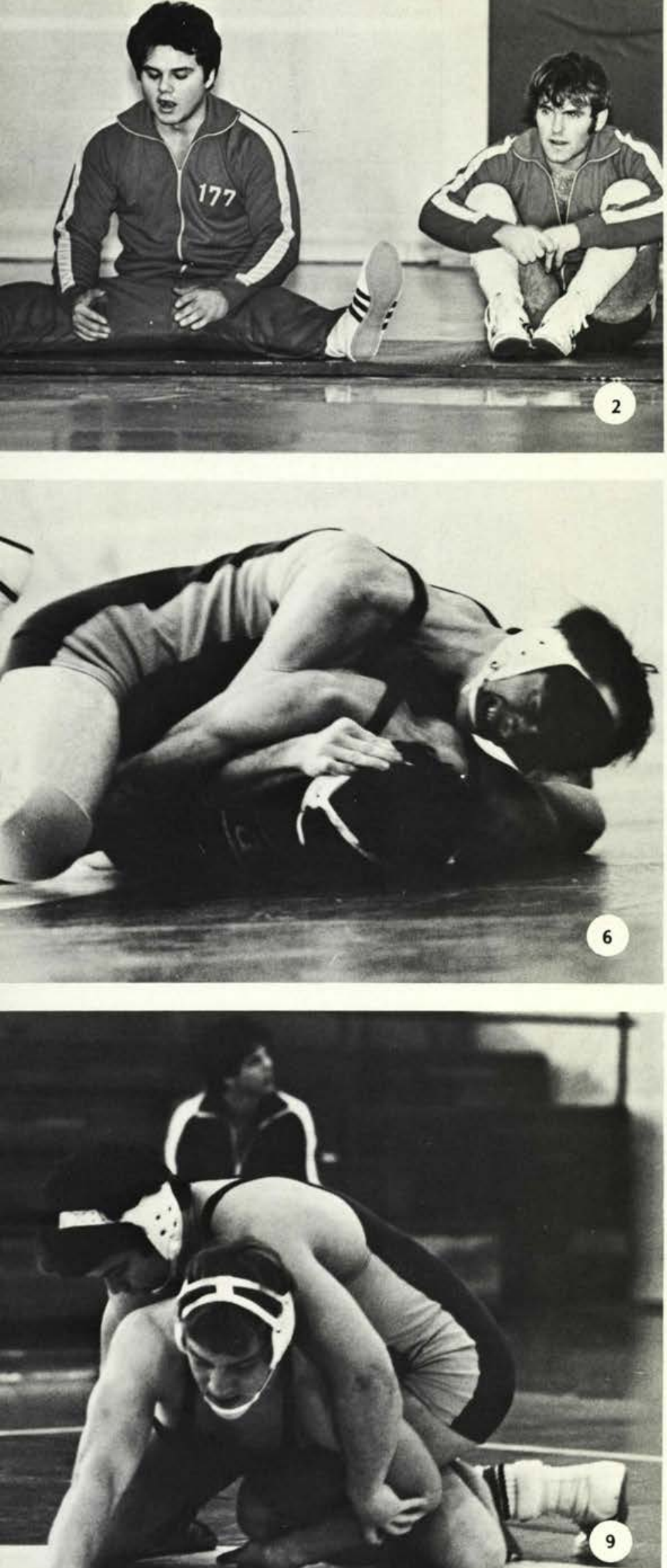
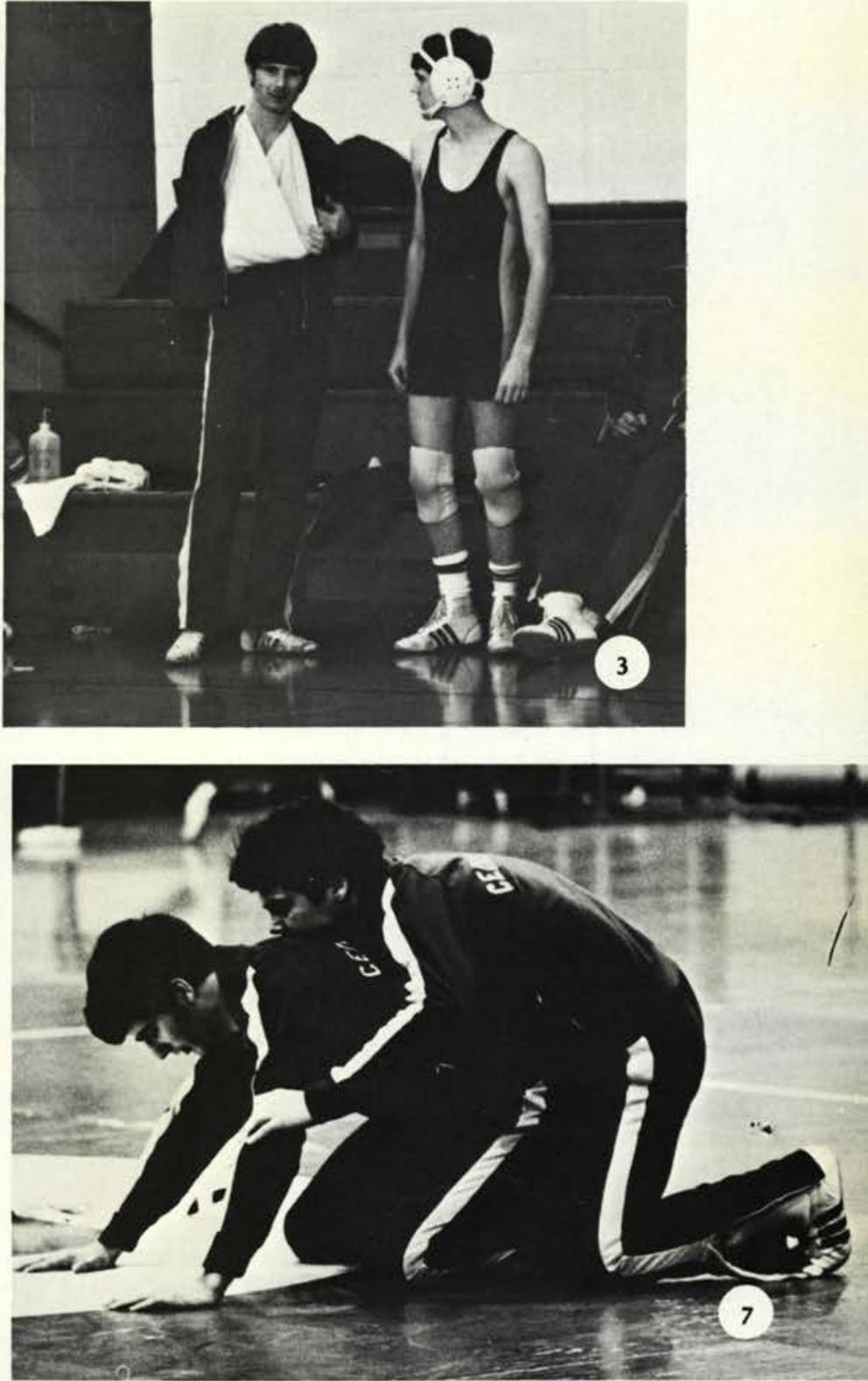

1. Tim Fisher attempts a take down. 2. Mike Ericson and James Tassell concentrate when not wrestling. 3. Mike Ericson is not concerned with the discussion of Mike Hunting and Todd Peterson. 4. Coach Battaglia waits for James Tassell to adjust his headgear. 5. The Wrestling Team sticks together. 6. Mike Ericson and Tim Fisher warm up for the meet. 8. Tim Fisher works on his opponent's neck. 9. Mike Ericson is on top of his opponent. 


\section{Wrestling}

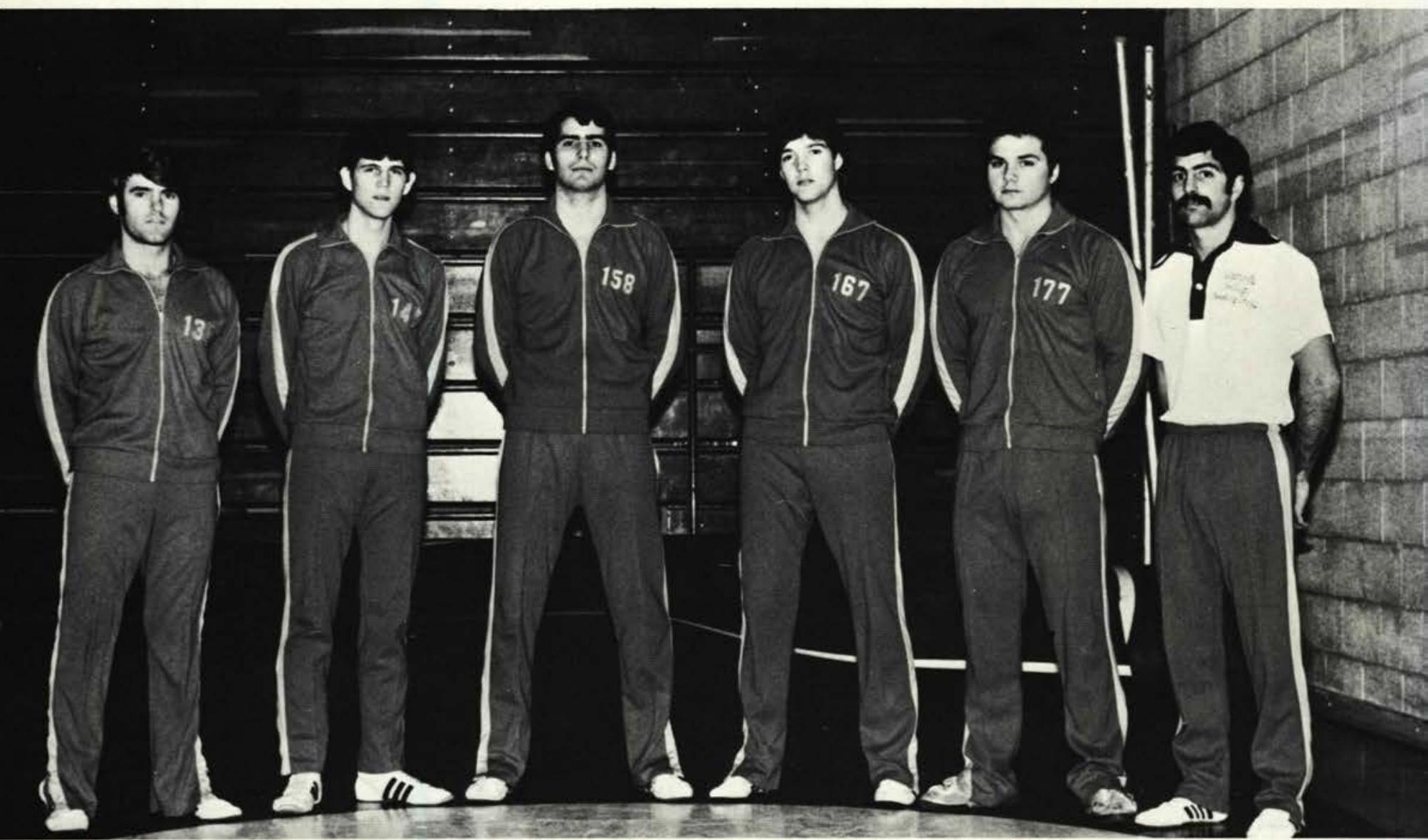

The Wrestling Team had a rough year as they went 1-7.

Coach John Battaglia attributes the record to the inexperience of the team. Every member of the team was a first year college wrestler; but says Coach Battaglia, the team has a good base to build upon next year.

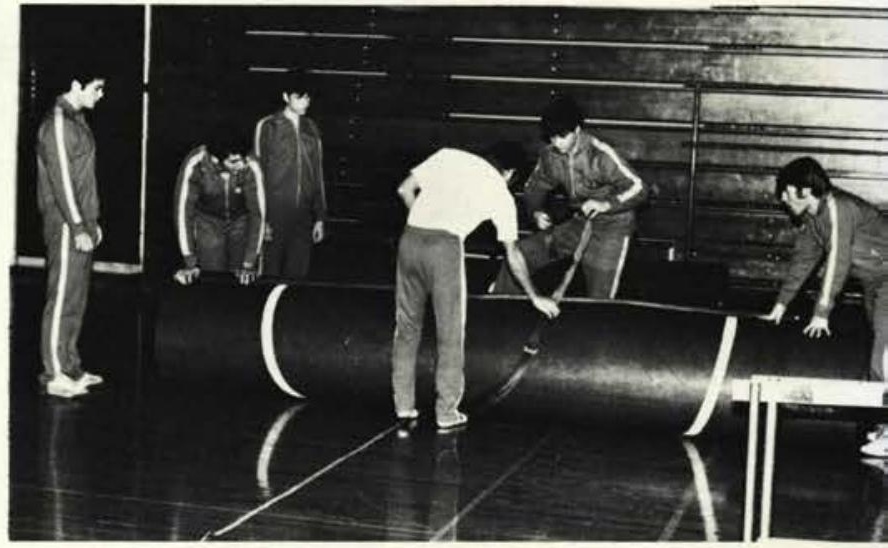

\section{TOP PHOTO}

James Tassell, Todd Peterson, Tim Fisher, Kevin Harding, Rob Shirk, John Battaglia, Coach. 


\section{Intramurals}

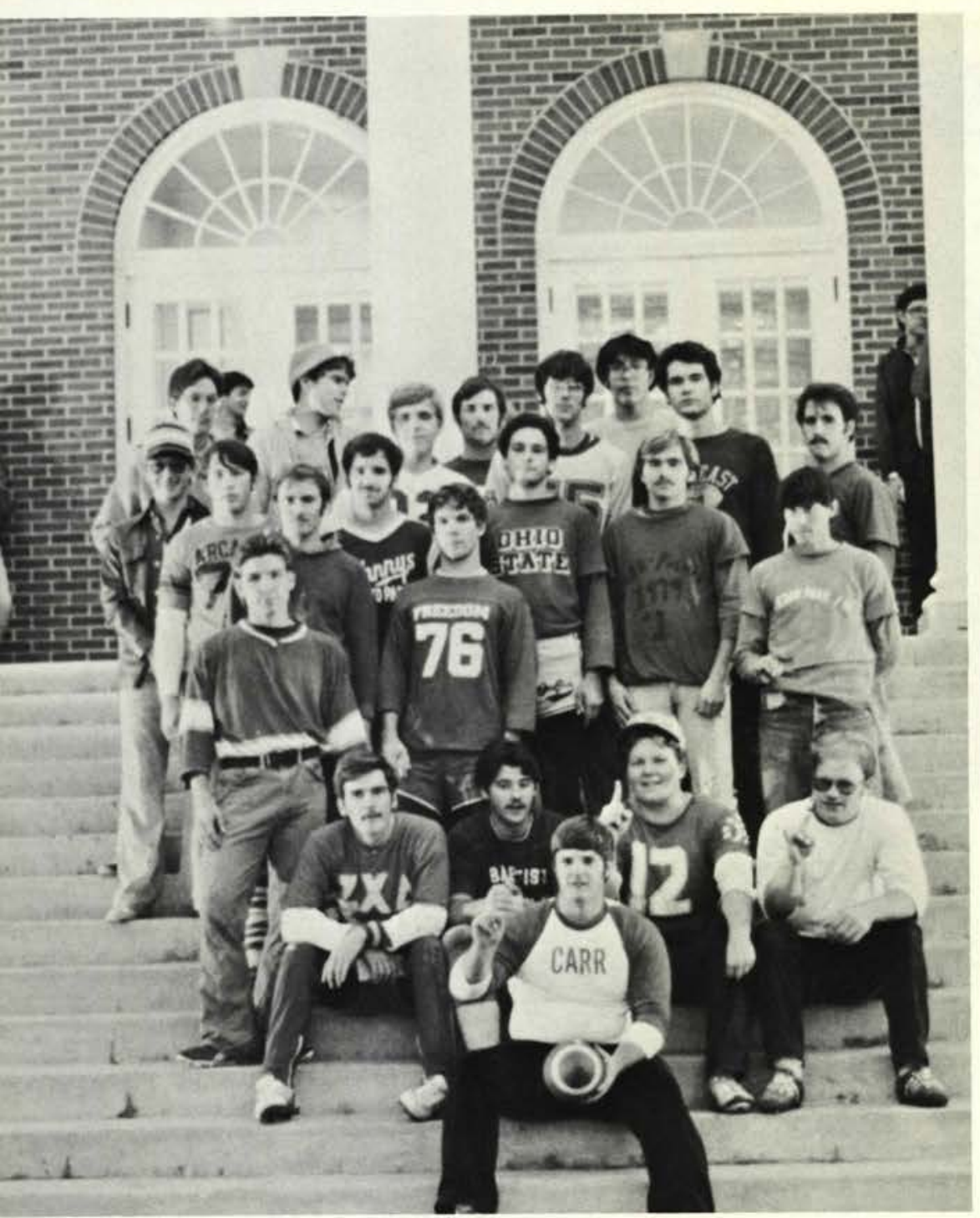

Cedarville College organizes several tournaments for the college personnel. This year they had flag football, three man and five man basketball for men and five man basketball for women. A Cross Country Run, Softball, Coed Volleyball, and Women's Volleyball were also played. An All-Star softball team was taken to the Miami University Tournament.

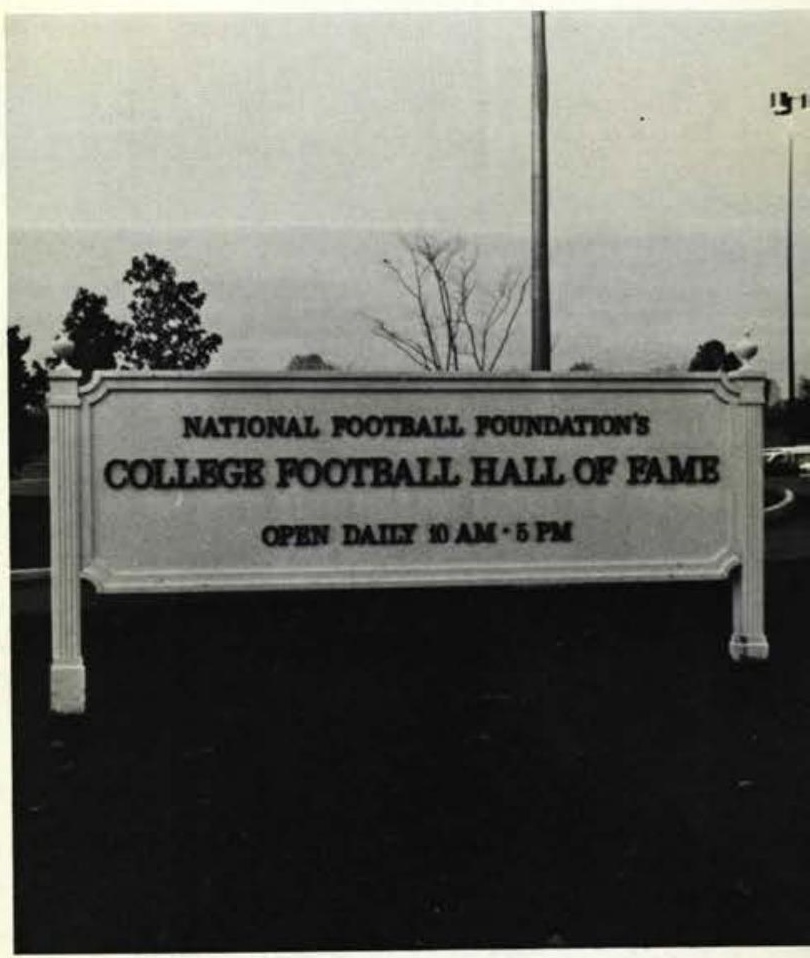

\section{AT LEFT}

The winning Carr/Palmer flag football team which went to the college football Hall of Fame. Other winners were: 3-man basketball, Mike Aitken, Dave Short, Mike Howard; 5-man basketball, Off-Campus; Cross Country Run, Julie Hutchins; and Softball, Lawlor. 

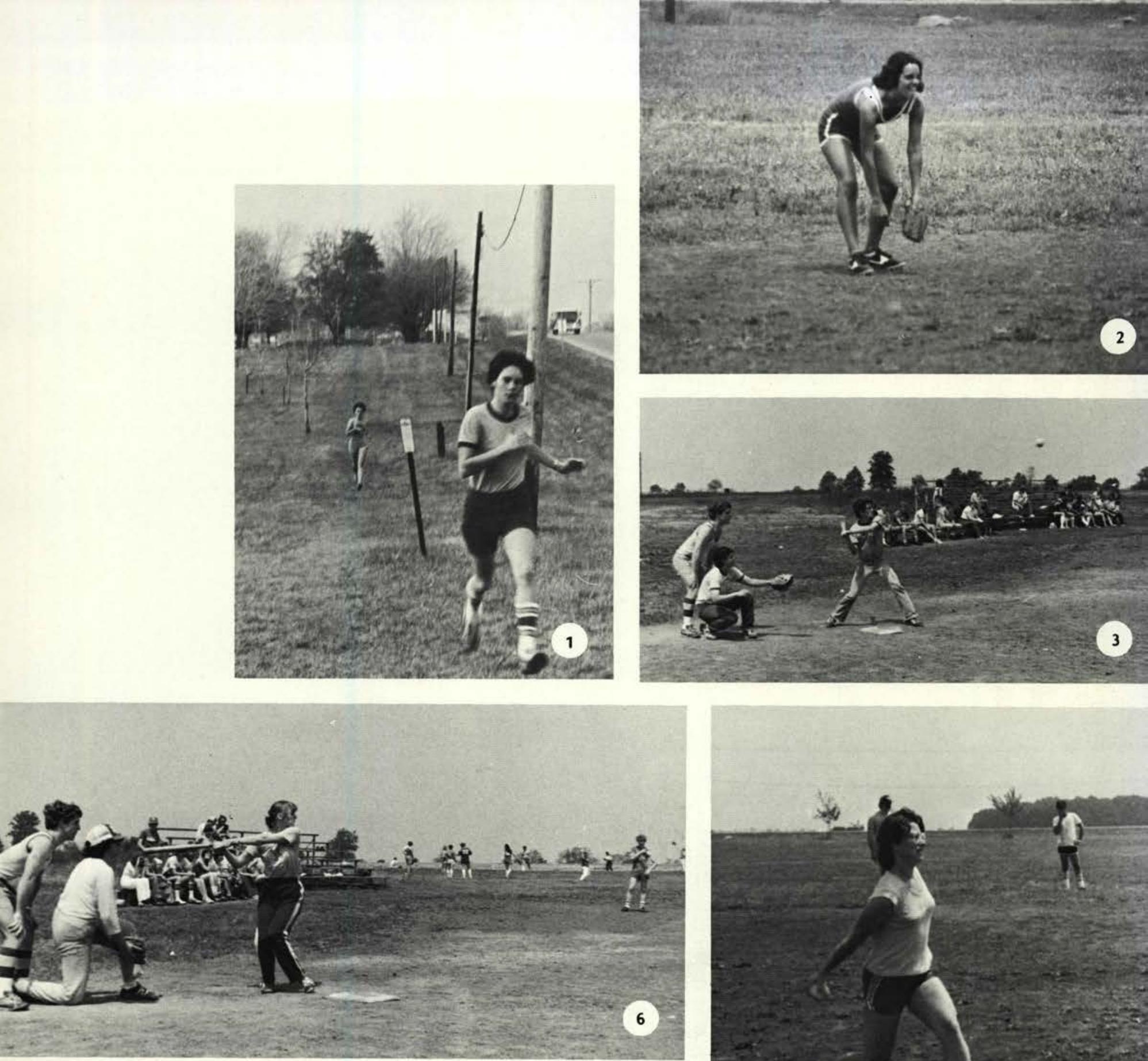

1. Several distance runs were sponsored by Cedarville. 2. Co-ed Softball provided relaxation for most participants. 3. Sometimes the games attracted a few spectators. 4. The girls' basketball resembled football at times. 5. Flag football assumed the same challenges as interscholastic football. 6 . Cedarville's women brought their unique style to the games. 7 . Of course, to let the boys play, the girls had to use slow-pitch rules. 8. Because the girls agreed to slow-pitch, men like he could hit the ball. 9. Basketball games scheduled during the winter months provided escape from studies. 10. It looks like the boys are taking the game seriously.

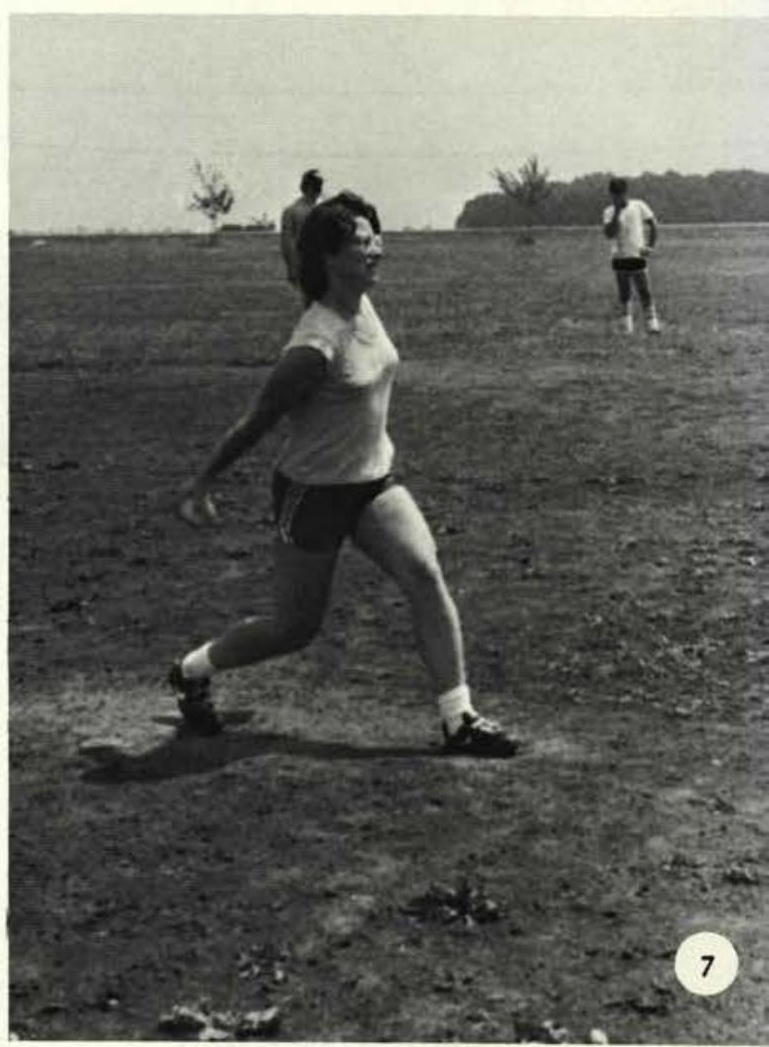




\section{Student}

Life

1. Trudy Tangblade and Carey Weaver show their Cedarville spirit. 2. Some Pi Sig guys are trying to charm the Printy girls with their beautiful voices. 3. Dana Treese takes a quick break from the action of a Yellow Jackets' game. 4. It takes two to eat ice cream at this social. 5. Good to the last bite!

\section{Student Rally}

A rally organized by Valde Garcia, who is a member of ROTC, demonstrated Cedarville's concern over the growing problems in Iran. Many students came out to give their support and show their interest in this serious situation facing our country.

1. Marnie Vail adds interest to the rally by bringing her horse with her. 2 . Cedarville flag wavers came out to give their support. 3 . Cedarville students lend vocal support. 4. Mr. Dicurci leads the band in a few patriotic numbers. 5. A group of enthused students show their true colors. 6. Randy Harper gives his opinion on the importance of unity in our country. 


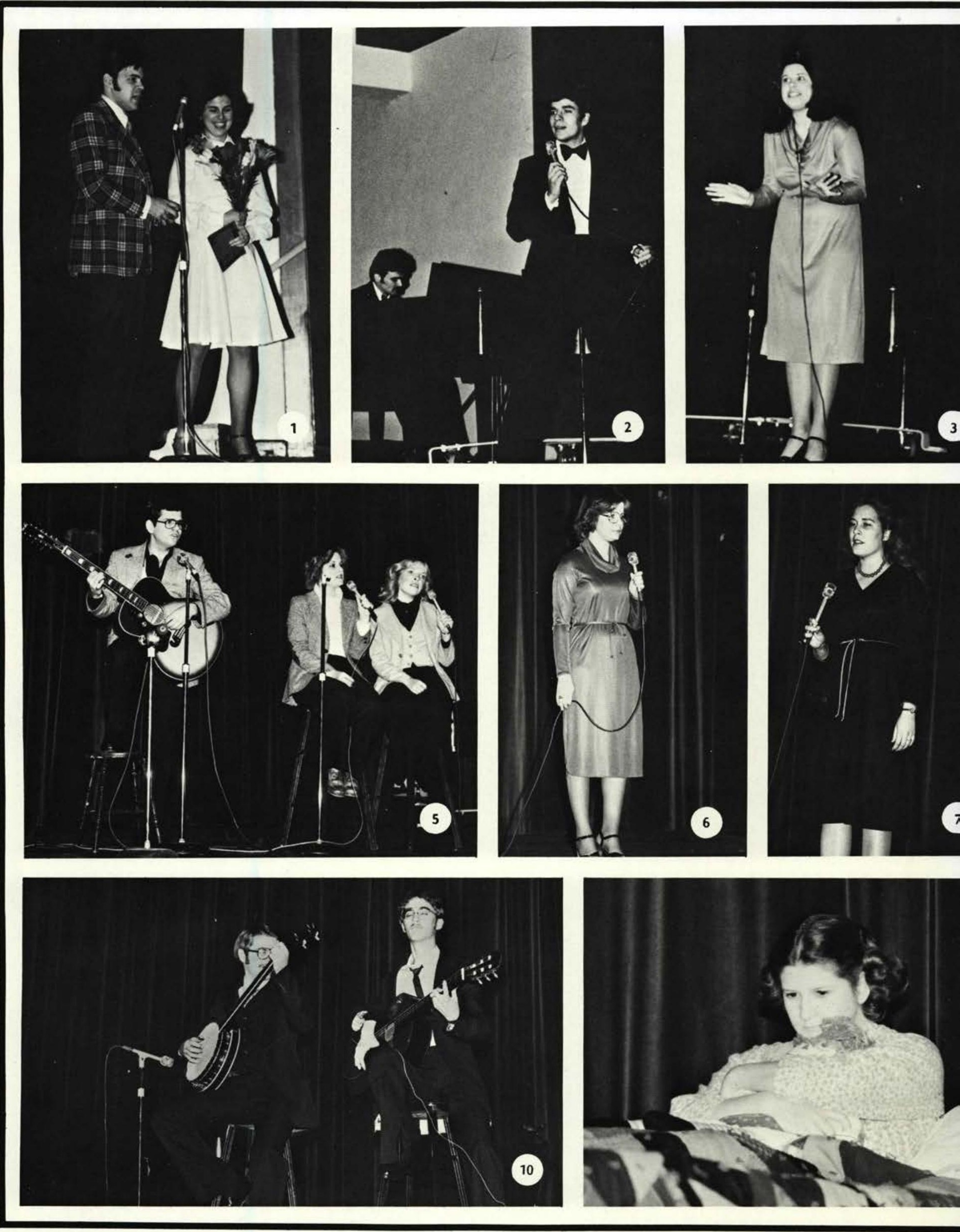




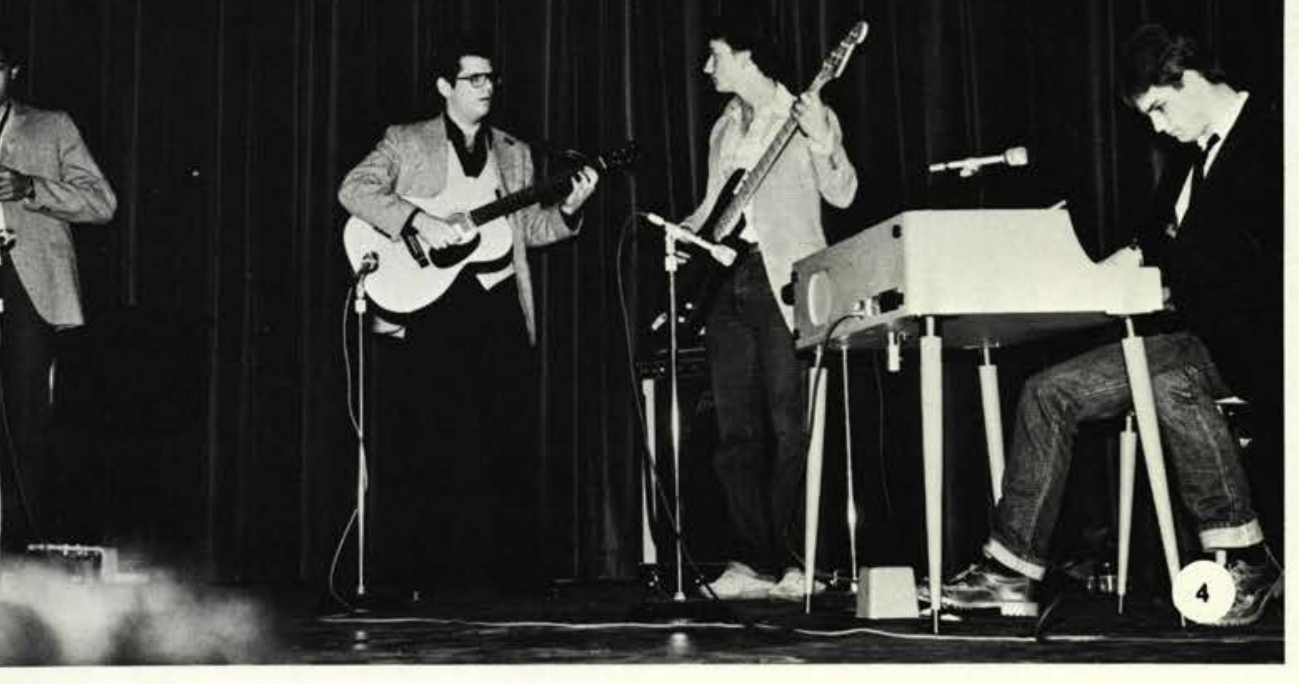

\section{AX Talent Night}

The Alpha Chi Talent Night featured many of our gifted students. Each year, AX holds auditions and selects those with excellent pieces and puts them together to form a program. Mr. and Mrs. Wes Baker hosted the event which included songs and skits. The theme for the 1980 show was LOVE. The songs and skits ranged from dreamers wishing for love to lost loves to loves for one's parents. The show was held for two nights. Both nights proved to be a great success.

1. Mr. Baker in keeping with the them, presents some flowers to his wife. 2. John Hart and John Duff, second place winners, did a skit called "My Sonny Lies Over the Ocean". 3. Jill Southward, first place winner, did a humorous skit on "Cinderella". . 4. These men provided extra entertainment. 5. The group "First Love" sang two love songs. 6 . Patty Cornell awaits the introduction to her selection. 7. Deborah Darling sings about the love of Christ. 8. Laura Smith takes a big risk at the hands of Steve Etner. 9. God, as our Savior and Creator, was the theme of New Covenants' number. 10. Steve Strock and Steve Keller provide a story in music, that of a Printy girl and a Lawlor guy meeting for the first time and falling in love. 11 .

Stacy Towle sings of a different kind of love. 12. Sue Parvin and Shirley Clark sing a bittersweet love song.

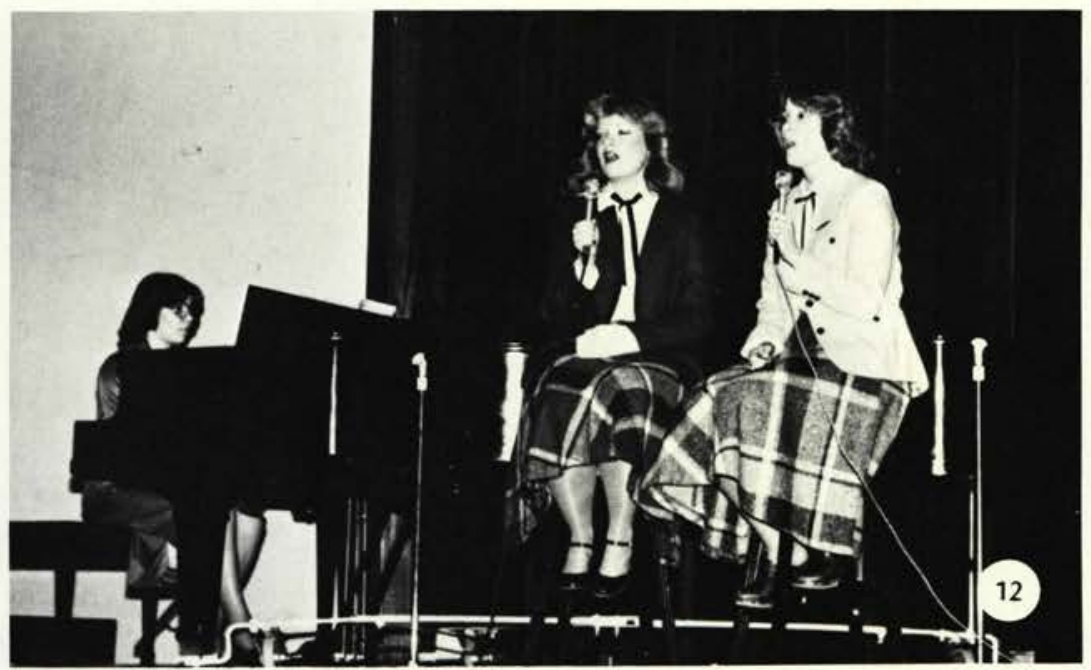


A

\section{Night With}

\section{Norman}

The Norman Tabernacle Choir is a unique group of highly versatile and talented students. The group this year did a variety of skits and musical numbers ranging from "The Looney Bin" to "The New and Improved Sound of Music" and closed with their spectacular slide presentation "You're in the Way". NTC's leader was of course Norman himself (Alias Craig Miller) and the choir consisted of: Becky Rupe, Ginny and Jannell Decker, Dana Treese, Lisa Ramsey, Stacey Towle, Kris Karsian, Beth Miller, Brenda McBride, Diane DeNicola, Lorraine Merkh, Dan Green, Dave Cox, Dave Carr, Doug Phillips, Steve Swayze, John Duff, Steve Keller, Ron Hobar, and Gary Moore. NTC's concert was held on April 12 in Alford. All the proceeds went to ABWE missionaries, graduates of Cedarville College working in Austin, Texas. These missionaries, Bruce and Bev McDonald and Sam and Judy Olsen, are planting churches in that area.

1. Dan Green sits admiring Stacey Towle's star. 2. Ron Hobar and Dave Carr are leading cheers. 3. Dan Green is "freshened" by his admirers. 4. Craig Miller and Ginny Deck. er perform the "Looney Bin". 5. Their professors wish they were given the same attention. 6. John Duff enjoys a temporary position of superiority. 7. Lisa Ramsey is "Mama" to her single missionary girls. 8. Jannell Decker is proud of her kids in "The New and Improved Sound of Music". 9. Norman leads one of the more serious songs: "Hey Diddle Diddle".
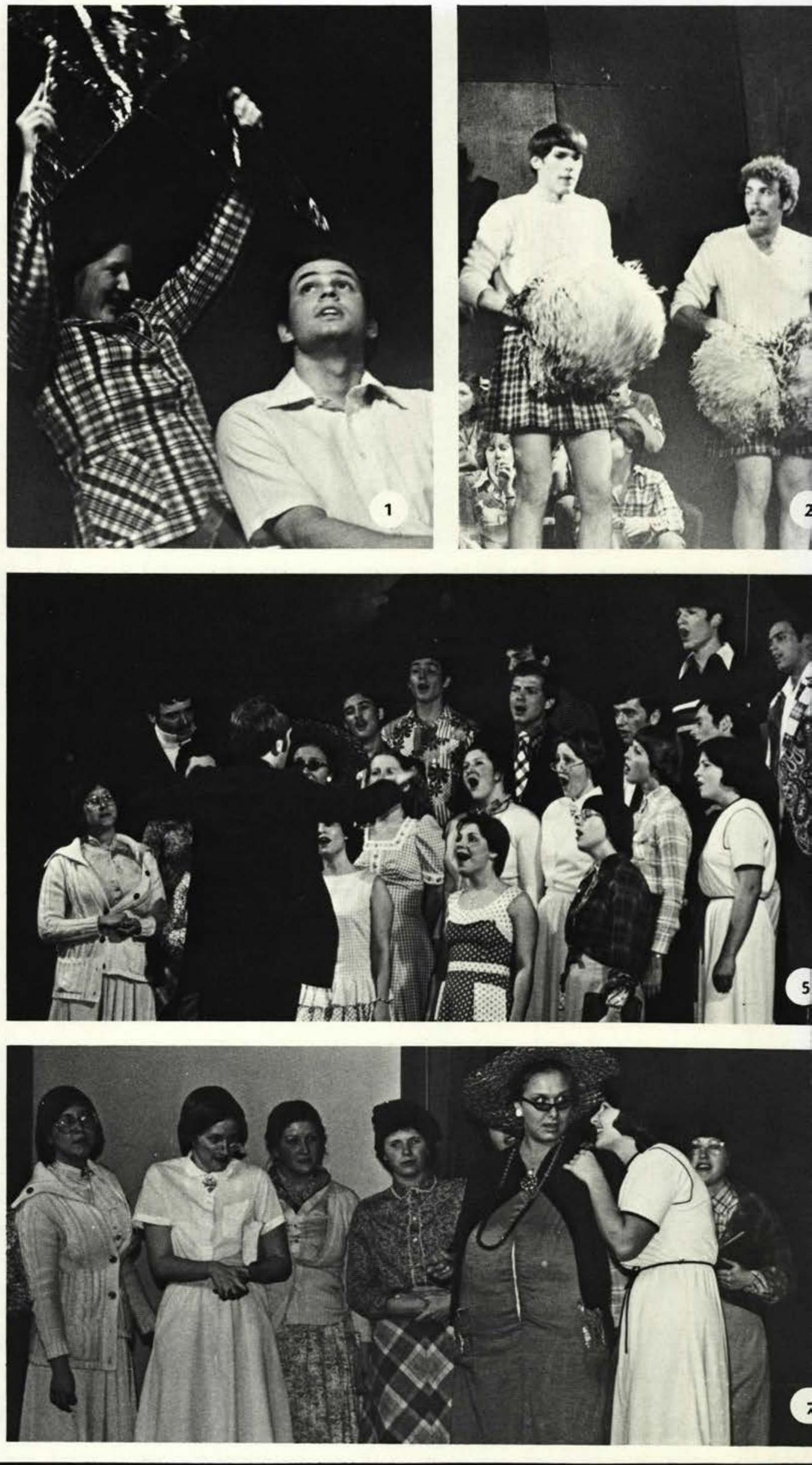

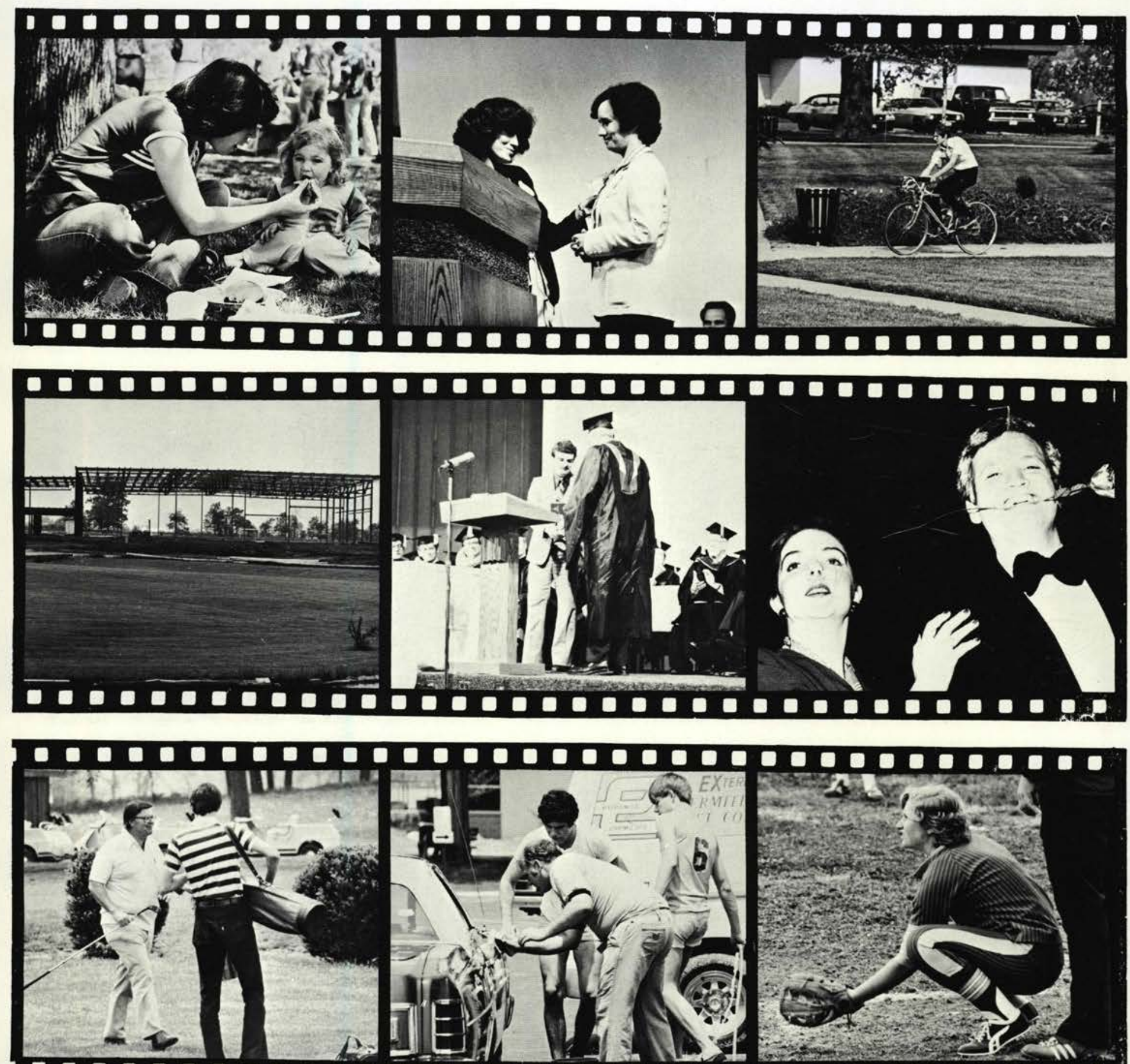

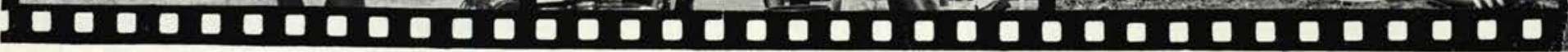

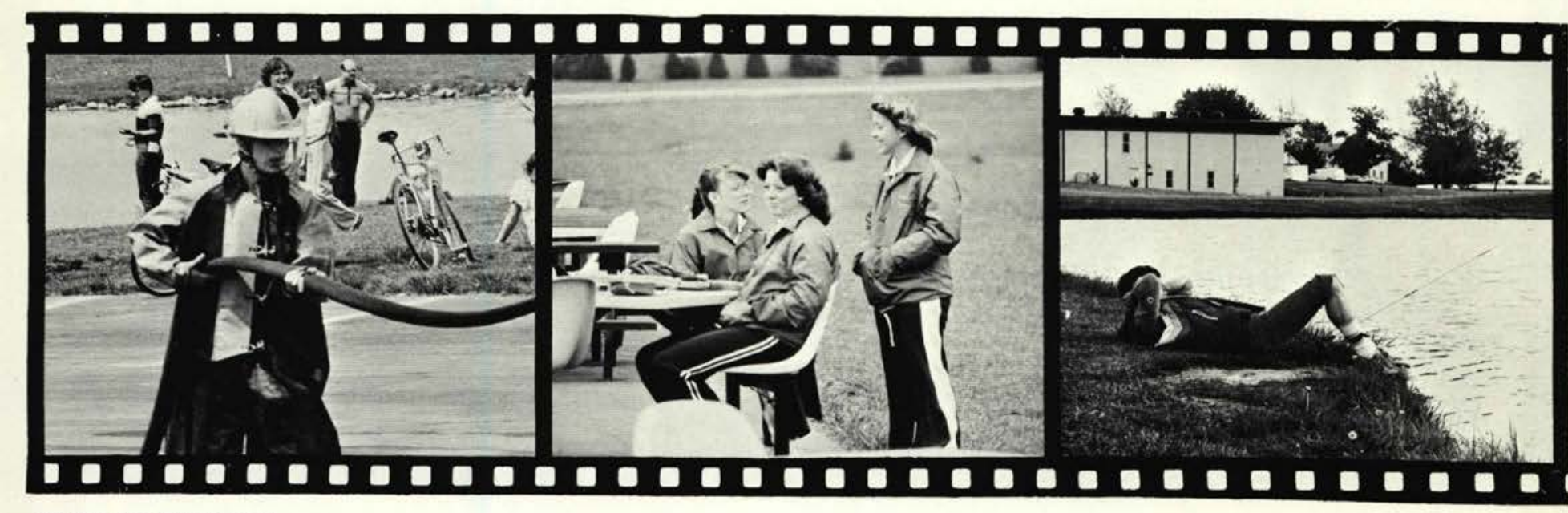




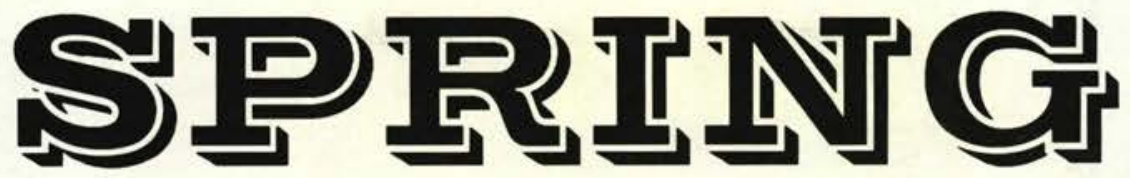

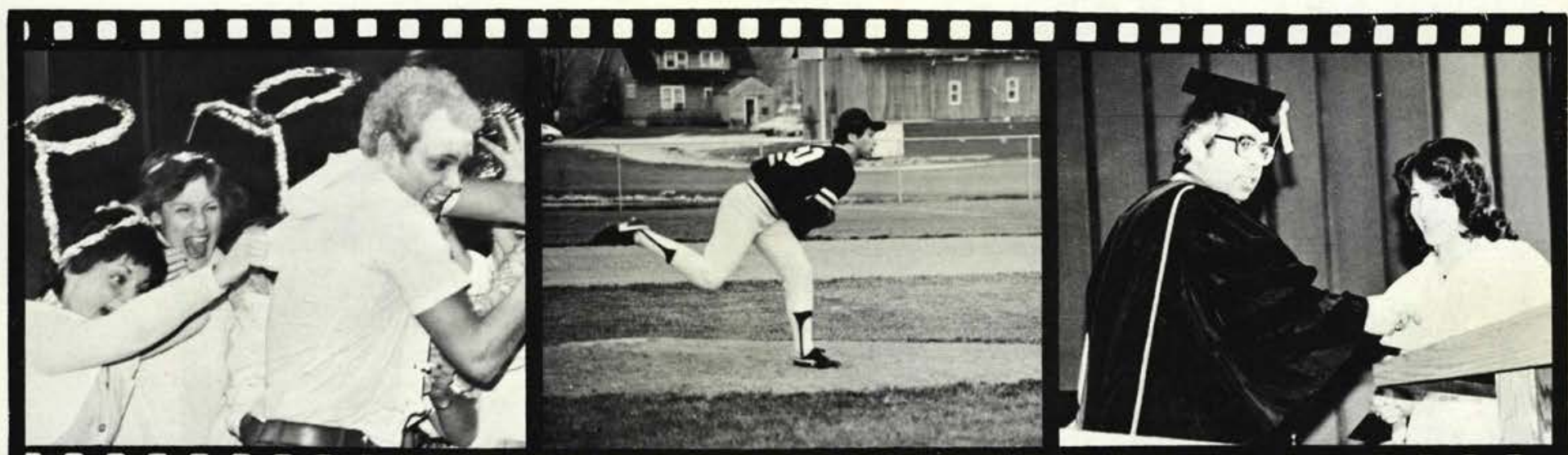

0000000000000000000000000000000000001
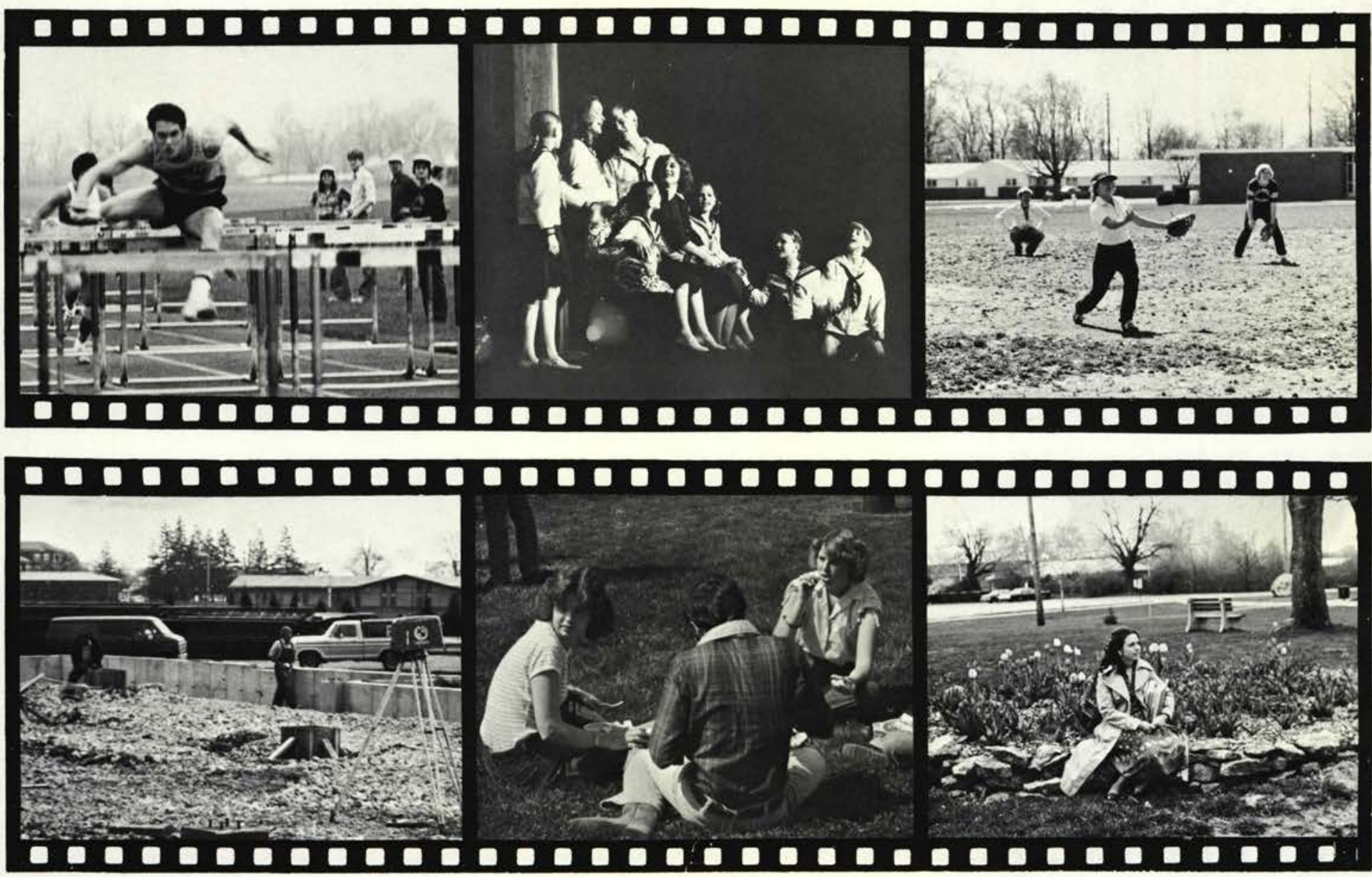

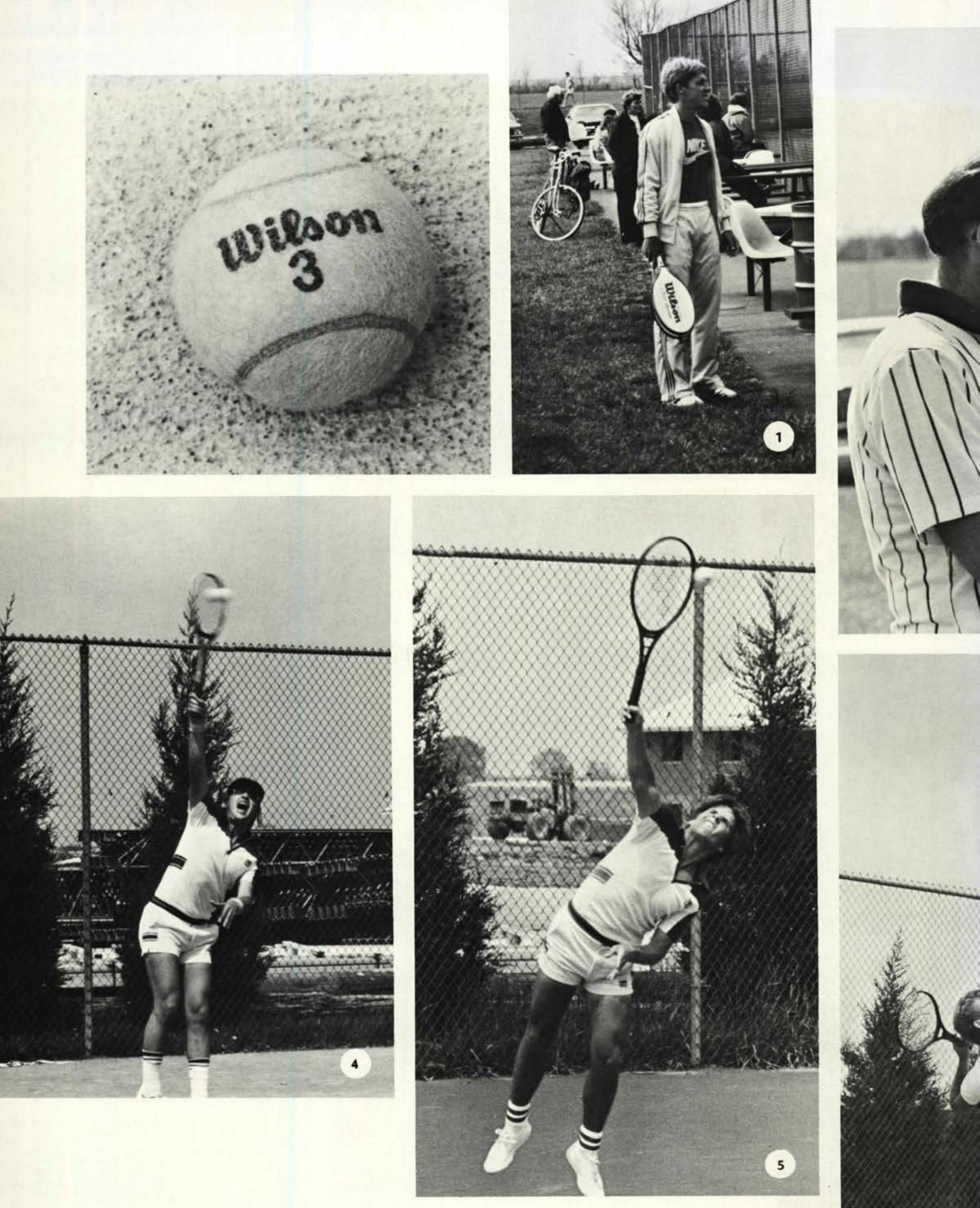

\section{8/Tennis}



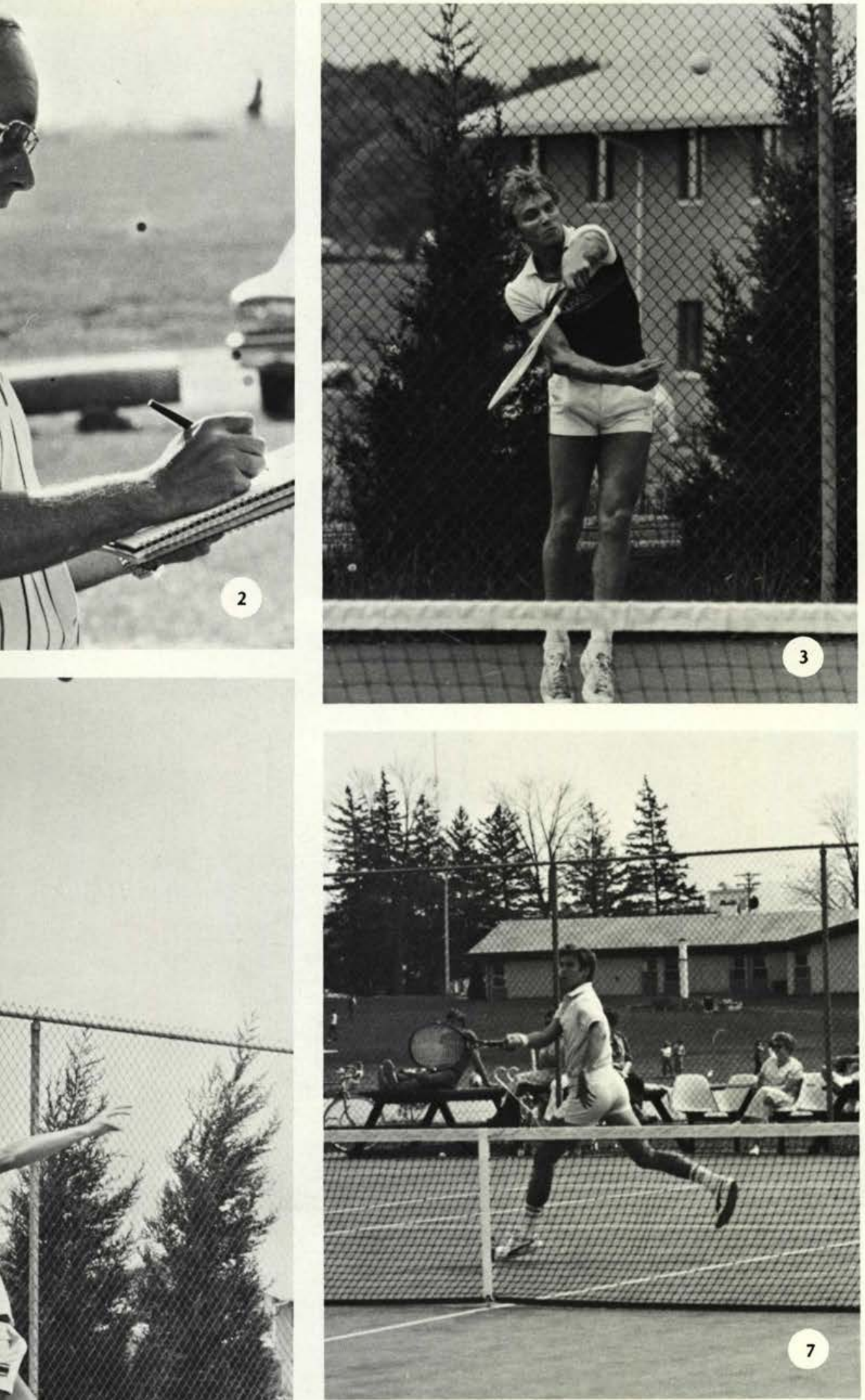

1. Curt Berger watches an ongoing match with interest. 2. Coach Murray Murdoch writes another win for his team. 3. Donnie Rawlings keeps his eye on the ball while serving. 4. Randy Wilson stretches for his serve. 5. Doug Wiseman concentrates on slicing his serve. 6. John Delancey winds up for another powerful serve. 7. Making it look easy, Ron Rost gracefully returns another volley. 8 . As Dale Schaecterle returns to the court, he muses, "How did I do that?"

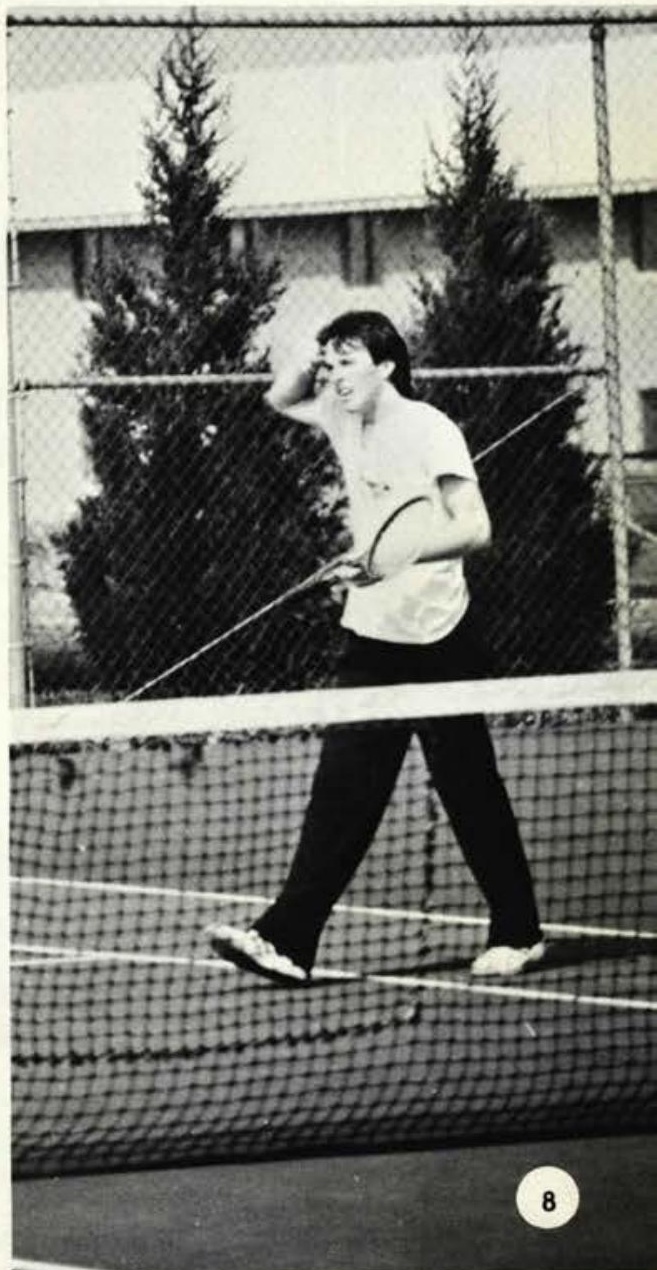




\section{Tennis}

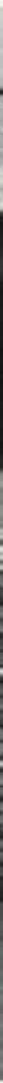

The Men's Tennis Team again posted a winning season. Dr. Murray Murdoch coached his team to an $18-2$ record. The team also won the MOC and NAIA District 22 tournaments for the ninth consecutive year and for the twelfth time of the last thirteen.

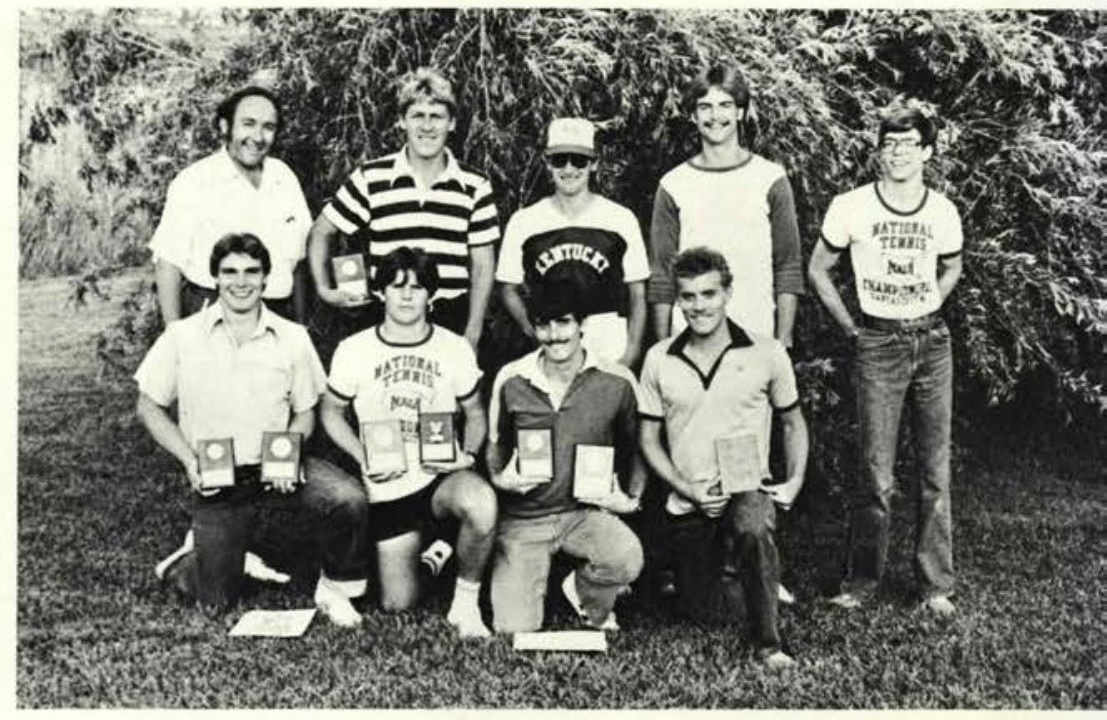

TOP PHOTO

Back row, left to right: Coach Murdoch, Dale Schaechterle, Curt Berger, Dan Murphy, Don Rawlings, Dan DeLancey, Ron Rost, Jeff Smith. Front row: Steve Lewis, Brian Medlock, John Snoke, Doug Wiseman, Randy Wilson, John Delancey, Tom Holwerda, Bob Smith.

\section{BOTTOM PHOTO}

Back row, left to right: Coach Murdoch; Curt Berger, All Conference; Randy Wilson; Dan Murphy; Bob Smith, Manager. Front row: John Snoke, All Conference, All Ohio, MVP, Most Improved; Doug Wiseman, All Conference, All Ohio, MVP; Dan Delancey, All Conference, All Ohio, Most Improved; John Delancey, All Conference, All Ohio. Not pictured: Dale Schaecterle, All Conference. 


\section{Tennis}

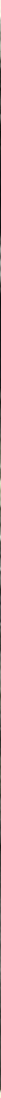

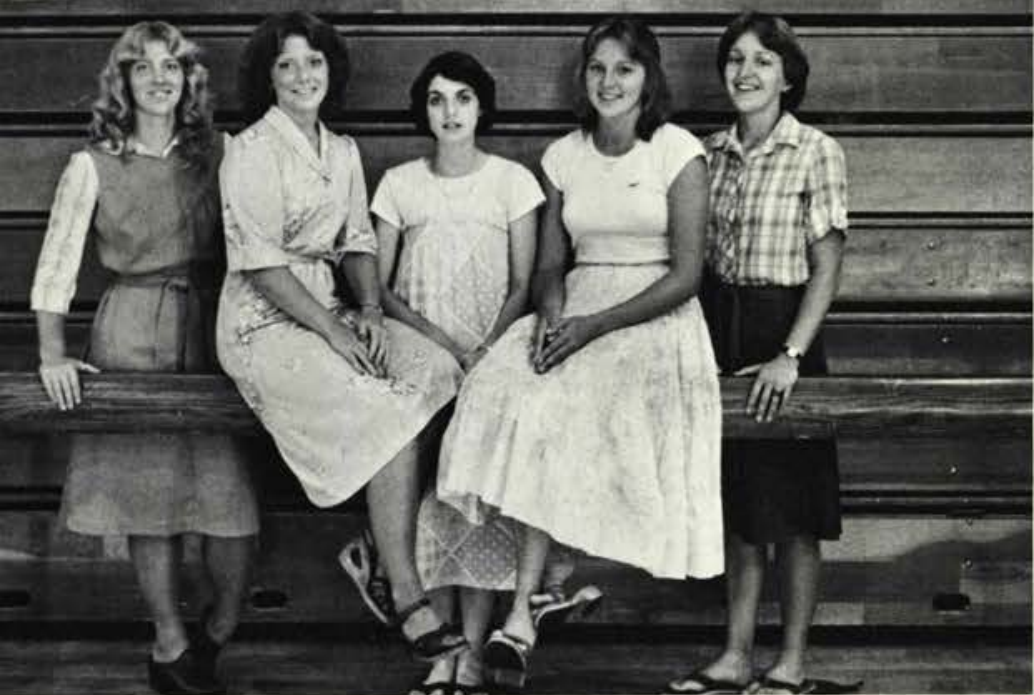

\section{TOP PHOTO}

Front row, left to right: Landa Penquite, Nancy Oscar, Glenda Maxey, Elaine Heyworth, Patti Harding, Beth Lindley, Jannell Decker. Back row: Rachel Scott (Manager), Connie Clemons, Cathy Boyd, Cheryl McMillan, Shawn Taylor, Colene Fox, Dr. Pamela Diehl (coach)

\section{BOTTOM PHOTO}

Colene Fox, Best Singles Record, Most Valuable Player; Cathy Boyd, Best Doubles Record; Landa Penquite, Most Valuable Player; Cheryl McMillan, Most Improved; Shawn Taylor, Most Valuable Player. Not pictured: Nancy Oscar, Best Doubles Record.
The Women's Tennis Team, coached by Dr. Pam Diehl, improved greatly over last year. The team as a whole improved as well as each individual member. Coach Diehl notes that their spiritual growth increased their enjoyment of the season. Four positions qualified for the state tourney but were eliminated early when they met the seeded players. 

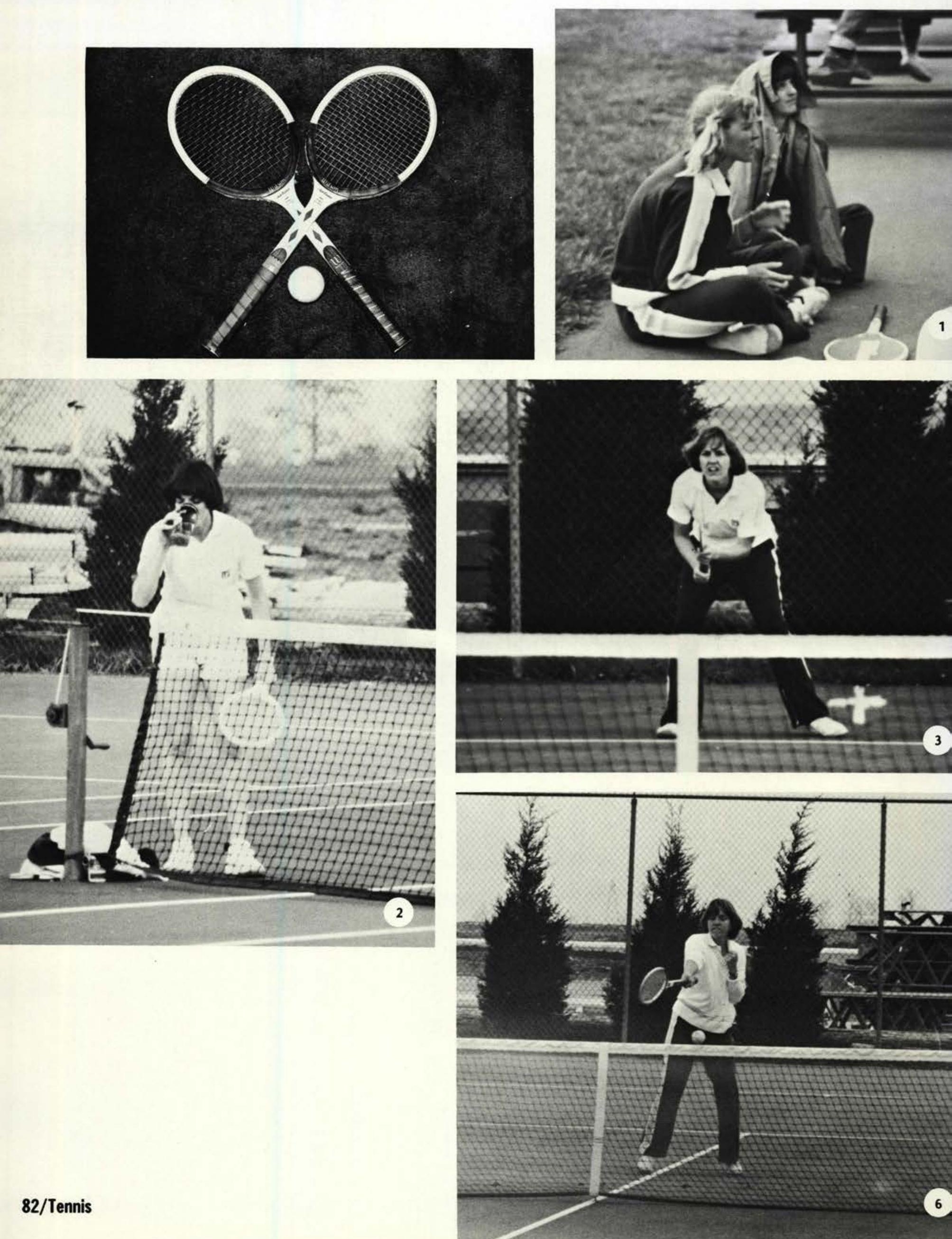

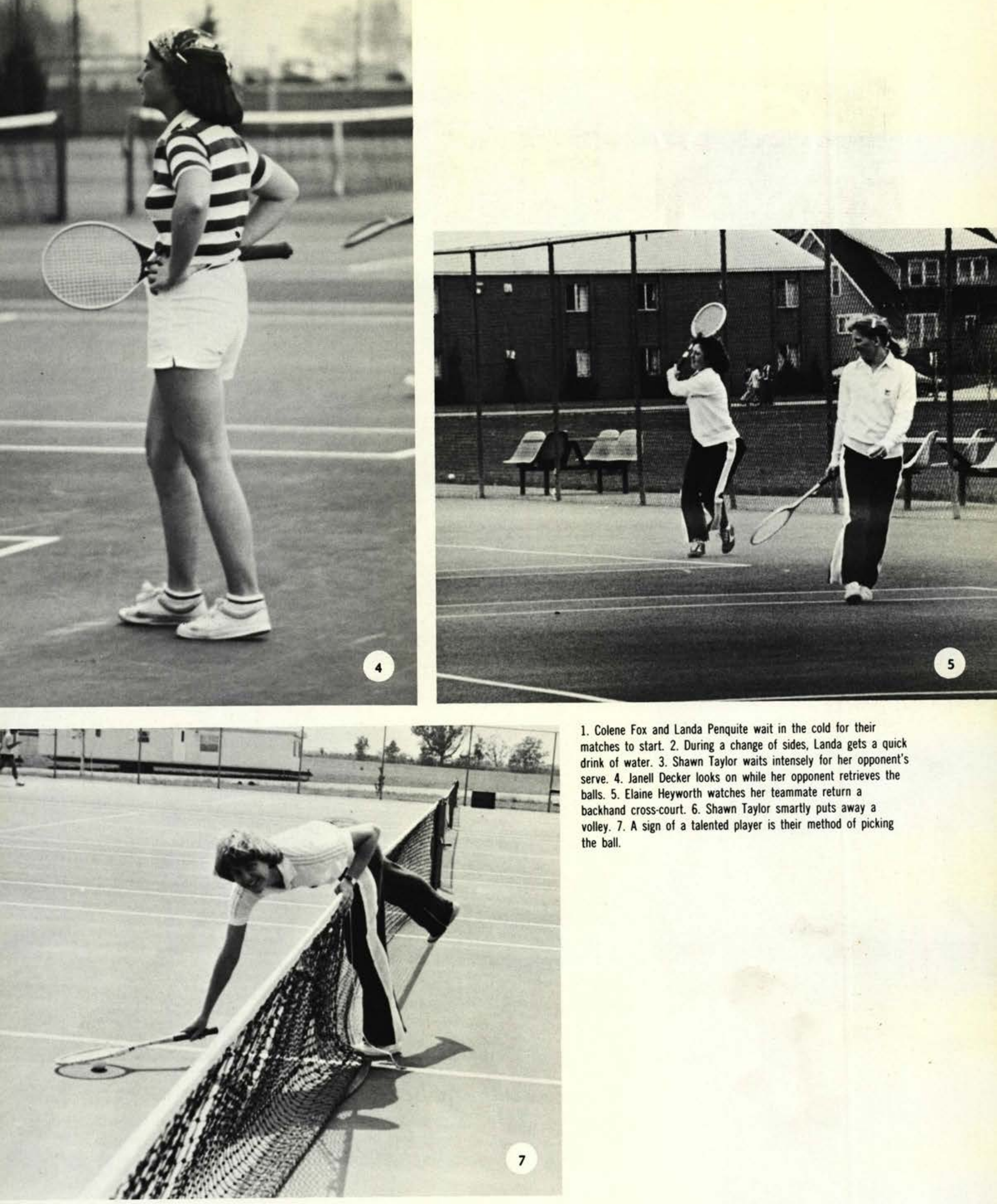

1. Colene Fox and Landa Penquite wait in the cold for their matches to start. 2. During a change of sides, Landa gets a quick drink of water. 3. Shawn Taylor waits intensely for her opponent's serve. 4. Janell Decker looks on while her opponent retrieves the balls. 5. Elaine Heyworth watches her teammate return a backhand cross-court. 6 . Shawn Taylor smartly puts away a volley. 7. A sign of a talented player is their method of picking the ball. 

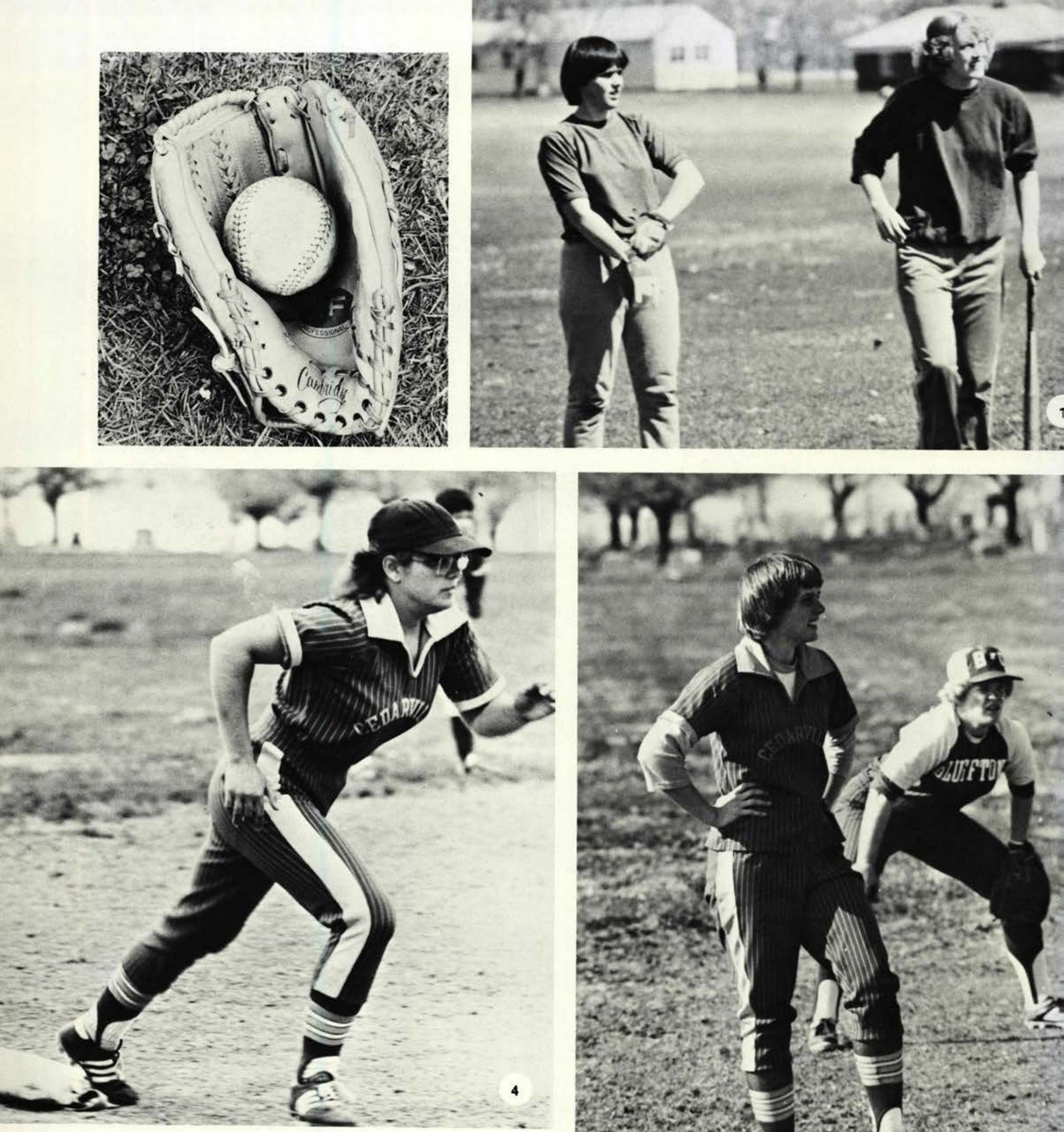


\section{Softball}

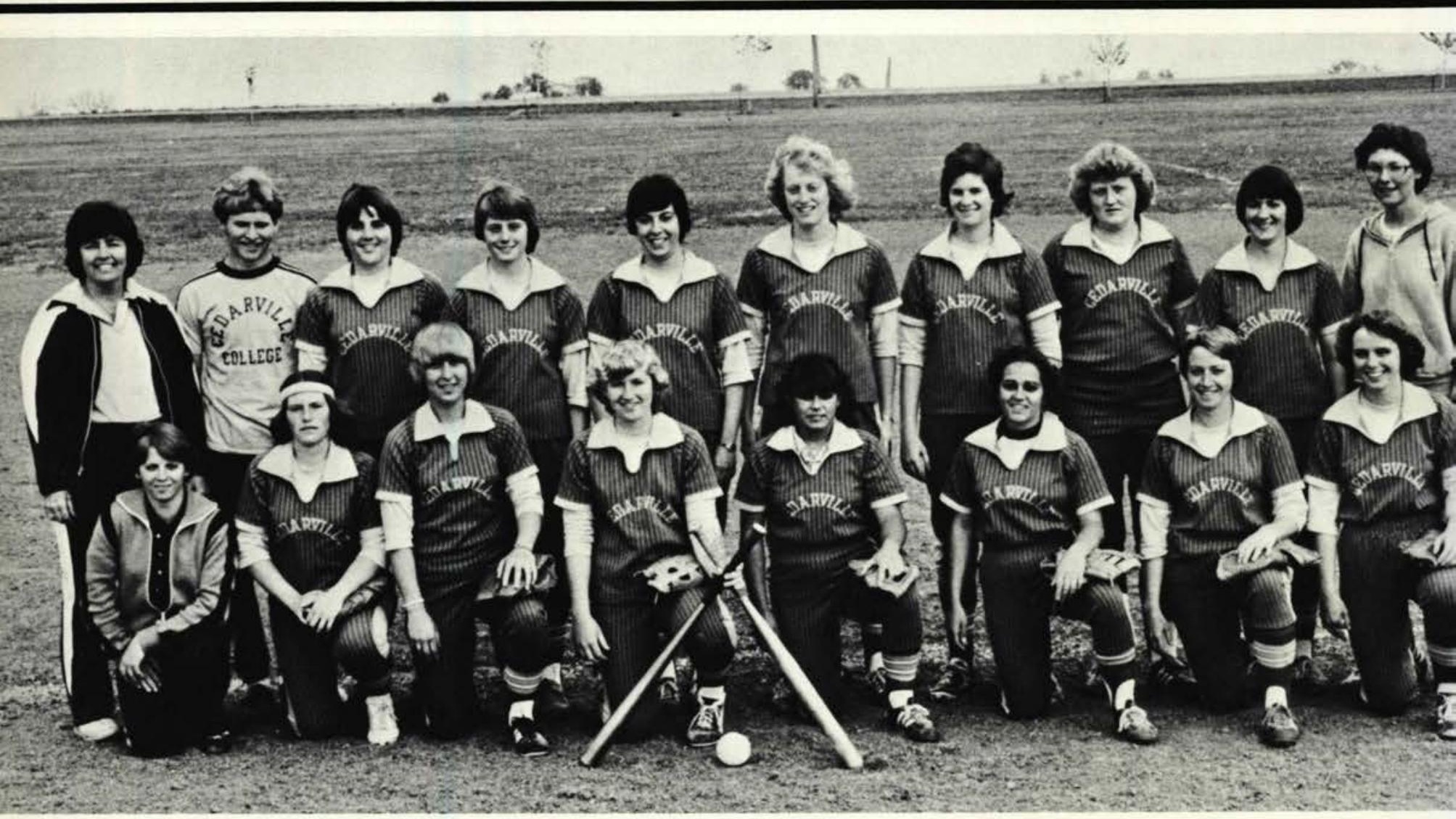

The Women's Softball Team posted a healthy record of $13-9$ this spring. Coach June Kearney attributed their success to more experience and better team batting; seven players finished with a 400 plus average for the season.

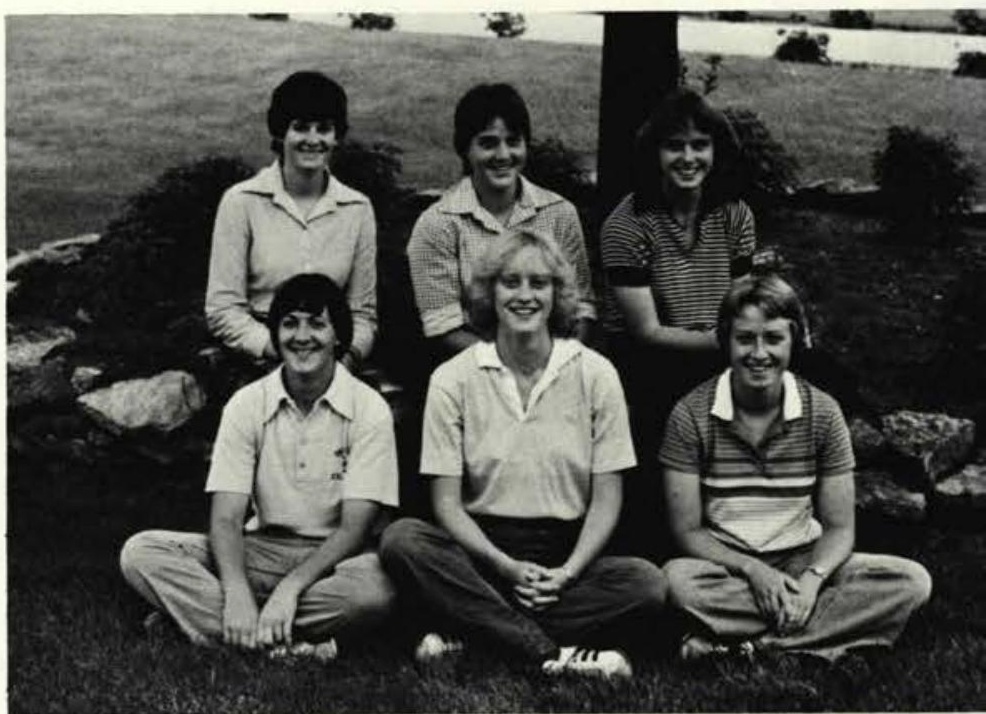

\section{TOP PHOTO}

First row, kneeling: Mary Stuenzi (Manager), Terri Aiken, Val Whisler, Jean Hatton, Darcy Morton, Marcy Morton, Susie Riegle, Luann Butler. Second row, standing: Dr. Kearney (Coach), Bill Burleson (Assistant Coach), Sue Kulp, Laurie Butler, Mel Bagg, Vicki Butler, Deb Fakan, Stacy Chasteen, Barb Vincent, Karen Lapp (Manager).

\section{BOTTOM PHOTO}

Barb Vincent, RBI Leader (33); Vicki Butler, All Tournament, Best Defense; Sue Riegle, Team Captain; Deb Fakan, Batting Champion (.483); Sue Kulp, Most Valuable, Team Captain, RBI Leader (33); Luann Butler, Most Improved. 


\section{Baseball}

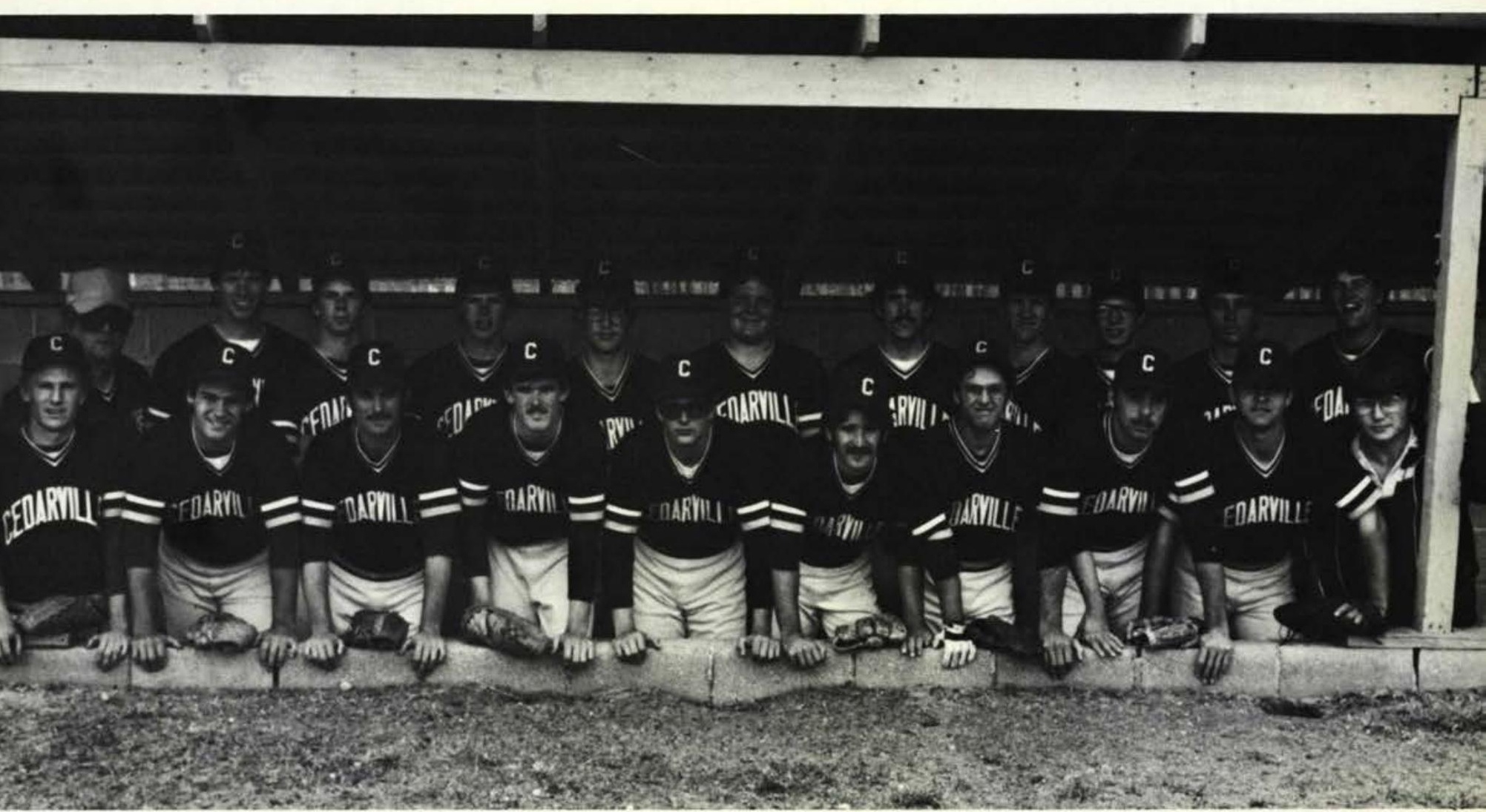

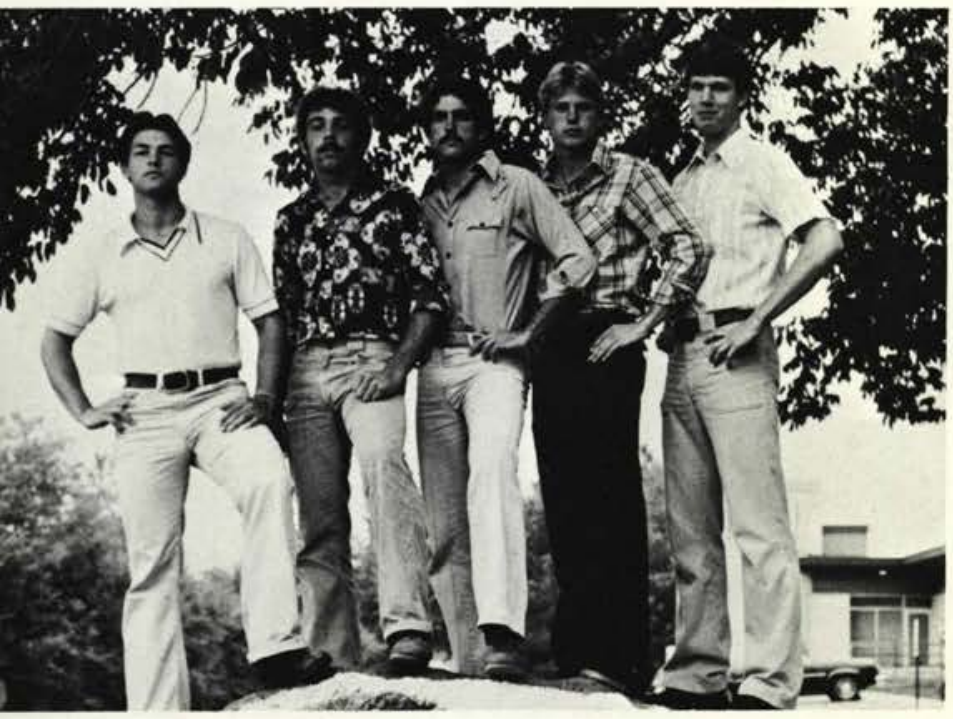

TOP PHOTO

Front row, left to right: Don Rickard, Rick Wilson, Jamie Darling, Tom DeYoung, Kurt Stewart, Bill Baldwin, Dan Fullmer, Ron Hobar, Marty Devine, Doug Sjoquist (Manager). Back row: Coach Clark, Greg Greve, Jeff Bowser, Ed Stewart, Steve Sadowitz, Rod Kane, Mark Mathews, Mike Smart, Dave Stewart, Brad Spradlin, Al Stewart. Not pictured: John Suciu, John Richmond.

\section{BOTTOM PHOTO}

Marty Devine, All District 22 NAIA, Most Valuable; Ron Hobar, All District 22 NAIA, All Conference, Top Batting Average; Mark Matthews, No Hit Game; Ed Stewart, All District 22 NAIA, Best Offense: Greg Greve, All Conference. Not pictured: Al Stewart, Best Defense.
The Baseball Team, under its new coach Keith Clark, posted a 16-16 record for the season. This team broke some records previously set: Hits 259, Doubles 42, Triples 21, and Home Runs 14. This year's team also had several individuals set new records. 

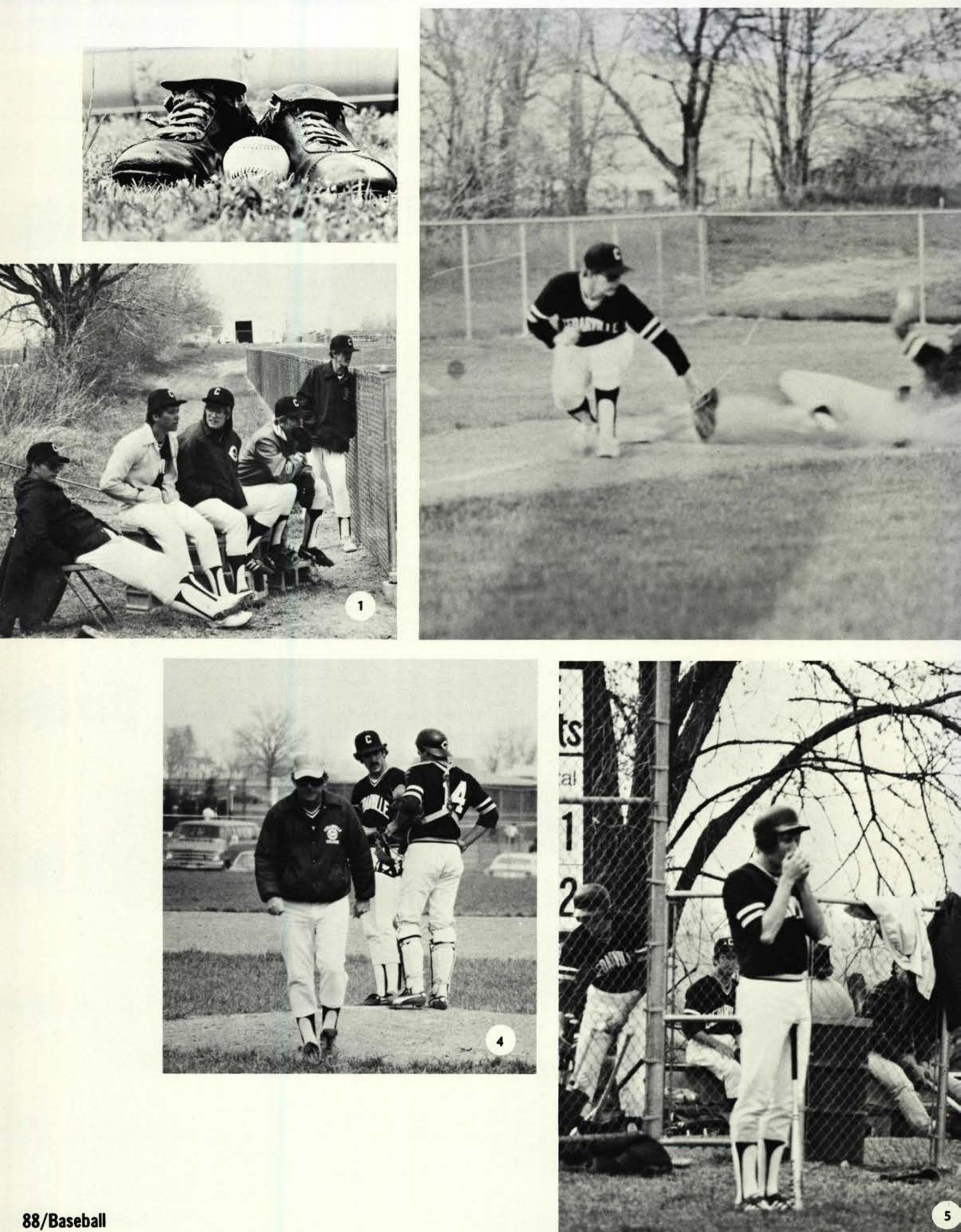


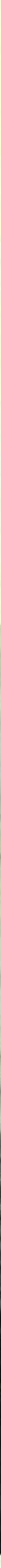

1. Sitting on the side lines can be the hardest part of a baseball game. 2. Cedarville's third baseman applies the tag. 3. Greg Greve concentrates on a meeting on the mound. 4. Coach Keith Clark leaves the mound after calming pitcher Mark Mathews. 5. Hot hands hold a hot bat! 6 . Ron Hobar receives congratulations from a teammate... 7. and accepts some pre-inning advice. 
1. Mark Brandt applauds as Jim Baldwin smiles over his putt. 2. Brian Johnson hits from a sand trap. 3. Brian Johnson mans the flag for a fellow golfer. 4. Doug Bauer heads for his clubs as the match progresses. 5. Mark Womach checks the lie for his next putt. 6 . Holding his club, Greg Molin heads for the next hole. 7. Using his putter, Doug Bauer eyes his next shot. 8. Jim Baldwin looks elated when returning from a match.
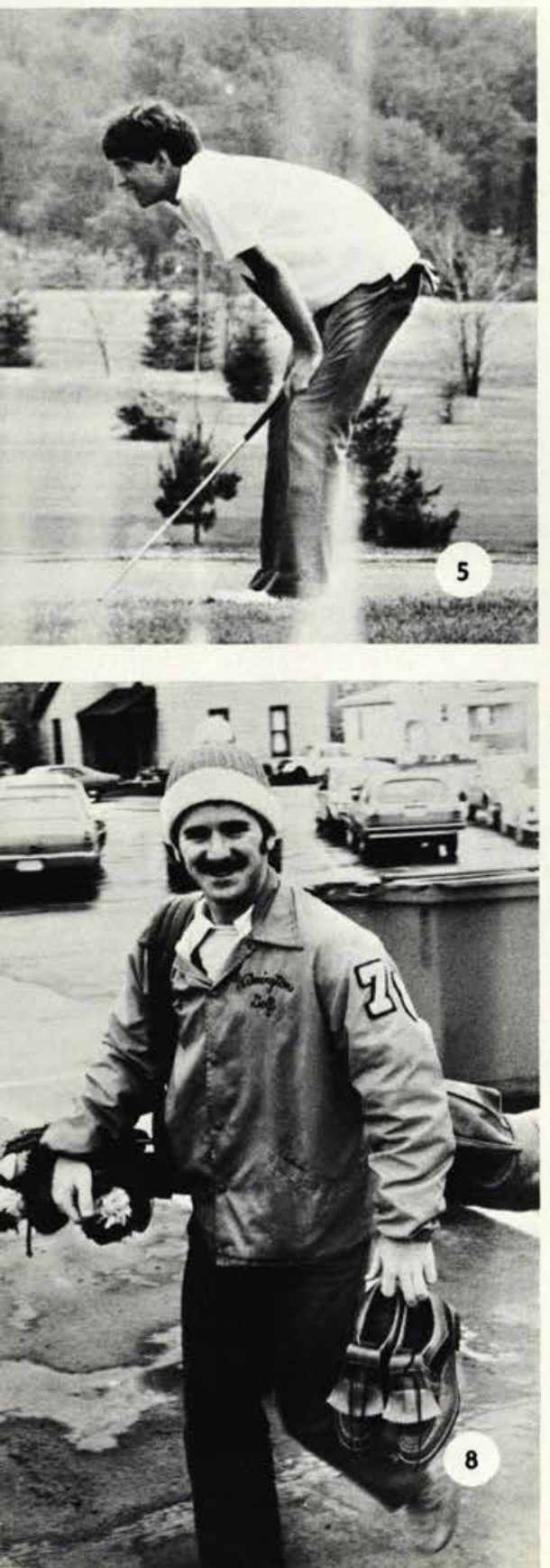

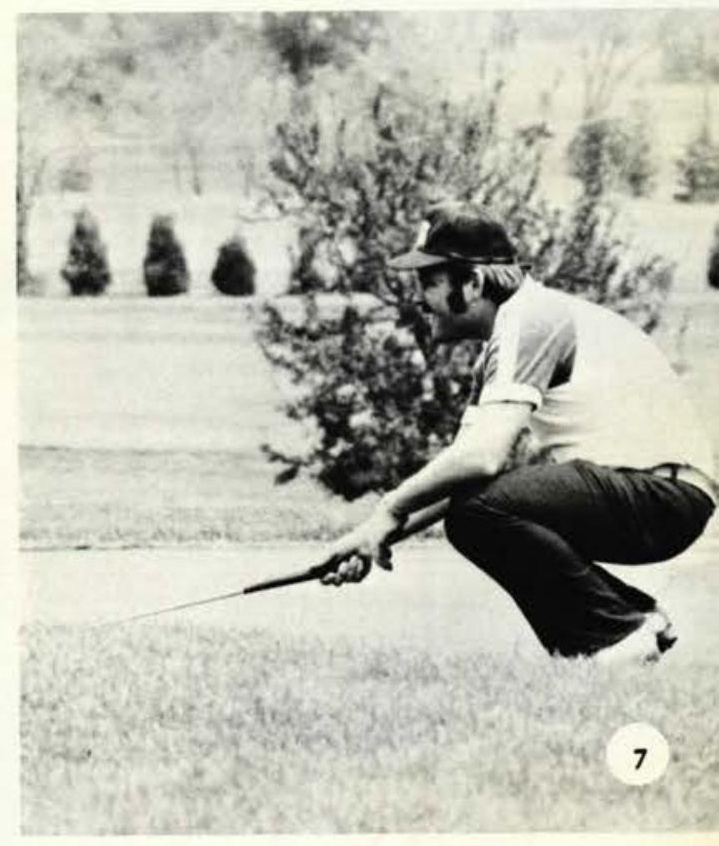




\section{Golf}

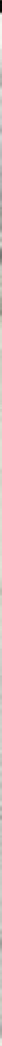

Cedarville College's golf team is coached by Dr. Allen Monroe. Even though the team's score was lower than previous years, the team ended with a $4-8$ record. According to Dr. Monroe, this is the first year the team had three men in the 70's, but the competition was much stronger, and thus the record.

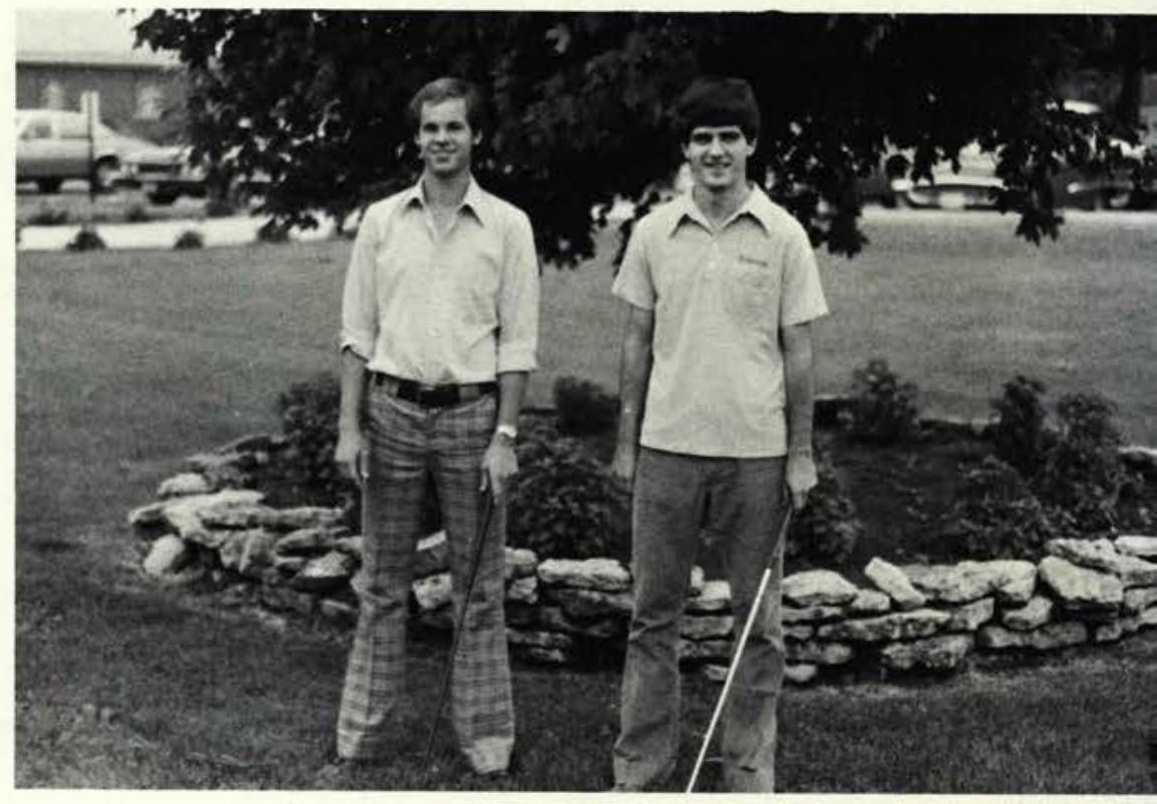

LEFT PHOTO

Left to right:Doug Bauer, Jim Baldwin, Mark Brant, Mark Womack, Brian Johnson, Ken Gentzler, Greg Molin, Coach Allen Monroe.

RIGHT PHOTO

Brian Johnson, Most Improved; Mark Womack, All-NAIA. 


\section{Track}

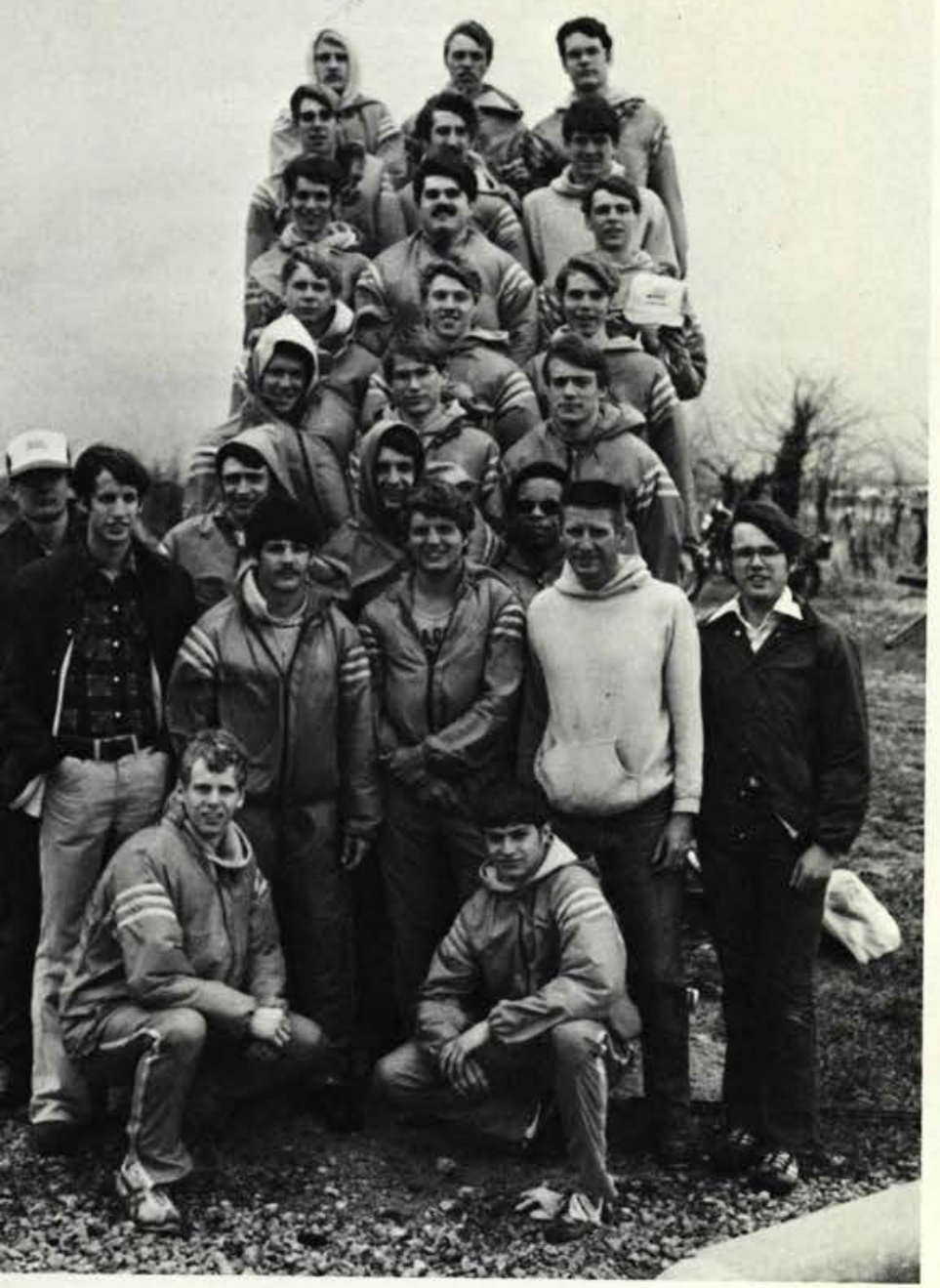

track team had a very successful year this year. The coach, Elvin King, states $t$ they finished strong after a slow start. They took third of twenty two in the ¿AA and second in the MOC and NAIA district 22. Mark Peters sets a new school ord in the Pole Vault at $15^{\prime} 6$ and $3 / 4^{\prime \prime}$.

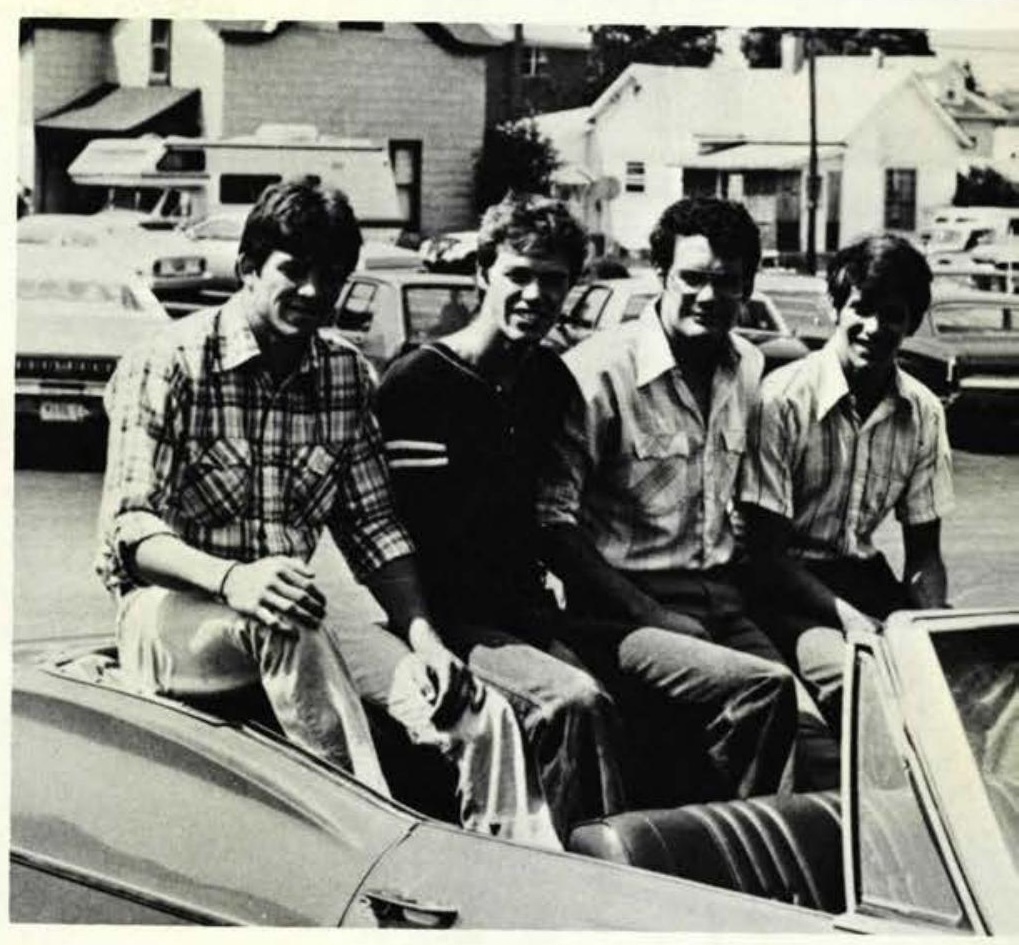

\section{TOP PHOTO}

First row, left to right: James Spurrier, Mark Bubel, Tom Seymour. Second row: Dave Treese, Mark Norman, Gary Yeager. Third row: Tom Yater, Rich Crist, Nate Hunter. Fourth row: Craig Herl, Tim Lord, Bob Boynton. Fifth row: Dave Black, Jon Seldon, Matt Parman. Sixth row: Coach Jon McGillivray, Rick Hickman, Dale Shaw, Luke Mason. Seventh row: Ryan Spencer, Phil Brumbaugh, Mark Peters, Coach Elvin King, Ken Kauffman (Manager). Kneeling: Dean Johnson, Mark Mills.

\section{BOTTOM PHOTO}

Gary Yeager, All-American; Mark Bubel, All-American, All-Conference, All-District; Tom Seymour, All-Conference, Most Valuable; Tom Yater, Captain. Not pictured: Mark Peters, All-Conference, All-District, Most Valuable. 

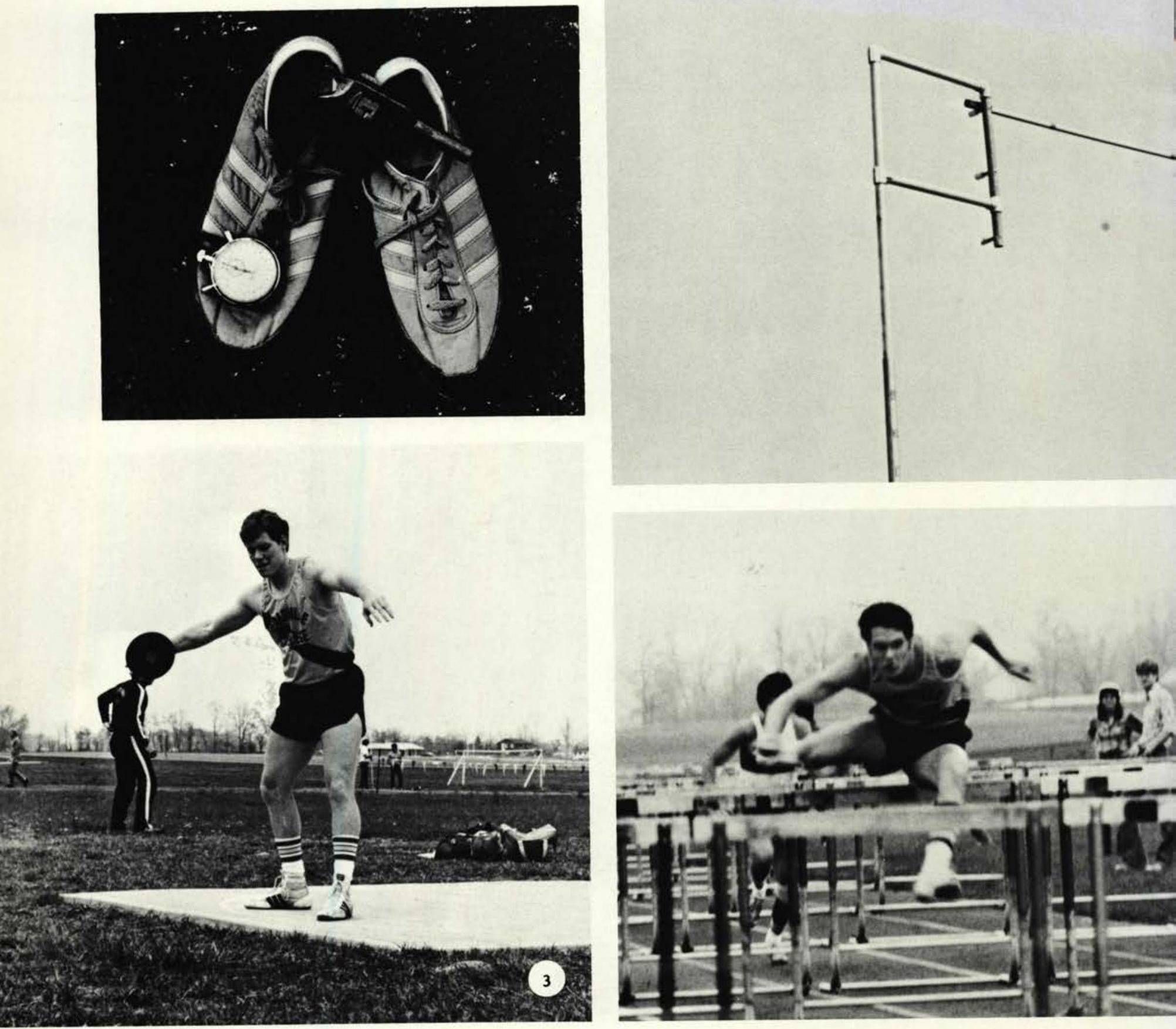

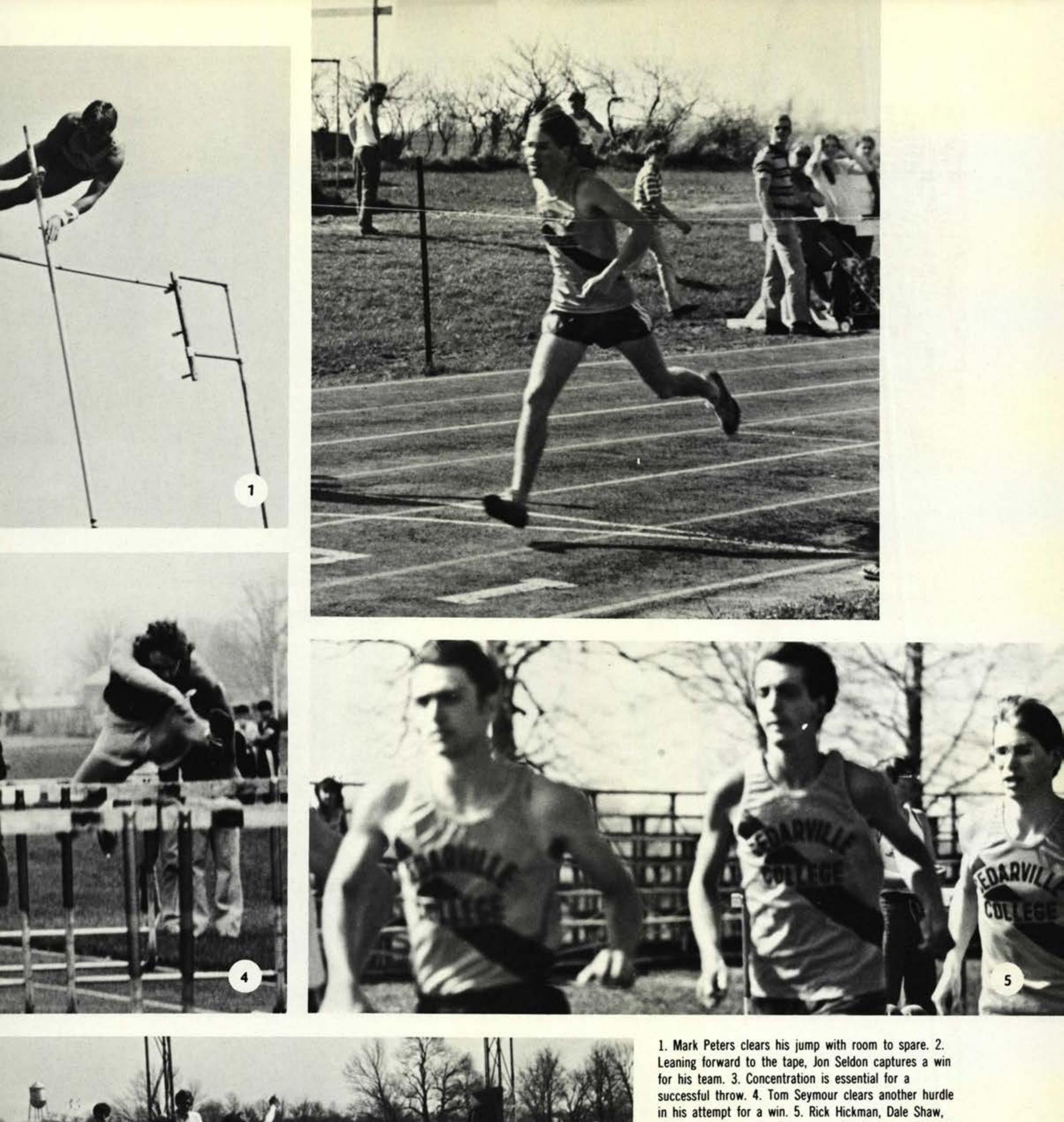

1. Mark Peters clears his jump with room to spare. 2 Leaning forward to the tape, Jon Seldon captures a win for his team. 3. Concentration is essential for a successful throw. 4. Tom Seymour clears another hurdle in his attempt for a win. 5. Rick Hickman, Dale Shaw, and Jon Seldon make distance running look easy. 6. Rick gauges the distance needed to take the lead. 7. The water hole is one hazard that makes the steeple chase a challenge. 


\section{The Sound Of Music}

The Village Players and MENC collaborated in an outstanding production of "The Sound of Music" on May 8, 9, and 10 . Involving a cast of over seventy-five members, the play was directed by Mr. Rebecca Baker with Mike Brumbaugh serving as assistant director and Charles Pagnard serving as orchestra director. The performance centered upon the captivating story of the tender romance between the spirited Maria Rainer and the overwhelming Captain Von Trapp. The entire cast is to be commended for its ability to recreate the tense, conflicting emo. tions of an Austria affected by the growing threat of Nazi takeover.

1. Maria Rainer (Cindy Ulmer) is the new nanny for the Von Trapp children. 2. Maria and Captain (Phil Stoner) share an intimate moment in song. 3 . The Von Trapp children must stand at attention for inspection by their father. 4. Elsa, played by Trudy Tangblade, and Max, played by Jon Harvey bring a lighter side to the play. 5. Liesl (Deb Gilbert) and Rolf (Cal Clark) are alone at last. 6. The children wish for Maria to return. 7. An angry Liesl knows that her friendship is over with Rolf. 8. The Captain takes command of the situation. 9. Captain Von trapp and his "wife to be". 10. The party guests of the Von Trapps are waiting to be served dinner. 11. Frau Schmidt (Stacy Towle), and Franz (Ken Andrus), are welcoming the party guests.
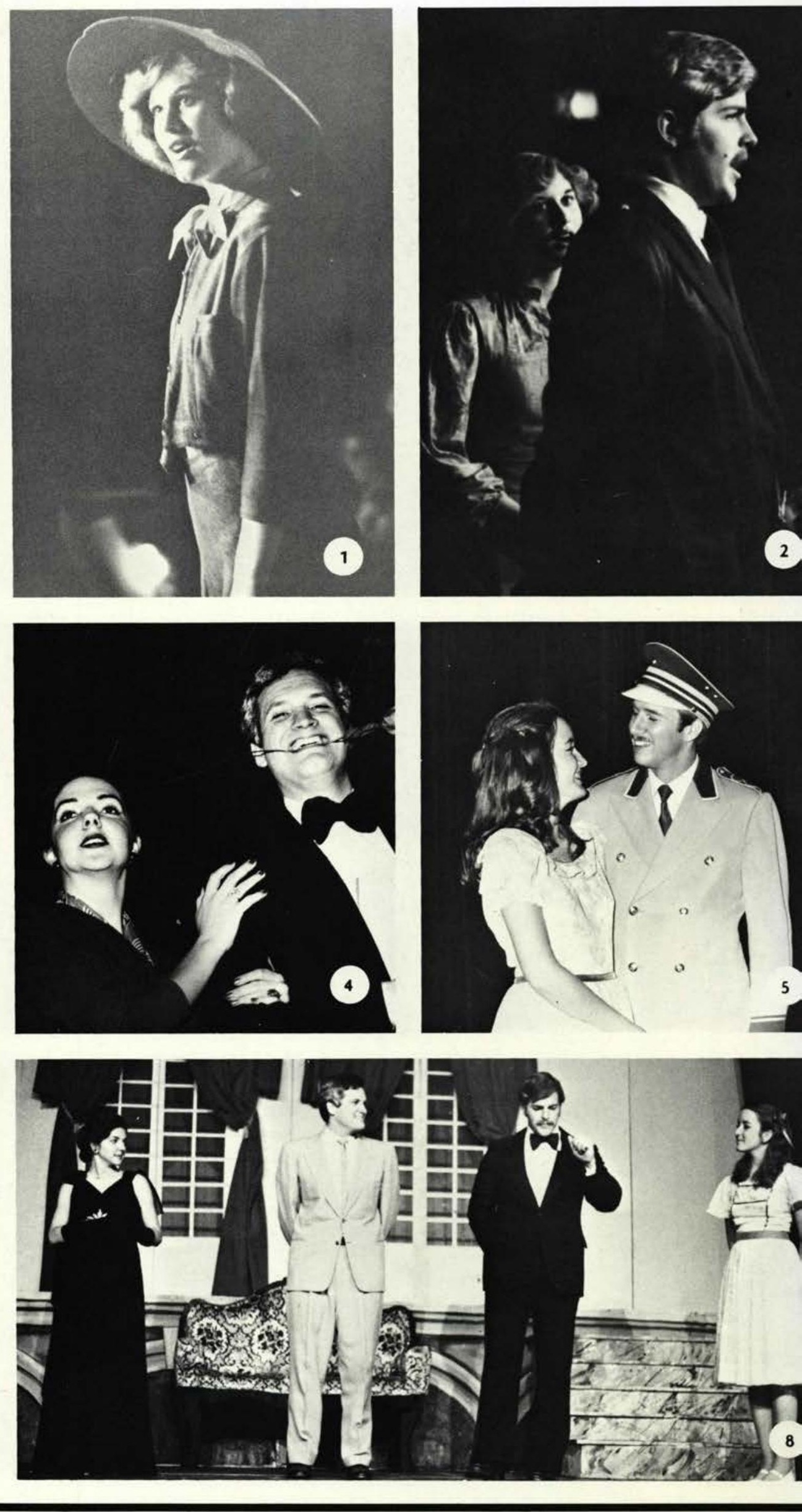
Cast: MARIA RAINER - Cynthia UImer, CAPTAIN GEORGE VON TRAPP - Philip Stoner, THE MOTHER ABBESS - Janis Traphagen, SISTER BERTHE - Diana Crabtree, SISTER MARGARETTA - Teresa Henney, SISTER SOPHIA - Marcia Mallare, FRANZ - Ken Andrus, FRAU SCHMIDT - Stacy Towle, VON TRAPP CHILDREN - LIESL - Deborah Gilbert, FRIEDRICH - Bruce Starks, LOUISA - Margaret Wheeler, KURT - Brian Brock, BRIGITTA Elizabeth Wheeler, MARTA - Johanna Wheeler, GRETL — Abigail Wheeler, ROLF GRUBER - Cal Clark, ELSA SCHRAEDER - Trudy Tangblade, MAX DETWEILER - Jon Harvey, URSULA - Colleen Engelmann, HERR ZELLER - Byron Major, MRS. ZELLER - Kristine Karsian, BARON ELBERFELD - Gene Wyse, BARONESS ELBERFELD - Anna Johnson, A POSTULANT - Jodi Ellington, ADMIRAL VON SCHREIBER - Mark Baugh

1. A Nazi officer tries to persuade Captain Von Trapp to take a position in the army. 2. The groom is awaiting his bride. 3. The wedding party. 4. Frau Schmidt tries to outwit a Nazi officer. 5. The Mother Abbess, played by Janice Traphagen, consoles Maria. 6. Maria's long awaited moment finally arrives. 7. The Von Trapp Family Singers perform for an Austrian concert. 8. The entire cast from "The Sound of Music".
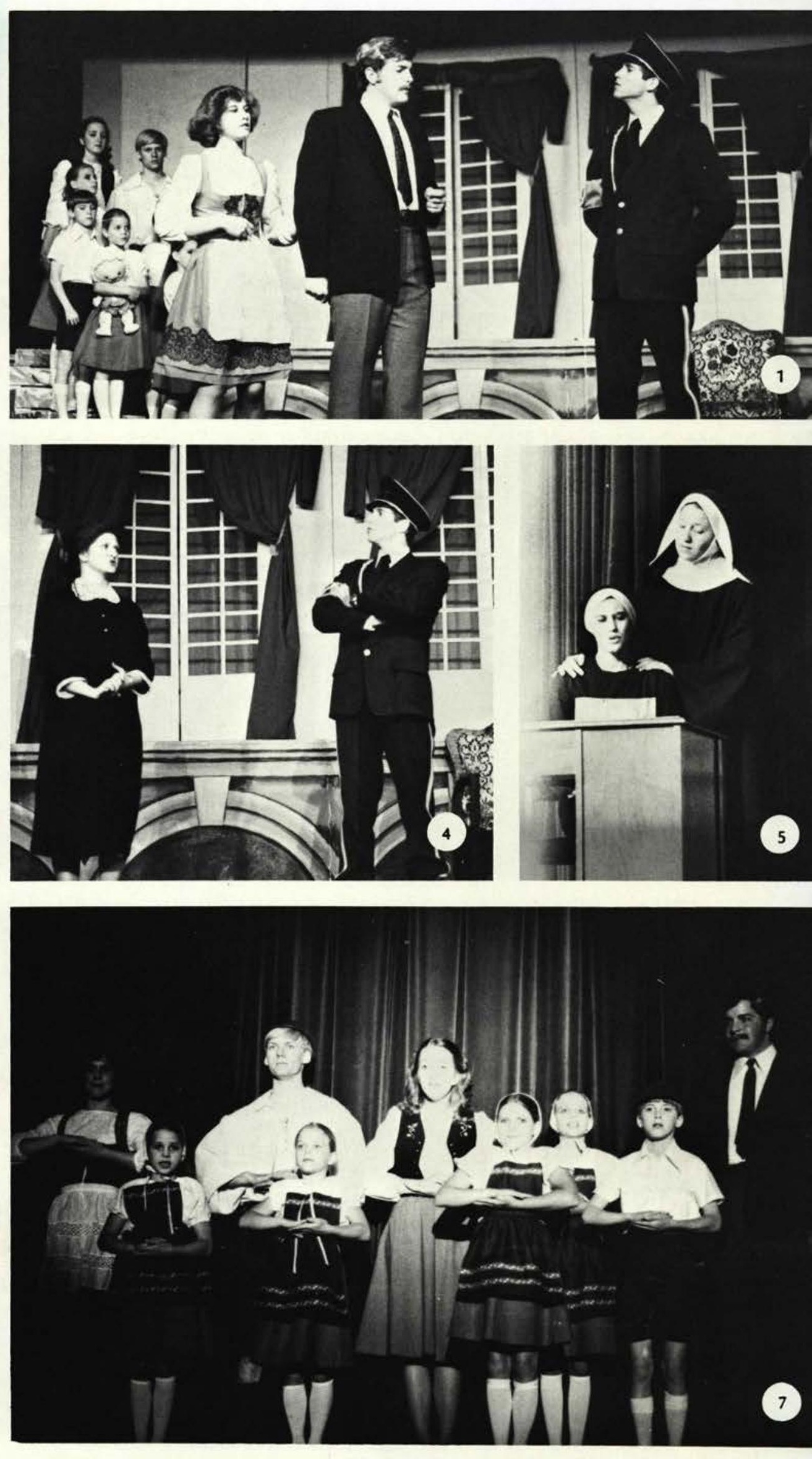

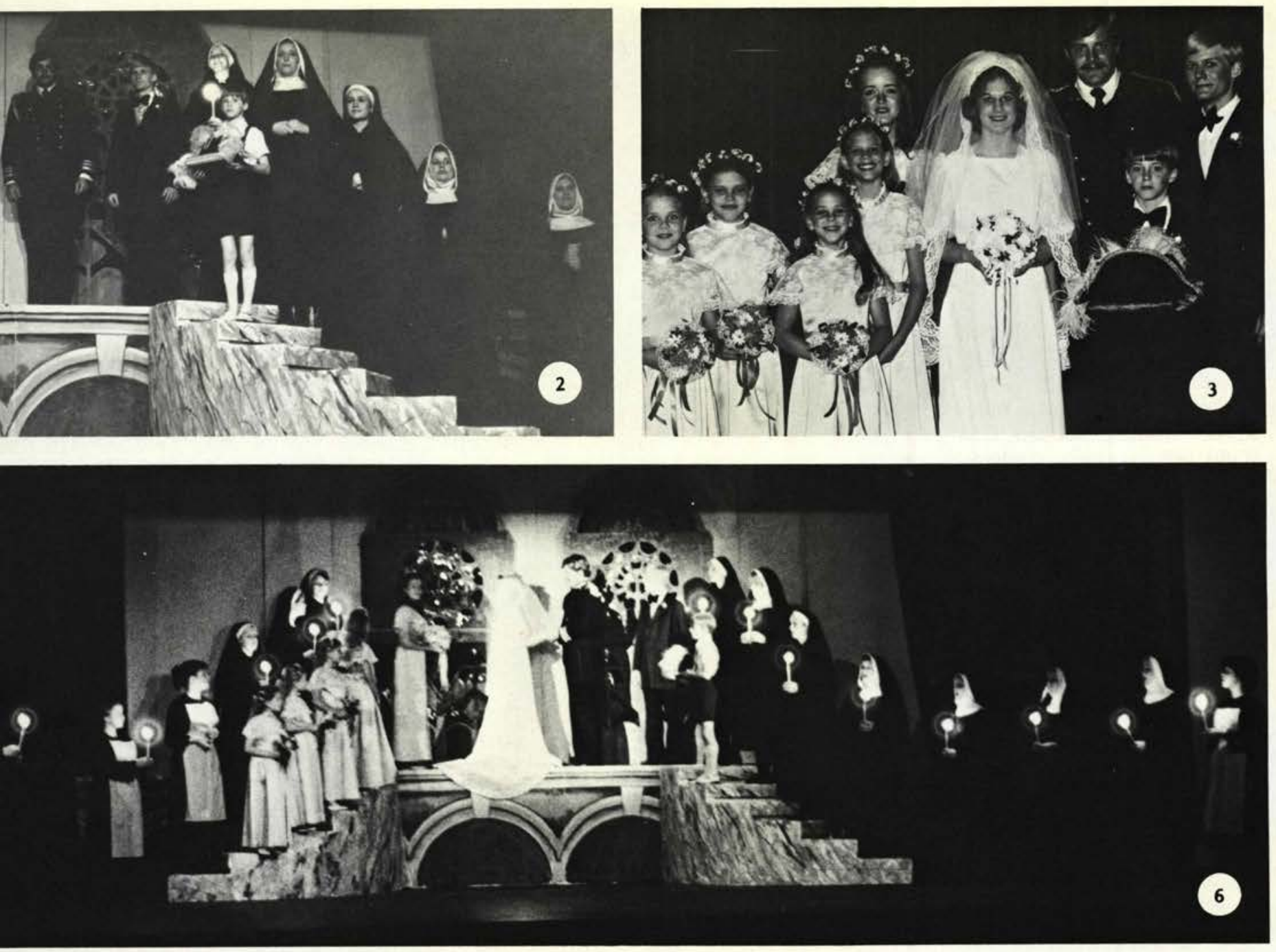

$$
\therefore<
$$

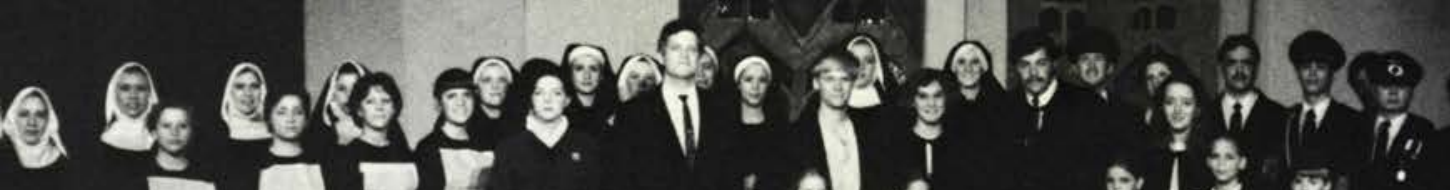

$$
\text { V.5. }
$$

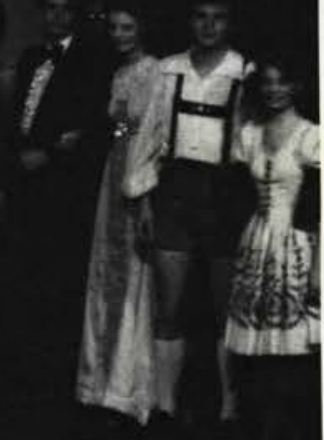

8 


\section{Cedarday Weekend}

The Honors Day Chapel, which started off Cedar Weekend, was held on May 2. The students who had obtained the Dean's Honor List with an average of 3.75 were given recognition as well as the students who had received an average of 3.25 or above and were placed on the Dean's List. The outstanding student of each major was given an award.

1. Karen Crawford struggles to get away from her "friends."

2. Ed Smith receives the Clara Mazdle Milner Award.

3. The Honors Award recipients are, left to right, front row: Tamera Kirby, Linda Hall, Janis Traphagen, Mrs. Terry Sparks, Lisa Meharry, Pat Michalski and Linda Grafton. Back row: Ed Smith, Tim Ronk, John Duff, Dr. Allen Monroe, and Paul Ware.

4. Rick Matter prepares a valiant knight for a water fight battle.

5. Dave Lewis is about to get his just deserts.

6. The Senior Broadcasting Award is given to Linda Grafton.

7. With coaches like the Grosh's, who else but Tim Ronk could receive the English Department Award?

8. The George Boyd Accounting Award brings a smile to the face of Tammy Kirby.

9. May the best, or the wettest man win. 10. John Duff presents the Faculty Member of the year award to Dr. Allen Monroe of the Social Science Department and

11. the Staff Member of the Year Award to Paul Ware.

12. With a G.P.A. of 4.00 , Mrs. Pat Michalski receives the highest honor of her class.
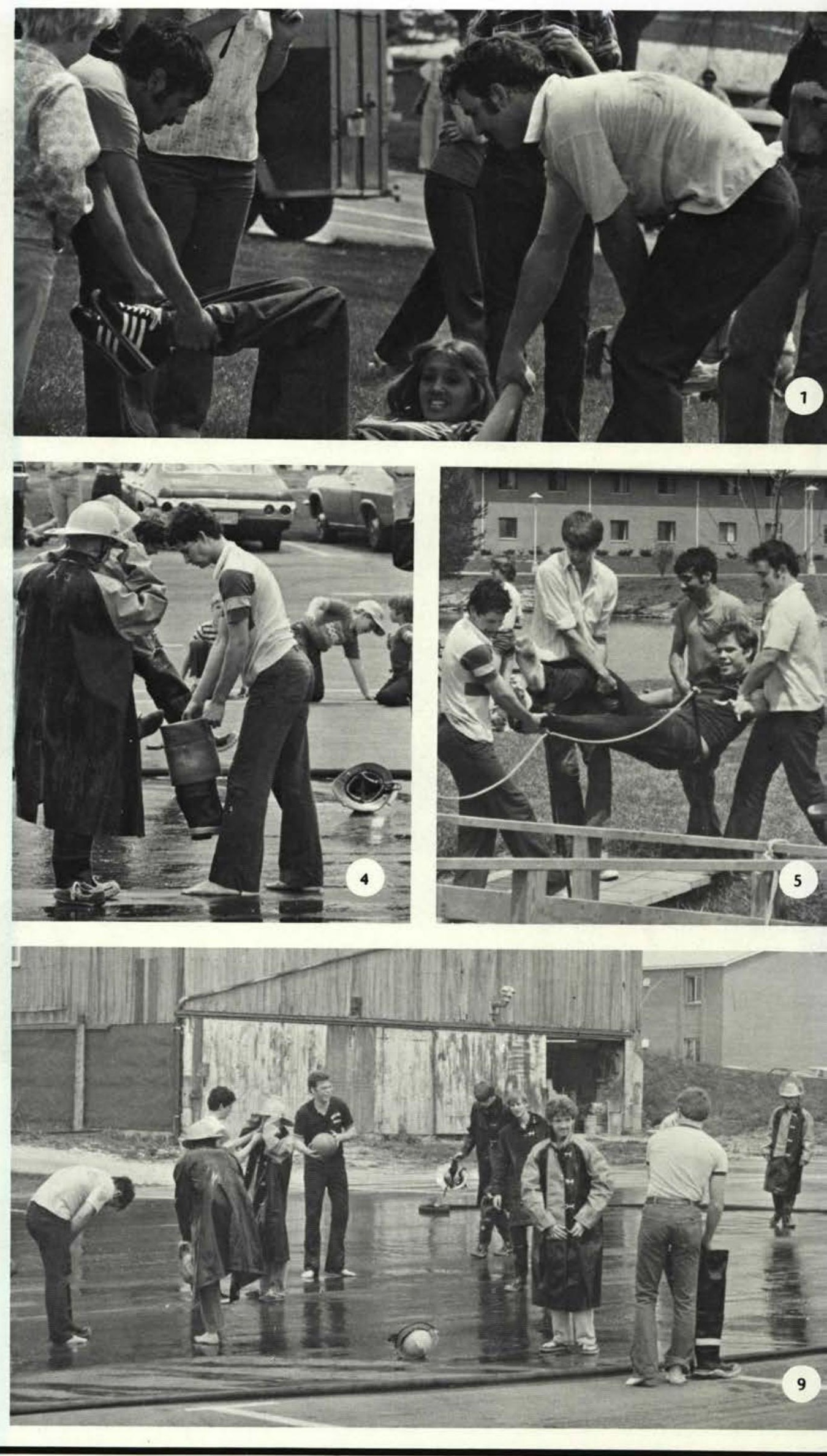

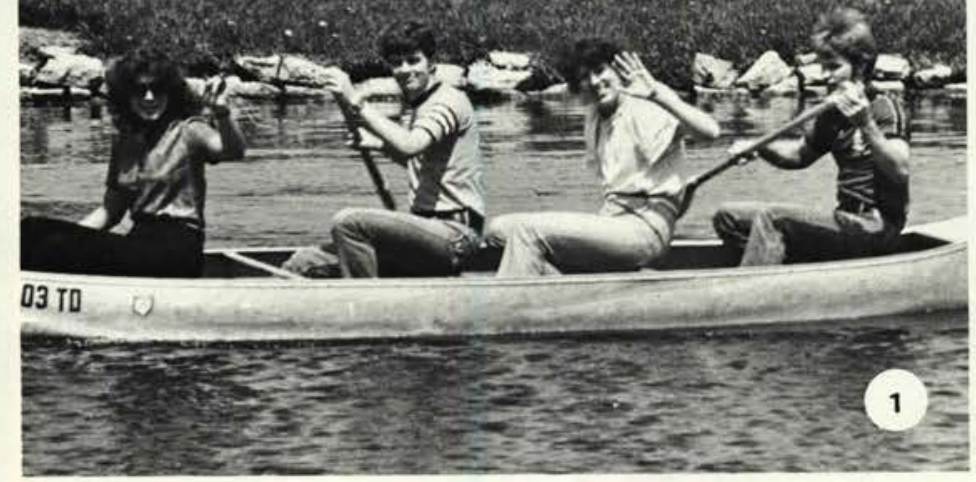

sterese

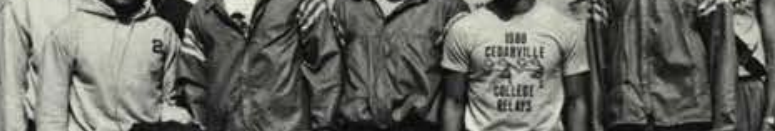

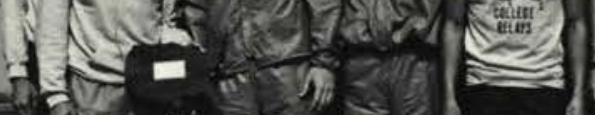
(3)
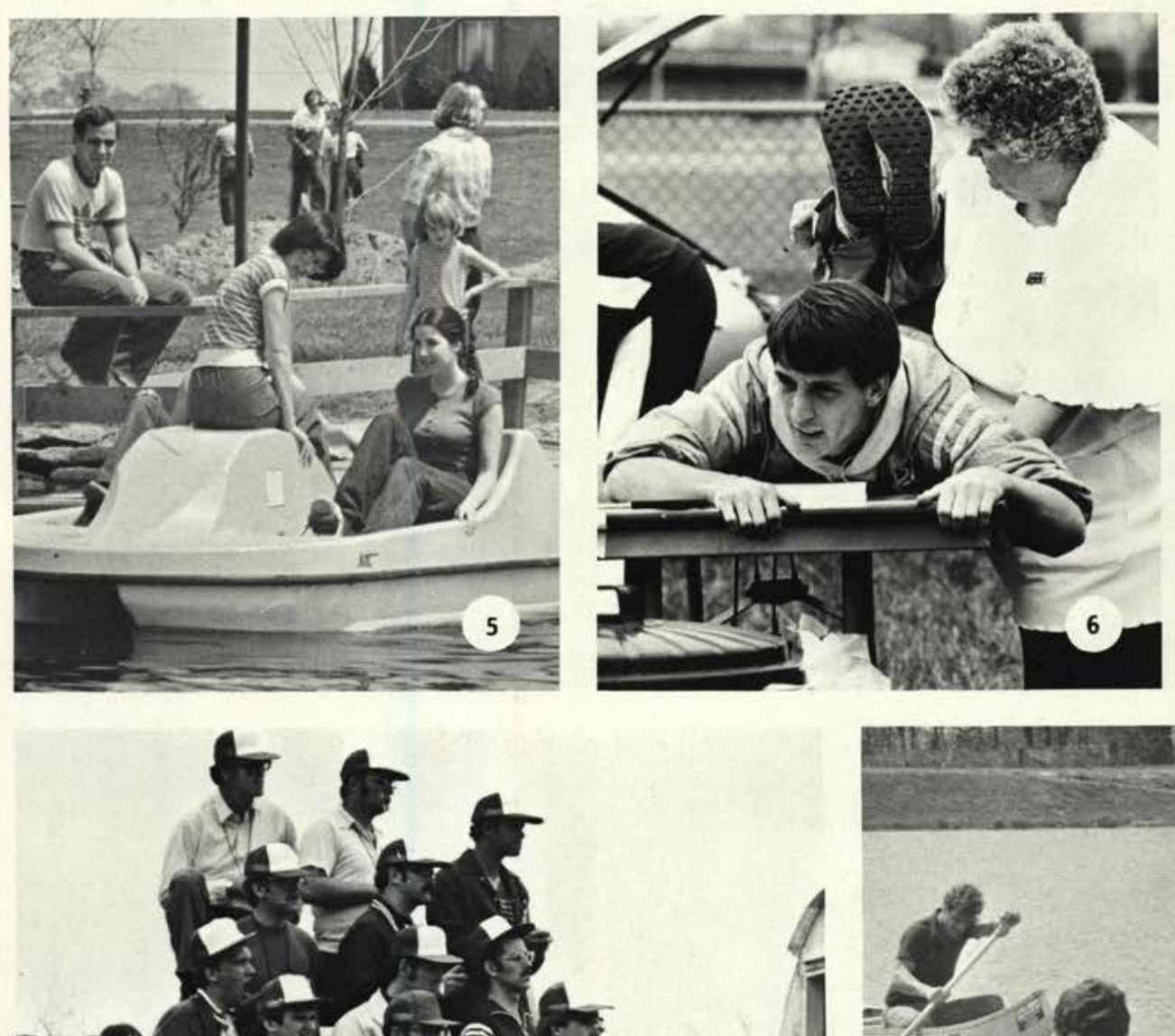

cer in tans

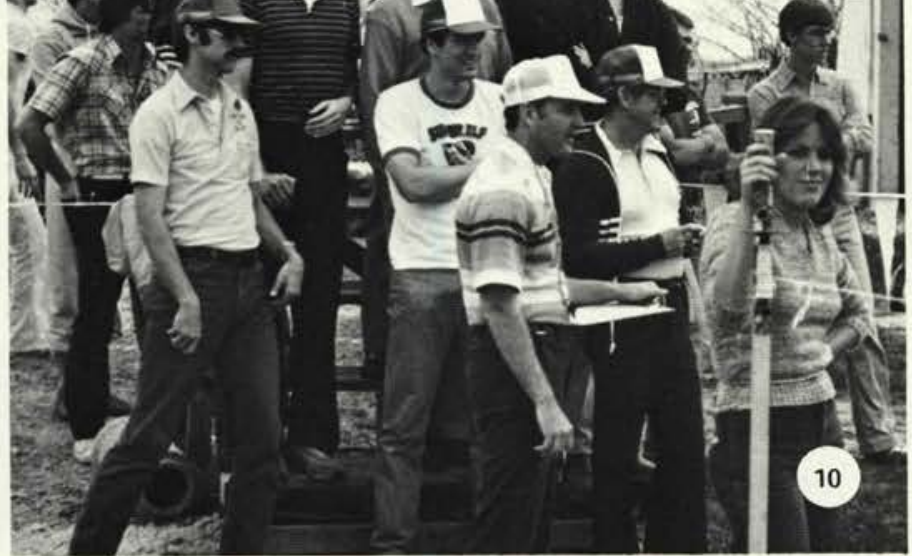

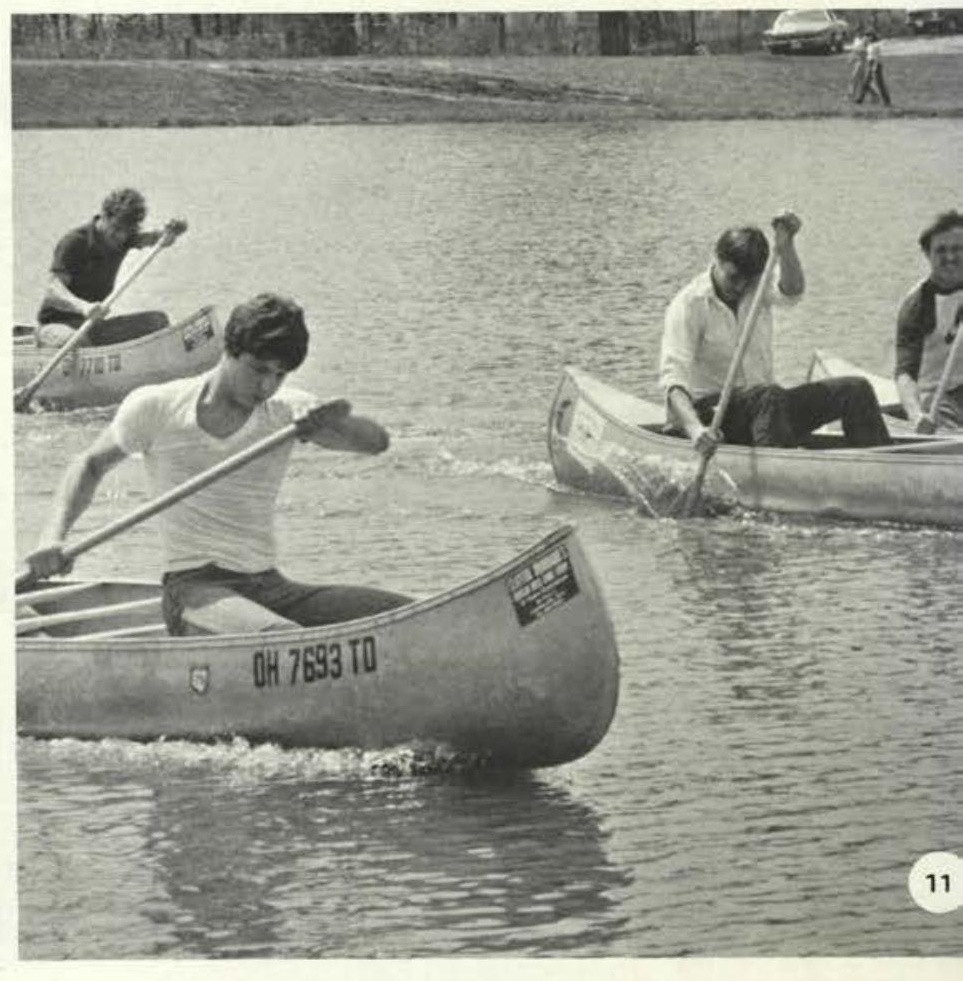




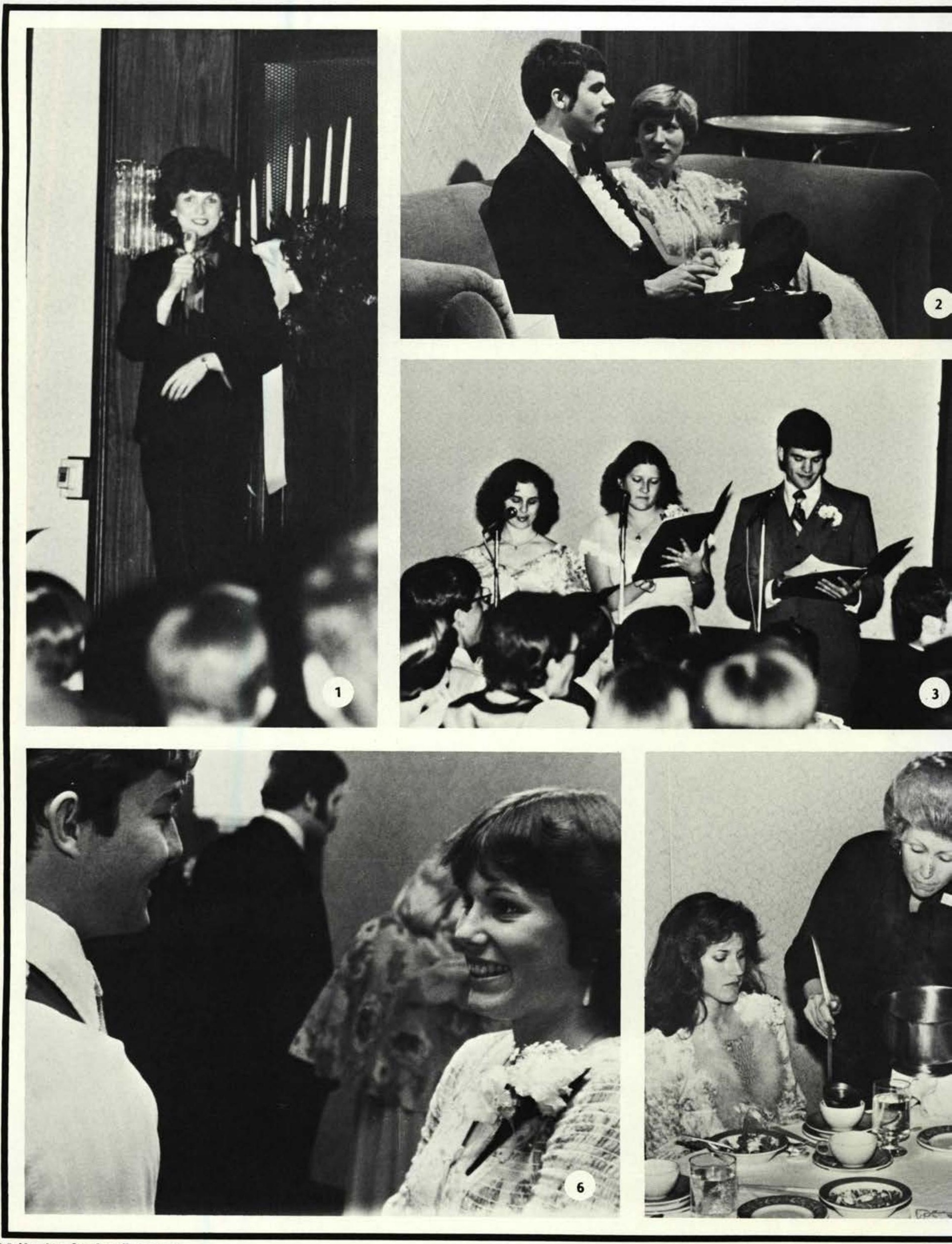




\section{Senior Chapel}

The Seniors presented a chapel service as a way of saying goodbye to the Cedarville College student body. Individual members of the class spoke about their personal, spiritual development during their college years. The Seniors expressed their gratitude to Mr. and Mrs. Wesley Baker, class advisors, and to Craig Colas, Class President.

\section{Pat}

On May 8, Pat Bates was recognized for her six years as Cedarville's outstanding Dean of Women. "Pat Bates Day" was initiated by Alpha Delta Omega, a woman's society, with many other Cedarville girls joining in the tribute. Activities honoring Dean Bates throughout the day included a special recognition in chapel.

1. Keith Willhite thanks Craig Colas for his four year leadership as Class President. 2. Mrs. Dixon, Mrs. Howell, Ma Printy and Pat enjoy the attention. 3. Pat Bates is surrounded by her admirers. 4 . These Senior class members wait for their turns to speak. 5 . Senior Chapel included special music from .... the Seniors! 6. Pat's roommate, Faith Whitelaw, and Tammy Kearbey enjoy the banquet held for Pat in Englewood, Ohio. 7. As a duet, Steve Swayze and Roger Michel contribute to the program. 8. "We love you, Pat Bates." 9. In a touch of aristocracy, Chauffeur Mark Warren escorts Pat from her limosine.
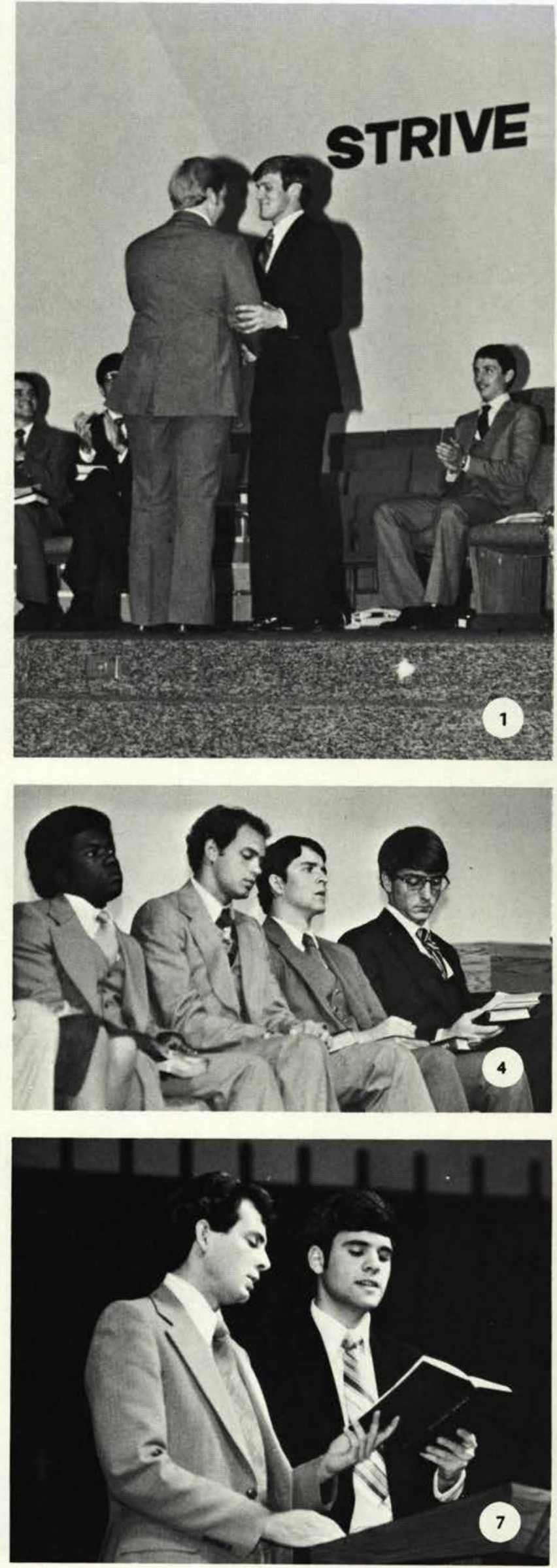
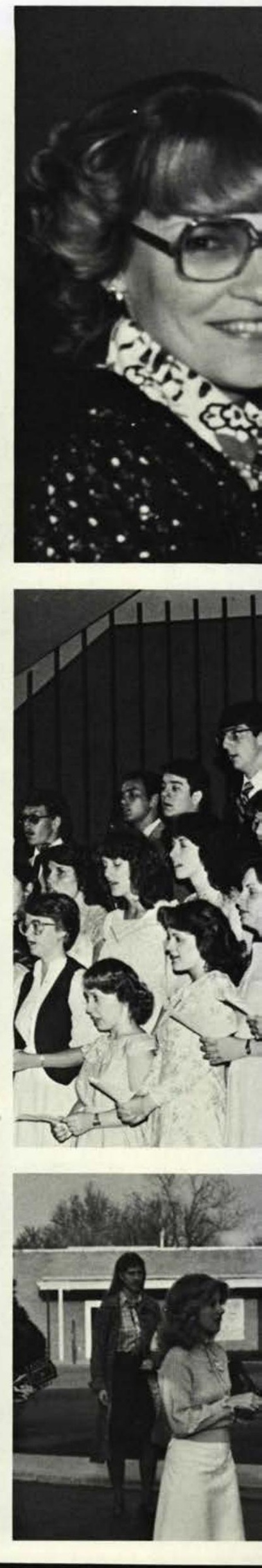


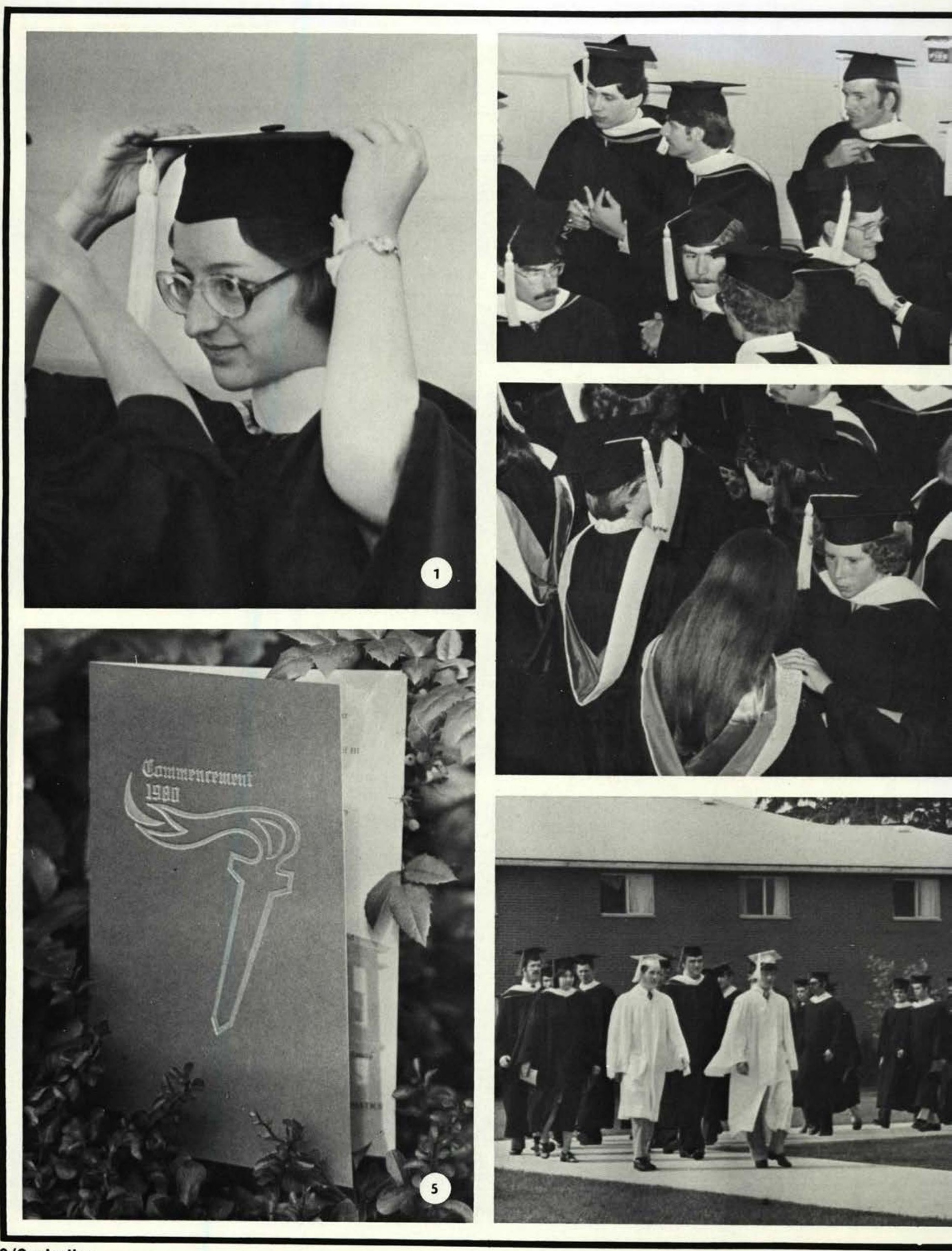



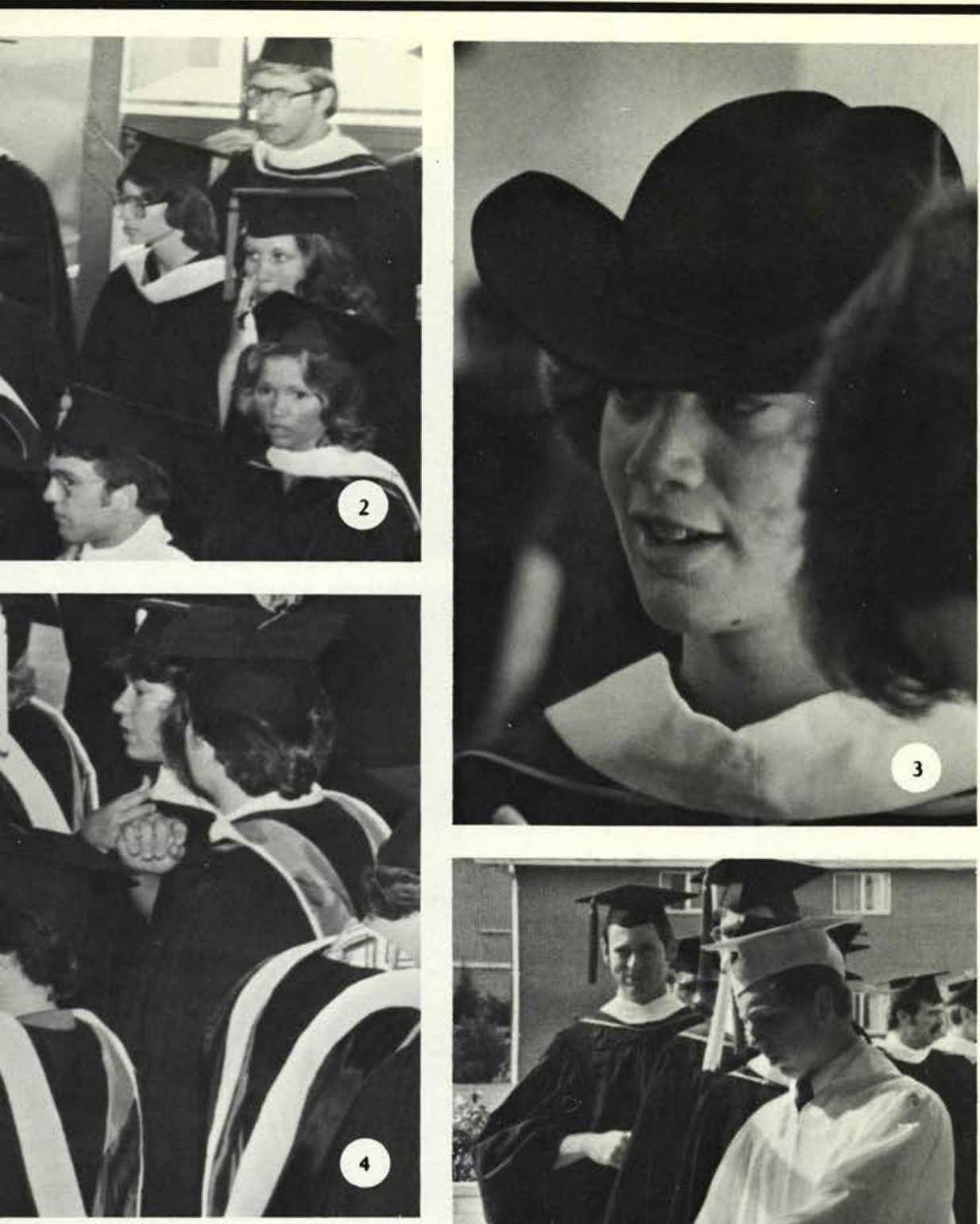

\section{Graduation}

Graduation is the highlight of the Cedarville year. This culmination of four years of dedication is celebrated with a large ceremony in the James T. Jeremiah Chapel.

1. Everything must be just right, so the mortarboard is placed very carefully. 2. Even the men adjust each other's hoods for this ceremony. 3. Marnie Vail relaxes a bit before she dons her cap. 4. Every girl gives and receives some adjustment before heading toward the chapel. 5. A list of graduates is provided for each parent and visitor. 6 . Finally, the procession begins as the graduated march to the chapel. 7 . Floyd Stanfill checks his watch while waiting to lead the graduates to their seats.

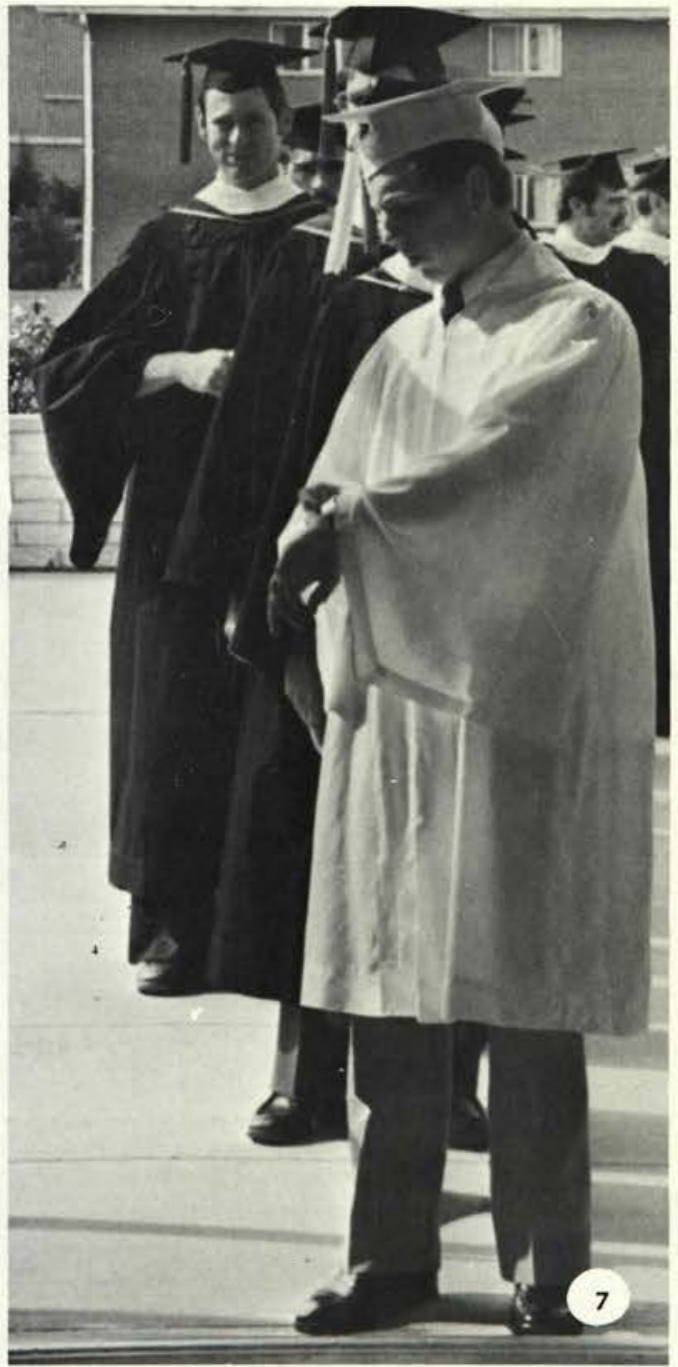




\section{Graduation}

President Dixon gives a charge to the graduates, the diplomas are awarded and some awards are presented to outstanding members of the Senior Class. Smiles beam and tears flow, but overall prevails a feeling of relief.

1. Before the graduates are seated, the faculty file in to take their places on the platform. 2. Barb Adams accepts her award from Dr. Johnson. 3. Congratulations are in order after the ceremony. 4. Lee Randall is all smiles as Dr. Dixon gives him his diploma. 5. The graduates listen intently as their class members receive their awards. 6 . Parents glow with pride toward their graduated daughter. 7. Ginny Decker, Karen Sewell, and Kim Hosack pose for a picture in their caps and gowns. 8. Shawn Taylor receives praise for her accomplishments.
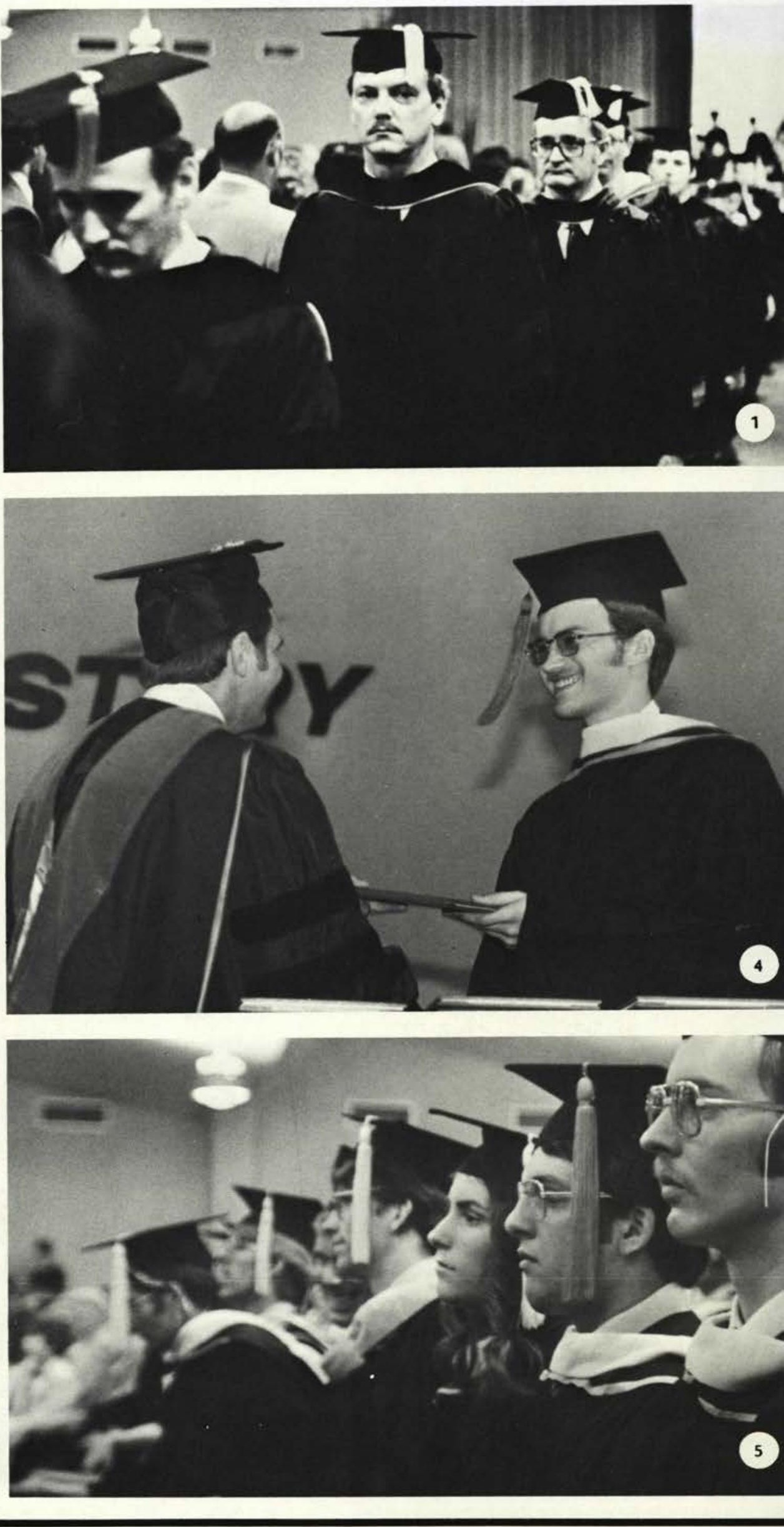


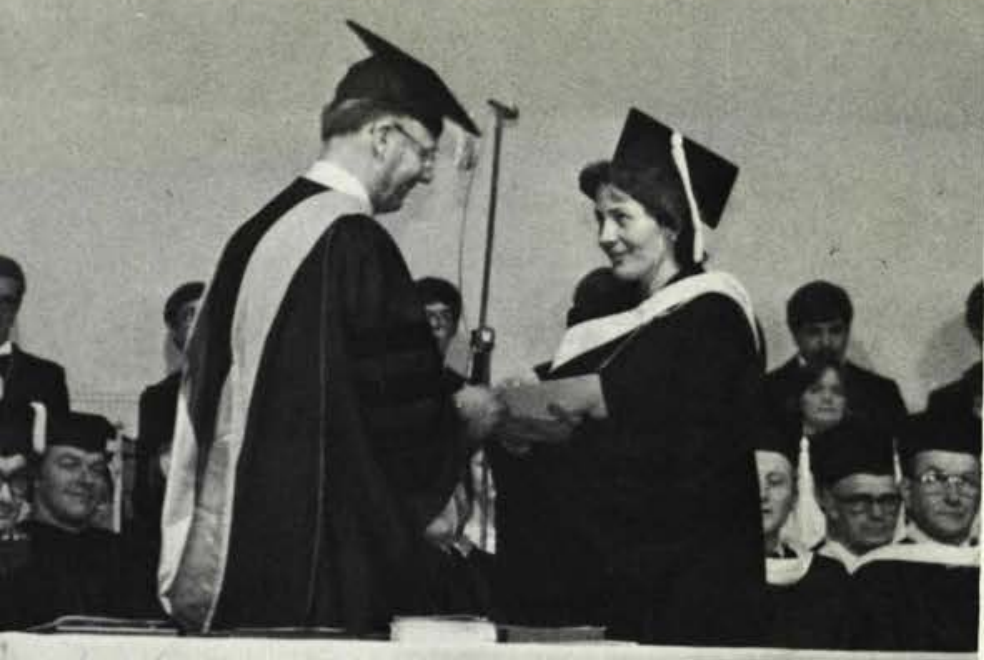

V

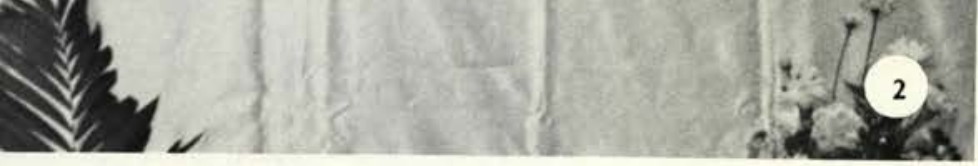

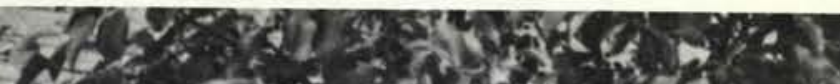
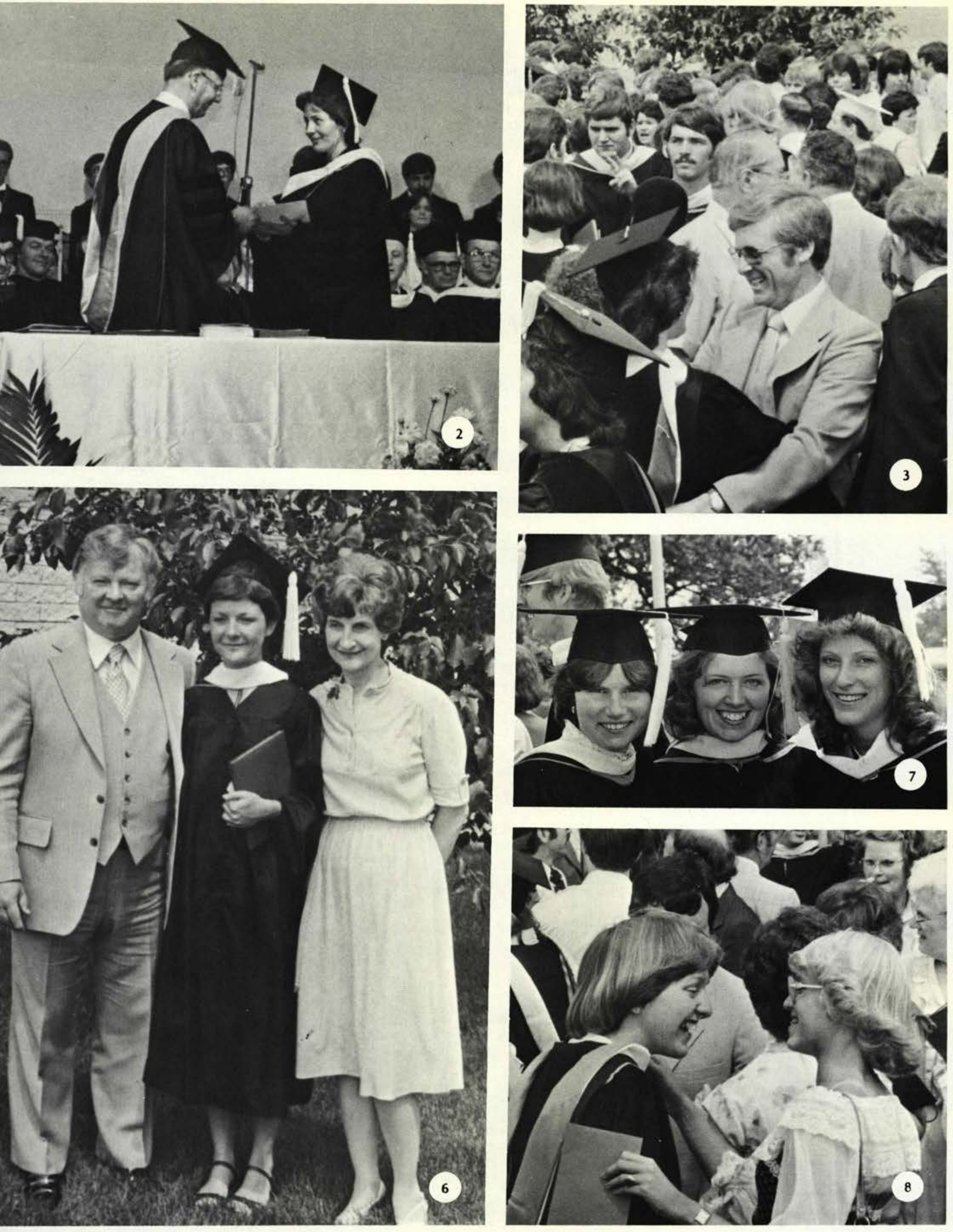


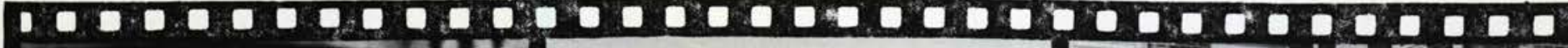
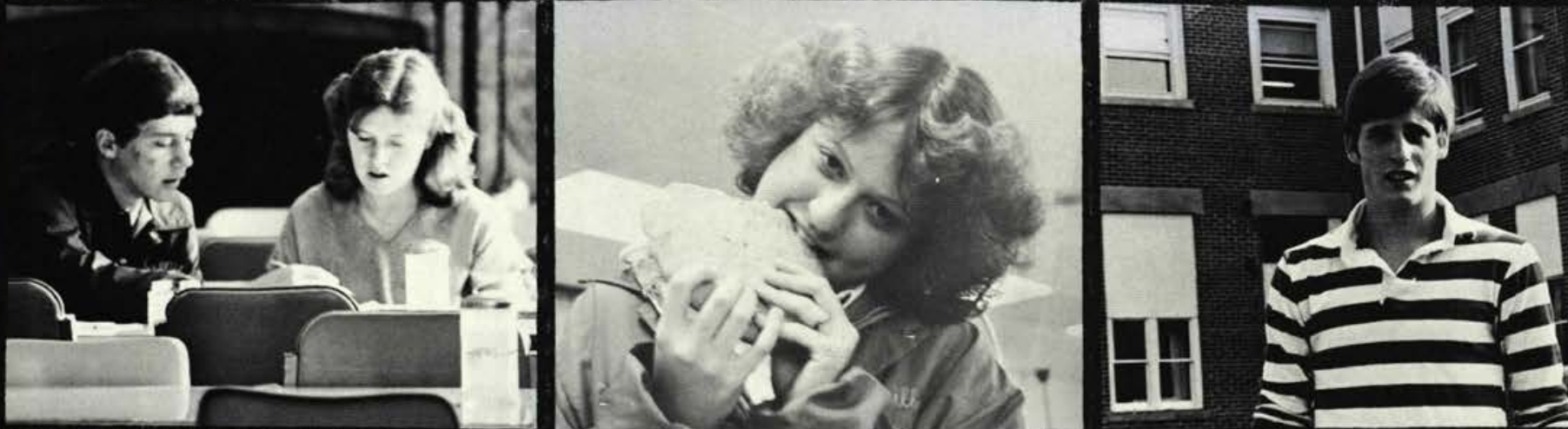

Q.

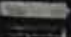

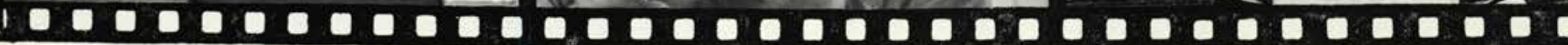
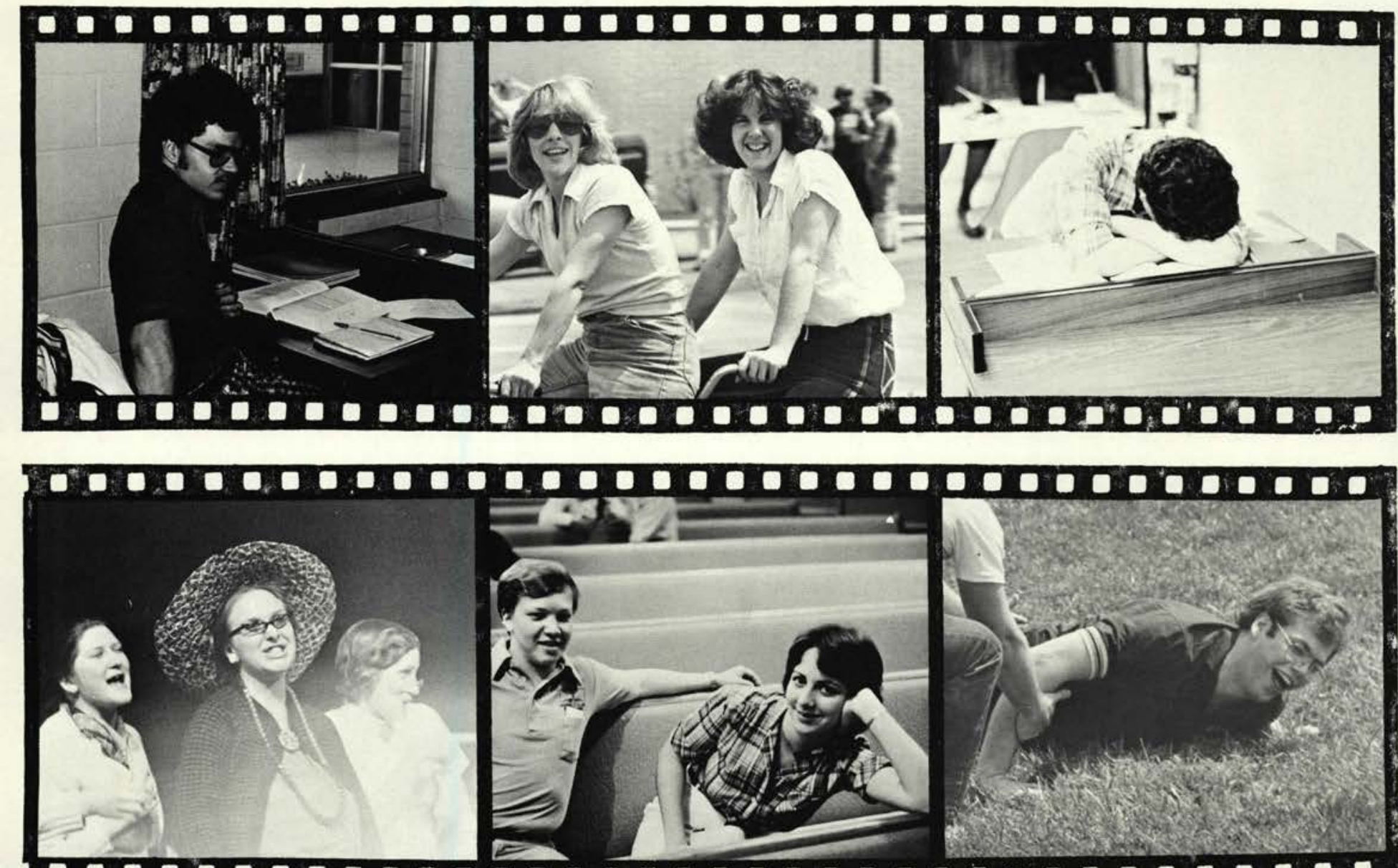

1000000000000000000000000000000

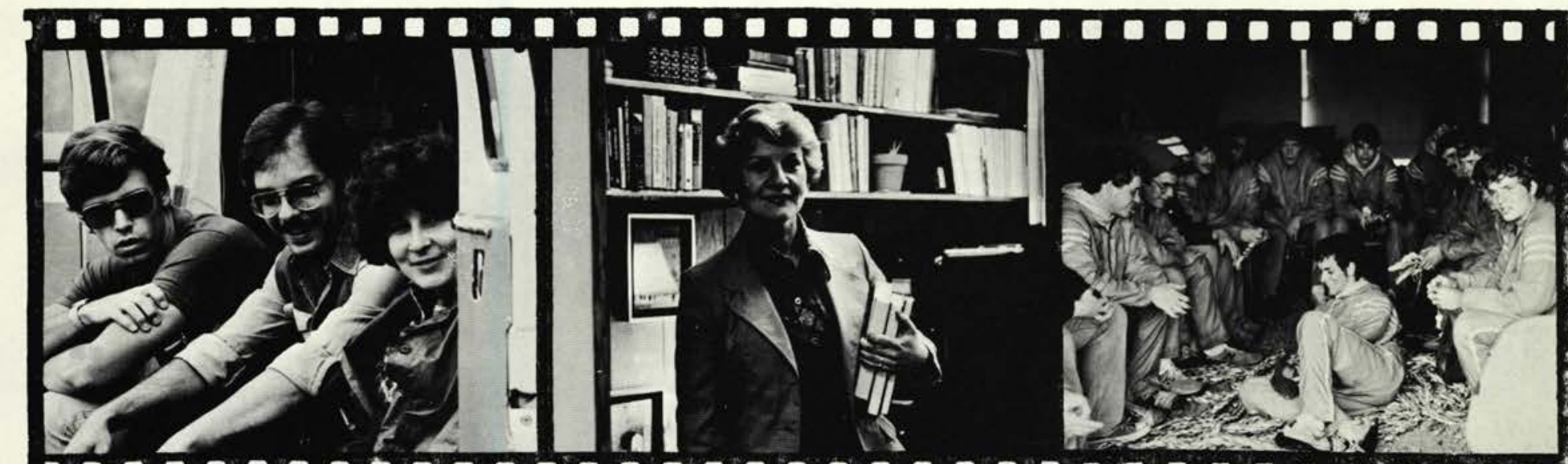

(

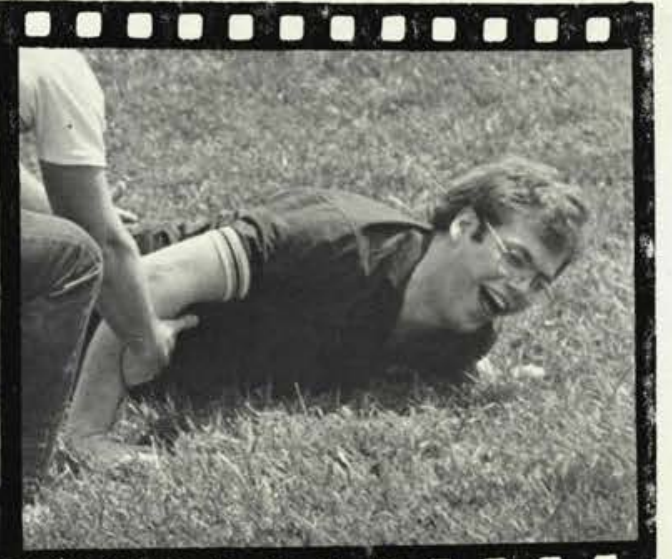

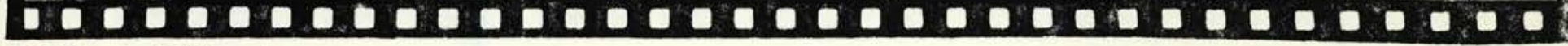




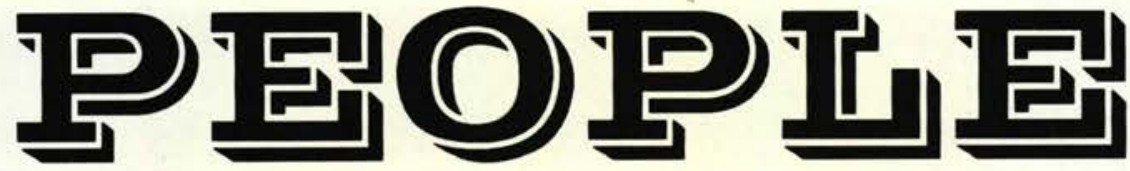
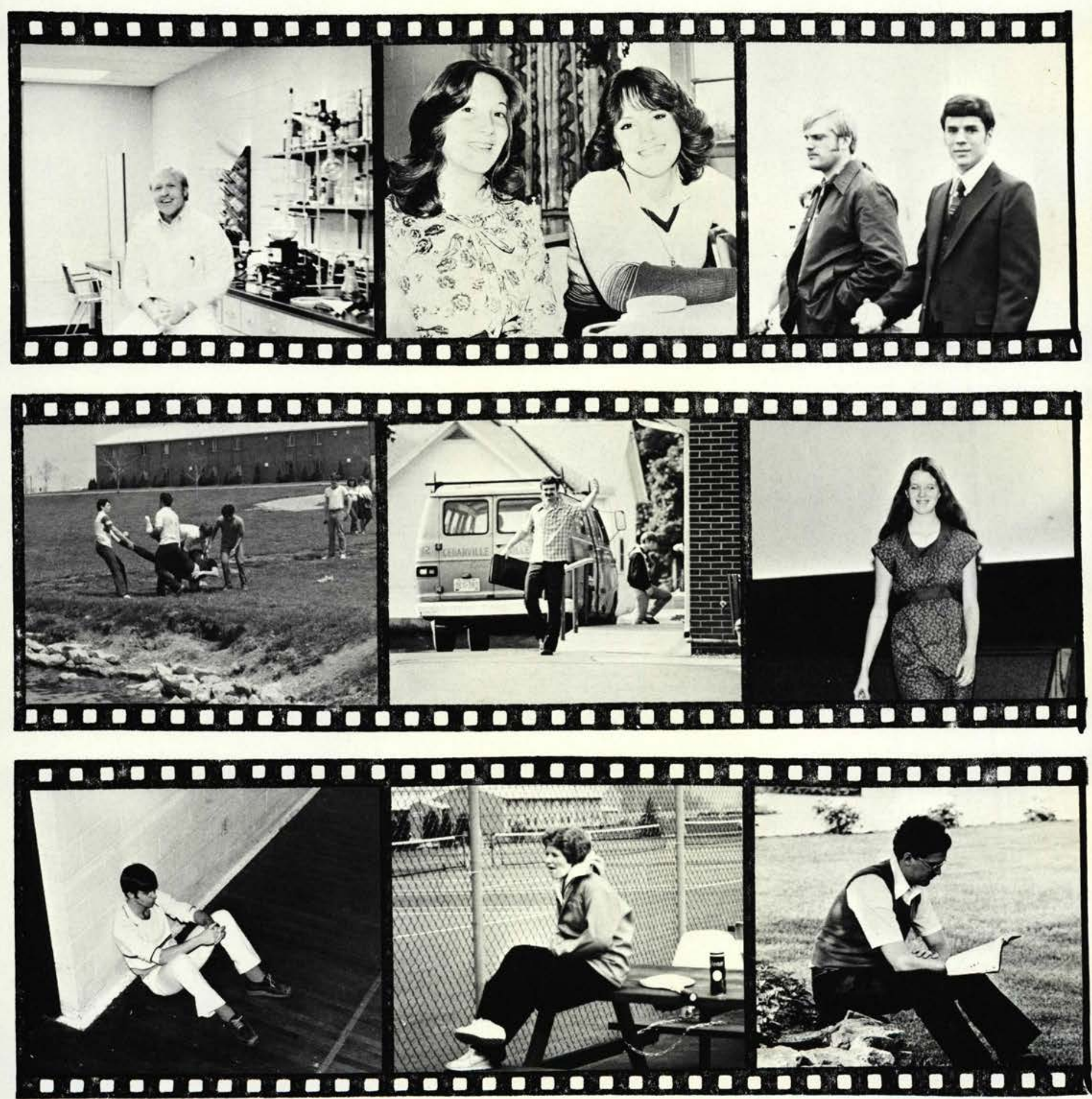


\section{II}

9.

- irita

10019

4 - 2.92 - $=10$ ra noy $\rightarrow$ on - fil de wh.
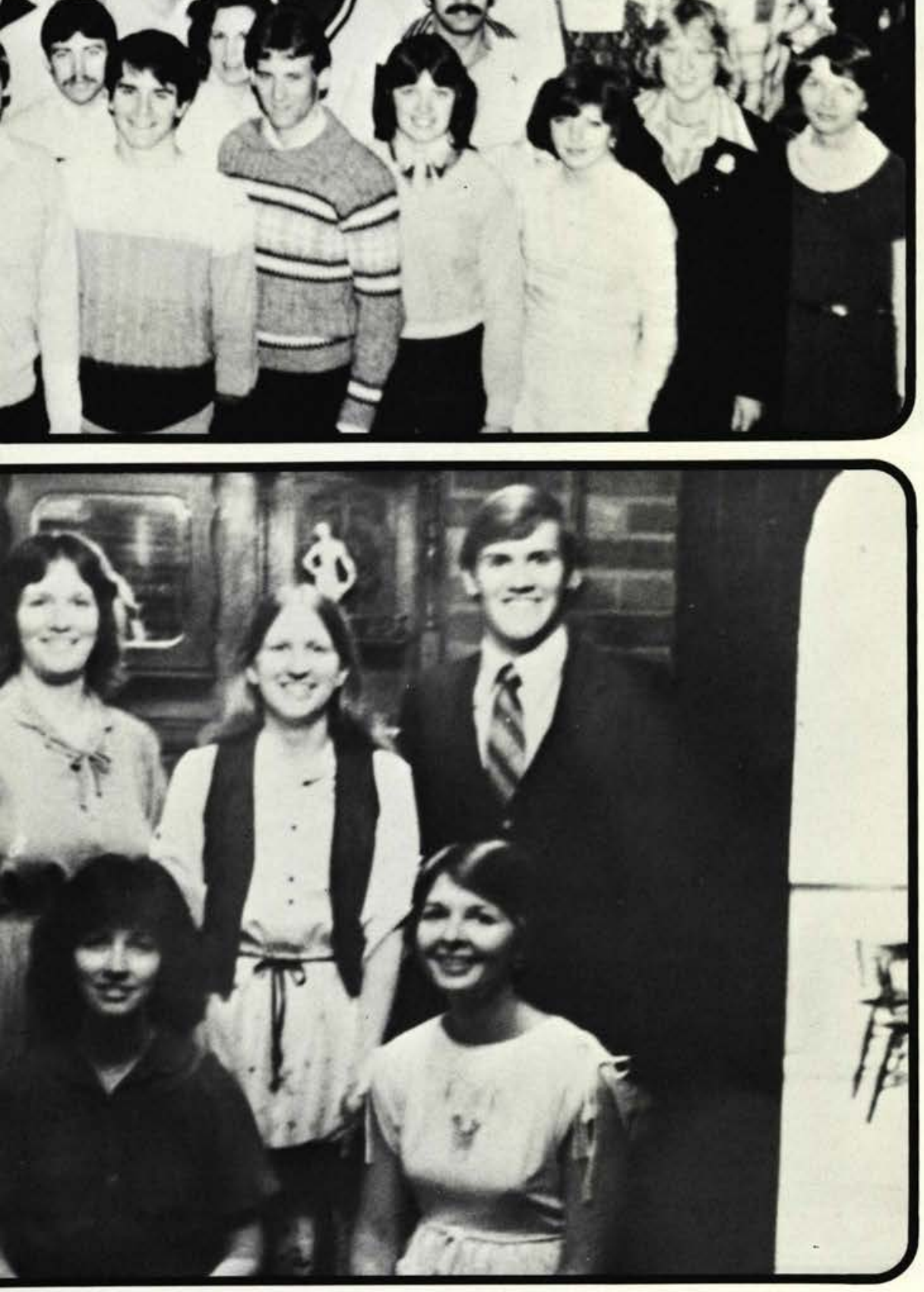

(1)

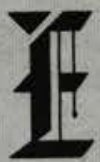

期

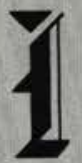

级

$\mathfrak{R}$

(4) 


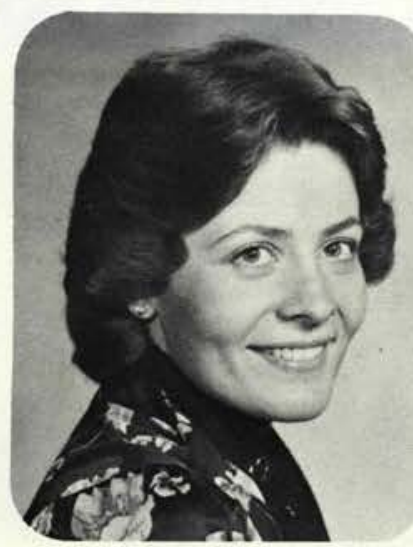

BARBARA ADAMS

Troy, Ohio

Music

I press toward the mark for the prize of the high calling of Christ Jesus. Philippinas 3:14

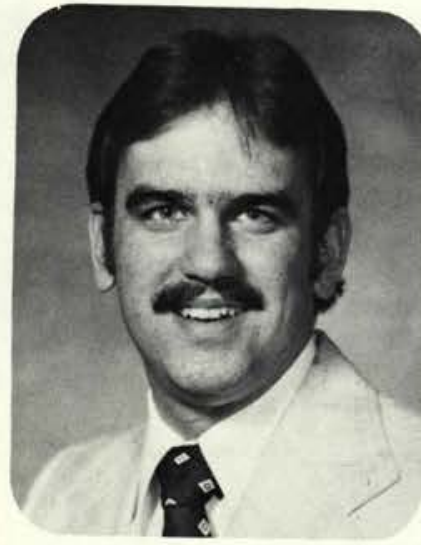

KEN ANDRUS

Erie, Pennsylvania

Biology Education

But let him that glorieth glory in this, that he understandeth and knoweth me, that I am the Lord.

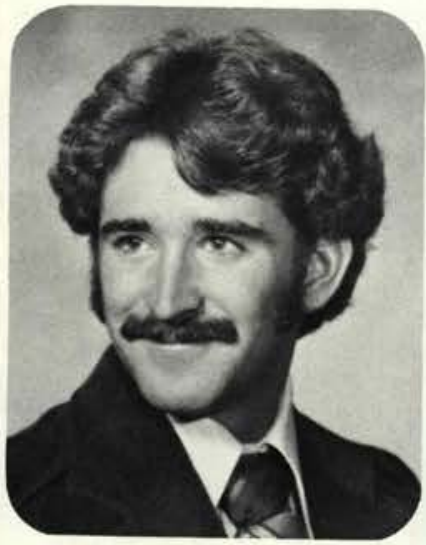

WILLIAM CHASE BALDWIN Cedarville, Ohio

Biology/Physical Education

For God has not given us the spirit of fear, but of power, and of love, and of a sound mind.

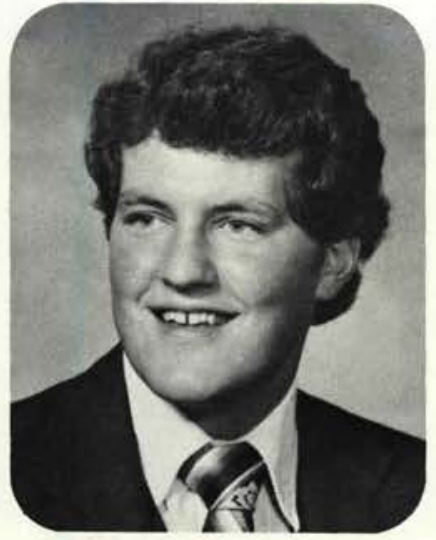

MICHAEL S. AIKEN

Jamestown, Ohio

Pre-Seminary

Be thou an example of believers in word, in conduct, in love, in spirit, in faith, in purity.

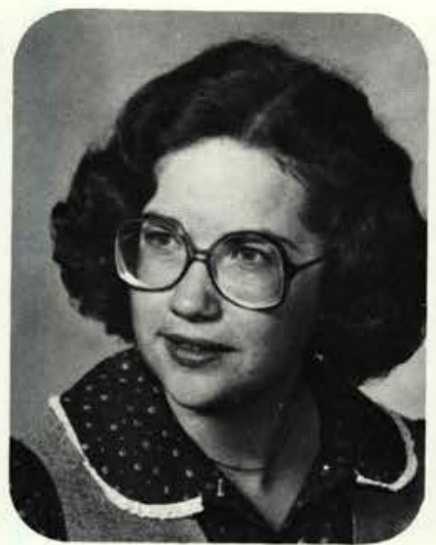

KATHLEEN DIANE ARMSTRONG

Portage, Indian

Chemistry

I will say of the Lord, He is my refuge and my fortress, my God; in Him will I trust. Psalm 91:2

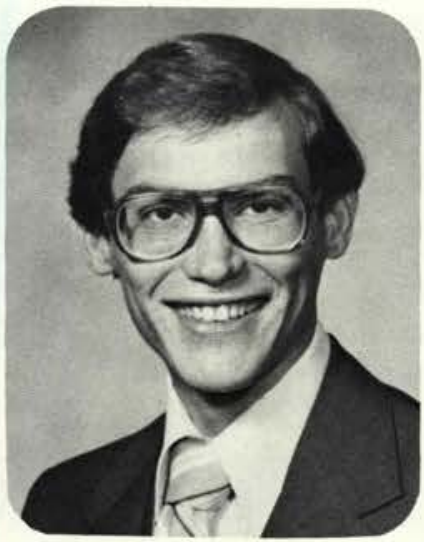

JEFFREY L. BEAN

Cresaptown, Maryland

Comprehensive Bible

In all thy ways acknowledge $\mathrm{Him}$ and $\mathrm{He}$ shall direct thy paths. Proverbs $3: 6$

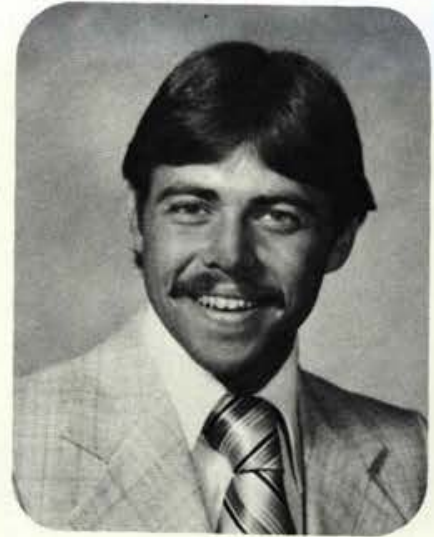

THOMAS STEWART AITKEN

Hasbrouck Heights, New Jersey Psychology

May my sight remain on Christ who has gone before me. Matthew 6:33/Philippians 3:13-14

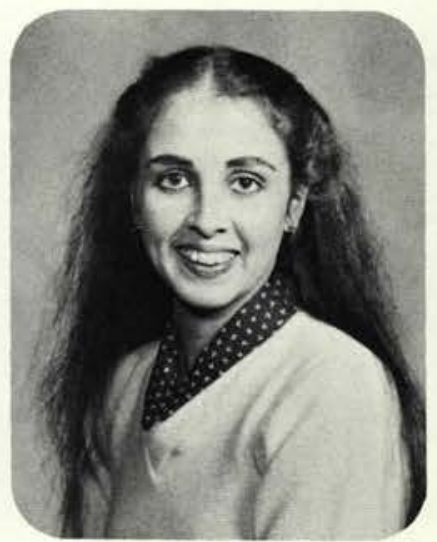

SARAH ELLEN ARTHUR

Norwalk, Ohio

Comprehensive Bible

Let me live that I may praise you. Psalm 119:175

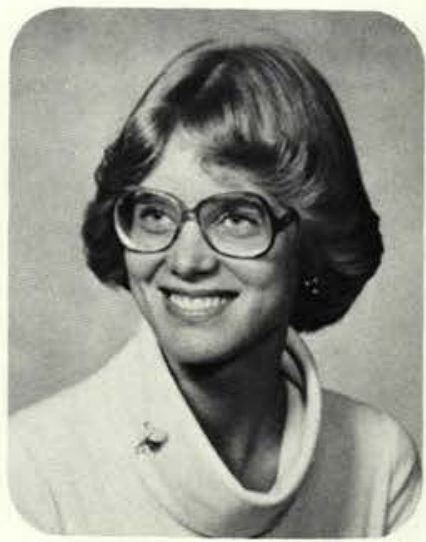

RACHAEL BEAN

Van Etten, New York

Behavioral Science

I know not what tomorrow holds, but I know who holds tomorrow.

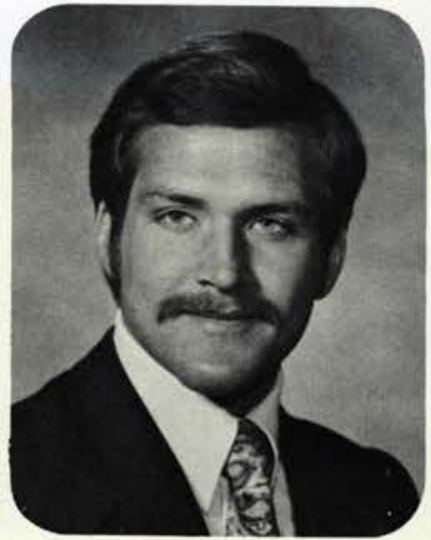

MICHAEL WARREN ALLEN

Munster, Indiana

Business Administration

Thou shalt remember the Lord thy God; for it is He who gives power to get wealth. Deut. 8:18

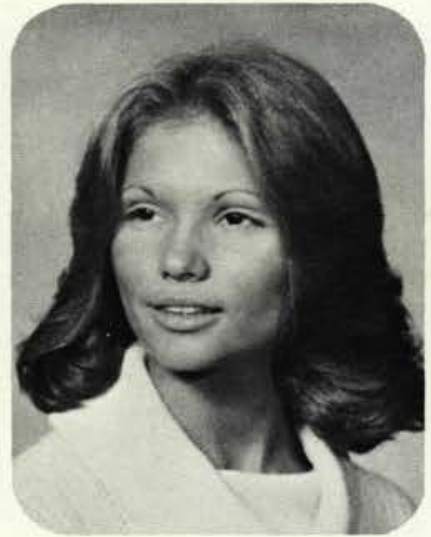

PAMELA JOY AXIOTIS

Silvis, Illinois

Psychology/Behavioral Science

All I have seen teaches me to trust the Creator for all I have not seen. - Emerson

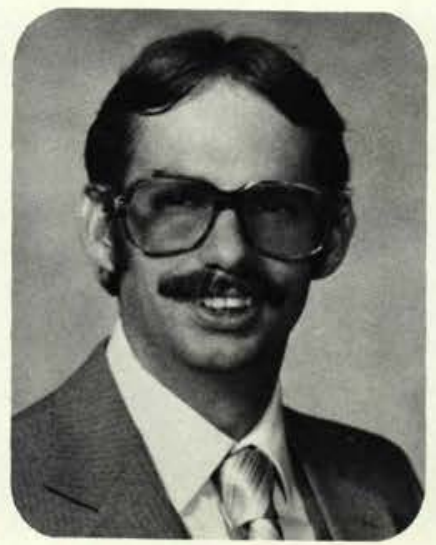

SCOTT BEIGHT

Zelienople, Pennsylvania

Pre-Seminary

I press toward the mark for the prize of the high calling of Christ Jesus. Philippians 3:13 


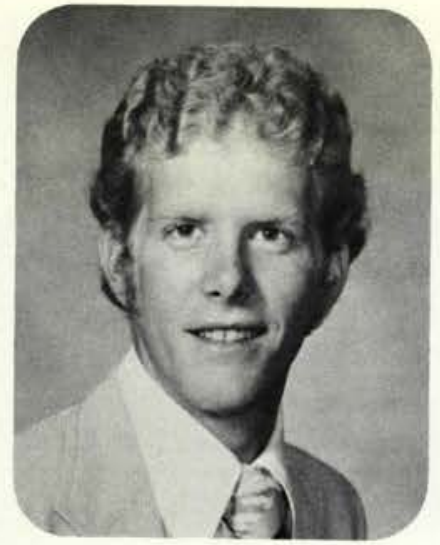

DANIEL E. BETTS

Georgetown, Delaware

Social Science Comprehensive

Whether then, you eat or drink or whatever you do, do all to the glory of God. I Cor. 10:31

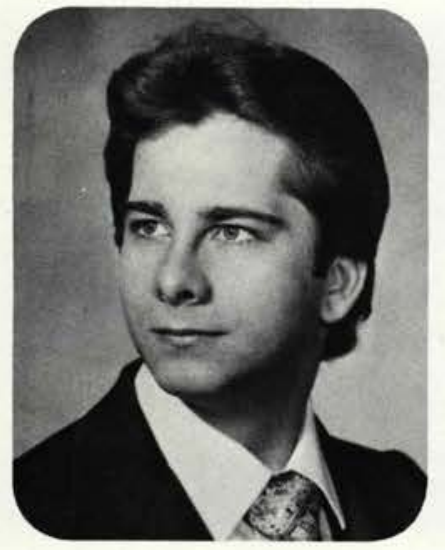

JOHN BOWERS

Columbia, Ohio

Business Administration

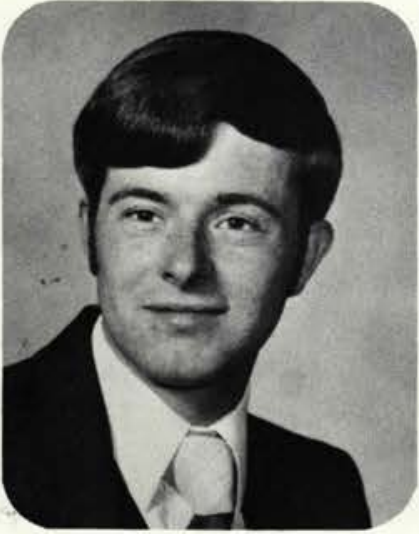

STEVEN E. BROWN

Gallipolis, Ohio

Pre-Seminary

Never be afraid to trust an unknown future to a known God.

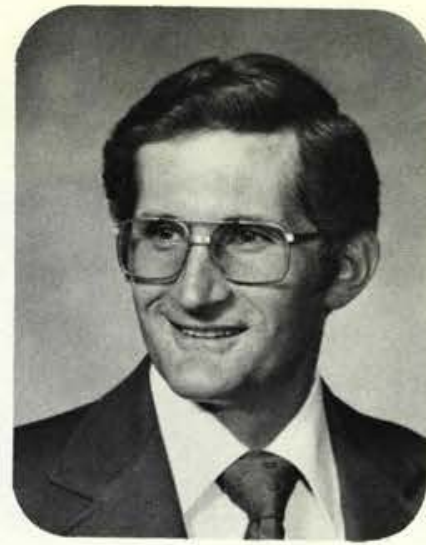

STANLEY BIRKY

Detroit Lakes, Minnesota History

For whatever is born of God overcomes the world; and this is the victory - our faith. John 5:4

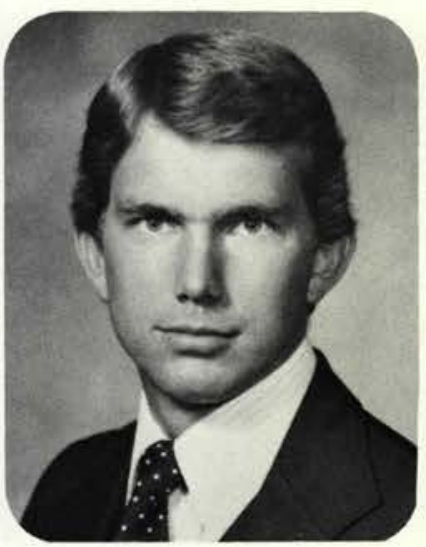

MICHAEL K. BRESSON

Sussex, Wisconsin

$$
\text { History }
$$

This is the day which the Lord hath made; we will rejoice and be glad in it. Psalm 118:24

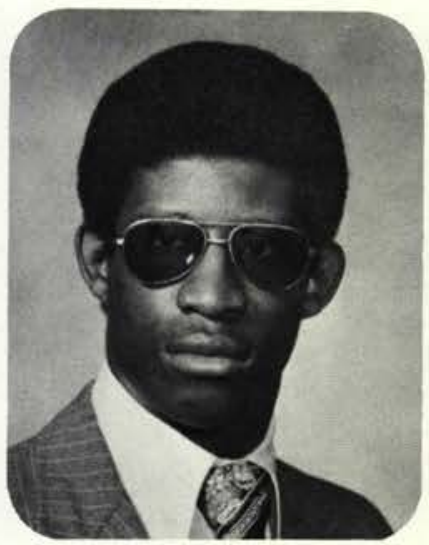

KEVIN GREGORY BROWNE Washington, DC Pre-Seminary

That Christ be exalted in word and deed through all my life I Peter 5:6-7

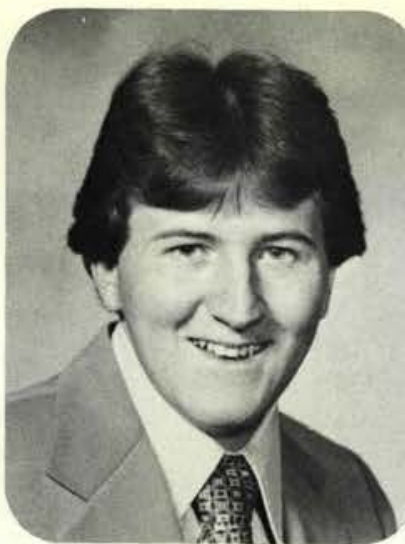

ANDREW A. BOONE

Richmond, Virginia

Business Administration

But seek ye first the kingdom of God; and all these things shall be added unto you.

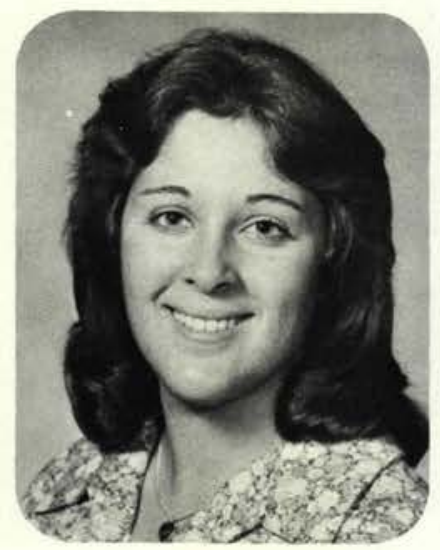

KATHLEEN BROWER

River Edge, New Jersey

Elementary Education

Only fear the Lord and serve Him in truth with all your heart ... I Samuel 12:24

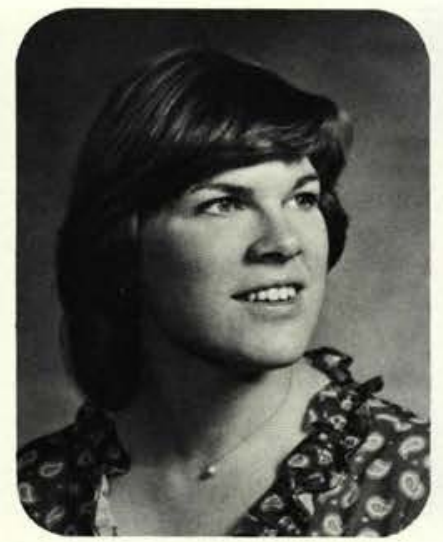

LAURIE ANN BRUENING

South Euclid, Ohio

Biology

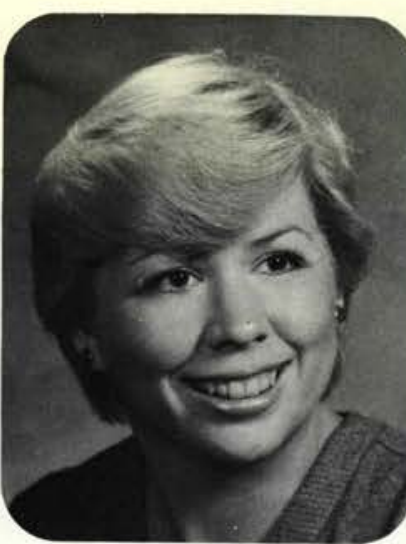

SANDRA BONZO Jackson, Ohio

Biology

The Lord is my strength and my shield; my heart trusted in Him and I am helped. Psalm 28:7

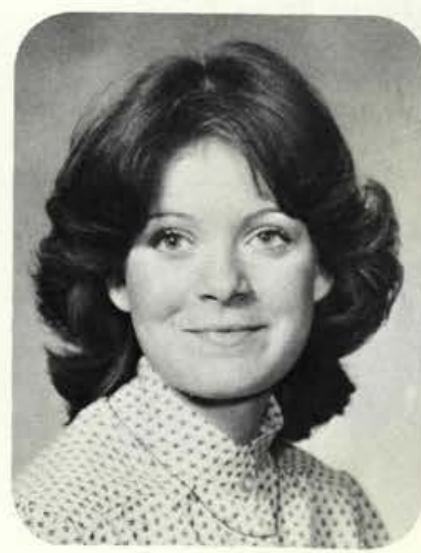

JUDY BROWN

Parma, Ohio

Elementary Education

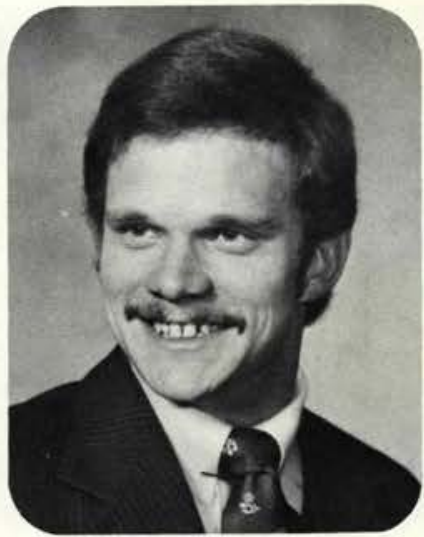

PAUL BUETTELL

Cleveland Heights, Ohio Business Administration

Micah 6:8 


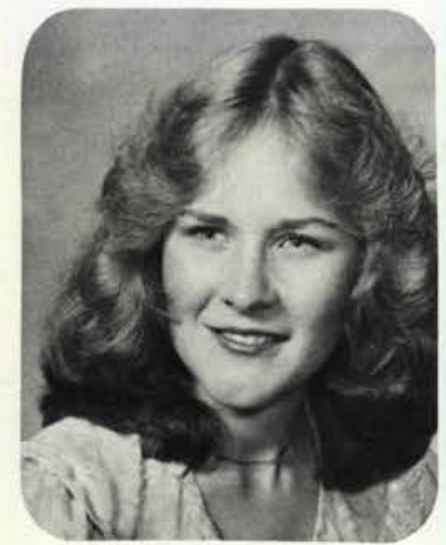

ESTHER BULTHUIS

Lynden, Washington Business Administration

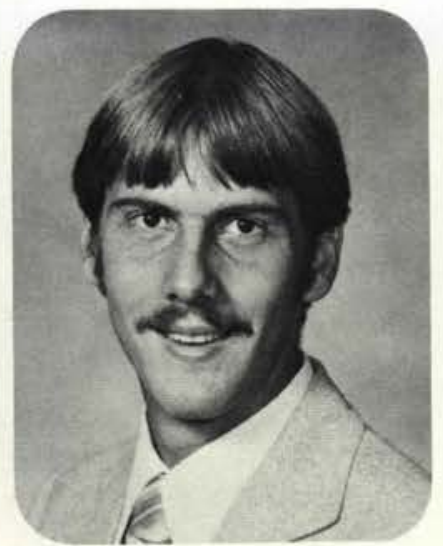

PETER BULTHUIS

Lynden, Washington English

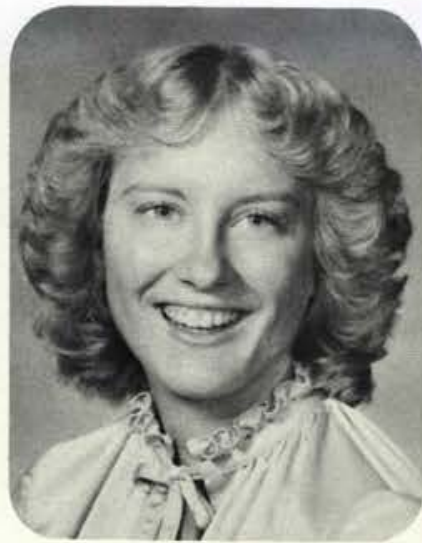

VICKI BUTLER

Eldora, lowa

Business Administration

Learn as if you were to live forever; live as if you were to die tomorrow.

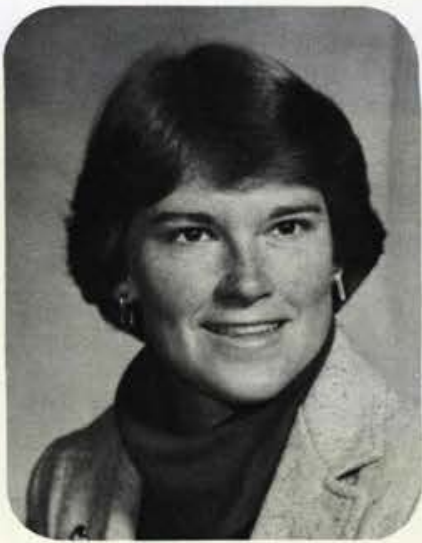

JAN CALLAN

Cedarville, Ohio

Elementary Education

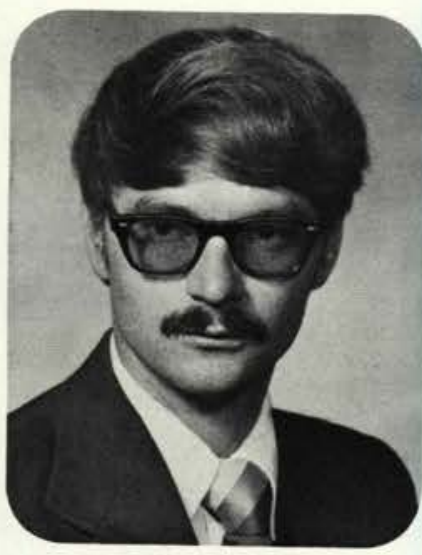

DALE CHANCE

Heislerville, New Jersey

Elementary Education

It will be worth it all when we see Jesus.

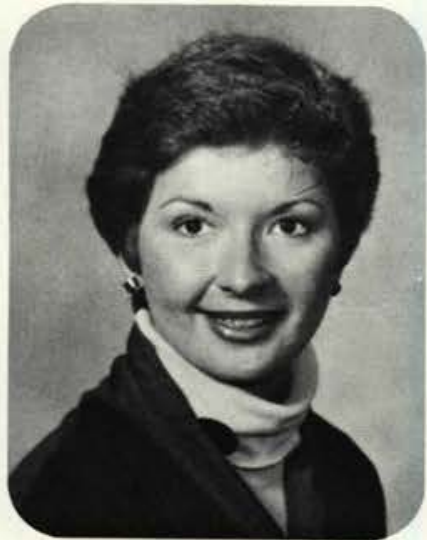

PAMELA COATES

Quincey, Illinois

Business Administration

The Lord stood with me and strengthened me. II Timothy 4:17

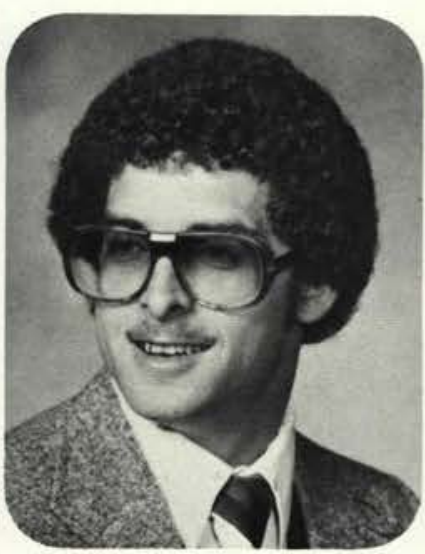

DENNIS CHESSER

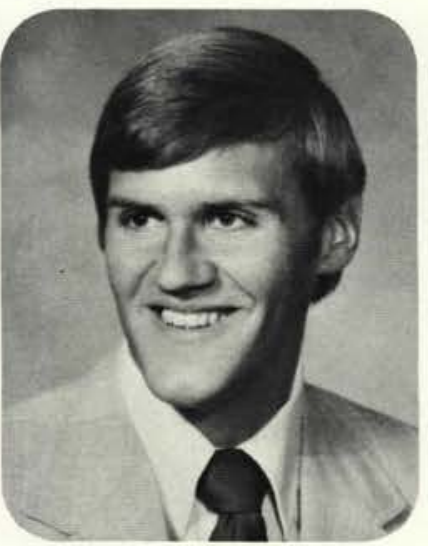

CRAIG COLAS

Littleton, Colorado

Chemistry

We all have ambitions and goals; it is what we do right now that determines what we will achieve later.

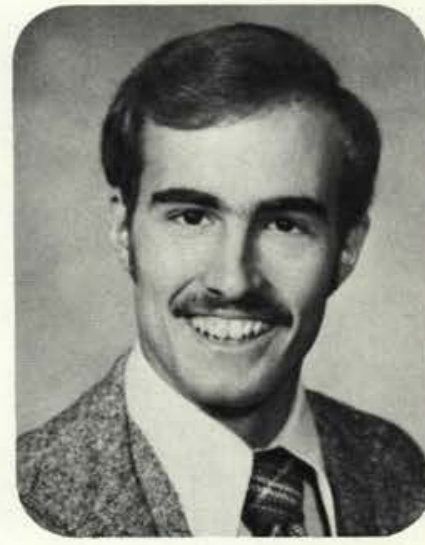

DALE ROBERT CHRISTIAN Brunswick, Ohio

Comprehensive Bible

To hear my Lord say, "Well done thou good and faithful servant." Philippians 3:13-14.

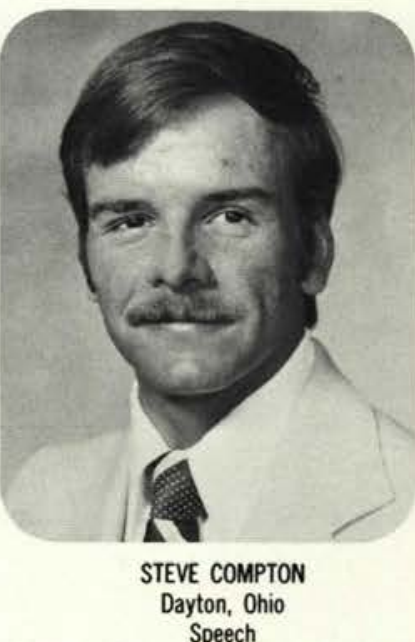

I want to live my life pleasing to God; in doing that; learn to seek Him first and to know Him.

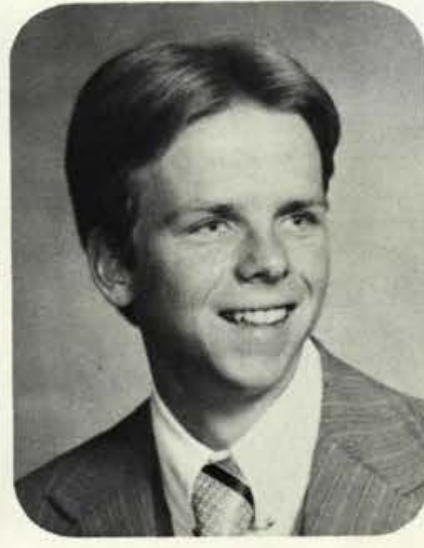

KENNETH E. CHURCHWARD Milwaukee, Wisconsin

Business Administration

I am His and $\mathrm{He}$ is mine. John 10:27.29

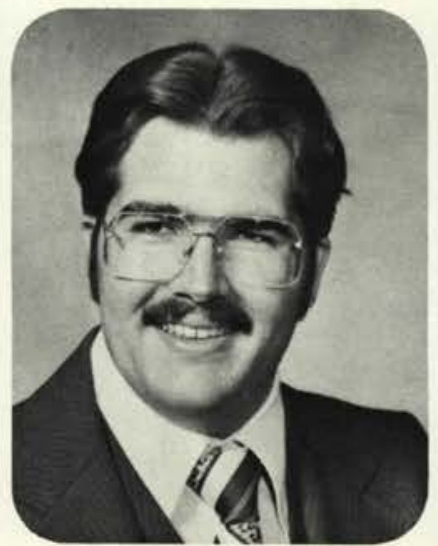

RICHARD D. CONNORS

Holland, Pennsylvania Music

He hath put a new song in my mouth, even praise unto our God. Psalm 40:3 


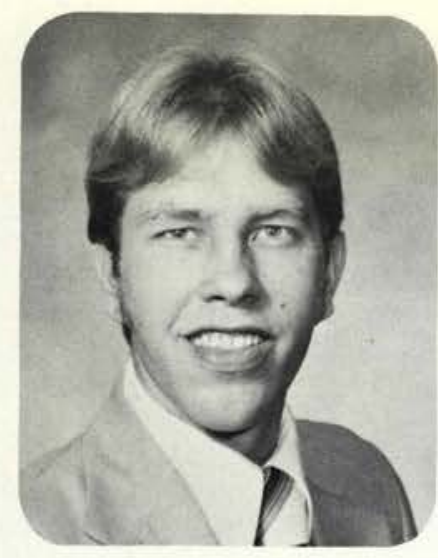

DAVID LEE CONRAD

Akron, Ohio

Pre-Seminary

That I may know Him, and the power of His resurrection, and the fellowship of His suffering ....

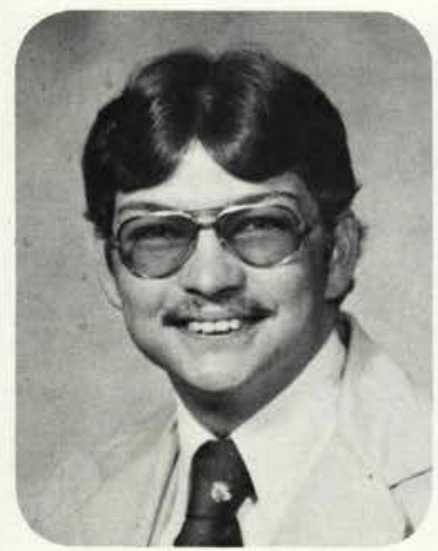

\section{DONALD LEON COX}

Dayton, Ohio

Business Administration

If one is to win the battles during the day, he must get the battle plan in the morning. Ps. 119:11

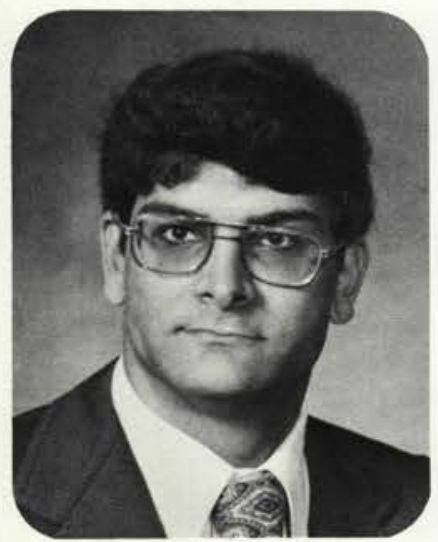

THOMAS H. DANUBE

Baraboo, Wisconsin

Politicial Science

Whatever word I speak will be performed, declares the Lord God. Ezekiel 12:28

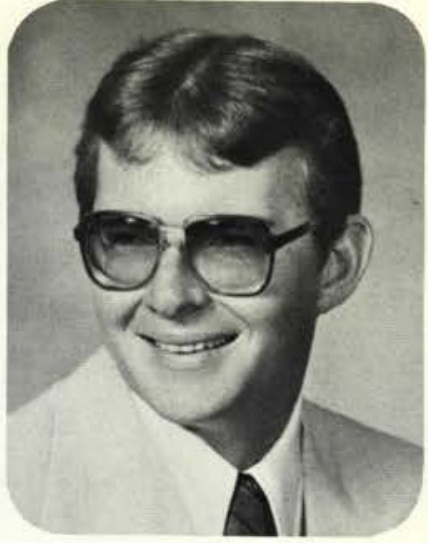

JEFFREY S. COOK

Cincinatti, Ohio

Comprehensive Bible

Galatians 2:20

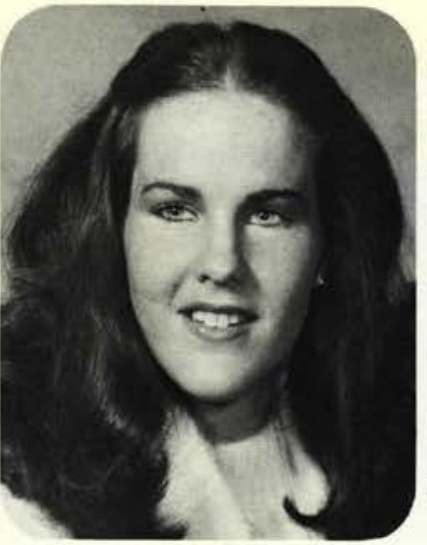

KATHI K. COOK

Brooklyn, New York

Elementary Education

Reaching forth .... I press toward the mark for the prize of the high calling of God.

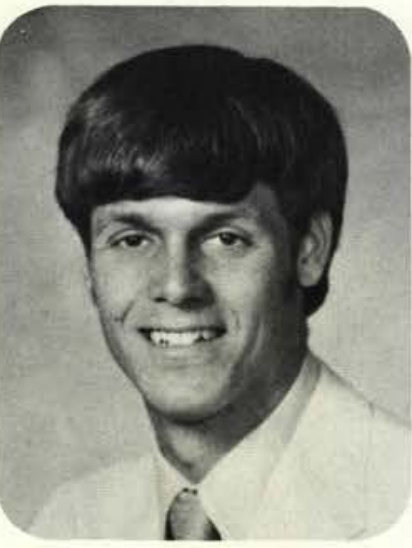

KENT ALAN CRAIG

Brownsburg, Indiana

Comprehensive Bible

... I being in the way, the Lord led me Genesis 24:27

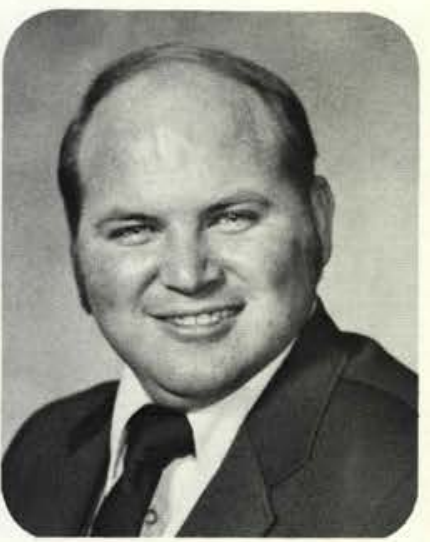

DONALD DAWSON

Comprehensive Bible

\section{DAVID N. CREMEAN}

Cedarville, Ohio

Physical Education

"Akita Mani Yo" (Remember everything as you walk) - Sioux Saying

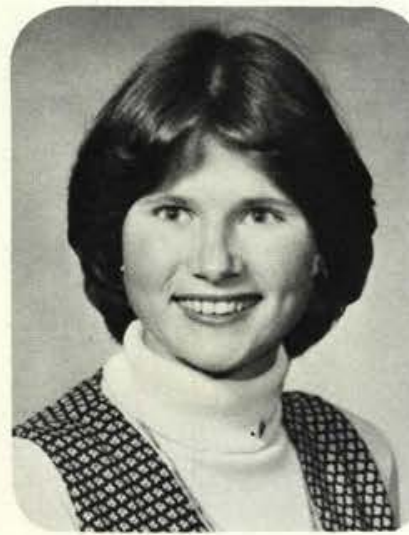

VIRGINIA MARIE DECKER

Forty Fort, Pennsylvania

English Education

Isaiah 40:31

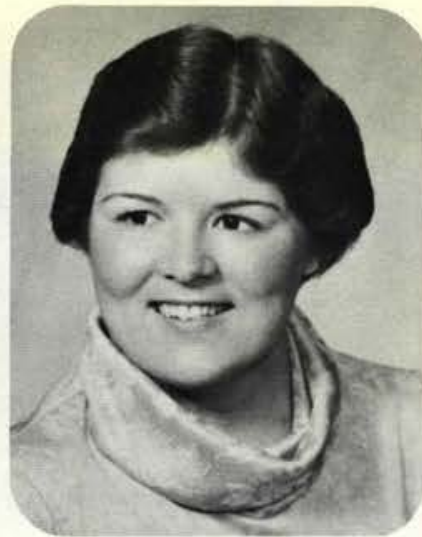

JOYCE ELAINE CORATHERS Stow, Ohio

Comprehensive Bible

As for God, His way is perfect ... he is a shield to all those who trust in Him. Psalm 18:30

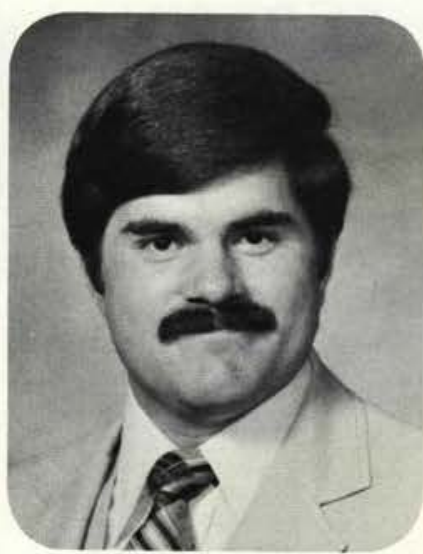

RICHARD ALLAN CRIST

Pennsville, New Jersey

Mathematics

For a great door and effectual, is opened unto me, and there are many adversaries. I Corinthians 16:9

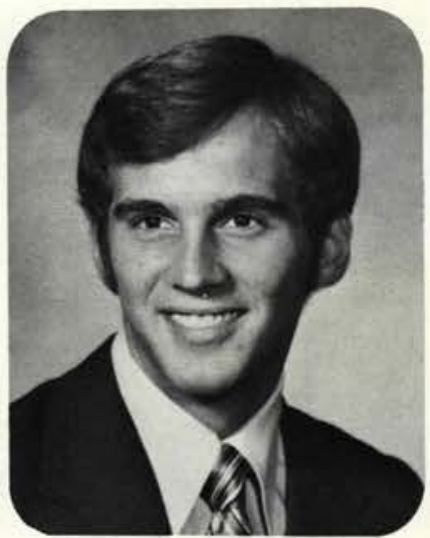

PAUL A. DELANGE

Bondurant, lowa

Biology Education

There is not hope without life, and no life without God. 


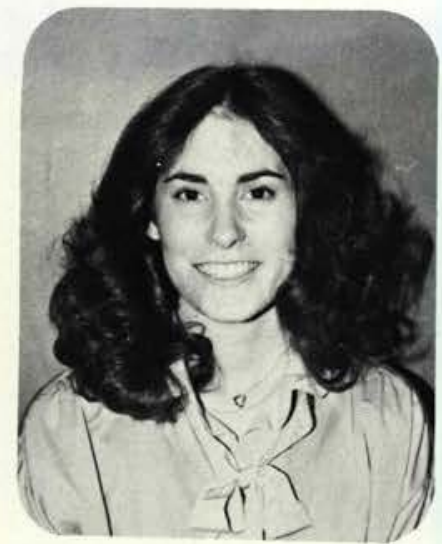

VALERIE DELL

Watervliet, Michigan

History

For ye are bought with a price: therefore glorify God in your body and in your spirit which are God's.

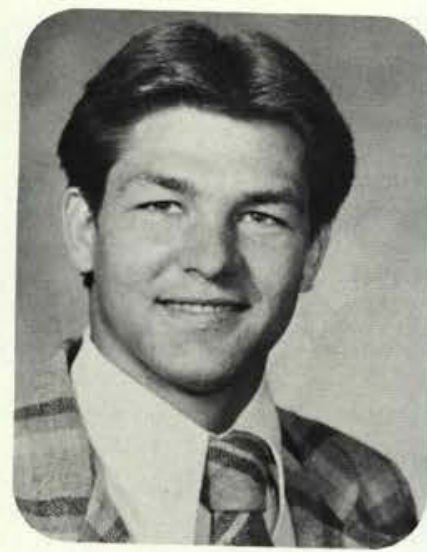

MARTY DEVINE

Crown Point, Indiana

Physical Education

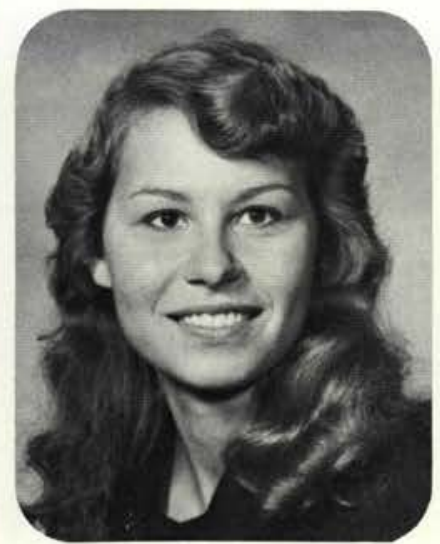

CINDY DENNY

Portlandville, New York

Elementary Education

Thou wilt shew me the path of life: in thy presence is fulness of joy; pleasures evermore. Psalm 16:11
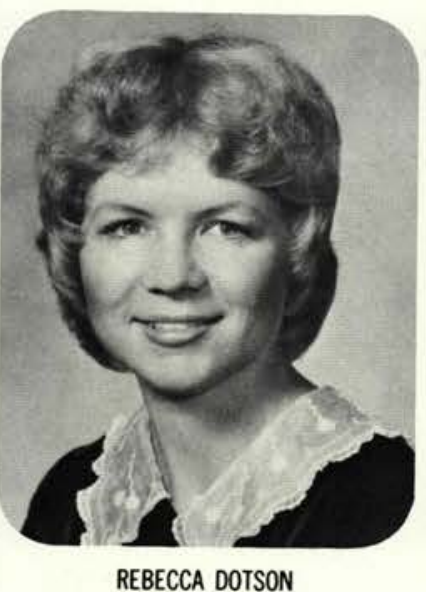

Gallipolis, Ohio

Elementary Education

Holding faith and a good conscience that all the earth may know that there is a God.

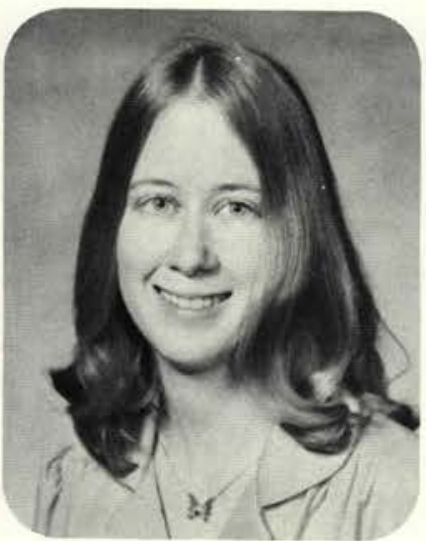

IDA EHRMAN

Derby, New York

Biology

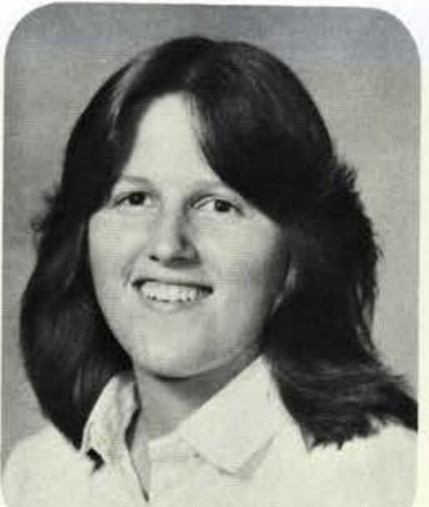

CHERIE DEPEW

Medina, Ohio

Behavioral Science/Psychology

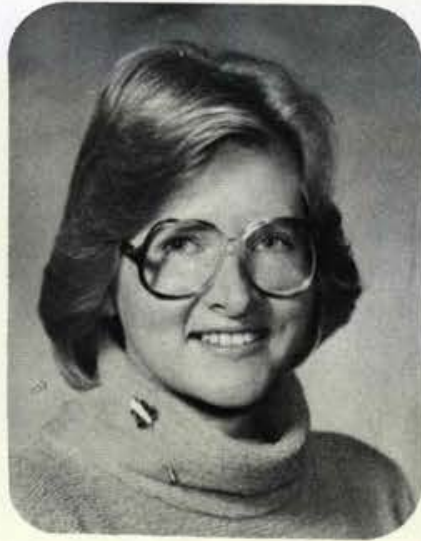

DEBORAH DETWEILER

Psychology

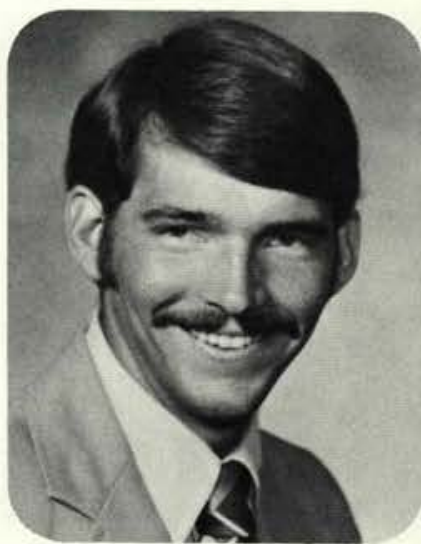

TIMOTHY DOWD

Moweaqua, Illinois

Physical Education

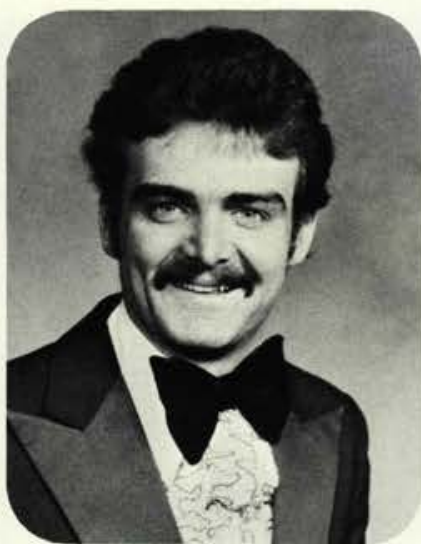

JOHN DUFF

Thomaston, Maine Pre-Seminary

As the hart panteth after the water brooks, so panteth my soul after thee, 0 God. Psalm 42:1

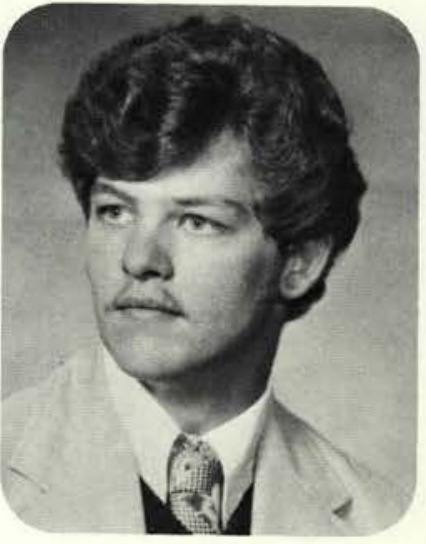

HOWARD ELMY Pontiac, Michigan Social Science For me to live is Christ.

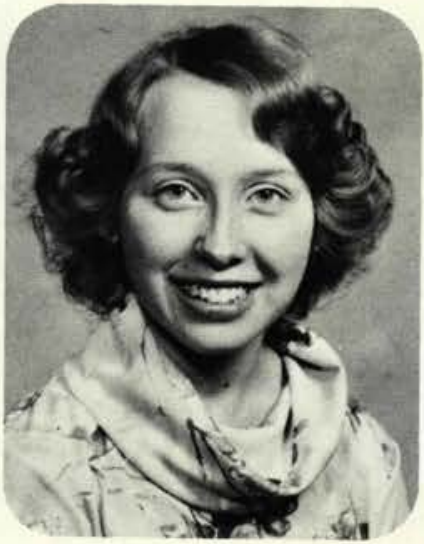

PATRICIA FARMWALD

Middlefield, Ohio

Elementary Education

Great is thy faithfulness .... the Lord is my

portion ... therefore will I hope in Him

... Lam. 3:23-24 


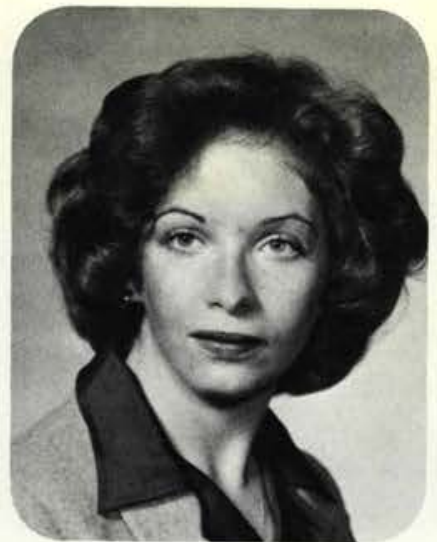

ANN FAVA

Riverdale, Maryland

English

Who redeemeth thy life from destruction; who crowneth thee with loving kindness and tender mercies. Ps. 103:4

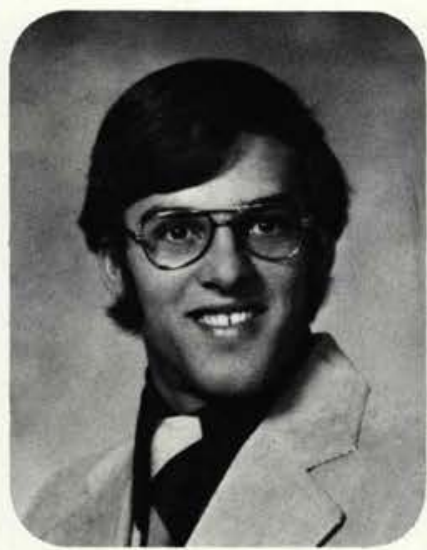

DANIEL R. FULLMER

Cincinnati, Ohio

Pre-Seminary/Bible/History

We impart to you, not only the gospel of God, but also our own souls, because ye are dear to us.

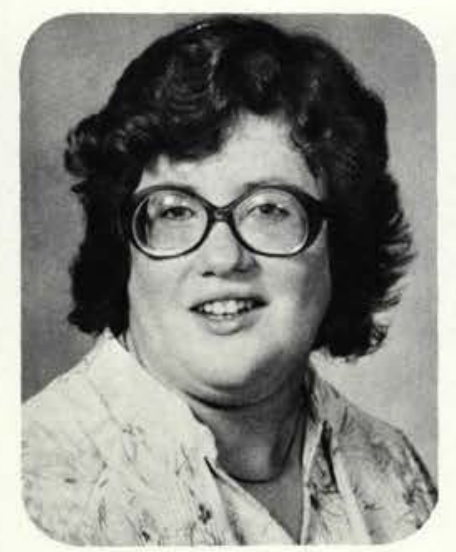

PAULA FLINT GIFFORD Hornell, New York English

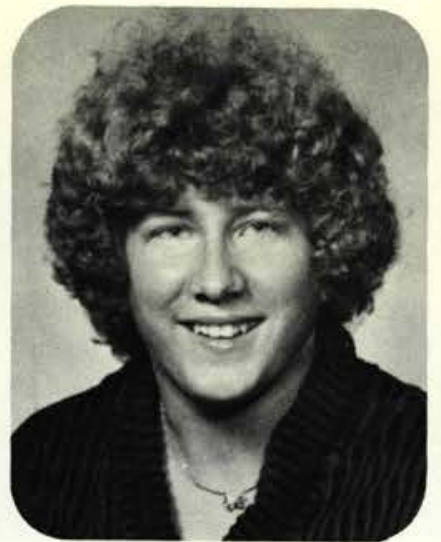

BECKY A. FESTAG

Elmira, New York

Elementary Education

God is my refuge and my fortress.

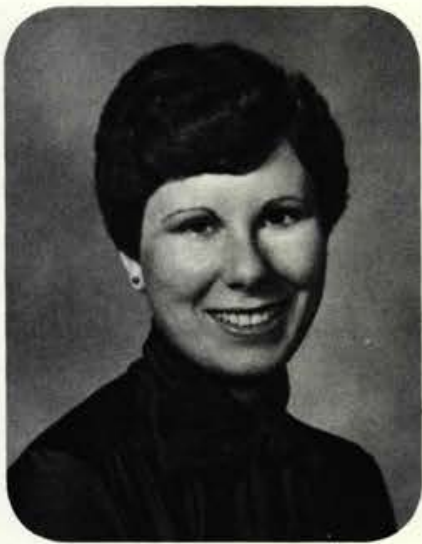

JAN LESLIE FUNTIK

Detroit, Michigan

English Education

$\ldots$ the only argument available with an east wind is to put on your overcoat. James Russell Lowell

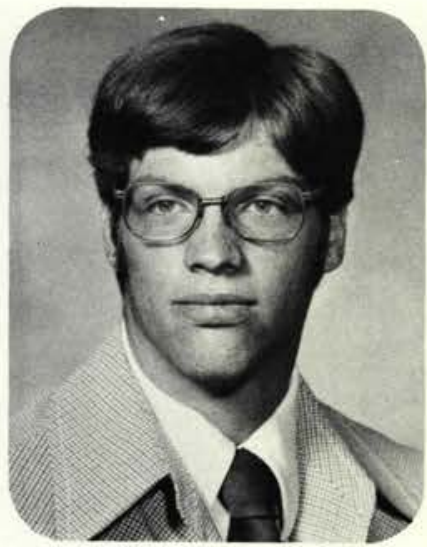

WYNN GIFFORD

Rockville, Maryland

Mathematics

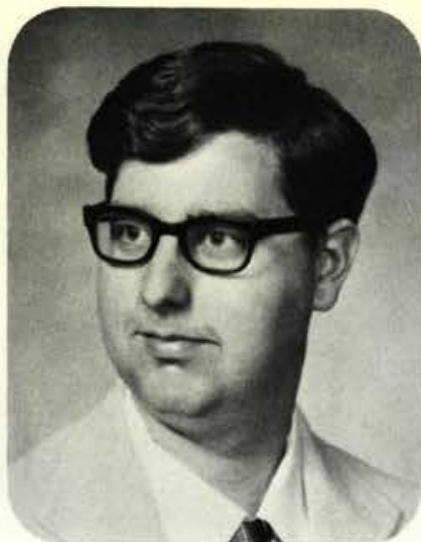

LAWRENCE A. FLOOD

Grafton, Ohio

Chemistry/Mathematics

The Lord is merciful and gracious, slow to anger and plenteou in mercy. Psalms 103:8

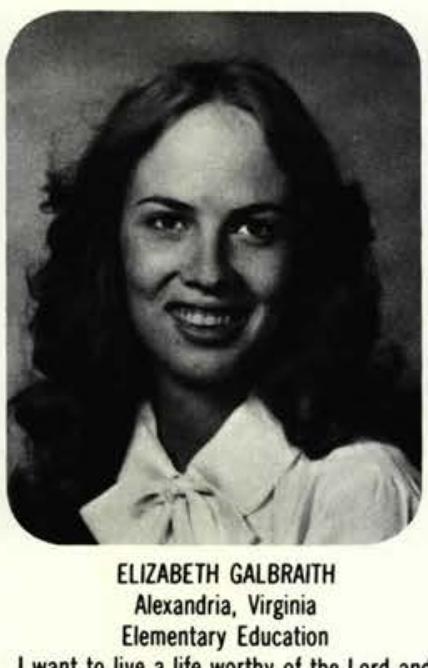

I want to live a life worthy of the Lord and please him in every way. Colossians 1:10

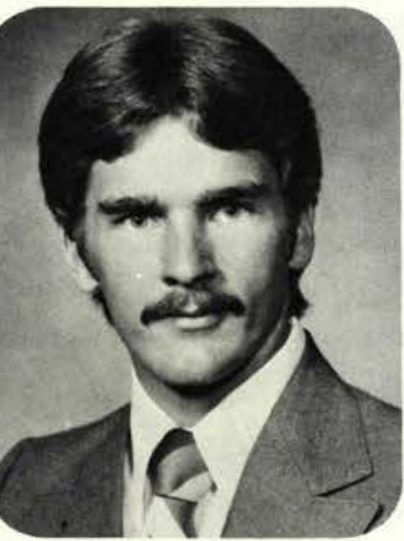

PHILLIP VAUGHN GIGGIE

Elliot Lake, Ontario, Canada

Business Administration

If you have faith as a grain of mustard seed

... nothing shall be impossible unto you

Matthew 17:20

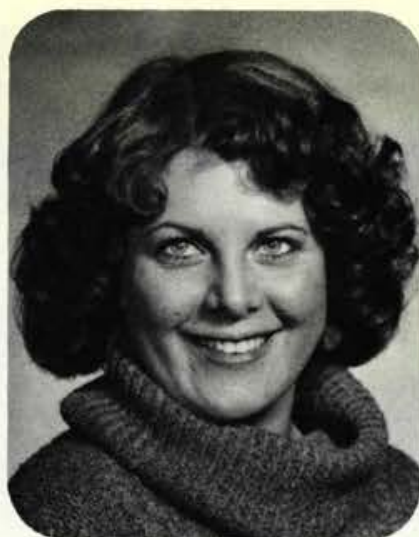

KRISTEN FREY

Pottstown, Pennsylvania

Business Administration

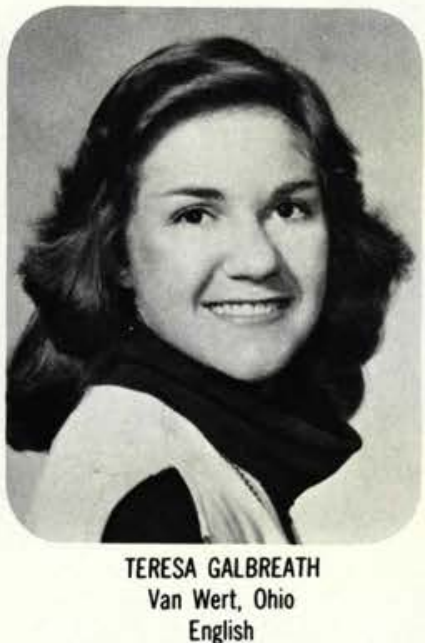

For of him, and through him, and to him, are all things: to whom be glory forever. Romans 11:36

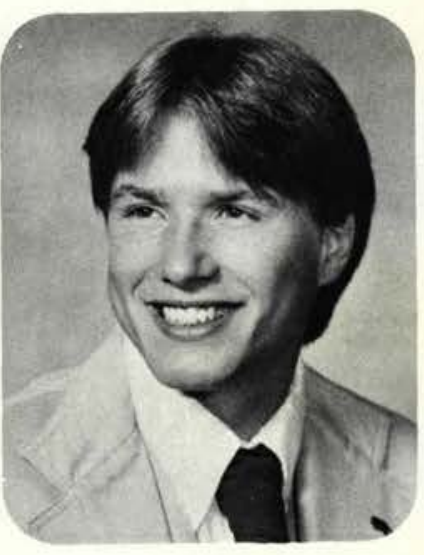

STEVE GOODBAR

Comprehensive Bible 


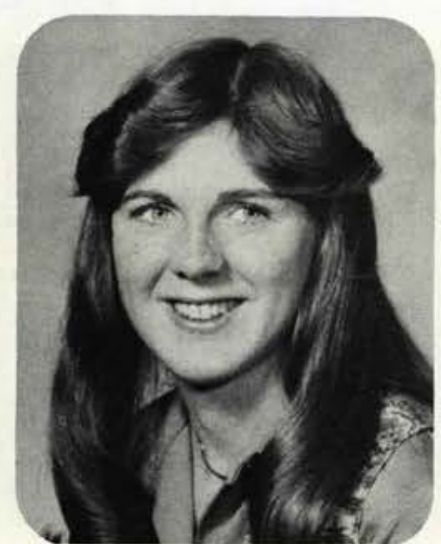

LINDA MARIE GRAFTON

Highland, Maryland

Broadcasting

James 1:22-25/II Timothy 2:15

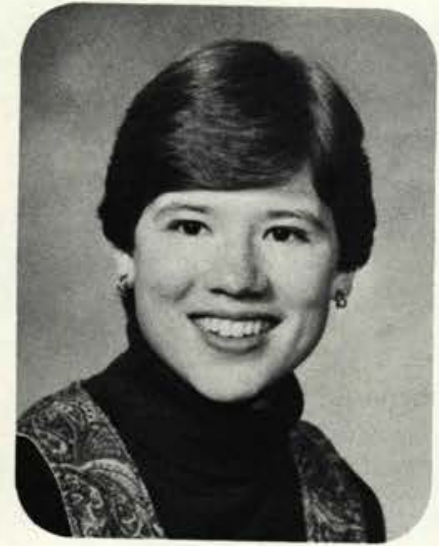

MARSHA GREVE

Greensburg, Indiana Elementary Education

What we are is God's gift to us - what we become is our gitt to God.

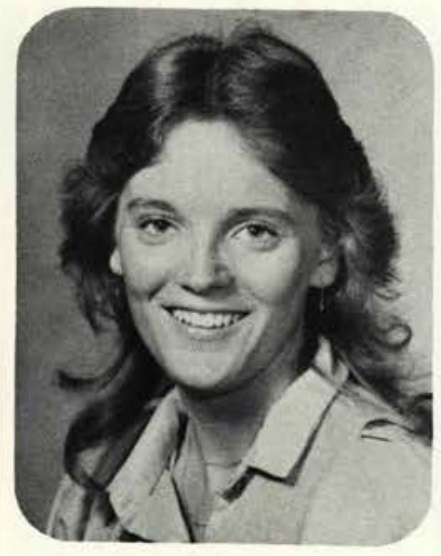

PAM HANMOND

Amherst, Ohio

Elementary Education

... with all boldness, Christ shall even now, be exalted in my body ... Philippians $1: 20$

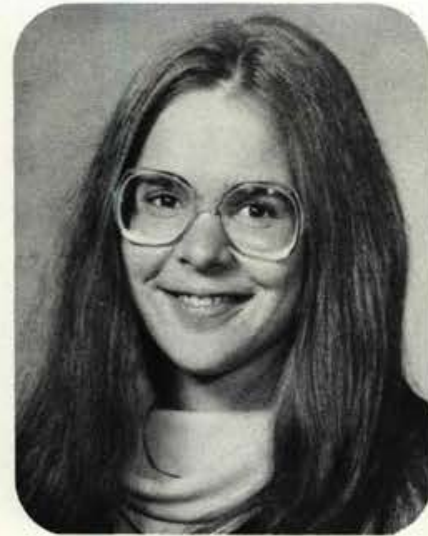

JOY GRAHAM

Milan, Ohio Psalm 16:11
Phil. 1:21 - To live is Christ. I Cor. 9:25 Strive for the mastery. II Tim. 2:2 - Commit to faithful men.

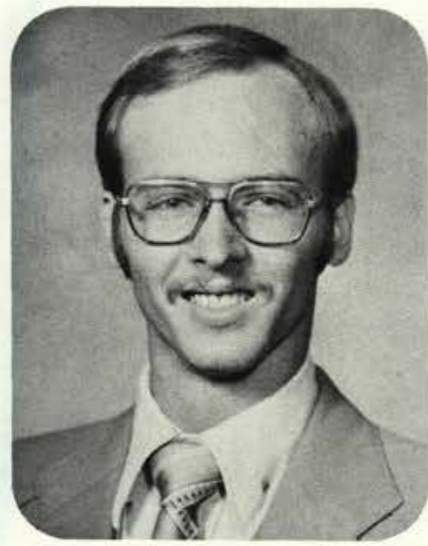

STEPHEN P. HANCOCK

Seaford, Delaware

History

Let no man despise thy youth; but be thou an example of the believers. I Timothy $4: 12$

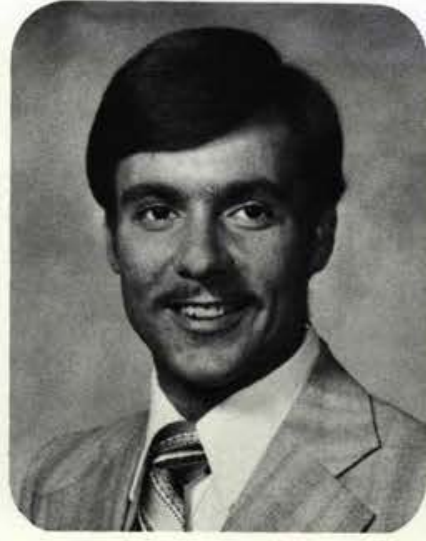

DANIEL BRIAN GREEN

Lakeland, Florida

Business Administration/Bible

He must increase, but I must decrease. John $3: 30$

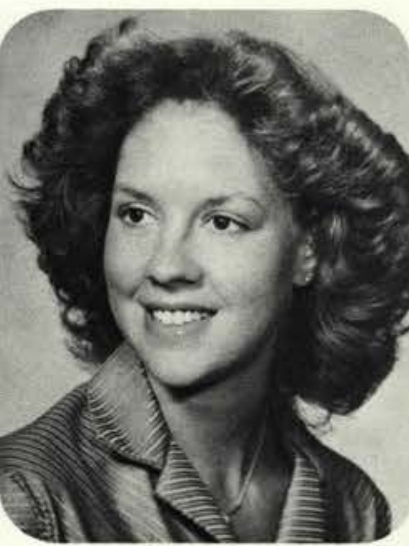

CATHERINE ANN GUENTHER

Fort Knox, Kentucky

Elementary Education

Psalm 103:10, 11

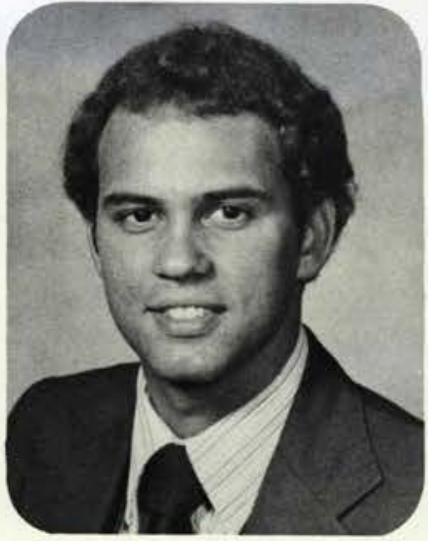

DANN CHARLES GREEN Cedarville, Ohio

Pre-Seminary

But I trusted in thee, 0 Lord: I said, thou art my God. My times are in thy hand. Psalm 31:14-15

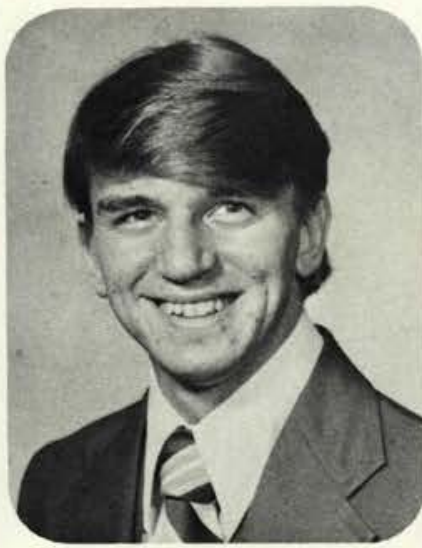

WILLLAM HALLMAN

Bloomsburg, Pennsylvania

Pre-Seminary/Bible

The redeemed are effectually called to be eternally saved, to be consistently Christian.

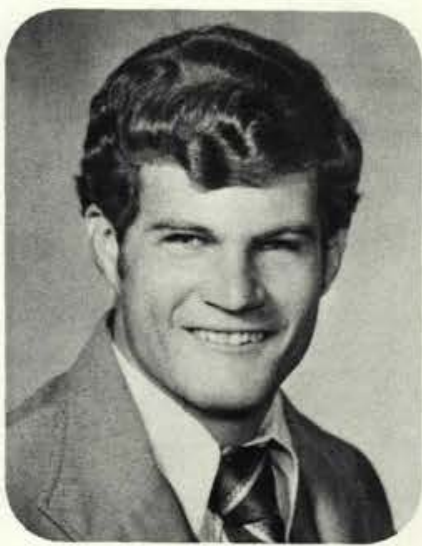

ROBERT HANSON

Colona, Illinois

Physical Education

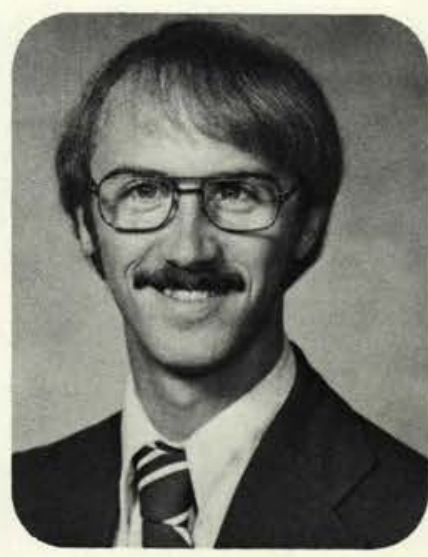

KEVIN L. HATHAWAY Madison, Ohio Speech

As for me and my house, we will serve the Lord. Joshua 24:15 


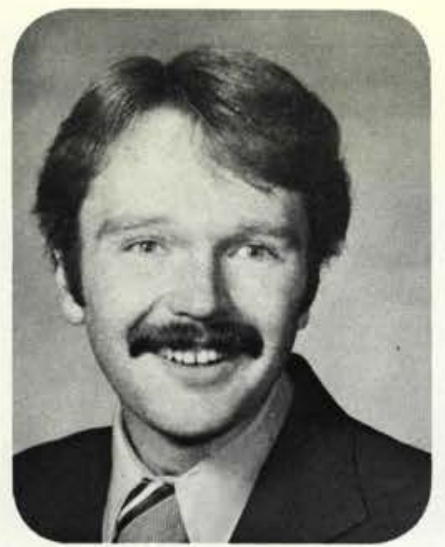

WILLIAM HAYES

Marlboro, Massachusetts

Elementary Education

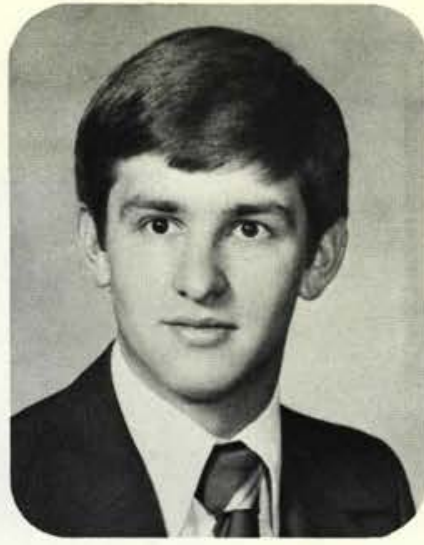

STEVEN H. HAYES

Brownsburg, Indiana

Business Administration

Behold, I am the Lord, the God of all flesh; is there anything too hard for me? Jeremiah 32:27

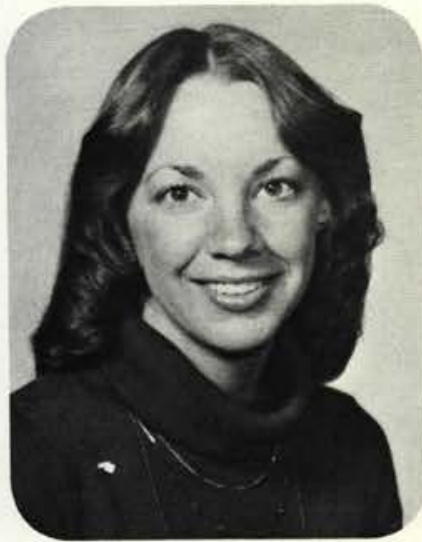

JANET RUTH HERRIMAN

Sterling Height, Michigan

Business Administration

Georgetown, Illinois

Business Administration

Wait on the Lord; be of good courage, and he shall strengthen thine heart. Psalm 27:14

For this God is our God forever and ever; he will be our guide even unto death. Psalm

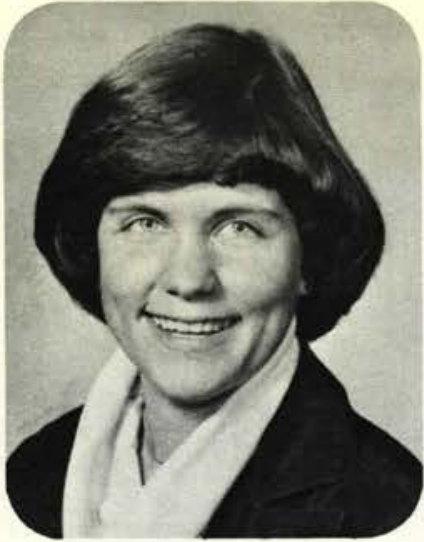

CATHY HEATLY

Kalkaska, Michigan

Music Education

Sing to the Lord a new song: for He has done marvelous things. Psalm 98:1

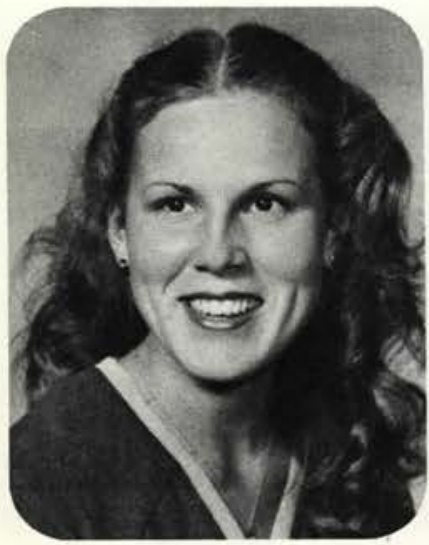

CHERYL LYNETTE HERRON

Behavioral Science/Psychology 48:14

He which hath begun a good work in you will perform it until the day of Jesus Christ. Philippians 1:6 Dawson, lowa

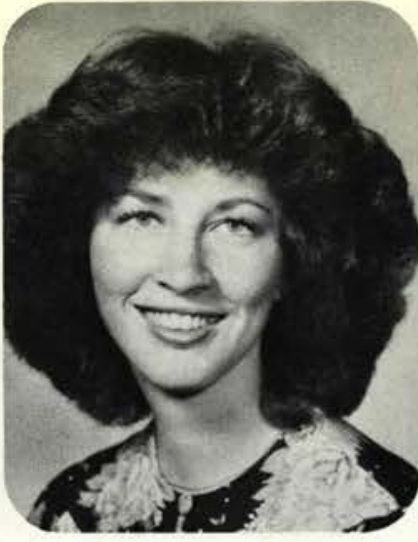

KIM HENDERSON

Ft. Mitchell, Kentucky Elementary Education

My goal in life is to grow mentally, physically, spiritually, and socially to become more like Jesus.

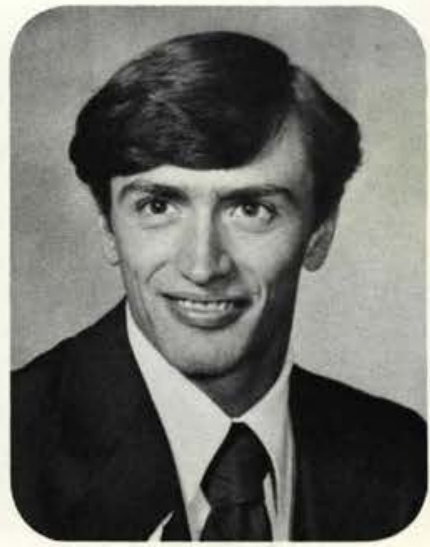

RICK HICKMAN

Slaney, Ohio

Physical Education

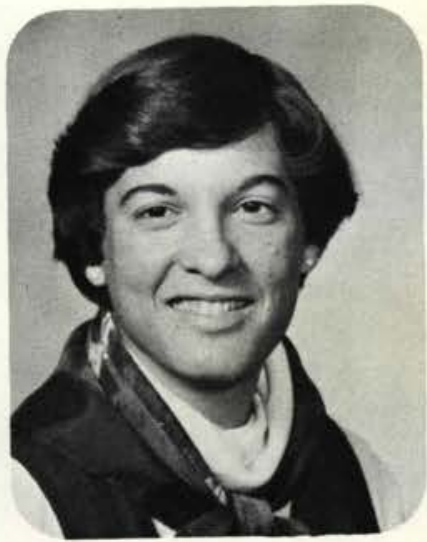

BRENDA HOBAR

Grafton, Ohio

Physical Education

Proverbs 3:5, 6

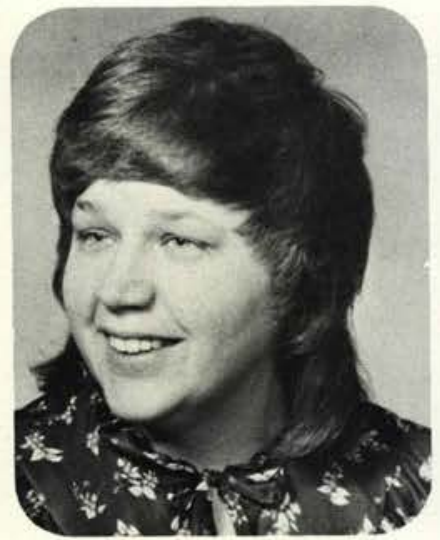

PAUL HIILL

Davidson, lowa

Business Administration

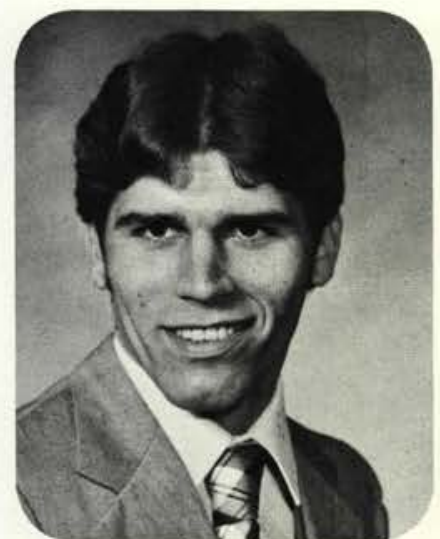

JANET MARIE HINES

Clinton, Washington

Elementary Education

My desire is to be willing to follow the Lord's leading, wherever He may lead. Proverbs $3: 5,6$ 


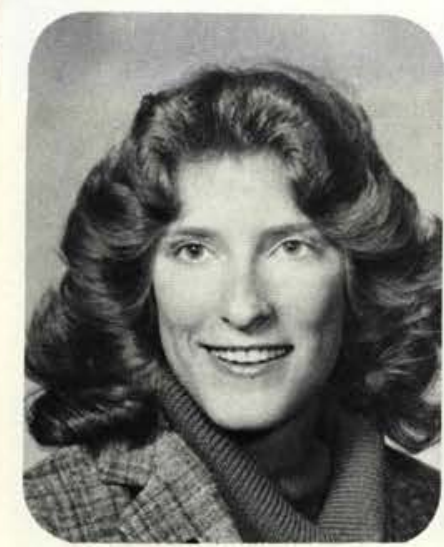

KIMBERLY SUE HOSACK

Elkhart, Indiana

Behavioral Science

As crossroads come in my life, I want to trust God for decisions, then walk in them. Jeremiah 6:16

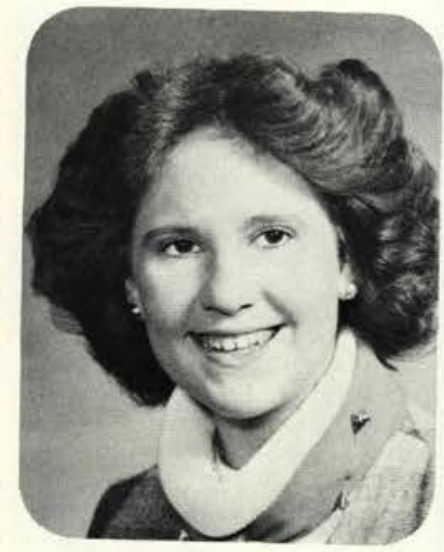

DAWN JANSEN

Maple Heights, Ohio

Elementary Education

In everything give thanks. I Thessalonians 5:18

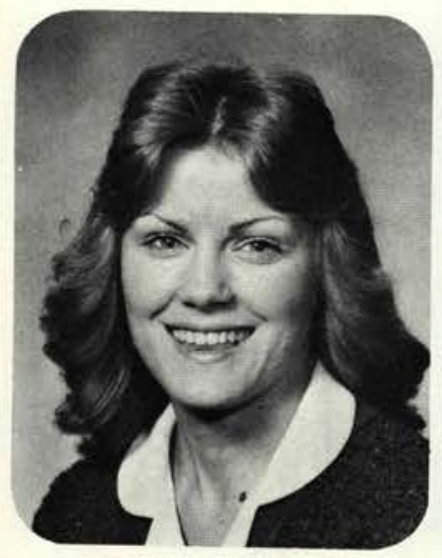

SHERRI JONES

Lafayette, Indiana

Elementary, Education

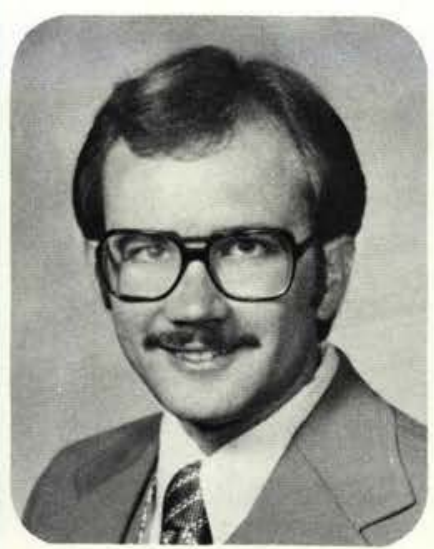

GREGORY L. HOWE

East Alton, Illinois

Elementary Education

People really need help but may attack you if you help them. Help people anyway.

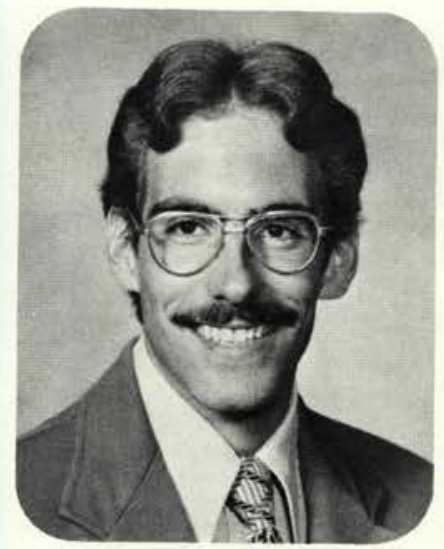

DAVID LANHAM JOHNSON Waterford, Pennsylvania

$$
\text { Chemistry }
$$

Life is like an experiment, you don't always get what you expect, and never more than you put into it.

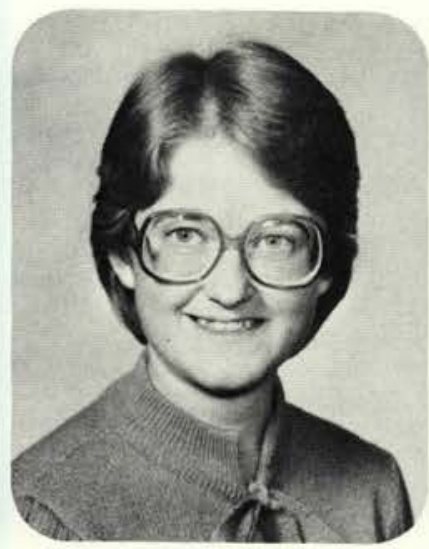

MARGARET KAMPHAUSEN

Collingdale, Pennsylvania

Elementary Education

May my spoken words and unspoken

thoughts be pleasing even to you, 0 Lord my Rock and my Redeemer.

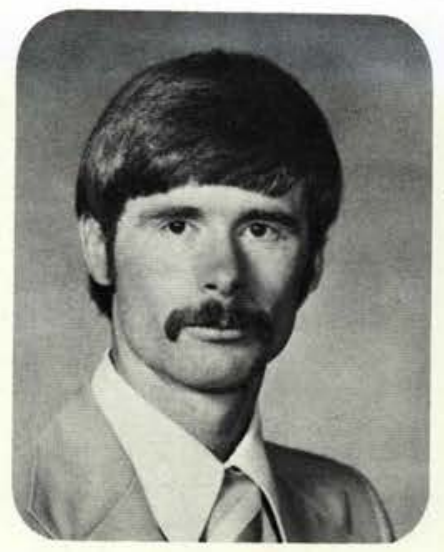

MICHAEL HUNTING

Grandview, Washington

Physical Education

To glorify God and enjoy Him forever.

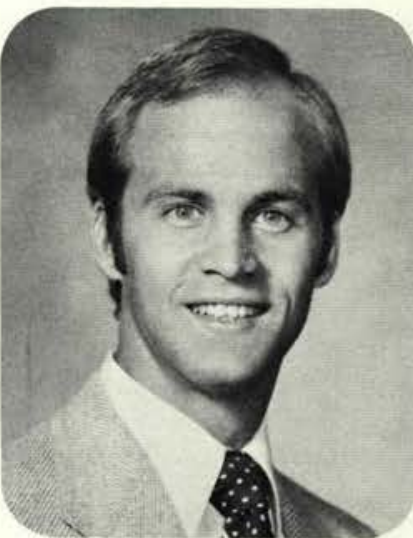

DONALD E. JOHNSON

Kettering, Ohio

Pre-Seminary/Bible

. and teaching them to obey everything I have commanded you. Matthew 28:30

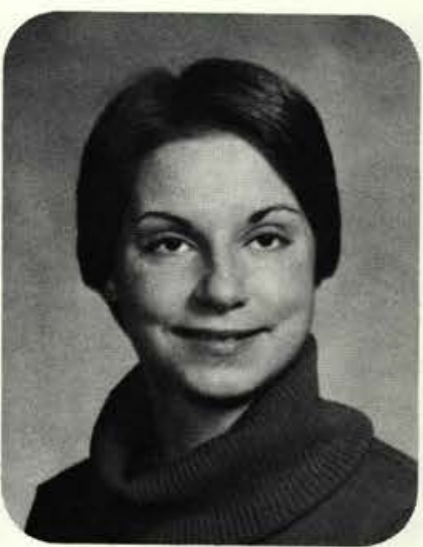

KRISTINE KARSIAN

Hackensack, New Jersey English

Let us press on to know the LORD. Hosea 6:3

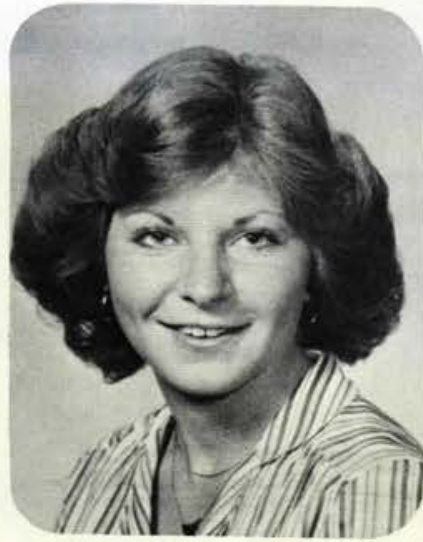

CINDY SUE JACOBS

Waterloo, lowa

Elementary Education

You shall follow the Lord your God, listen to His voice, serve Him, and cling to Him. Deut. 13.4

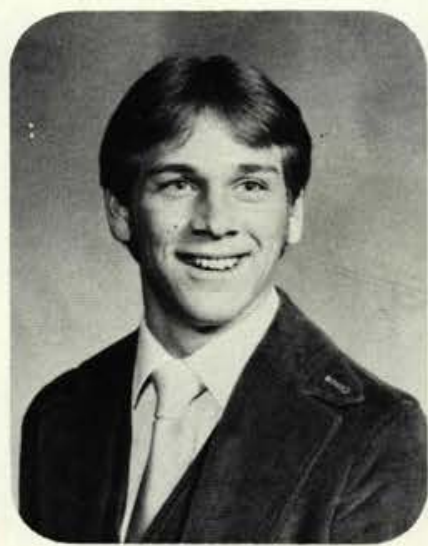

MARK JONES

Muskegon, Michigan

Business Administration

The man whose pleasures are simpler is happier more of the time.

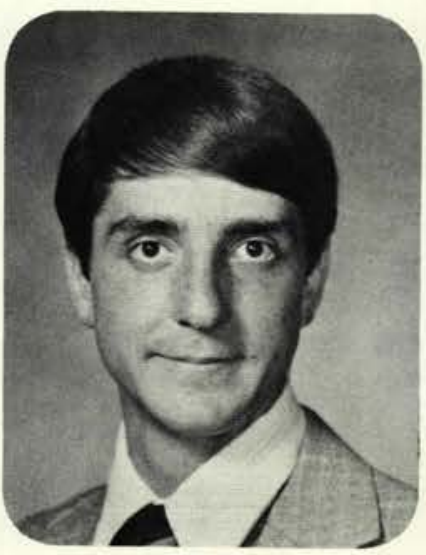

KIMBER F. KAUFFMAN

Brownsburg, Indiana

Pre-Seminary/Bible

So then everyone of us shall give account of himself to God. Romans 14:12 


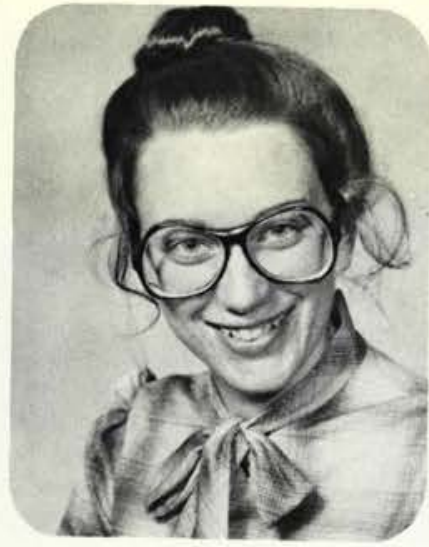

DEBRA KEYS

Midland, Ohio

Elementary Education

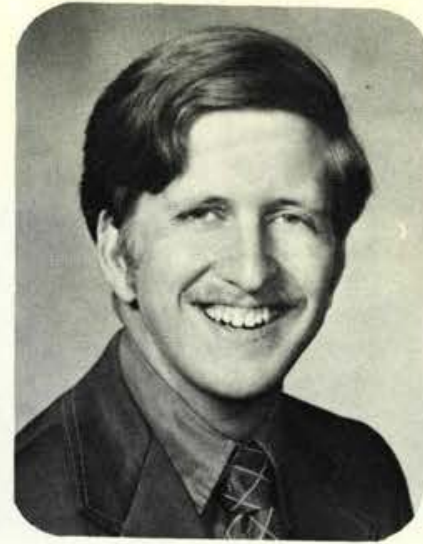

ROBERT KING

Peoria, Arizona

History/Political Science

I heard the voice of the Lord, saying, Whom shall I send ... ? Here am I; send me. Isaiah 6:8

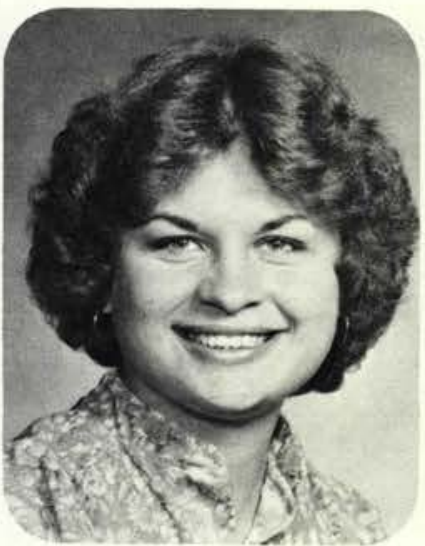

ANNA KOCH

Middleport, New York

English

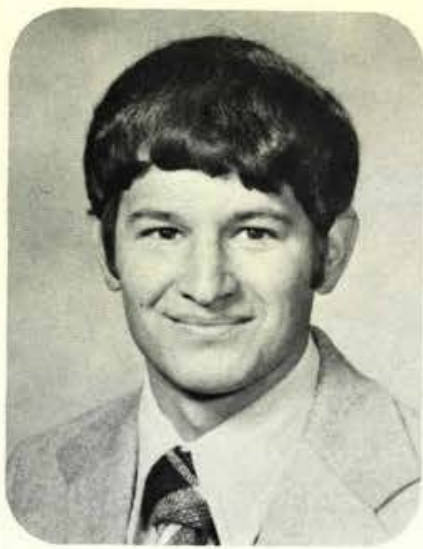

MARK KIRBY

Prospect, Ohio

Physical Education

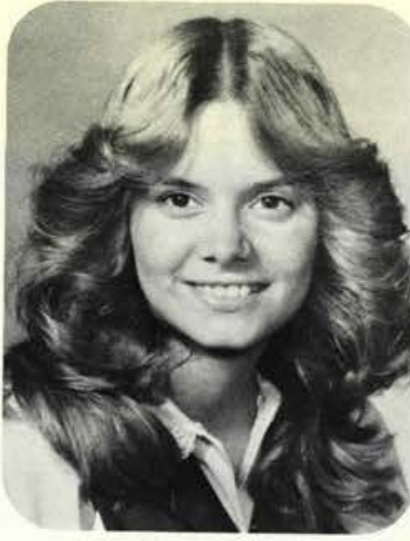

JO ANN KISER

Little Hocking, Ohio

Business Administration

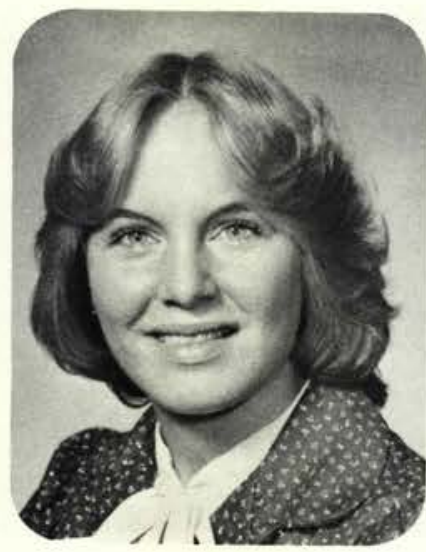

CYNTHIA KRAMER

Elementary Education
Music

And whatsoever ye do in word or deed, do all in the name of the Lord Jesus. Colossians 3:17

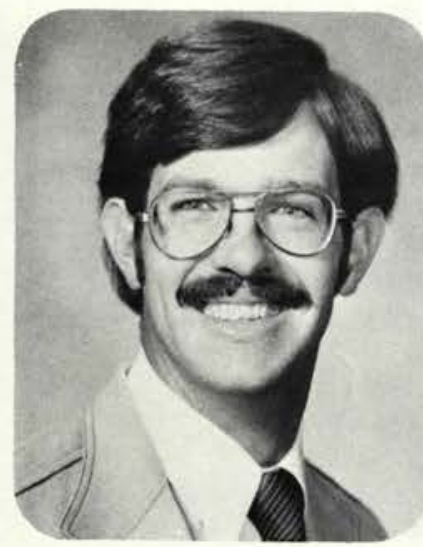

CRAIG KUNS

Brawley, California

Comprehensive Bible

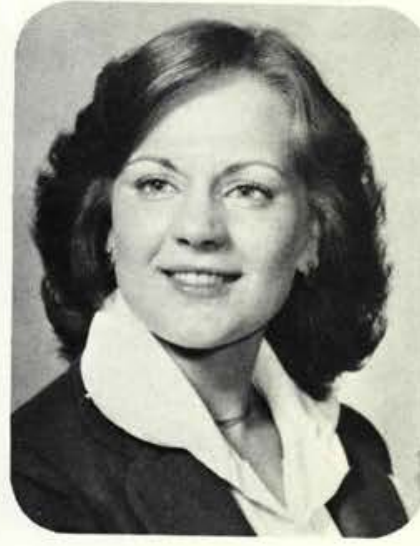

LINDA JEAN KUSCHEL

North Tonawanda, New York

Biology Education

But let him that glorieth glory in this, that he understandeth and knoweth that I am the Lord.

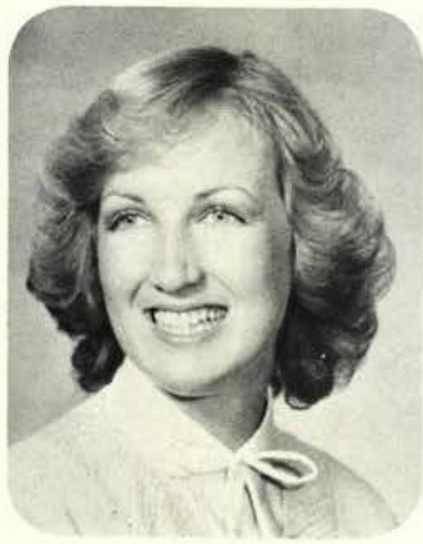

LORI KIM LAHAYE

San Diego, California Speech Education

Philippians 4:8-9

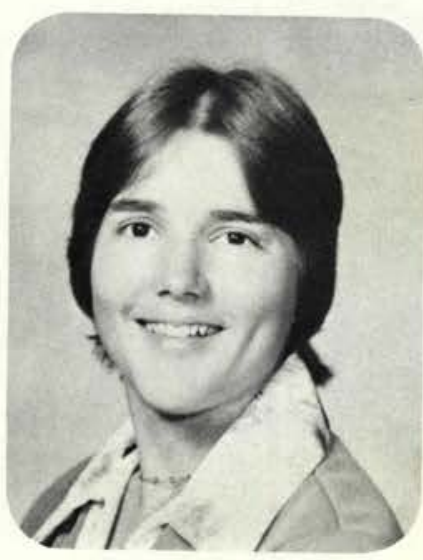

SUSAN E. KULP

Port Allegany, Pennsylvania

Physical Education

To lead, one must follow, to attain one must compete, to achieve one must understand

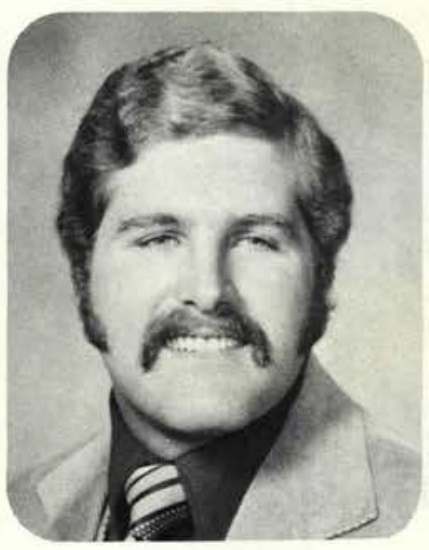

JERRY LANT2

Speedway, Indiana

Social Science Comprehensive

Philippians 3:13-14 


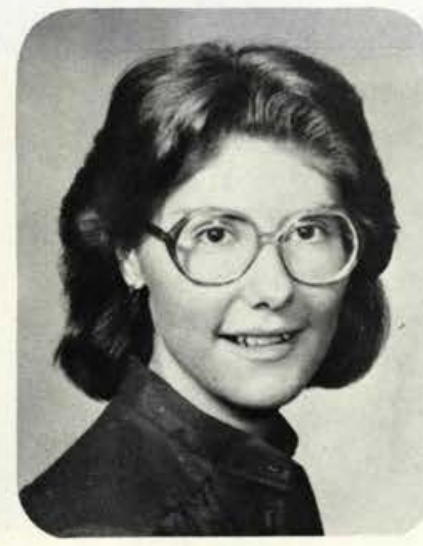

KAREN LAPP

Winfield, Illinois

Business Administration

What you are is God's gift to you. What you become is your gift to God.

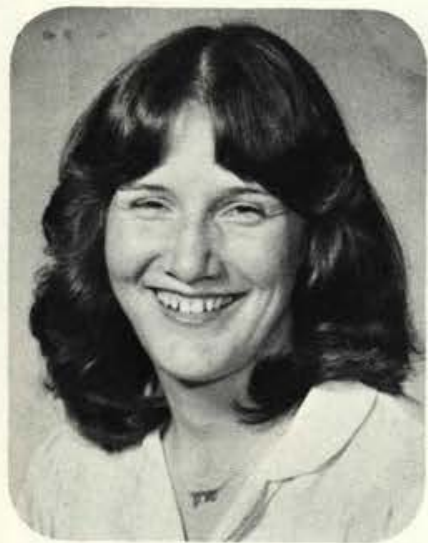

SHARON LEVIN

Thornton, Colorado

Psychology

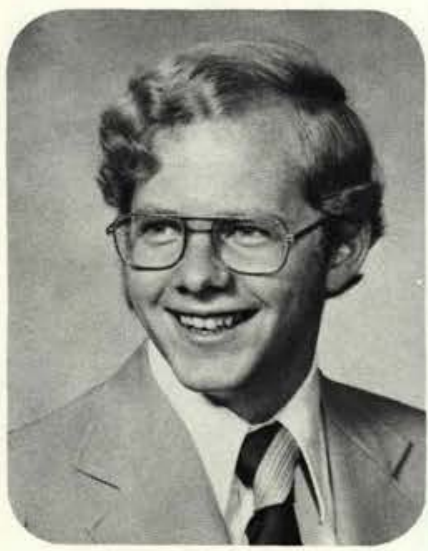

NORMAN MACKENZIE

South Otselic, New York

Physical Education

Rejoice in the Lord always; and again I say, Rejoice. Philippians 4:4

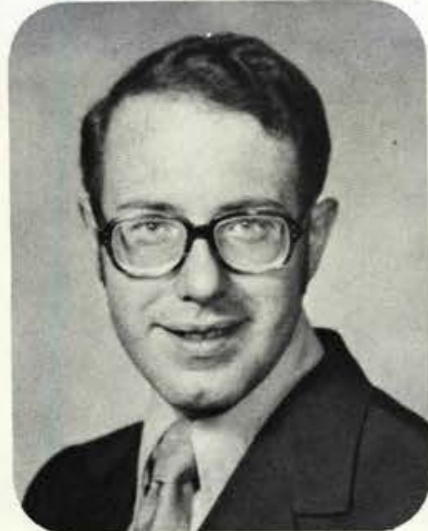

DAVID C. LARUE

Frostburg, Maryland

Psychology

and he was called the friend of God. James 2:23

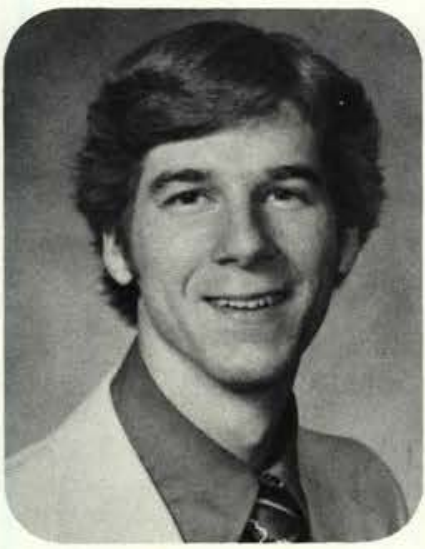

MARK EDWARD LONES

Fruitport, Michigan

Pre-Seminary/Bible

Who shall I send, and who will go for us? Then said I, Here am I; send me. Isaiah 6:8

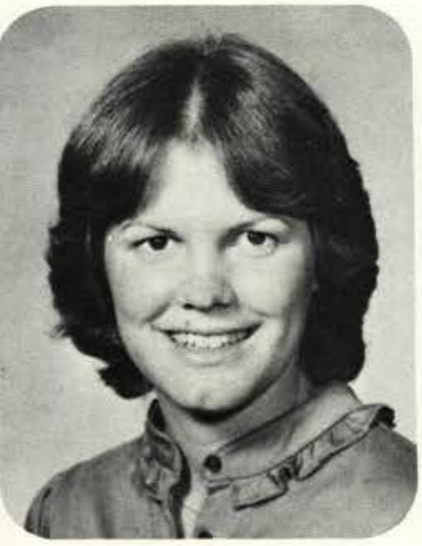

JULIE MARIHUGH

Delphos, Ohio

Biology/Mathematics

Too low they build who build beneath the stars.

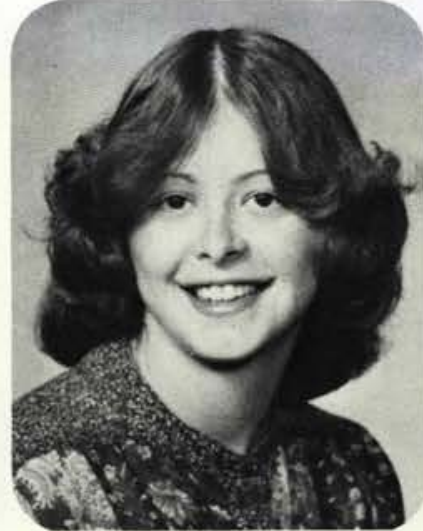

BETH E. LEIGHTENHEIMER Portsmouth, Ohio

Elementary Education

But as for me and my house, we will serve the Lord. Joshua 24:15

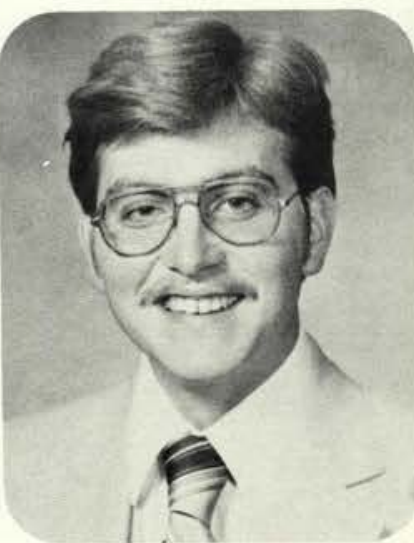

\section{NATHAN J. LONGNECKER \\ Benton, Pennsylvania} Psychology

To progessively know, commune with, and obey the commands of the sustainer of life.

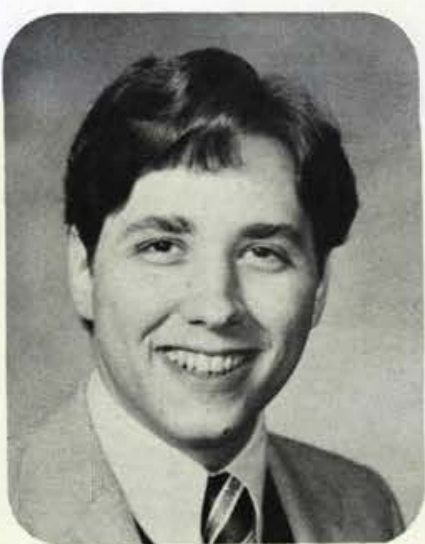

JAMES 0 . LEIGHTENHEIMER Portsmouth, Ohio

Speech/Broadcasting

But as for me and my house, we will serve the Lord. Joshua 24:15

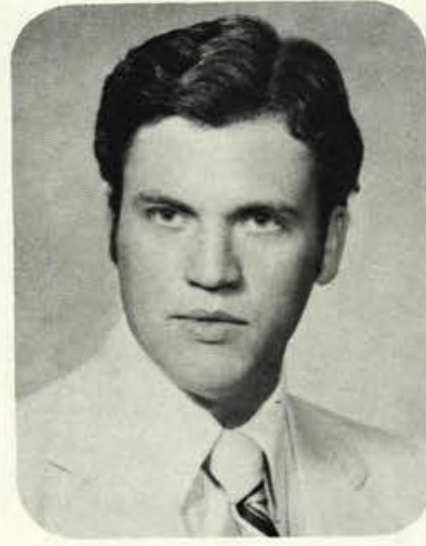

JAMES M. LUCE

Willsville, Kansas

Pre-Seminary/Bible

Commit thy works unto the Lord, and my thoughts shall be established. Proverbs 16:3

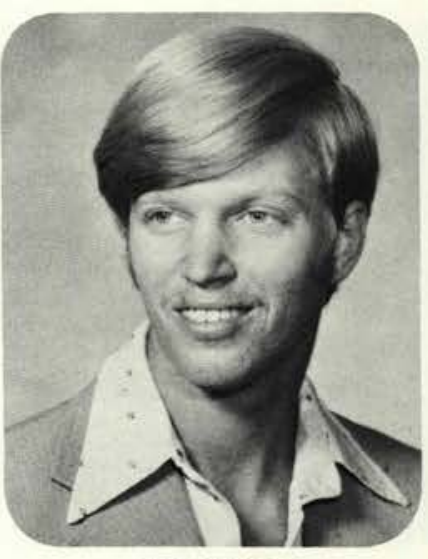

PETER MARTENS

Business Administration

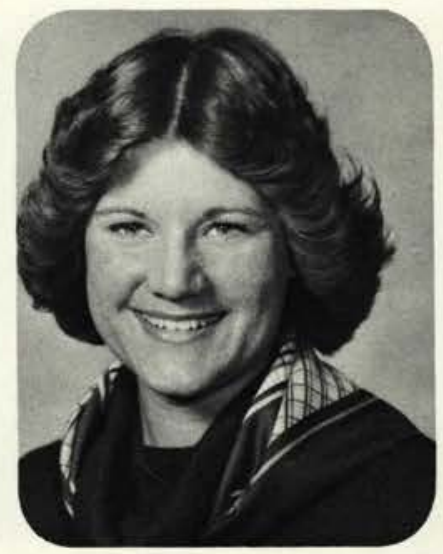

CINDY MARTIN

Hopewell, Virginia Elementary Education 


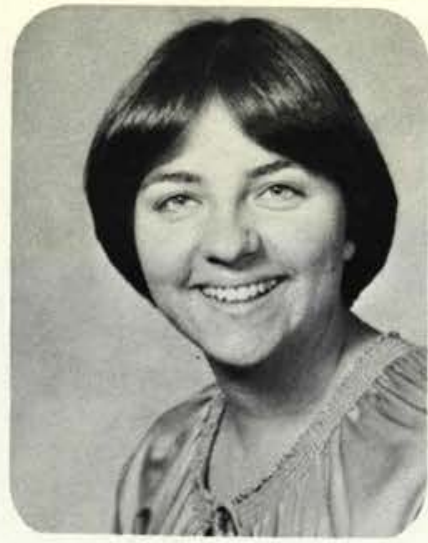

RUTH MARTIN

Grethel, Kentucky

Comprehensive Bible

I will instruct thee and teach thee in the way which thou shalt go; Psalm 32:8

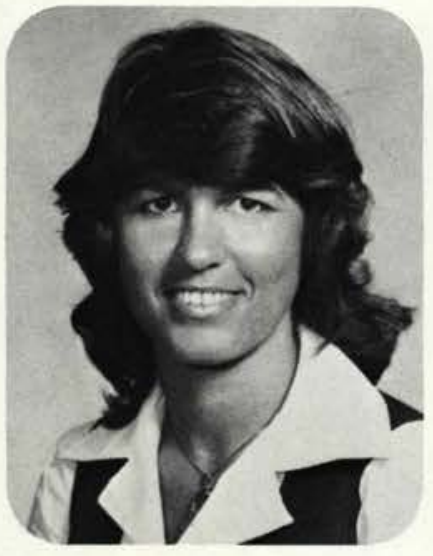

PATRICIA A. MICHALSKI

Cedarville, Ohio

Behavioral Science/Psychology

and bringing into captivity every thought to the obedience of Christ; II Corinthians $10: 5$

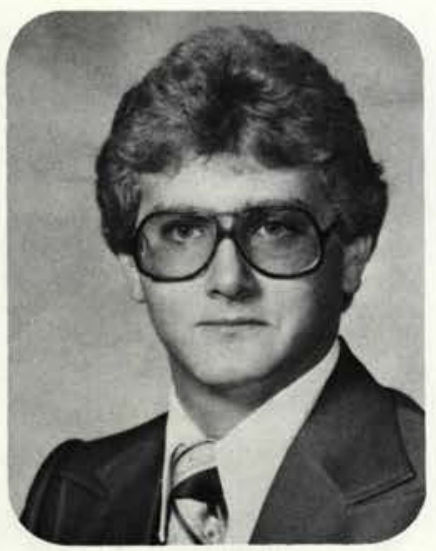

TIMOTHY MOORE

Columbia City, Indiana History

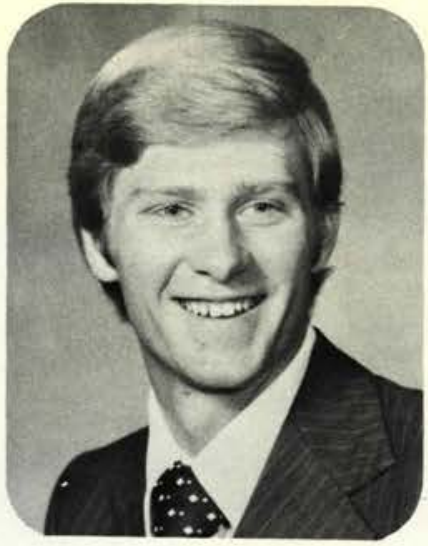

KEVIN MASTERS

Cincinnati, Ohio

Psychology

be transformed by the renewing of your mind, that you may prove what the will of God is ... NASV

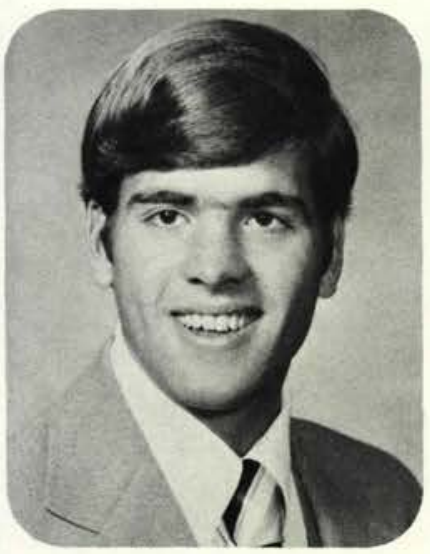

ROGER THOMAS MICHEL

Montour Falls, New York

Mathematics Education

Commit thy way unto the Lord; trust also in him, and he shall bring it to pass. Psalm 37:5

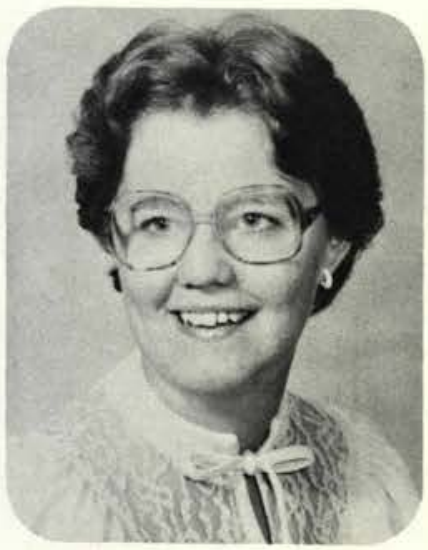

DEBRA MYERS

Greenville, Ohio

Elementary Education

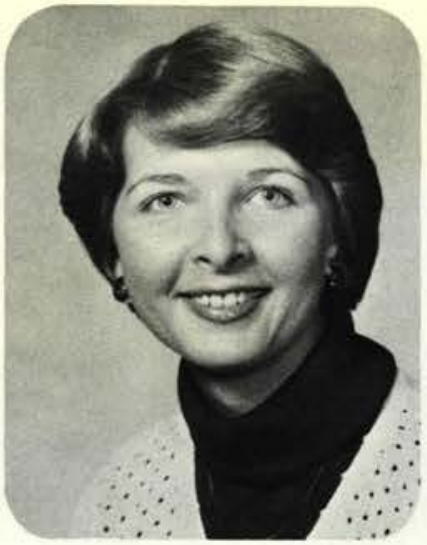

BRENDA MCBRIDE

Louisville, Kentucky Elementary Education

Proverbs 3:5.6

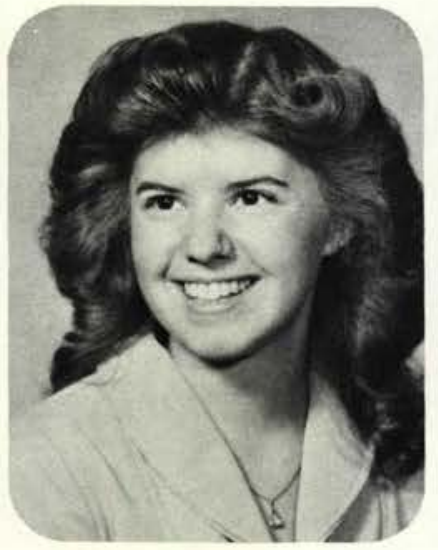

\section{CYNTHIA A. MILLER Laurel, Maryland \\ Mathematics}

Fear the Lord, and serve Him in truth with all your heart; for consider how great things He hath done for you.

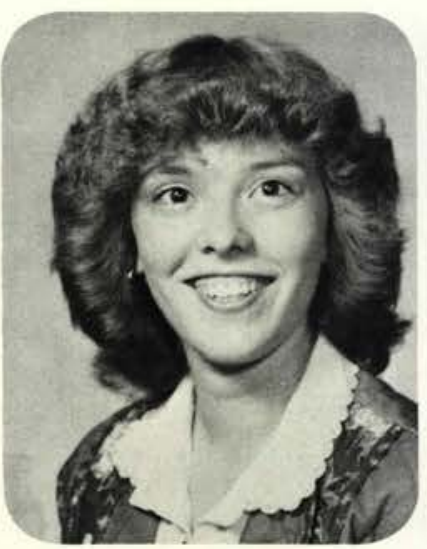

CAROLYN NAPIER

Fort Madison, lowa

English Education

Two roads diverged in a wood, and I took the one less traveled by, and that has made all the difference.

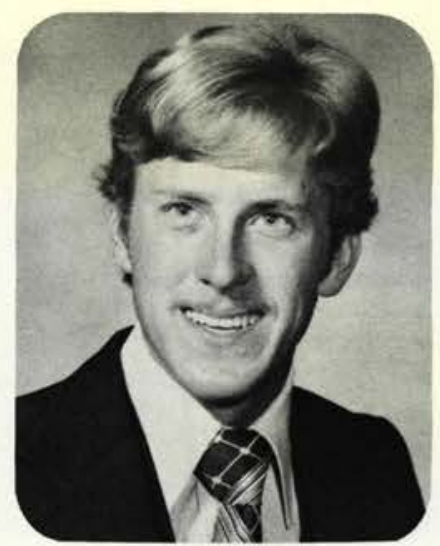

DAVID MCCULLOUGH

Business Administration

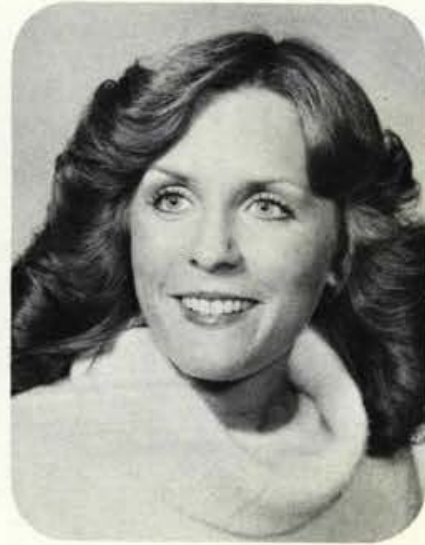

PATTI MOLIN

Burton, Michigan

Elementary Education

Proverbs 3:5.6

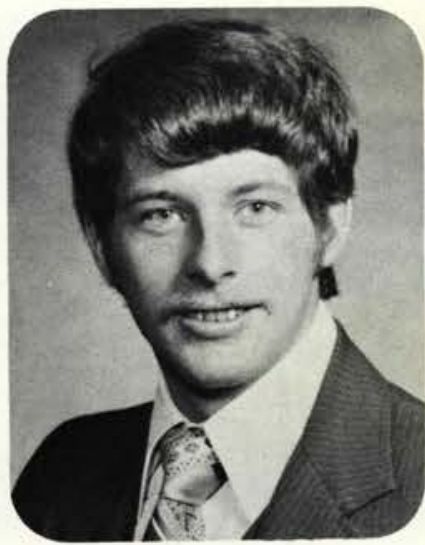

JAMES DAVID NEELY

Kettering, Ohio

Business Administration

God's will is never contrary to His Word. 


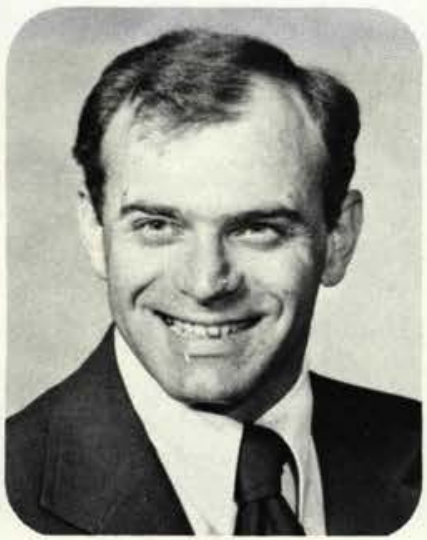

DANIEL NEVITT

Comprehensive Bible
MICHAEL NICHOLS

Biology

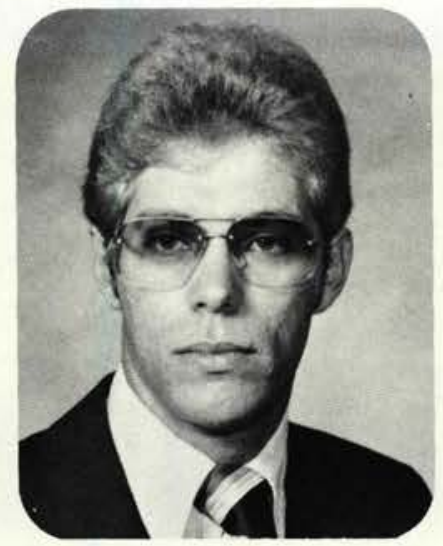

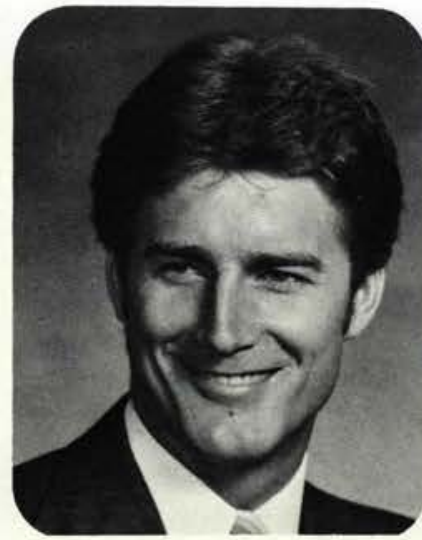

MICHAEL ALLEN O'QUINN

Altamonte Springs, Florida English

... the commandment is a lamp, the teaching is light; reproots for discipline are the way of life.

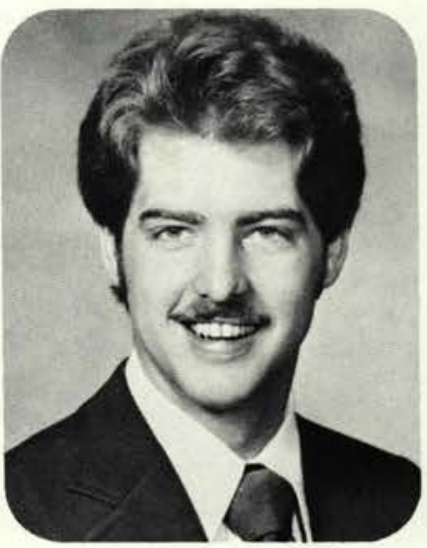

DONALD A. PARVIN

Cedarville, Ohio

Pre-Seminary/Bible

Except the Lord build the house, they labor in vain that build it ... Psalm 127:1

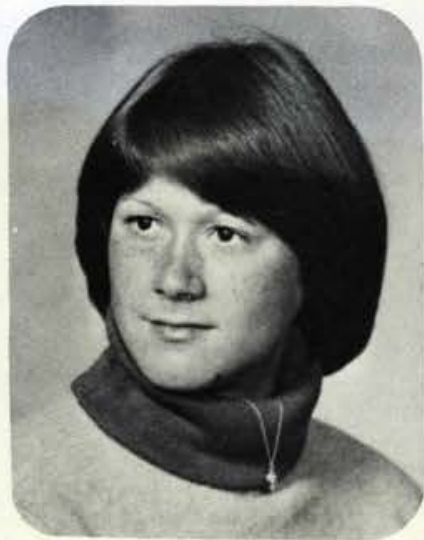

SUE PALMER

Mosherville, Pennsylvania Physical Education

He who hath begun a good work in you will perform it until the day of Jesus Christ. Philippians 1:6

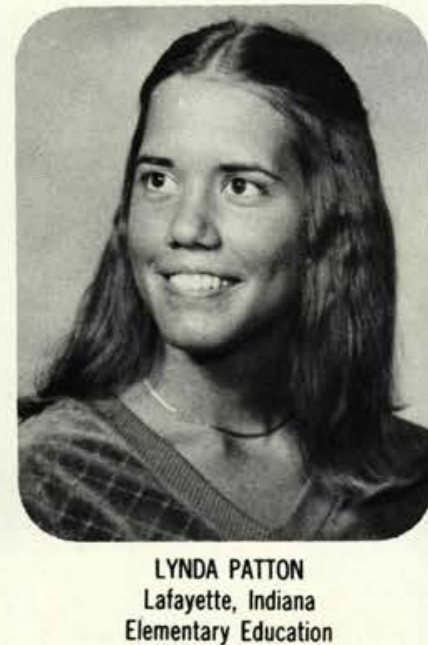

Walk worthy ... be fruitful. Increase in the knowledge of God. Colossians 1:10

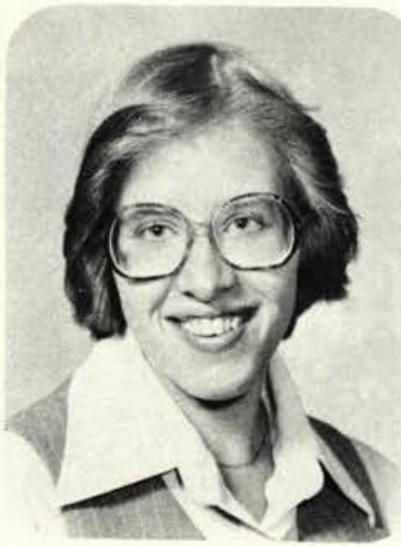

KATHLEEN PAYNE Elmira, New York Biology

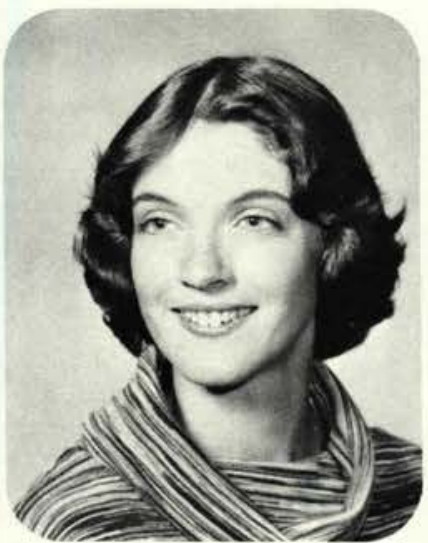

LANDA PENQUITE

Xenia, Ohio

Physical Education

That in all things He might have the preeminence.

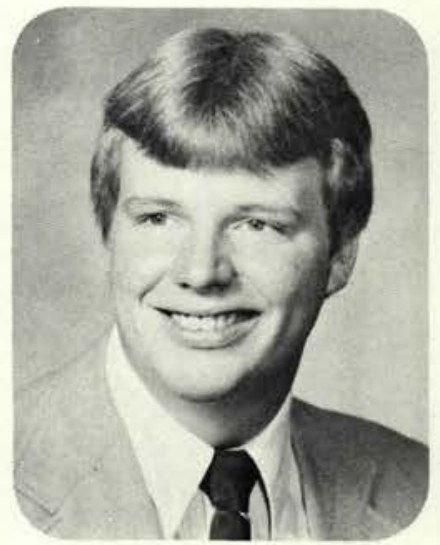

RICHARD L. PETERSON

$$
\text { Colona, lllinois }
$$

Business Administration

But seek ye first the kingdom of God ... Matthew 6:33

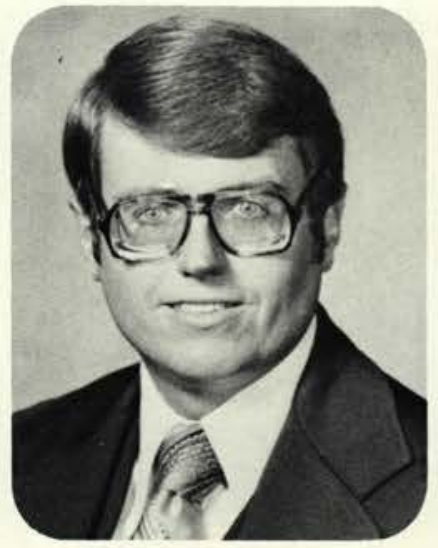

STEVE PETRY

Dayton, Ohio

Comprehensive Bible

That I may know him, and the power of His resurrection. Philippians 3:10 


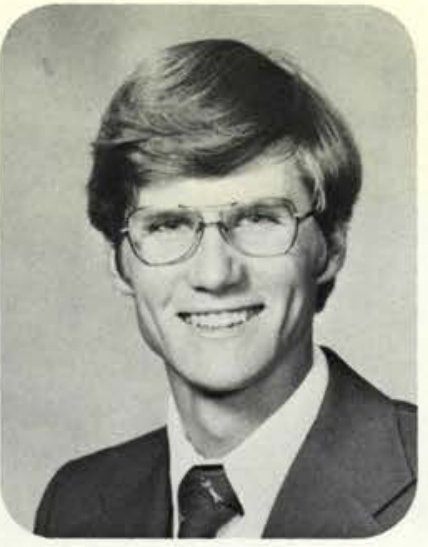

MARK PIERCE

Beavercreek, Ohio

Pre-Seminary/Bible

To submit myself unto God and commit my ways to Him.

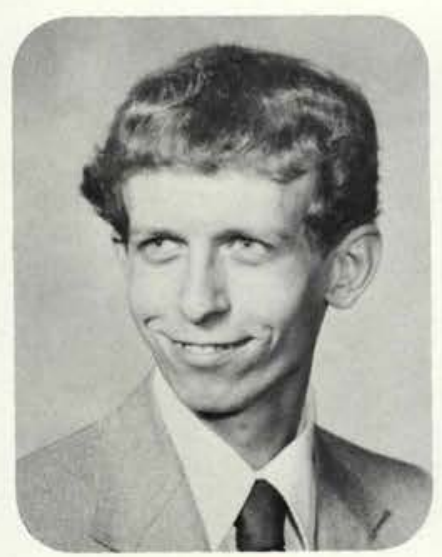

CHARLES RADCLIFF

Caldwell, Ohio

Business Administration

Seest thou a man diligent in his business? He shall stand before kings ... Proverbs 22:29

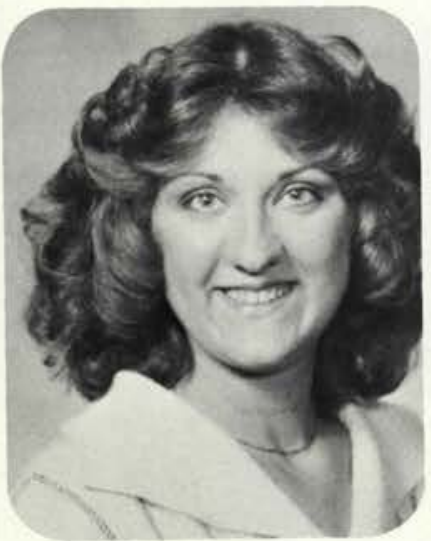

DEBORAH REID

Romeo, Michigan

Behavioral Science

Lord stand beside me staunchly, and with your own firm fingers guide my hand.

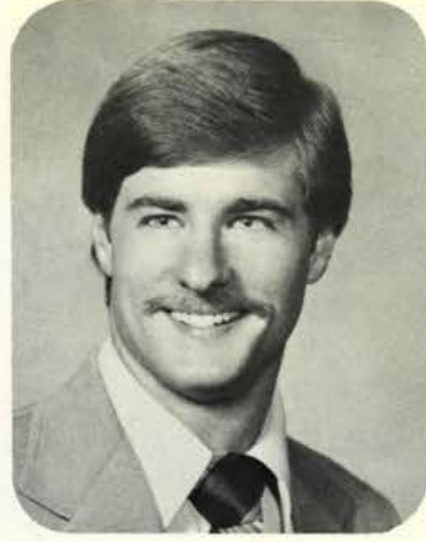

DONALD PIPPIN

Fort Wayne, Indiana

Business Administration

Whatsoever ye do in word or deed, do all to the glory of God. Colossians 3:17

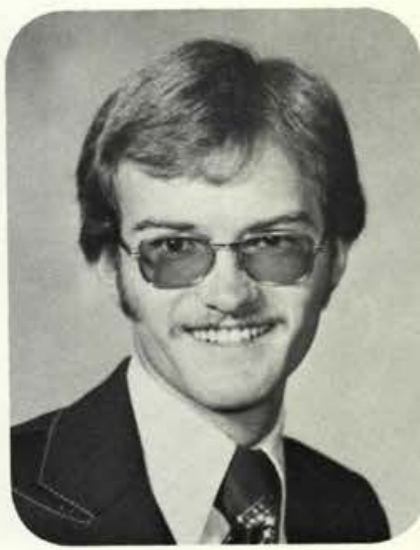

R. LEE RANDALL

Grove City, Ohio

Business Administration

Maturity comes not by age but by forgetting self.

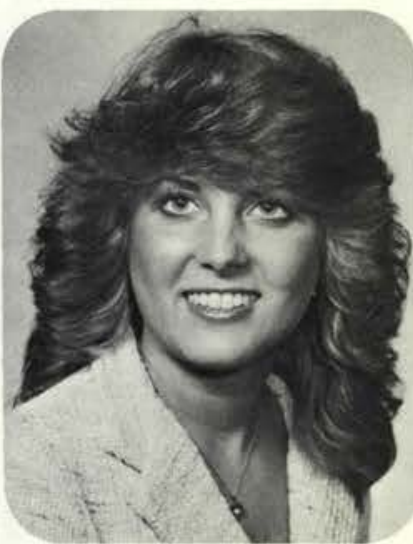

DARLENE REPP

Greensburg, Ohio

Elementary Education

But let patience have her perfect work, that ye may be perfect and entire, wanting nothing. James 1:4

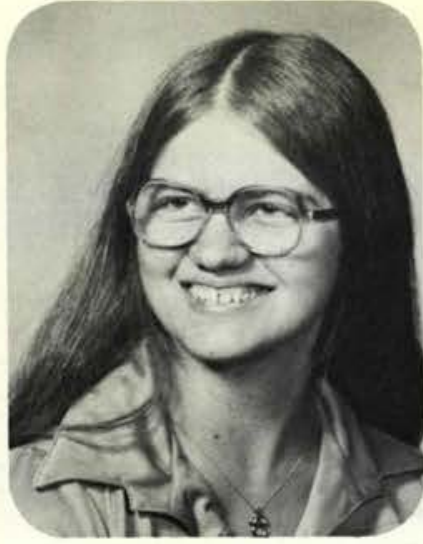

CONNIE MCLANE PITTS

Huntsburg, Ohio

Business Administration

I Corinthians 10:31

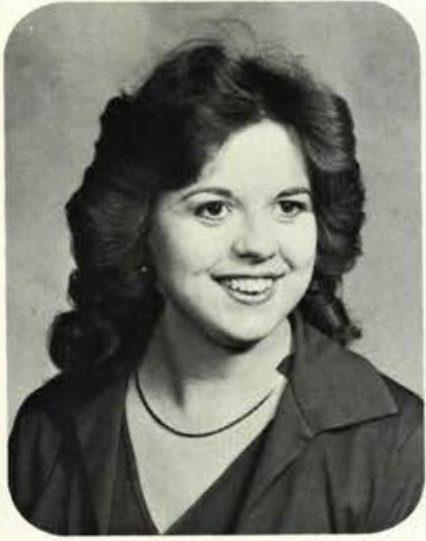

DEBRA M. RAPINCHUK Westmont, Illinois

English

Psalm 37:3-8

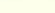

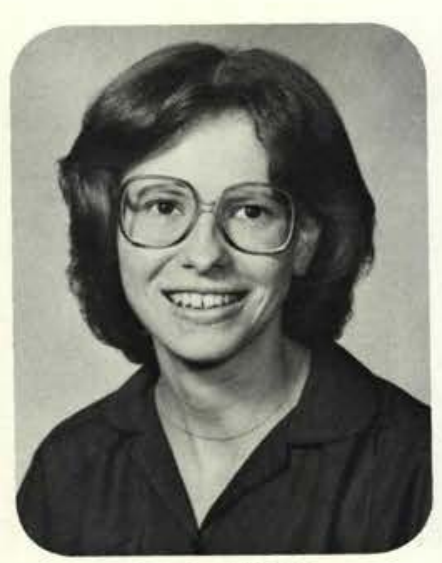

SANDY REYNOLDS

Paulo, Kansas

Business Administration

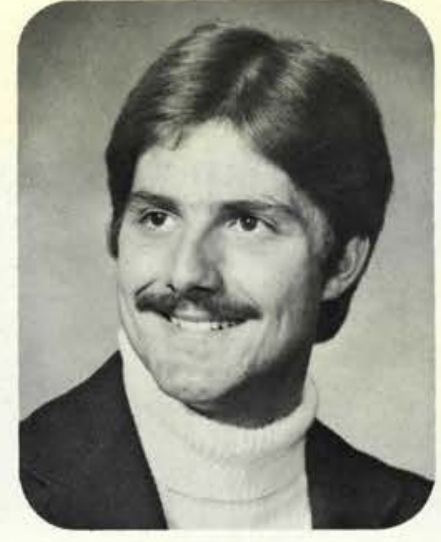

DANIEL POOLE

Ferndale, Michigan

Broadcasting

He must increase, but I must decrease. That I may know Him. John 3:30/Philippians 3:10

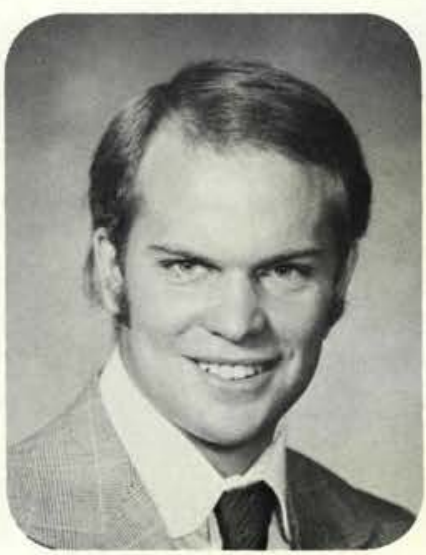

NATHAN MARTIN REHN

Pre-Seminary

I press on that I may lay hold of that for which also I was laid hold of by Christ Jesus. Philippians 3:12

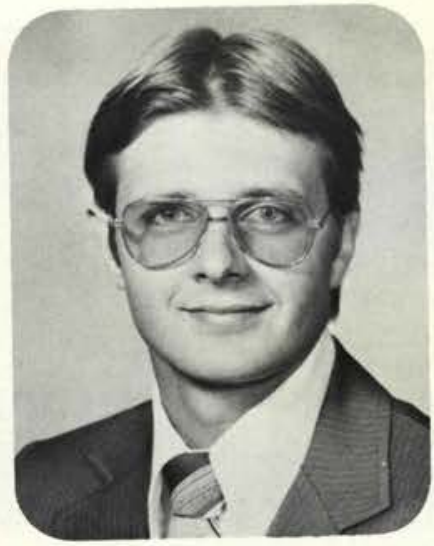

KEITH RICE

Eden, New York

Business Administration 


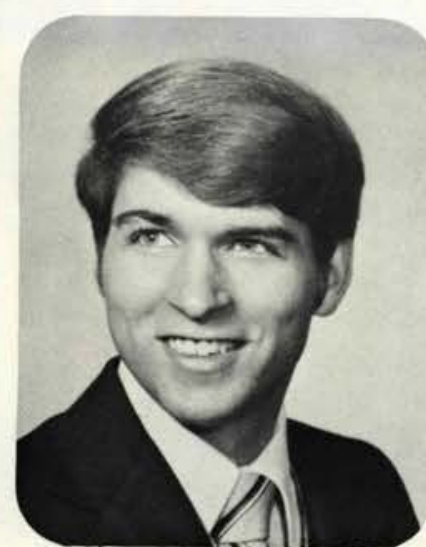

DOUGLAS DEAN RICHARDSON

Huntsburg, Ohio

Chemistry

... that in all things He might have the preeminence. Colossians 1:18

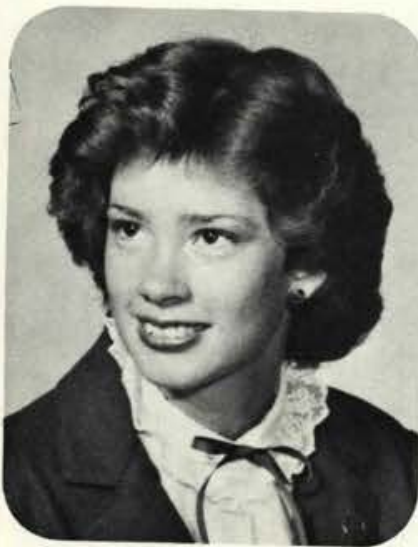

SANDRA ROTH

Woodlyn, Pennsylvania

Business Administration

My life is not made of the dreams that I dream, but by the choices that I make.

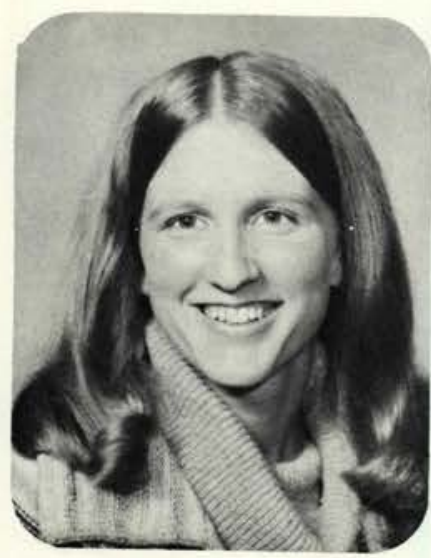

REBECCA RUPE

Gallipolis, Ohio

History/English Education

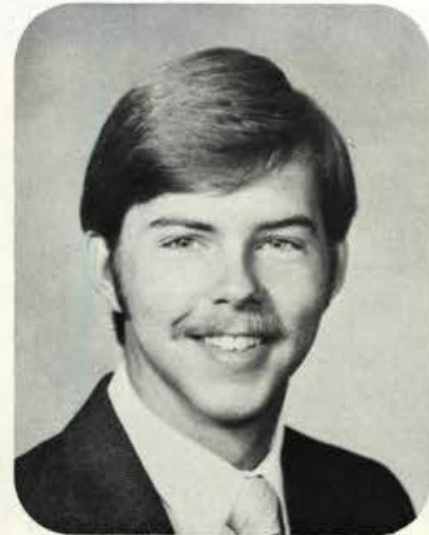

BRIAN L. RIGGS

Indianapolis, Indiana

Biology

Grow in the knowledge of Jesus, for he is most merciful, most just, and most wise.

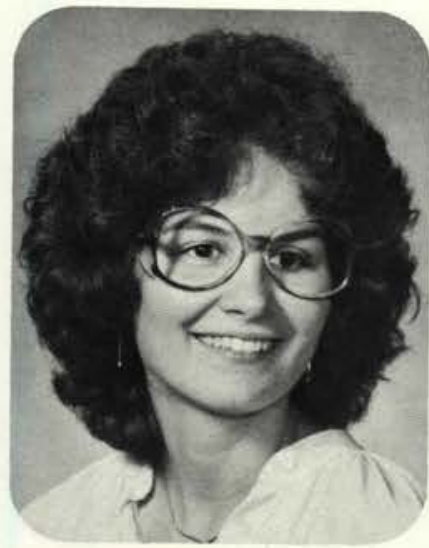

DEBORAH ROTHAAR

Toledo, Ohio

Behavorial Science/Psychology

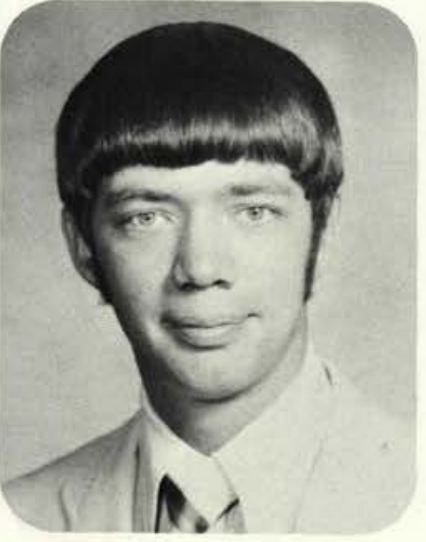

CLYDE SARVER

Rose Hill, lowa

Business Administration

Let this mind be in you, which was also in Christ Jesus. Philippians 2:5

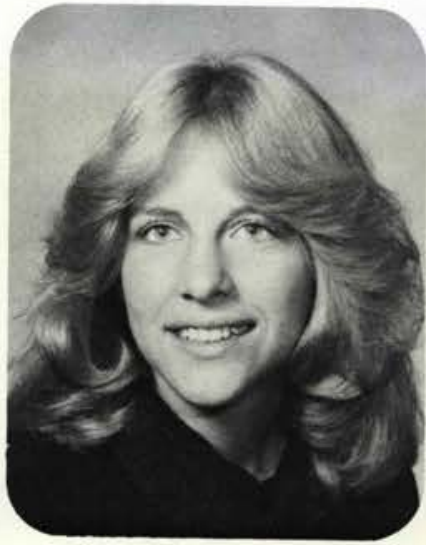

SUSAN RIKE

Behavorial Science

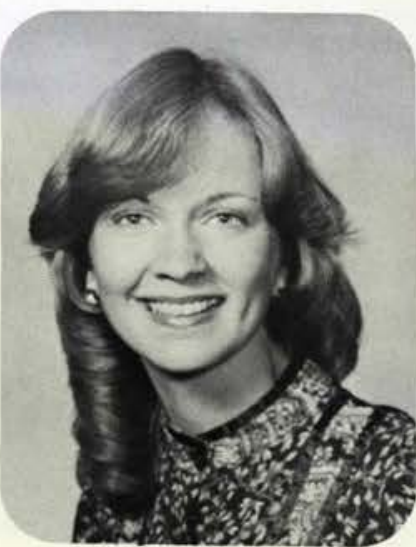

CYNTHIA ROBB

Elementary Education

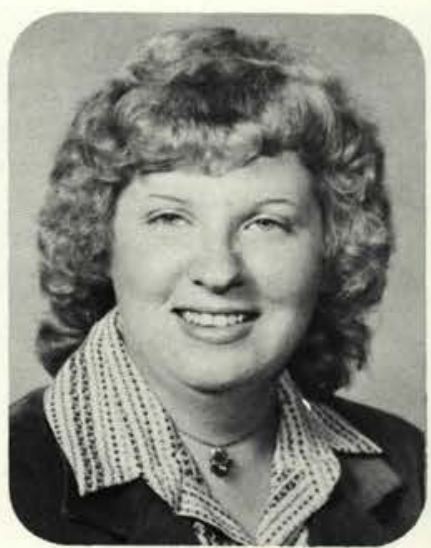

JANICE REU

Villa Park, Illinois

Elementary Education

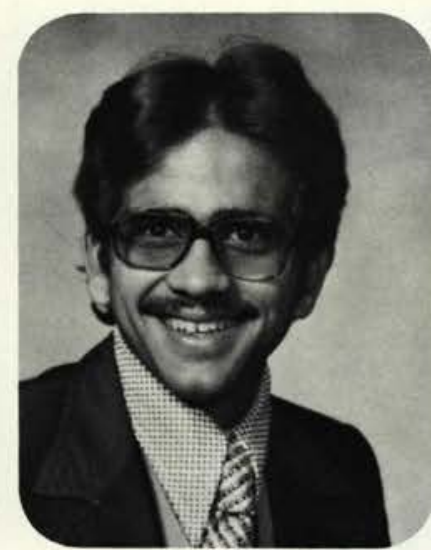

TOMAS ELIUD RUIZ

Caguas, Puerto Rico

Pre-Seminary/IDS

That my thinking will be captive to His Graphes until the Telos of time.

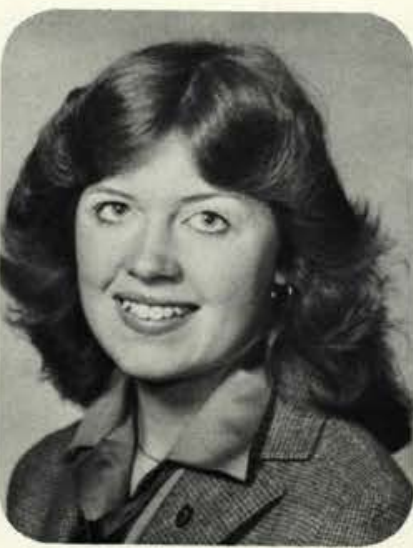

KAREN SEWELL

Lee's Summit, Missouri

Biology

I can do all things through Christ, who strengtheneth me. Philippians 4:13 


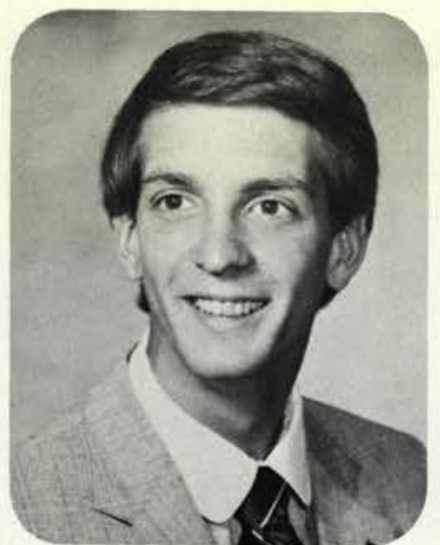

DALE REESE SHAW

Indianapolis, Indiana

Elementary Education

Teach me knowledge and good judgement, for I believe in your commands. Psalm 119:66

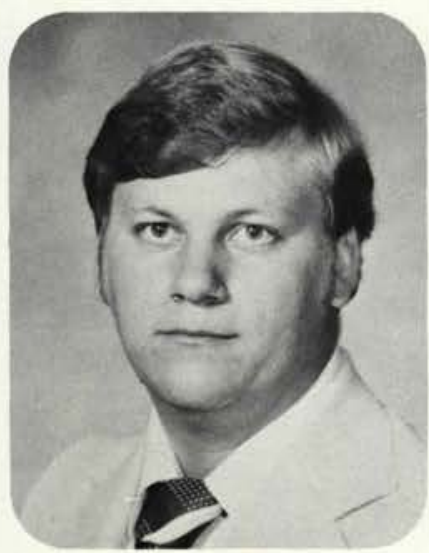

JACK L. SMITH

Springfield, Ohio

Music Education

Although this life is very odd, "Be still and know that I am God." Psalm 46:10

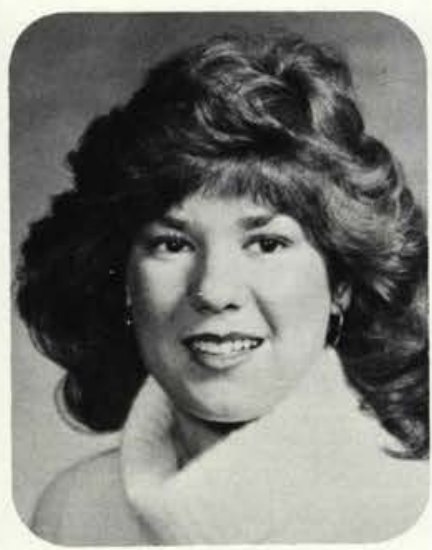

\section{KAREN SNYDER}

Strasburg, Ohio

Elementary Education

Delight thyself also in the Lord, and he shall give thee the desires of thine heart. Psalm $37: 4$

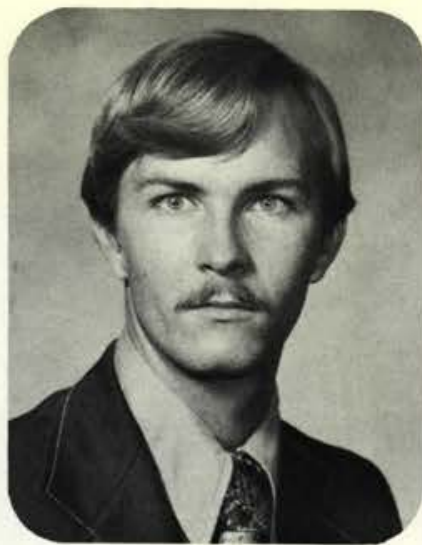

TIMOTY SHUBERT

Saunemin, Illinois

Comprehensive Bible

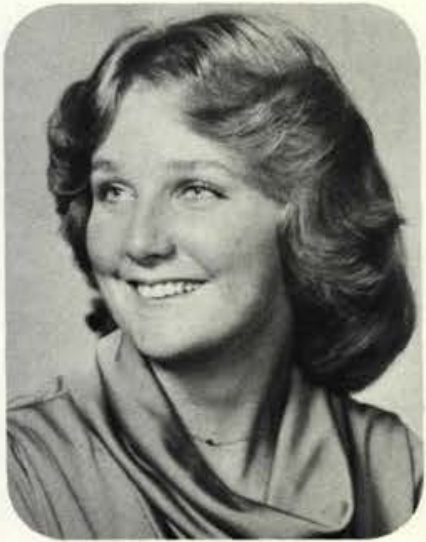

KIMBERLY SMITH

Scottsville, Kentucky

Behavioral Science/Psychology

Man is made to encounter difficulty, but never made to suffer defeat. - Hemingway

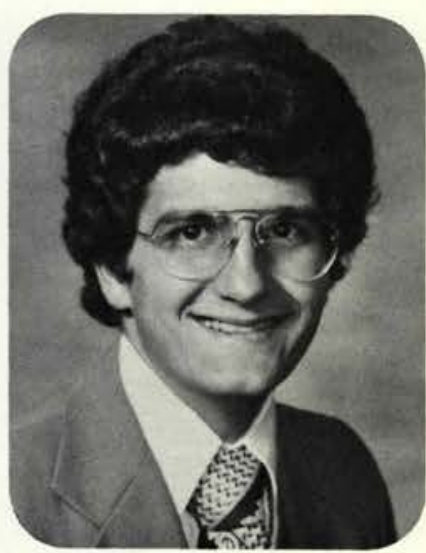

STEVE SNYDER

Plymouth, Indiana

Psychology

To renew the image of God in my life out of love for God, for the purpose of glorifying Him.

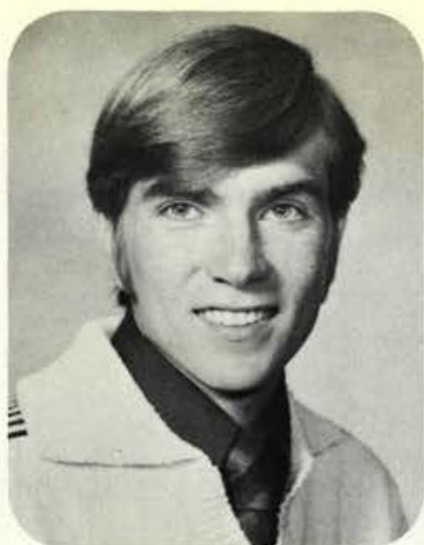

\section{ANDREW LEE SIMPSON \\ Fort Dodge, lowa \\ Pre-Seminary}

For God hath not given us the spirit of fear, but of power, and of love, and of a sound mind.

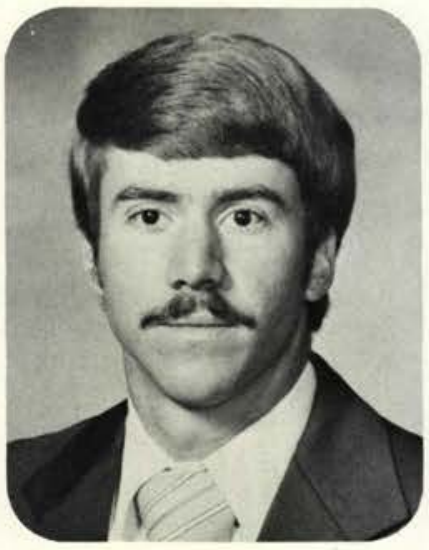

\section{RICHARD KEITH SMITH \\ Roanoke, Virginia \\ Chemistry}

Be strong and of good courage, for the Lord thy God is with thee wherever thou goest. Joshua 1:9

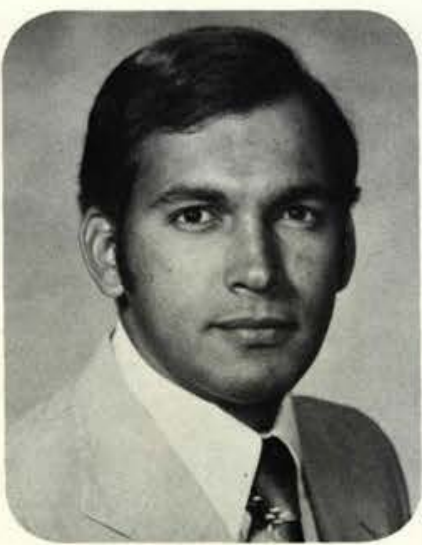

FRANCISCO FIGUEIREDO DE SOUZA

Rio de Janeiro, Brazil Psychology

The righteous shall live by faith. Romans $1: 17$

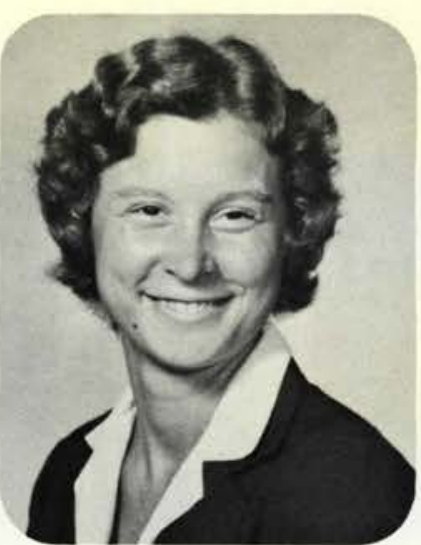

COLLEEN SIRKA

Indianapolis, Indiana

Mathematics Education

The Lord is my shepherd; I shall not want.

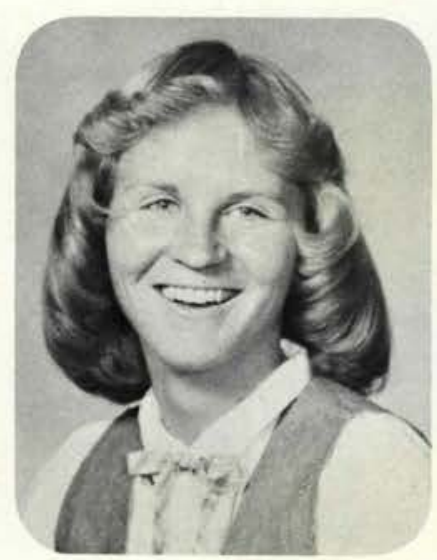

NANCY SNOOK

Cedarville, Ohio

Physical Education

Let your light so shine before men.

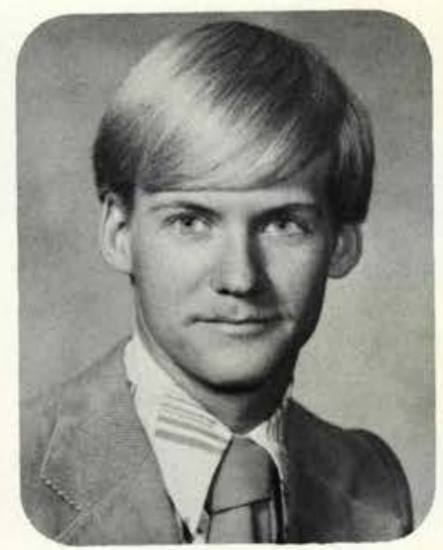

BRUCE SPARKS

Bricktown, New Jersey Comprehensive Bible 


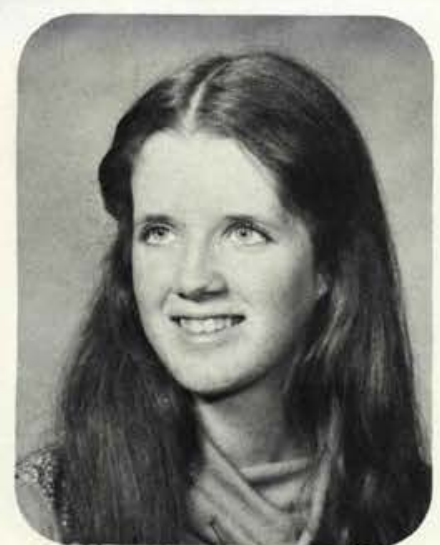

TERRI DAVIS SPARKS

Camden, Maine

Elementary Education

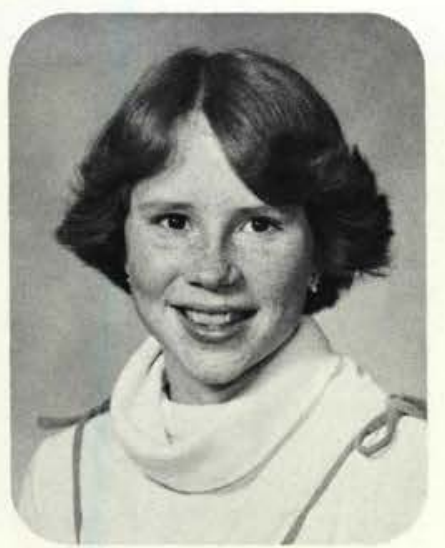

CHERYL SPRUNGER

Cincinnati, Ohio

Elementary Education

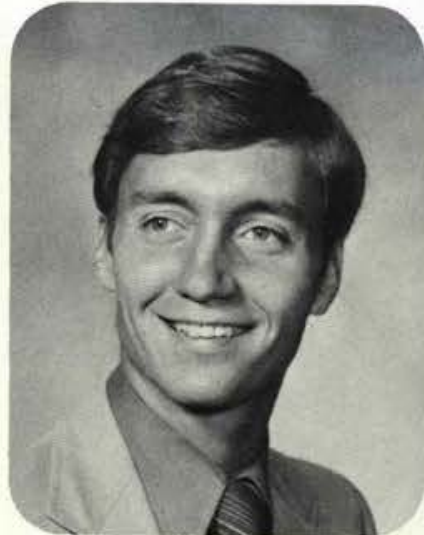

DANIEL STANDRIDGE

Rome, Italy

Psychology

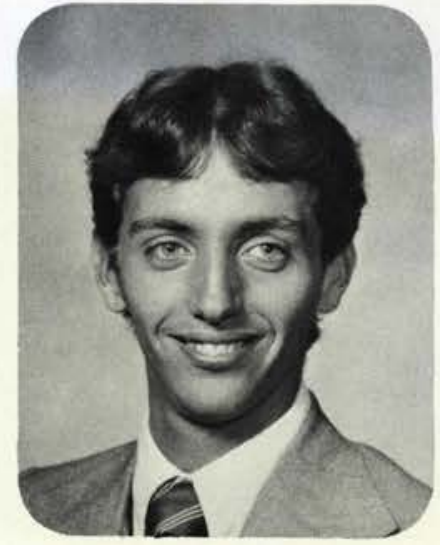

DAVID STANDRIDGE

Rome, Italy

Business Administration

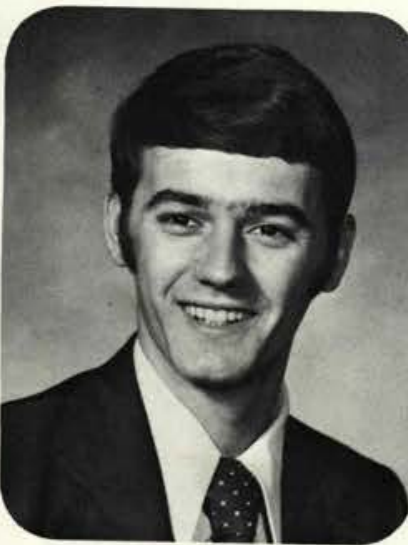

CHRISTOPHER R. STARBUCK

West Liberty, Ohio History

They desire a better country .... wherefore God is not ashamed to be called their God. Hebrews 11:16

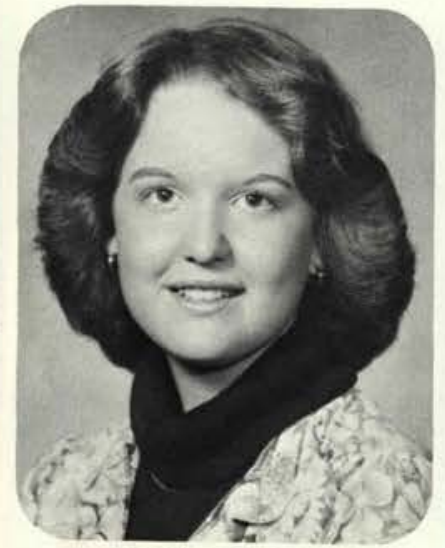

VIRGINIA LEIGH STONE

Bunker Hill, Illinois

Speech

.. desire that ye might be filled with the knowledge of his will in all wisdom.

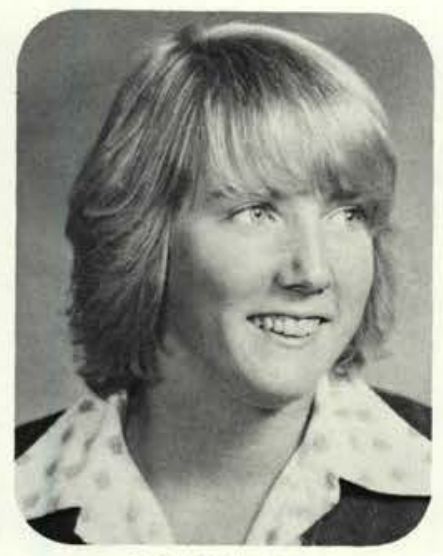

KAREN STEINHOFER

New Milford, New Jersey

Behavioral Science/Psychology

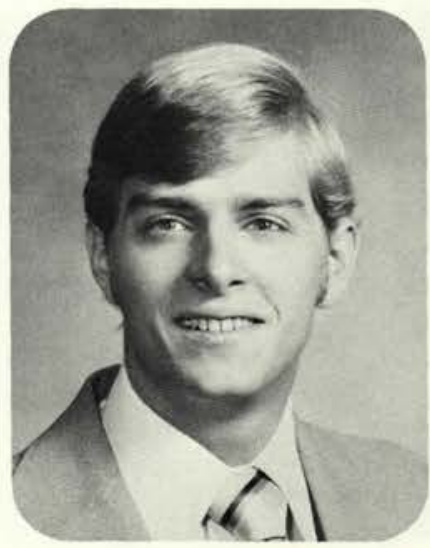

MICHAEL STEPHENS

Berea, Ohio

Business Administration

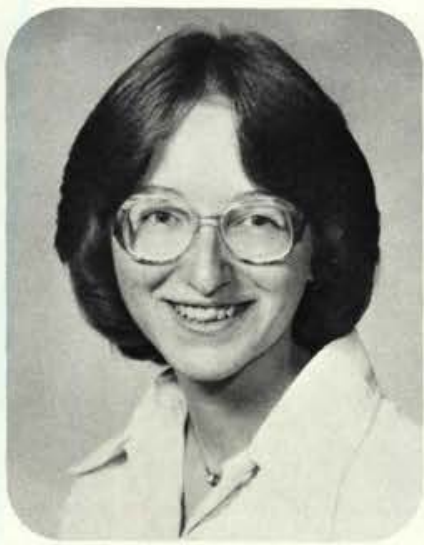

CHARLENE LOUISE STORER

Tidioute, Pennsylvania

$$
\text { English }
$$

But I will hope continually and will yet praise thee more and more. Psalm 71:14

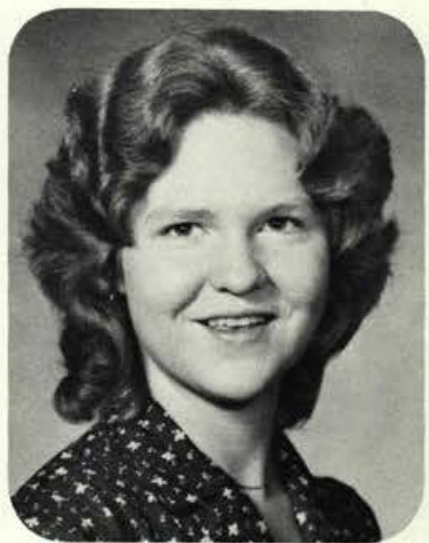

JUNE STRIEGEL

Cincinnati, Ohio

History

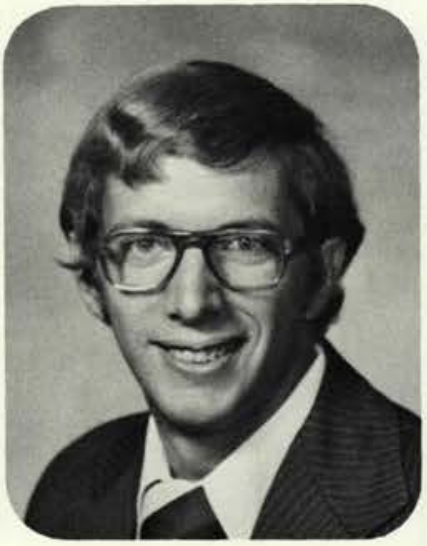

DAVID STEWART

Caldwell, Ohio

Business Administration

For by these I have run through a trap; but by my God have I leaped over a wall. II Samuel 22:30

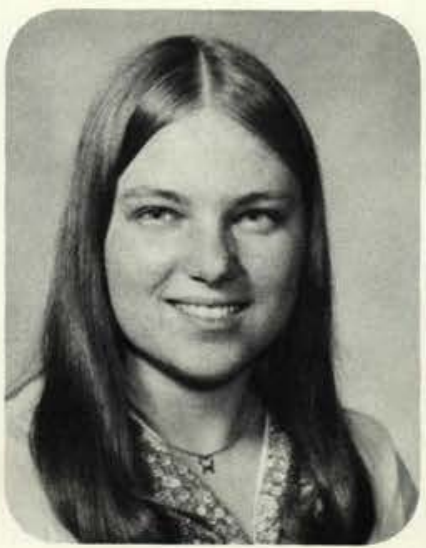

CAROL SUPPLEE

Fremont, Michigan Secretarial Science

In all thy ways acknowledge $\mathrm{Him}$, and $\mathrm{He}$ shall direct thy paths. Proverbs 3:6 


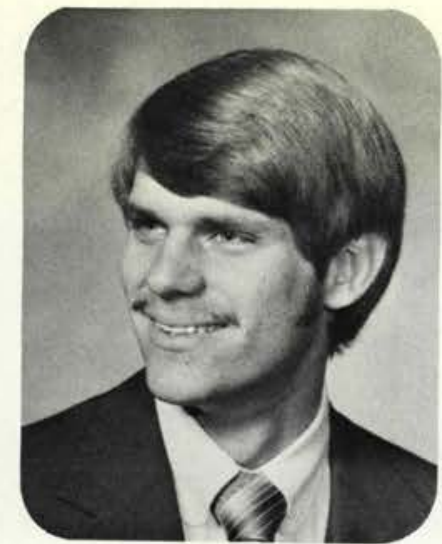

CALVIN CRAY SWANK

Noblesville, Indiana

Business Administration

Philippians 3:13-14

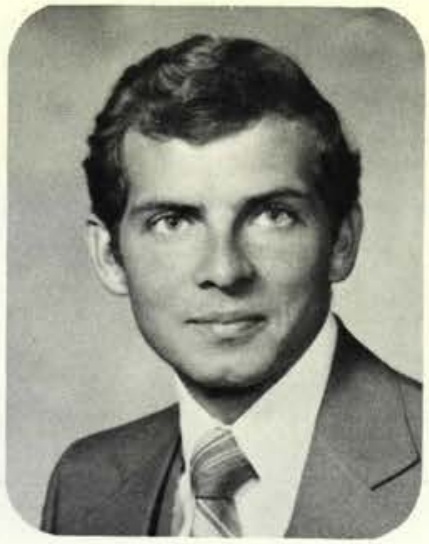

STEVEN SWAYZE

Lapeer, Michigan History

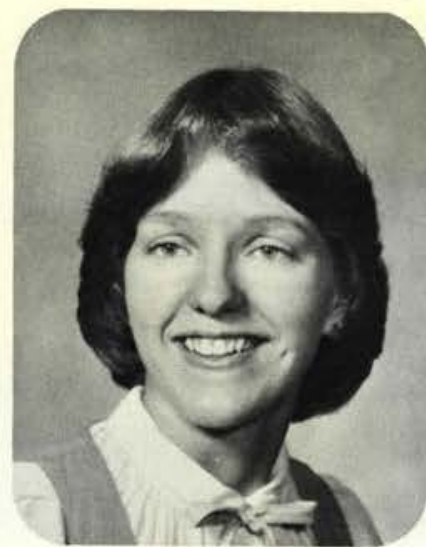

SHAWN MARIE TAYLOR

Preston, Maryland

Biology

God knows the secret plan of the things He will do for the world using my hand.

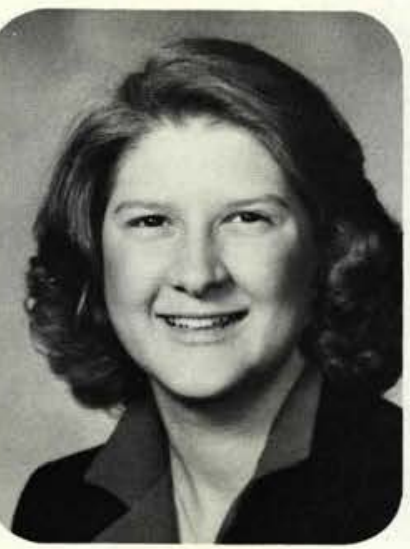

STACY LYNN TOWLE Rochester, New Hamphsire English/Speech

Lead me in the paths of righteousness for His name's sake.
My friends are God's gift. I dearly love my precious gift. Yet, even more, the Giver.
Horseheads, New York

Elementary Education

Galatians 2:20

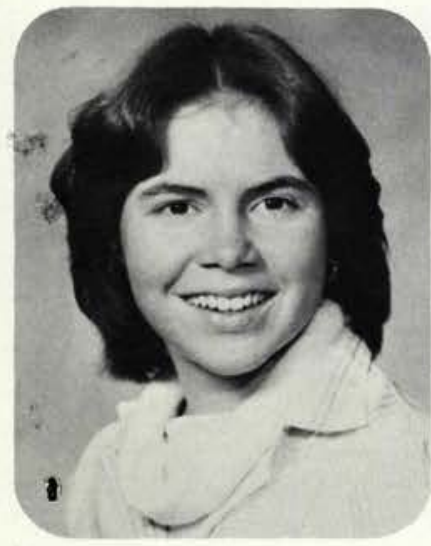

\section{KATHLEEN ELLEN TURNER}

Rochester, New York

Physical Education

If you work hard at anything you will achieve it.

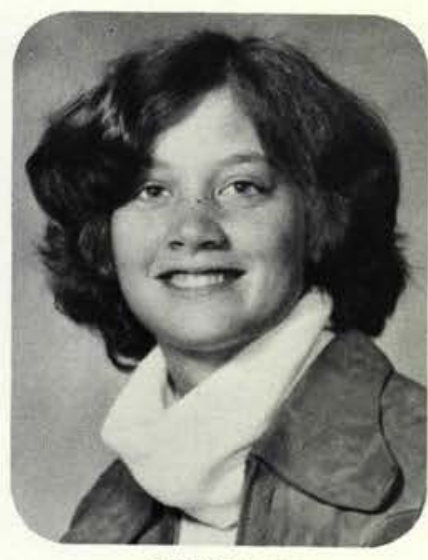

\section{MARIENNE VAIL}

Shaker Heights, Ohio

Speech

Never give in! Never give in! Except to convictions of honour and good sense. Churchill

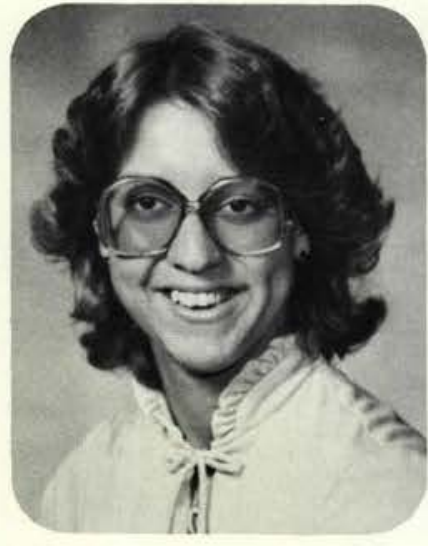

DEB VAN LOAN Rochester, New York

English Education

The Lord is good to those who wait for Him, to the person who seeks Him. Lamentations 3:25

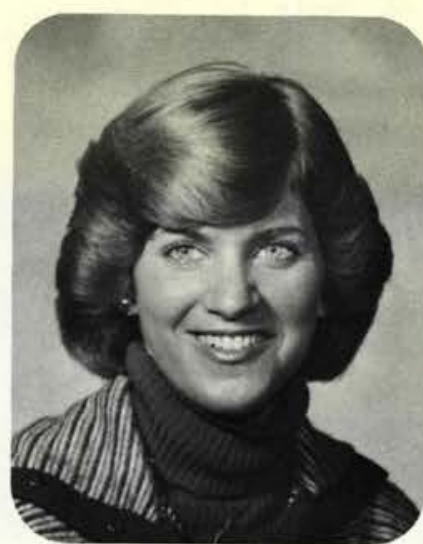

JANE CLAIRE TEDESCHI

Phoenixville, Pennsylvania

English Education

I press toward the mark for the prize of the high calling of God in Christ Jesus. Philippians $3: 14$

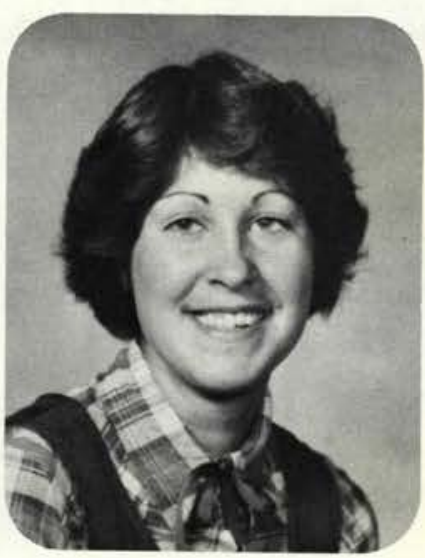

DANA TREESE

Berea, Ohio

Elementary Education

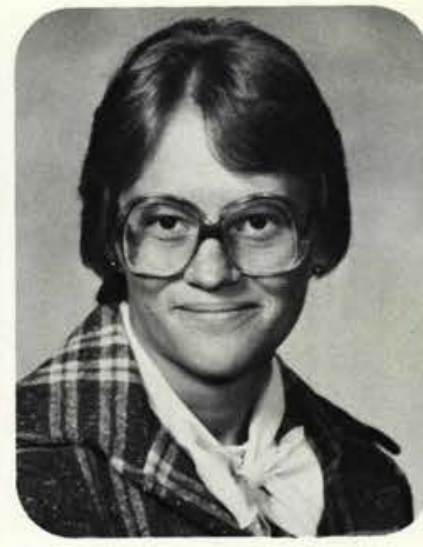

CAROLYN VANNATTA

DeKalb, Illinois

Speech

Approved workmen are never ashamed. 


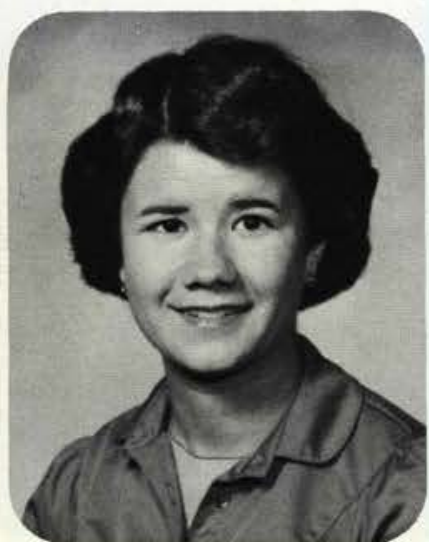

DEBRA VAN RYN

Grand Rapids, Michigan

Elementary Education

I Samuel 12:24

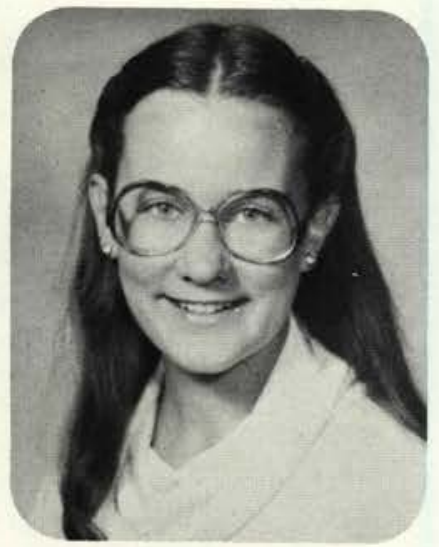

KIMBERLY A. WAITES

Burton, Michigan

Psychology

But seek ye first the kingdom of God, and His righteousness ... Matthew 6:33

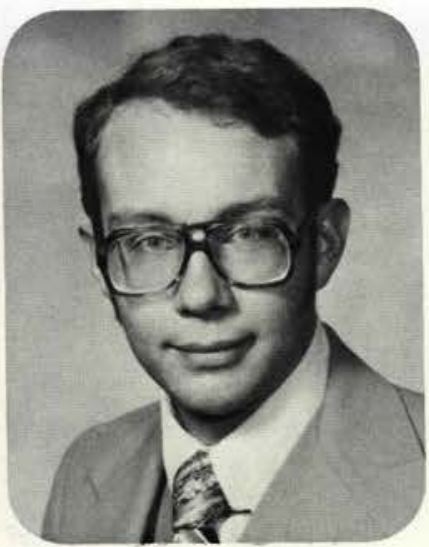

MATT D. VINCENT

Wytheville, Virginia

Pre-Seminary/Bible

Fear God and keep his commandments, for this is the whole duty of man. Ecclesias. tes 12:13

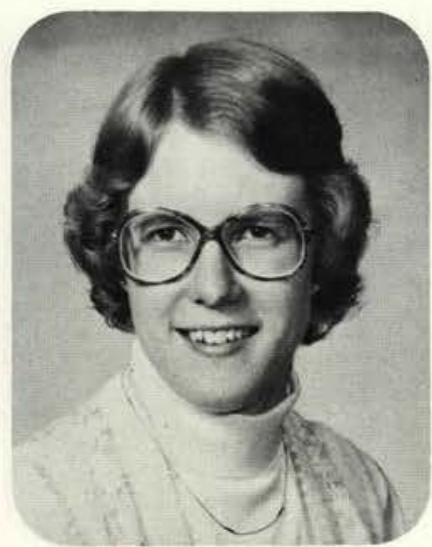

\section{VIRGINIA WARD}

Horseheads, New York Music

The Lord is my strength and song, and is become my salvation. Psalm 118:14

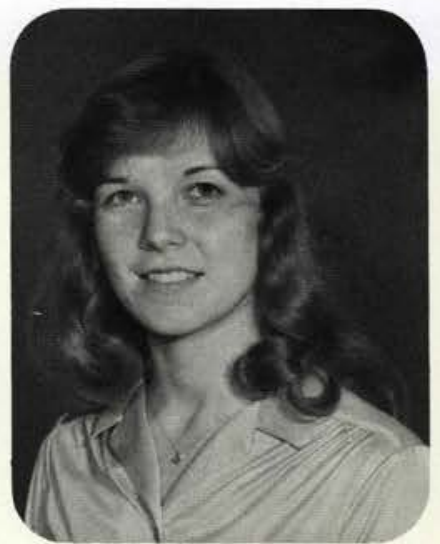

\section{SUSAN L. VONADA}

Mill Hall, Pennsylvania

Business Administration

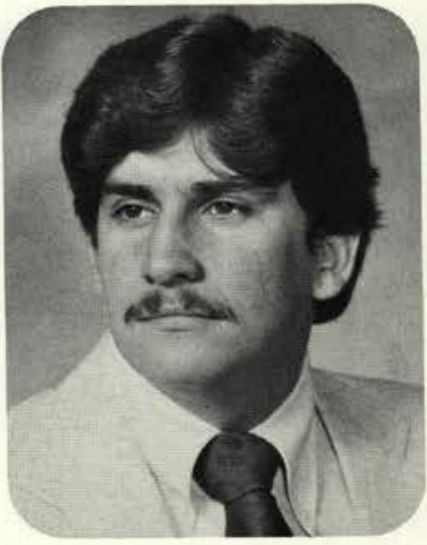

JEFF WARIX

Delhi, Ohio

Elementary Education

In all things seek to glorify Him.

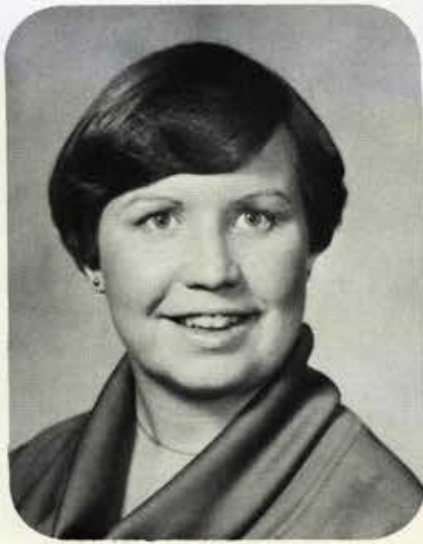

KAREN LYNN WAINWRIGHT

Roebling, New Jersey

Chemistry/Biology

Reach high, for stars be hidden in your soul. Deep deep, for every dream preceeds the goal.

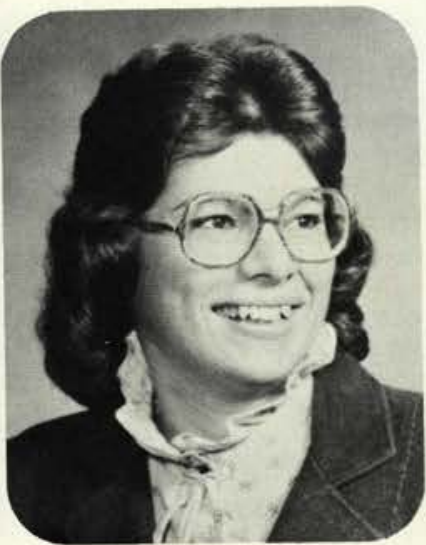

KAREN SUE WEBSTER

Lakeland, Florida

Elementary Education

Philippians 1:6/Ephesians 3:20

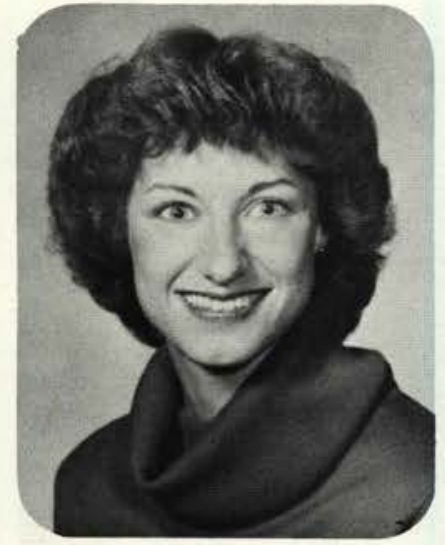

SHARON WEISS

Apalachin, New York

Business Administration

Let the words of my mouth and the meditation of my heart be acceptable in thy sight, 0 Lord.

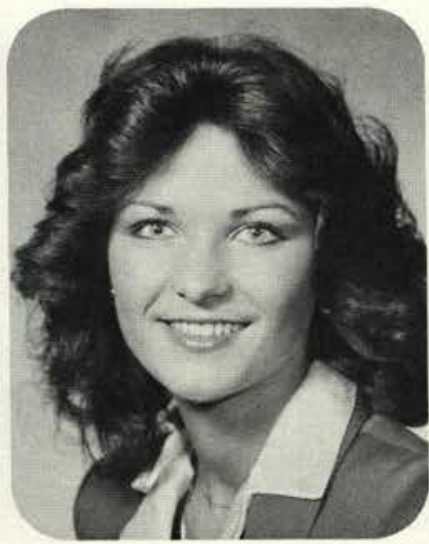

\section{DANETTE ELAINE WETZEL}

Cedarville, Ohio

Music Education

the commandment is a lamp, the teaching is light; reproofs for discipline are the way of life.

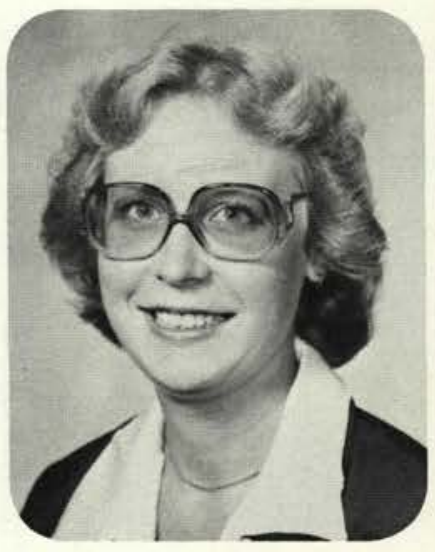

MIRIAM WILL Minford, Ohio Music

My flesh and my heart fail, but God is the strength of my heart, and my portion forever. Psalm 73:26

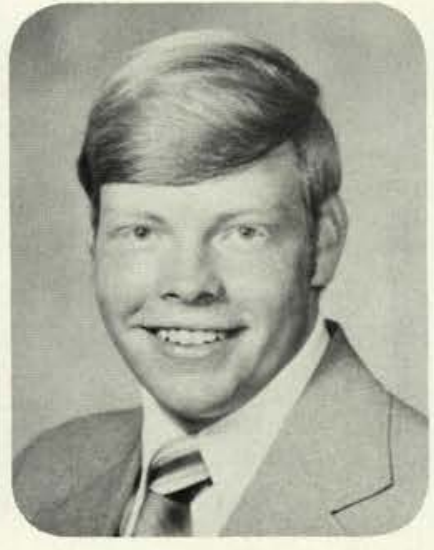

R. KEITH WILLHITE Louisville, Kentucky

Pre-Seminary/Bible

0 that my ways were directed to keep thy statutes! Psalm 119:5 


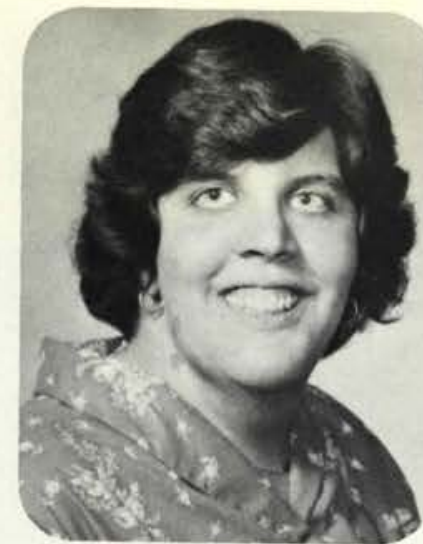

EVELYN G. WILLIAMS

Maine, New York

Political Science/Spanish

Let the words of my mouth and the meditation of my heart be acceptable in Thy sight, 0 Lord ...

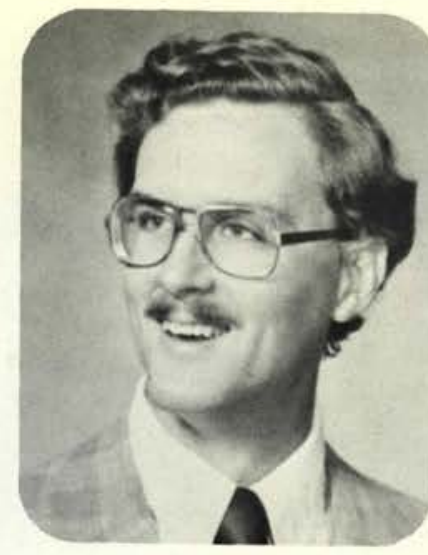

RAPHAEL GUSTAVE WOLFF III

Fort Wayne, Indiana

English

To know God and enjoy Him forever.

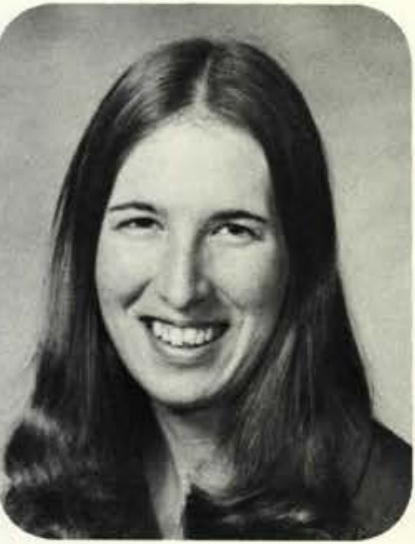

JANICE M. YODER

West Liberty, Ohio

Elementary Education

God has given me this day. I can waste it or grow in its light. God's glory is in this day.

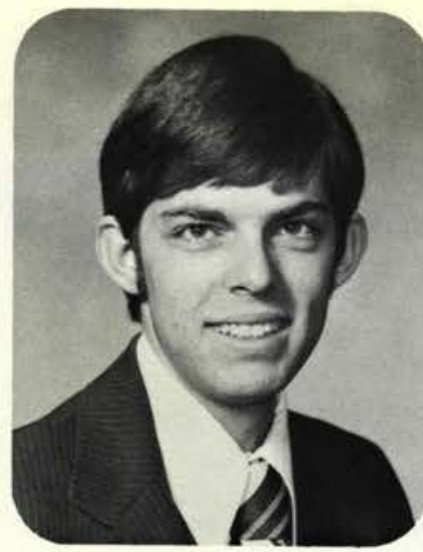

KENNETH WOODS

Elyria, Ohio

Music

For as the heavens are higher than the earth, so are my ways higher than your ways ... Isaiah 55:9

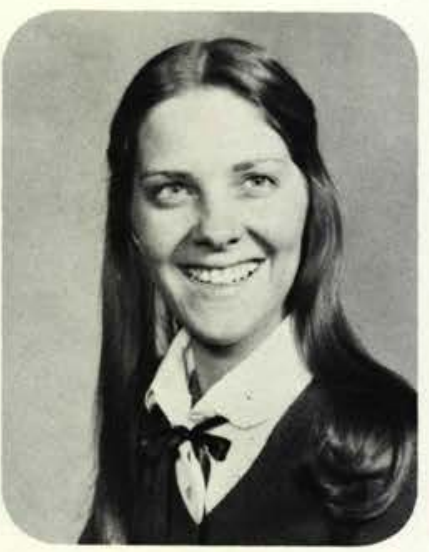

MARLENE YODER

Plain City, Ohio

Psychology

To be obedient to God, Honest with myself,

Transparent before others.

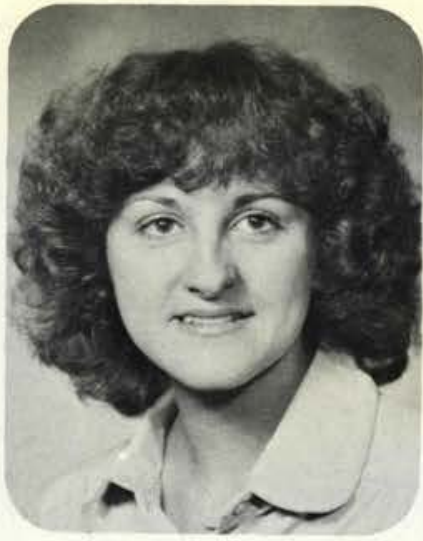

MICHELE WOZNIAK

Middleport, New York

Psychology

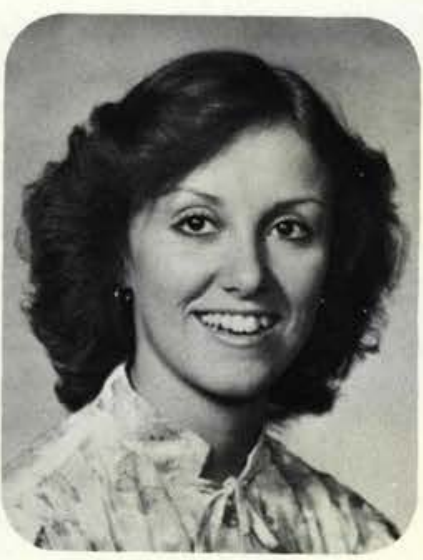

AMY YOUNG

Conklin, New York

Biology
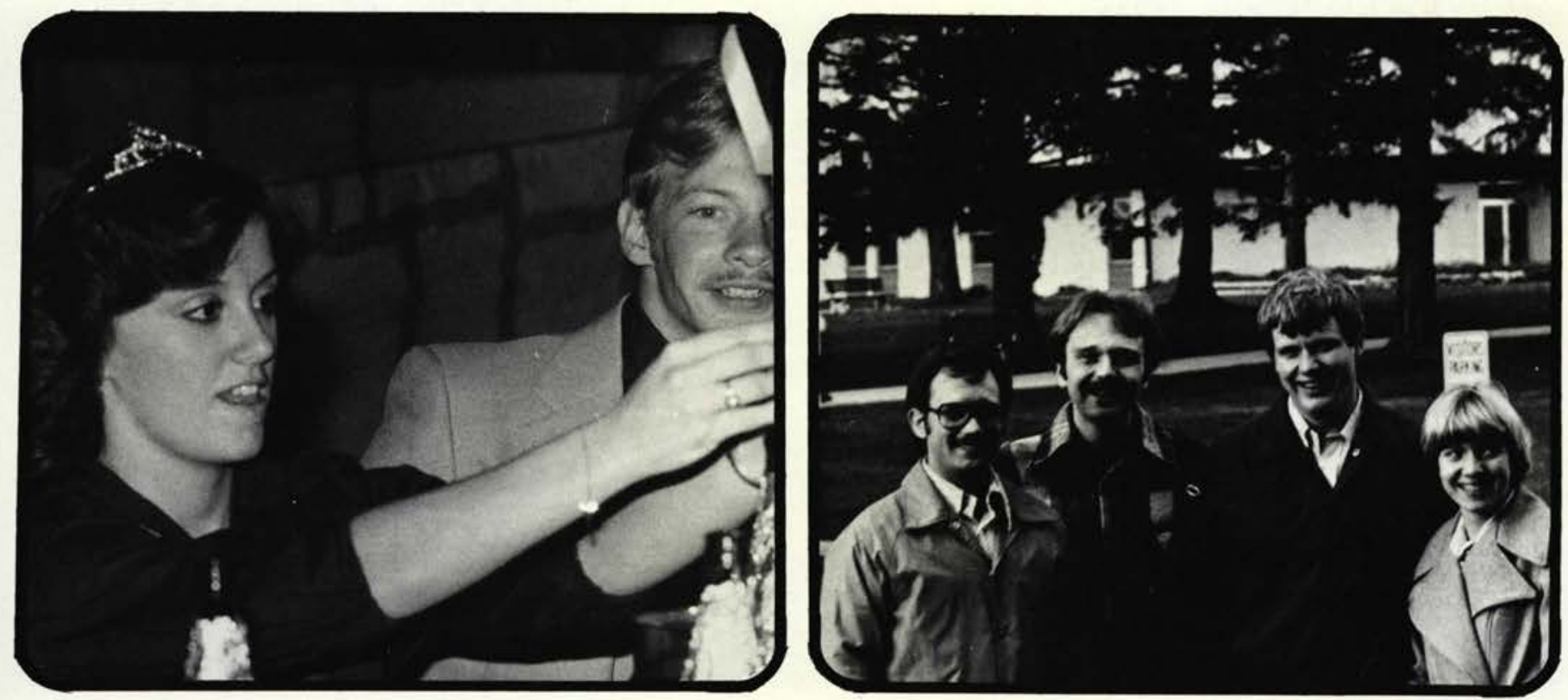


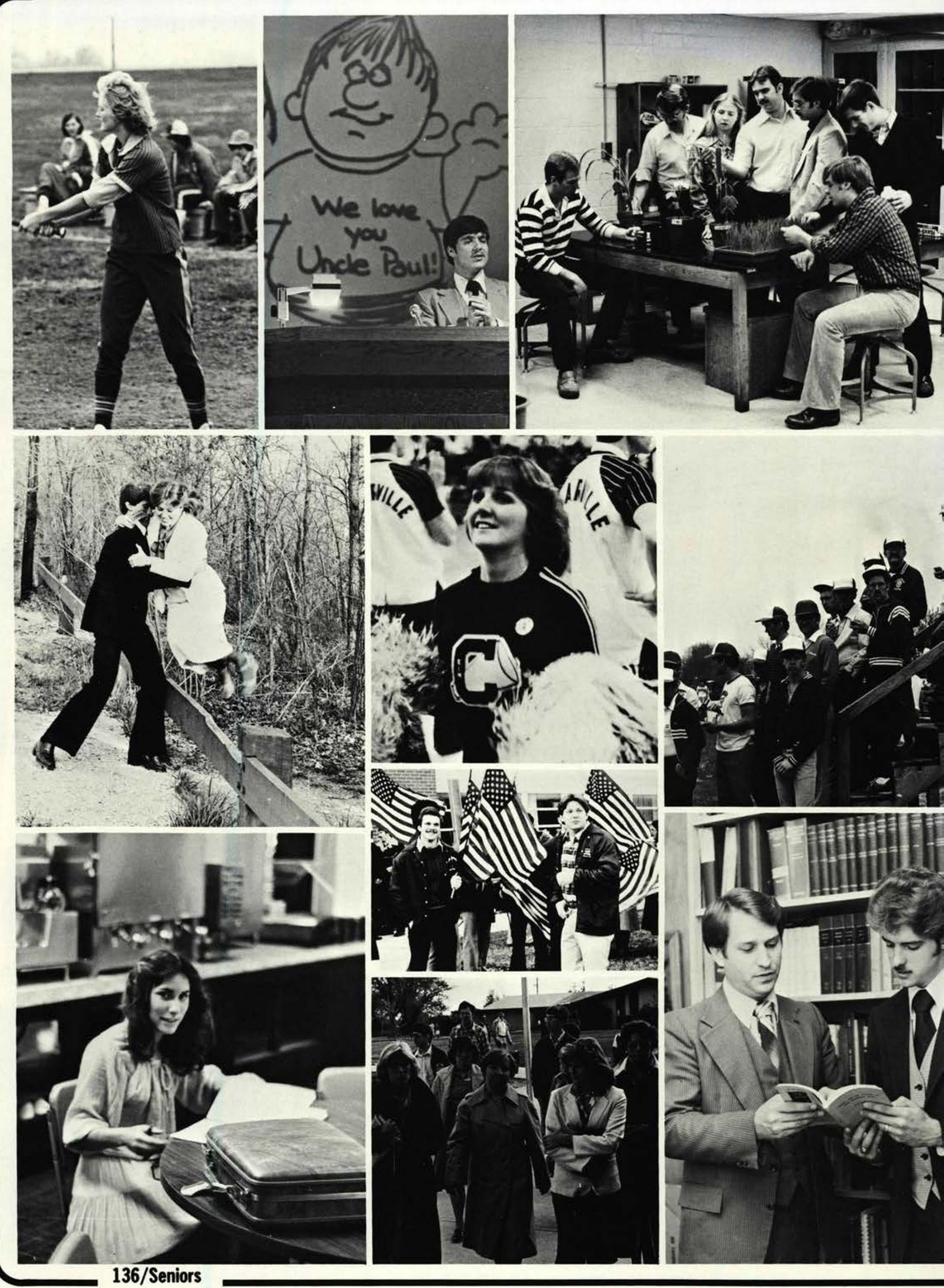




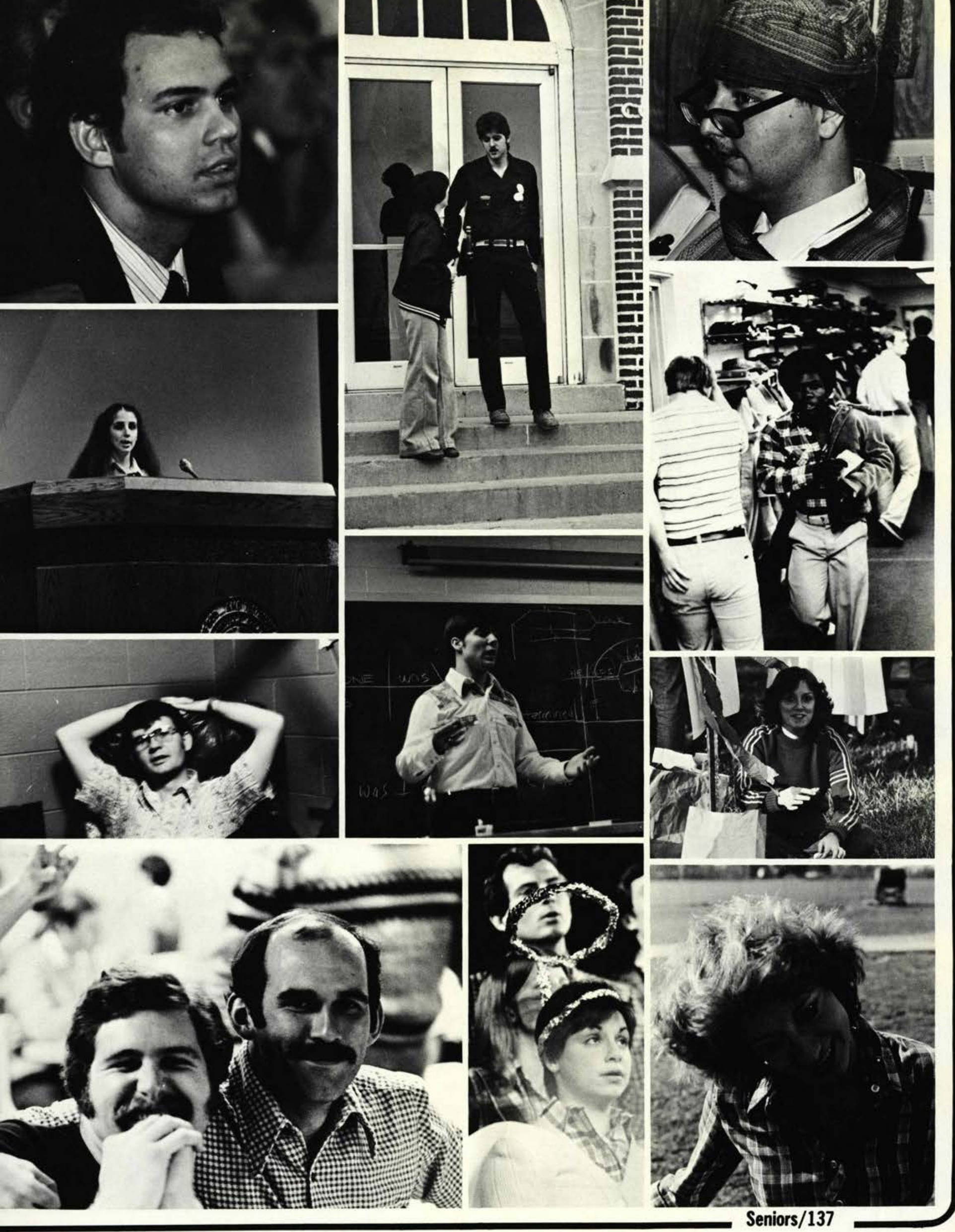



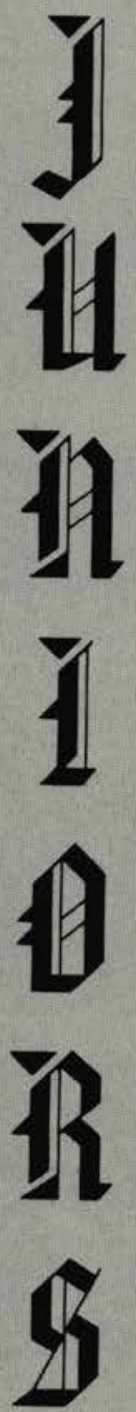

Junior Class Officers:

Randy Harper, Pres.

Larry Seawell, Chap.

Karen Johnson, Secr.

Rick Matter, Treas.

John Hart, V. Pres.

Cathey Swaney, Stu. Sen. Rep.

Joe Colyer, Stu. Sen. Rep.

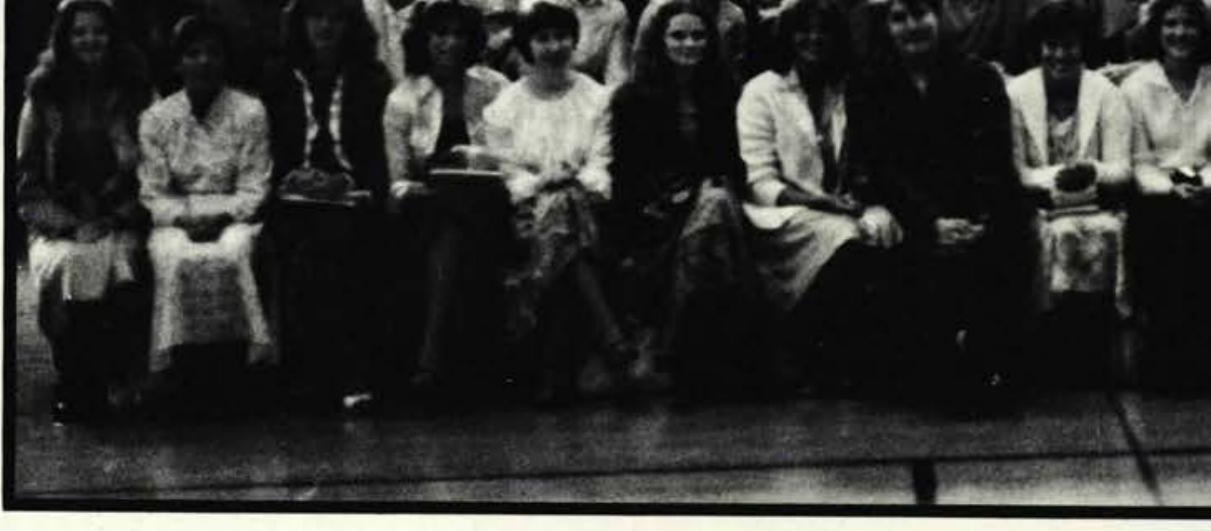


4y

Int -20

2a. $(19)$ in voln

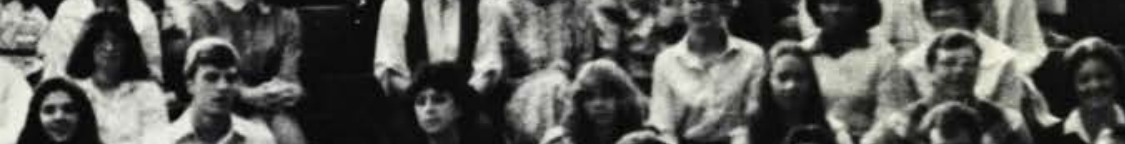
a
1
rise
$x$

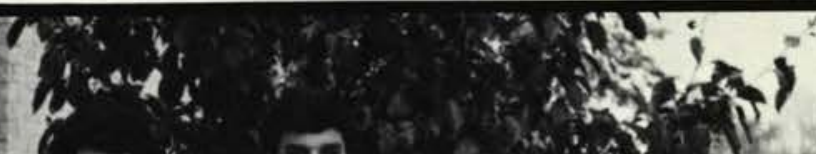

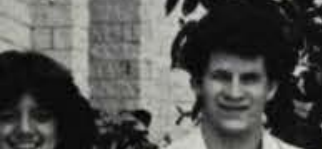

3

A

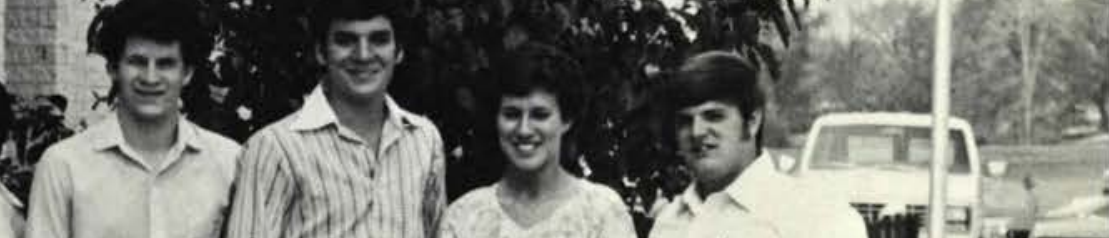
1 1) $f^{2}$ ree

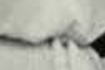

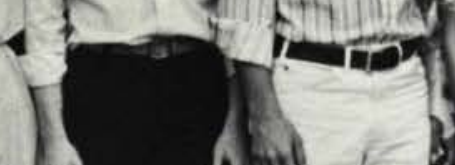

c
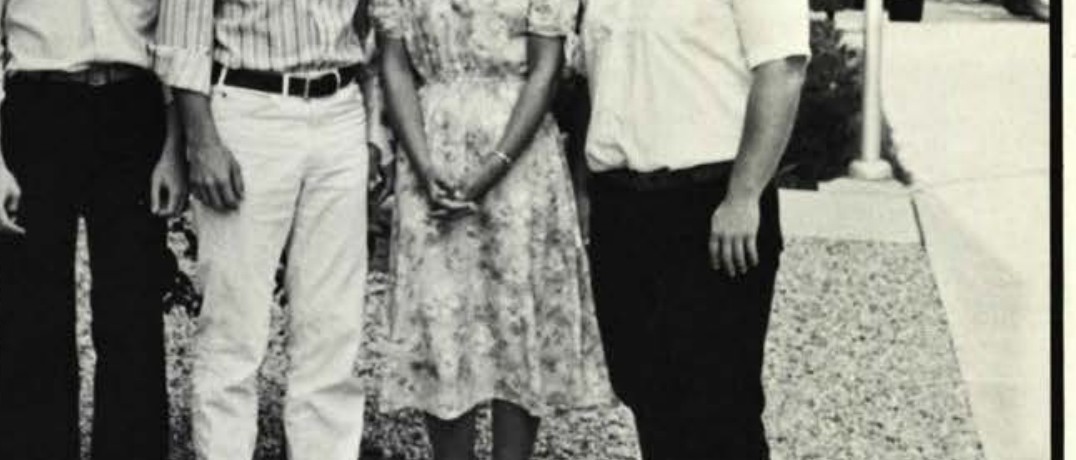

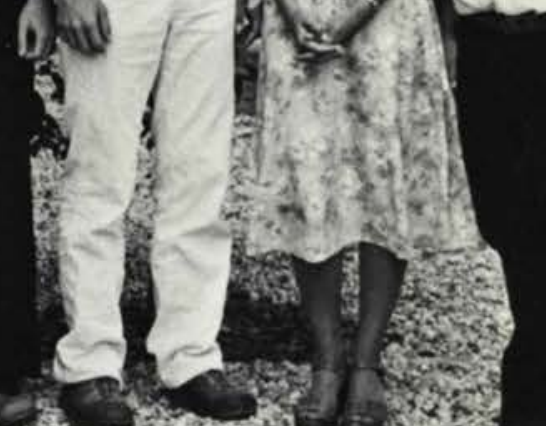

$\mathfrak{R}$

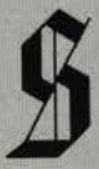



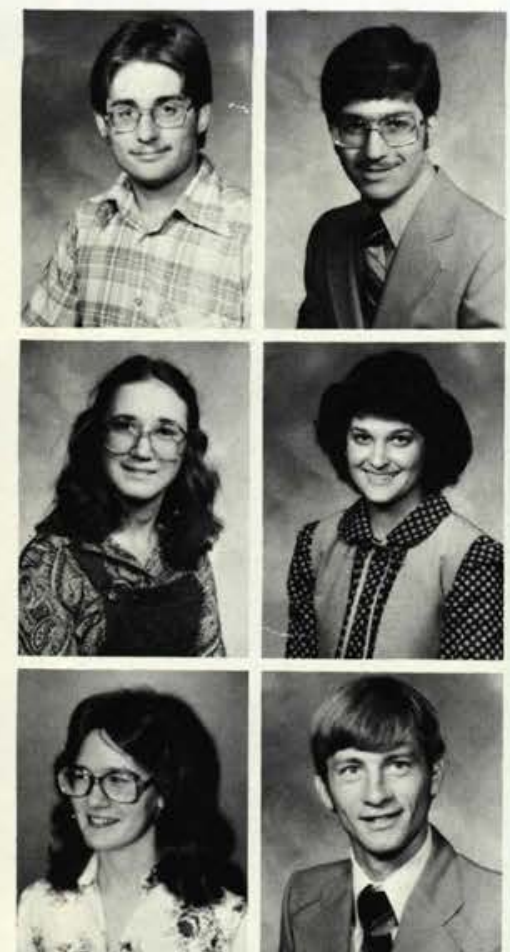

$\frac{1}{2}-20 \frac{6}{8}$
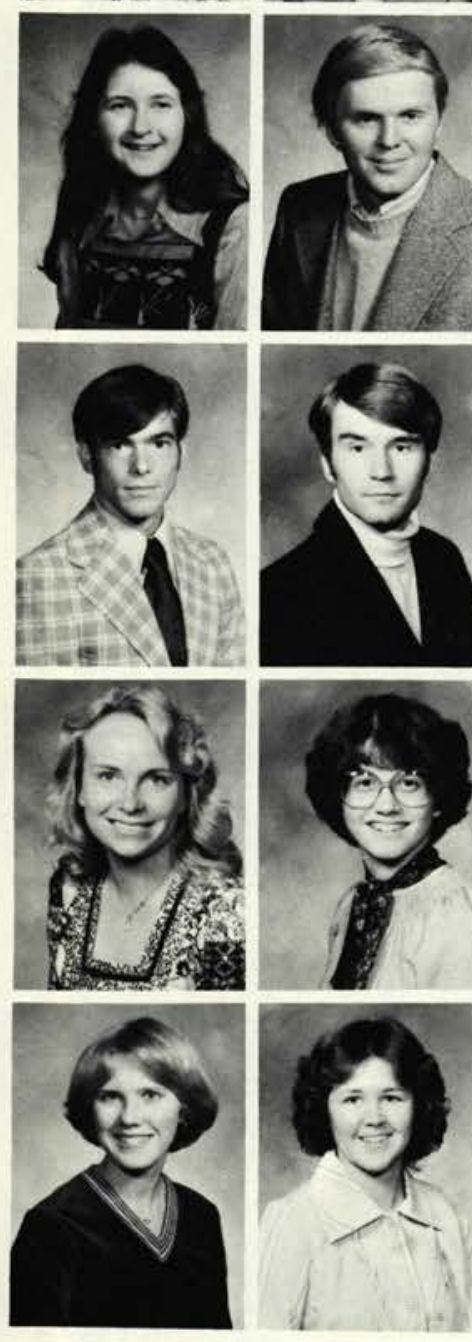

Gary Abbott

Ron Abbott
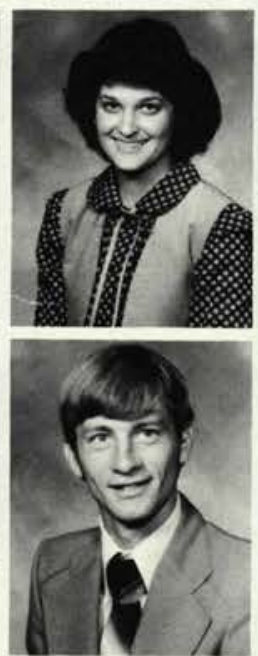

Linda Barker

James Barrett

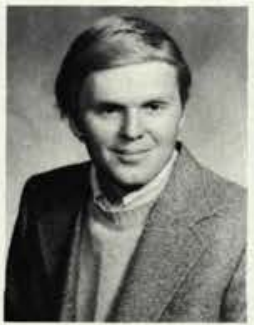

Laura Bearss

Clayton Beck

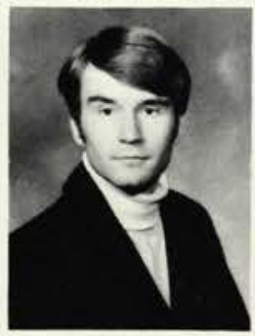

Carleton Birch

Gregg Birkholz

Beth Boomgarden

Margaret Bracken

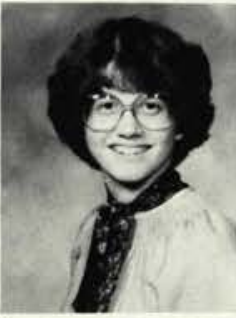

Beth Bullock

Linda Burchett

Deborah Ames

Craig Anderson

Mark D. Anderson

Mark L. Anderson

Tom Bartling

Douglas Baver

William Baughman

Deborah Beacham

Dave Begley

Beth Beikert

David R. Bergandine

Curt Berger

James Bocian

Brenda Boley

Debby Bonzo

Ruth Ann Book

Joann Bradshaw

Dave Brown

Shirley Brown

Tim Burel

Frank Burrell

Tim Butler

Richard Cabaniss
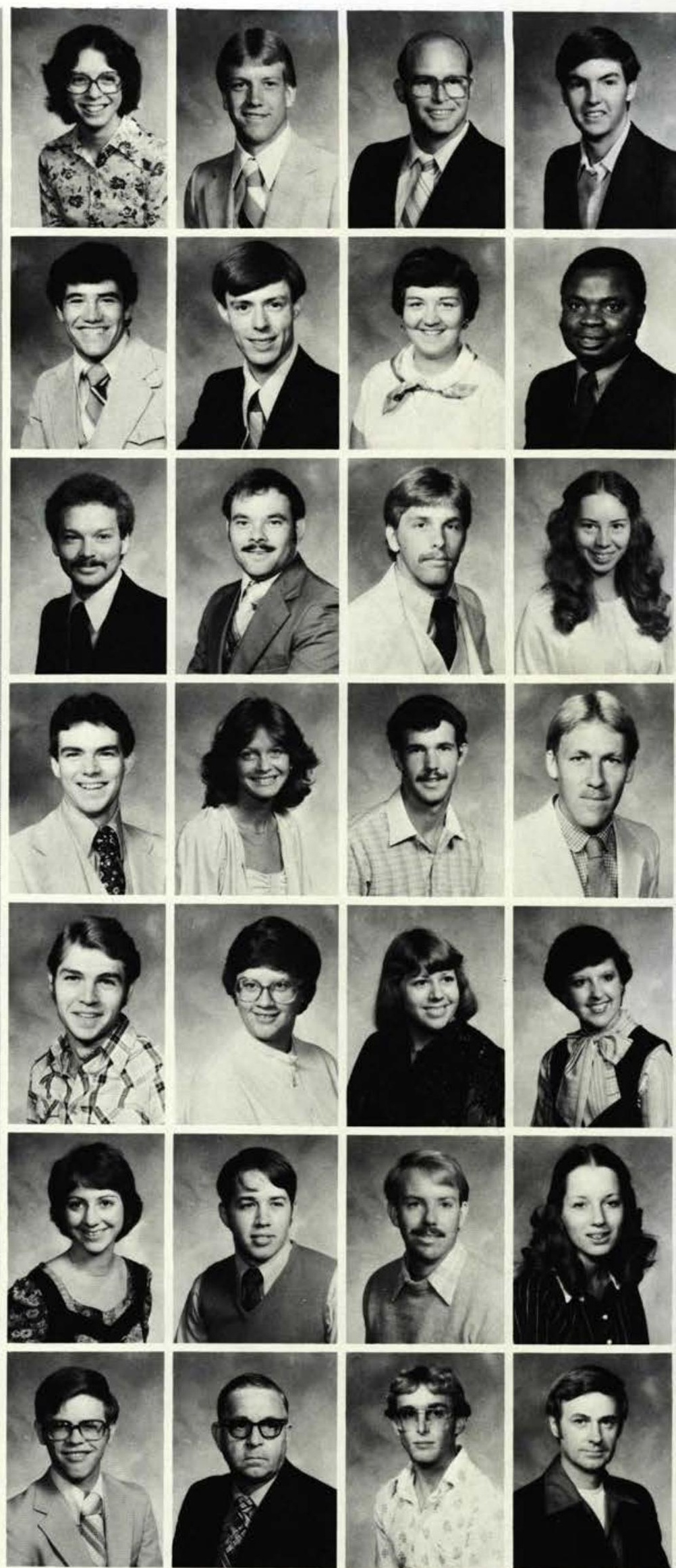
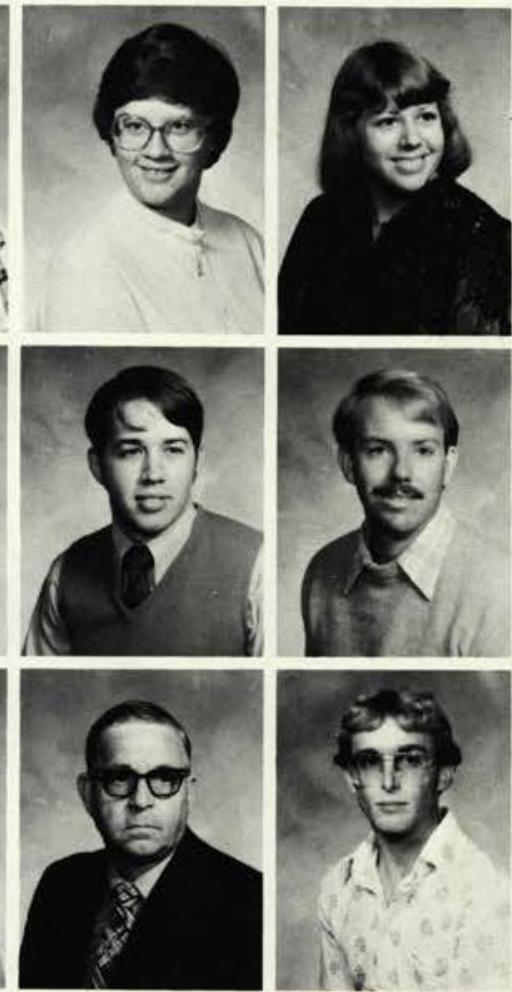
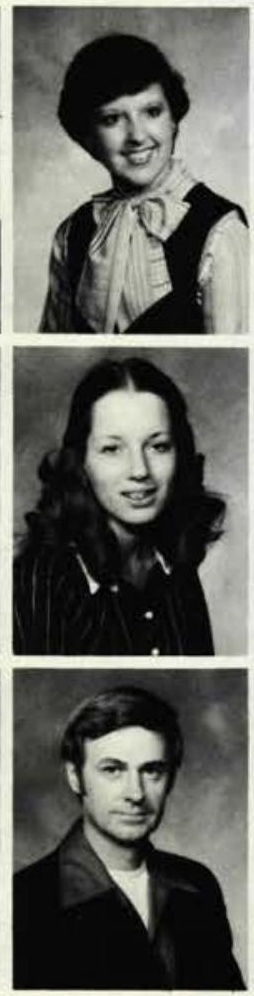

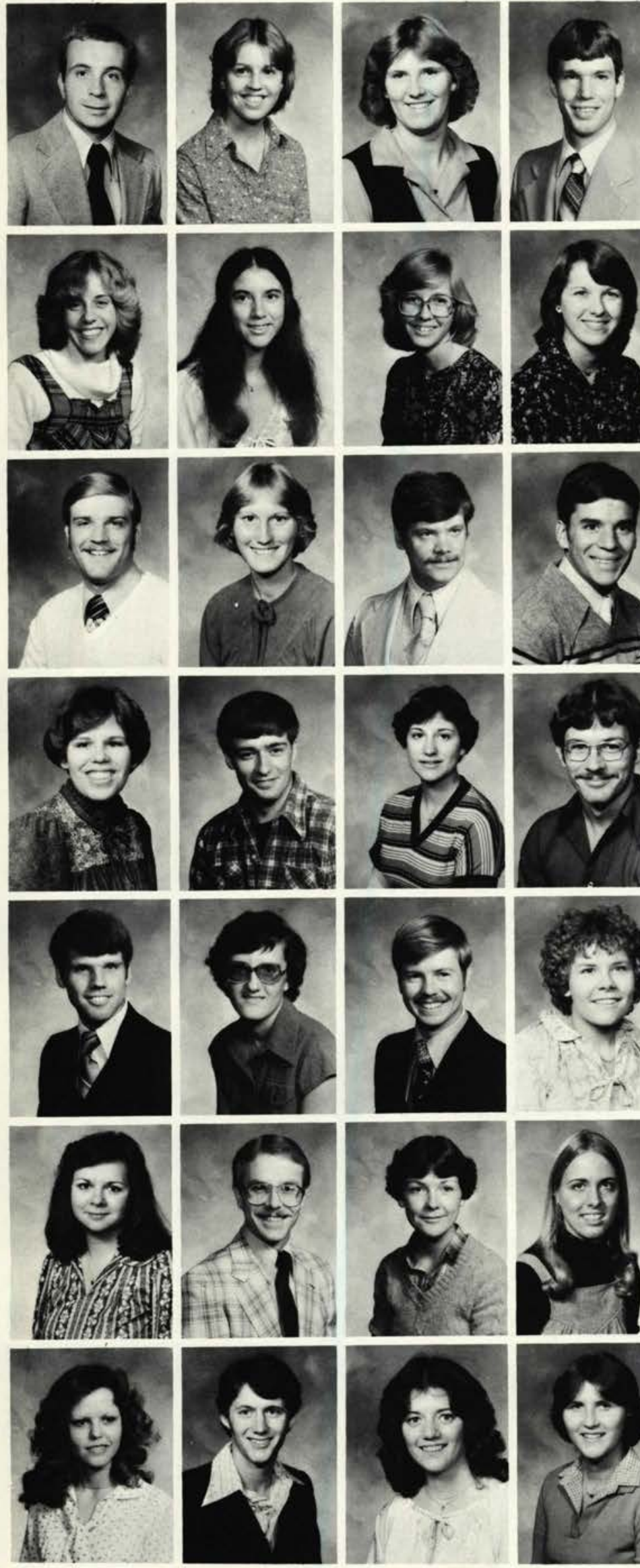
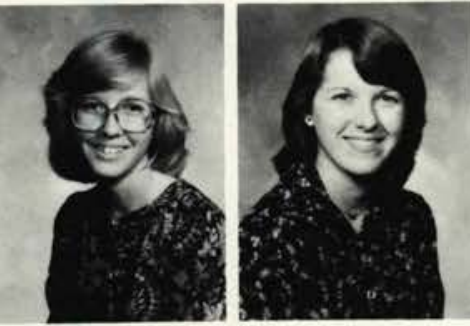

Kevin G. Grant

Ellen Gray

Mary Greening

Greg Greve
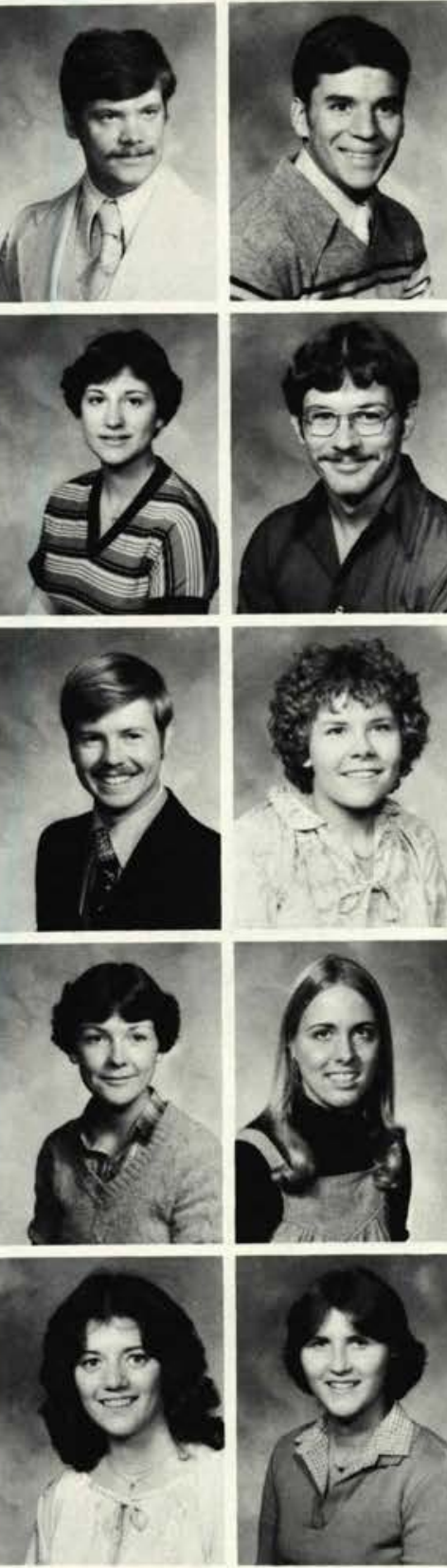

Randy Harper

Peggy Harrel

Dallas Harris

John Hart

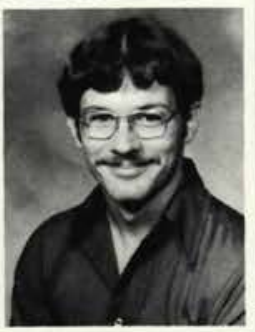

Joy Haynes

David Hattenfield

Cindy Heinrich

Ed Hennessee

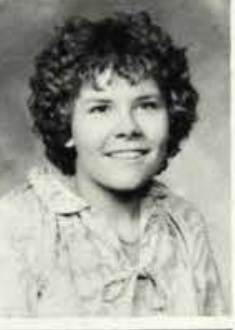

Chuck Hickey

Tammy Hicks

Charlie High

Carol Hippard

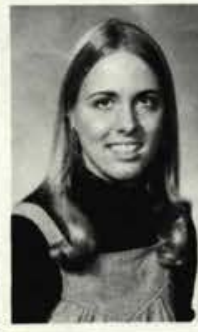

Mary Howard

Fritz Huber

Paula Humphrey

Julie Hutchins

Jill Griswold

John Guenther

Patty Harding Roberta Harmon

Rhonda Hettinger Elaine Heyworth

Tim Hoganson Vicky Hollenbeck

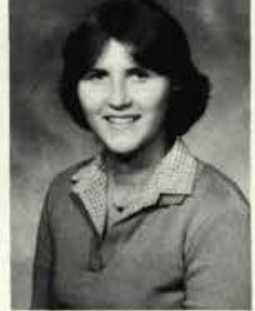

Diana Jakstad

Scott Jelsma

Karen Johnson

Marilyn Johnson

Mark Johnson Rebecca Jones
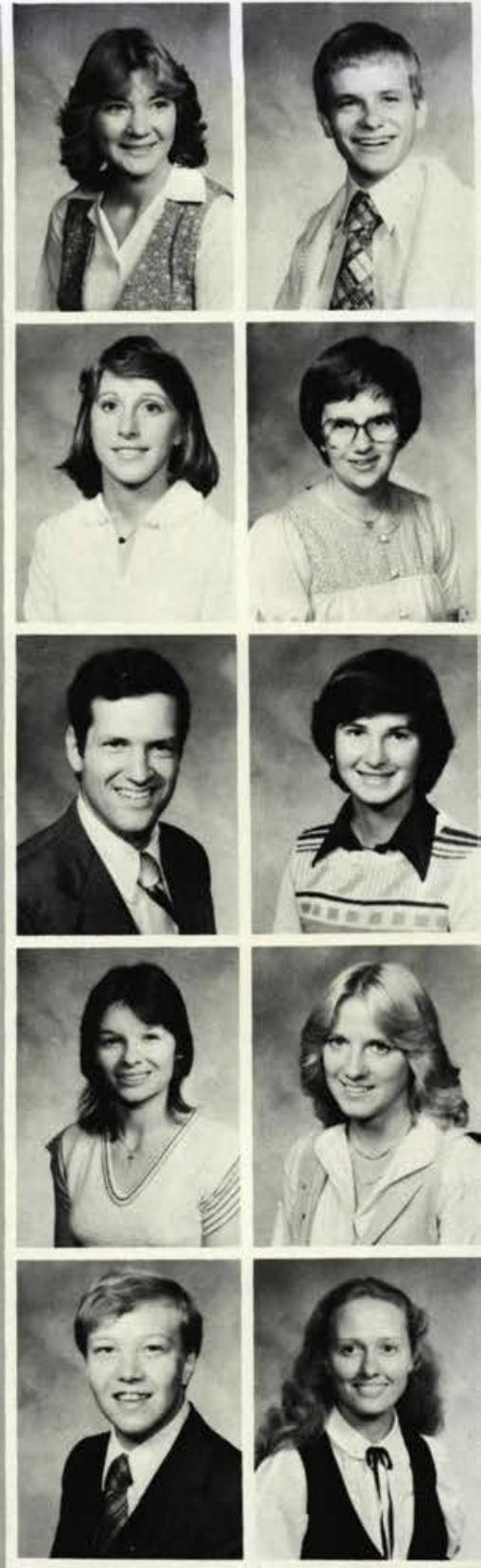
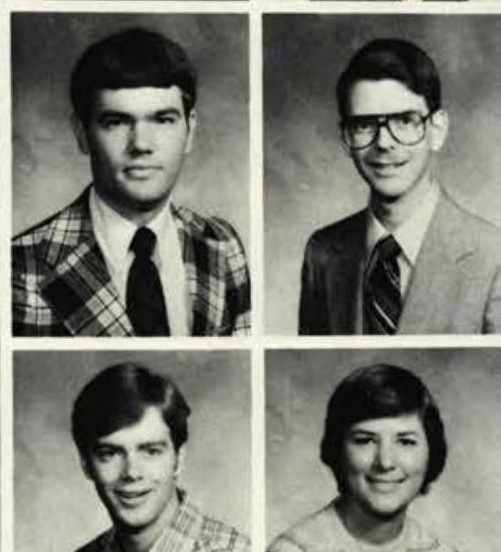

.1 

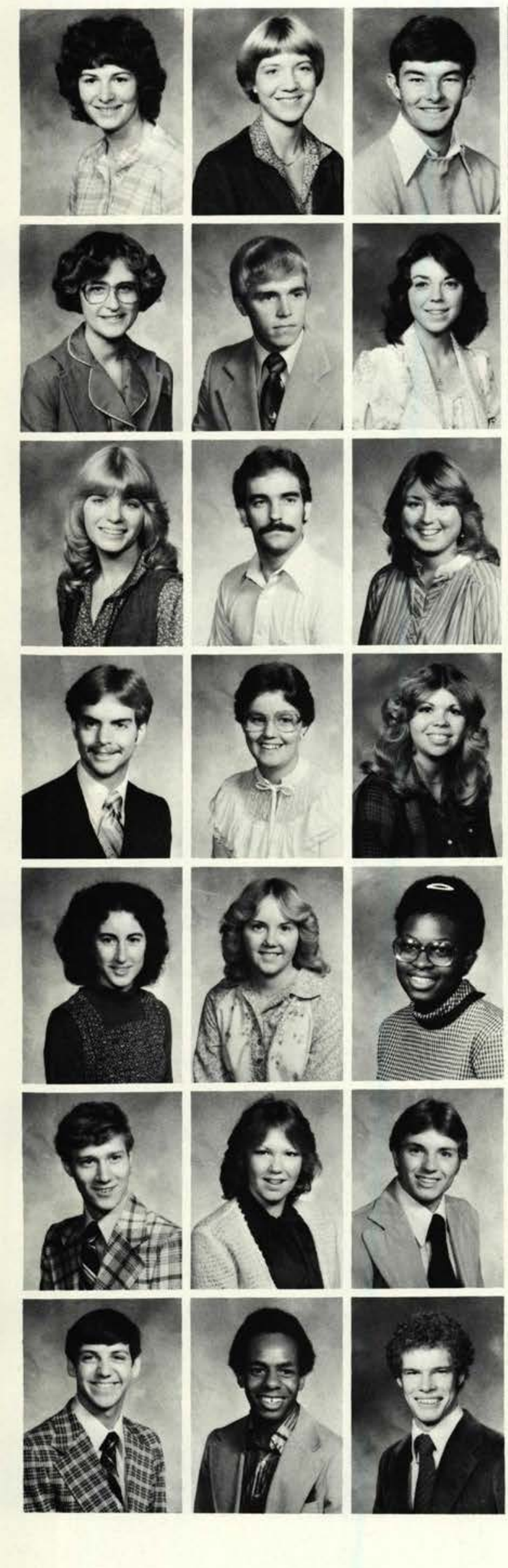

Lisa Meharry

Rebecca Meibuhr

David Merkh

Tyann Minnich

Larry Moline

Linda Lee Monroe

Barbara Morris

David Morris

Michelle Moser

Daniel R. Murphy

Debbie Myers

Becky Needles

Judy Ockert

Laura Olsen

Elizabeth Parker

Paul Perry

Robin Perry

Mark Peters

Randal Pope

Jay Presley

David Price
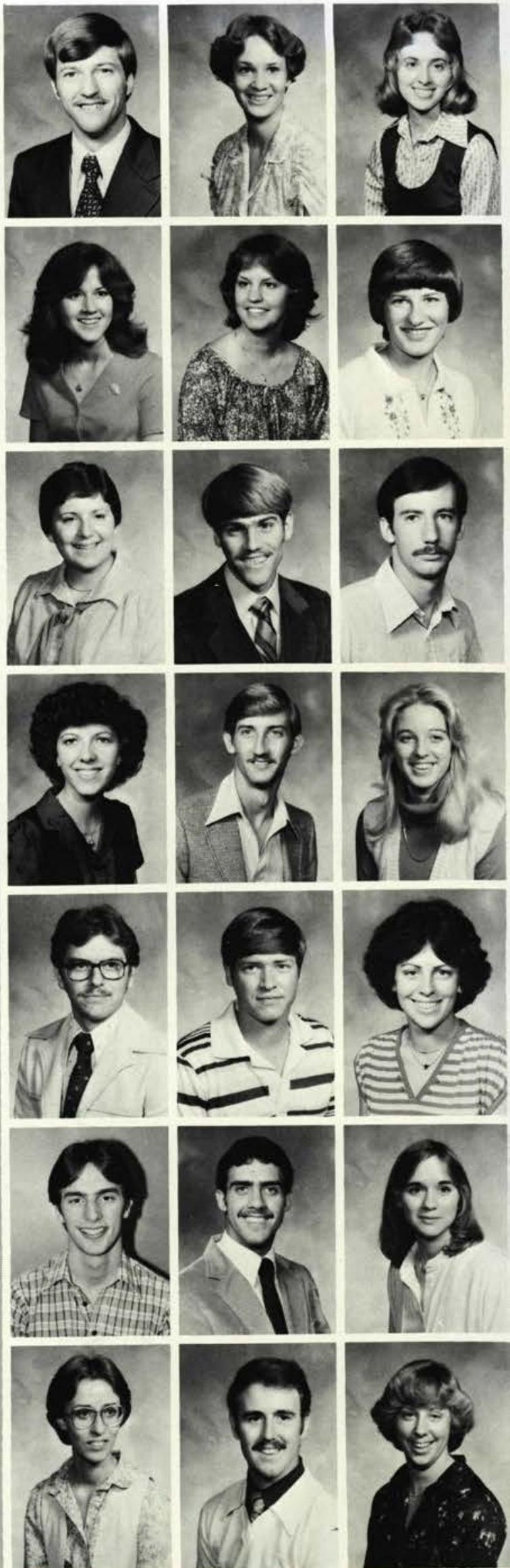

Ron Phillips, Jr.

Steve Piazza

Julie Pitts

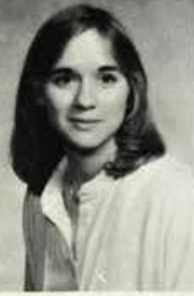

Nancy Price Carl Prokop. Jr. Kathy Putnam

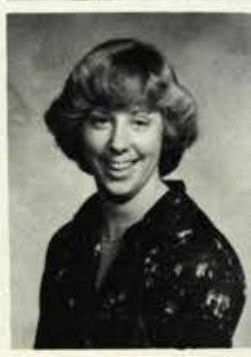



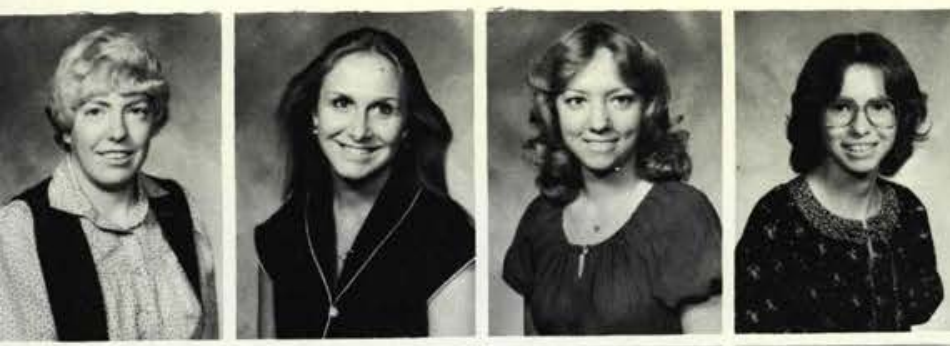

Robin Raabe

Lisa Ramsey

Marilynn Reinholdt

Sandy Reynolds
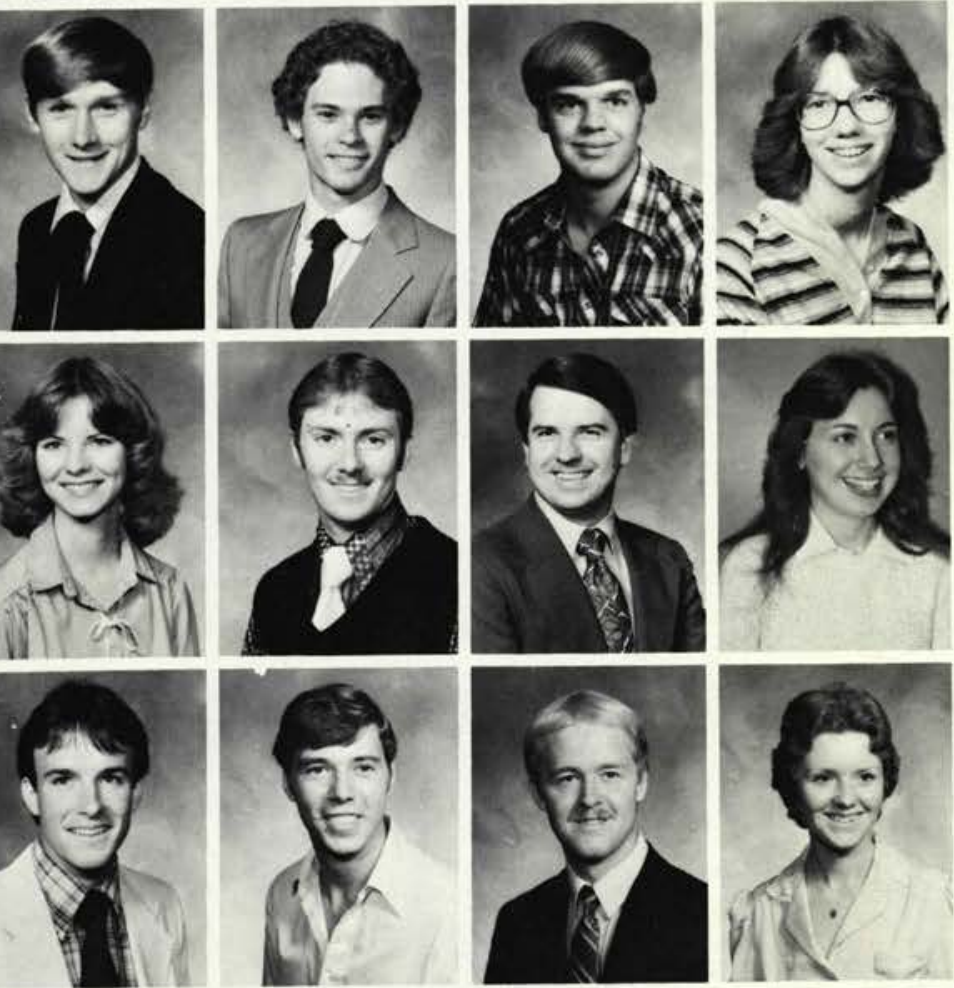

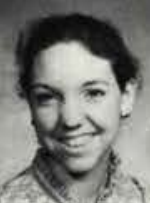
in $x$ is 0.9
$\times 19$

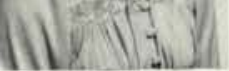

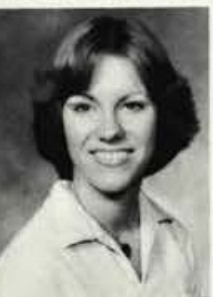

a
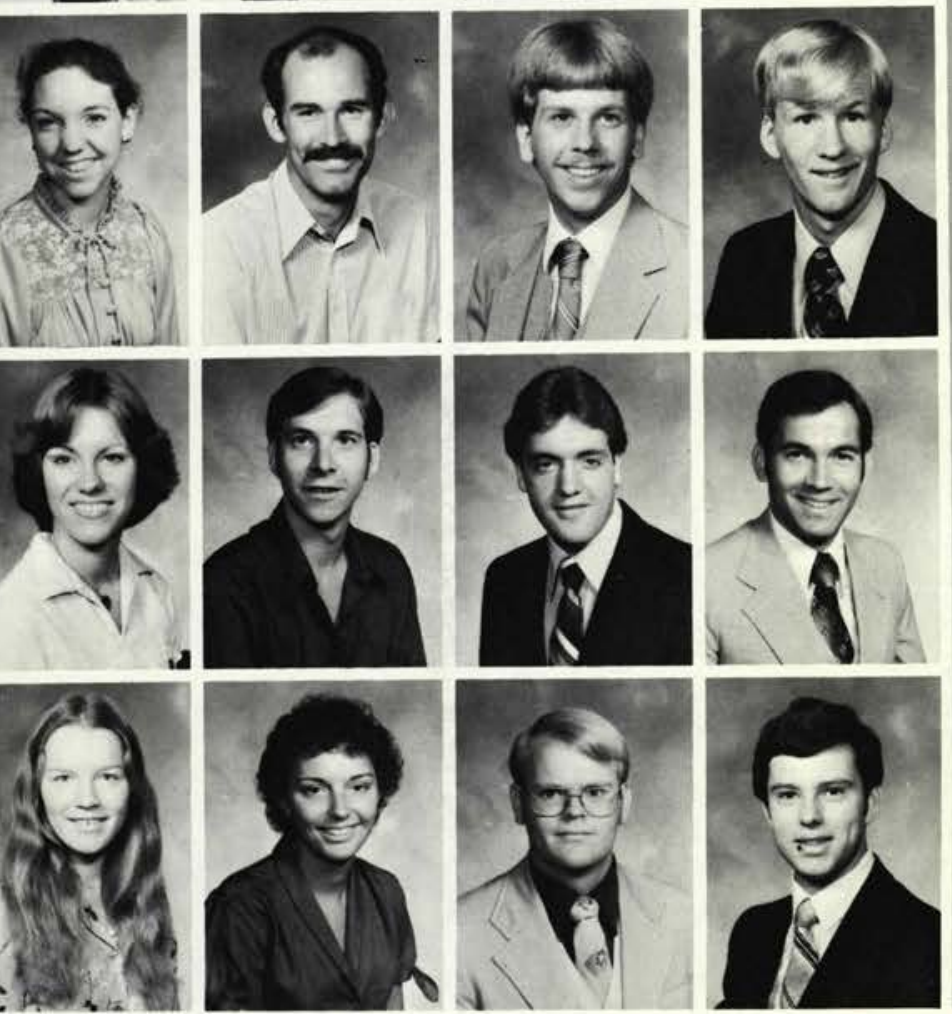

John Ring

Tim Ronk

John Rosenau

Cheryl Roth

Sandra Runge

Philip Said

Donald Sanders

Tina Savant
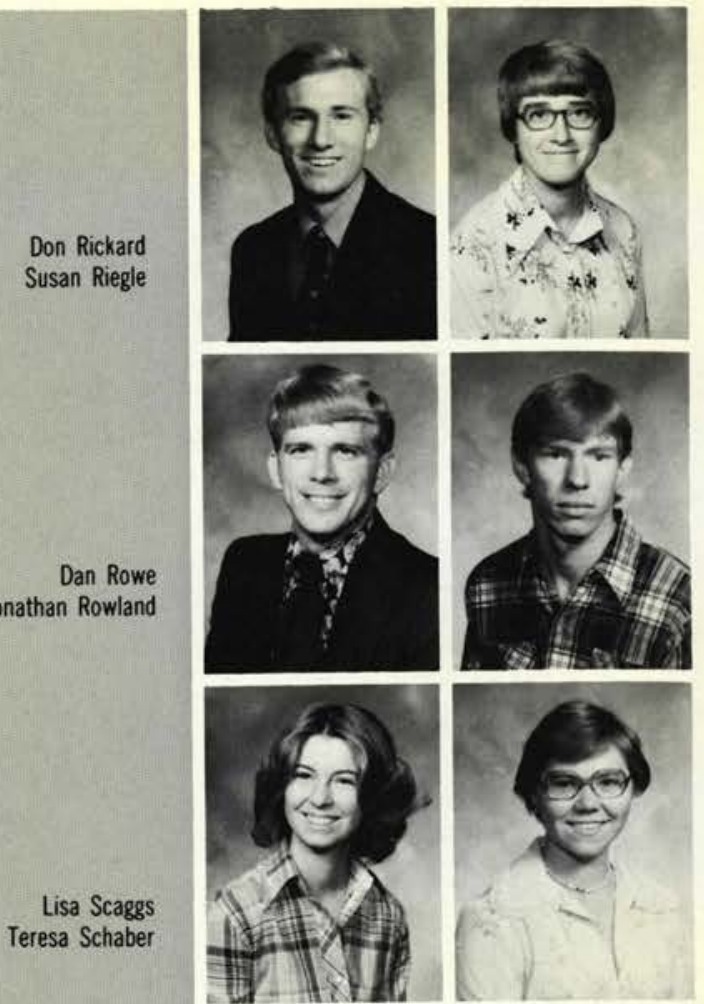

Dale Schaecterle

Roger Schultz

John Schwendler

Rachel A. Scott

Susan Shaffer

Dave Short

Craig Shuneson

Michael Smart

Lisa Scaggs
Teresa Schaber
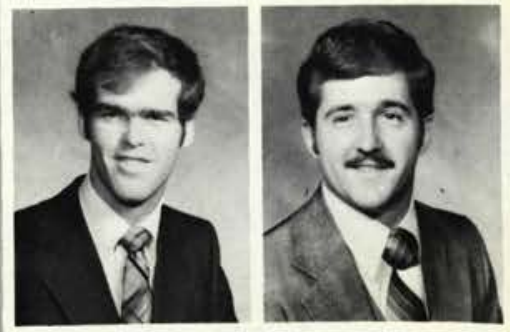

Lawrence Seawe

David Sensene

\section{Tammy Smiley}

Ed Smith

Gwen Smith

Joel Smith

Dan Sorber

Fransisco Souza

\section{Deborah Standridge}

Stephen Stange

Anne B. Starbuck

Karen Steinmuller

Richard Stephenson

Mark Stevens

Al Stewart Becky Stewart
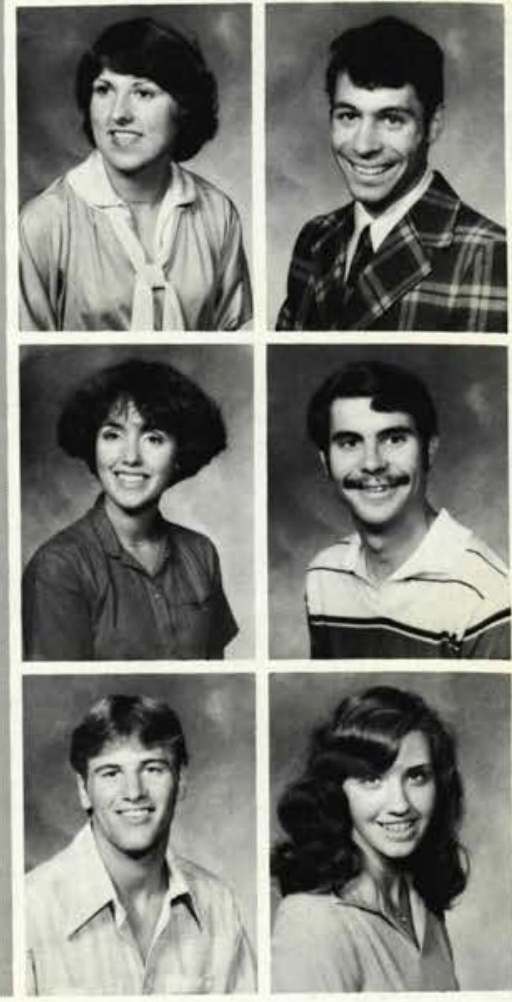

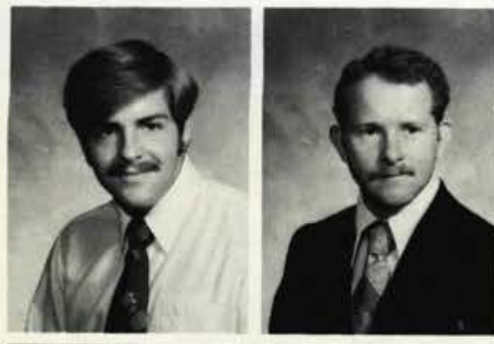

Philip P. Stoner

Randy Strobridge
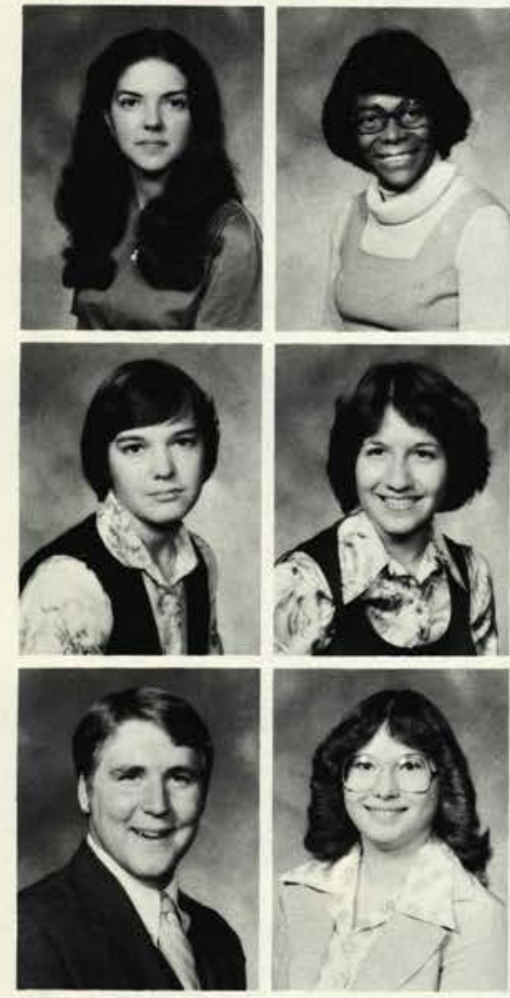

Linda Towne

Janis Traphagen

Trudy Tangblade

Lillie Tapp
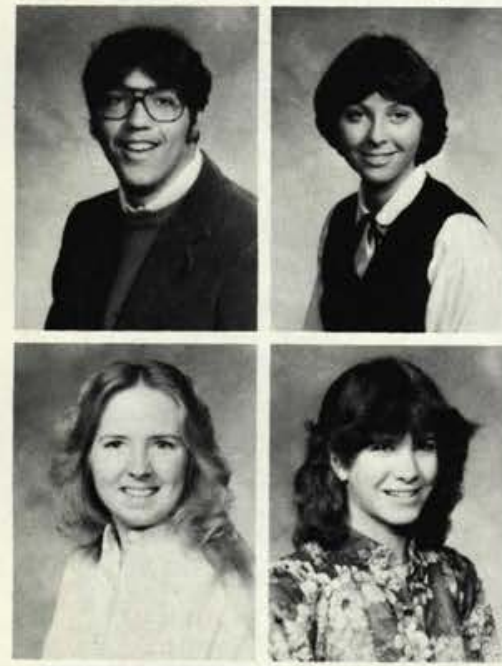

Jeff Waldo

Mary Wallace

Douglas VanderMeulen

Patricia Turner

Debbie Tyler

Donna Uimer

Joel Veldt

Teresa Varhola

Bonnie G. Vesilko Barb Vinson

Paul Vollmer Sandra Wagner

Deborah Wellinghoff

Lori A. West

Daryl Waterman

Carey Weaver Kenneth Webb

Bonnie Webber
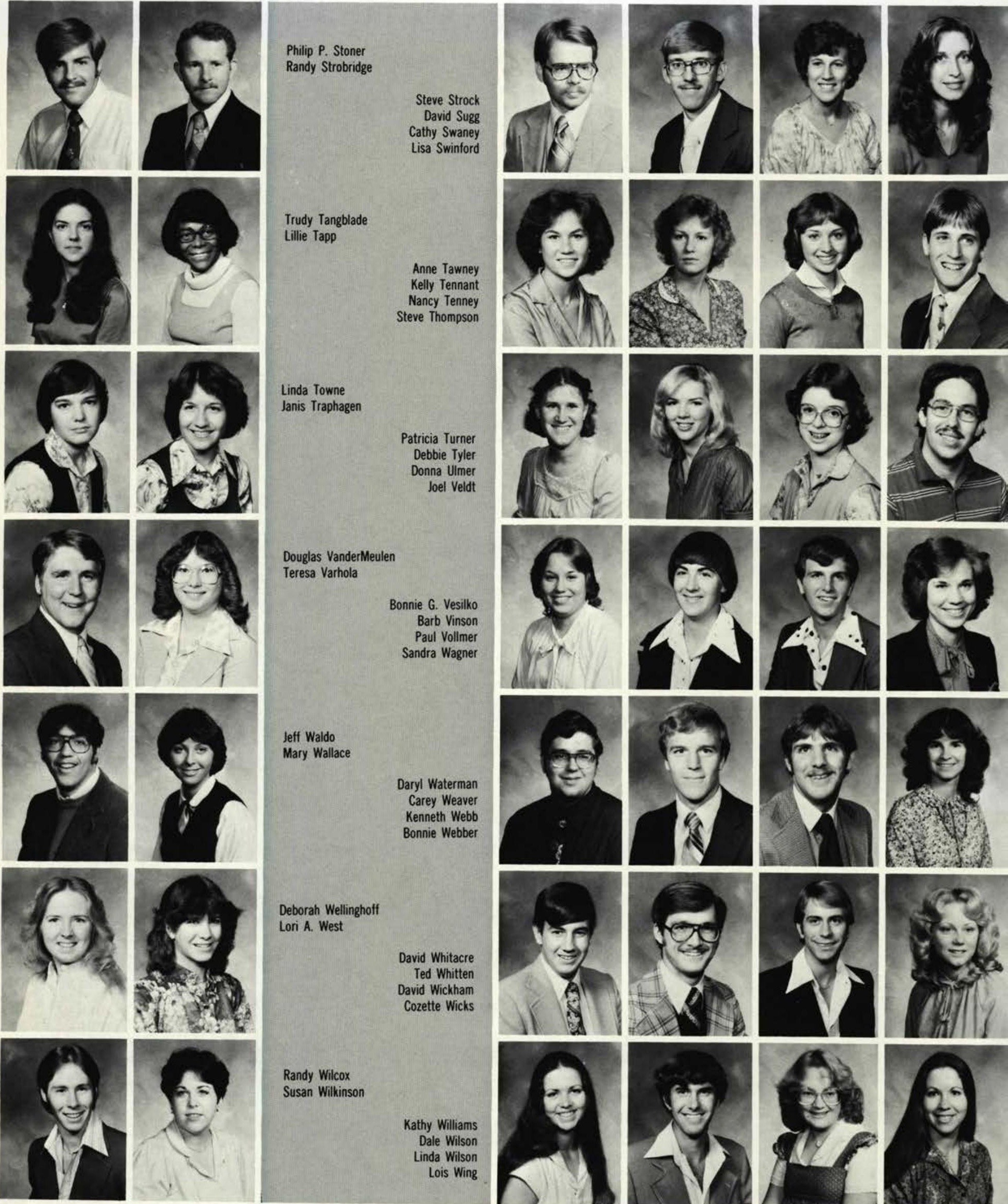

Randy Wilcox

Susan Wilkinson

Kathy Williams Dale Wilson

Linda Wilson Lois Wing
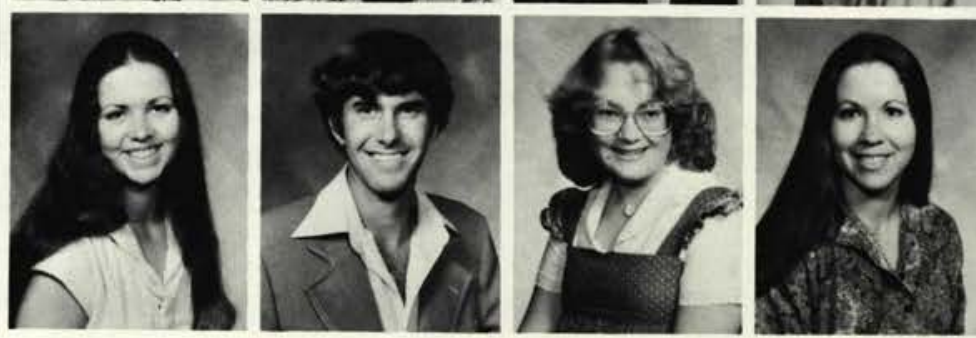


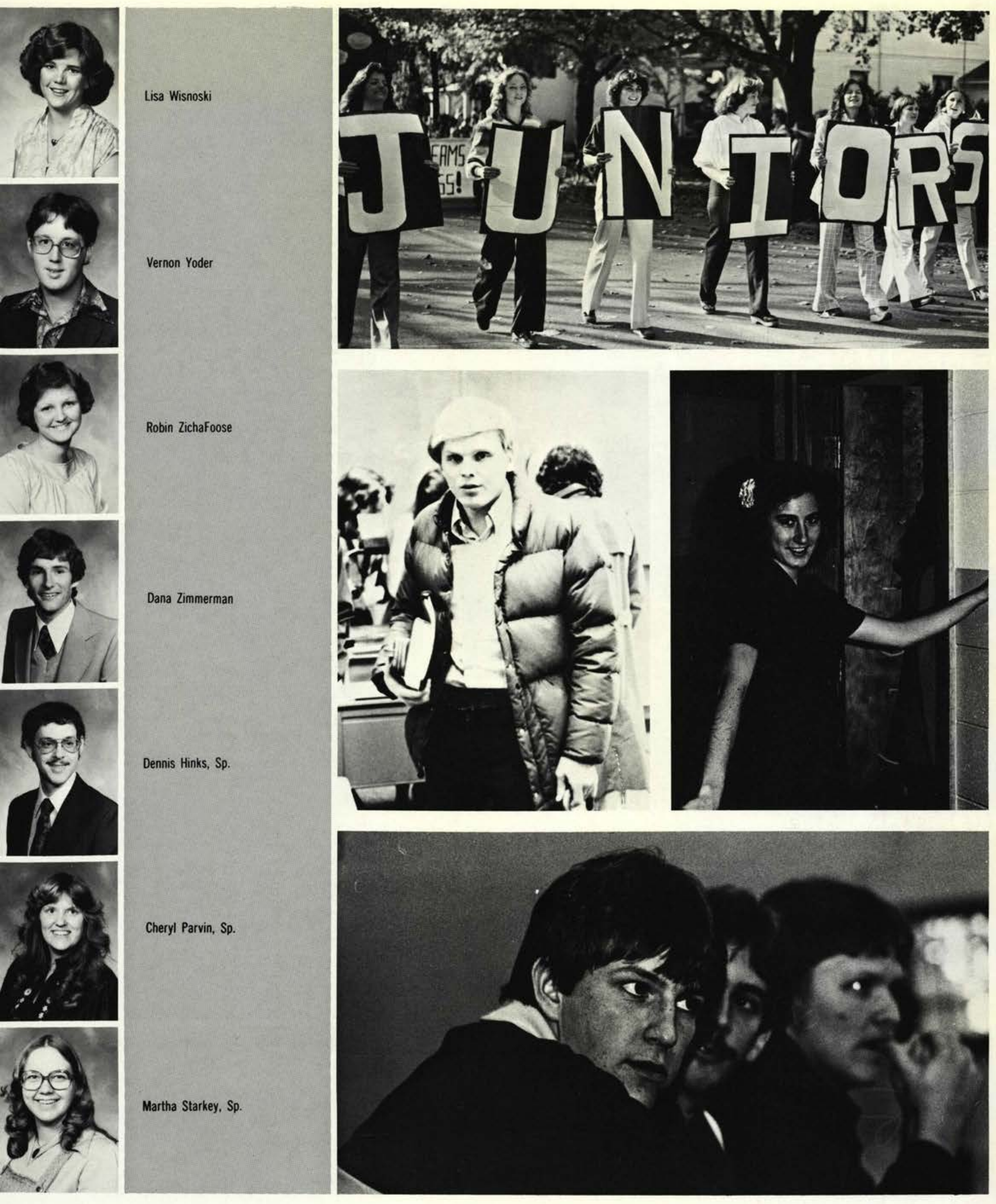




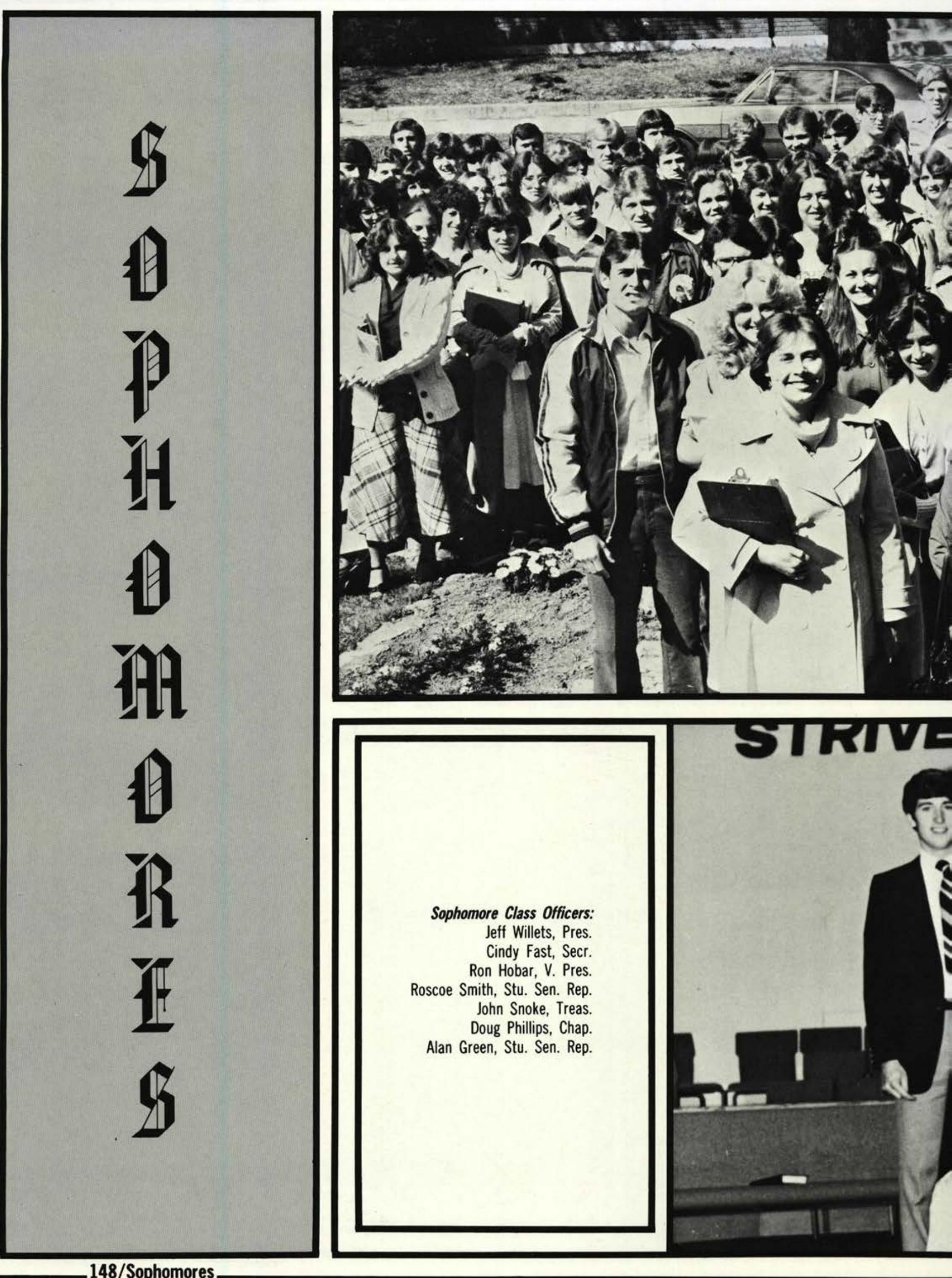



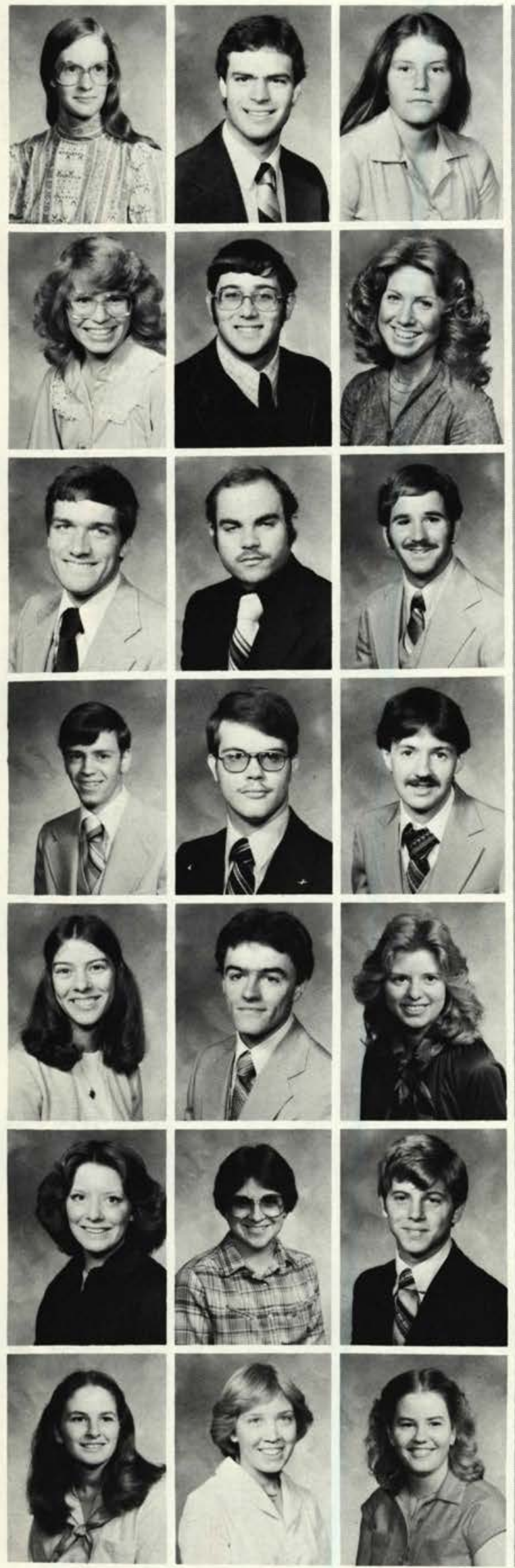

Annette Adams

Tom Ahlgrim

Terri Aiken

Theresa Ankenman

Wayne Anthony

Jan Ashcraft

Drew Baker

John Balacuis

Iim Baldwin

Keith Beach

Larry Beaver

Chuck Benedict

Joyce Blackmer

Richard Blanc

Julie Bonham

Cathy Boyd

Rose Ann Branham

Mark Brant

Donna Britt

Angela Brown

Margie Brown
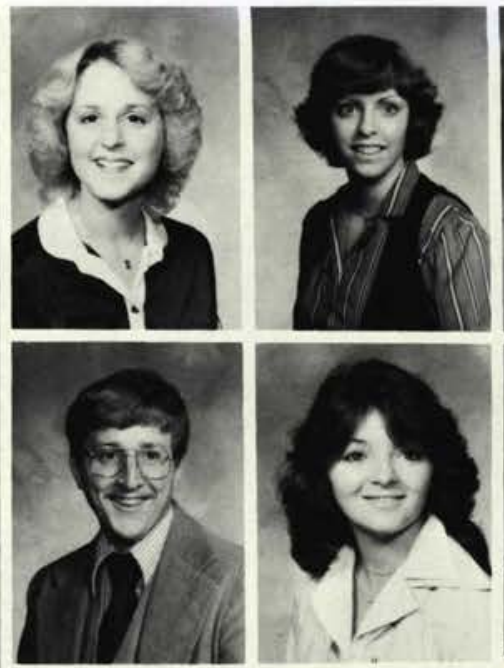

Kerry Autio Kelly Avery Melodie Bagg

Debbie Barnett Lenna Barrand Jeff Bartling

Jennifer Bennett Andy Berger Vernon Bissonette

Terry Bonzo Angela Bowers Jeff Bowser

aura Brazelton Paul Briggs Linda Brindley

Philip Brumbaugh Mark Bubel Jackie Burdick
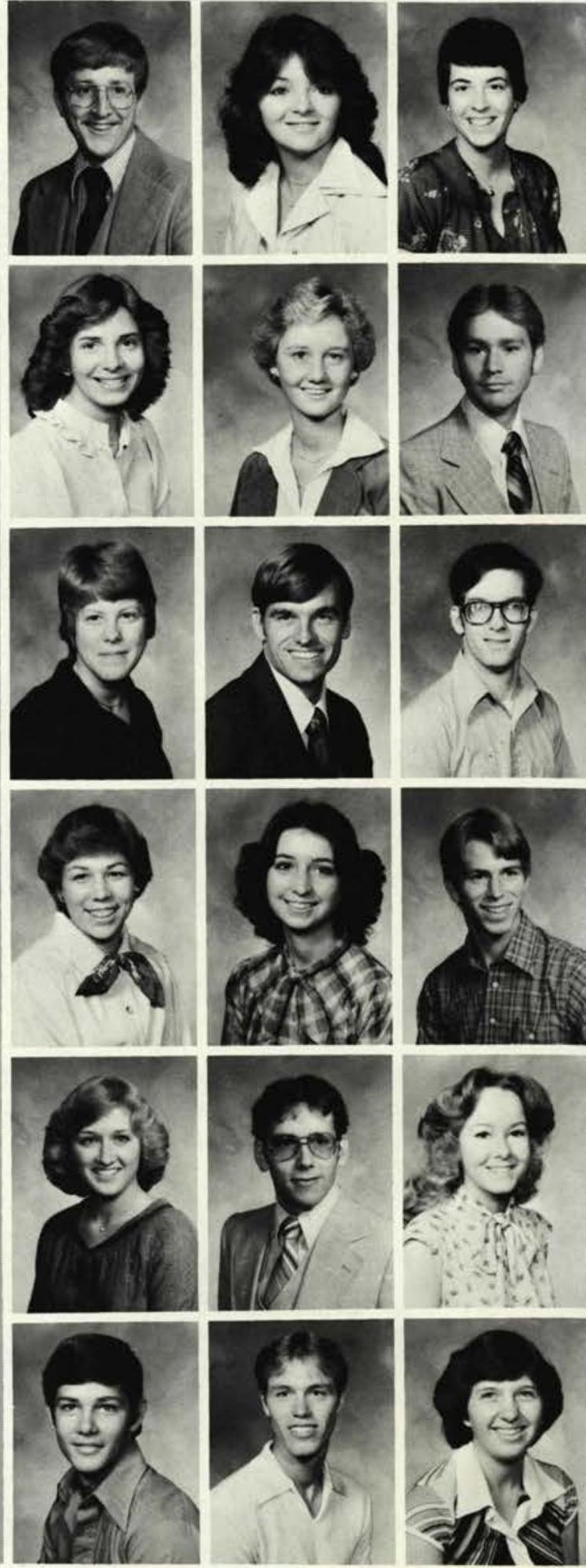
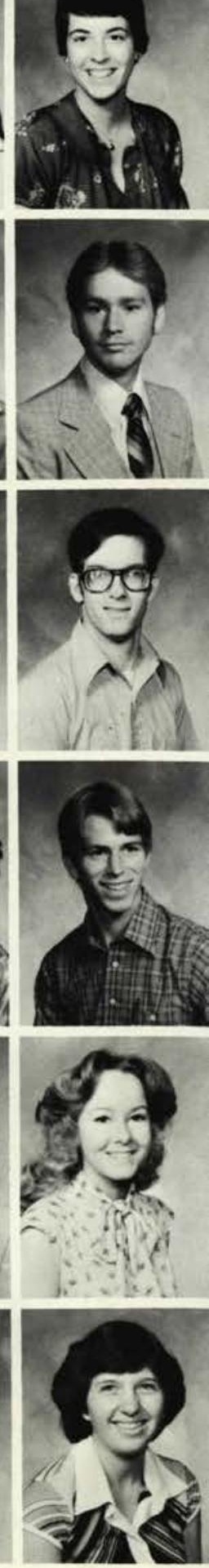

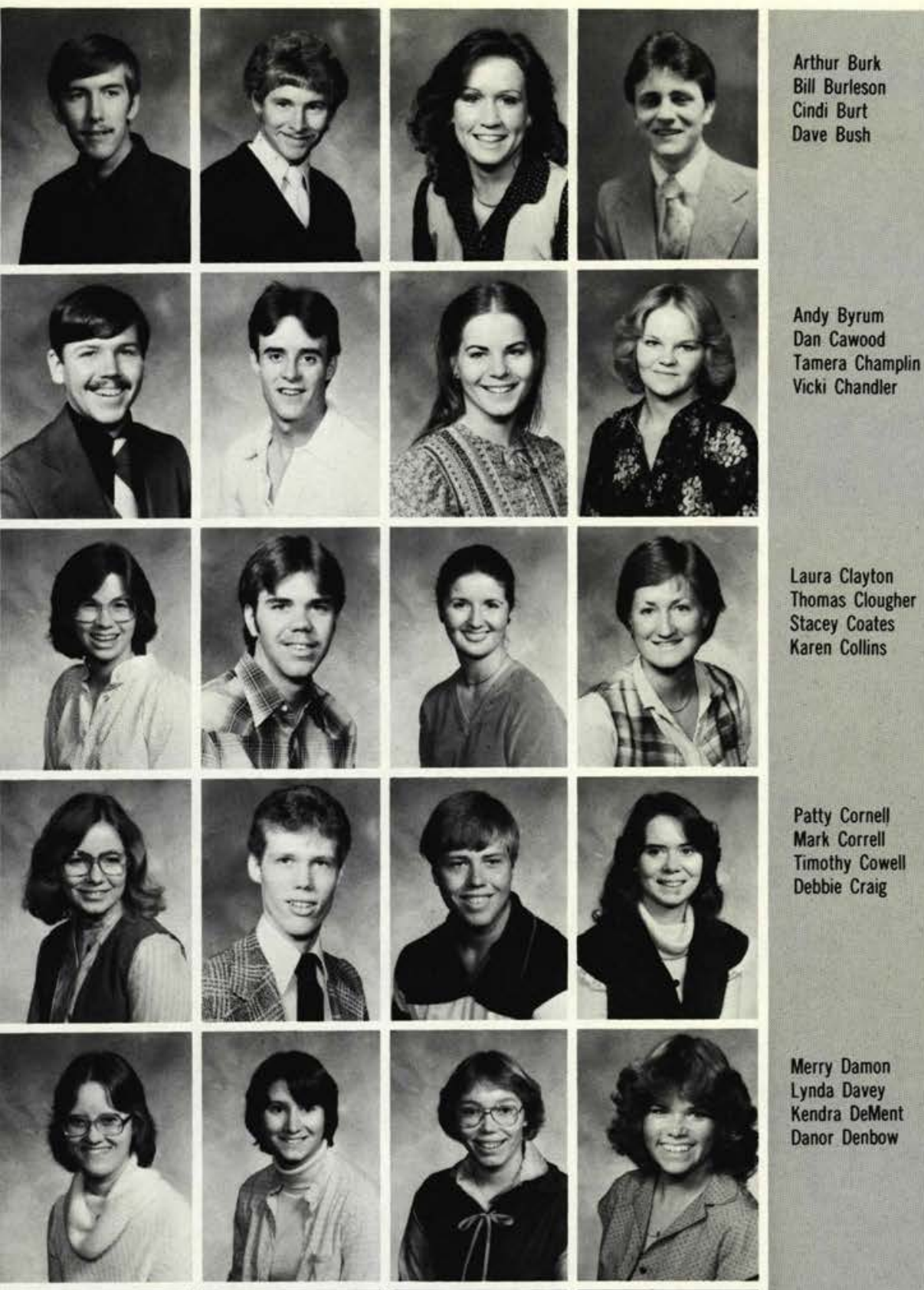

Laura Clayton

Thomas Clougher

Stacey Coates

Karen Collins

Patty Cornell

Mark Correll

Timothy Cowell

Debbie Craig

Merry Damon

Lynda Davey

Danor Denbow
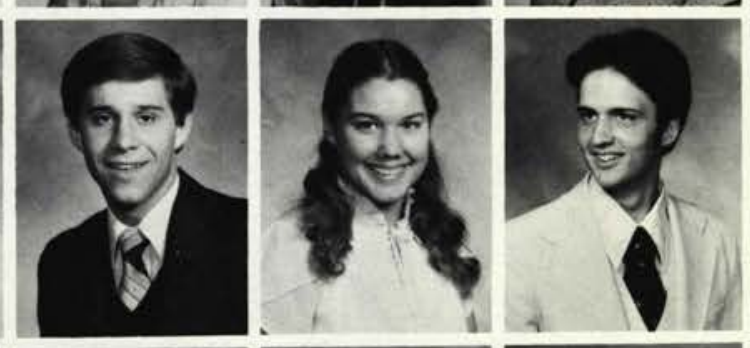

Tom DeYoung

Tadd Dieringer

Kimberley Dodds

Peter Donaldson

April Duff

Crystal Eaker

Karen Ebersole

Marlene Eissens
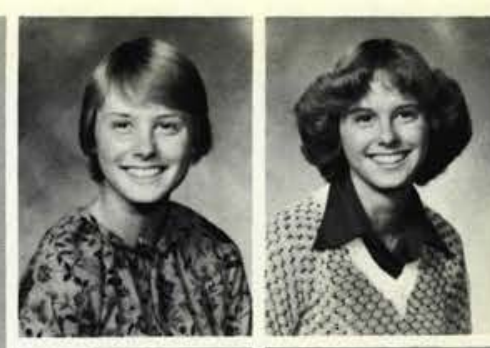

Wayne Chase

Shirley Clark

Keith Conklin

James Cordes

Keith Crankshaw

Kathy Cunningham

Donna Dennis

Steve Detwiler

Stanley Douglas Rick Dustin

Cynthia Eiser Barbara Ehrman
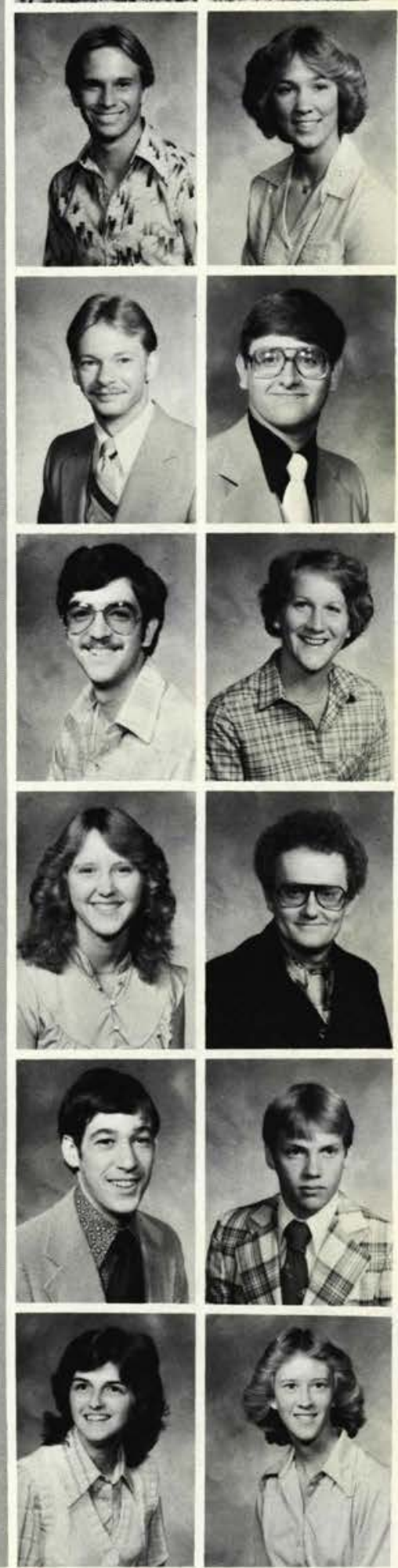

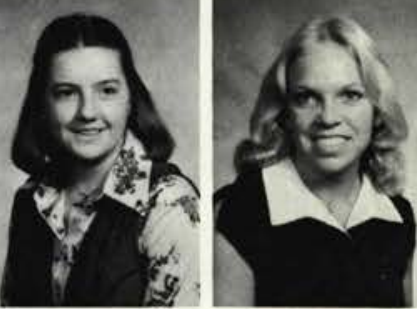



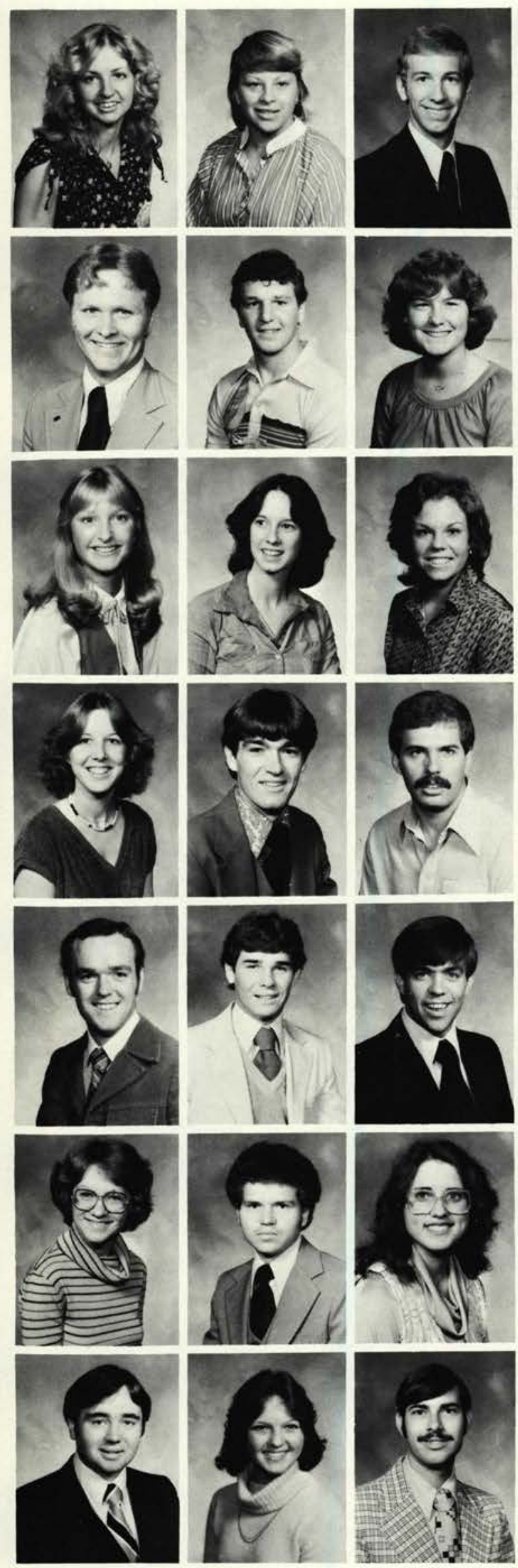

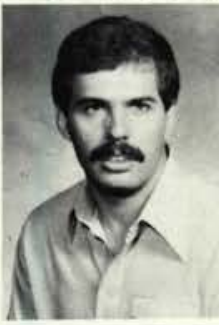

Beth Ellenwood

Colleen Engeimann

Stephen Etner

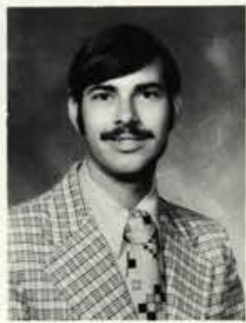

Cass Ferris

Wallace Fields

Joyce Fischer

Sarah Fox

Jenifer Freebourn

Kellie Frost

Laurie Gardner

Alan Geist

Mearl Gibson

Robert Goodrich

Tim Graham

Alan Green

Donna Hague

Gregory Hallett

Sandra Ham

Cynthia Fast Jeffrey Fawcett Becky Ferrell

Cathy Fisher

Bonnie Flint

Colene Fox

John Funtik

Laura Galbraith

Donna Gall

Scott Gillette Christine Gilmour

Judy Goft

Larry Green David Grosso Cindy Groves

Michael Hamilton Kevin Harding Cathy Hart

Brian Hayes

Jane Heers

David Hegarty
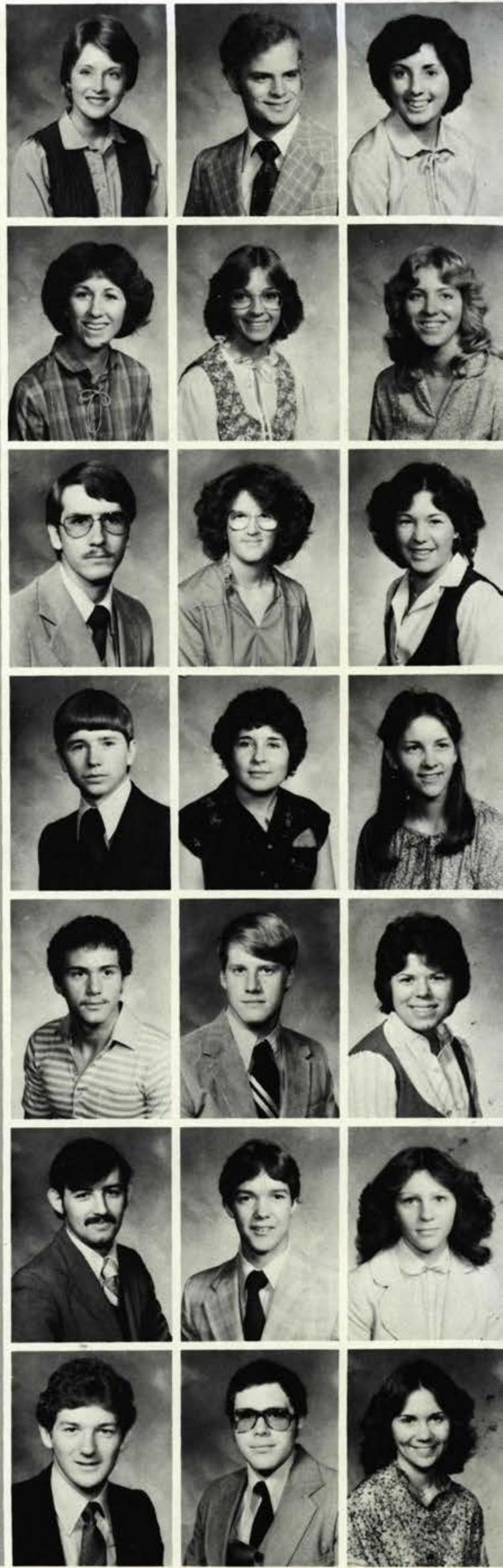

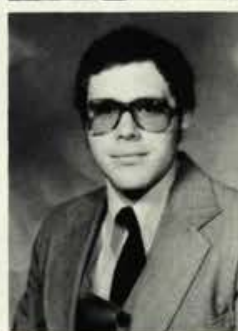

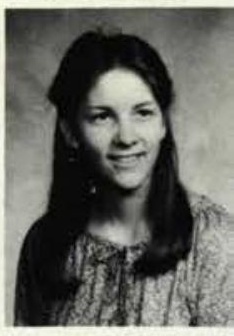
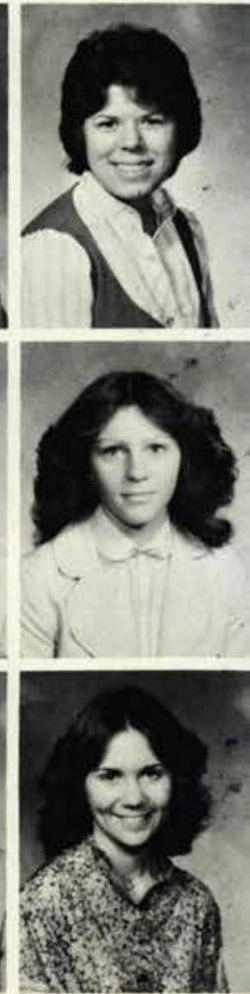

Timothy Heider Eric Henderson Sandra Henslin 

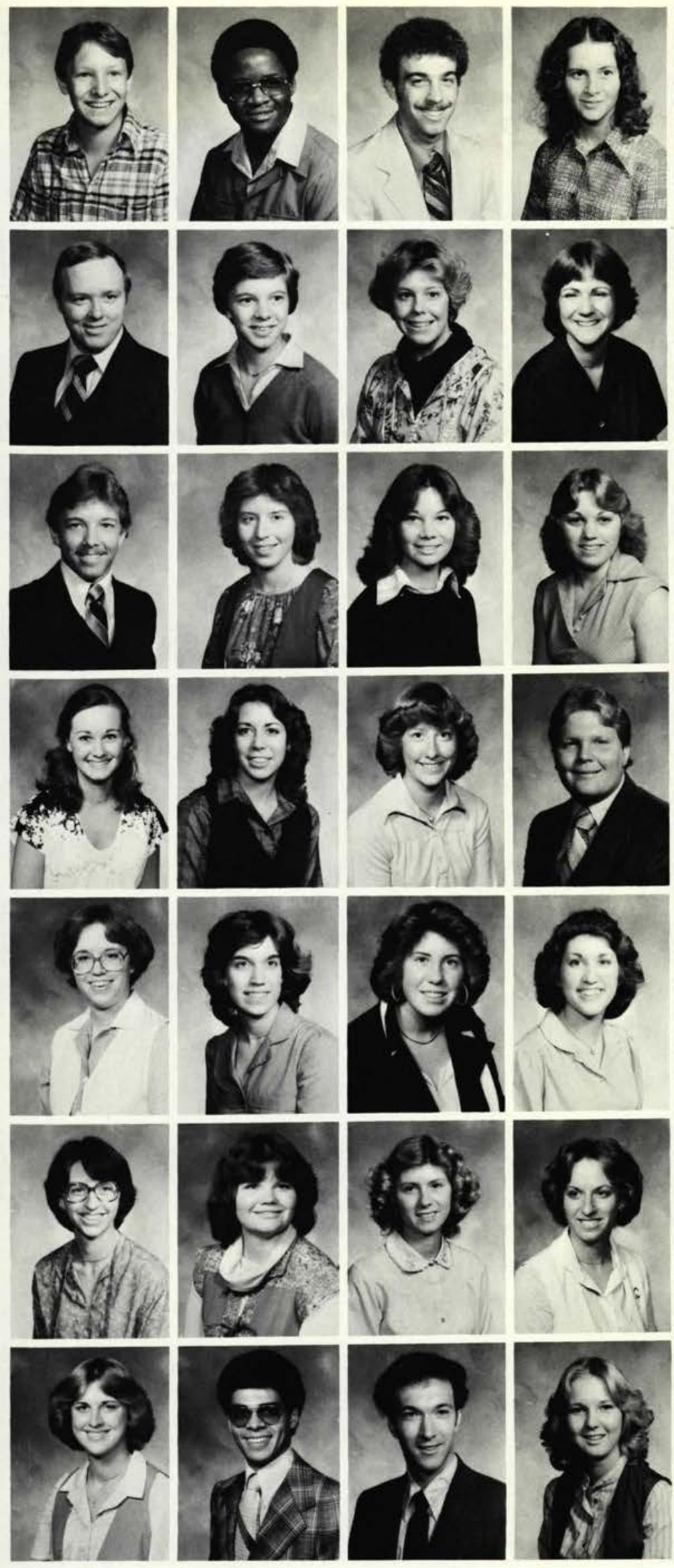
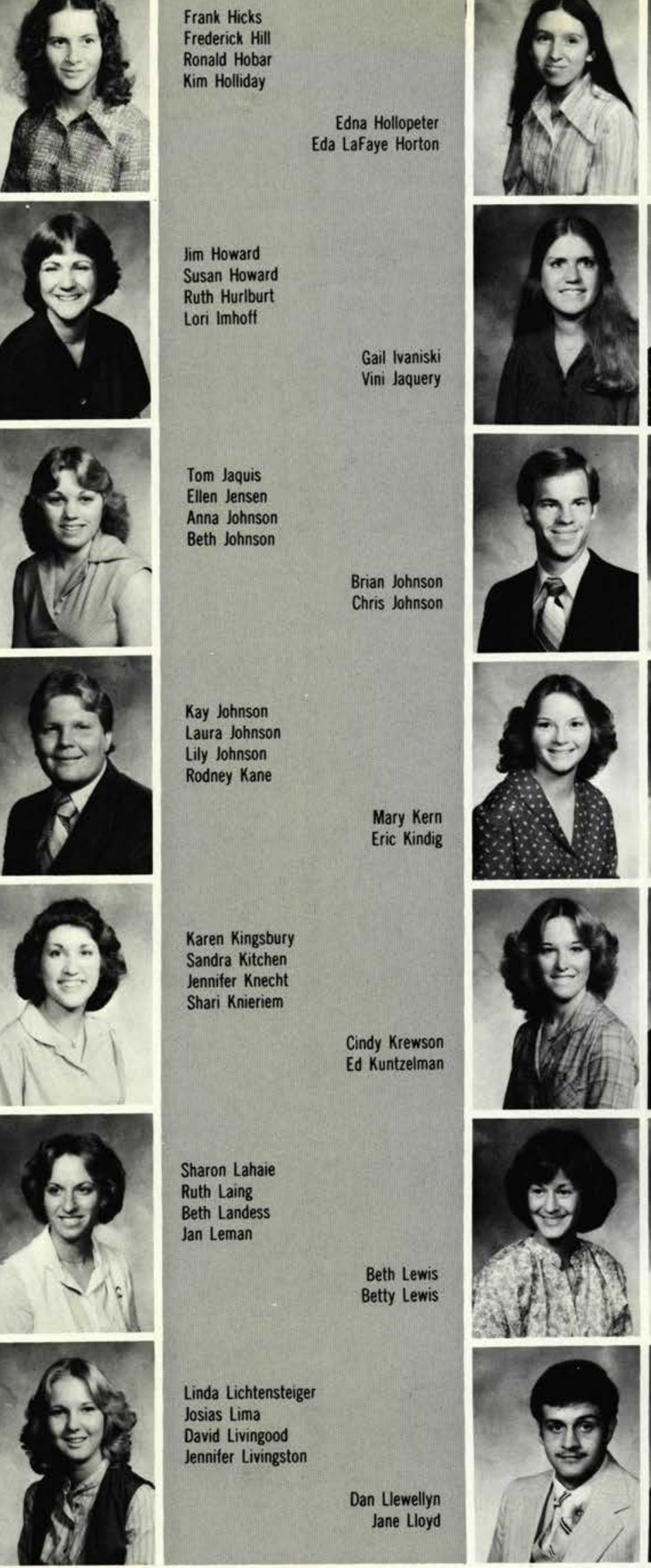

lim Howard

Susan Howard

Ruth Hurlburt

Lori Imhoft

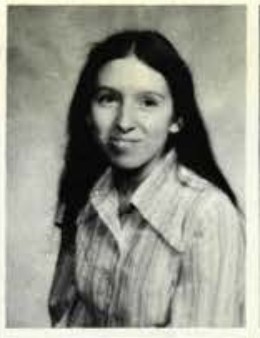

Edna Hollopeter
Eda LaFaye Horton

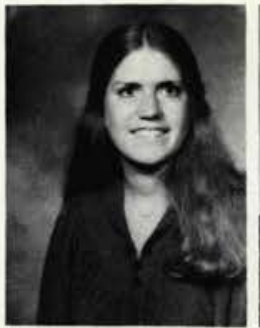

Tom Jaquis

Ellen Jensen

Anna Johnson

Beth Johnson

Brian Johnson

Chris Johnson

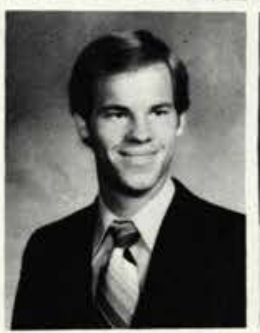

Kay Johnson

Laura Johnson

Lily Johnson

Rodney Kane

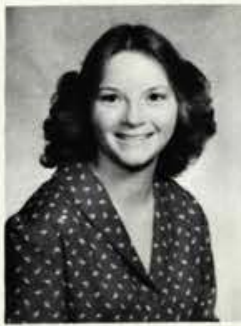

Cindy Krewson

Ed Kuntzelman

Kangsbury

Jennifer Knecht

Shari Knieriem

Sharon Lahaie

Ruth Laing

Beth Landess

Jan Leman

Beth Lewis Betty Lewis
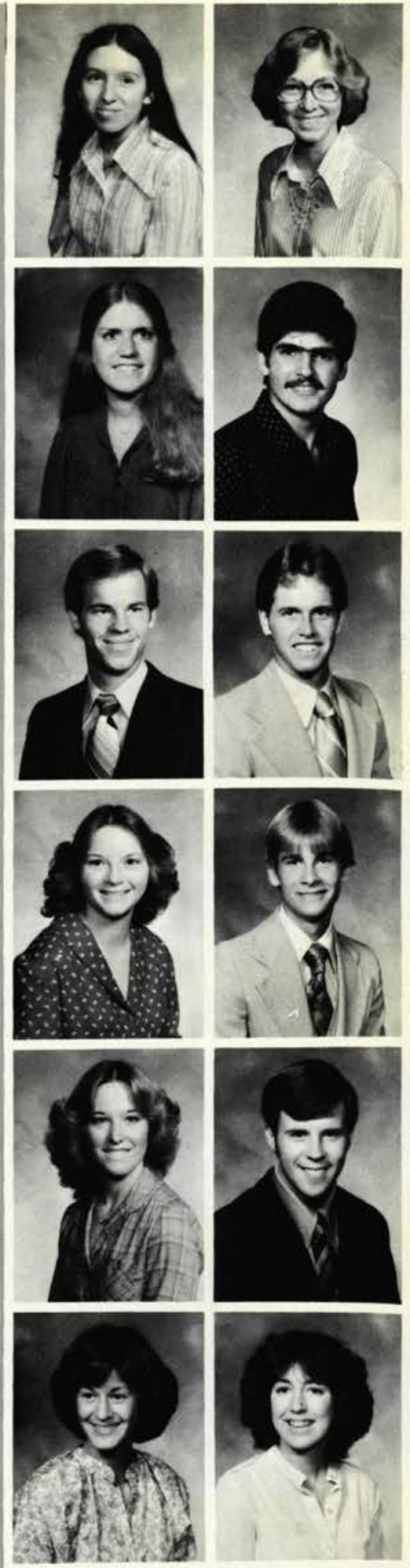

Linda Lichtensteiger

Josias Lima

David Livingood

Jennifer Livingston

Dan Llewellyn

Jane Lloyd

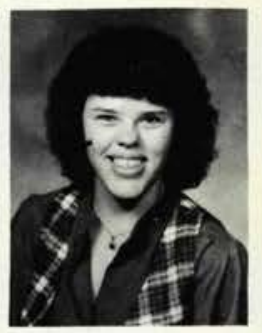



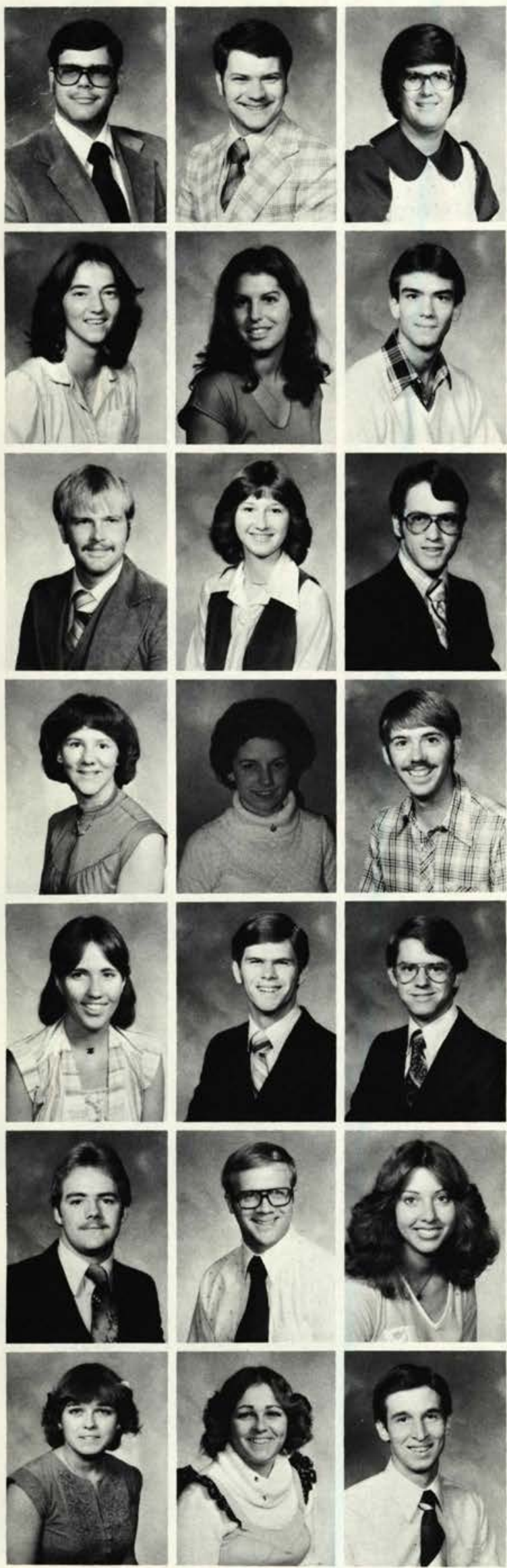
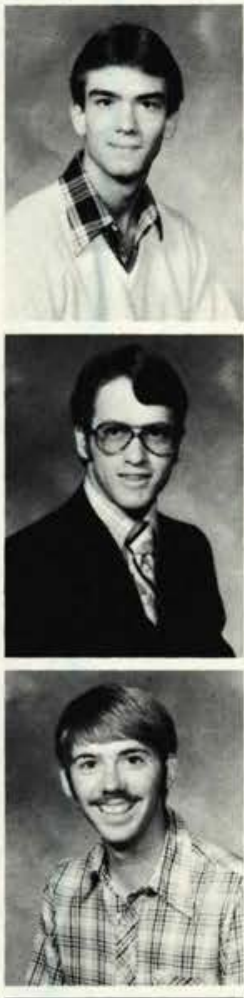

Tom Longacre

Robert Longnecker

Lois Lyon

Cynthia Mackenzie

Myron Major

Patty Maloney

Cindy Mannering

Christal Marihugh

David Marstellar

Jerry Maxey

Laura McConnell

Cory McDaniel

Karen McHugh

Pam McKever

Mark McIntosh

Anne Miller

Brian Miller

Raymond Miller

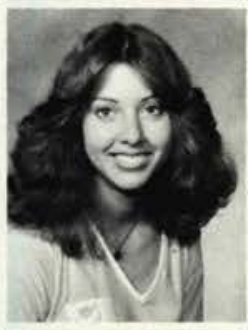

Ron Moehn

Deke Motfitt

Linda Moody

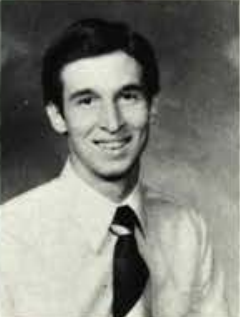

Natalie Martin Tim Mathewson Mark Matthews

Dave McDaniel Robert McGuckin Donna McHugh

Loraine Merkh Tim Messenger Debbie Meyer

Mark Mills John Mitchell

Darcella Morton

Marcella Morton Rick Mourlam

Kevin Mulder Sandy Neely Cindy Newcomb
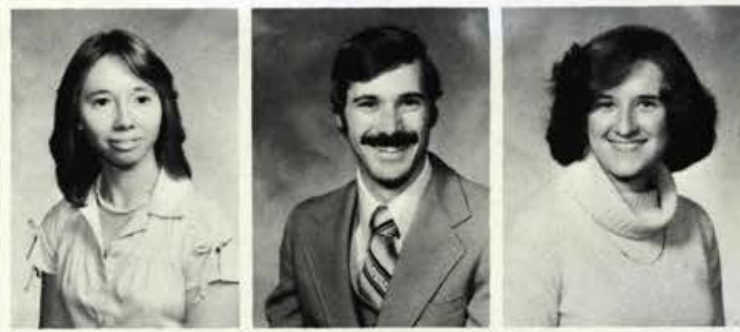
William Minckler

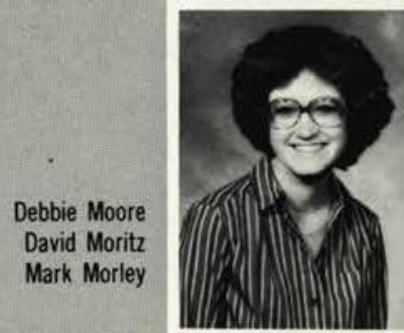

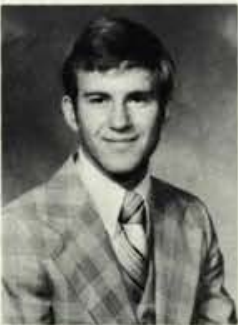
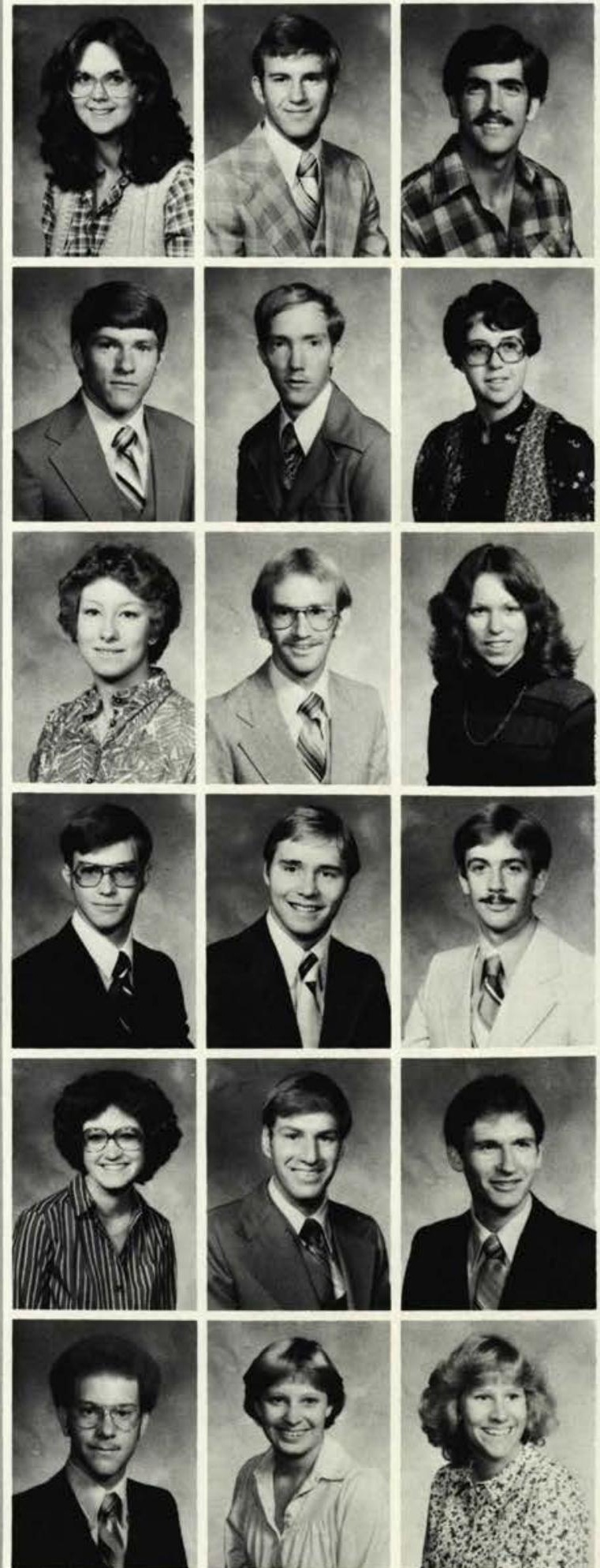

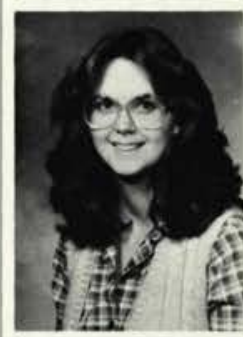



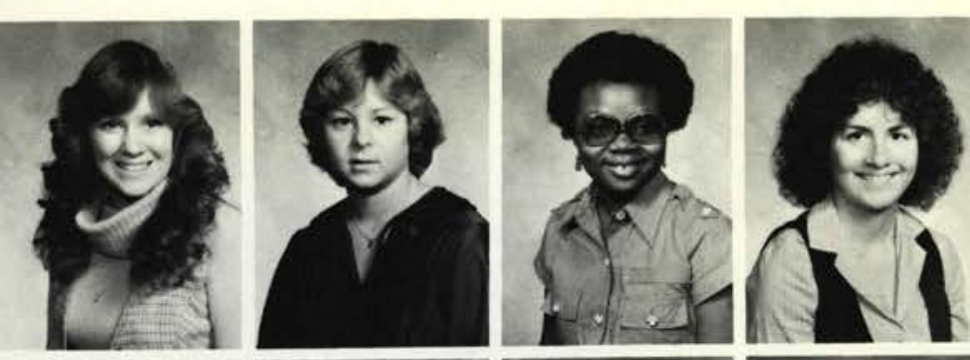

Anne Kitles

Lymin O'Boyle

Robert Ocran

Dethic OSver
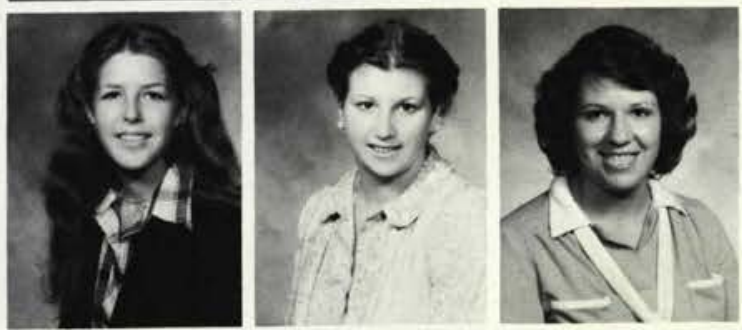

Mart Osbone

Deanna Palner

Gayle Paradiso

Sheila Parsons
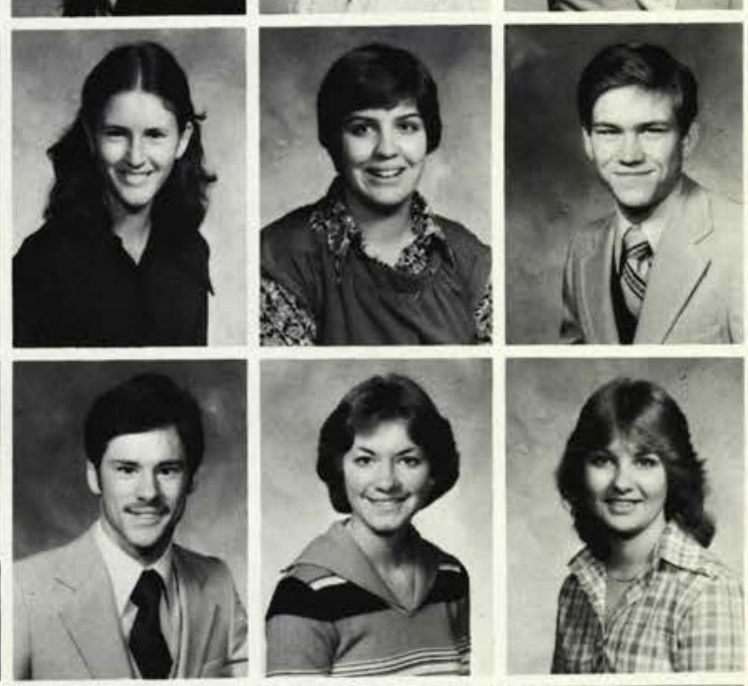

Cinny Payne

Kin Payton

Sharyn Penquite

Timolthy Peterson
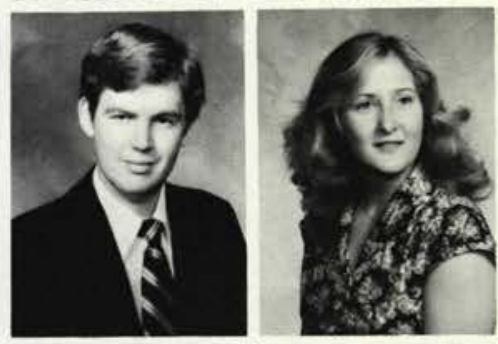

$\left(\frac{3}{4}\right)$
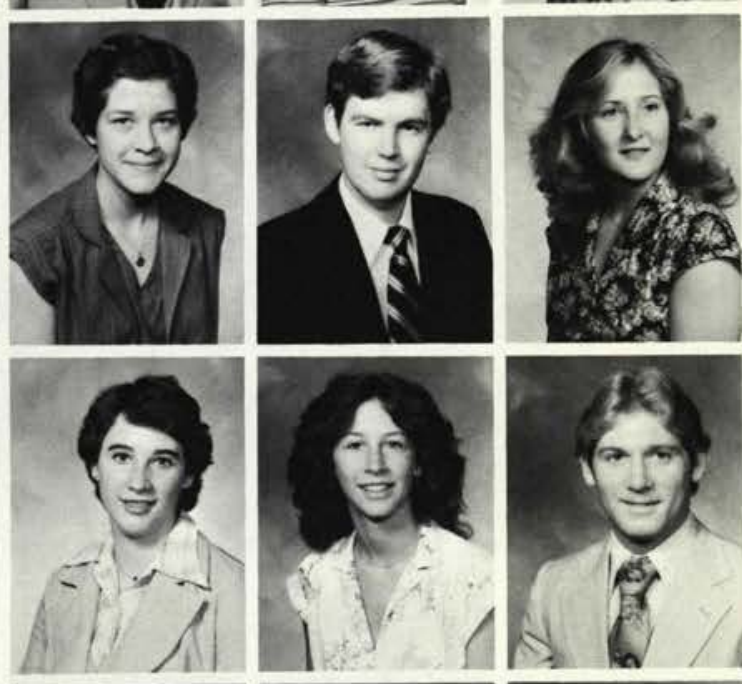

Becky Pruden

Greg Pippin

Amy to Plaggemars

Karen Pleshiko
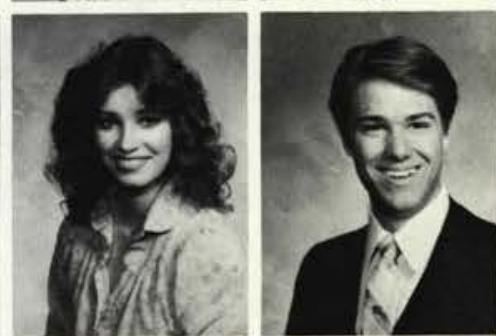

Elaine Riggs
Tom Prall

Julie Prentice

Kevin Pringle

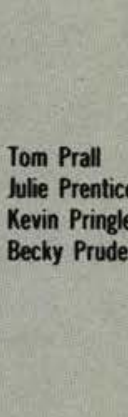

Sharon Rawson

Elaine Rayder

Diane Reese

Brad Reinhart

Brian Olson Linch Ormsbee

\section{Susan Parvin}

Diane Pasco

Delana Phillips

Doug Phillips

Teresa Potter

Timothy Power

Michelle Randall

Donnie Rawlins

Richard Reinhart Gregory Reinholdt

Lori Richards

Brian Rickard

Keith Risser
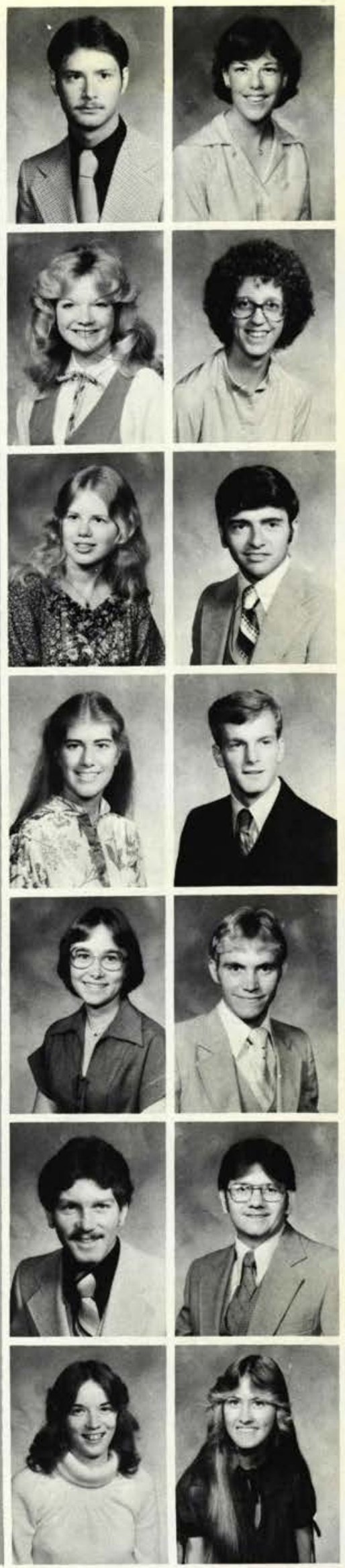

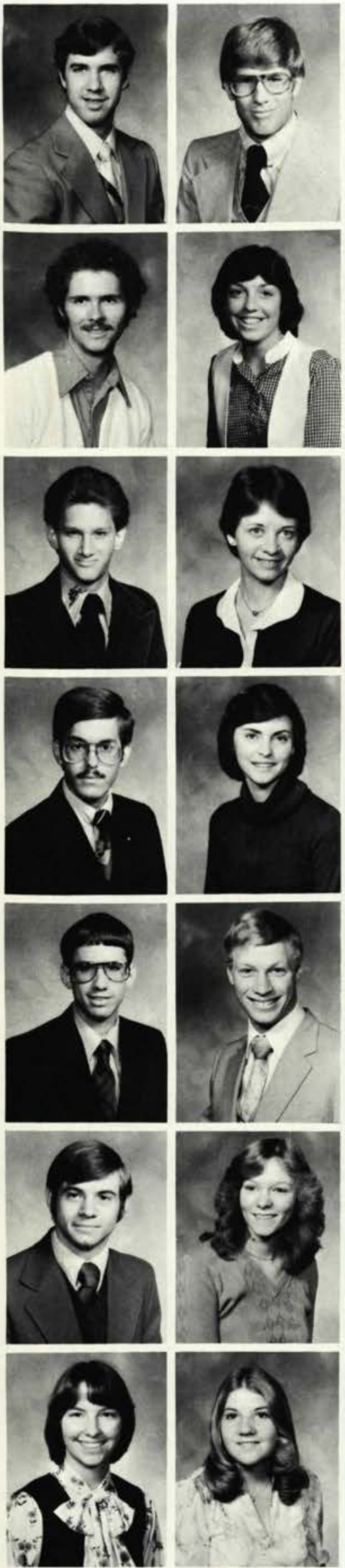

Ronald Rost

Steve Sadowitz

Justin Sewell

Patty Shaffer

Mark Skiles

Debra Sloan

John Smith

Linda Smith

Richard Soper

Philip Southwell

George Stephens

Diana Stewart

Donna Supplee

Jane Sutherland

Elaine Swartwood Annette Taylor

Thomas Teall

Lisa Teske
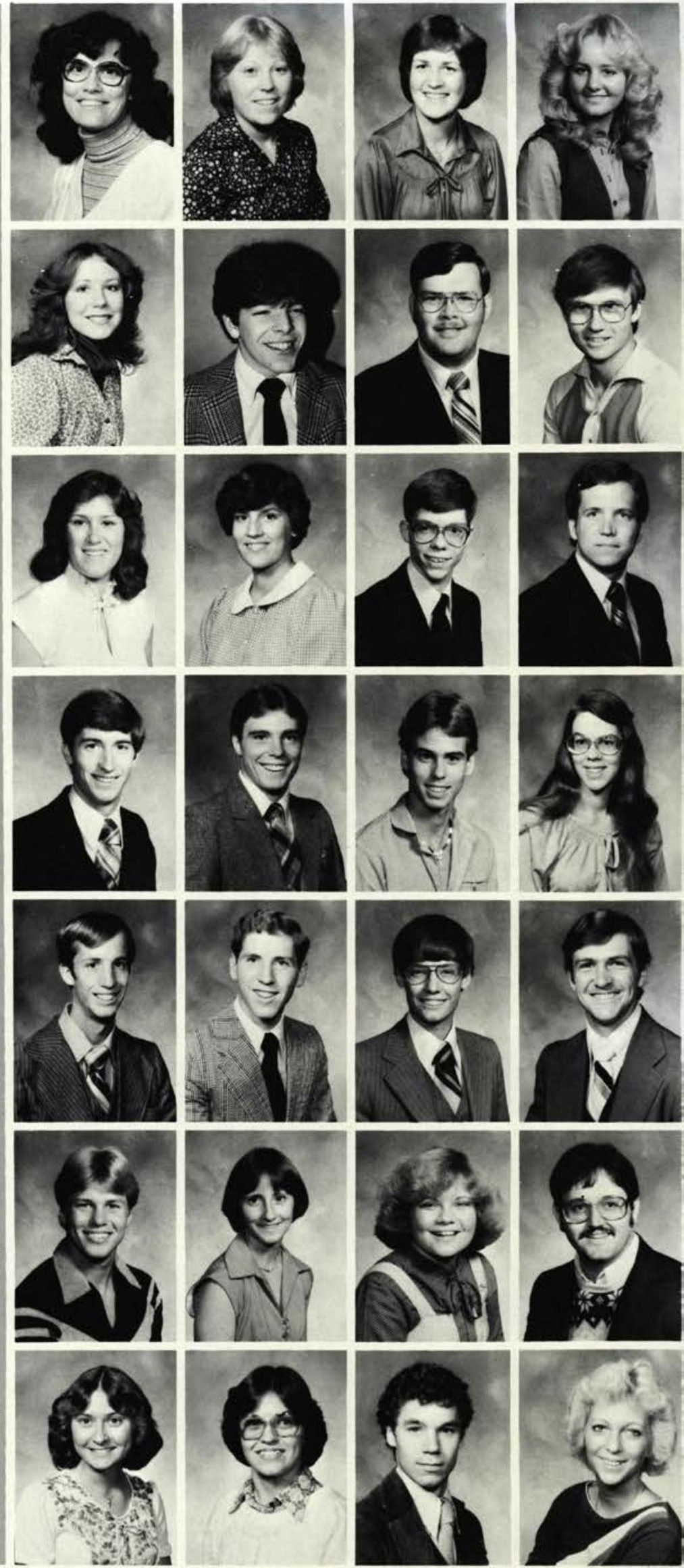

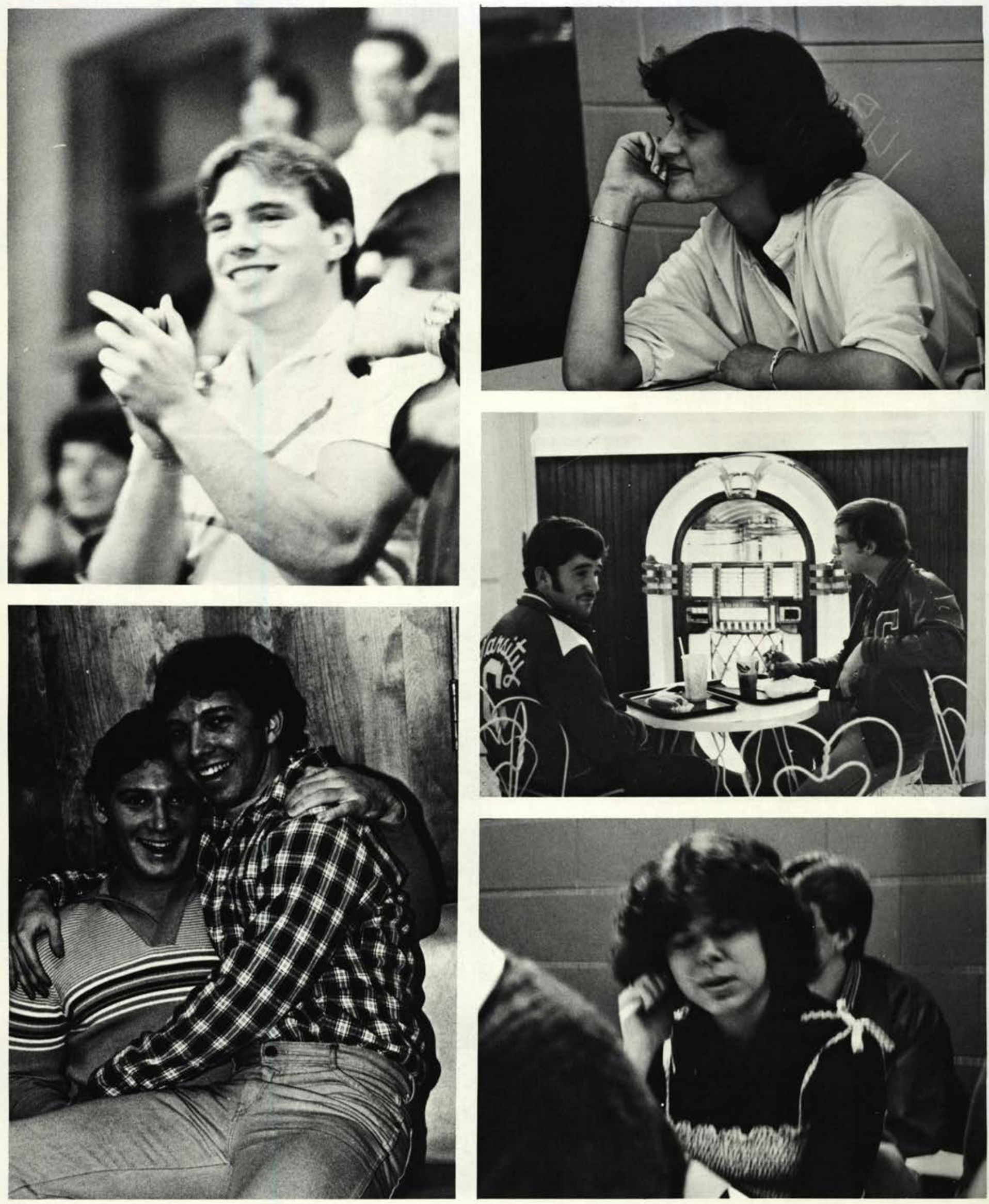

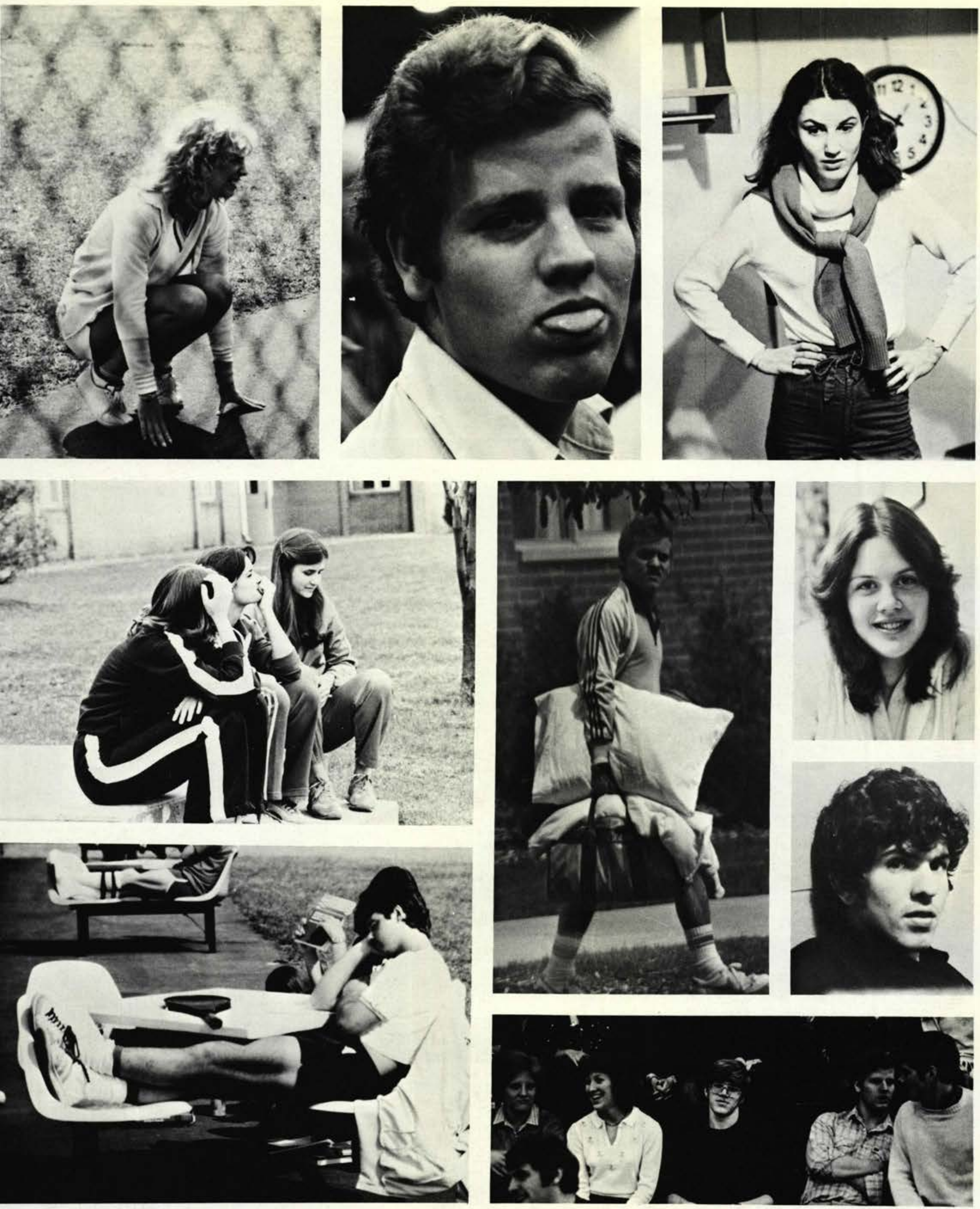

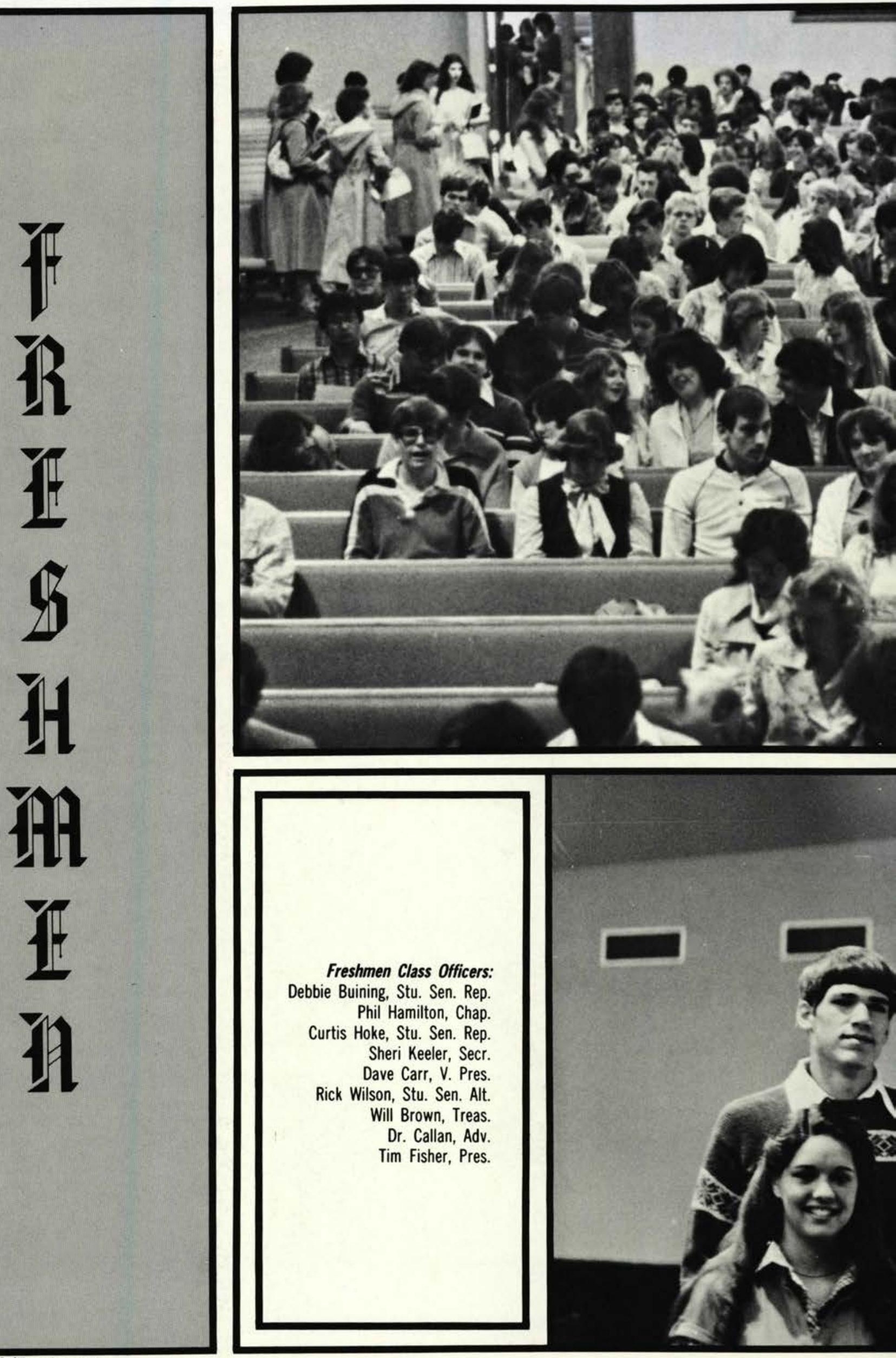

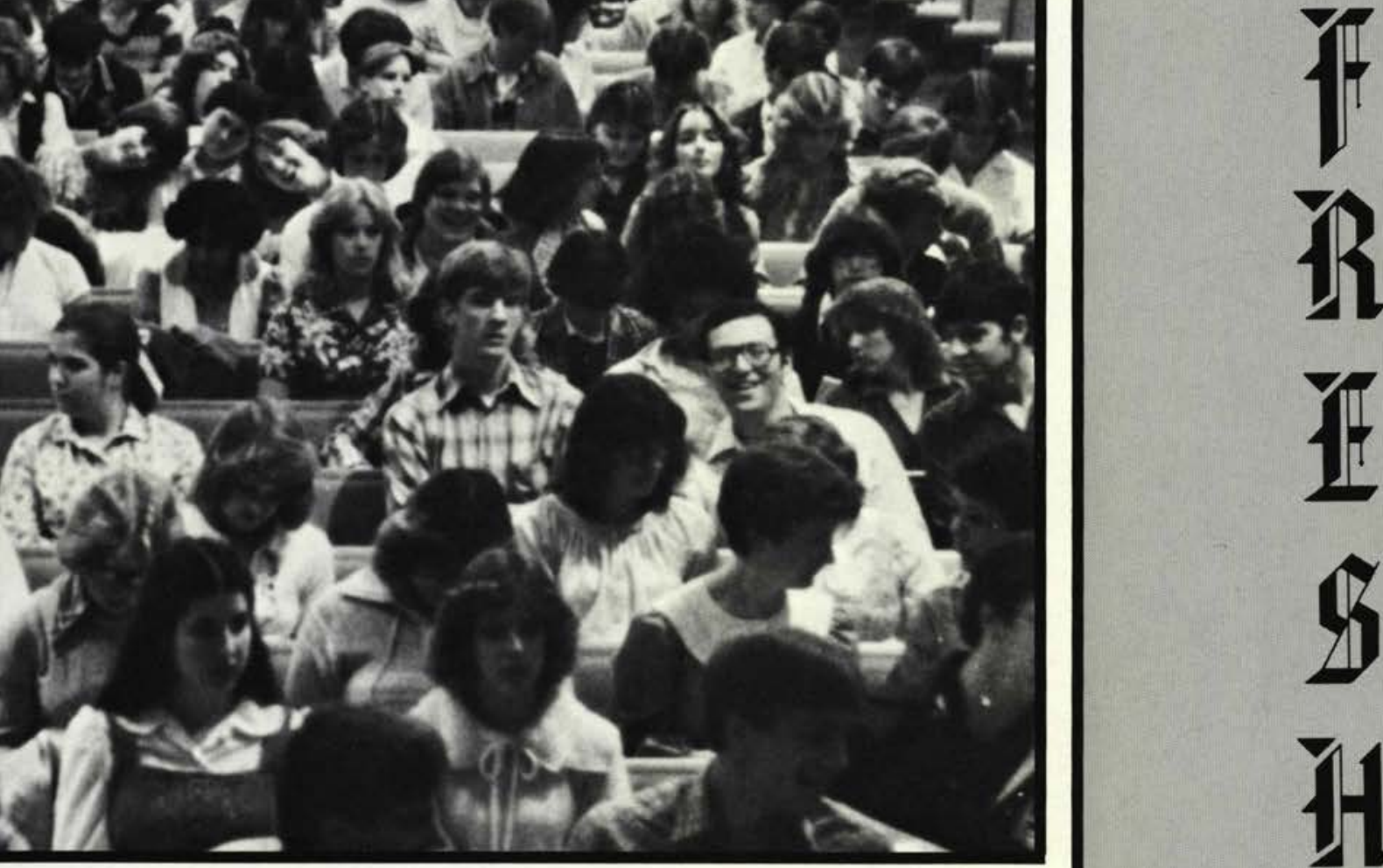

It
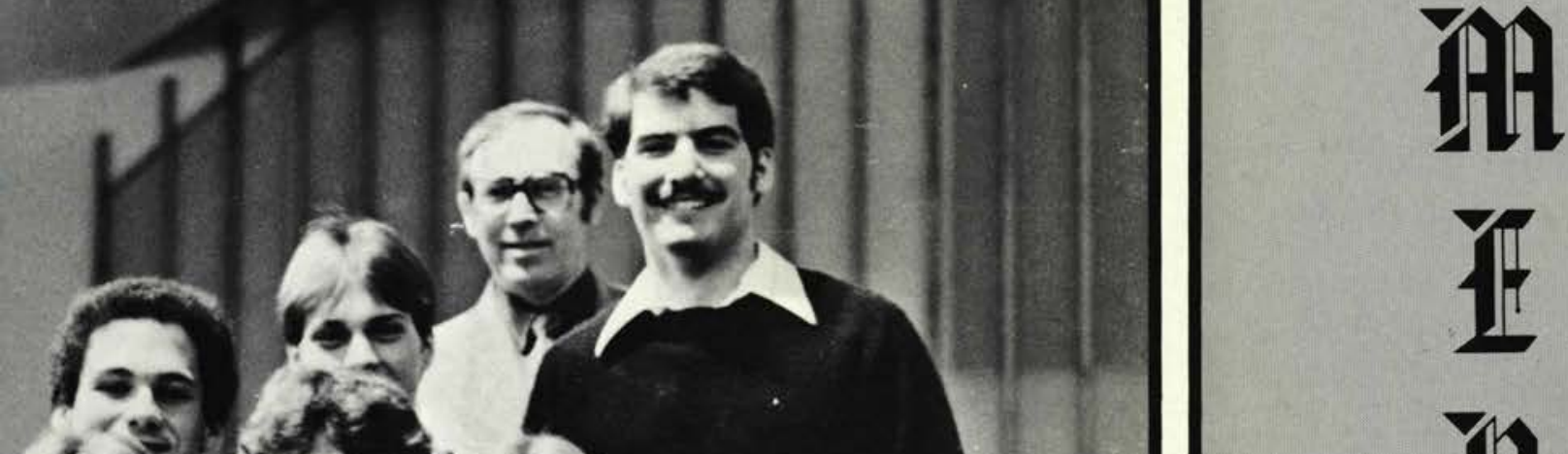

8 $r \cos$
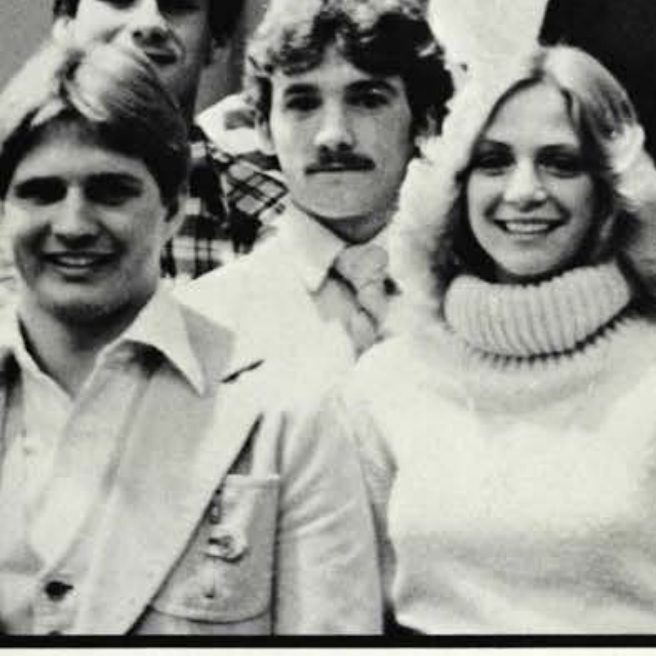

Q $\Leftrightarrow$
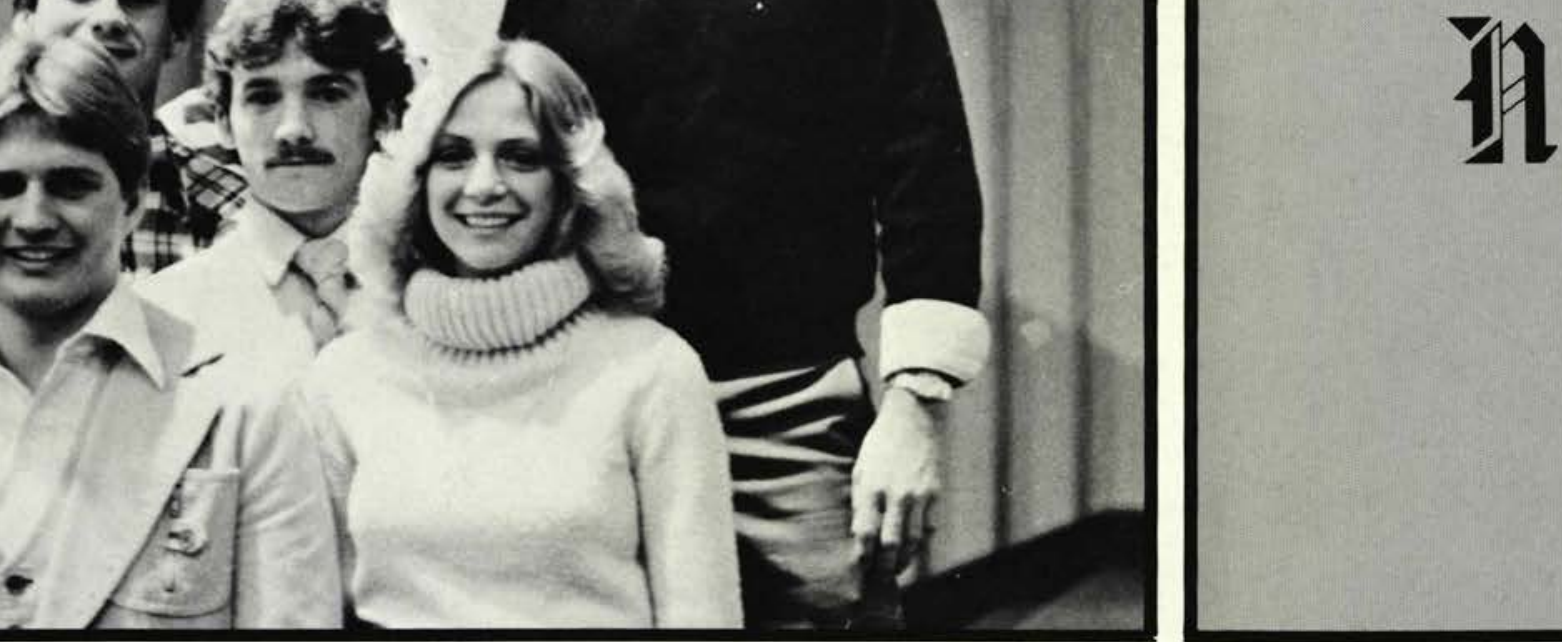

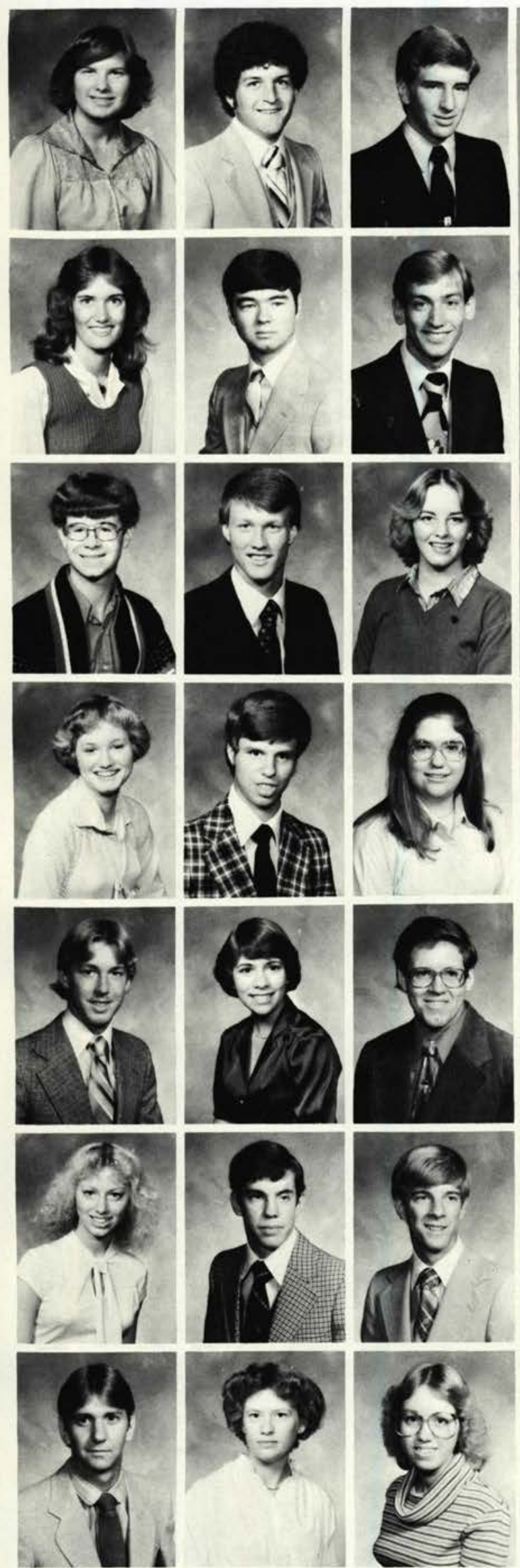

Bradley Brandt

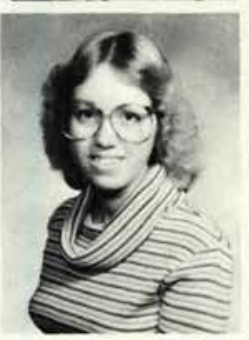

Stephen Bontekoe

Shawnie Booher

Joseph Bosler

Christien Boudreau Tina Bowersock Robert Boynton, Jr.

Judith Bingman Roxanne Birk David Black

Devon Block

Roger Bloyd

Teresa Bohn Robert Boynton, Jr.

Sherri Bragg

Jeffrey T. Brammer

Randolph Breon Cynthia Brown Will Brown
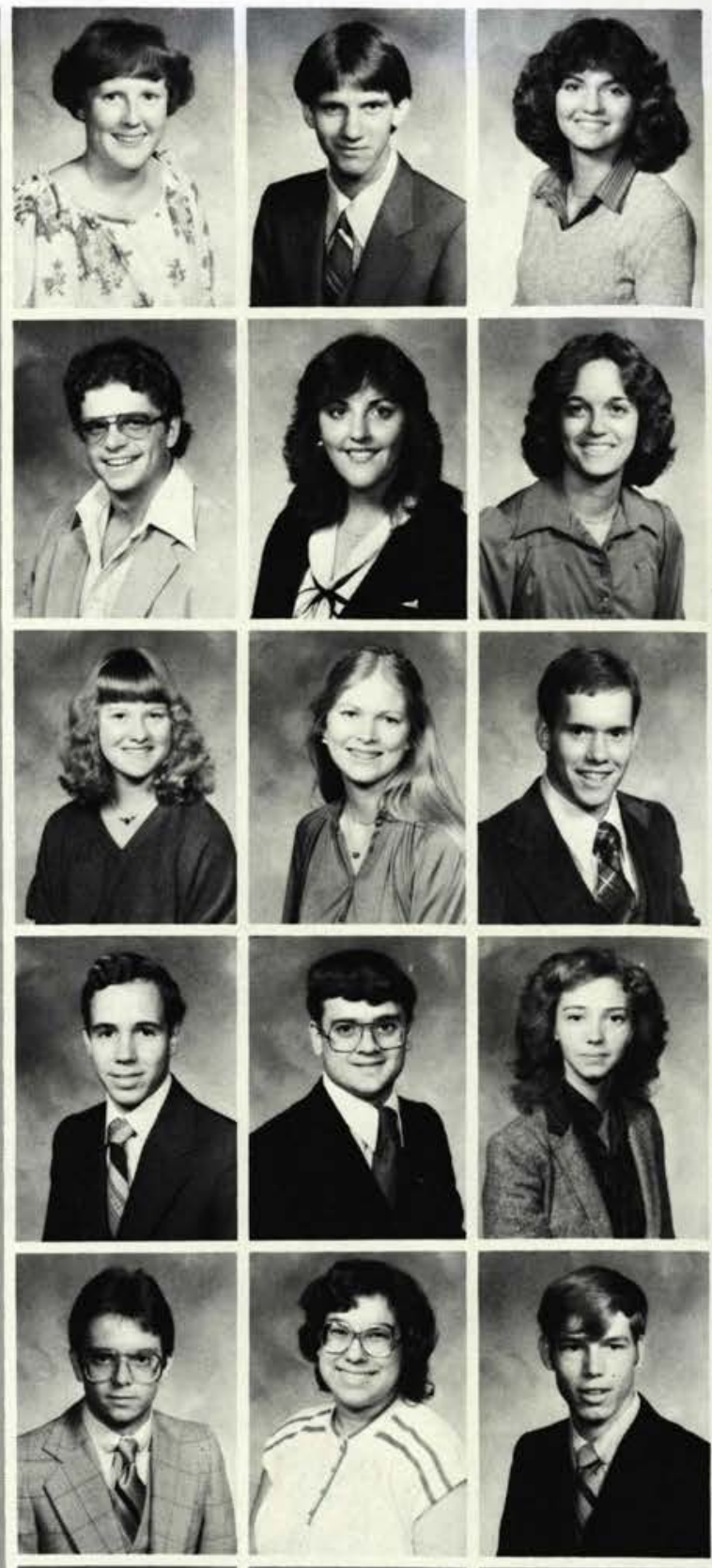

Bruce Brueckner

Rhonda Brugger

Debra Bubel
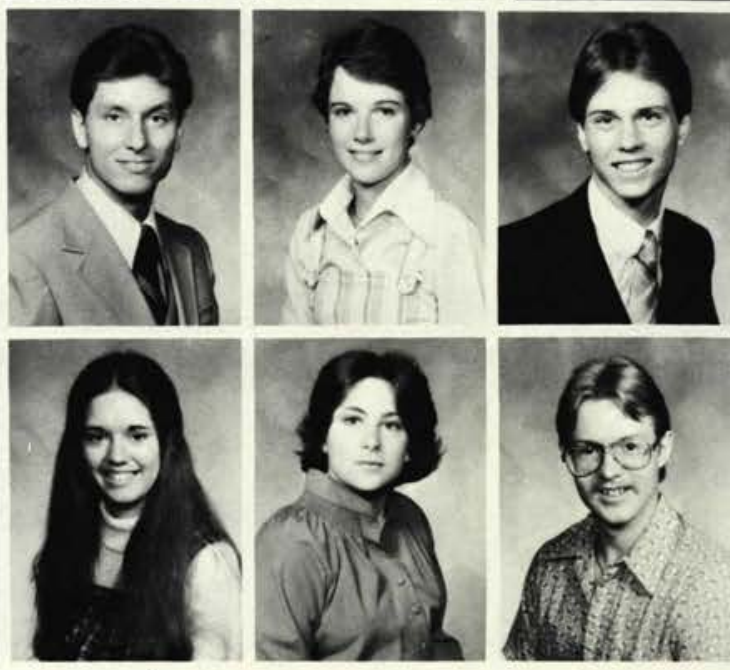

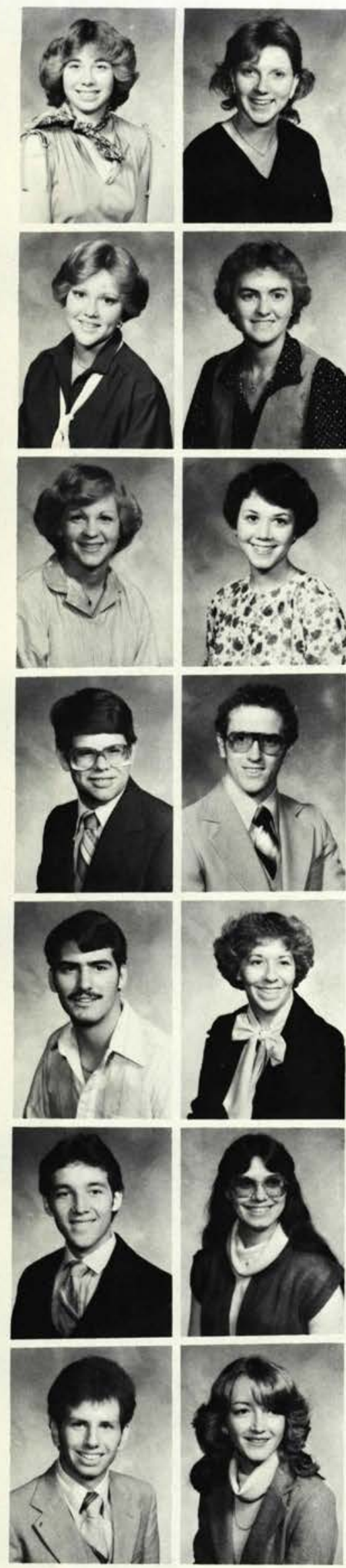

Marcy Dresbach

Lori Duffield

Vickie Demming

Robin DePoyster

Wanda Dever

Patty Dillinger

Kay Donaldson

Michael Draa

Renee Dundon

Dale Durham

Janie Easter

Karen Eddy

Lee Ann Eichelberger

Jodi Ellington

Carol Elmore

Lorraine Emery

Mary Ernst

Ruth Fareno

Christopher Felt

Steven Ferrel

Michele Feura

Melinda Filer

James Fischer

Karen Fisher

Tim Fisher

Constance Fitch

Linda Ford

Stephanie Frank

Lori Franklin

Roy A. Fuller

Scott Fuller

Sarah Fulmer

Daniel Garrison

Nancy Gedicks

Kenneth Gentzler II

Larry Gibbs

Cullen Gibson

Deborah Gilbert

Jeff Grafton

Brian Green

Dan Greening

Sally Greetham
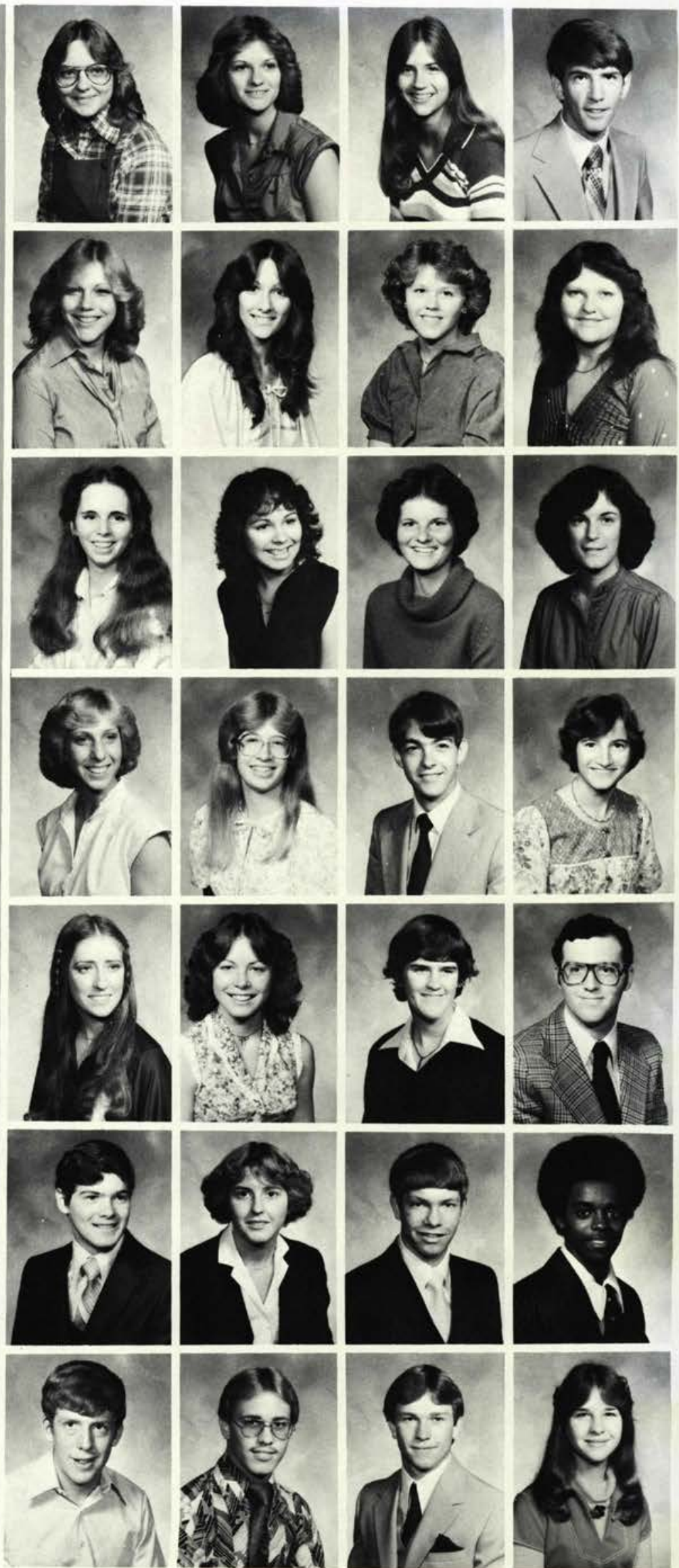

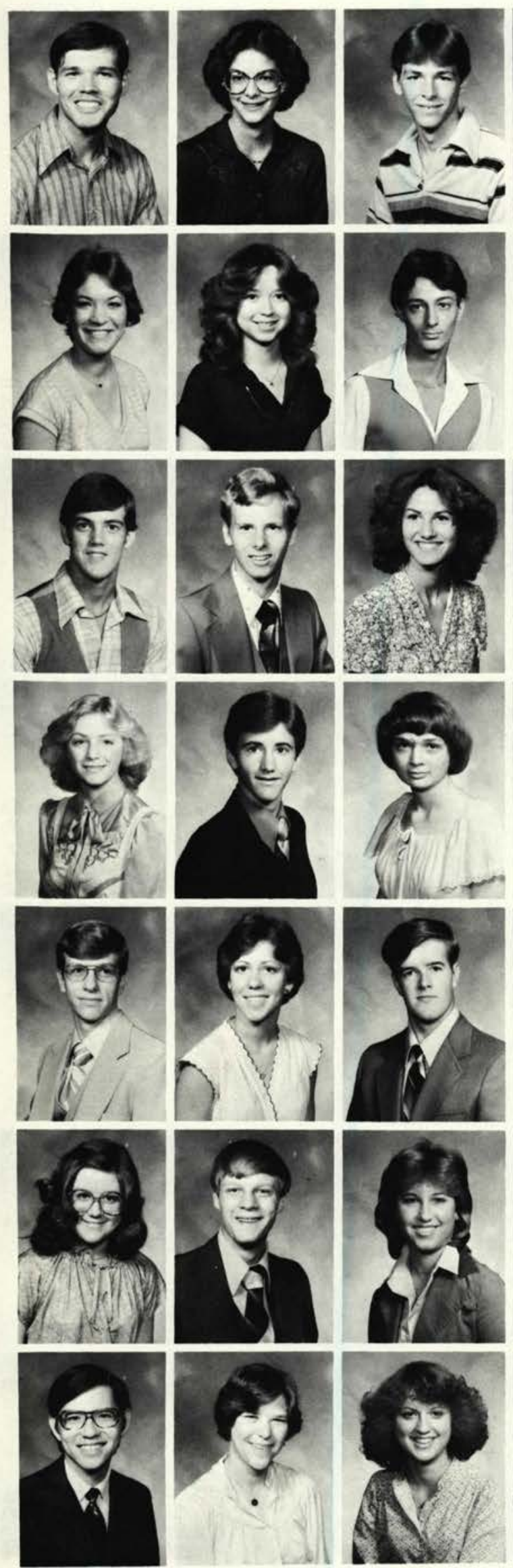

$2=$

10

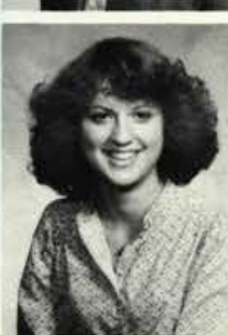

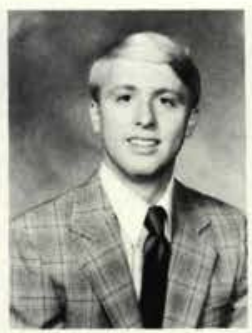

\section{Marvin D. Humphreys \\ Jammy Humnaman \\ Nate Hunter \\ Barry Hutchins}
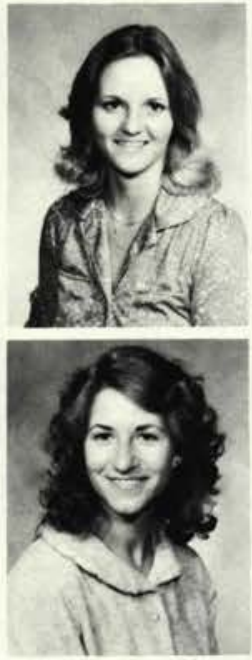

Jim Jobson

Dean Johnson

Jannell Johnson

Kelly Kandle
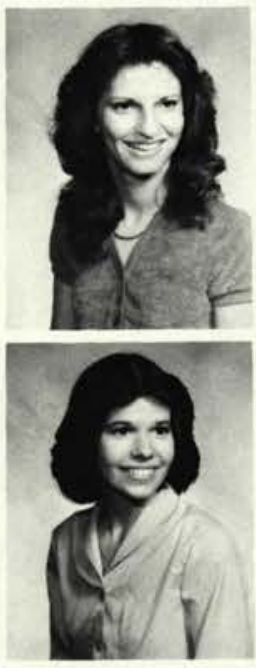

Sheri Keeler

Kirk Keller

Ruth Marie Kemp

Norman Kendall

Michelle Kauffman Ken Kauiman

Rébekah Jewell
Nancy lindra

David Hyslop

Ellen Jackson

Faith Kenoyer

Kim Kensinger

Brian Kenyon

Dawn Kessler

Dale Klenke

Janice Klingenberg

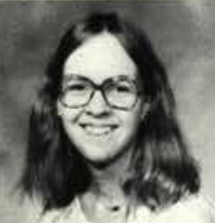

Susan Kreidle

David Krueger

Joy Laxton

Kathy Leathers

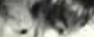
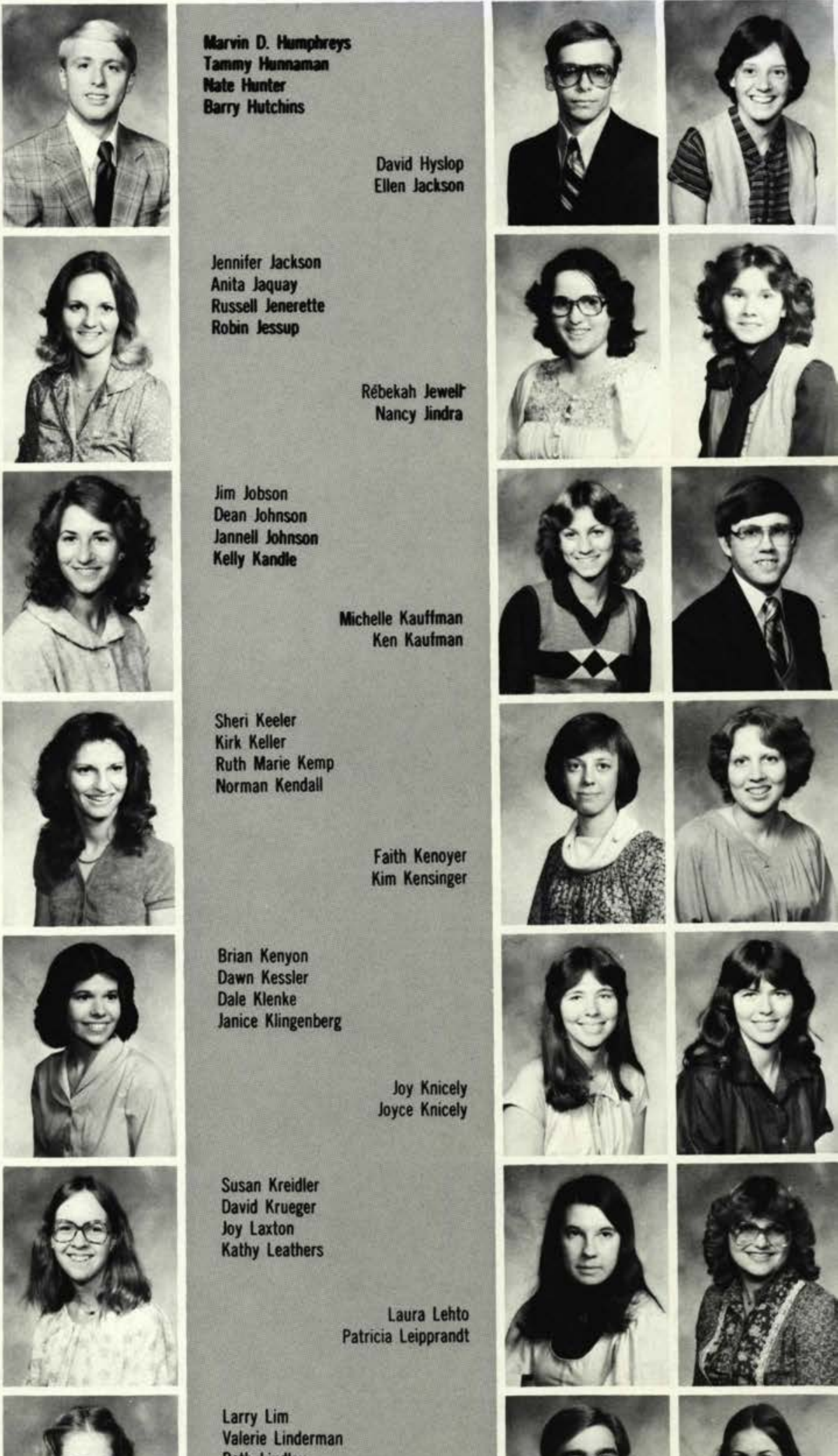

Joy Knicely

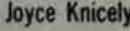

Beth Lindley

Faith Linn

Matt Little

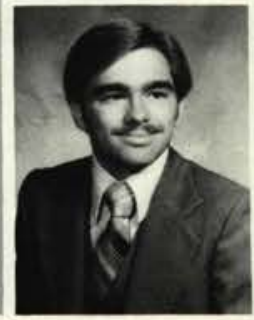

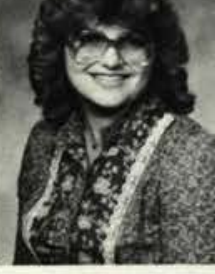

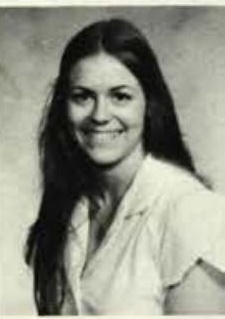



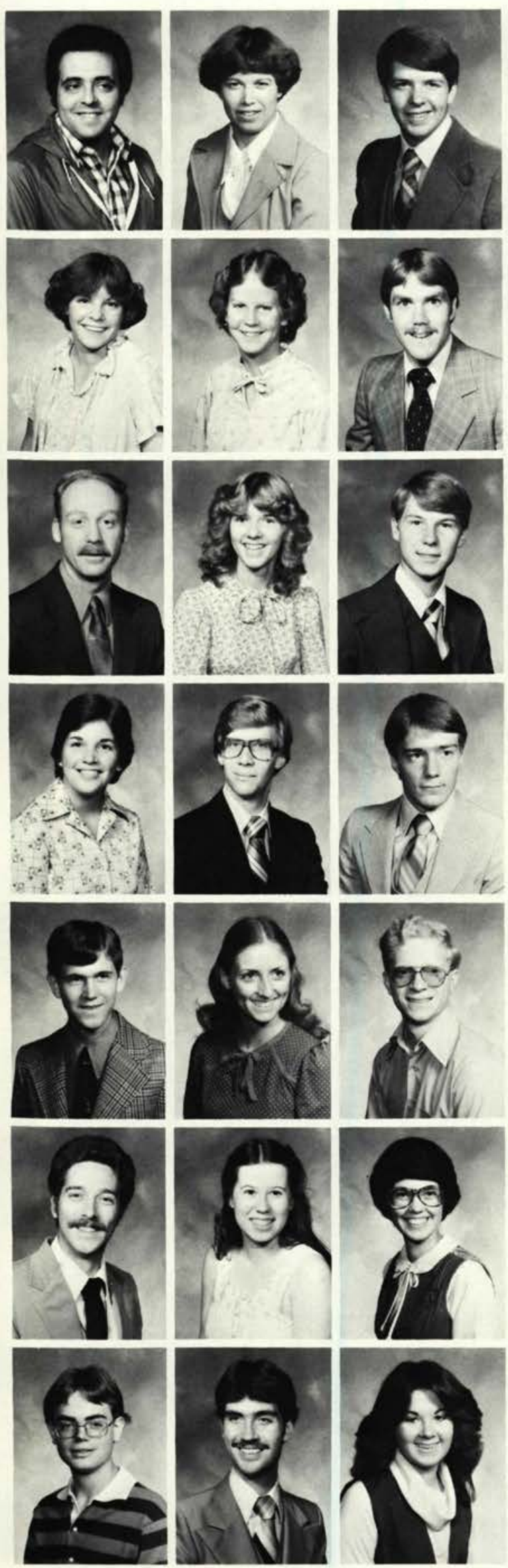

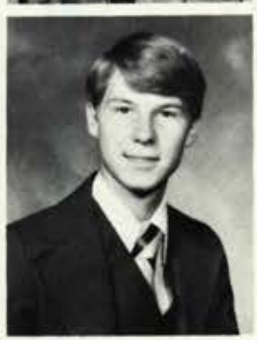

Steve Neatherton

Jennifer Nestor

Curtis Nice

John Nicholas
Elizabeth Niedzialek

John Norlim

Gail Pack Pamela Paddock

Dave Palmer

Patricia Pantzer

Tim Parker

Matthew Parmon

Jeff Parry

Norman Patterson

Jeff Pedneau

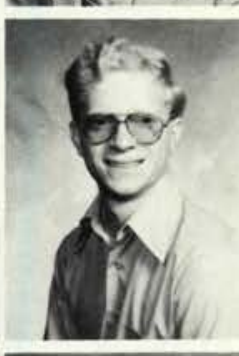

Todd Peterson

Katherine Perry

Charles Phillips
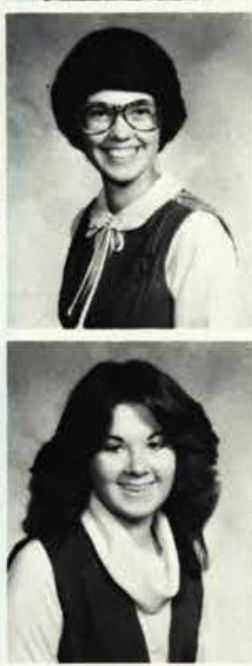

Mark Pitrone

Deitra Plott

Dianna Popa

Cheryl Phillips

Holly Pierce

Mark Pinkerton

Mary Popio
Miriam Pressau
Dan Price

Dave Pryce

Kevin Purdin

Skip Pyatte

Jenny Raught

Natalie Rawlins

Lori Redmond
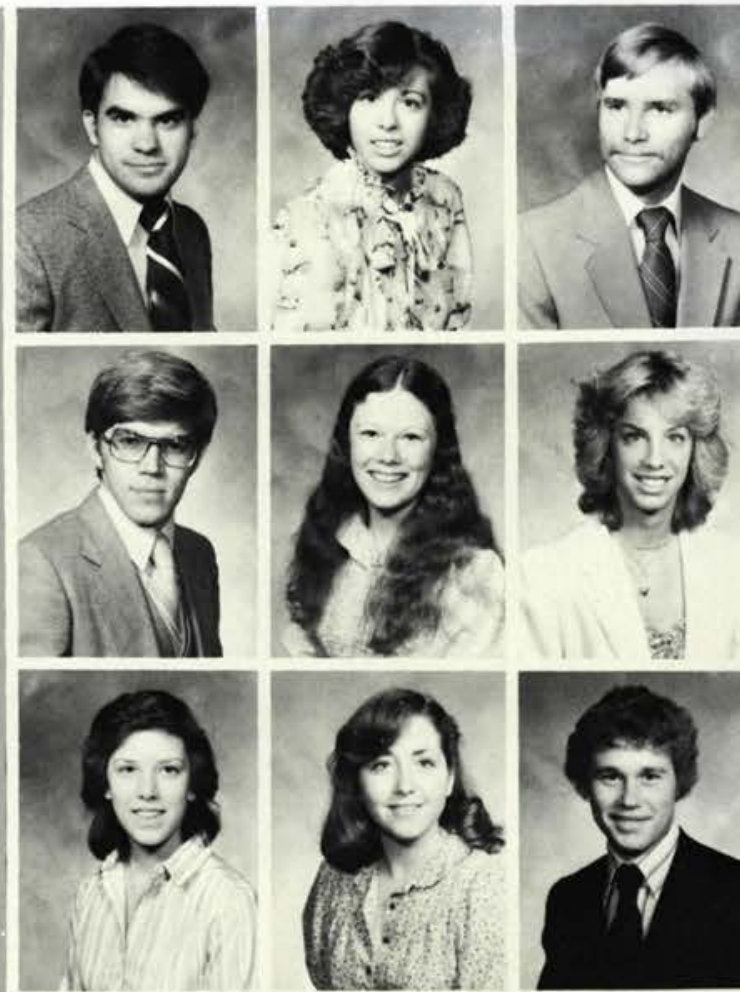
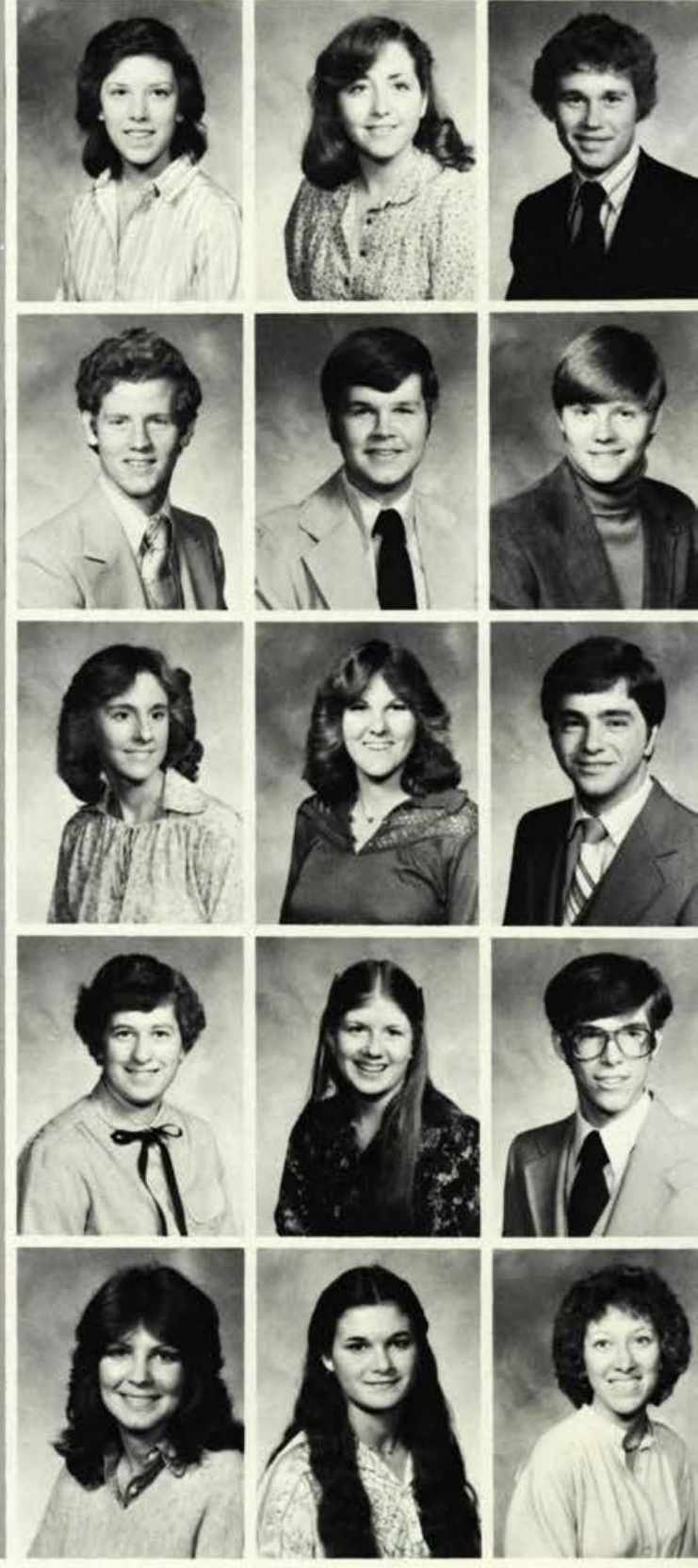
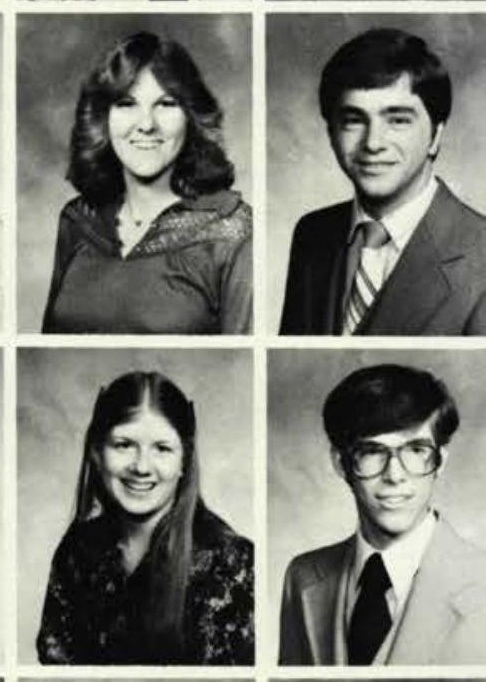

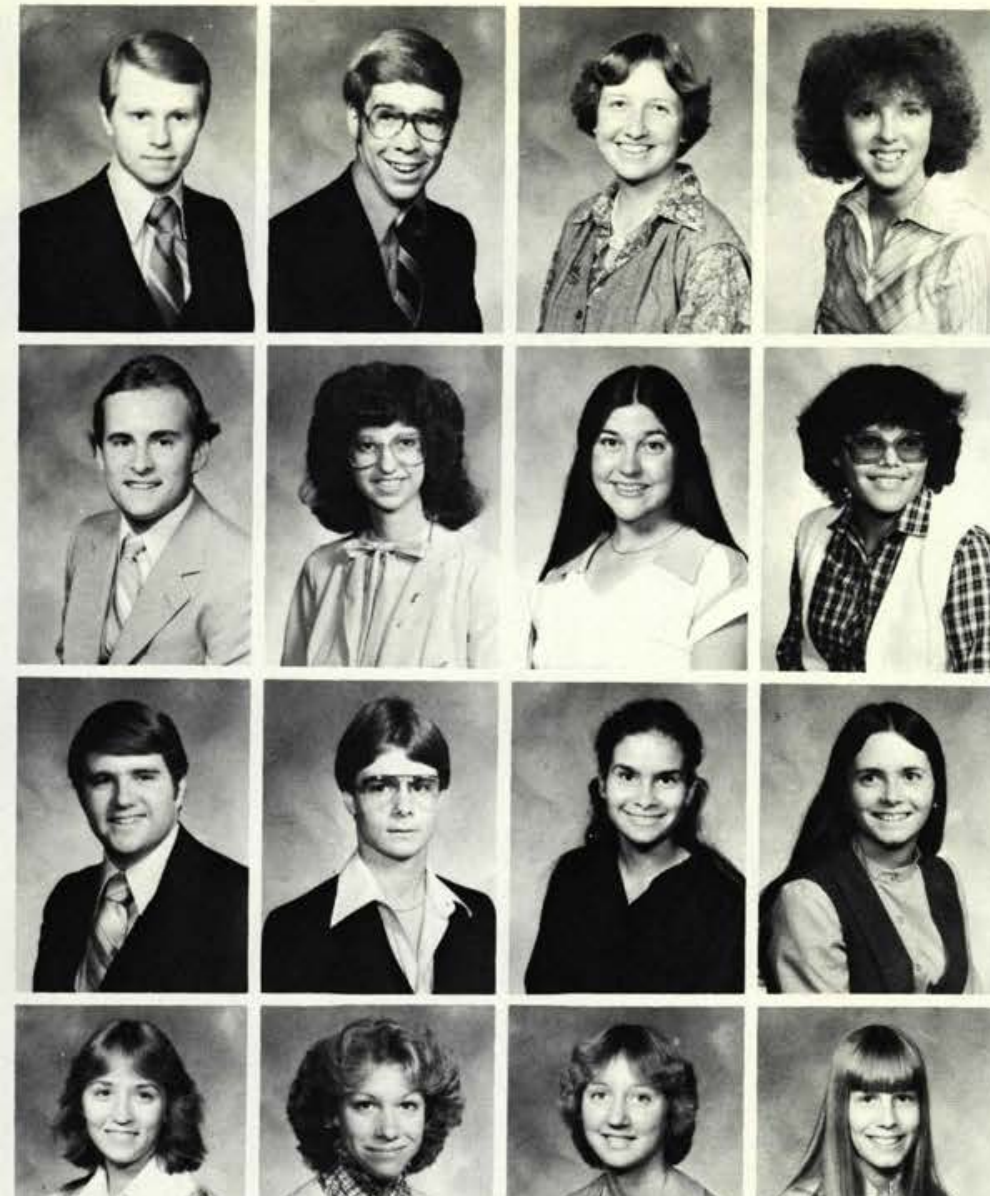

in $\wedge$ a

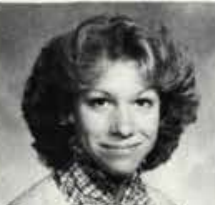

dict
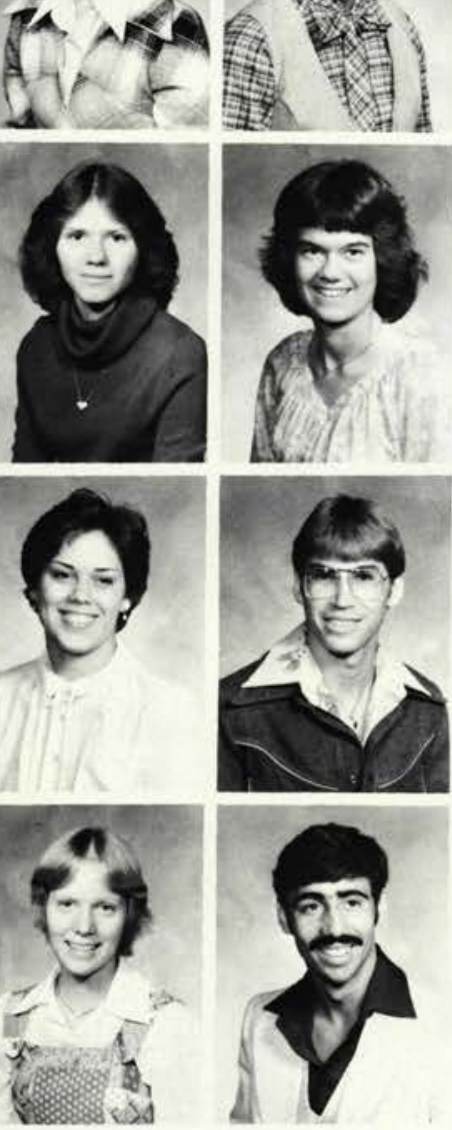
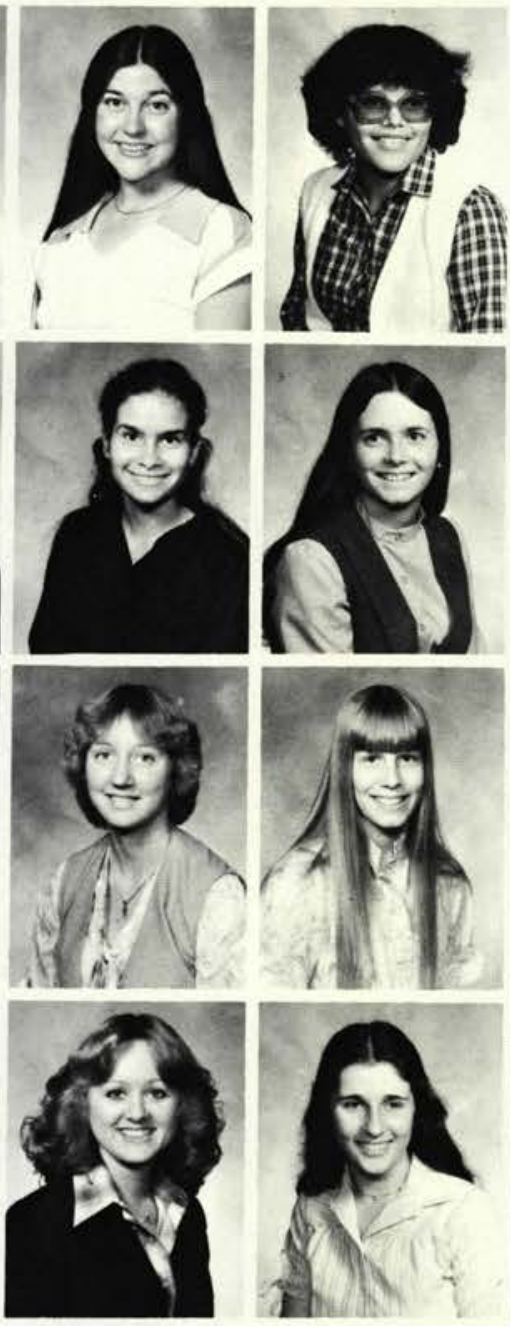

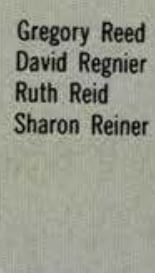

Mark Riley

Karina Ritchie

Lana Robinson

Carmen Rodriguez

Gary Rouster

Carl A. Ruby

Elizabeth Ruiz

Lori Sanford

Karla Sayles

Judith Schad

Joan Schmidt

Terri Schmidt

Cheryl Schuler

Dawn Schulz

Donna Schwartz

Rebecca Schwenk

Sundie Seefried

Jonathan Selden

Paul Sewell

Lynn Sherman

Bobby Shomo

Betty-Lou Silver

June Slonaker
Thomas Seymour

John Richmond

Jeff Rider

Sara Ronk Michele Roop

Jane Sauer Andrea Sayen

David S. Schonfeld

Jim Schreiner

Mark Shearer Sandra Shepherd

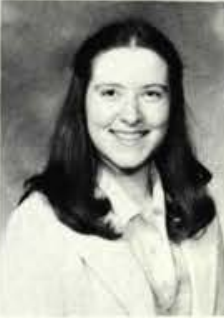

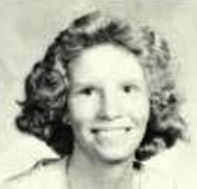

Neil Slonecker Sharon Slover
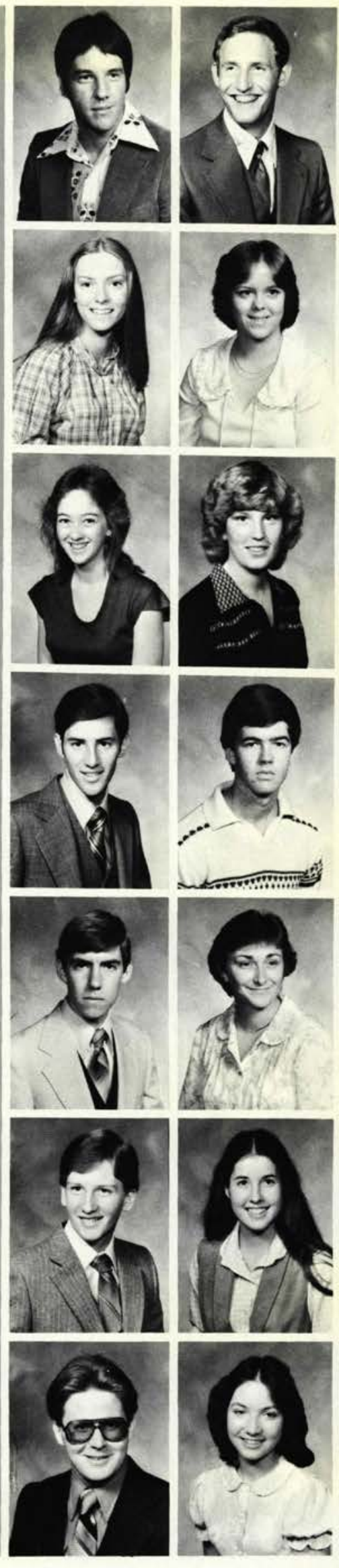

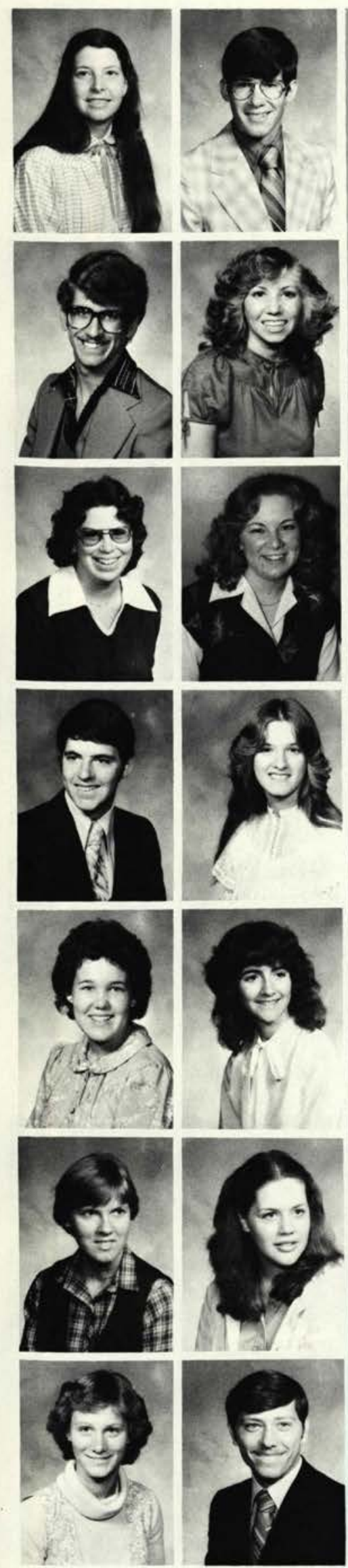

Esther Smith

Jeffery Smith

Laura Smith

Michael Smith

Reve' Smith

Sonny Snell

Dan Snyder

Lorna Snyder

Michele Snyder Melody Southward Lynne Sparks Jack Spears

Judy Spencer

Marsha Spencer

Brad Spradlin Anita Sprague Melody Stage Donald Staley

Kevin Starbuck

Connie Stelfox

Sheila Stephenson Dallas Stewart

Kurt Stewart Steve Stewart

Valerie Stone

Tonya Stretch

Mary Stuenzi Steven Stump John Suciu Jeff Summerlin

Pam Swayze

Rachel Swindler

James Tassell

Lori Taylor Arna Terkildsen Brenda Thompson

Jayne Thornton

Scott Tinkham

Ron Titus Janet Trickett David Tupps Kimberley Turner
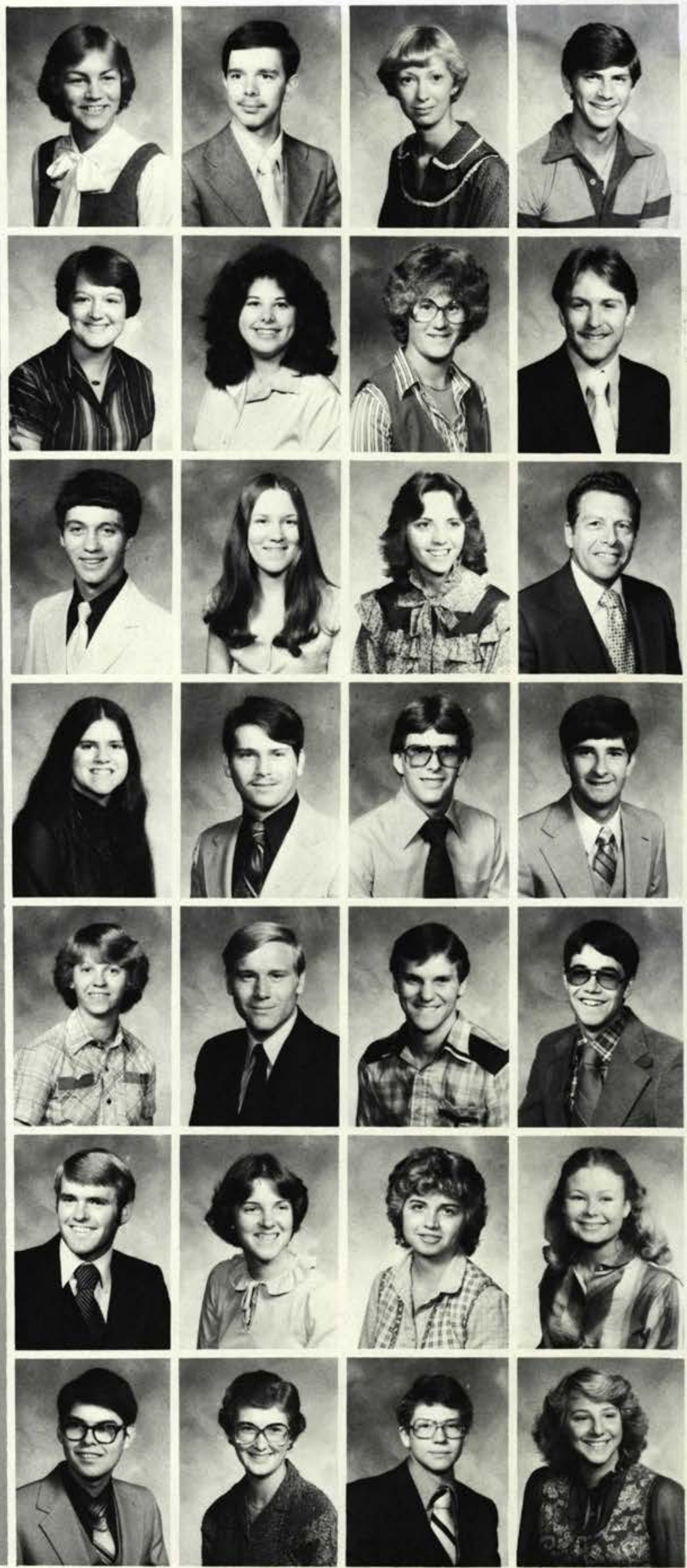

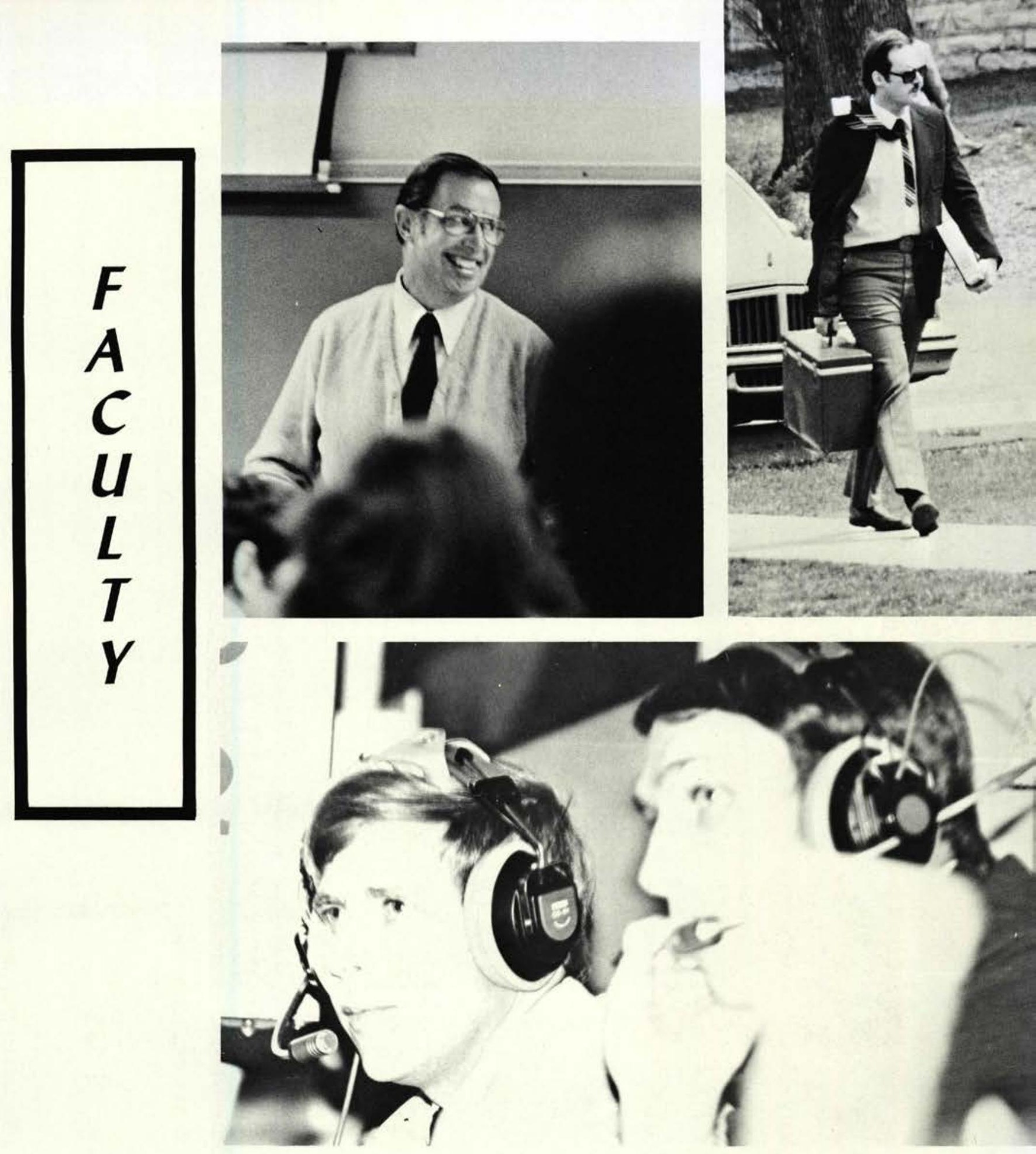
"Peter instructed us to 'grow in grace and in the knowledge of our Lord and Saviour Jesus Christ.' This has been a year of growth in so many ways for our Cedarville College family. I rejoice in our Lord for making this possible for all of us."

1. President Paul Dixon, D.D.

2. Chancellor James T. Jeremiah, D.D., Litt.D.
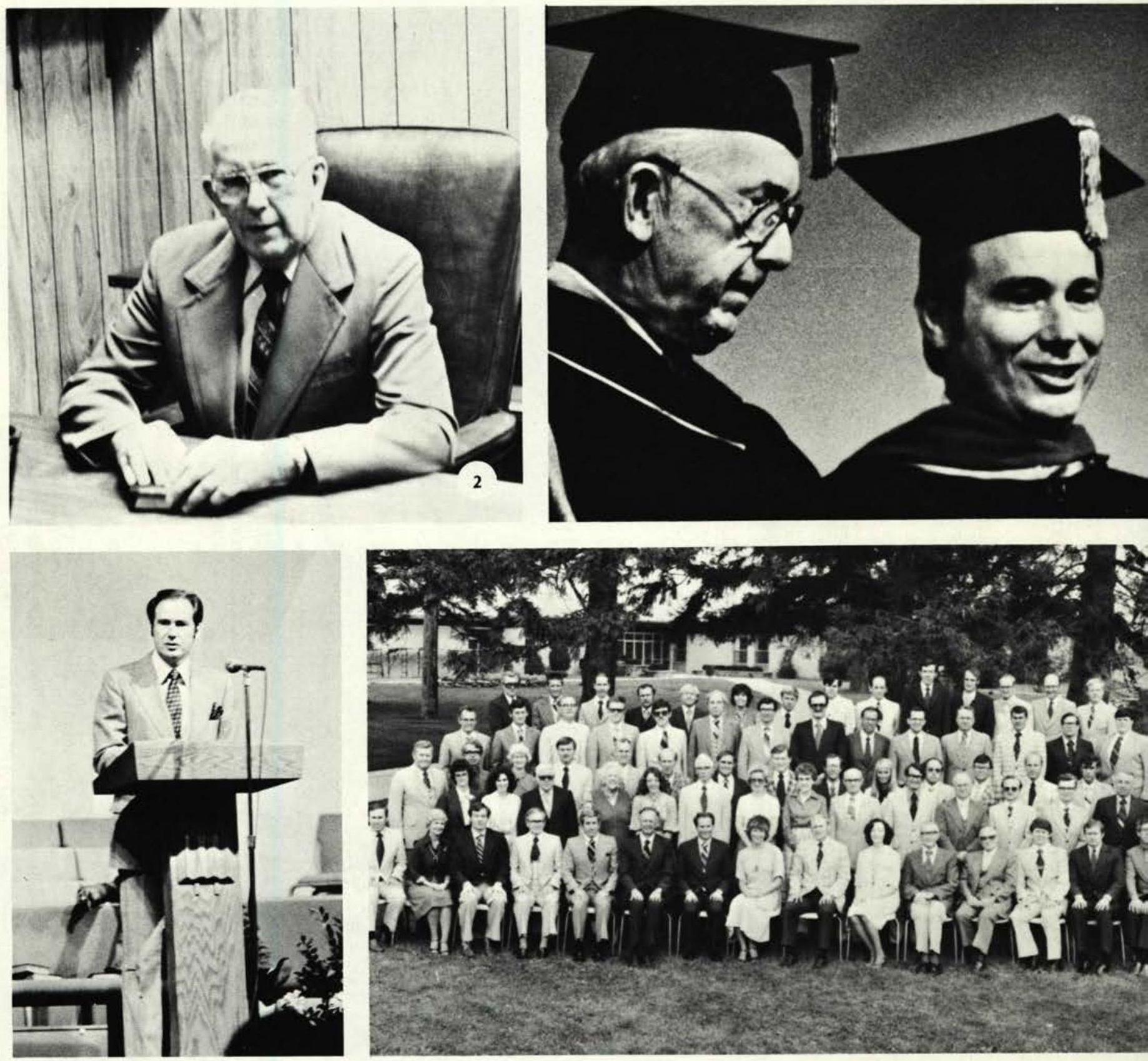

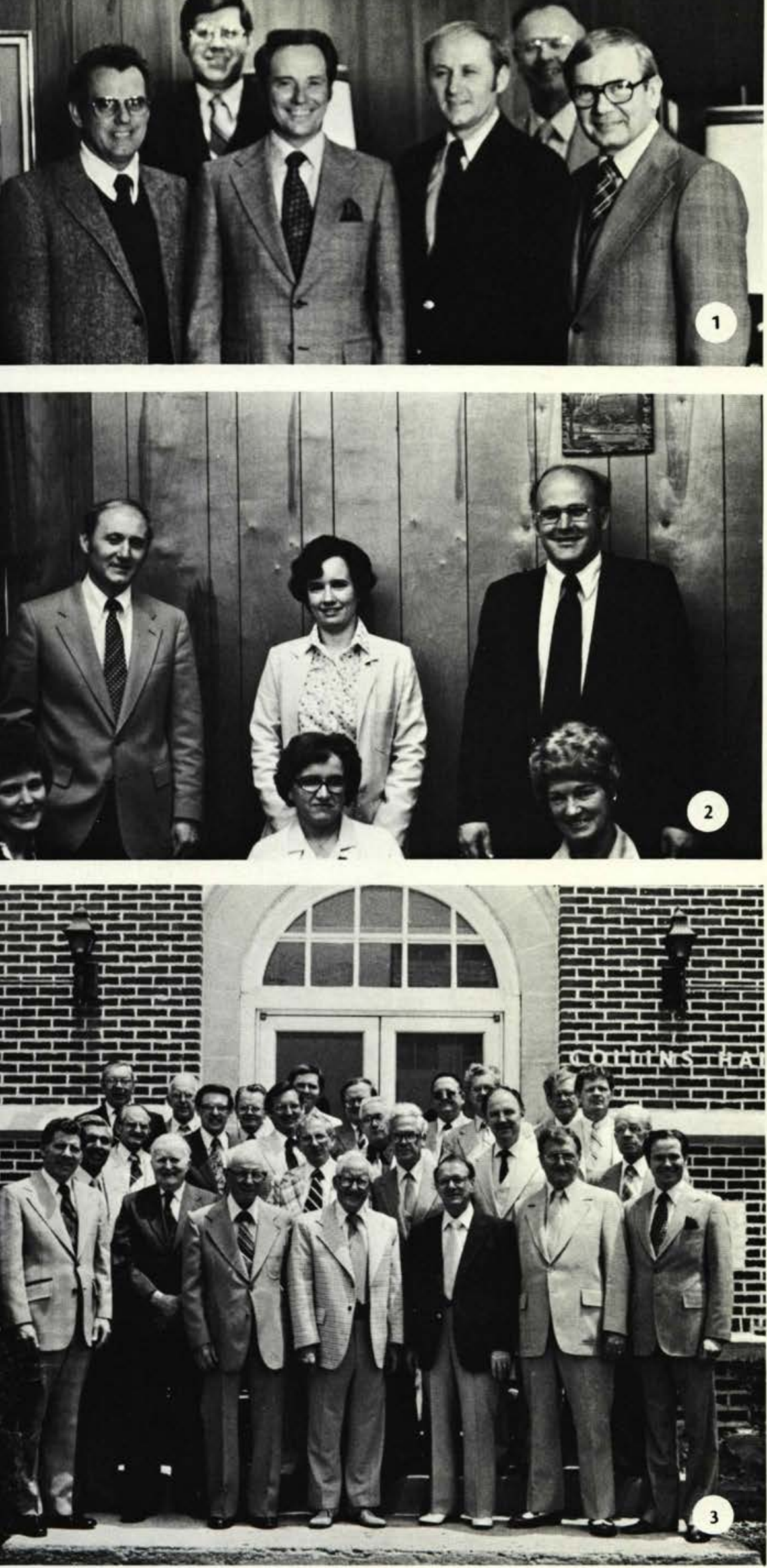

1. ADMINISTRATORS: left to right, front row: Harold Green, Th.D., Director of Christian Service; Paul Dixon, D.D., President; Donald Rickard, M.A., Dean of Students; Kenneth St. Clair, M.S., Business Manager. back row: Charles Ross, B.S., Director of Development; Clifford Johnson, D.Ed., Academic Dean.

\section{DEANS AND SECRETARIES: left to right, sitting:} Peg Rickard, Receptionist; Sherry Coy, Secretary to the Deans; Helen Stephens, Receptionist. standing: Donald Rickard, Dean of Students; Patricia Bates, Dean of Women; Richard Walker, Dean of Men.

3. TRUSTEES: left to right, row one: Jack W. Jacobs, Earl V. Willets, Charles A. Barth, Earl D. Umbaugh, William A. Brock, J. Dale Murphy, Paul Dixon. Row two: Gil Brueckner, Francis Bresson, George F. O'Bryan, Donald Tyler, William B. Patterson. Row three: Paul Vernier, Lawrence G. Fetzer, Roy G. Guenin, Jack Cline, Gerald V. Smelser, J. Don Jennings. Row four: George Englemann, James T. Jeremiah, Robert L. Sumner, Galen, C. Call, Eugence Apple, James B. Carraher, Rudy Bedford.

\section{ACADEMIC DEAN: Clifford Johnson, D.Ed.}

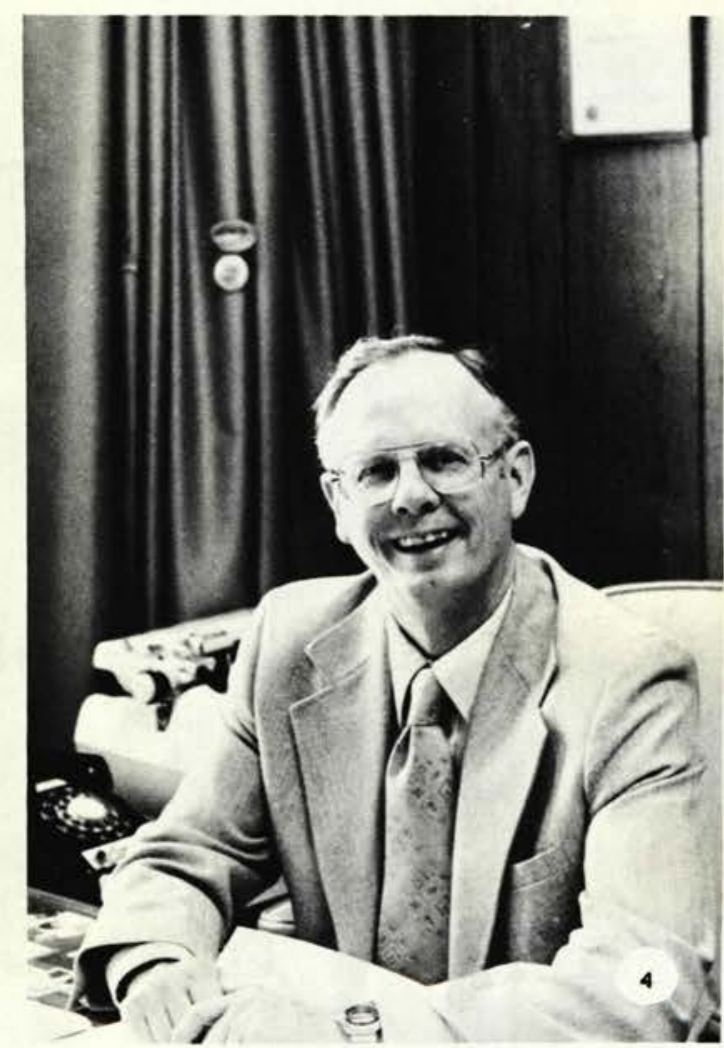




\section{Bible}

Left to right, front row: Robert Gromacki, Th.D., Chairman; Jean Fisher, M.A.; James Grier, Th.M. Back row: Donald Parvin, M. Div.; Richard Durham, S.T.M.; Jack Riggs, Th.D.; Richard Mclntosh, Th.M.
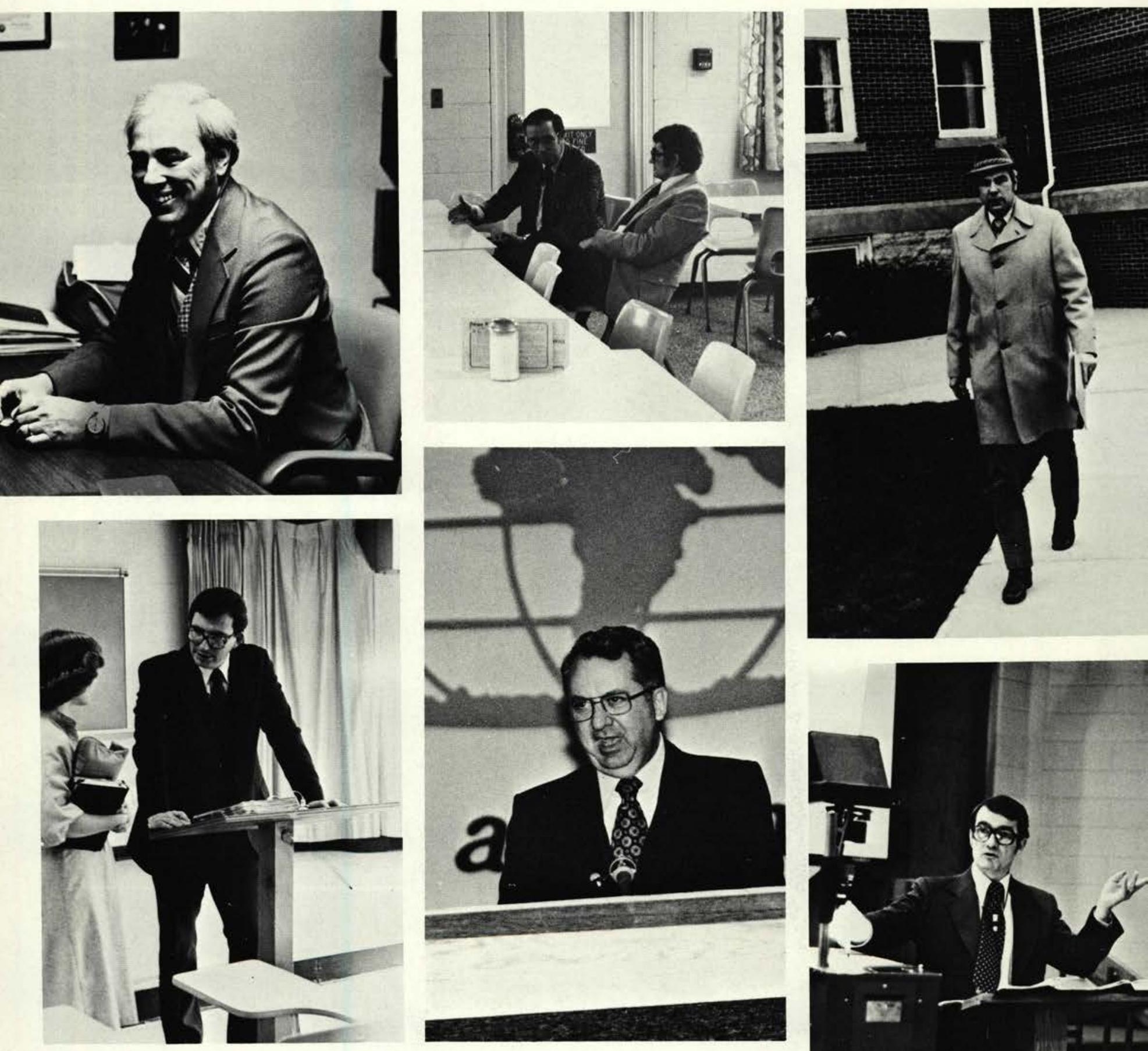

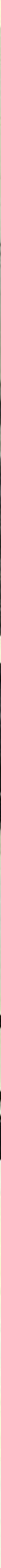

\section{Business}

Left to right: Ronald Walker, B.A.; William Riter, M.S., C.P.A. Chairman; James

Seaman, Ph.D.; Geoffrey Phillips, M. A; Richard Baldwin, M.B.A. 


\section{Education}

left to right, sitting: Sue Baker, M.A.; Helen Hall, M.A.; Ellen Glanville, M.S.; Beverly Monroe, M.A. standing: Dwayne Frank, D.Ed.; James Biddle, Ph.D., Chairman; Merlin Ager, Ph.D.
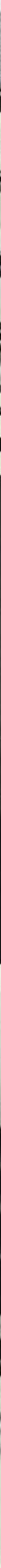

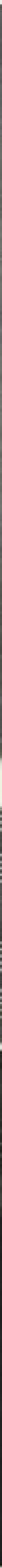

\section{Music}

left to right, front row: Charles Pagnard, M.M.; Phillip McClure, M.M. back row: Charles Ellington, Ph.D.; Michael DiCuirci, M.M.; Karl Stahl, M.A.; David Matson, Ph.D., Chairman; Lyle Anderson, Ph.D.

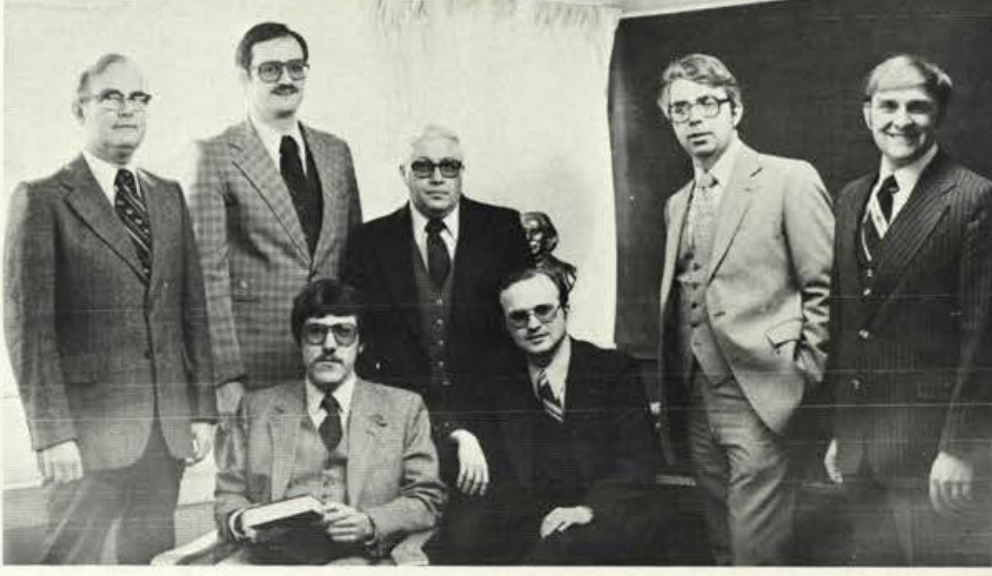



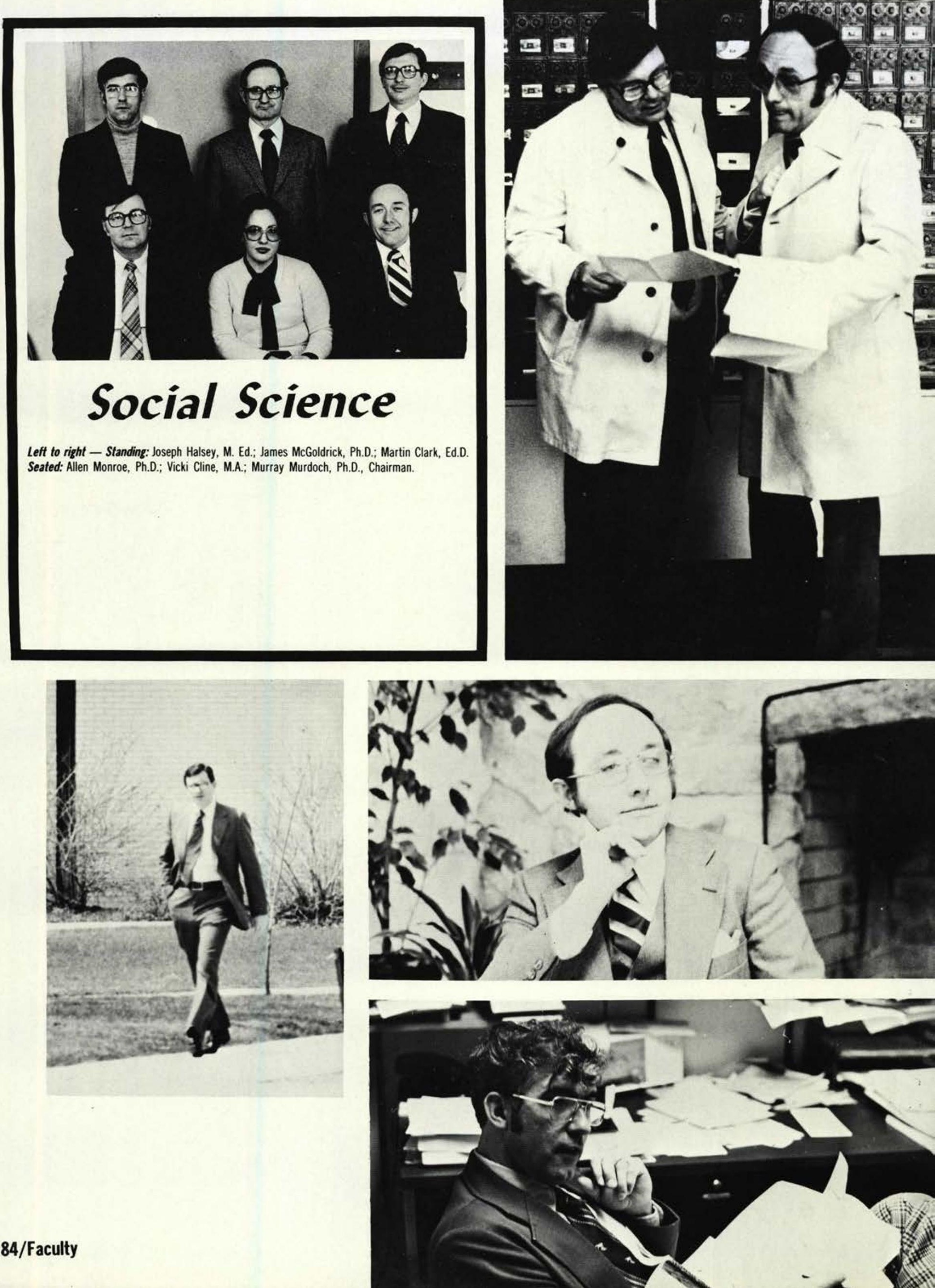
1. RECORDS OFFICE: Barbara McIntosh

2. RECORDS OFFICE: Molly Ross

3. ADMISSIONS: Debby Stephens

4. ADMISSIONS: Dr. Robert White, Registrar and Director of

Admissions

5. ADMISSIONS: Marabeth Elmore

6. PUBLIC RELATIONS: Dave Ormsbee

7. DEVELOPMENT: left to right, front row: Leah Battaglia,

Wilma Conklin, Irene Taylor, Virginia Taylor, Mary Short, Sheryl Theetge. back row: Ron Coriell, Director of Public Relations; Charles Ross, Director of Development; Dianna Conrad; Sue Larson; Henry Phillips; Gary Kuhn, Director of Alumni.

8. LIBRARY: left to right, front row: April Dailey; middle row: Ethel Rayburn; Donna Brock; Linda Divan; back row: Susan Smith; Cathy Ackley. Not shown: Lynn Brock, Director; Steve Brown, Ass't. Director; Anita Hunting: Mary Filson.
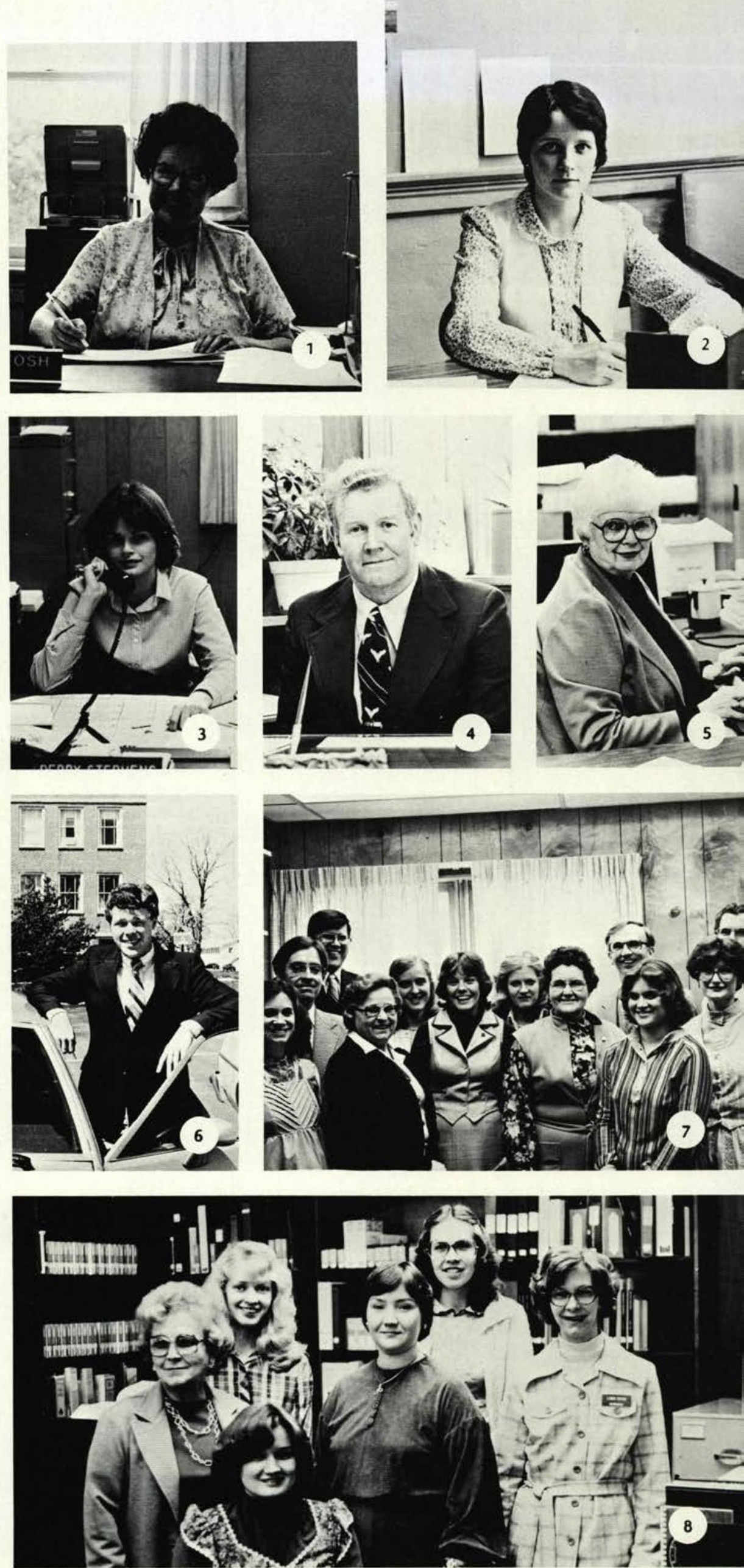
1. PURCHASING: James Hunter

2. STUDENT ACTIVITIES: standing, left to right: Debbie Moody, Dana Treese, Carey Weaver, Criss Wilson, Secretary. sitting: Myron Youngman, Director.

3. FINANCIAL AIDS: left to right: David Gidley, Director; Nova Berkenstock, Assistant Director; Teri Jo McIntosh, Secretary.

4. BUSINESS OFFICE: left to right: Margaret Burrichter, Dorothy Spencer, Nancy Fissel, Eileen Kaufman.
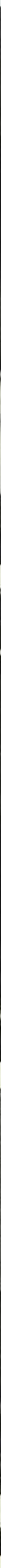

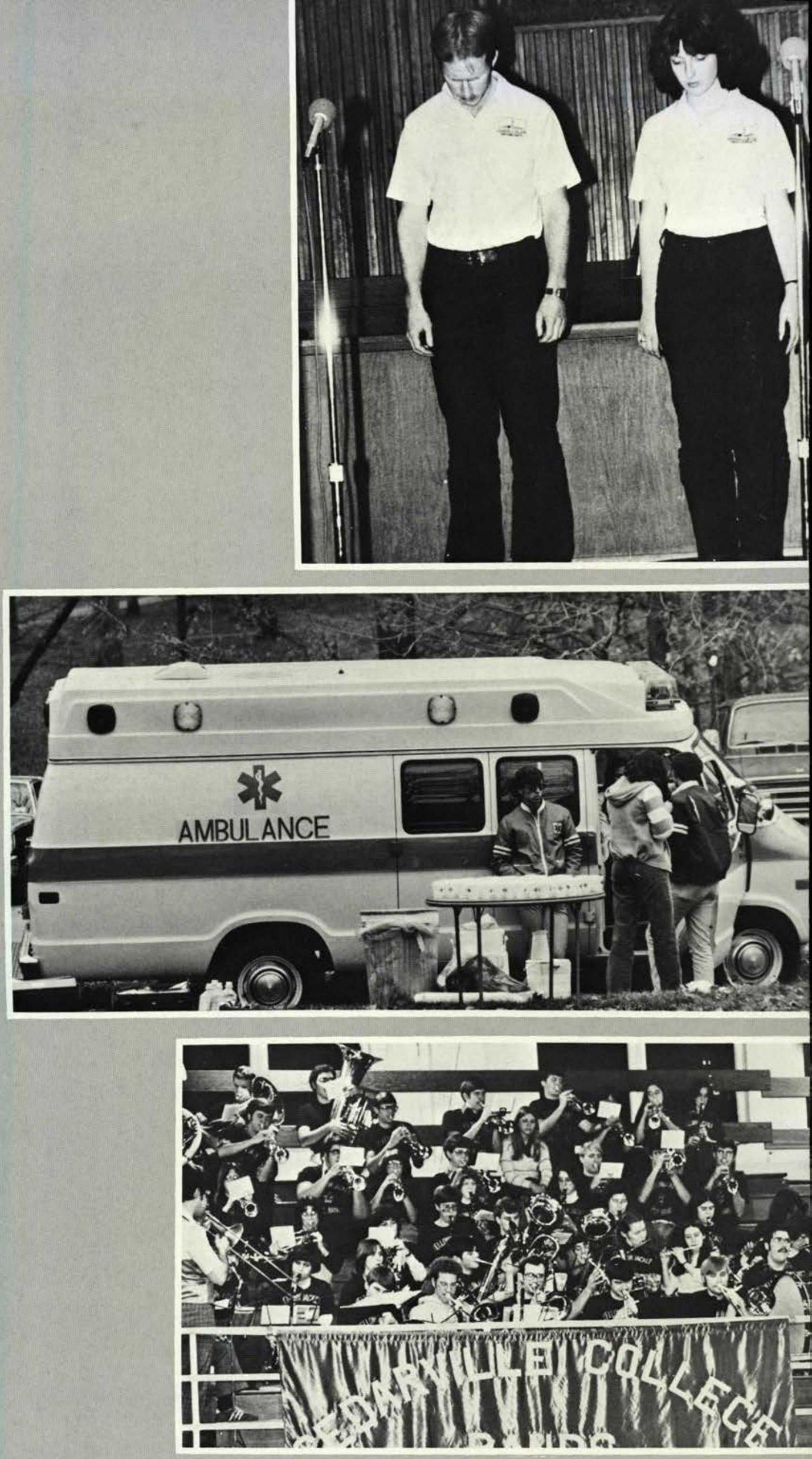


\section{ORGANIZATIONS}
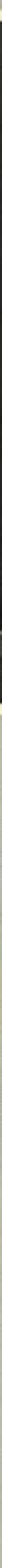


\section{Gamma Chi Alpha Chi \\ Pi Sigma Nu}

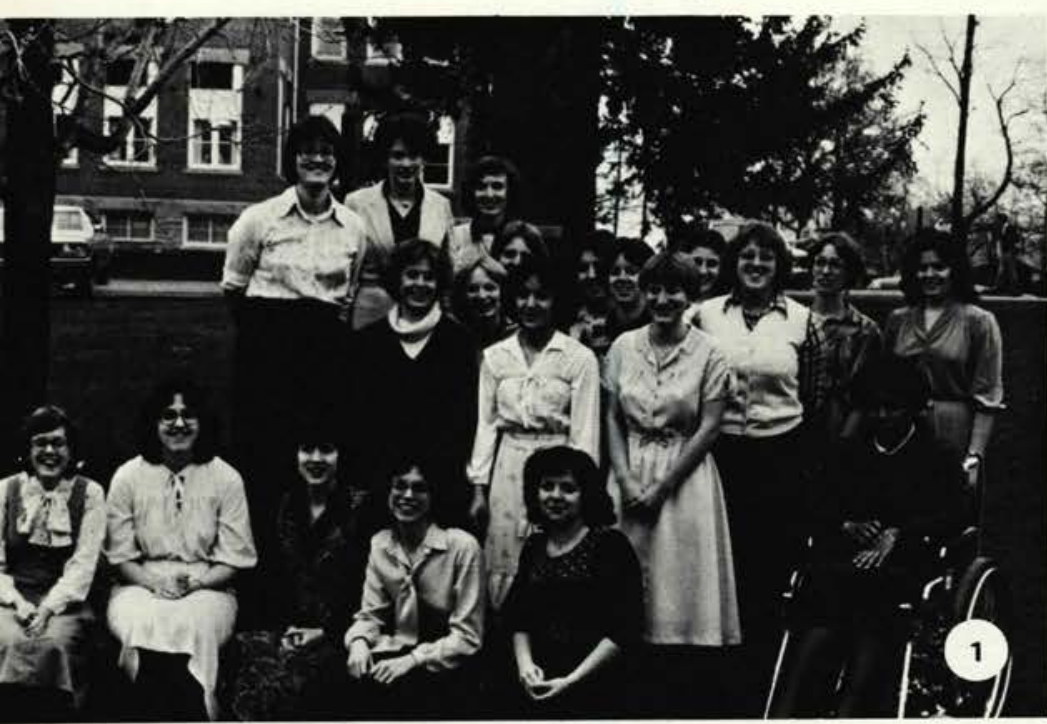

1. Gamma Chi is a society for women that seeks to develop personality, leadership, and poise. Members are: Seated: Sally Webster, Vicki Waterman, Marsha Greve, Julie Kitchen, Mary Howard, Denise Gilmore. Standing: Ruth Hurlburt, Donna McDaniels, Kim

Kensinger, Diane Castellanos, Linda Gawthrop, Anita Zimmerman, Diane Morgan, Rebecca Schwenk, Darlene Tyson, Nancy Price, Cindy Fowler. Top: Merry Damon, Sandi Roth, Mrs. Grosh.

2. Alpha Chi is an honorary society for men that helps to cultivate Christian personality and leadership. Members are: Front: Cory

McDaniel, George Grice, Todd Peterson, Eric Kindig, Jim Matson. Middle: Kevin Harding, Alan Green, Timothy Power, Stefan Pabst, Mark McIntosh. Back: Cal Clark, Raymond Miller, Jeff Fawcett, Steve Keller, Don Rickard, Bob Hanson.

3. Pi Sigma Nu is a campus men's group that teaches through service projects and social activities. Members are: Row 1: Jerry Lantz, Brian Hull, Brian Riggs, Mike Bresson, Steve Lewis. Row 2: Kimber Kauffman, Larry Green, David Lawhead, Jamie Darling. Row 3: Dan Murphy, Al Stewart, Randy Wilson, Dave Merkh, Ron Hobar. Row 4: Dann Green, Eric Mounts, Tom Aitken, Steve Sadowitz. Row 5: Dick Walker, Dan Standridge, Chris Johnson, Dale Shaw, Ed Stewart.

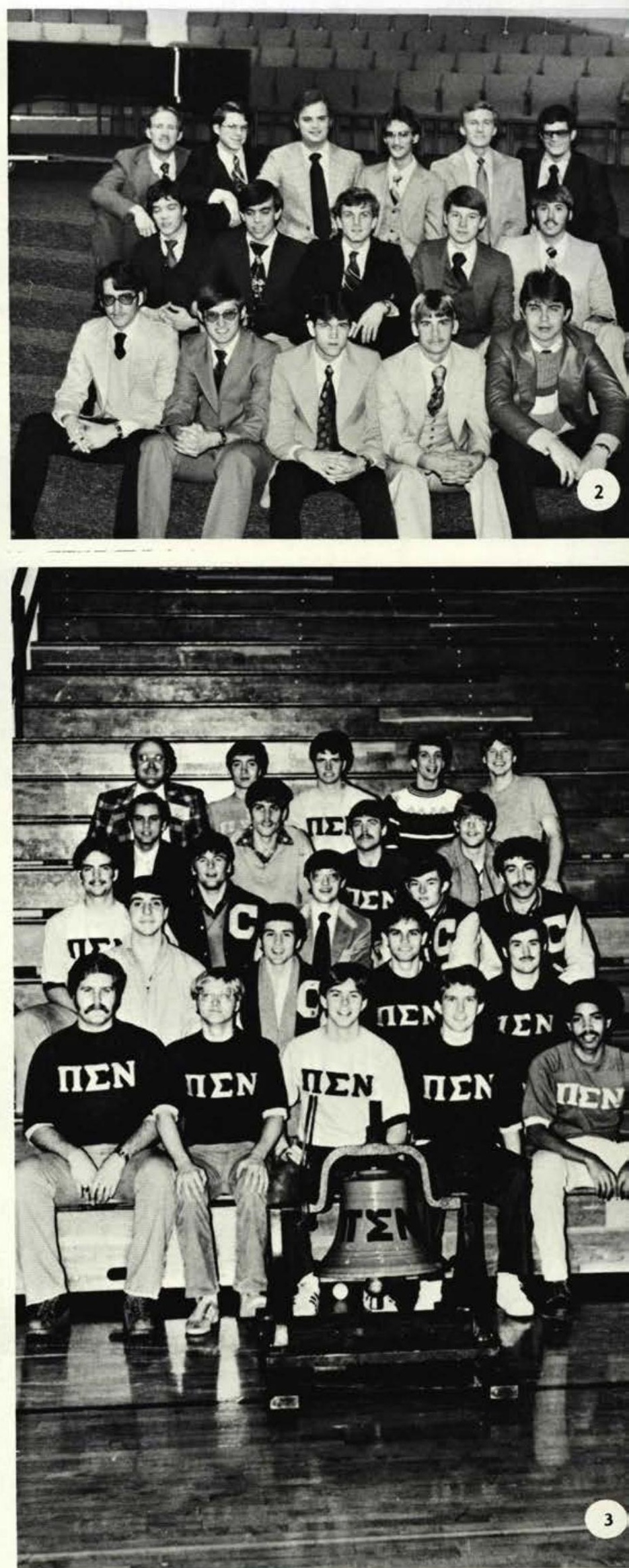




\section{Fellowship Choir}

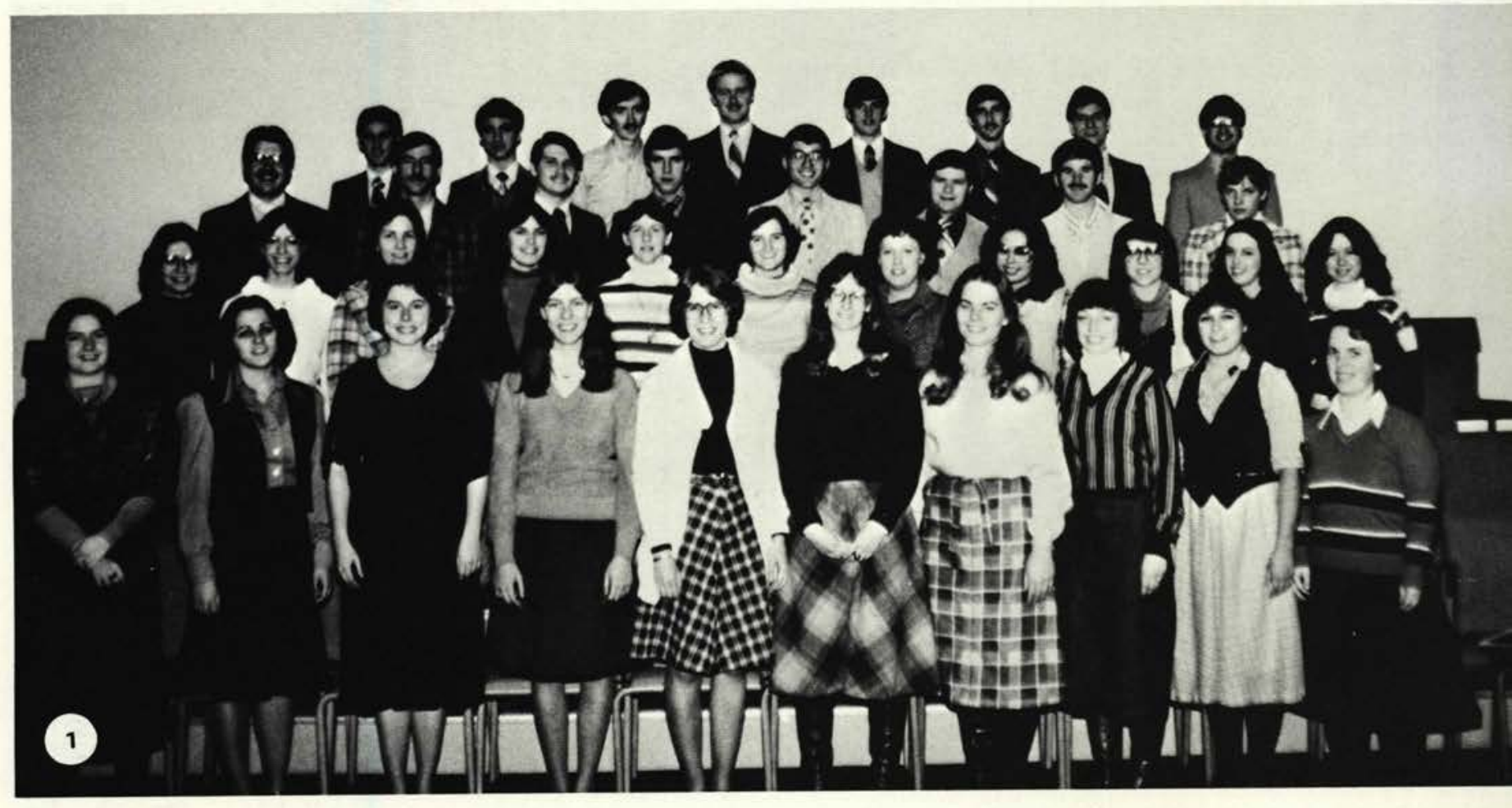

1. The Fellowship Choir provided special music for the Sunday morning worship services at the Chapel. Choir members are: Row 1: Karen Ebersole, Marcy Morton, Carol Elcan, Joyce Blackmer, Ginger Ward, Linda Barker, Tammy Champlin, Patti Aberth, Darcy Morton, Debbie Witt, Row 2: Patty Cornell, Bonnie Flint, Judy Goff, Sally Fullmer, Karen McHugh, Karen Fisher, Patty Shaffer, Lorraine Emery, Nadine Pruitt, Lisa Parsley, Anita Jaquay, Row 3: Rich Conners (director), Dan Murphy, Dallas Stewart, Ron Rost, Chris Yoder, Robert Longnecker, Jim Baldwin, Rick Dustin. Row 4: Dave Schonefeld, Brad Spradlin, Jeff Ward, John Schwendler, Jim Jobson, Mark Norman, Randy Breon, Ron Abbott.

\section{Kingsman}

2. The main ministry of the Kingsman Quartet was to provide edification through music. They performed in Churches, Christian Schools, and Nursing Homes. In December they had the unique opportunity to make a television appearance on the Bob Braun Show with Dr. Dixon. They traveled two to three weekends a quarter, and they made a ten week summer tour of the eastern states. Members include: David Lawhead, Will Brown, Steve Ward, Rusty Burk, and David Moritz (pianist).

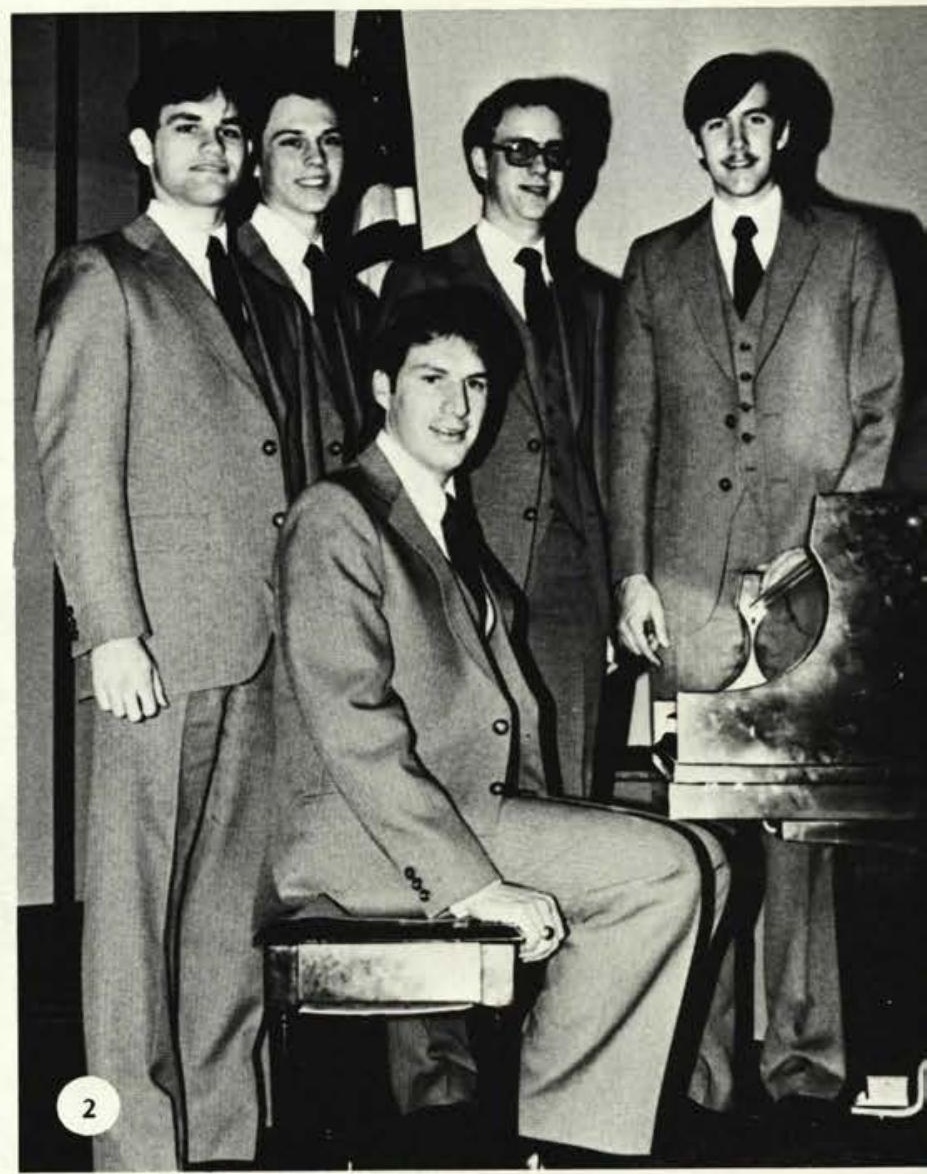




\section{Concert Chorale}

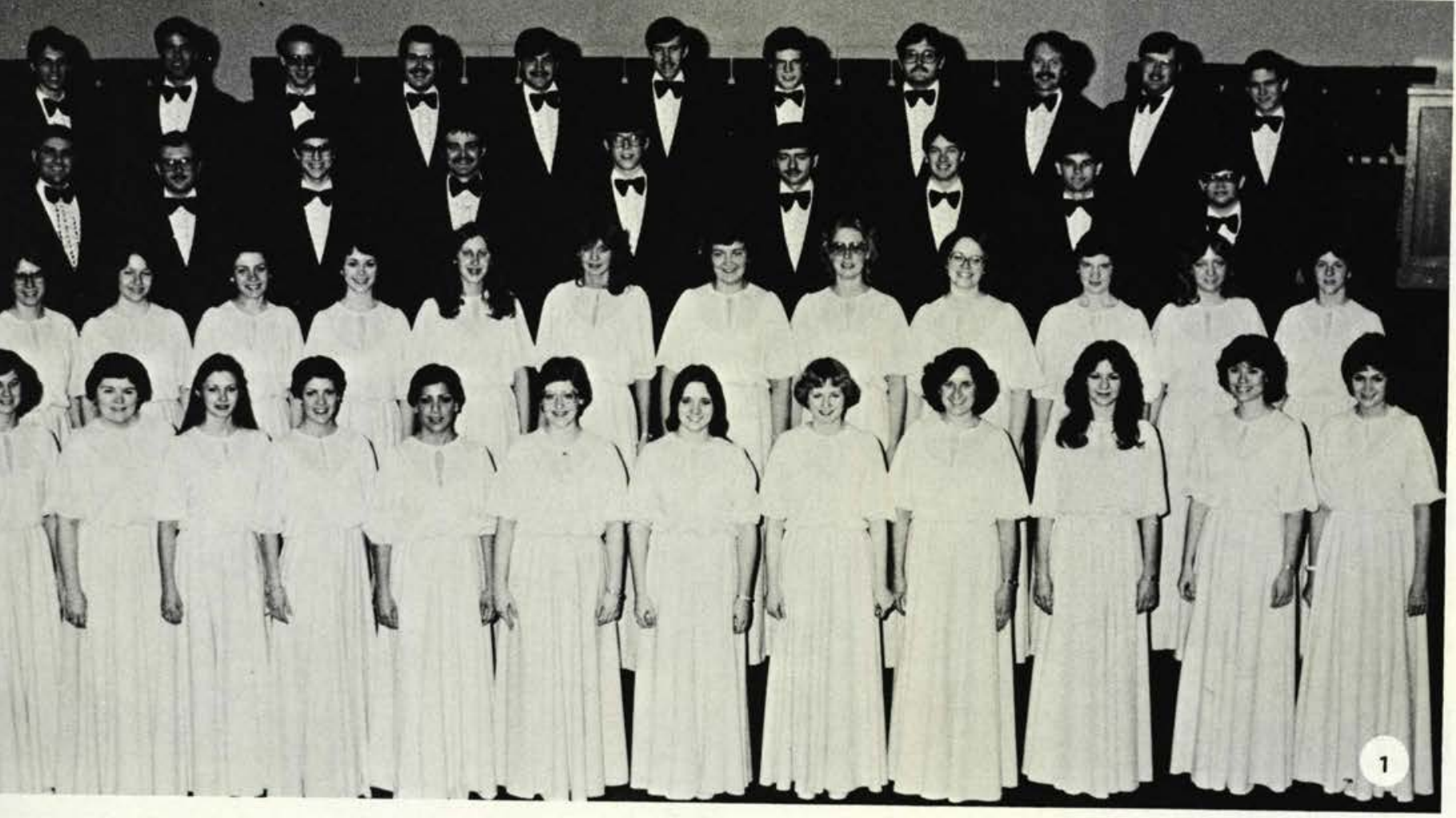

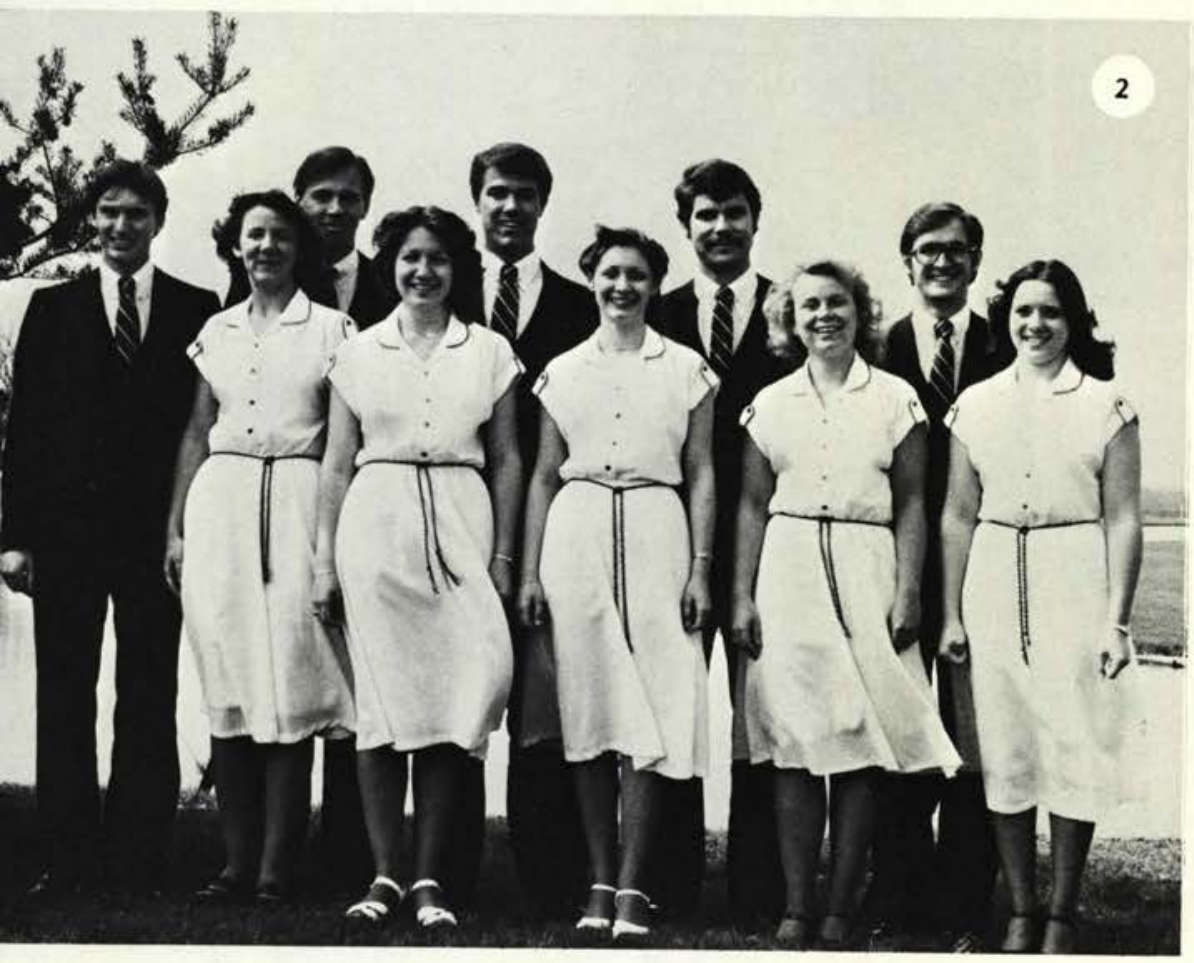

Abundant Life
1. The Concert Chorale provided a singing ministry throughout the year. On weekends they sang in churches throughout the area. Over Spring Break they made a tour of the eastern states. They also provide concerts here on campus. Members were: Row 1: Cindy Ullmer, Joyce Corathers, Debbie Wita, Marcia Mallare, Kathy Mallare, Crystal Eaker, Brenda Wagenschutz, Geri Black, Patty Maloney, Gail Gromacki, Becky Hofstra, Debbie Jackson, Row 2: Ginger Ward, Janis Traphagen, Barb Adams, Jodi Ellington, Tammy Will, Beth Beikert, Nancy Baker, Mariam Will, Karen Kingsbury, Teresa Heeney, Marilynn Reinholdt, Karen McHugh. Row 3: Dr. Anderson, Greg Howe, Byron Major, John Duff, Dan Price, Doug Phillips, Chris Hahn, David Lawhead, Chris Felt. Row 4: Will Brown, Keith Risser, Steve Ward, Rich Connors, Philip Stoner, Rusty Burk, Dave Price, Edd Sturdevant, Bill Hayes, Dave Short, Tim Peterson.

2. The Abundant Life team performed a singing ministry in churches. They traveled throughout the school year on weekends. During the summer they traveled for ten weeks, performing in churches throughout New York and the New Eng. land States. Team members were: Front Row: Karen McHugh, Janis Traphagen, Debbie Wita, Beth Boomgarden, Brenda Wagenschutz. Back Row: Steve Churchill, Marty Loper, Keith Risser, Steve Stange, Ted Whitten. 


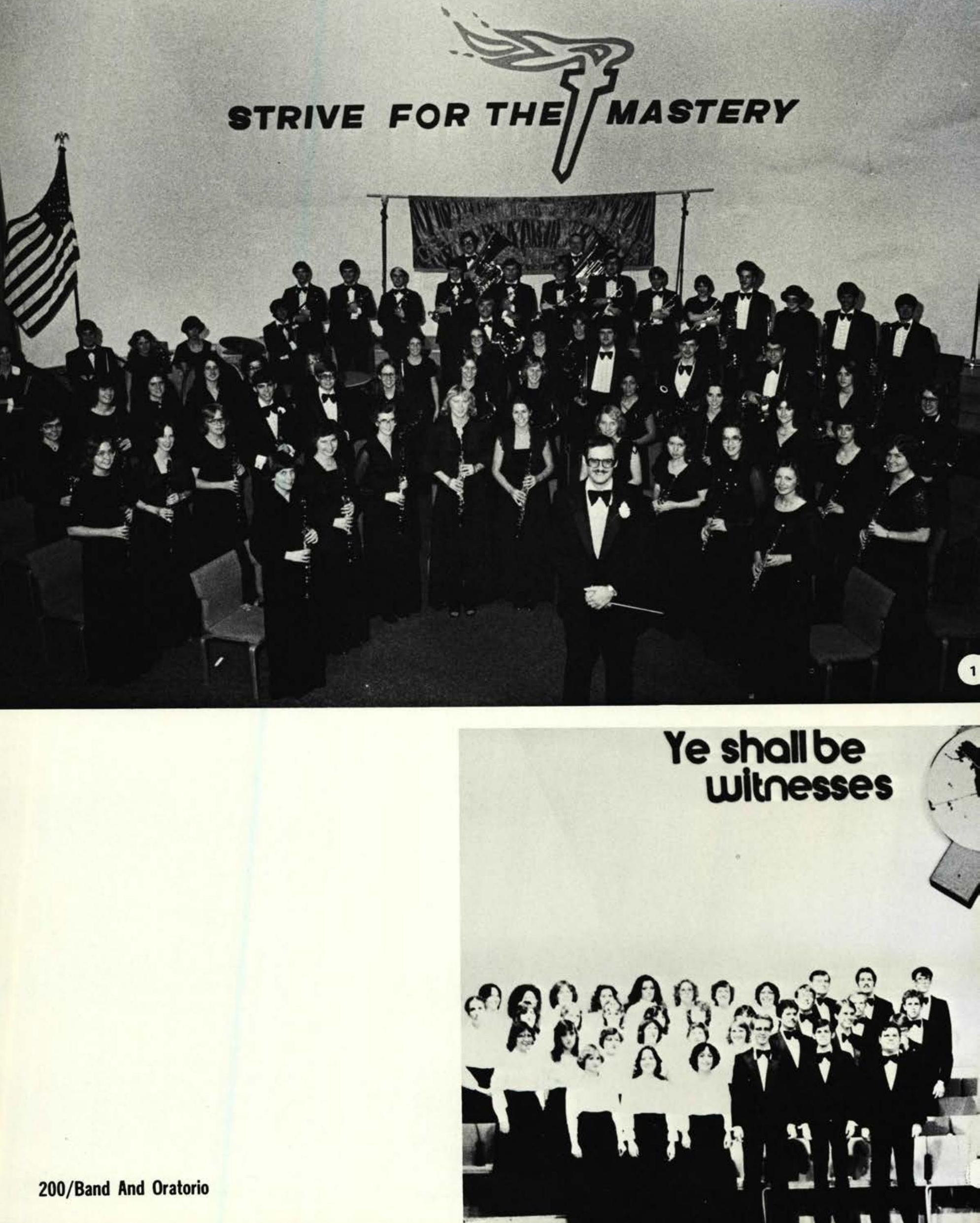




\section{Symphonic Band}

1. Symphonic Band really made a big step forward. For Homecoming they marched in the Homecoming Parade. They traveled to different cities to give concerts, and performed three major home concerts under the direction of their new band director, Mr. DiCuirci. Members were: Center front: Mr. DiCuirci, conductor. Row 1: Cathy Heatly, Cindy Garrison, Janet Trickett, Vicki Butler, Kelly Kandle, Melinda Miller, Edna Hollopeter, Vicki Waterman, Debbie Wita. Row 2: Elaine Swartwood, Jeni Freebourn, Ruth Miller, Ken Woods, Chris Carothers, Kathy Leathers, Laura Smith, Nancy Jo Snook, Kathy Mallare, Melody Stage, Tonya Stretch, Faith Kenoyer, Joyce Fischer. Row 3: Teresa Schaber, Dawn Schulz, Sheila Stephenson, Sandy Ham, Tina Bowersock, Linda Wilson, Marcia Mallare, Tonya Anderson, John Norlin, Lisa Meharry, Gwen Smith, Gary Rouster, Mike Smith, Bob Couch, Karla Sayles, Ginger Ward. Row 4: Cheryl Coates, Doug Cooley, Cozette Wicks, Jenny Nestor, Wayne Anthony, Kevin Harding, Norm Patterson, Barry Hutchins, Curt Nice, Jack Smith, Lloyd Roberts, Daryl Waterman, Rick Dustin, Roseann Branham, Kevin Mulder, Jeanice Arnold, Craig Schuneson, Mark Baugh. Row 5: Eric Henderson, Jim Howard.

\section{Oratorio Chorus}

Oratorio Chorus spent one and a half quarters preparing Elijah, the Oratorio by Felix Mendelssohn, and combined with an orchestra for a Sunday afternoon concert. Members were:

2. Row 1: Geri Black, Brenda Wagenschutz, Diana Castellanos, Steve Ward, Ken Woods, David Murdoch. Row 2: Patty Cornell, Becky Stewart, Tyann Minnick, Karen McHugh, Teresa Heeney, Ruth Ellyn Cook, David Ellington, Will Brown, Chris Felt. Row 3: Sarah Arthur, Tami Behymer, Cheryl Bevington, Gwendelyn Smith, Sheri Hakes, Becky Hofstra, Lurie Morazzano, Chris Yoder, Don Shaffer, D. Randy Wilson. Row 4: Donna Supplee, Debbie Oliver, Karen Kingbury, Debbie Darling, Rachel Wagner, Miriam Will, Ruth Reid, Susan Knicely, Donald A. Parvin, Rich Connors, Dan Price.

3. Row 1: David Lord, Phil Stoner, David Lawhead, Robert Longnecker, Marcia Mallare, Debbie Wita, Rhonda Brugger, Deborah Wellinghoff. Row 2: Jeff Acker, Joel Veldt, David Cox, Donald Parvin, Joyce Carothers, Crystal Eaker, Janis Traphagen, Cynthia Mackenzie. Row 3: George Stephens, Chris Hahn, Doug Phillips, David Moritz, David Price, Ginger Ward, Patty Maloney, Debbie Reid, Rachel A. Scott, Shirley Clark. Row 4: Edd Sturdevant, Arthur Burk, David R. Short, Lois Wing, Barbara Adams, Tamara Will, Rachel Lyons, Ruth Ann Collins, Nancy Gedicks, Deborah Gilbert.

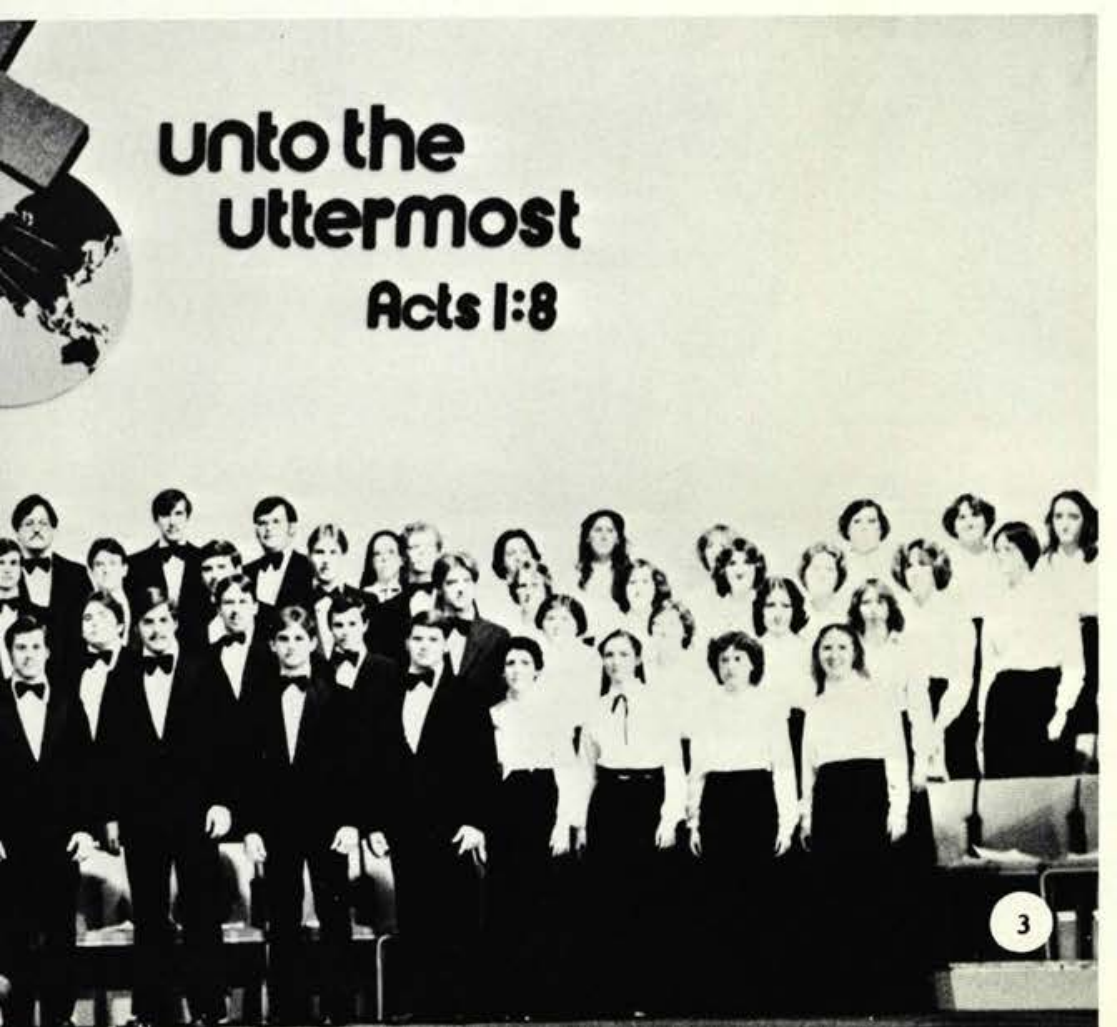



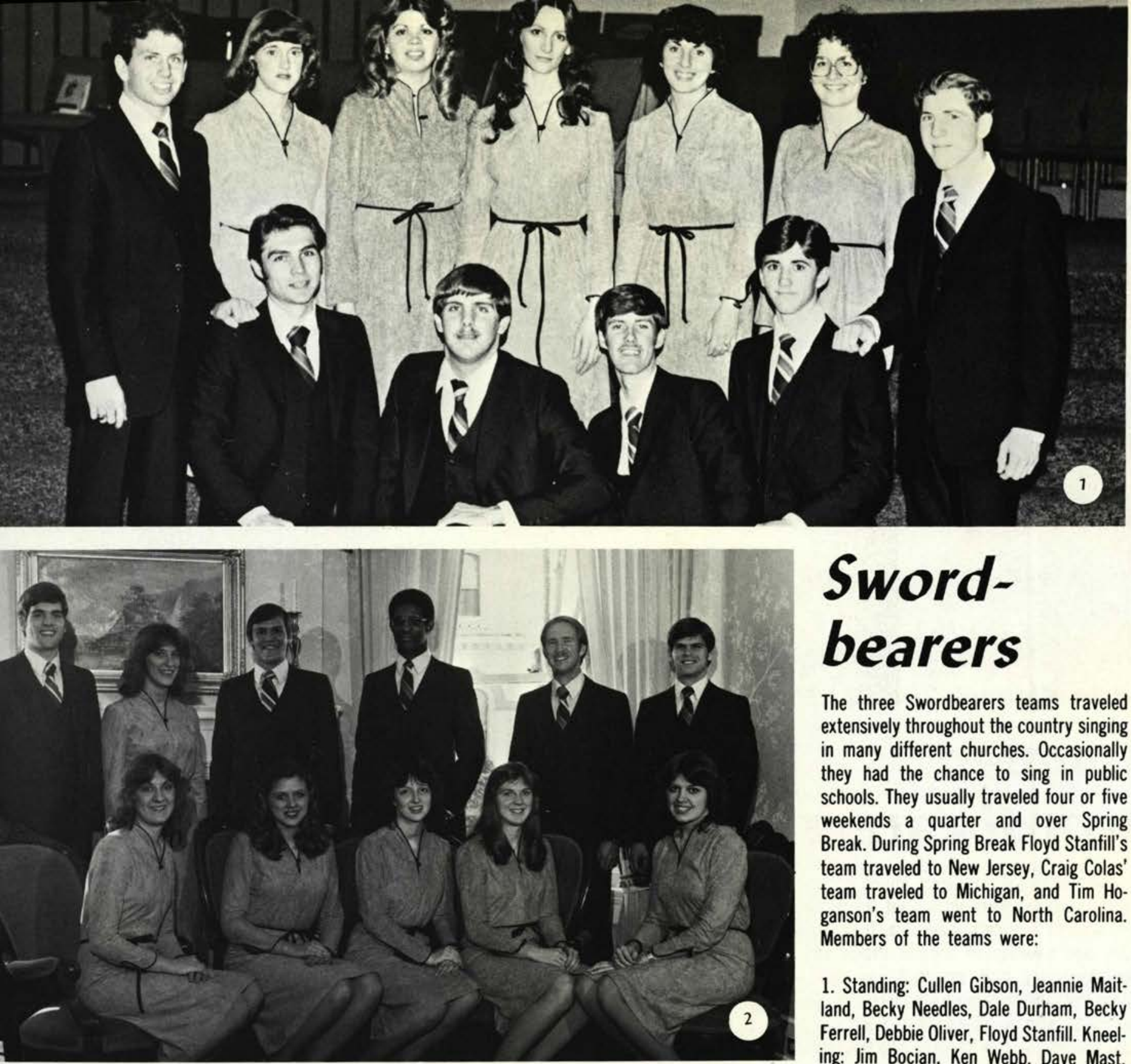

\section{Sword- bearers}

The three Swordbearers teams traveled extensively throughout the country singing in many different churches. Occasionally they had the chance to sing in public schools. They usually traveled four or five weekends a quarter and over Spring Break. During Spring Break Floyd Stanfill's team traveled to New Jersey, Craig Colas' team traveled to Michigan, and Tim Hoganson's team went to North Carolina. Members of the teams were:

1. Standing: Cullen Gibson, Jeannie Maitland, Becky Needles, Dale Durham, Becky Ferrell, Debbie Oliver, Floyd Stanfill. Kneeling: Jim Bocian, Ken Webb, Dave Mast, Kirk Keller.

2. Standing: Roger Michel, Kim Hosack, Craig Colas, Kevin Browne, Calvin Clark, Brian Miller. Sitting: Deborah Reid, Maria McDonald, Diane Crabtree, Linda Grafton, Karen Sewell.

3. Left to Right: Dave Lewis, Rick Matter, Cheryl Herron, Pam Bergandine, Joann Bradshaw, Beth Boomgarden, Kathy Williams, Carl Prokop, Bobby Shomo, Dan Fulmer, Tim Hoganson. 


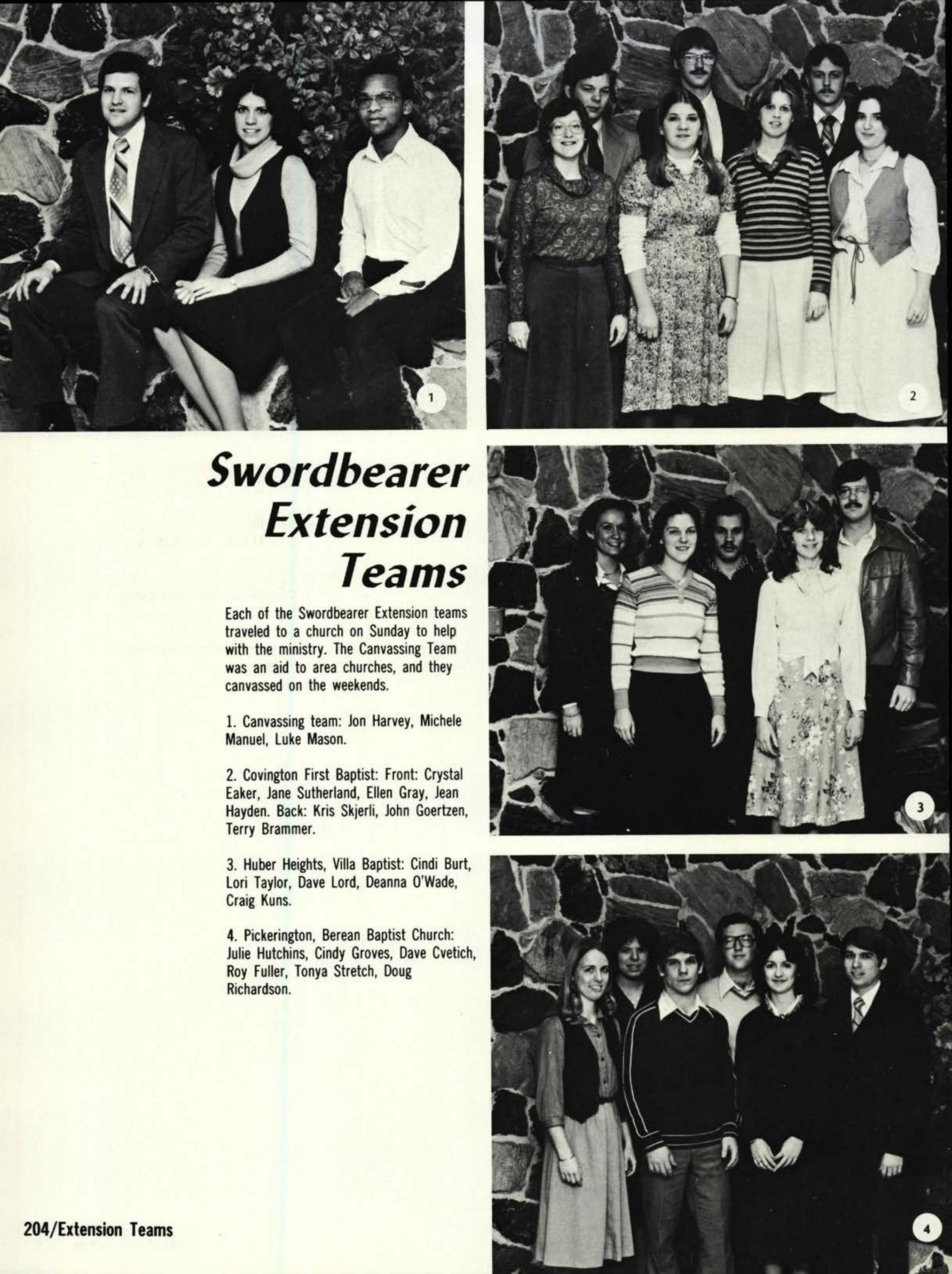




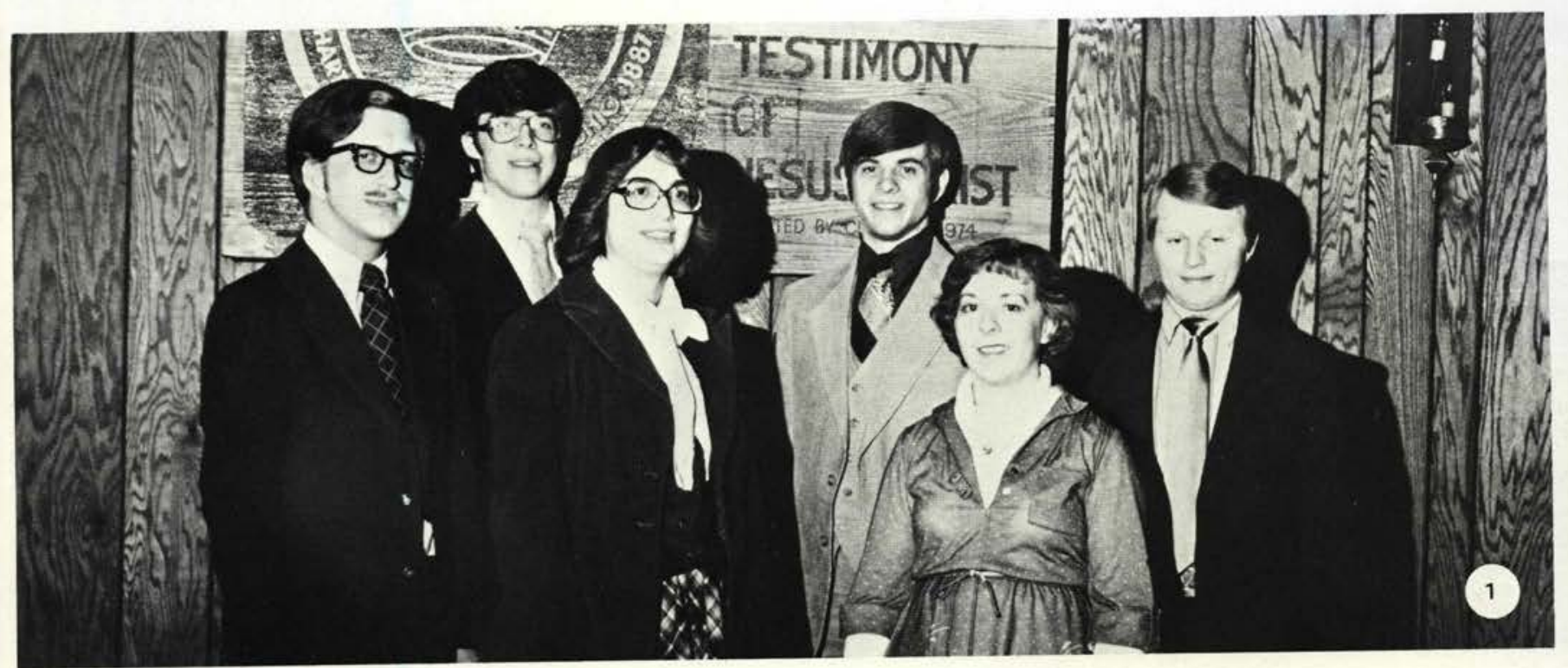

1. Faith Baptist, Commercial Point: Bob King, Dan Price, Sharon Van Etten, George Stephens, Connie Fitch, Greg Reed.

2. Grace Baptist, Mr. Sterling: Mike Smith, Chris Felt, Tom Yater, Kathy Cunningham.

3. Ohmar Park Community, Dayton: Chuck Hickey, Rhonda Coventry, evon Block, Gail Gromacki, Gary Yeager, Belinda Major, Charlie High, Geri Black.
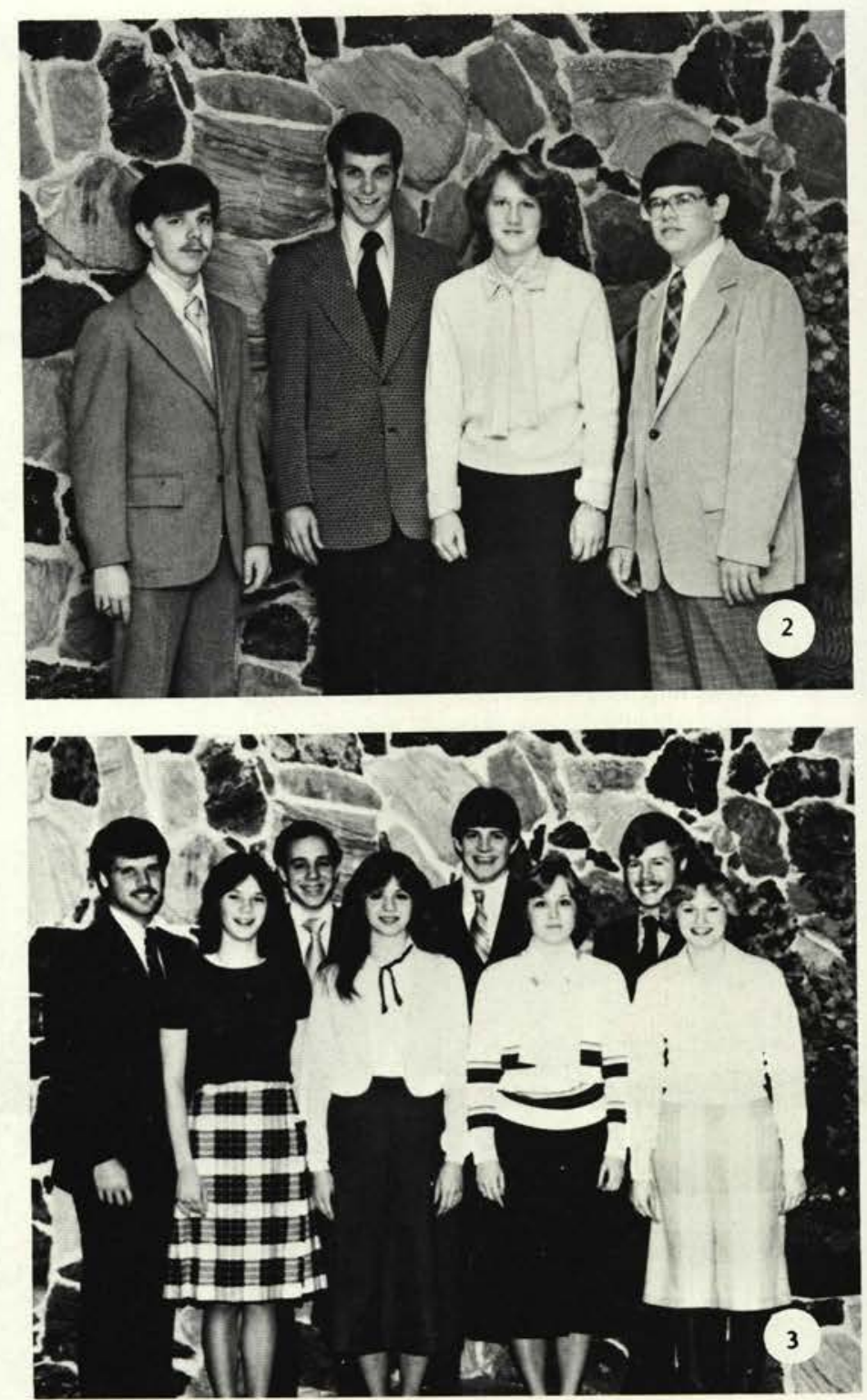


\section{Resthome Workers}

These students ministered in five different resthomes; Greenwood Manor, Knights of Pythias, Oddfellows, Hospitality, and Heathergreen. They held Sunday morning services, sang songs, and performed plays and skits. Individually they spent time visiting with the residents and had many opportunities to share the gospel. Students in picture 6 had a very similar type of ministry at Muellers Residential Center, a home for the mentally retarded.

1. Greenwood Manor members were: Front Row: David Hyslop, Jim Cordes, Barry Hutchins. Back Row: Karen Kingsbury, Joyce Fischer, Kelly Kandle, Becky Stewart, Linda Gawthrop.

2. Knights of Pythias members were: Front Row: Larry Flood, Ken Woods. Back Row: Rick Jones, Charles Radcliff, Bill Hallman, Nate Longnecker, Kay Johnson.

3. Oddfellows members were: Front Row: Paul Perry, Danny Rowe. Standing: Patti Aberth, Nadine Pruitt, Faith Kenoyer, June Slonaker, Julie Schad, Donna Logan, Carol Zehner.
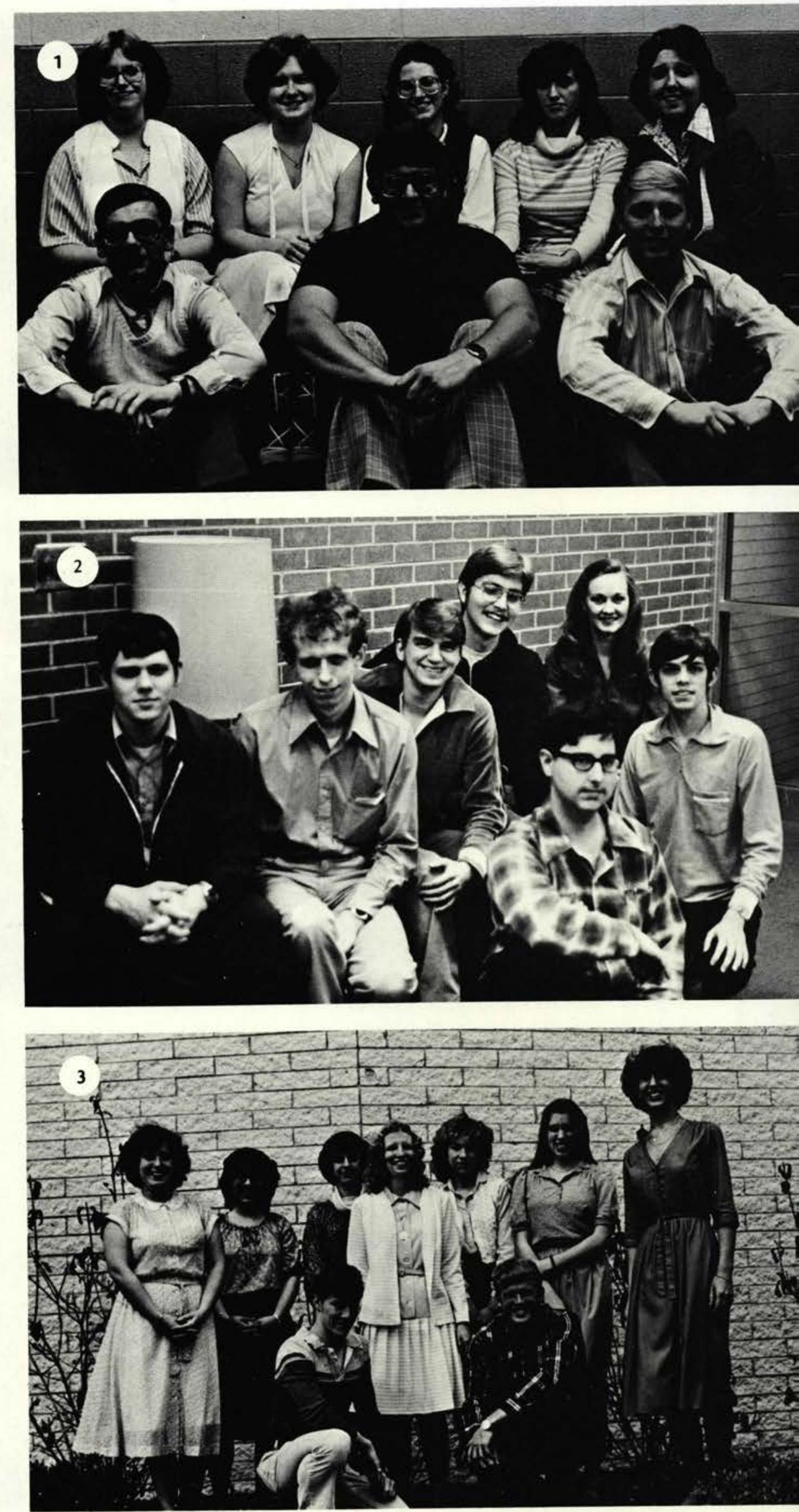


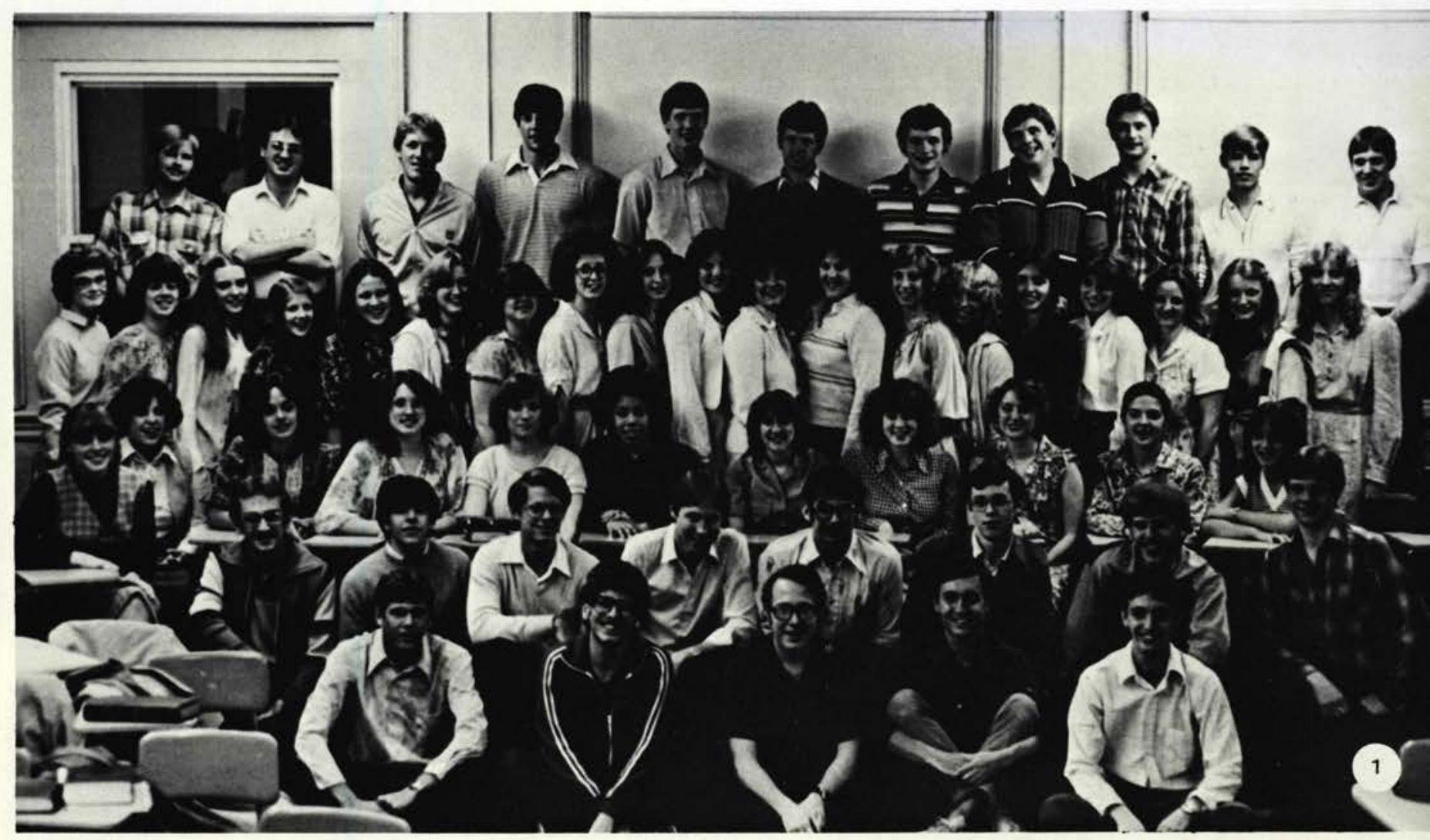

OVCH workers went to the Ohio Veterans' Children's Home to perform a variety of services. The A.M. workers taught Sunday School and helped out during the morning service. The P.M. workers brought Bible lessons, led song times, and played games with the children. Both groups worked to develop personal relationships with the kids in order to get the chance to share the gospel.

1. P.M. workers were: Front Row: Todd Peterson, Dan Snyder, Dave LaRue, Dan Standridge. Second Row: Luann Butler, Tim Messinger, Rob Shirk, Raymond Miller, Randy Wilson, Scott Beight, Mark Osborne, Craig Shuneson, Carl Ruby. Third Row: Susan Wilkinson, Bonnie Beikert, Sandra Ham, Jennifer Jackson, Lori Davis, Brenda Hitchcock, April Duff, Becky Davis, Trudy Tangblade, Joan Weber, Connie Williams, Anita Zimmerman, Sara Ronk, Miriam Pressau, Cyndi Hepburn, Laura Brazelton, Lori Richards, Diane Pasco, Lisa Swinford, Jane Heers, Karen Johnson, Kathi Cook, Michele Feura, Nancy Oscar, Debbie Standridge, Becky Blackburn, Robin Jessup, Sara Fox, Colene Fox. Fourth Row: Jerry Maxey, Ernie Francis, Curt Berger, John Richmond, Greg Greve, Chris Johnson, Gene Wyse, Ken Webb, Brian Olson, Bob Boynton, Gordon Downey.

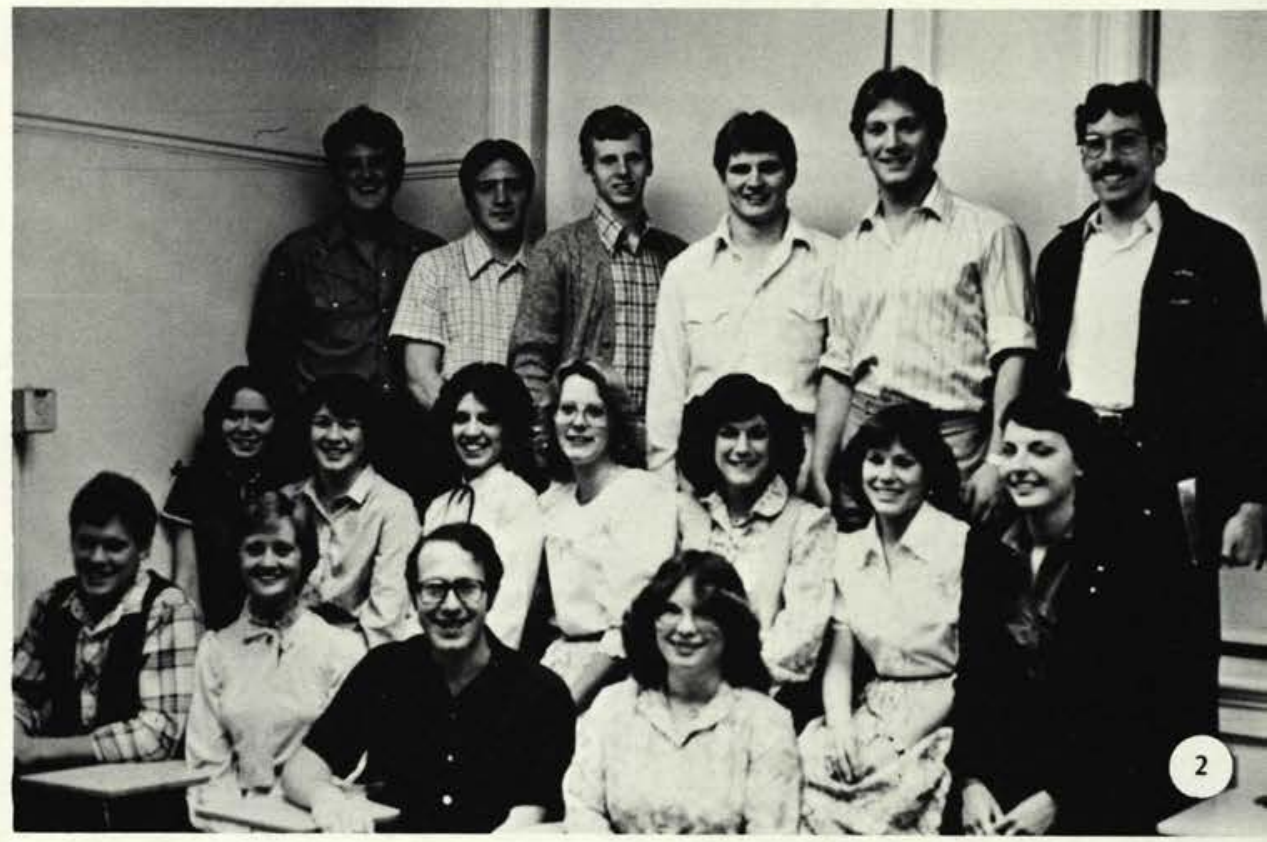

2. A.M. workers were: Front Row: Dave Black, Lenna Barrand, Dave LaRue, Teresa Varhola. Second Row: Debbie Craig, Donna Gall, Michele Manuel, Karen Grant, Ruthie Fareno, Carol Sue Cox, Third Row: Mike Aiken, Matt Parman, Dean Johnson, Phil Hamilton, Brad Reinhart, Dave Johnson.

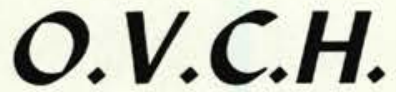




\section{Dayton}

\section{Detention Home,}

\section{Cincinnati}

\section{Rescue Mission,}

Operation Rebirth

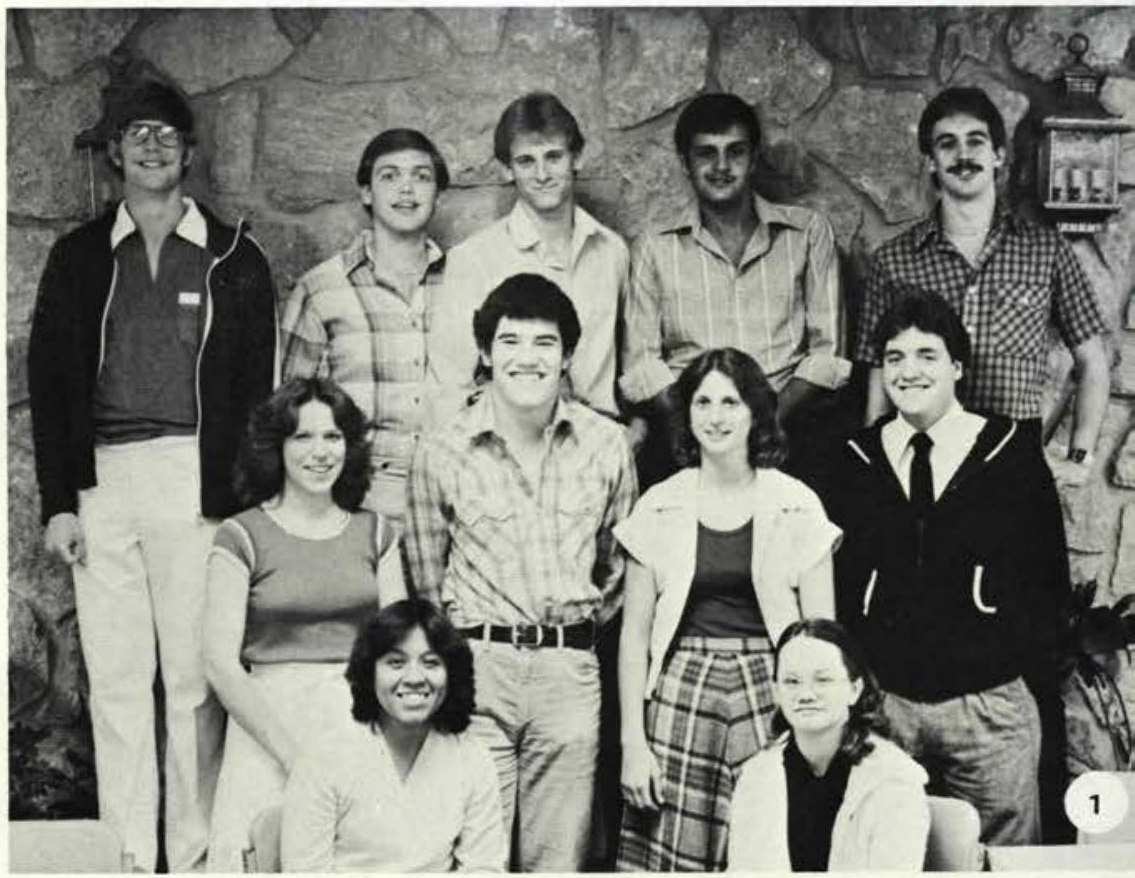

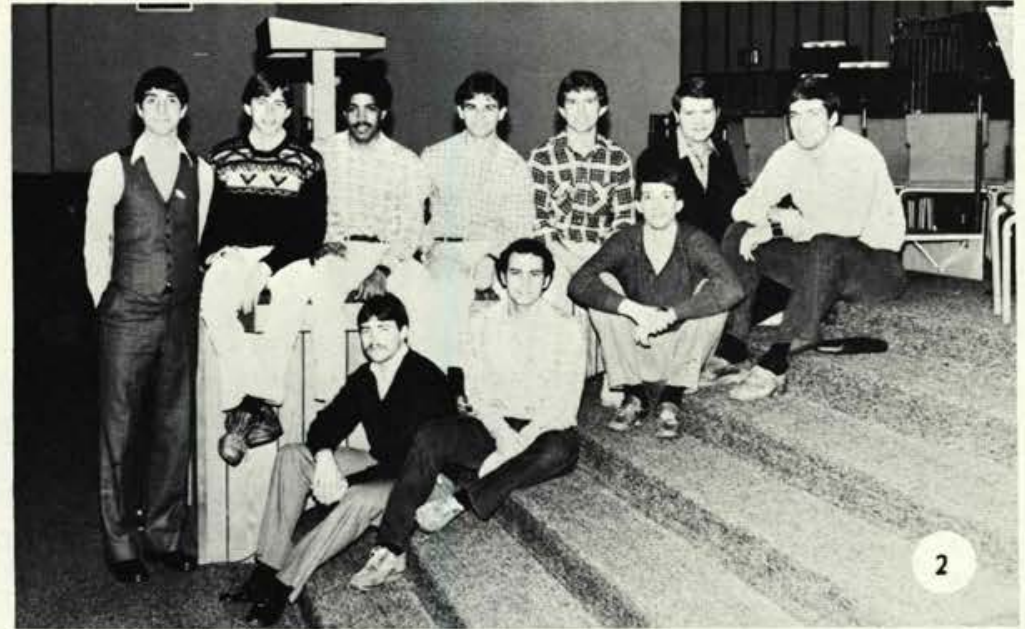

1. Dayton Detention Home workers was a group that worked with kids there that were from the ages of 8 to 17 every Sunday. Members were: Front: Maria Martinez, Donna Winters. Middle: Debbie Meyer, Tom Bailey, Deb Kearsley, Dan Sorber. Back: Steve Sadowitz, David Gabriel, Dick Krewson, Dan Llewellyn, John Mitchell.

2. Cincinnati Rescue Mission workers was a group that went there on the first Sunday of each month to hold services for adult men and women. Members were: Front: Tom Aitken, Dann Green, Dale Shaw, Drew Baker. Back: Kimber Kauffman, Brian Riggs, Steven Lewis, David Lawhead, Mike Bresson, Robert Longnecker.

3. Operation Rebirth was a group of workers that went to the boys' detention home and held services weekly. Members were: Sheri Levin and Neil Slonecker.

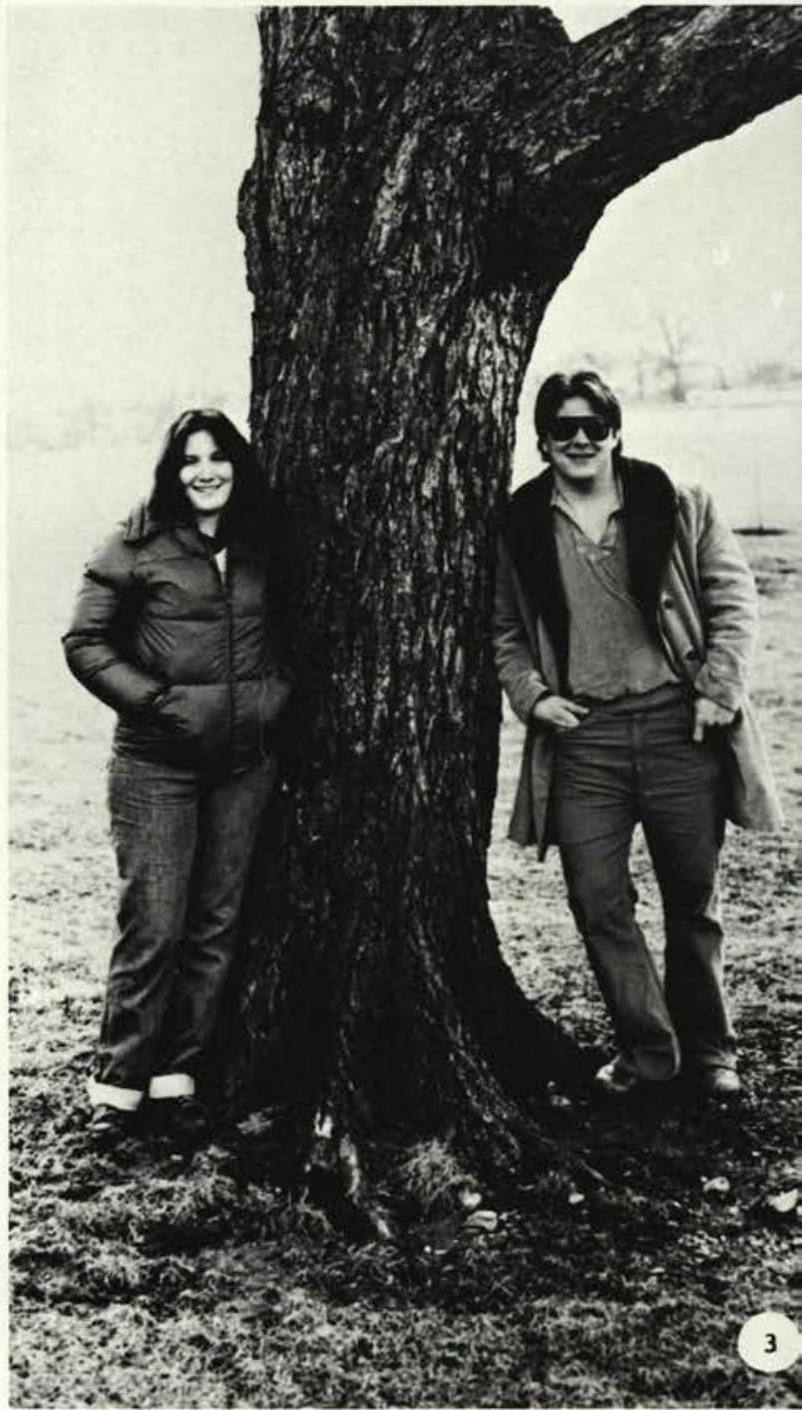



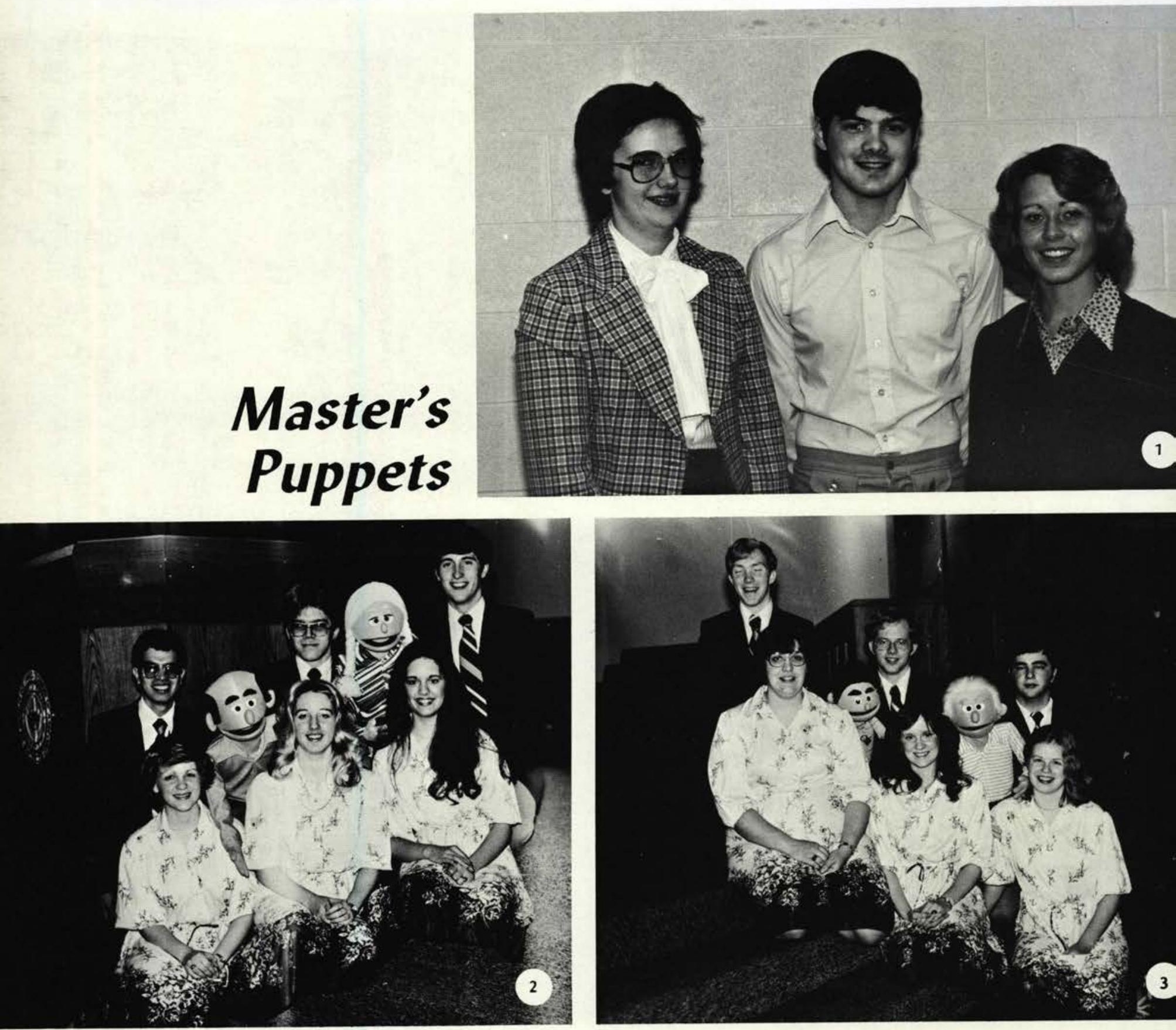

The Master's Puppets consisted of traveling teams and a Production Team. The traveling teams gave puppet presentations on weekends, and they toured during the summer. The Production Team was involved in writing the scripts that the traveling team used for their presentations.

1. Production Team: Roberta Harmon, Dan Garrison, Glenda Maxey.

2. Roscoe's Team: Front: LeeAnn Eichelberger, Bonnie Nycum, Debbie Buining. Back: Valde Garcia, Mike Orban, Roscoe Smith.

3. Norm's Team: Front: Sharon Penquite, Anne Nikles, Dee Phillips. Back: Bob McGuckin, Norm Mackenzie, Mark Pinkerton. 

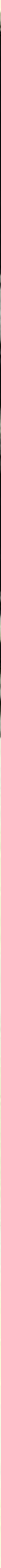

\section{Student Senate Rescue Squad}

1. Student Senate is a representative assembly of the student body. Their purpose is to provide an effective program of co-curricular activities. Members are: Front Row Seated: Deb Buining, Curtis Hoke, Paul Hill, Keith Willhite, Kim Hosack, Kim Henderson, Second Row Seated: Linda Wilson, Tammy Smiley, Sandi Roth, Karen Grant, Sandy Runge, Front Row Standing: Brian Medlock, Kathy Swaney, Beth Lindley, Cherie Depew, Greg Howe, Joe Collier, Marcia Miller, Valde Garcia, Bob Smith, Dan Green, Donald Rickard (Advisor). Second Row Standing: Roy Fuller, Clayton Beck, Dave Bergandine, Steve Evans, Dave Lewis, Joe Curtis, Edd Sturdevant, Kevin Mulder, Alan Green.

2. Rescue Squad is a team of qualified men who take care of emergencies for the college. Members included: Front Row: Dave Stevens, Keith Beach, Mark Leach, Back Row: Mark Stevens, Mark McFadden, Phil Wolfe, Paul Briggs. 


\section{MIS}

The Missionary-In-Service teams were groups and individuals that stayed for the summer in different countries to help missionaries or mission boards.

1. Brazil team members were: Row 1: Lorna Snyder, Ginger Ward, Lenna Barrand, Becky Ferrell, Amy Young, Carol Stoltzfus. Row 2: Kiko Souza, Cal Clark, Craig Kuns, Vini Jaquery, Jim Neely, Tim Hoganson.

2. Australia team members were: Front: Ginny Stone. Second Row: Lisa Meharry, Dawn Jansen, Third Row: Dave Bergandine, Shirley Clark, Faith Linn. Fourth Row: Rich Crist, Bobby Shomo, Jill Griswold, Carl Prokop. Fifth Row: George Stephens, Cozette Wicks, Jim Bocian.

3. Individual MIS students were: Evie Williams - Mexico, Tammy Champlin — USA, Karen Johnson - Scotland, Deanna Palmer Scotland, Gary Canter - Ivory Coast.

4. Israel team members were: Dallas Stewart, Beth Wind, Becky Blackburn, Marsha Spencer, Anne Tawney, Donna Gall, Michelle Wickham.

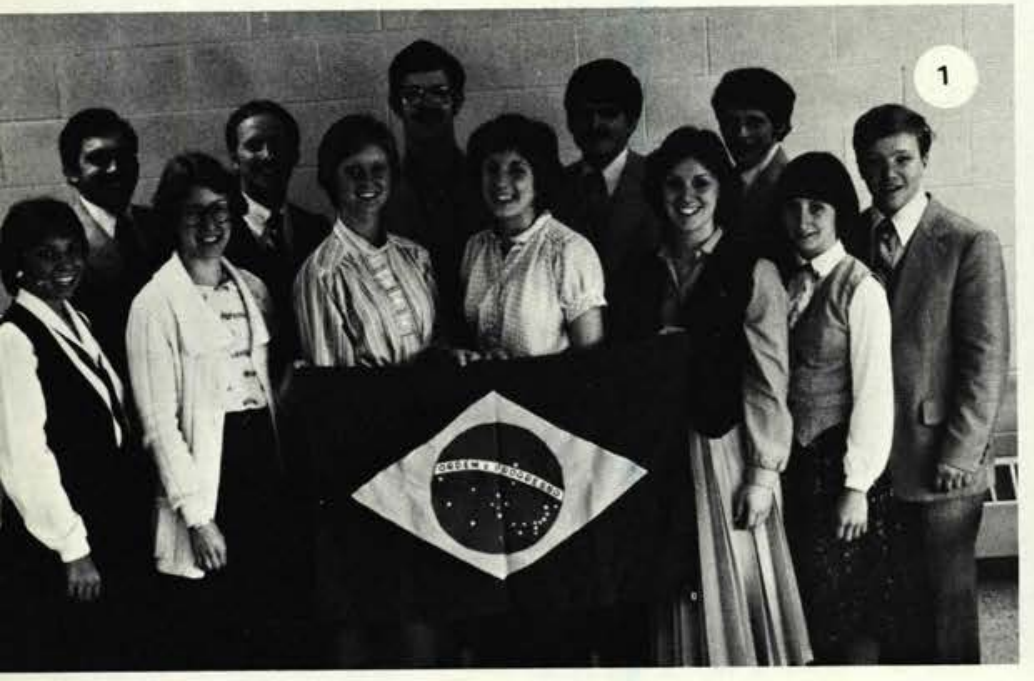

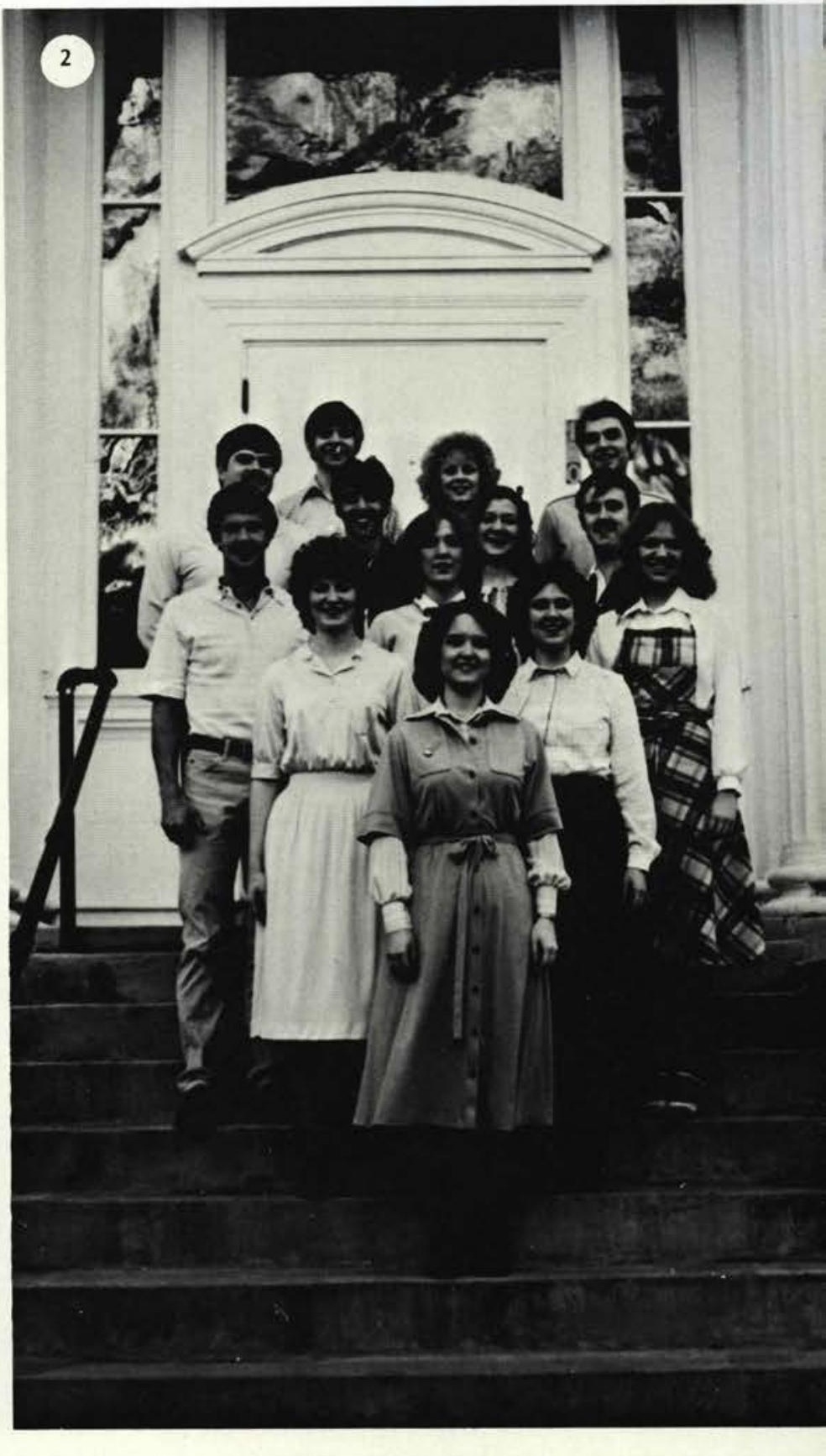

3

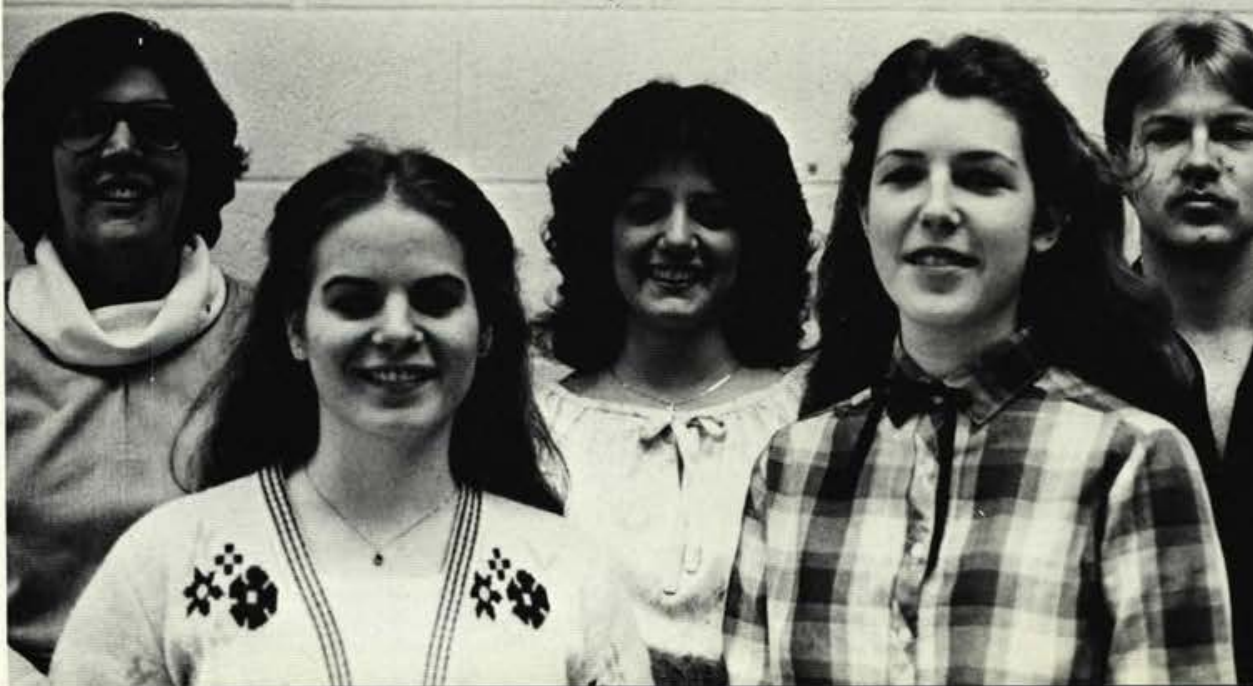




\section{$F W M$}

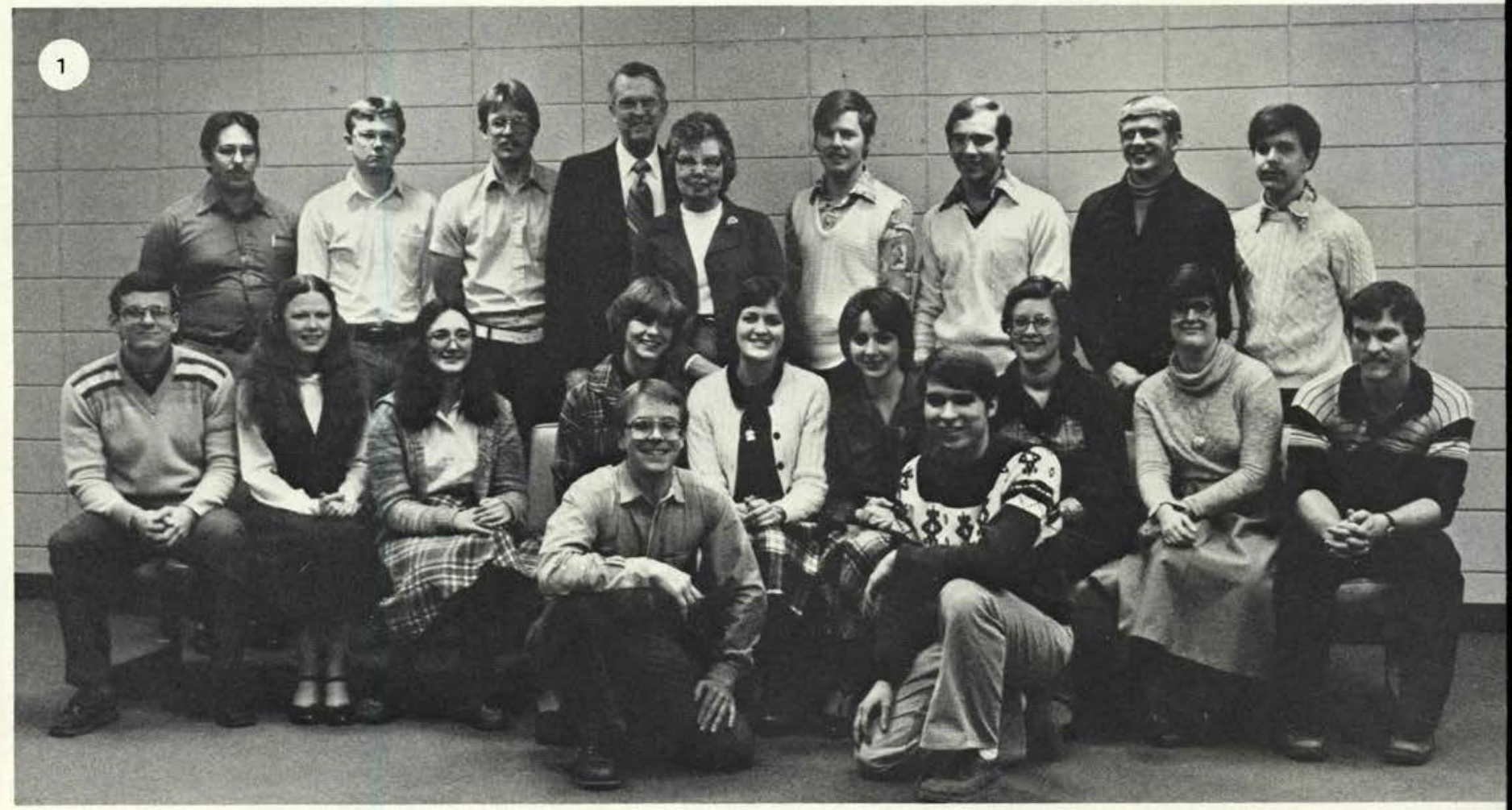

1. Fellowship for World Missions members were: Kneeling: Fritz Huber, Doug Richardson, Sitting: Mark Wells, Kathy Ormsbee, Tonya Anderson, Sandy Runge, Lord Schumm, Joann Bradshaw, Brenda Boley, Lois Lyon, John Suciu. Standing: Joel Veldt, Randy Coolbaugh, Gary Canter, Mr. and Mrs. Richard Durham, Charlie High, Dave Fogle, Dan Rowe, Mike Smith.

2. Student Academic Advisory Board members were: Seated: Valerie Dell, Teresa Galbraith, Lisa Meharry, Dana Treese, Pat Michalski, Vicki Butler. Standing: Dr. Johnson, Dave Cremean, Doug Richardson, John Duff.

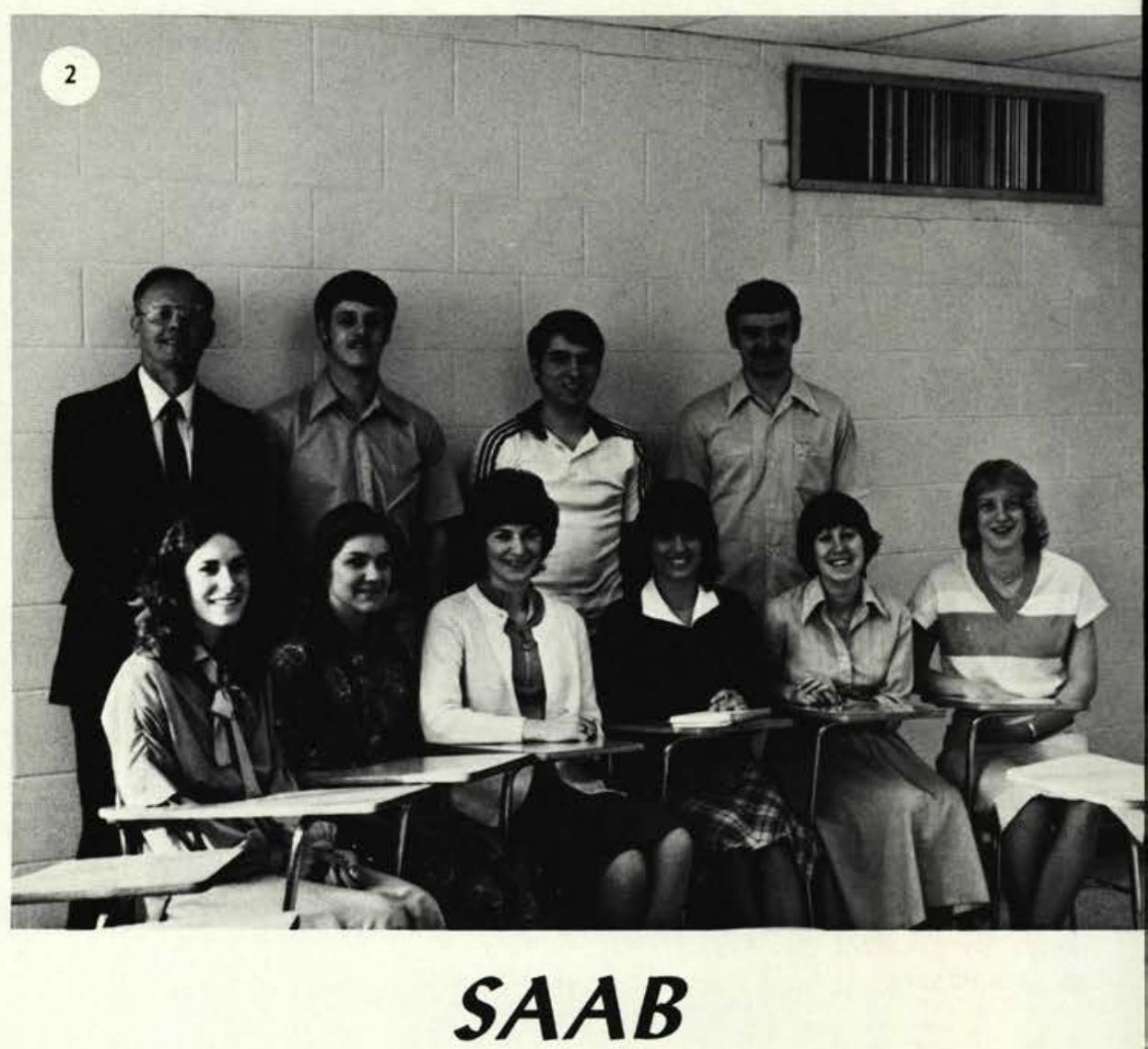




\section{Clubs}

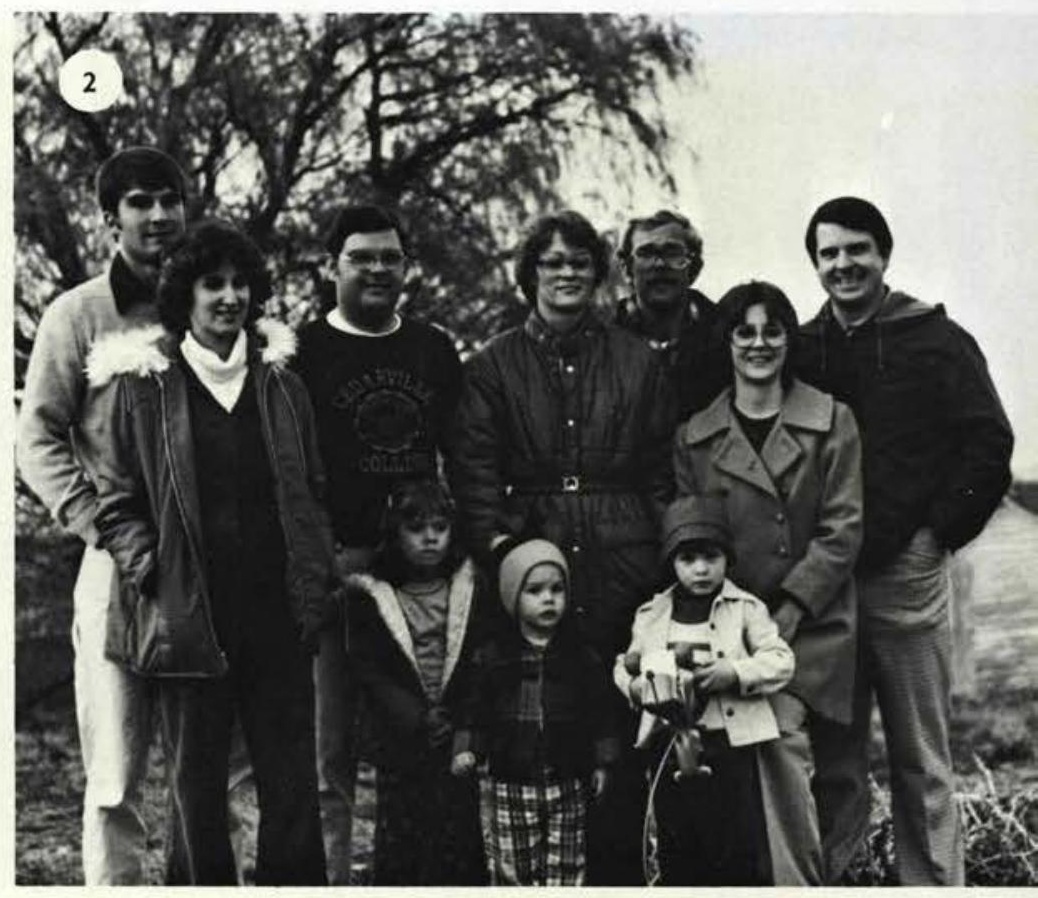

1. Timalathian members included: Ted DeShields, David Sugg, Stacy Towle, Ken Andrus, Kris Karsian.

2. Married Students Club members were: Adults: Greg Birkholtz, Corrine Birkholtz, Dave Murdoch, Carolyn VanNatta, Paul VanNatta, Mary Sanders, Don Sanders. Kids: Dwana Murdoch, David Murdoch, Daniel Sanders.

3. Physical Education Majors and Minors club members included: Front Row: Donna McHugh, Darcy Morton, Marcy Morton, Mary Stuenzi, Debbie Kearsley. Second Row: Brian Medlock, Karen Cooper, Laurie Butler, Sue Kulp, Sue Riegles, Julie Hutchins, Joe Colyer. Third Row: Julie Jones, Laura Hall, Becky Needles, Barb-Vinson, Amy Smith, Jill Griswald, Bett Snouffer. Back Row: Rick Hickman, Norm MacKenzie, Tim Dowd, Rodney Cane, Matt Mills, John Richmond.

4. Advisory 7 members were: Front Row: Dave Kisner, Ken Gaines, Steve Swayze, Pastor Green. Back Row: Keith Willhite, Mark Lones, Kim Kauffman, Jeff Willetts.
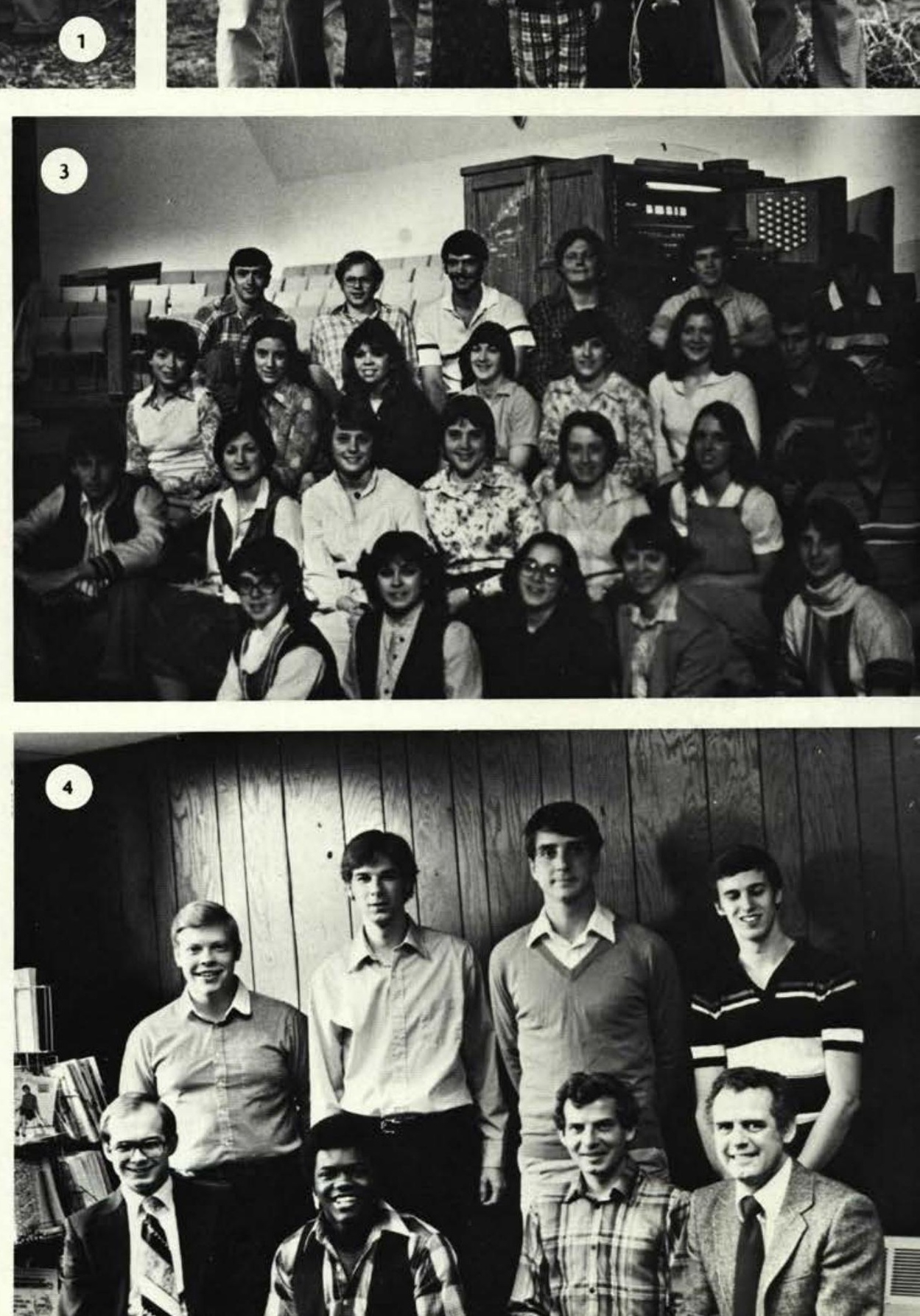


\section{Varsity $\mathcal{C}$}

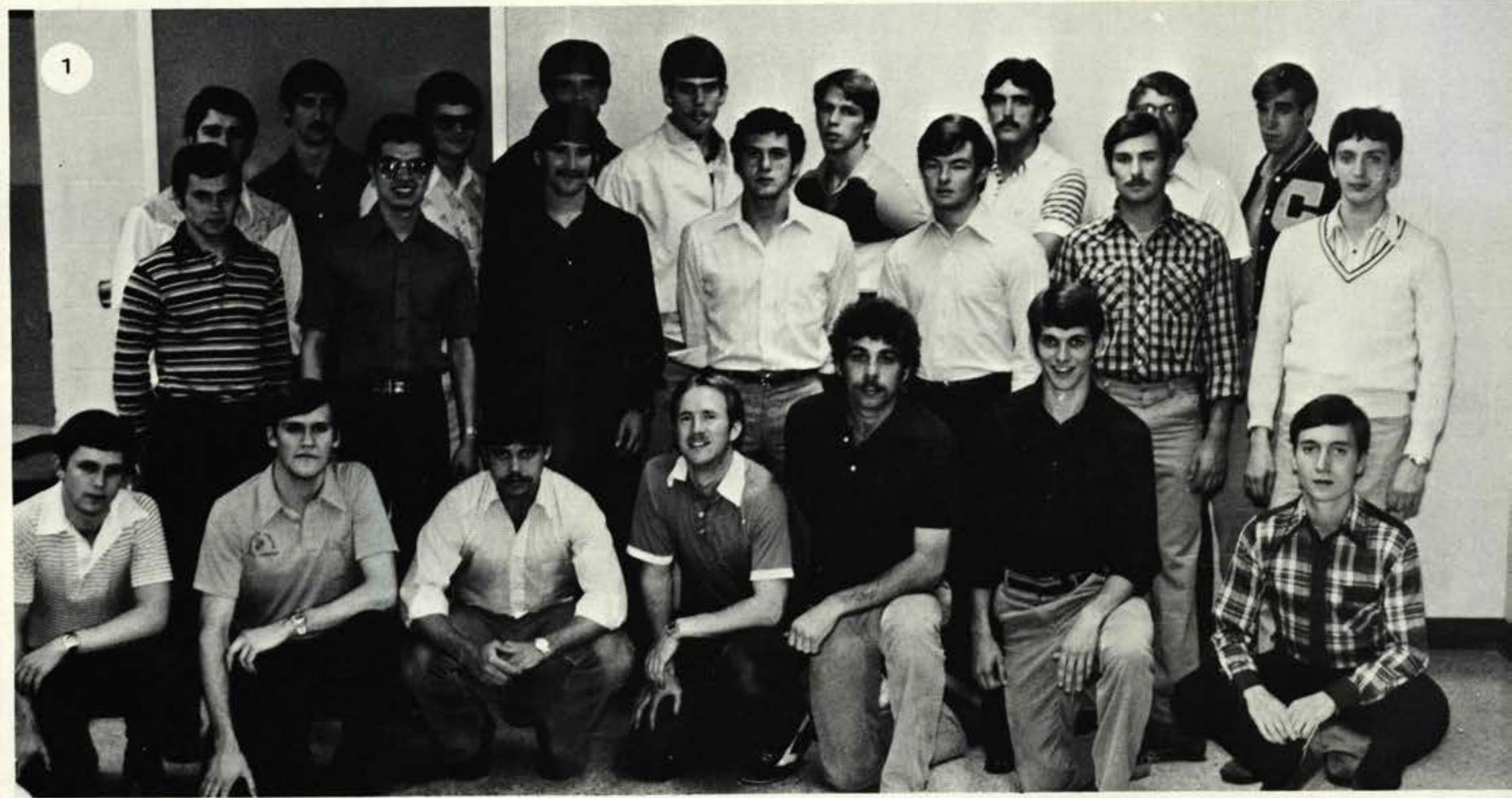

1. Varsity C members were: Row 1: Mark Leach, Craig Colas, Tom Aitken, Cal Clark, Ron Hobar, Tom Yater, Dan Standridge. Row 2: David Cox, Valde Garcia, Bill Baldwin, Larry Green, Dave Merkh, Jamie Darling, Dave Standridge. Row 3: Gary Gromacki, Mark Norman, Bob Hanson, Mark Womack, Eric Mounts, Jeff Bowser, Mark Matthews, Steven Sadowitz, Dave Treese.

2. Music Educators National Conference members were: Row 1: Edna Hollopeter, Cindy Garrison, Crystal Eaker, Cathy Heatly, Janis Traphagen, Dave Layhead, Ken Woods. Row 2: Karen McHugh, Nancy Geddicks, Patty Maloney, Joyce Knicely. Row 3: Dr. Ellington, Teresa Heeney, Sue Knicely, Wayne Anthony. Row 4: Dean Wagner, Debby Wita, Gwen Smith, Danette Wetzel, Gary Rouster. Row 5: Rich Conners, Rusty Burke, Ed Sturdevant, Curt Nice, Dave Short. Row 6: Jeff Acker, Cheryl Sprunger.

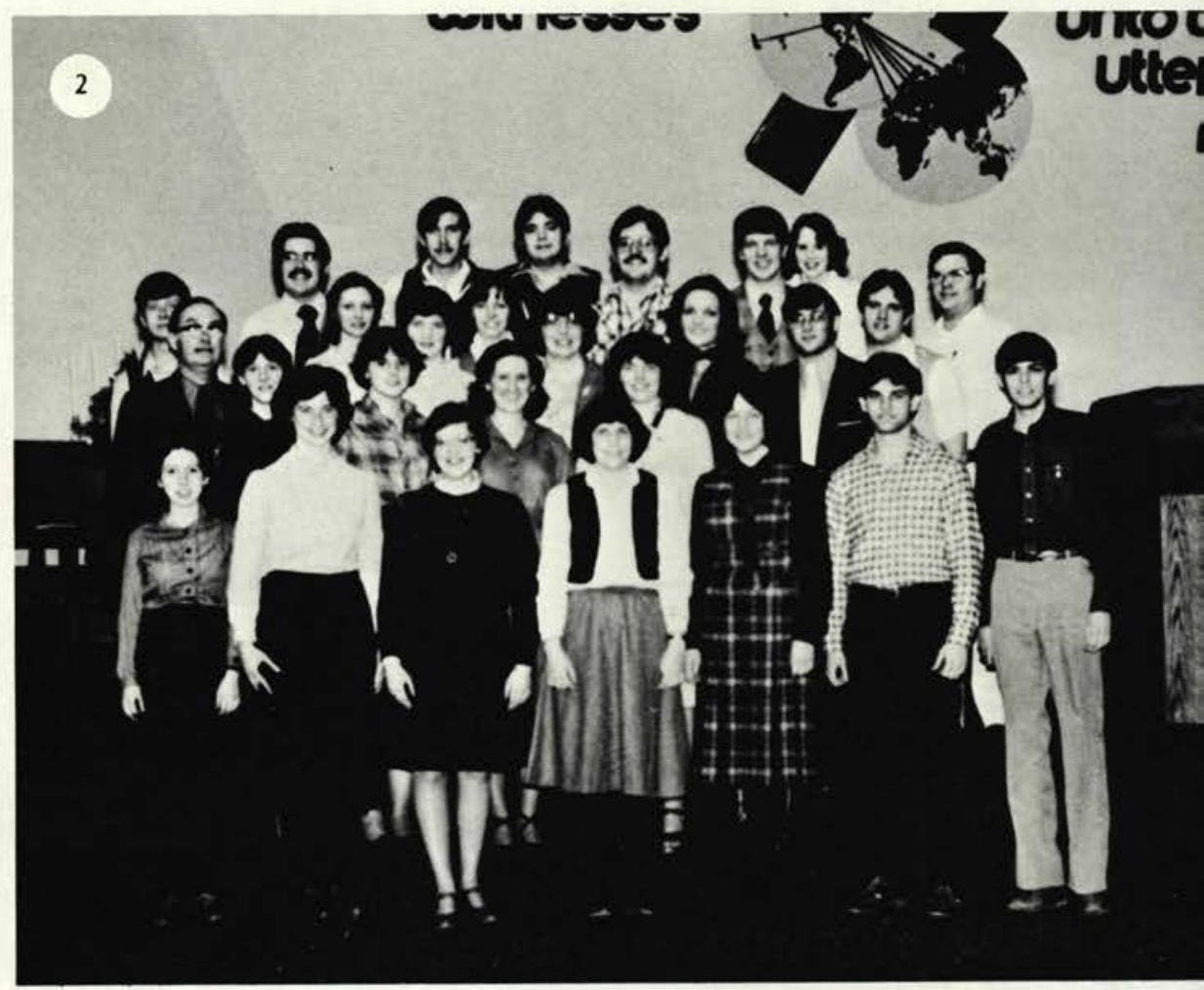



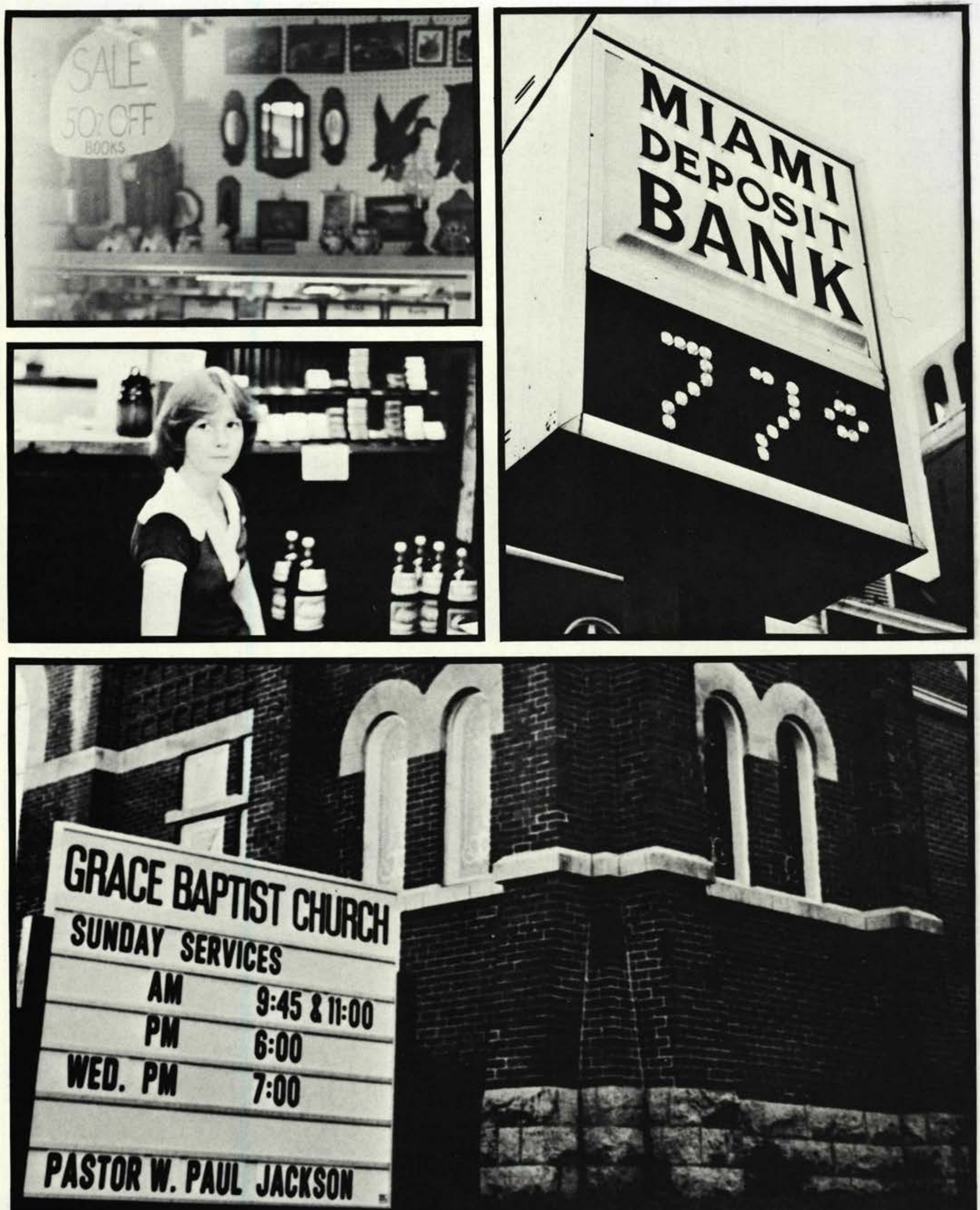

werdy

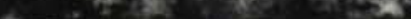

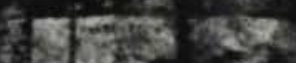

ogrags

30

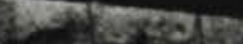

7
$\times$

[B?tid?

Piry? 


\section{ADVERTISING}
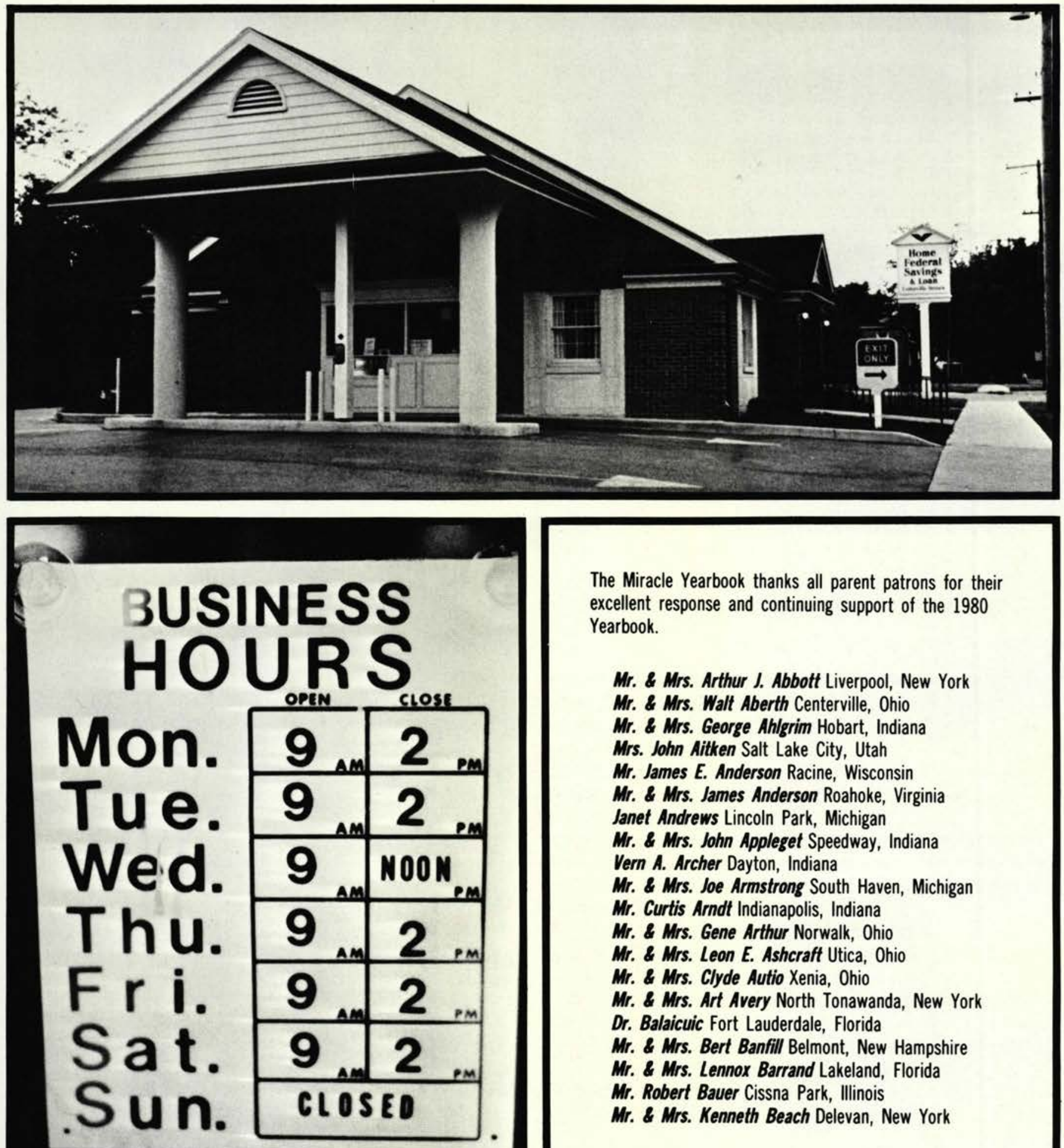

The Miracle Yearbook thanks all parent patrons for their excellent response and continuing support of the 1980 Yearbook.

Mr. \& Mrs. Arthur J. Abbott Liverpool, New York Mr. \& Mrs. Walt Aberth Centerville, Ohio Mr. \& Mrs. George Ahlgrim Hobart, Indiana Mrs. John Aitken Salt Lake City, Utah Mr. James E. Anderson Racine, Wisconsin Mr. \& Mrs. James Anderson Roahoke, Virginia Janet Andrews Lincoln Park, Michigan Mr. \& Mrs. John Appleget Speedway, Indiana Vern A. Archer Dayton, Indiana Mr. \& Mrs. Joe Armstrong South Haven, Michigan Mr. Curtis Arndt Indianapolis, Indiana Mr. \& Mrs. Gene Arthur Norwalk, Ohio Mr. \& Mrs. Leon E. Ashcraft Utica, Ohio Mr. \& Mrs. Clyde Autio Xenia, Ohio Mr. \& Mrs. Art Avery North Tonawanda, New York Dr. Balaicuic Fort Lauderdale, Florida Mr. \& Mrs. Bert Banfill Belmont, New Hampshire Mr. \& Mrs. Lennox Barrand Lakeland, Florida Mr. Robert Baver Cissna Park, Illinois Mr. \& Mrs. Kenneth Beach Delevan, New York 
Mr. \& Mrs. Robert L. Beacham Elkhart, Indiana

Mr. \& Mrs. Harold Beaver Bradford, Ohio

Reverend \& Mrs. Charles P. Benedict Huntington Station, New York

Mr. \& Mrs. Glenn Berger Olney, Illinois

Mr. \& Mrs. William C. Betts Georgetown, Delaware

Mr. \& Mrs. William H. Bingman Boothwyn, Pennsylvania

Mrs. Madaline Black Madison, Ohio

Mr. Donald Block Gladwin, Michigan

Mr. \& Mrs. Fred Booher Xenia, Ohio

Mr. \& Mrs. Troy C. Brammer Florissant, Missouri

Mr. \& Mrs. Richard Braun New Haven, Indiana

Mr. \& Mrs. F. Bresson Sussex, Wisconsin

Mr. \& Mrs. Dwight W. Briggs Springfield, Virginia

Mr. \& Mrs. Daniel S. Brown Jefferson, Ohio

Mrs. Doris Browne Washington, District of Columbia

Mr. \& Mrs. G. Brnecknet Menomonee Falls, Wisconsin

Dr. Ronald R. Bubel Wessington Springs, South Dakota

Mr. \& Mrs. Alan Bullock Huntington Station, New York

Mr. \& Mrs. George Butler Steamboat Rock, lowa

Mr. \& Mrs. Millard Canter Pleasantville, Ohio

Mr. \& Mrs. John B. Carr Elyria, Ohio

Mr. \& Mrs. Ken Chadwell Allen Park, Michigan

Mr. \& Mrs. Don F. Chasteen Kokomo, Indiana

Mr. \& Mrs. Joseph D. Childers Monroe, Ohio

Mr. \& Mrs. Ken Christmas Brunswick, Ohio

Mr. \& Mrs. Howard Clark Lindoln Park, Michigan

Mr. \& Mrs. Ronald K. Clark Hudson, New Hampshire

Mr. \& Mrs. John A. Clayton, Ir. North Salem, Indiana

Mr. \& Mrs. Windle Clearwater Speedway, Indiana

Mr. \& Mrs. Harold L. Coates Quincy, Illinois

Reverend \& Mrs. Preble Cobb Framingham, Massachusetts

Mr. \& Mrs. Gene Connone Lorain, Ohio

Mr. \& Mrs. Samuel M. Conrad Akron, Ohio

Mr. \& Mrs. Ralph Coolbaugh Salem, Wisconsin

Mr. \& Mrs. Tom Coules Buir Ridge, Illinois

Mr. \& Mrs. Daniel L. Cox Dayton, Ohio

Mr. \& Mrs. David Cox Sao Paulo, Brazil

Mr. \& Mrs. Harry Crist Pennsville, New Jersey

Mr. \& Mrs. Louis Cvetich Conway, Pennsylvania

Stella J. D'Amico Lakewood, Ohio

Reverend \& Mrs. Albert H. Damon Akron, New York

Mr. \& Mrs. John D. Davis Cincinnatus, New York

Mr. 7 Mrs. Bruce Detweiler Tallmadge, Ohio

Mr. \& Mrs. Stanley Douglas West Islip, New York

\section{FIRST BAPTIST CHURCH}

1101 - 9th Avenue

Silvis, Indiana

"The All Family Church"

Greetings to Pam Axiotis

and Lisa Ramsey from all

the Folk at First Baptist.

"The end of your search for a friendly church."

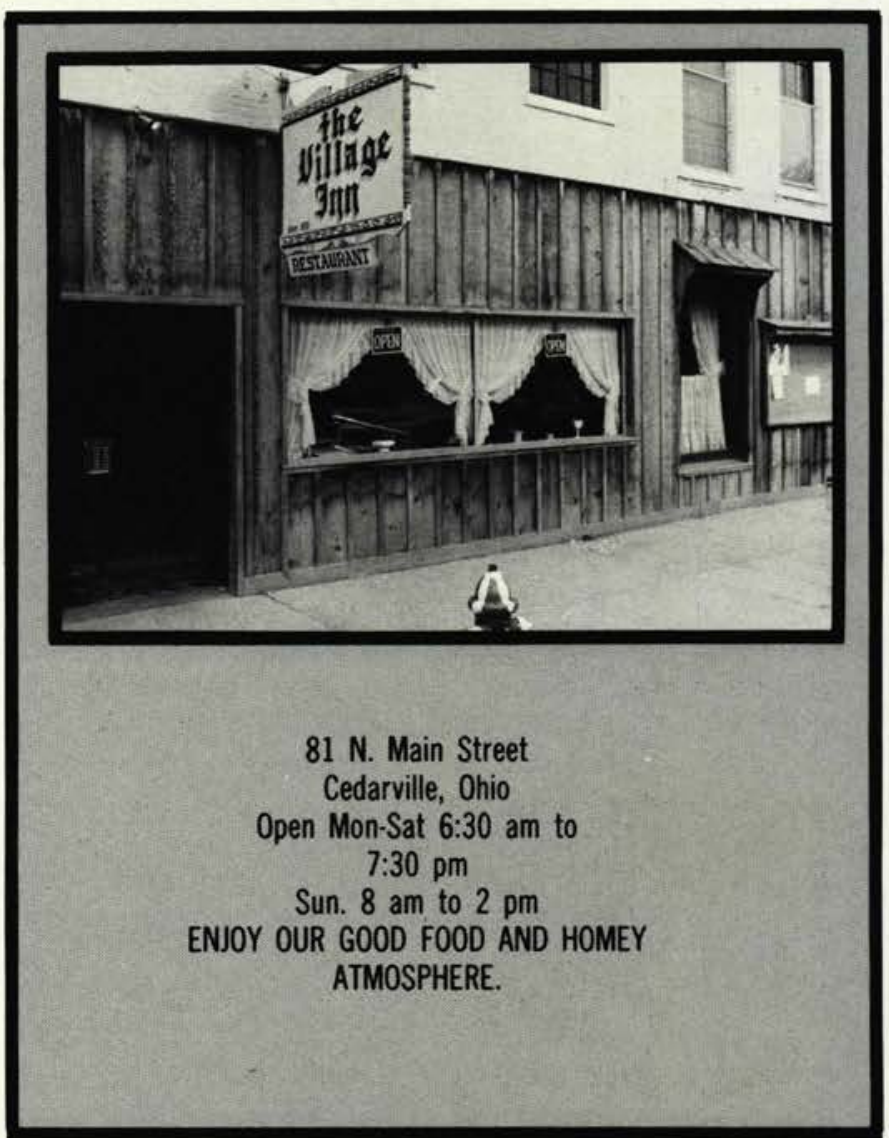

CONGRATULATIONS TO THE CLASS OF ' 80 !

"Faithful is he that calleth you, who also will do it." - I Thessalonians 5:24

\section{FIRST BAPTIST CHURCH}

414 East Lincoln Street

Breman, Indiana $\mathbf{4 6 5 0 6}$

Rev. James K. Holmes, Pastor 


\title{
WHEELERSBURGH BAPTIST CHURCH
}

"The Church of the Open Bible"

8140 Gallia St. Wheelersburg, Ohio 45694

Dick Sumner, Pastor

Dennis Burns, Youth Pastor

Gary Storm, Director

Scioto Hills Reservation

"Let your light so shine before men,

We congratulate the class of

that they may see your good works.

' 80 and proudly salute those

and glorify your Father who is

in Heaven." Matthew 5:16

students presently attending

Cedarville College from

Wheelersburg Baptist

Church ...

\author{
Ken Massie \\ Bonnie Merrill \\ Cheryl Miller \\ Reve Smith \\ Steve Stewart
}

\section{FIRST BAPTIST CHURCH}

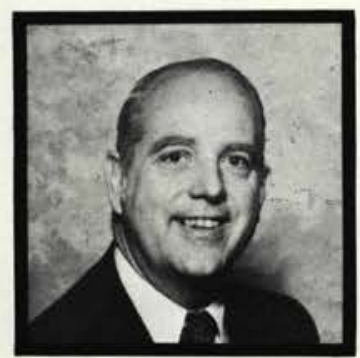

NORMAN HOAG

Pastor

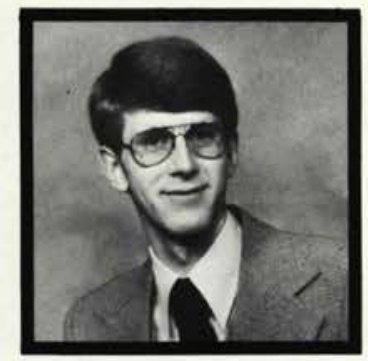

DENNIS JINGST

Assoc. Pastor
1001 N. Lincoln St.

Creston, lowa 50801 SUNDAY SCHOOL 9:45 A.M.

classes for all ages MORNING WORSHIP 11 A.M. (Broadcast over KSIB Radio) YOUNG PEOPLE'S HOUR

$$
6 \text { P.M. }
$$

EVENING SERVICE 7 P.M. MID-WEEK SERVICE 8 P.M.. (Wednesday)

\section{COLONIAL PIZZA}

\section{N. MAIN STREET \\ CEDARVILLE, OHIO \\ Phone 766-5779}

BEST WISHES TO THE

STUDENTS AND GRADS

AT CEDARVILLE COL-

LEGE. 


\section{COMMUNITY BOWLING LANES}

66 S. Allison Avenue
Xenia, Ohio
376.9496

"We invite you to enjoy bowling with us'

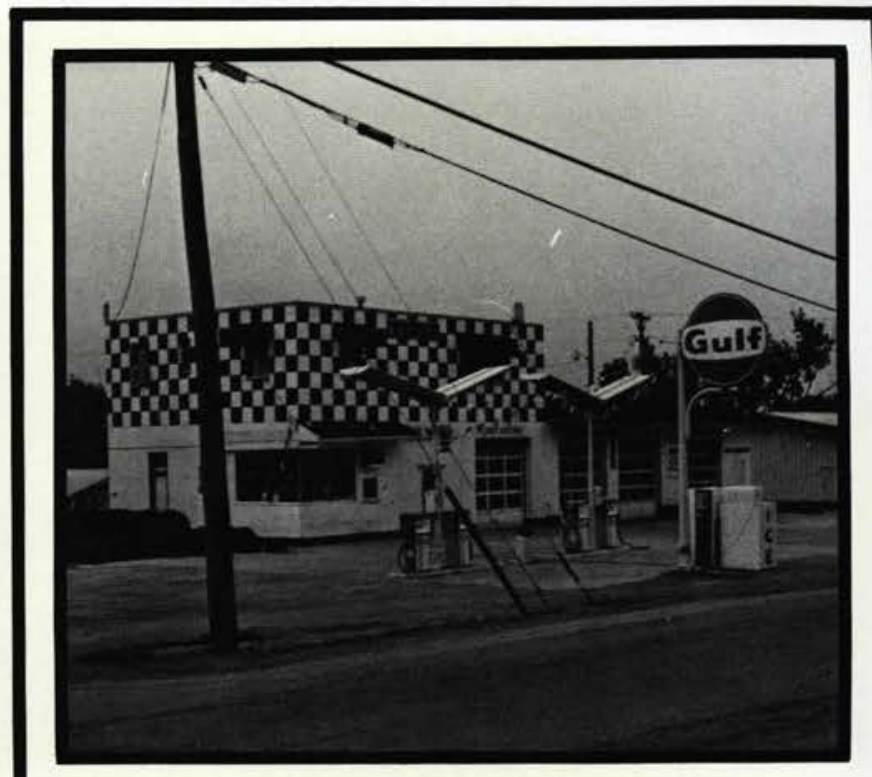

ED'S TIRE and AUTO SERVICE, INC.

Special price on tires to STUDENTS and FACULTY

ST. Rt. 42

Ph. $766-2761$
Mr. Glenn E. Duff Houlton, Maine

Mr. \& Mrs. John Duffield Valley Falls, Kansas

Mrs. Letter H. Edelin Washington, District of Columbia

Phyllis Edwards Whitesboro, New York

Mr. \& Mrs. John M. Eiser Ellerlie, Maryland

Dr. \& Mrs. G.C. Elcan St. Albans, West Virginia

Ms. June M. Ericson Spencerville, Ohio

Mr. \& Mrs. Donald Ernst Waterloo, lowa

Mr. \& Mrs. Thomas Fareno Warminster, Pennsylvania

Mr. \& Mrs. Robert Farmwald Middlefield, Ohio

Mr. \& Mrs. Arnell Fast Van Wert, Ohio

Mr. Eugene Fisher Columbus, Ohio

Mrs. Norma Fisher Chagrin Falls, Ohio

Mr. \& Mrs. Alton Flint Newfane, New York

Mr. \& Mrs. Donald R. Flood Grafton, Ohio

Mr. \& Mrs. John A. Fogle Elwhurst, Illinois

Mr. Walter Folkmann Brunswick, Ohio

Mr. \& Mrs. Thomas J. Footman Baltimore, Maryland

Mr. \& Mrs. Earl F. Foreman Van Wert, Ohio

Mr. \& Mrs. Joe Fowler Mattoon, Illinois

Mr. \& Mrs. Ernest $L$. Fox Red Bank, New Jersey

Mr. \& Mrs. Ernest L. Francis, Sr. Valparaiso, Indiana

Mr. \& Mrs. John F. Freebournfranklin, Pennsylvania

Reverend \& Mrs. Graham C. Freeman Muncy, Pennsylvania

Mr. \& Mrs. H.L. Freeman, Jr. St. Albans, West Virginia

Mr. \& Mrs. William A. Friley Springfield, Ohio

Mr. \& Mrs. Lee Fullmer Cincinnati, Ohio

Reverend \& Mrs. Willsworth Gaines Willow Grove, Pennsylvania

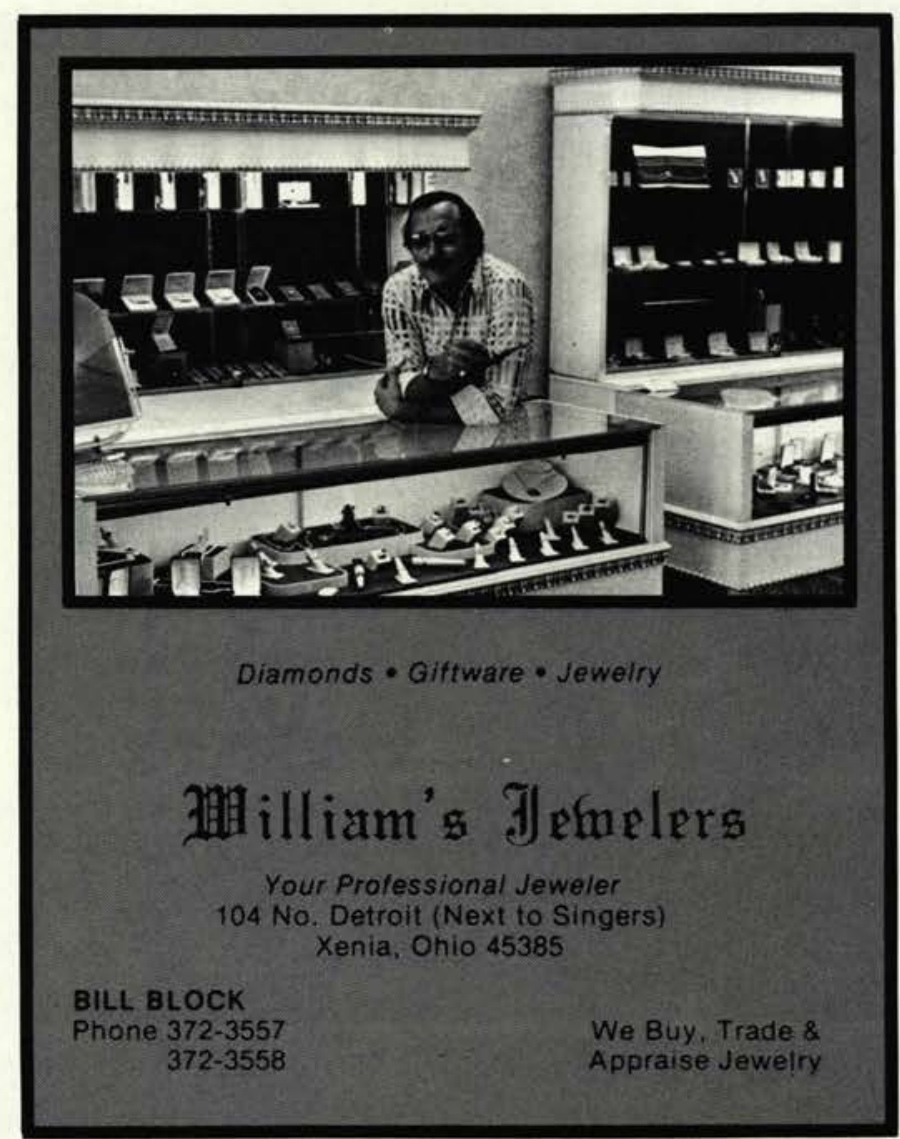




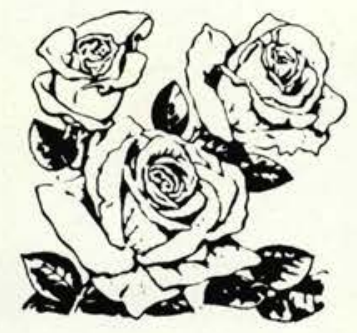

\section{WEBBER'S FLORIST and Gift SHOPPE}

Mr. \& Mrs. James R. Galbreath Van Wert, Ohio

Mr. \& Mrs. Carl Gawthrop Fairmont, West Virginia

Mr. \& Mrs. Herb Gedicks Pittstown, New Jersey

Mr. \& Mrs. James Geist Meadville, Pennsylvania

Mr. \& Mrs. Vaughn Giggie Elliot Lake, Ontario Canada

Mr. \& Mrs. William F. Gilmour Niles, Ohio

Mr. \& Mrs. Charles Grafton Highland, Maryland

Mr. \& Mrs. Donald Graham Milan, Ohio

Reverend \& Mrs. Harold Green Cedarville, Ohio

Mr. \& Mrs. Fred Greetham Wellington, Ohio

Mr. \& Mrs. Keith Greve Greensburg, Indiana

Mr. \& Mrs. Clifton Groves Parma, Ohio

Mr. \& Mrs. Carlyle Hayes Brown City, Michigan

Mr. \& Mrs. Lavern Hague Tulare, South Dakota

Mr. \& Mrs. Orlin O. Hale Rootstown, Ohio

Mr. \& Mrs. James L. Hammond Amherst, Ohio

Reverend \& Mrs. Gary Hanson Colona, Illinois

Mr. \& Mrs. Robert G. Harmon Johnstown, Pennsylvania

Mr. \& Mrs. Donald Harper Des Plaines, Illinois

Reverend \& Mrs. George Hattenfield Columbus, Ohio

Mr. \& Mrs. Wayne Heal Bunker Hill, Illinois

Mr. \& Mrs. Bill C. Heatly Ardmore, Oklahoma

Mr. \& Mrs. Paul Heers Austin, Minnesota

Mr. \& Mrs. Carl Henderson Ft. Mitchel, Kentucky

Mr. \& Mrs. William A. Henderson New Bethlehem, Pennsylvania

Mr. \& Mrs. Clifford E. Herl Rives Jct., Michigan

Mr. \& Mrs. Rebert Hill Mansfield, Ohio

Audrey Charlotte Hiller Akron, Ohio

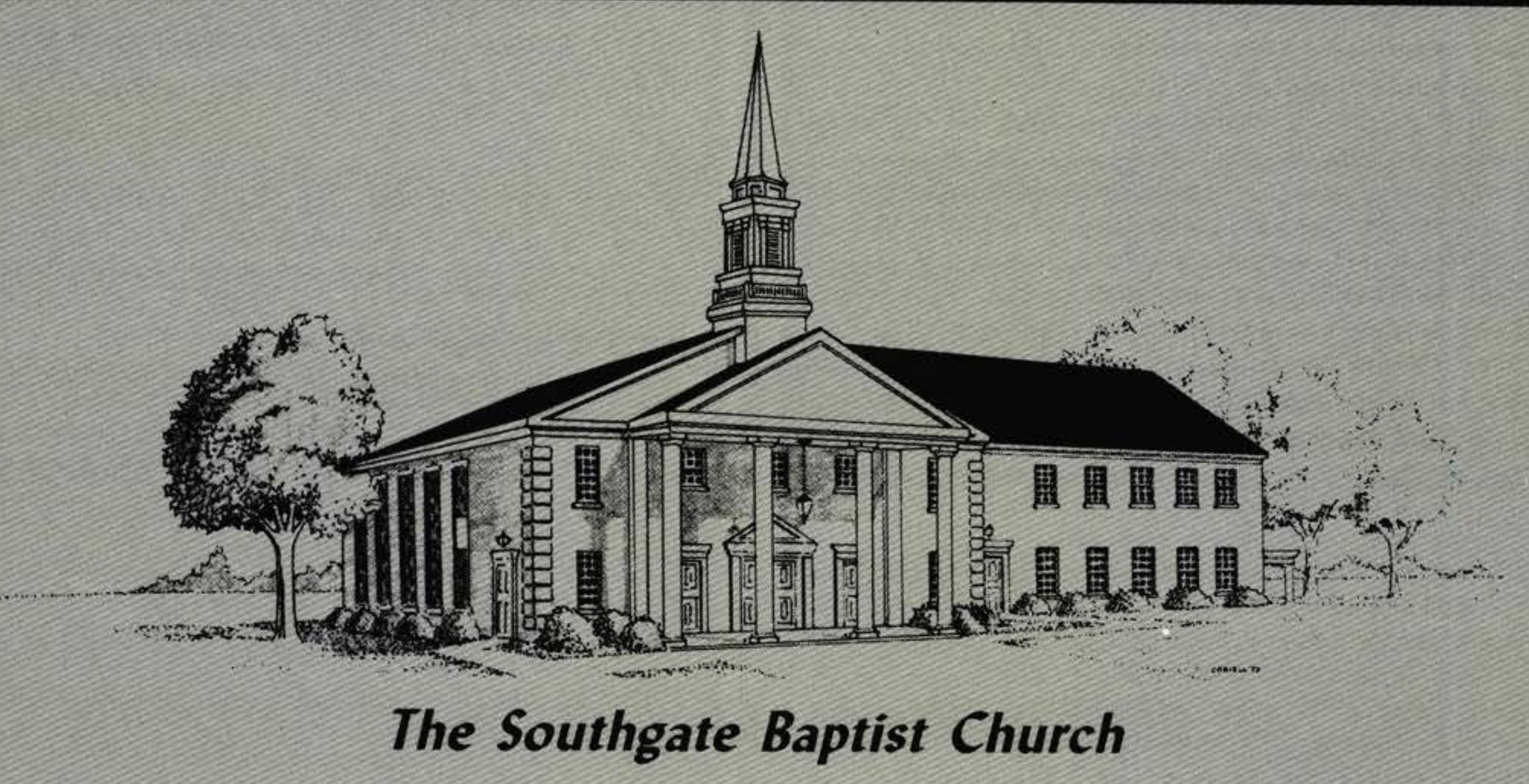

2111 S. Center Blvd.

Springtield, Ohio 45506

John R. Greening, Pastor

Congratulations to the Class of 1980 .

Thomas M. Hopewell, Ass. Pastor 


\section{Bethel Baptist Church}

1704 Springdate Foad. Cherry Hill, New Jersey, 98004

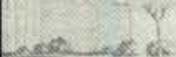

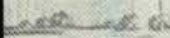

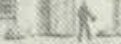

zosos

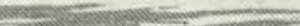

Congratulations to the Class of 1980

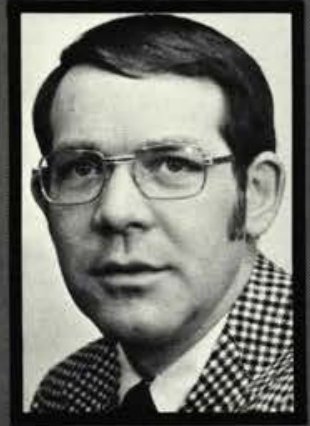
from

\section{BETHEL BAPTIST CHURCH}

1704 Sprindale Road, Cherry Hill, N.J. 08003

Rev. Virgil W. Stoneking, Pastor

Rev. Wayne Baker, Ass. to the Pastor

Donald Whipple, Ass. to the Pastor

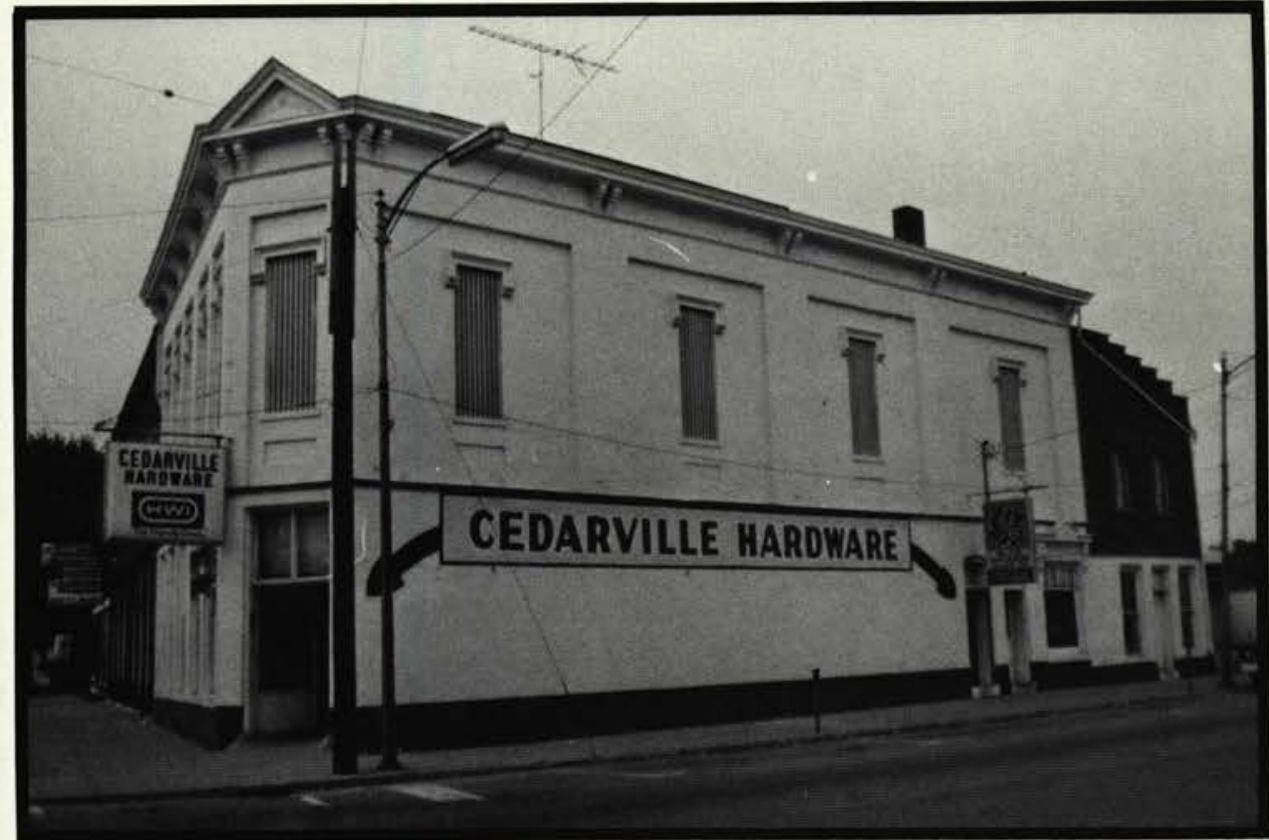

MAIN \& XENIA STS

Cedarville, $\mathrm{OH}$

FOR YOUR

BEST DEAL IN

GENERAL ELECTRIC

APPLICANCES

HARDWARE

and GIFTS

FREE GIFT

WRAPPING

CONGRATULATIONS CLASS OF 1980 


\section{FIRST BAPTIST CHURCH}

125 Grand Ave.

Wellington, Ohio 44090

Pastor Gerald G. Wagner

Sunday School 9:30 AM

Morning Worship 10:45 AM

Evening Service 7:00 PM

Wednesday Evening

Service 7:00 PM

Phone 216-647-2477

Wellington Members attending

Cedarville College:

Ruth Collins

Sally Greetham

Criss Wilson

Laura Olsen

Randy Wilson
Reverend \& Mrs. John Hippard Shelbyville, Illinois

Mr. \& Mrs. Patrick Hitchcock Hnintown, Ohio

Mr. \& Mrs. Allen Hoganson Laurium, Michigan

Mr. \& Mrs. Richard Hoke Meadville, Pennsylvania

Mr. \& Mrs. Robert E. Hottel, Sr. Indianapolis, Indiana

Mr. \& Mrs. Bill Howard Amherst, Ohio

Mr. \& Mrs. William J. Howe East Alton, Illinois

Mr. \& Mrs. Henry Huffman Indianapolis, Indiana

Mr. \& Mrs. Richard Humphrey Walnut Creek, Ohio

Mr. \& Mrs. Ed Hurst Hamilton, Ohio

Mr. \& Mrs. William I. Hutchins Corning, New York

Mr. \& Mrs. Clifford Imhoff Riverview, Michigan

Mr. \& Mrs. Alan K. Ingalls Flint, Michigan

Mr. \& Mrs. Lloyd Jackson Bloomfield, Indiana

Reverend \& Mrs. Jack Jacobs Waterloo, lowa

Mr. Richard W. Jessup Mt. Vernon, Ohio

Mr. \& Mrs. James Jobson Franklin Lakes, New Jersey

Mr. Clifton C. Johnson, Jr. Comstock Park, Michigan

Mr. \& Mrs. Don Jones Altoona, Pennsylvania

Mrs. Linda M. Jones Eldorado, Wisconsin

Mr. \& Mrs. LaVerne Kandle Massillon, Ohio

Mr. Helmut Kamphausen Collingdale, Pennsylvania

Mr. \& Mrs. Dillon Karsian Hackensack, New Jersey

Mrs. Neua Kauffman Brownsburg, Indiana

Mr. \& Mrs. Harold D. Kendall Waupaca, Wisconsin

Mr. \& Mrs. Kenneth Kidd Cincinnati, Ohio

Royal C. King Peoria, Arizona

Mr. \& Mrs. Stanley Kirby Prospect, Ohio

Mr. \& Mrs. Harry Klingenberg Temperance, Michigan

Mr. \& Mrs. James Krohn Grant Park, Illinois

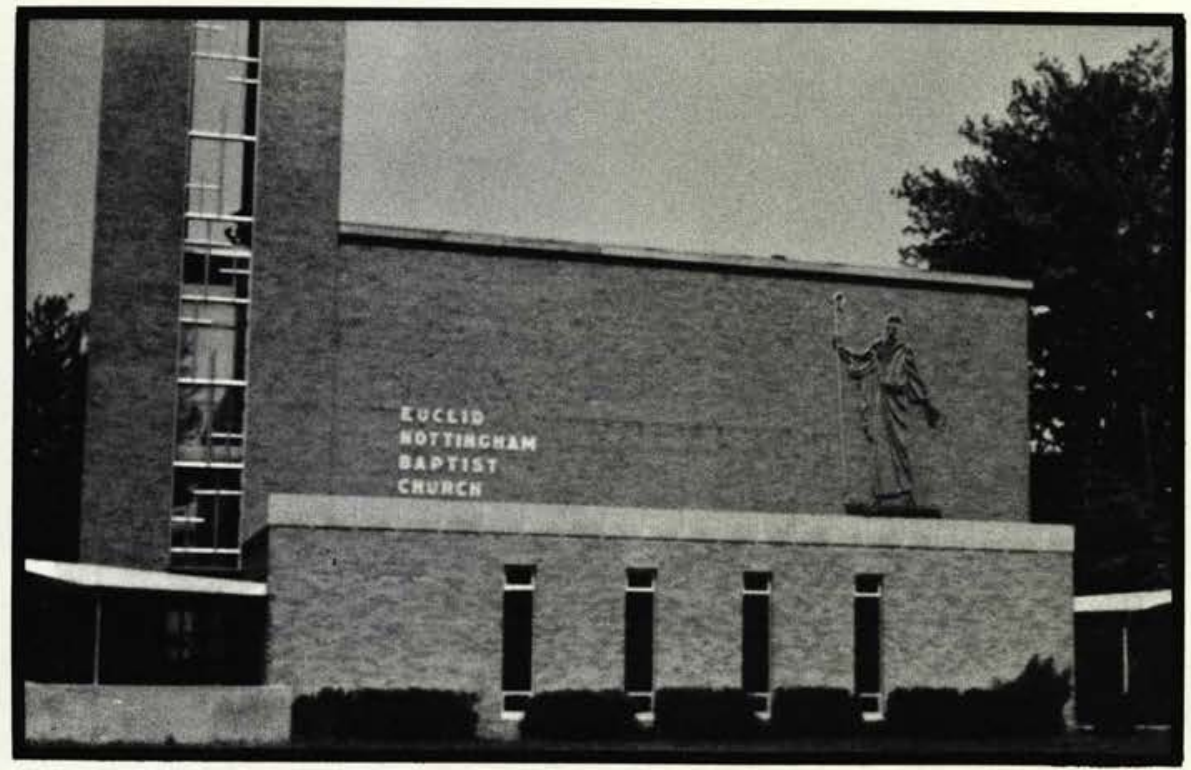

"THE LORD HATH DONE GREAT THINGS FOR US, WHEREOF WE ARE GLAD." - PSALM 126:3
EUCLID. NOTTINGHAM BAPTIST CHURCH

18901 Lake Shore Blvd. Euclid, Ohio 44119

Pastor: Donald McClintic

$$
\text { SUNDAY - }
$$

9:45 am - Bible School 11:00 am - Worship 6:30 - Eve. . Service

Wednesday -

7:00 pm - AWANA Clubs 7:15 pm - Midweek Service 
Reverend \& Mrs. Fred A. Krueger Hemlock, Michigan

Mr. \& Mrs. Richard H. Lapp Winfield, Illinois

Mr. Warren E. Lawrence Warren, Ohio

Mr. \& Mrs. Melvin J. Leman Francesville, Indiana

Mr. Clayton H. Lewis Griffith, Indiana

Mr. \& Mrs. Jerome Lewis Charleston, West Virginia

Mr. \& Mrs. Robert Linn Sagamore Hills, Ohio

Mr. \& Mrs. Richard L. Livergood Belmont, New York

Mr. \& Mrs. Vern Longacre Fostoria, Ohio

Mr. \& Mrs. David G. Lord Perry, lowa

Mr. \& Mrs. Don Love Hilongos, Leyte Philippines

Mr. \& Mrs. Merton Luce Wellsville, Kanas

Mr. \& Mrs. Robert McBride Lonisville, Kentucky

Mr. \& Mrs. Joseph L. McClendon Shawnee, Kansas

Mr. \& Mrs. Jacob J. McDonald Noblesville, Indiana

Mr. \& Mrs. Paul McHugh Pittsburgh, Pennsylvania

Mr. \& Mrs. Richard McKay Brochway, Pennsylvania

Mr. \& Mrs. Paul McMillan Carmel, Indiana

Mr. Jerry Mackey Solon, Ohio

Reverend \& Mrs. Ralph L. Mantz Deansboro, New York

Mr. \& Mrs. Elmer G. Martin Grethel, Kentucky

Mr. Ralph G. Massie Wheelersburg, Ohio

Mr. \& Mrs. Everett C. Mathews Grove City, Ohio

Mr. \& Mrs. Dan Matter Jr. Fort Wayne, Indiana

Mr. \& Mrs. R.L. Medlock Tacoma, Washington

Mr. \& Mrs. George C. Meibuhr Menton, Ohio

Dr. \& Mrs. Robert Michel Montour Falls, New York

Mr. \& Mrs. Matthew M. Mierta Burton, Michigan
Congratulations To The Seniors From

Pastor Ernest Pickering

and

\section{Emmanuel Baptist Church and Schools}

4207 Laskey Road

Toledo, Ohio 43623

Proclaiming Christ: Crucified, Risen, and Coming Again.

\section{BLESSED HOPE Baptist Church}

\section{Fishburg Road} Dayton, Ohio 45424

William Tallman, Pastor

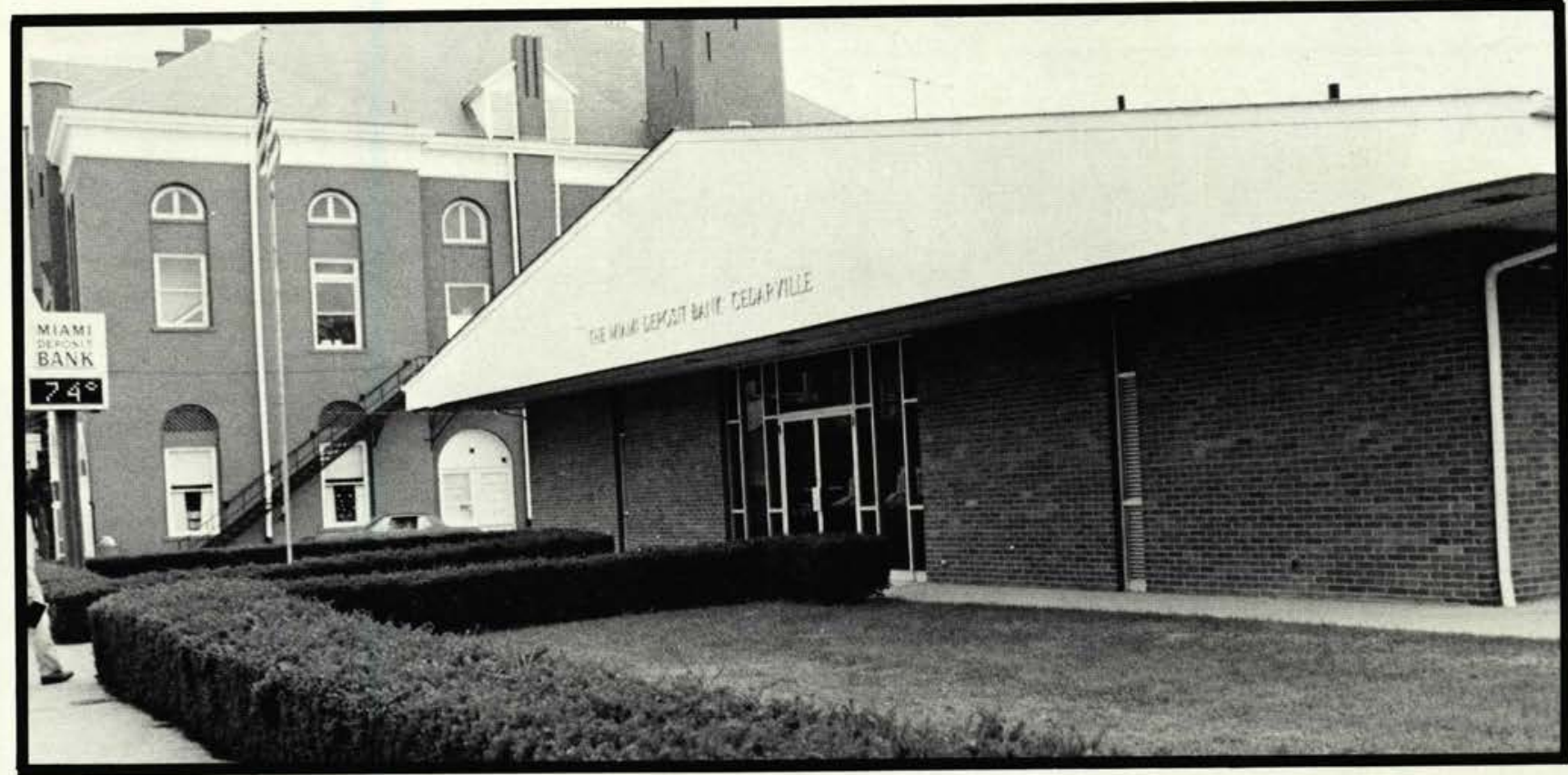

\section{MIAMI DEPOSIT BANK}

69 N. Main Street

Cedarville, Ohio 766-2311
Yellow Springs, $\mathrm{OH}$

761-7212

\section{"HERE TO SERVE YOU"}

Beaver Valley, $\mathrm{OH}$ 429-3420
DEPOSIT INSURED

UP TO $\$ 100,000$

MEMBER OF F.D.I.C. 


\section{CONGRATULATIONS \\ TO \\ THE CLASS OF ' 80 \\ KUNZELMAN'S ICE CREAM}

Manufactured by

ELIZABETH CREAMERY CO., INC.

519 S. Market St.

Elizabethtown, $\mathrm{Pa} 17022$ 


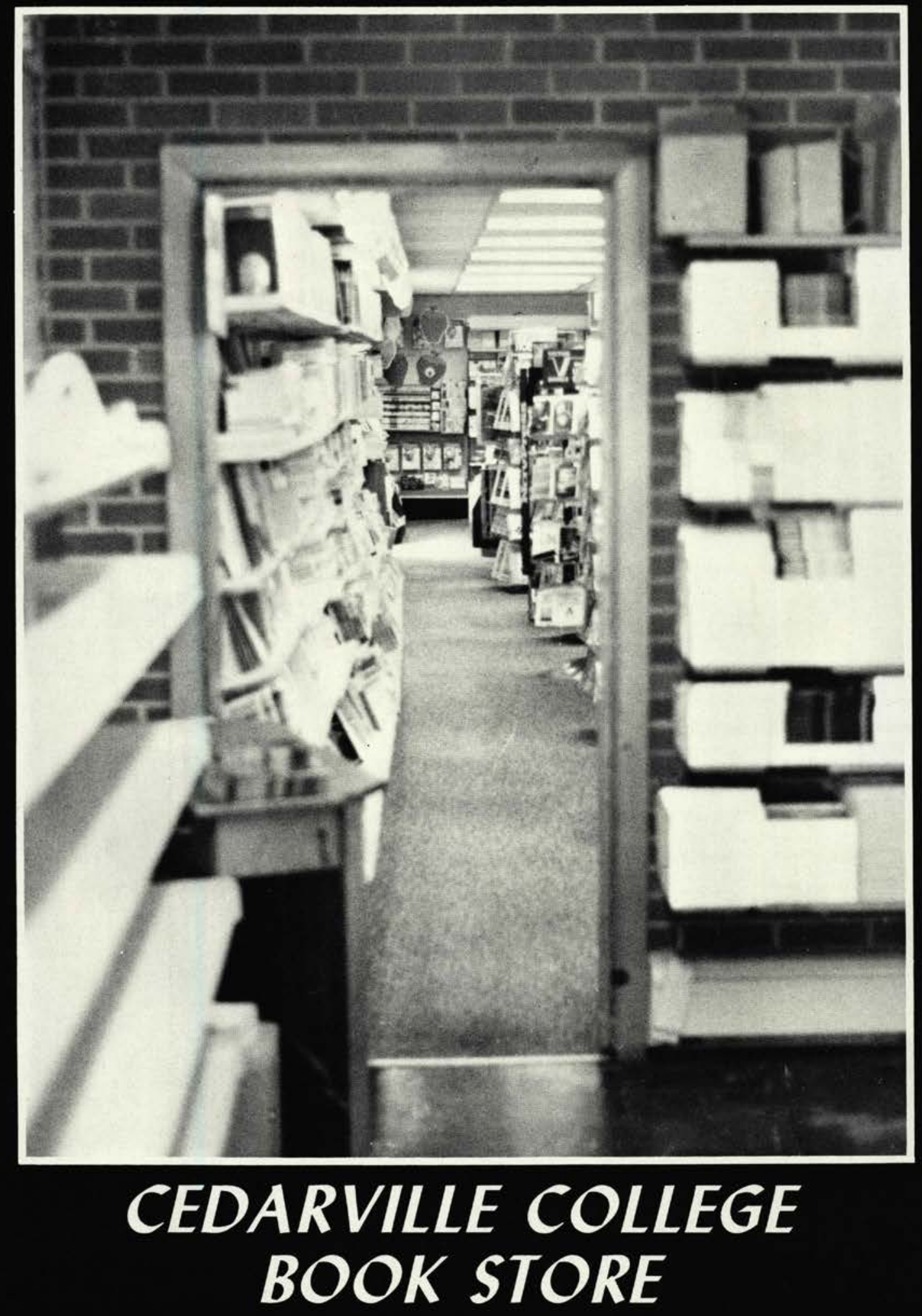

Congratulations to the Class of 1980 


\section{THE FIRST BAPTIST CHURCH}

106 East Main Street Cambridge City, Indiana 47327

(317) 478-3988

Thomas Jones, Pastor

"... Christ in you, the hope of glory; whom we preach ..."

Col 1:27-28
Mr. \& Mrs. B.J. Miller Wheelersburg, Ohio

Mr. \& Mrs. Russell A. Miller Jr. Laurel, Maryland

Seth S. Miller Goshen, Indiana

Reverend \& Mrs. Roger A. Mills Ypsilanti, Michigan

Mr. \& Mrs. Robert Moeller New Milford, New Jersey

Mr. \& Mrs. Melvin Moffitt Port Byron, Illinois

Mr. \& Mrs. William Montie Parma, Ohio

Mr. \& Mrs. Lane Moody Schofield, Wisconsin

Mr. \& Mrs. Kenneth Moore Marysville, Ohio

Mr. \& Mrs. Donald F. Morgan Elkhart, Indiana

Mr. \& Mrs. Donald D. Morgan LaVale, Maryland

Mr. \& Mrs. Rufus L. Morgan Haddon Heights, New Jersey

Mr. \& Mrs. James W. Morton Great Valley, New York

Mr. Jack Mounts Springfield, Ohio

Dr. \& Mrs. John B. Mulder Lawrence, Kansas

Muskoka Baptist Conference Huntsville, Ontario Canada

Mr. \& Mrs. Mel Nycum

Mr. \& Mrs. James Dale Oliver Blacksburg, Virginia

Mr. \& Mrs. Marcus Ormsbee Perry, Ohio

Mr. \& Mrs. William F. Oscar Milltown, New Jersey

Mr. \& Mrs. W.R. Pack Lima, Ohio

Mr. \& Mrs. Leston M. Paddock Veedersburg, Indiana

Mr. \& Mrs. Dean Palmer Glen Mills, Pennsylvania

Mr. \& Mrs. Russell Palmer Elida, Ohio

Mr. \& Mrs. Clayton H. Partridge Blasdell, New York

Mr. \& Mrs. Norman L. Patterson Cincinnati, Ohio

Dr. \& Mrs. Charles N. Patton Lafayette, Indiana

Reverend \& Mrs. Ray Payne Livermore, Maine

Mr. \& Mrs. William F. Pedneau Middletown, Ohio

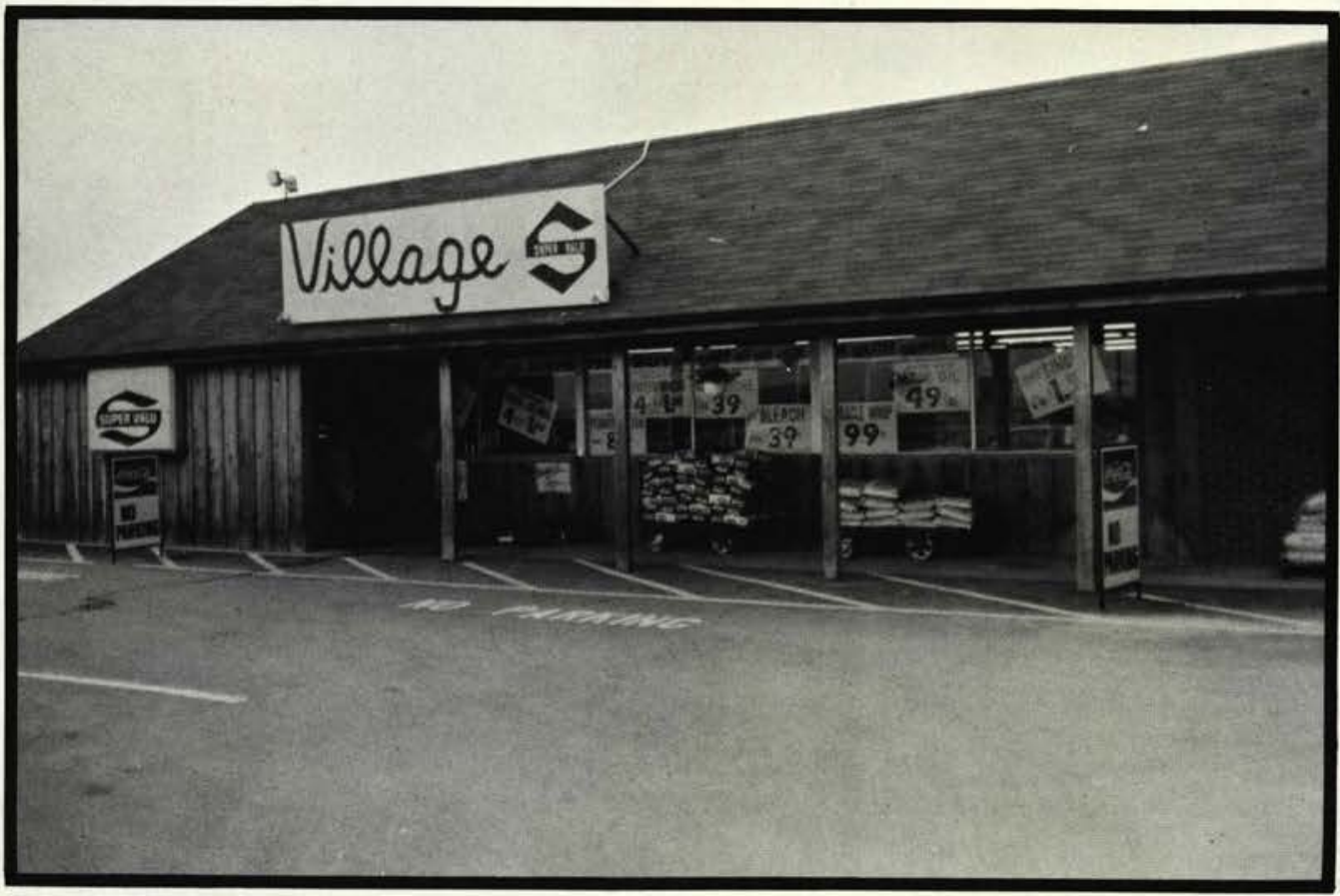

VILLAGE SUPER $V A L U$

360 N. MAIN

Cedarville

Phone: 766-1201

HOME OF

.OW, LOW PRICES 


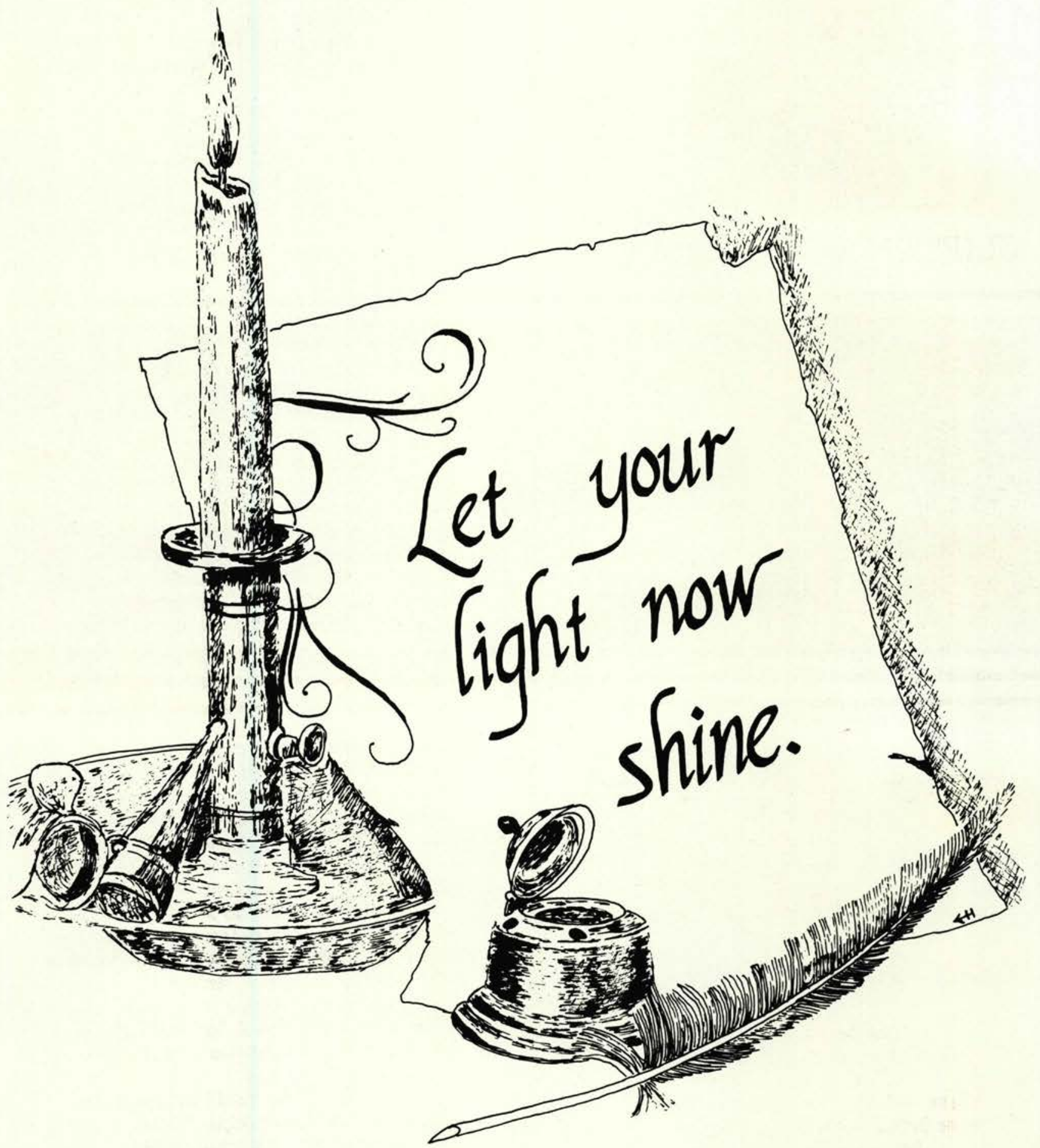

We refoice with you in God's potential for your life.

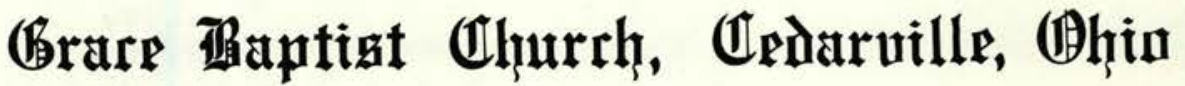




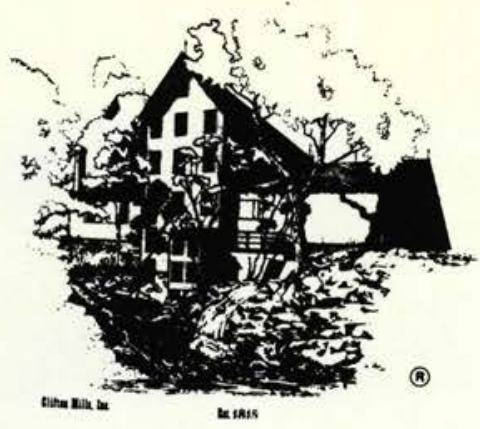

CLIFTON MILLS
(B) INC.
AMERICA'S LARGEST WATER POWERED

GRIST MILL

Established 1815

Clifton, OH 45316 Phone (513) 767.5501

Whole Grain - Stoneground

Corn Meal, Flour \& Mixes

No Preservatives or Additives

Old Fashioned Country Store

Unique Gifts, Candy \& Foods

TOURS: M-F 9-5:30, Sat 9-6, Sun 11-6

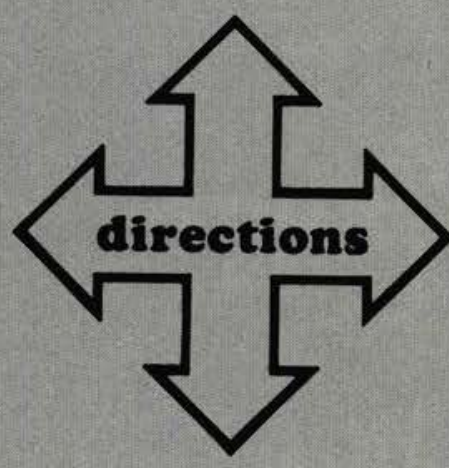

260 Northland Blvd.

Cincinnati, Ohio 45246

Phone: (513) 772-4000

\section{IN PHOTOGRAPHY}

\section{GERARD}

(since 1896)

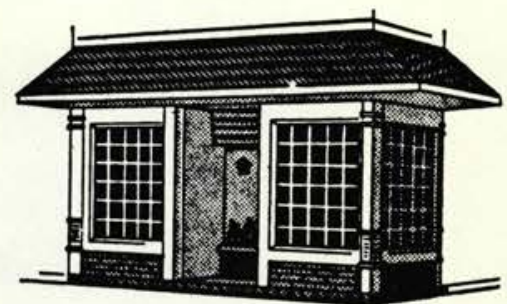

"Your Independent Insurance Agent Serves You First." A FULL SERVICE AGENCY Life - Auto - Fire - Boat - Bonds Home Owners - Health - Pension Programs

Business - Farm - Industrial

1 WEST WASHINGTON, JAMESTOWN, OH

Ph. $675-9321$ or $372-2600$

Earl Gerard - Res. 372-2600

Dick Baker - Res. 426-2920
Mr. \& Mrs. Jim Perry Elkhart, Indiana

Mr. Joe Phillips Wilmington, Ohio

Dariel Plott Golion, Ohio

Mr. \& Mrs. Anthony C. Popio Richfield, Ohio

Mr. \& Mrs. Charles Prall Mitchellville, lowa

Mr. \& Mrs. Harry S. Price Sharon Hill, Pennsylvania

Mr. \& Mrs. A. Rapinchuk Westmont, Illinois

Dr. \& Mrs. James D. Rawlins Jr. Maitland, Florida

Mr. \& Mrs. Alfred Rawson Springfield, Vermont

Mr. \& Mrs. Samuel C. Reese Audubon, Pennsylvania

Mr. Sam Redmonds Gaines, Michigan

Mr. \& Mrs. Lewis A. Regnier Toledo, Ohio

Reverend \& Mrs. William J. Reid Romeo, Michigan

Mr. \& Mrs. D. Duane Repp North Canton, Ohio

E.H. Reu Villa Park, Illinois

Mr. \& Mrs. John O. Richmond Merrillville, Indiana

Mr. \& Mrs. Leo C. Rider Delphi, Indiana

Mrs. Esther M. Riggs Indianapolis, Indiana

Mr. \& Mrs. Earl G. Robb Spencerport, New York

Mr. \& Mrs. Stanley Roberts Apalachin, New York

Mrs. J. Rodriquez Dunkirk, New York

Reverend \& Mrs. Ernest Ronk Millville, New Jersey

Mr. \& Mrs. Cliff Roop Columbia Station, Ohio

Mr. Donald G. Rost New Lenox, Illinois

Mr. \& Mrs. Robert B. Roth Woodlyn, Pennsylvania

Mr. \& Mrs. Wayne I. Rouster Belleville, Michigan 


\section{VISIT FAIRBORN CAMERA}

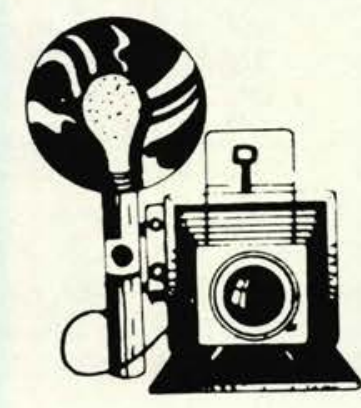

14 E. Main

Fairborn, $\mathrm{OH}$

COURTEOUS, PROFESSIONAL ADVICE

ALWAYS AVAILABLE from Our

CERTIFIED PHOTOGRAPHIC COUNSELORS

TRADES WELCOME OPEN DAILY 9-6

DISCOUNT HOUSE PRICES CLOSED Wed. \& SUn.

CAMERA STORE KNOW-HOW Phone 878-4392

\author{
Nikon * Canon * Olympus * Pentax \\ Minolta * Mamlya * Konica \\ Vivitar \& Bushnell Lenses
}

\section{BLESSED HOPE BAPTIST CHURCH}

315 S. Kensington Place

"Just off North Limestone Street"

Springfield, Ohio 45503

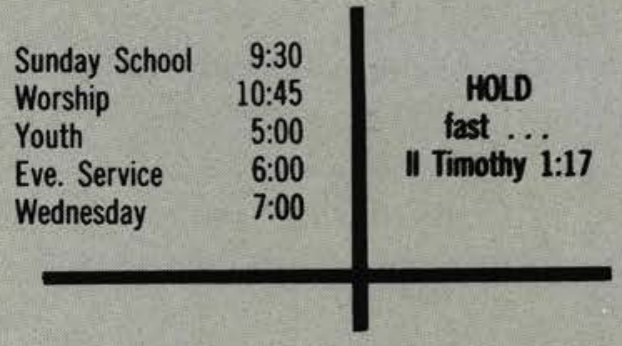

$$
\begin{aligned}
& \text { Adhering to God's Word } \\
& \text { Building Spiritual Lives } \\
& \text { Christ Centered } \\
& \text { James Roark, Pastor 399-2885 }
\end{aligned}
$$

Mr. \& Mrs. Claude Ruby Oxford, Michigan

Mr. Marshall Runge Rochester, New York

Mr. \& Mrs. Arthur Rupe Jr. Gallipolis, Ohio

Mr. \& Mrs. Peter Sadowitz Binghamton, New York

Mr. \& Mrs. Alfred Said Brunswick, Ohio

Mr. \& Mrs. H.L. Sargent Galion, Ohio

Mr. Donald Sarver Rose Hill, lowa

Mr. \& Mrs. Dominic Savant Berlin, Ohio

Mr. \& Mrs. Walter Schmidt Union Grove, Wisconsin

Mr. \& Mrs. Stan Schonfeld Upper Brookville, New York

Mr. Donald Schuchard Crystal, Minnesota

Mr. \& Mrs. Gene Schuler Akron, New York

Mr. \& Mrs. Charlie Shaw Indianapolis, Indiana

Mr. \& Mrs. Robert Shearer Lincoln Park, Michigan

Mr. \& Mrs. R.J. Shirk Trenton, New Jersey

Mr. \& Mrs. Myrl Short Wauseon, Ohio

Mr. \& Mrs. Rex Simon Medina, Ohio

Mr. \& Mrs. Sam Simpson Fort Dodge, lowa

Mr. \& Mrs. William W. Sirka Indianapolis, Illinois

Mr. John J. Skiles Flora, Indiana

Mr. \& Mrs. Carl Slonecker Bellefontaine, Ohio

Mr. \& Mrs. Jack R. Smith Indianapolis, Indiana

Mr. \& Mrs. John H. Smith Scottsville, Kentucky

Mr. \& Mrs. Larry D. Smith Grand Rapids, Michigan

Roscoe F. Smith Binghamton, New York

Mr. \& Mrs. Darwin Snyder Union Springs, New York

Reverend \& Mrs. James C. Southward Belleville, Michigan

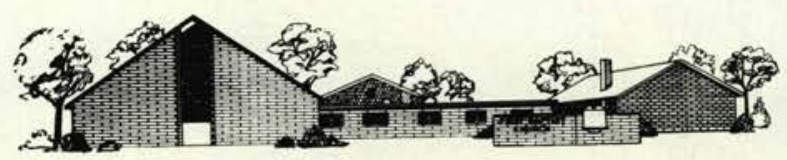

\section{First Baptist Church of Willingboro}

Sunset Road, Willingboro, NJ 08046

Rev. Richard W. Wilson, Pastor

Mr. Nick Troupos, Assistant to the Pastor

Congratulations to the Class of 1980

Sunday School

OUR PROGRAM

Morning Worship

9:45 A.M.

Training Hour

Evening Service

Wed. Prayer Service

Fri. Awana Clubs
11:00 A.M.

6:00 P.M.

7:00 P.M.

7:30 P.M.

7:00 P.M. 
WE WEL COME YOU

\section{NORWARD BAPTIST CHURCH 2037 Courtland Avenue Cincinnati, Ohio 45212}

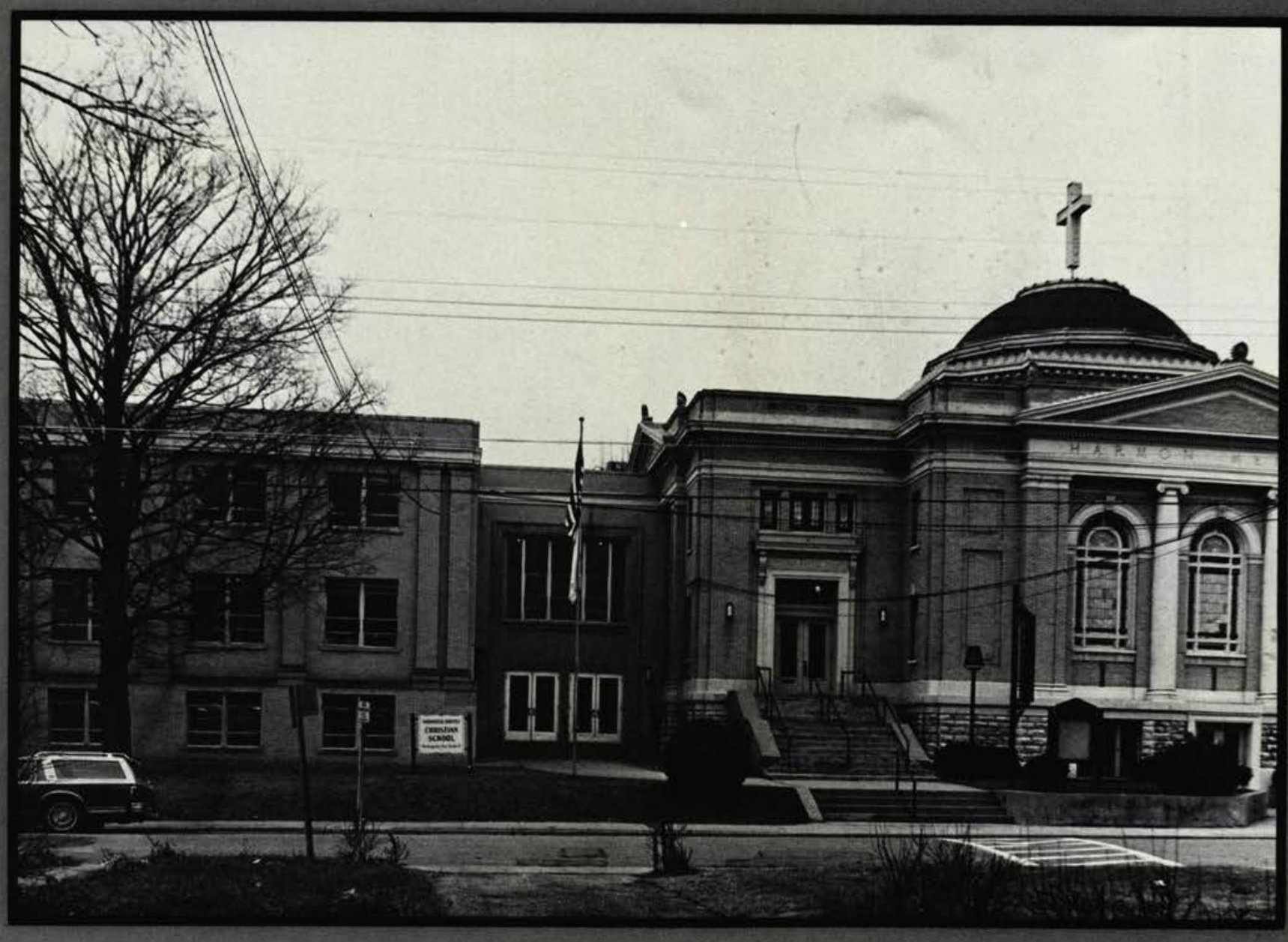

Our Services

Sunday School

Morning Worship

Hour of Inspiration
Sunday

9:30A.M. Prayer Meeting

10:30A.M. King's Teens 7:00P.M.

Norward Baptist Christian School

Felix J, O'Donnell, Administrator

Grades $1-8$

Lee W. Fullmer, Pastor

Cincinnati's only Regular Baptist Church
Wednesday

7:30P.M.

7:30P.M 


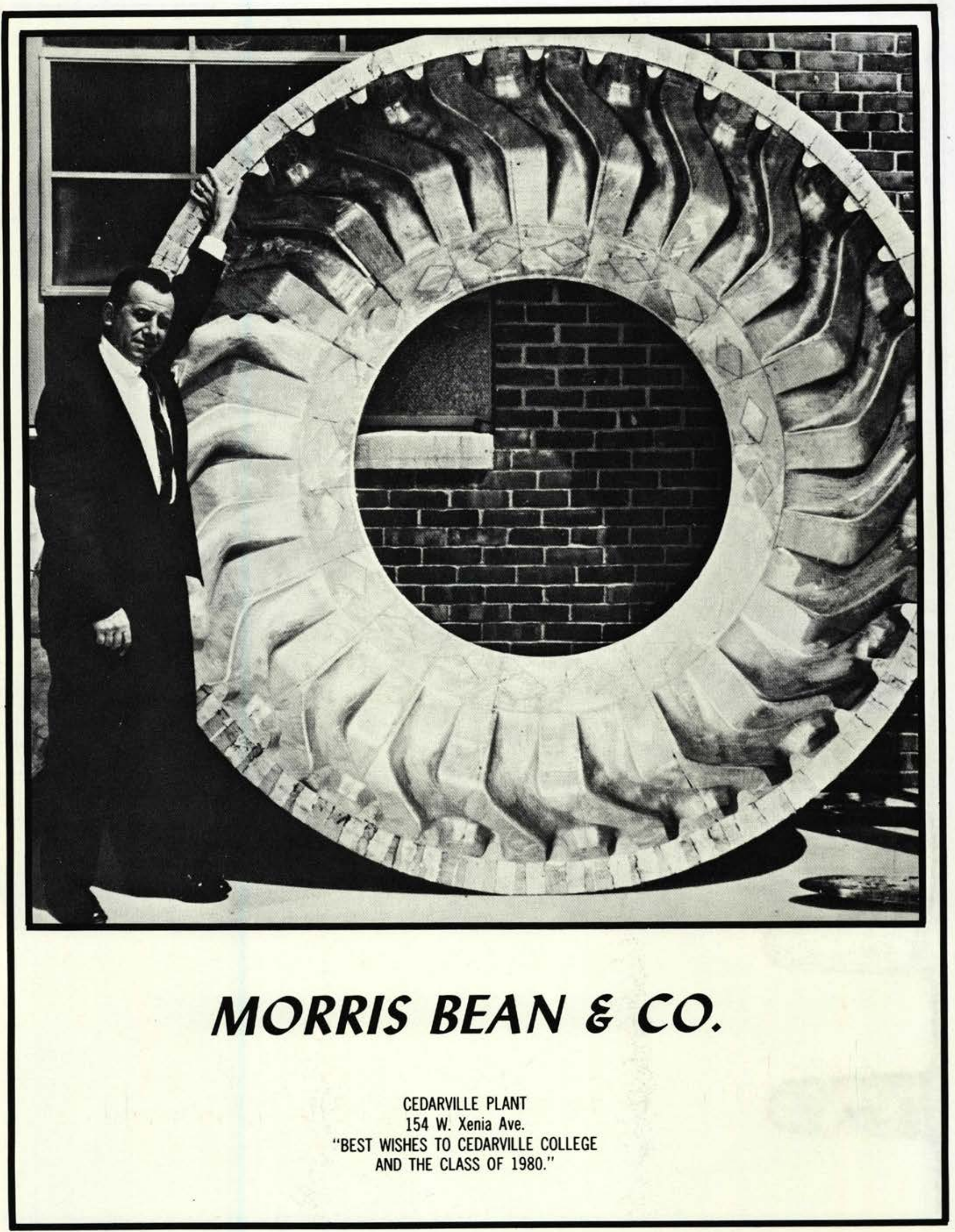




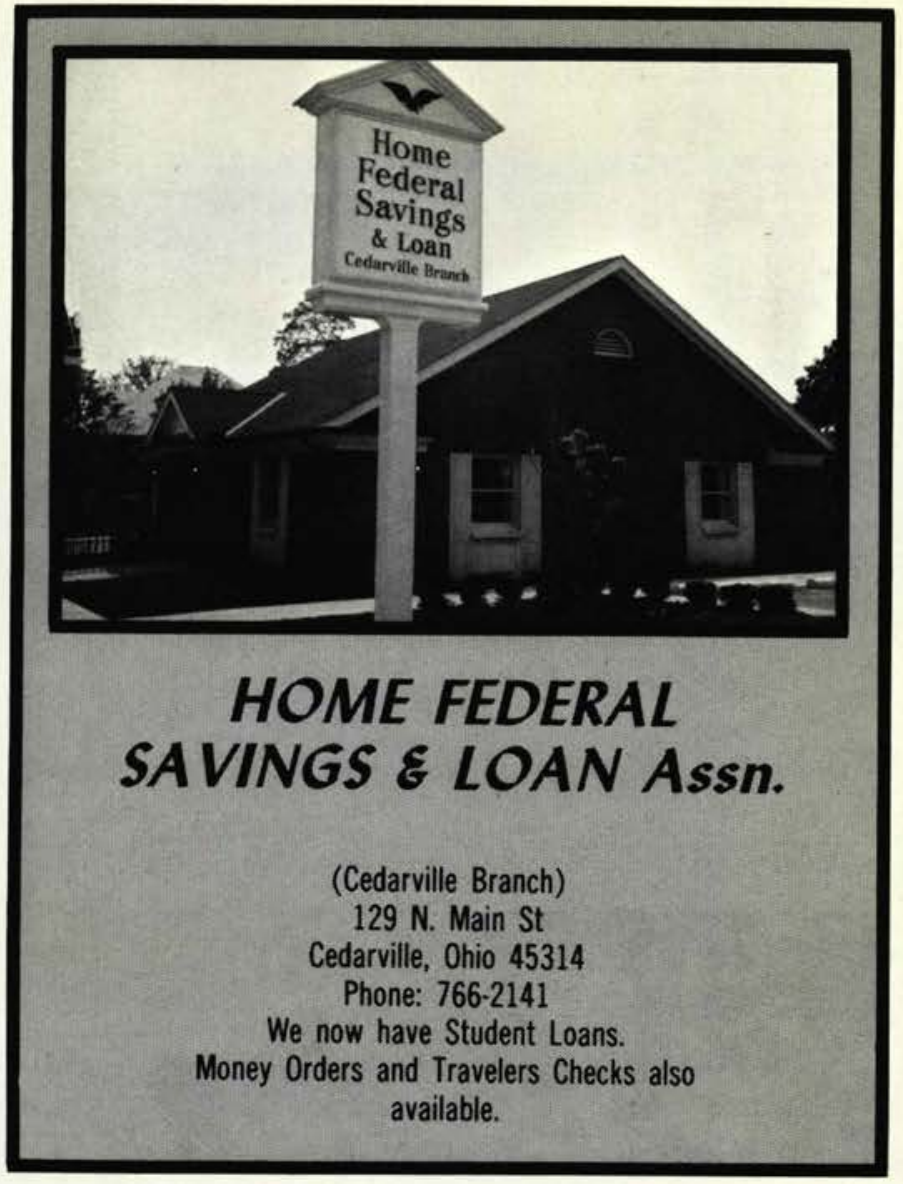

Mr. \& Mrs. Robert C. Sparks Trenton, New Jersey Mrs. Barbara J. Spencer Kankakee, Illinois Mr. \& Mrs. John W. Spencer Columbus, Ohio Dale B. Spradlin Wheelersburg, Ohio Mr. \& Mrs. C. Richard Steinhofer New Milford, New Jersey Mr. \& Mrs. Jack Stephenson Moline, Illinois Mr. \& Mrs. Arnold Stewart Wheelersburg, Ohio Mr. \& Mrs. Carl Stewart Valparaiso, Indiana Ammon P. Stoltzfus Elverson, Pennsylvania Mr. \& Mrs. Robert L. Supplee Fremont, Michigan Mr. John R. Tangbalde Kansas City, Kansas Mr. \& Mrs. M. Tedeschi Phoenixville, Pennsylvania Mr. \& Mrs. Ronald Tenny Binghamton, New York Mr. \& Mrs. Jack Tindall Oxford, Michigan Mr. \& Mrs. Robert V. Iraphagen Fort Worth, Texas Mr. \& Mrs. Daniel Turner Rochester, New York Mr. \& Mrs. Donald L. Tuttle Spring City, Pennsylvania Mrs. H. Lansing Vail Jr. Shaker Heights, Ohio Mr. \& Mrs. A.V. Vantrease Findlay, Ohio Mr. \& Mrs. Steve Vesilko Austintown, Ohio Mr. \& Mrs. Teunis Vet Fairview Park, Ohio Mr. James C. Viguers Media, Pennsylvania Mr. \& Mrs. Wilber Wagenschutz Marshall, Michigan Virgil R. Wagner Columbus, Ohio Mr. \& Mrs. J.H. Wainwright Roebling, New Jersey Mr. \& Mrs. Samuel D. Waite Tyrone, Pennsylvania Mr. \& Mrs. Harold Walker Gallipolis, Ohio Mrs. Ralph Waltenbaugh Wilmington, Ohio Mr. \& Mrs. Carl Ward Horseheads, New York

\title{
GRANDVIEW PARK BAPTIST CHURCH
}

\author{
1701 East 33rd Street \\ Des Moines, lowa 505317 \\ Phone: 262.8289
}

"For the Word of God and the testimony of Jesus Christ"

Rev. David W. Board, Sr., Assistant to the Pastor

Rev. David L. McClintic, Christian Education Evangelism

Rev. Elmer Carrithers, Hospital \& Shutins 


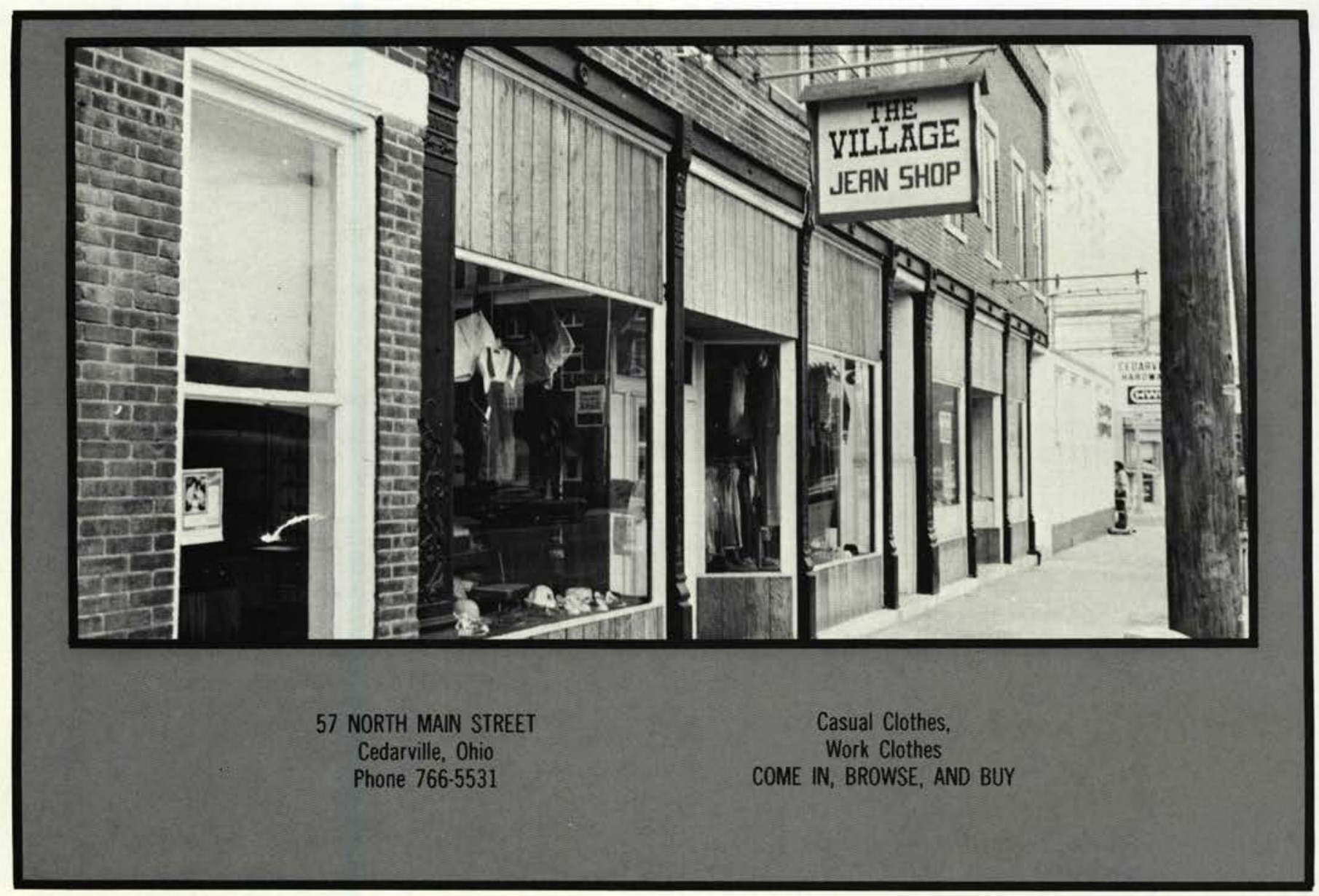

Mr. \& Mrs. George Webb Hackensack, New Jersey

Dr. \& Mrs. Warren L. Webber Cedarville, Ohio

Mr. \& Mrs. Cecil R. Webster Lakeland, Florida

Mr. \& Mrs. Richard I. Weiss Sr. Dayton, Ohio

Mr. \& Mrs. Richard I. Weiss Jr. Apalachin, New York

Mrs. Charles $\boldsymbol{H}$. West Valparaiso, Indiana

Mr. \& Mrs. Willard Whisler Mansfield, Ohio

Mr. \& Mrs. Robert White Flint, Michigan

Mr. Robert J. Wilkinson Hammonton, New Jersey

Mr. \& Mrs. Gary Wickham Wichita, Kansas

Mr. Harold G. Williams Cheyenne Wells, Colorado

Mr. \& Mrs. Roger Williams Sr. Mesa, Arizona

Mrs. C. Ann Wilson Waterloo, lowa

Mr. \& Mrs. David Wilson Wellington, Ohio

Mr. \& Mrs. Paul Wilson Covington, Kentucky

Mr. \& Mrs. Gordon Wind Spring Valley, Illinois

Mr. \& Mrs. John Wisnoski Plantation, Florida

Ira B. Wolfel Gahanna, Ohio

Mr. \& Mrs. Wolff Fort Wayne, Indiana

Mr. \& Mrs. Jay D. Womack Churubusco, Indiana

Mr. \& Mrs. Francis A. Wozniak Middleport, New York

Mr. \& Mrs. Jacob Yager Kissimmee, Florida

Mr. \& Mrs. Richard Yater Crawfordsville, Indiana

Mr. \& Mrs. Wilbur C. Yerkes Lumberton, New Jersey

Mr. \& Mrs. Clyde Zehner Berwick, Pennsylvania

Mr. \& Mrs. Larry R. Zimmerman Brownsburg, Indiana

Mr. \& Mrs. John Zmierski Cass City, Michigan

\section{JOHNNY'S AUTO PARTS}

50 N. Main St.

Cedarville, $\mathrm{OH}$

766-2381

38 N. Main St.

Bellbrook, $\mathrm{OH}$.

848-2835
51 Washington St.

Xenia, $\mathrm{OH}$

372.9286

(Foreign \& Domestic)

1791 W. Second St.

Xenia, $\mathrm{OH}$.

373-9075, 376-9300
- Wholesale Auto Parts •

- Machine Shop Service •

- Radiator Service •

Congratulations to the Class of 1980 ! 

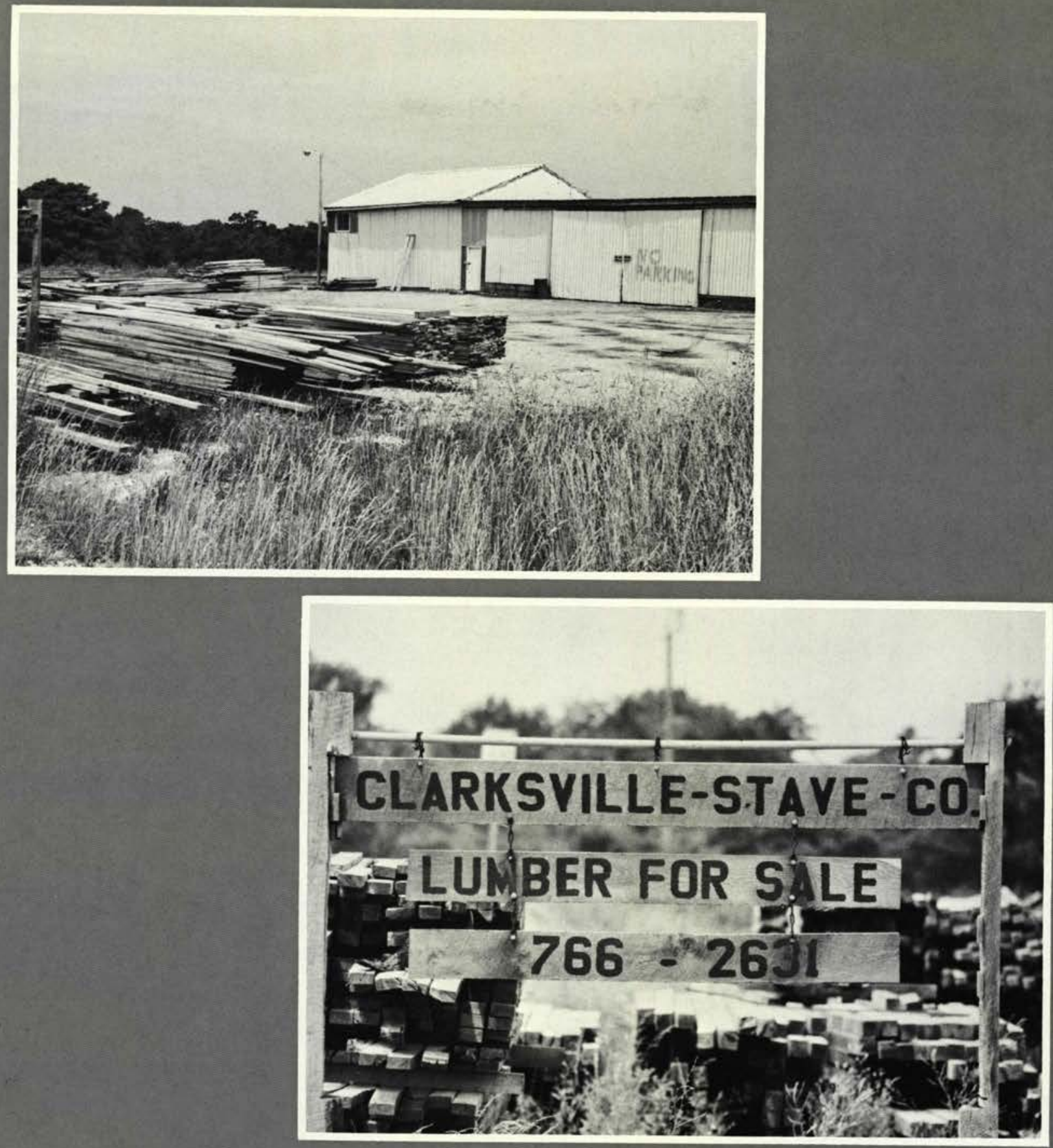

A Special Thank You to the

\section{CLARKSVILLE-STAVE CO.}




\section{College Students}

Abbott, Gary, 140

Abbott, Ron, 140, 198

Aberth, Patti, 198, 208

Acker, Jeft, 201, 222

Adams, Annette, 150, 20

Adams, Barbara, 110, 116, 196, 199, 201, 110

Ahlgrim, Tom, 150

Niken, Michael, 116, 210

Niken, Terri, 32, 86, 150

Nithen, Tom, 25, 116, 194, 207, 212, 222

Allen, Michael, 116, 219

Avey, Jenny, 162

Ames, Debora, 140

Anderson, Craig, 140

Anderson, Jan, 37, 72, 150

Anderson, Mark D., 140, 202

Anderson, Mark L., 140, 219

Anderson, MaryBeth, 150

Anderson, Tonya, 140, 196, 201, 218

Anderson, William, 150

Andrus, Kenneth, 97, 116, 137, 220

Ankenman, Theresa, 150, 205, 217, 223

Anthony, Wayne, 150, 197, 201, 222

Appleget, JoEllen, 140

Archer, Dale, 209

Armstrone, Kathleen, 116, 196

Arndt, Sheldon, 18, 162

Arnold, Jeanice, 162, 201

Arthur, Sarah, 18, 27, 116, 137, 201, 207

Ashcraft, Jan, 62, 150, 197

Autio, Kerry, 150

Averill, David, 162

Avery, Kelly, 150, 202

Axiotis, Pamela, 116

Bare. Melodie, 86, 150

Bailey, Tom, 57, 140, 212

Baker, Drew, 57, 58, 59, 150, 212, 217

Baker, Mark, 140

Baker, Nancy, 140, 199

Balaicuis, John, 150

Baldwin, Jim, 45, 67, 91, 92, 150, 198

Baldwin, William, 116, 222

Bamgbose, Michael, 140

Barker, Linda, 140, 198

Barnette, Bev, 162

Bernett, Debbie, 150

Barrand, Lenna, 62, 63, 150, 197, 210, 216

Barrett, James, 24, 25, 26

Bartling. Jeft, 45, 150

Bartling. Tom, 140

Basye, Judith, 32, 162

Baver, Douglas, 91, 92, 140, 221

Baugh, Mark, 162, 201

Baughman, William, 140

Beach, Keith, 150, 215

Beacham, Deborah, 140, 219

Bean, Christopher, 162

Bean, Jeftrey, 116

Bean, Rachael, 116

Beane, Tim, 162, 211

Bearss, Laura, 140, 223

Beaver, Larry, 150, 195

Beck, Clayton, 46, 140, 215, 219

Bedell, Ron, 136

Begley, Dave, 140

Behymer, Tamera, 162, 201, 205

Beight, Scot, 116, 196, 210

Beikert, Beth, 140, 196, 199

Beikert, Bonnie, 33, 162, 195, 210

Benedict, Chuck, 150

Bennett, Jennifer, 15

Benson, Bryan, 162

Bentrude, Brian, 57, 61, 162

Bergandine, David, 140, 187, 203, 207, 215, 216

Berger, Andrew, 150, 189

Berger, Curt, 57, 59, 79, 80, 140, 210

Betts, Daniel, 117

Bevington, Cheryl, 162, 195, 201

Bingman, Judith, 136, 162, 197

Birch, Carleton, 26, 140

Birk, Roxanne, 162

Birkhoiz, Gregs, 140, 220

Birky, Stanley, 117

Bissonette, Vernon, 150

Black, David, 93, 162, 210

Black, Geri, 162, 199, 201, 206

Blackburn, Becky, 45, 196, 210, 216

Blackmer, Joyce, 150, 198

Blair, Brian, 162

Blanc, Richard, 150

Blanchard, Lizbeth, 162

Block, Devon, 162, 206

Bloyd, Rozer, 162

Bocian, James, 73, 140, 203, 216

Bohn, Teresa, 162

Boley, Brenda, 140, 195, 205, 207, 209, 218
Bonham, Julie, 150

Bontekoe, Stephen, 57, 62, 162

Bonzo, Terry, 150, 196

Bonzo, Debby, 140, 187, 196

Bonzo, Sandra, 117

Booher, Shawnie, 162

Book, Ruth Anne, 140, 196

Boomgarden, Beth, 140, 199, 203

Boone, Andrew, 117

Bosler, Joseph, 162

Boudreau, Christien, 26, 162

Bowers, Angela, 46, 150

Bowers, John, 117, 219

Bowersock, Tina, 162, 201

Bowser, Jeff, 24, 25, 26, 87, 150, 222

Boyd, Cathy, 81, 150

Boynton, Robert, 26, 93, 162, 210

Bracken, Margaret

Bradshaw, Joann, 140, 203, 218

Brage Sheri, 162

Brammer, Jeffrey, 162, 204

Brandt, Bradley, 57, 91, 162

Branham, RoseAnn, 150, 197, 201

Brant, Mark 92, 150

Brass, Sheri, 195

Brazelton, Laura, 150, 197, 210

Breon, Randolph, 162, 198

Bresson, Brian, 194

Bresson, Michael, 117, 212

Briges, P.aul, 150, 215

Brindley, Linda, 150

Britt, Dona, 150

Brower, Kathleen, 117

Brown, Angela, 150, 223

Brown, Cynthia, 162

Brown, Dave, 67, 140

Brown, Judy, 117

Brown, Linda

Brown, Margie, 150, 221

Brown, Michael, 140

Brown, Shirley, 140

Brown, Steven, 117, 195

Brown, Will, 160, 162, 198, 199, 201

Browne, Kevin 117, 203

Brueckner, Bruce, 162

Bruening, Laurie, 117

Brugger, Rhonda, 162, 20

Brumbaugh, Mike, 21

Brumbaugh, Philip, 93, 150

Bubel, Debra, 162

Bubel, Mark, 93, 102, 150

Buettel, Paul, 117, 136

Buining. Deborah, 160, 162, 214, 21

Bullock, Beth, 140, 207

Bulthius, Esther, 118

Bulthius, Paul, 118

Burchett, Linda, 140, 196

Burdick, lackie, 150

Burel, Tim, 140

Burk, Arthur, 151, 198, 199, 201, 222

Burleson, William, 86, 151

Burrell, Frank, 140

Burt, Cindi, 151, 204

Bush, Dave, 151

Butler, Laurie, 55, 56, 85, 86, 151, 22

Butter, Luann, 151, 210

Butler, Tim, 140

Butler, Vicki, 54, 55, 56,85, 86, 118, 201, 218

Byrum, Andy, 151

Cabaniss, Richard, 140

Cafterty, Brian, 141

Callan, Jan, 31, 32, 118, 207

Calvert, Beverly, 162

Cane, Rodney, 220

Canter, Gary, 162, 207, 216, 218

Cantley, Sherri

Carothers, Chris, 163, 197, 201

Carothers, loyce, 187, 201

Carr, Connie, 21, 163

Carr, David, 45, 57, 74, 160, 163

Carr, Scott, 57, 61, 141

Carroll, James, 141

Carver, Davena, 163

Castellanos, Diane, 163, 194, 201

Castellanos, Doreen, 163

Cawood, Dan, 51, 15!

Chadwell, Ken, 163

Champlin, Tamera, 151, 198, 216

Chance, Dale, 11

Chandler, Vicki, 151

Chase, Wayne, 151

Chasteen, Stacy, 86, 163

Chesser, Dennis, 118, 197

Chilcott, Claude, 163

Childers, Cynthia, 163

Christian, Dale, 118
Christian, Denea, 163

Christmas, Karen, 163

Churchill, Steven, 141, 199

Churchward, Kenneth, 118

Clark, Cal, 27, 29, 97, 98, 141, 194, 203, 216, 222

Clark, Joseph, 163

Clark, Shirley, 73, 151, 201, 216

Clark, Stephen, 163, 197

Clayton, Laura, 27, 151, 209

Clearwater, Mark, 163

Clemons, Connie, 81, 141, 211

Clemons, Michael, 163

Clougher, Thomas, 151

Coates, Cheryl, 46, 141, 201

Coates, Pamela, 118

Coates, Stacey, 151

Colas, Craig, 27, 29, 106, 114, 118, 187, 203, 222

Colborn, Tom, 163, 219

Coldren, Sonja, 163

Coleman, Tina, 163

Collins, Karen 56, 151

Collins, Ruth, 163, 201

Colyer, Barbara Sue, 163

Colyer, Joe, 67, 138, 141, 215, 220

Compton, Steve, 118

Conklin, Keith, 151

Connors, Richard, 118, 197, 198, 199, 201, 222

Conrad, Becky, 163, 221

Conrad, David, 119

Conrads, Lisa, 163

Cook, Jeftrey, 118, 141

Cook, Kathi, 119, 210

Cook, Ruth Ellyn, 163, 201, 209

Coolbaugh, Randy, 163, 218

Cooley, Douglas, 141, 197, 201

Cooper, Erika, 163

Cooper, Karen, 220

Corathers, loyce, 119, 188, 199

Cordes, James, 151, 208

Cornell, Patty, 72, 151, 198, 201

Correll, Mark, 151

Couch, Robert, 141, 201

Coules, John, 163

Coulson, Cheryl, 44, 141, 207

Coventry, Rhonda, 163, 206

Cowell, Tim, 151

Cox, Carol Sue, 105, 210

Cox, David, 26, 45, 141, 201, 202, 207

Cox, Donald, 119

Cox, Richard, 163

Crabtree, Diana, 163, 203

Cragoe, Chris, 141

Craig. Debbie, 151, 210

Craig. Kent, 119, 187, 205, 207, 217

Cranick, Jill, 141, 196, 197, 205, 209

Crankshaw, Keith, 151

Craw, Cheryl, 163

Crawtord, 163

Crawtord, Karen, 100, 163, 207

Cremean, David, 119, 218

Crist, Richard, 93, 119, 216

Cunningham, Kathy, 151, 206

Curtis, Joseph, 163, 195, 215

Cretich, David, 67, 141, 204

Damon, Merry, 151, 19

Danube, Thomas, 119

Darling, Deborah, 72, 163, 201

Darline, James, 87, 141, 194, 222

Davey, Linda, 151

Davies, Don, 163

Davis, Becky, 163, 210

Davis, Joanne, 141

Davis, Lori, 163, 210

Davis, Rosemary, 163

Dawning, Deborah, 14!

Dawson, Donald, 119

Decker, Jannell, 75,141

Decker, Virginia, 75, 81, 82, 110, 114, 119, 207

Delancey, Dan, 26, 80, 163

Delancey, John, 26, 79, 80, 163, 202

De Lange, Paul, 119

Dell, Valerie, 19, 46, 120, 197, 207, 218

Dellent, Kendra, 15 1

Dernming. Vickie, 164

Denbow, Danor, 151

Dennis, Donna, 151, 187, 205

Denny, Cindy, 120

De Pew, Cherie, 120, 215

Depoyster, Robin 164

DeShields, Theo, 51, 61, 141, 207, 217, 220

Detweiler, Deborah, 120

Detwiler, Steve, 151

Dever, Wanda, 164

Devine, Marty, 87,120

DeYoune. Tom, 87, 151, 197, 219

Dieringer, Tadd, 15 1

Dillinger, Patti, 16

Dodds, Kimberly, 151, 209 
Garcia, Valde, 57, 141, 195, 215, 222, 324

Gardner, Laurie, 152

Garrison, Cindy, 141, 197, 201, 222

Garrison, Daniel, 164, 197, 214

Gawthrop, Linda, 141, 194, 208

Gedicks, Nancy, 164, 201, 222

Geist, Alan, 152

Gentzler, Kenneth, 92, 164

Gibbs, Larry, 57, 61, 164

Gibson, Collen, 164, 203

Gibson, Mearl, 38, 152

Gifford, Paula, 12:

Gittord, Wynn, 26, 121

Giggie, Phillip, 67, 121

Gilbert, Deborah, 96, 97, 98, 99, 164, 201

Gilmore, Denise, 141, 194

Gillette, Scott, 152

Gilmour, Christine, 152

Goertzen, John, 204

Gott, Judy, 152, 197, 198

Goodbar, Steve, 121

Goodrich, Robert, 152, 205

Grafton, Jeftrey, 164

Grafton, Linda, 44, 101, 105, 122, 196, 203

Graham, Joy, 122, 219

Graham, Tim, 24, 24, 26, 152

Grant, Karen, 141, 187, 207, 210, 215

Grant, Kevin, 142, 205

Gray, Ellen, 142, 204

Green, Alan, 148, 152, 194, 215

Green, Brian, 164

Green, Daniel, 122, 137, 202, 207, 215

Green, Dann, 19, 45, 57, 74, 75, 122, 137, 194, 212

Green, Larry, 57, 61, 152, 194, 207, 217, 222

Greening. Dan, 26, 164

Greening. Mary, 33, 142

Greetham, Sally, 164

Greve, Gree, 57, 59, 61, 87, 89, 142, 210, 217

Greve, Marsha, 122, 194

Grice, George, 165, 194

Griswold, Jill, 33, 35, 142, 216, 220

Gromacki, Gail, 165, 199, 205

Gromacki, Gary, 45, 114, 122, 187, 196, 222

Gross, Milinda

Grosso, David, 152

Grosvenor, David, 165, 221

Groves, Cynthia, 152, 204

Gruenberg. Jim, 165

Guenther, Cathy, 122

Guenther, John, 142

Gunlock, Jon, 165

Haas, Shari, 165

Hager, Glenda, 165

Haggerty, Dave, 195, 219

Hague, Donna, 152

Hahn, Chris, 199, 201

Hakes, Kim, 142

Hakes, Shari, 165, 201

Hale, Pam, 165

Hall, Laura, 142, 220

Hall, Linda, 100, 165

Hall, Nancy, 142

Hall, Troy, 57, 165

Halladay, Lorraine, 165

Hallett, Gregory, 152, 207

Hallman, William, 122, 208

Ham, Sandra, 152, 197, 201, 210

Hamilton, LoAnna, 142, 223

Hamilton, Michael, 152

Hamilton, Phil, 160, 165, 210

Hammond, Pam, 122

Hancock, Amy, 165

Hancock, Steve, 122

Hanna, Betsy, 165, 223

Hanson, Robert, 122, 294, 211, 222

Hanson, David, 165, 205

Harbeck, John, 165

Hardine, Kevin, 66, 152, 194, 201

Harding. Patty, 81, 142, 196

Harkleroad, Joy, 165

Harmon, Roberta, 142, 214

Harper, Randy, 19, 70, 105, 138, 142

Harrell, Peggy, 37, 142

Harrington, Karen, 165

Harris, Dallas, 142, 219

Hart, Cathy, 152

Hart, John, 72, 138, 142, 195, 217

Hartman, Denise, 209

Harvey, John, 96, 142, 204

Hathaway, Kevin, 122

Hattenfield, David, 142

Hatton, Jean, 56, 86, 165

Hayden, Jean, 165, 204

Hayes, Bill, 123, 199, 219

Hayes, Martha, 142

Hayes, Brian, 152

Hayes, Steve, 123, 187, 195

Haynes, Joy, 142, 196

Heatly, Cathy, 123, 197, 201, 222

Heeney, Teresa, 165, 199, 201, 221, 222

Heers, Jane, 152, 210
Hegarty, David, 152

Heider, Timothy, 152

Heinrich, Cindy, 142, 187

Heinrich, Tamara, 165

Henderson, Eric, 152, 197, 201

Henderson, Kim, 114, 123, 197, 215, 219

Hennessee, Ed, 142

Henslin, Sandra, 152

Hepburn, Cyndi, 123, 210

Herl, Craig 26, 93, 165

Herriman, Janet, 123, 219

Herron, Cheryl, 123, 203

Hettinger, Rhonda, 142

Heyworth, Elaine, 81, 82, 142

Hickey, Chuck, 142, 206

Hickman, Rick, 57, 93, 95, 123, 220

Hicks, Frank, 153

Hicks, Lester, 123, 136, 137, 195

Hick, Tammy, 142

High, Charlie, 142, 189, 195, 206, 207, 209, 218

Hill, Frederick, 153

Hill, Paul, 123, 187, 215

Hill, William,

Hindes, Michael, 165

Hines, Janet, 123

Hinks, Dennis, 147

Hinks, Stephen, 165

Hippard, Carol, 142, 205

Hitchcock, Brenda, 165, 210

Hixenbaugh, Kathleen, 165

Hobar, Brenda, 33, 35, 123

Hober, Ronald, 72, 87, 89, 148, 153, 194, 222

Hotstra, Becky, 165, 199, 20

Hoganson, Timothy, 43, 142, 203, 216

Hoke, Curtis, 160, 165, 215

Holihan, Michael, 165

Hollenbeck, Vicky, 142

Holliday, Kim, 153, 109

Hollopeter, Edna, 153, 197, 201, 222

Holwerda, Tom, 67, 80, 165

Holzwerth, Teresa, 165

Horton, Cherie, 165

Horton, Eda La Faye, 153

Hosack, Kimberly, 110, 124, 196, 203, 215

Hottel, Anna, 165

Howard, Jim, 153, 201

Howard, Kevin, 165

Howard, Mary, 142, 194, 195

Howard, Susan, 32, 153

Howdyshell, Carolyn, 165

Howe, Greq, 124, 197, 199, 215, 219

Howell, Matthew, 165

Hubbard, Steve, 165, 219

Huber, Fritz, 43, 142, 207, 218

Huddleston, Kellie, 165

Huffman, Deatra, 165, 202

Hull, Brian, 194

Humphrey, Paula, 142

Humphreys, Marvin, 165

Hennaman, Jammy, 166

Hunter, Nate, 93, 166

Huntine Michael, 65, 124

Hurlburt, Ruth, 44, 153. 194, 209

Hutchins, Barry, 166, 201, 208

Hutchins, Julie, 27, 142, 196, 202, 204, 220

Hyslop, David, 166, 208

Inbody, Brad, 142

Ingalls, Alan, 142

Imhott, Lori, 153

Ivaniski, Gail, 153

Jackson, Debbie, 199

Jackson, Ellen, 166

Jackson, Jennifer, 166, 210

Jacobs, Cindy, 43, 124

Jakstadt, Diana, 142

Jansen, Dawn, 124, 216, 219

JaQuay, Anita, 166, 198

Jaquery, Vini, 47, 153, 216

Jaquis, Tom, 153

Jelsma, Scott, 142

Jenerette, Russell, 26, 166

Jensen, Ellen, 43, 153

Jessup, Robin, 166, 21

Jewell, Rebekah, 166

Jindra, Nancy, 166, 209

Jobson, Jim, 26, 166, 197, 198

Johnson, Anna, 97, 153, 197

Johnson, Beth, 153

Johnson, Brian, 91, 92, 153

Johnson, Chris, 153, 194, 210, 217

Johnson, David, 124, 210

Johnson, Dean, 27, 93, 166, 210

Johnson, Donald, 124

Johnson, Janell, 62, 63, 166, 196, 223

Johnson, Karen, 138, 142, 210, 216

Johnson, Kay, 153, 208, 211

Johnson, Laura, 153

Johnson, Lily, 153

bohnson, Marilyn, 142

Johnson, Mark, 103, 142, 211

Jones, Julie, 31, 32, 54, 56, 220

Jones, Mark, 124

Jones, Rebecca, 142

Jones, Rick, 143, 202, 208

Jones, Sherri, 124

Jones, William, 136, 143

Kamphausen, Pezgy, 124, 219

Kandle, Kelly, 166, 201, 208

Kane, Rodney, 87, 153

Karsian, Kristine, 137, 124, 220

Kauftman, Kimber, 57, 58, 93, 124, 212, 220

Kauffman, Michelle, 166

Kaufman, Ken, 166

Kearbey, Tamera, 100, 106, 143, 195, 196, 217

Kearsley, Debbie, 32, 143, 211, 212, 220

Keeler, Shen, 160, 166, 205

Keller, Kirk, 27, 28, 29, 166, 202, 203

Keller, Steve, 72, 143, 194

Kemp. Ruth Marie, 166

Kendall, Norma, 166

Kenoyer, Faith, 166, 201, 208

Kensinger, Kim, 166, 194

Kenyon, Brian, 166

Kern, Mary, 153

Kessier, Don, 166, 221

Keys, Debra, 125

Kindie. Eric, 153, 194

Kine Robert, 125, 206, 209, 223

King. Tammy, 46, 143, 195, 205

Kingsbury, Karen, 153, 199, 201, 208

Kirby, Mark, 105, 125

Kirkbride, Kathy 10, 143

Kiser, JoAnn, 125

Kitchen, Julie, 143, 194, 219

Kitchen, Sandra, 153, 219

Klenke, Dale, 166

Klenke, Kathy, 143

Klingenberg. Janice, 166

Knapp, Mark, 143

Knapo, Mary, 125

Knecht, Jennifer, 33, 153

Knicely, Joy, 166

Knicely, Joyce, 166, 222

Knicely, Susan, 143, 201, 222

Knieriem, Shari, 15

Koch, Anna, 125

Kramer, Cindy, 125, 143

Kreidler, Sheryl, 143, 187, 196, 219, 221

Kreidler, Susan, 166

Krewson, Cindy, 62, 63, 15

Krewson, Richard, 47, 143, 197, 207

Krewson, Kathy, 143

Krueger, David, 166

Kulp, Susan, 33, 55, 56, 85, 86, 125, 220

Kuns, Craie 125, 197, 204, 216

Kuntzelman, Ed, 153

Kuschel, Linda, 125

Lahaie, Sharon, 153, 223

La Haye, Lori, 125

Laing. Ruth, 153

Lamm, Joseph, 143

Lantz, Jerry, 38, 137, 125, 19

Lapp. Karen, 33, 35, 86, 126, 18

La Rue, David, 126, 210

Lash, Susan, 143

Latimer, Gary, 143

Lawhead, David, 143, 194, 198, 199, 201, 212, 222

Laxton, Joy, 166

Leach, Mark, 26, 143, 187, 215, 222
Leathers, Kathy, 166, 196, 201

Lehto, Laura, 166

Leightenheimer, Beth, 125

Leightenheimer, James, 126, 189

Leipprandt, Patricia, 166, 205

Leman, Jan, 153

Levin, Sharon, 114, 126, 187, 195, 197, 212, 223

Lewis, Beth, 153, 207

Lewis, Betty, 43, 153

Lewis, David, 100, 143, 195, 203, 215

Lewis, Steven, 80, 143, 194, 212

Lichtensteiger, Diane, 56, 143

Lichtensteiger, Linda, 54, 55, 153

Lim, Larry, 166, 223

Lima, Josias, 25, 26, 153

Linderman, Valerie, 166

Lindley, Beth, 81, 166, 197, 215

Linn, Faith, 20, 21, 22, 97, 166, 202, 216

Lintz, Kris, 143, 221

Little, Matt, 166

Livergood, Lorrie, 166, 223

Livingood, David, 153 
Moffitt, Deke, 154

Moffitt, Greg. 167

Molin, Gregory, 91, 92, 167

Molin, Patti, 127, 196

Moline, Larry, 144

Monroe, Linda, 144

Montie, Jett, 167, 197

Moody, Deb, 144, 190

Moody, Linda, 63, 154

Moore, Debbie, 154

Moore, Gary, 20, 21, 22, 97, 167

Moore, John 167

Moore, Timothy, 127

Morazzano, Laurie, 167, 201

Morgan, Carol, 31, 32, 144, 196, 205

Morgan, Diane, 24, 105, 144, 184

Moritz, David, 154, 198, 201

Morley, Mark, 154, 223

Morris, Barbara, 144

Morris, David, 144, 209

Morrow, Amy, 167

Morton, Darcella, 33, 34, 85, 86, 154, 198, 220

Morton, Marcella, 33, 34, 85, 86, 154, 198,220

Moser, Michelle, 144

Mounts, Eric, 57, 58, 59, 144, 197, 207, 222

Mourlam, Rick, 154

Muckley, Ed, 167

Mulder, Kevin, 154, 197, 201, 209, 215

Mullican, Patty, 32, 144

Murdoch, David, 167, 201, 220

Murphy, Daniel, 144, 198

Murphy, Daniel, 80, 144, 194

Myers, Debbie 127, 144, 209

Napier, Carolyn, 128

Neatherton, Steve, 168

Needles, Becky, 144, 203, 220

Neely, James, 128, 189, 216

Neely, Sandy, 154, 197

Nestor, Jennifer, 168, 197, 201

Nevitt, Dan, 128

Newcomb, Cindy, 154

Newman, Debbie, 14

Nice, Curtis, 168, 197, 201, 222

Nicholas, John, 168

Nichols, Michael, 128

Niedzialek, Elizabeth, 168

Nikles, Anne, 155, 214

Norlin, John, 168, 197, 201

Norman, Mark, 93, 144, 198, 222

Nycum, Bonnie, 144, 214

O'Boyle, Lynn, 155

O'Boyle, Pam, 168, 223

Ockert, Juvy, 144, 223

Ocran, Roberta, 155, 219

Ole, Sandra, 168

Oliver, Debbie, 155, 201, 203

Oliver, Michael

Olsen, Laura, 144

Olson, Brian, 155, 210

O'Neal, Joe, 26, 168

O'Quinn, Michael, 19, 128

Orban, Michael, 168, 214

Ormsbee, Kathy, 168, 218

Ormsbee, Linda, 155

Osborne, Mark, 155, 196, 210

Oscar, Nancy, 81, 168, 210

Osenga, Jerry, 168

O'Wade, Deanna, 168, 204

Pabst, Stefan, 25, 26, 168, 194, 197

Pack, Gail, 168, 209

Paddock, Pamela, 168

Palmer, Dave, 168, 211

Palmer, Deanna, 155, 216

Palmer, Susan, 33, 35, 128

Pantzer, Patricia, 168

Paradiso, Gayle, 155

Parker, Elizabeth, 14

Parker, Evelyn, 128

Parker, Tim, 168

Parman, Matthew, 93, 168, 210

Parry, Jett, 168

Parsley, Lisa, 197, 198

Parsons, Sheila, 155

Partridge, Donna, 128

Parvin, Cheryl, 147

Parvin, Donald, 128, 137, 189, 196, 201

Parvin, Phil, 144

Parvin, Susan, 73, 155

Paschall, Tom, 144, 187, 195

Pasco, Diane, 155, 195, 210

Patterson, Norman, 168, 197, 201

Patton, Lynda, 27, 128

Payne, BethAnne, 19, 30, 32, 144

Payne, Ginny, 155

Payne, Kathy, 128, 223

Payton, Kim, 155

Pedneav, Jeft, 168

Penquite, Landa, 81, 82, 128

Penquite, Sharyn, 155, 214

Perry, Katherine, 168

Perry, Paul, 144, 208
Parry, Robin, 144

Peters, Mark, 93, 95, 144

Peterson, Richard, 129

Peterson, Timothy, 155, 199

Peterson, Todd, 64, 65, 168, 194, 207, 210

Petry, Stephen, 129

Phillips, Charles, 168

Phillips, Cheryl, 168, 197, 205

Phillips, Delana, 155, 214

Phillips, Doug 48, 148, 155, 199, 201

Phillips, Garry, 155

Phillips, Ron, 144

Piazza, Steve, 26, 144

Pierce, Holly, 168

Pierce, Mark, 129

Pinkerton, Mark, 168, 214

Pippin, Donald, 129

Pippin, Greg. 155

Pitrone, Mark, 168

Pitts, Connie Mclane, 129

Pitts, Julie, 144, 205

Plaggemars, Amy 10, 155, 187

Pleshko, Karen, 155

Plott, Deitra, 168, 196

Poole, Daniel, 129, 195

Popa, Dianna, 168, 195, 197

Pope, Randal, 144

Popio, Mary, 168

Potter, Teresa, 18, 155

Power, Timothy, 155, 194, 197

Prall, Tom, 155, 219

Prentice, Julie, 155, 196, 209

Presley, Jay, 144

Pressau, Miriam, 168, 210

Price, Dan, 168, 199, 201, 206

Price, David, 144, 199, 201

Price, Nancy, 144, 194, 209, 219

Pringle, Kevin, 155

Prokop, If., Cari, 67, 144, 203, 216

Pruden, Becky, 155

Pruitt, Nadine, 198, 208

Pryce, Dave, 168

Purdin, Kevin, 168, 219

Putnam, Kathy, 144, 219

Pyatte, Skip, 168

Raabe, Robin, 145

Radclitt, Charles, 129, 208

Ramsey, Lisa, 40, 74, 145, 196, 202, 207

Randall, Lee, 110, 129, 195, 223

Randall, Michelle, 155, 223

Rapinchuk, Debra, 129

Raught, Jenny, 168

Rawlins, Donnie, 79, 80, 155, 205

Rawlins, Nathalie, 168

Rawson, Sharon, 155, 202

Rayder, Elaine, 155

Redmond, Lori, 168

Reed, Gregory, 169, 196, 206

Reese, Diane, 32, 155

Regnier, David, 169

Rehn, Nathan, 129

Reid, Deborah, 129, 187, 201, 203

Reid, Ruth, 169, 201, 205, 217

Reiner, Sharon, 169

Reinhart, Brad, 155, 210

Reinhart, Richard, 155

Reinholdt, Gregory, 155

Reinholdt, Marilynn, 145, 199

Repp. Darlene, 19, 129

Reynolds, Sandy, 130

Reynoids, Sandy, 145, 209

Rice, Keith, 130

Richards, Lori, 155, 210

Richardson, Douglas, 130, 204, 218

Richmond, John, 169, 210, 211, 220

Rickard, Brian, 155

Rickard, Don, 87, 145, 194

Rider, Jett, 169, 197, 211

Riegle, Susan, 33, 35, 86, 145, 220,

Riggs, Brian, 130, 194, 212

Riges, Elaine, 155

Rike, Susan, 130

Riley, Mark, 169

Ring John, 145

Risser, Keith, 155, 199

Ritchie, Karina, 169

Robb, Cindy, 130

Robb, Lori, 155

Roberts, Lloyd, 197, 201

Robinson, Lana, 169

Rockey, Denise, 155

Rodriguez, Carmen, 169

Ronk, Sara, 169, 210

Ronk, Tim, 101, 145

Roop, Michele, 169

Rosenau, John, 136, 145, 197

Rost, Ronald, 79, 80, 156, 198

Roth, Cheryl, 145, 219

Roth, Sandi, 130, 194, 215, 219, 223

Rothharr, Debby, 130

Rouster, Gary, 169, 201, 222

Rowe, Dan, 145, 189, 207, 208, 218

Rowland, Jonathan, 145

Ruby, Carl, 47, 169, 210

Rue, Janice, 130

Ruiz, Elizabeth, 169, 219

Ruiz, Thomas, 130

Runge, Sandra, 145, 215, 218

Rupe, Becky, 114, 130

Sadowitz, Steve, 26, 87, 156, 194, 212, 222

Sagraves, loyce, 156

Said, Philip, 145

Sanders, Donald, 145, 220

Sanford, Lori, 169

Sarver, Clyde, 130, 205

Saver, Jane, 169

Sayen, Andrea, 169

Sayles, Karla, 169, 107, 201

Savant, Tina, 145

Scaggs, Lisa, 145, 187

Schaber, Teresa, 145, 201

Schad, Judith, 169, 208

Schaechterle, Dale, 79, 80, 145

Schmidt, Joan, 33, 34, 169

Schmidt, Terri, 169, 197, 209, 223

Schmitz, Jane, 156, 195, 207

Schonfeld, David, 169, 198

Schreiner, Jim, 169

Schubert, Timothy, 131

Schukard, Mark, 131

Schuler, Cheryl, 169

Schultz, Ir., Roger, 145

Schulz, Dawn, 169, 201

Schumm, Lori, 156, 211, 218

Schwart, Donna, 169

Schwendler, John, 145, 198

Schwenk, Rebecca, 169, 194

Scoggins, Lori, 169

Scott, Rachel, 81, 145, 201, 223

Scott, Susan, 169

Seals, Sandy, 156, 217, 219

Seawell, Lawrence, 138, 145

Seefried, Sundie, 169

Selden, Jonathan, 27, 93, 95, 169

Senseney, David, 145

Sewell, Justin, 156

Sewell, Karen, 110, 131, 136, 187, 202, 213

Sewell, Paul, 169, 223

Seymour, Thomas, 93, 95, 169

Shafter, Don, 201

Shafter, Patricia, 156, 198

Shatter, Susan, 145

Shaw, Dale, 18, 27, 93, 95, 102, 131, 212

Shearer, Mark, 169

Shepherd, Sandra, 169

Sherman, Lynn, 169

Shirk, Evelyn, 103, 156, 197, 207

Shirk, Rob, 66, 156, 210

Shomo, Bobby, 25, 26, 169, 187, 203, 216

Short, Dave, 156

Short, Dave, 137, 145, 199, 201, 222

Shuneson, Craig, 145, 197, 201, 210

Silver, Betty-Lou, 169, 195, 196

Simpson, Andrew, 13!

Sirka, Colleen, 131

Sjoquist, Doug. 87, 156

Skjerli, Kris, 204

Skyles, Mark, 36, 156

Sloan, Debra, 156

Slonaker, June, 169, 208

Slonecker, Neil, 136, 169, 212

Slover, Sharon, 169

Smart, Michael, 57, 61, 87, 145

Smart, Terri, 187, 205

Smiley, Tammy, 103, 145, 197, 215

Smith, Amy, 156, 220

Smith, Bob, 36, 80, 156, 215

Smith, David, 156

Smith, Ed, 100, 101, 145

Smith, Esther, 170

Smith, Gwendelyn, 145, 201, 222

Smith, Jack, 131, 197, 201

Smith, J.R., 156

Smith, Jeft, 80, 17

Smith, Joel, 145

Smith, Kim, 62, 63, 131, 197

Smith, Laura, 73, 170, 201

Smith, Linda 47, 156

Smith, Michael 170, 197, 201, 206, 218

Smith, Reve, 170,221

Smith, Richard, 132

Smith, Roscoe, 148, 156, 195, 214

Snell, Sonny, 27, 170 
Treese, Cindy, 27, 157, 196 Ireese, Dana, 70, 133, 190, 196, 218 Treese, Dave, 28, 93, 222 Trickett, Janet, 170, 201 Tupps, David, 170

Turner, Kathleen, 36, 133

Turner, Kimberly, 33, 43, 170

Turner, Patricia, 32, 146

Tuttle, James, 171, 197

Imilla, David, 15?

Tyler, Debbie, 146, 196, 221

Tyson, Darlene, 171, 194, 106

Ulmer, Cindy, 47, 96, 97, 98, 99, 171, 199, 205

Ulmer, Donna, 146

Underwood, Brenda, 157

Underwood, Lora, 171

Vail, Marnie, 70, 109, 133, 202

VanderMeulen, Douglas, 146, 211

VanEtten, Sharon, 171, 206

Yanleak, Kent, 26, 171

Van Loan, Debra, 134

Van Natta, Carolyn, 134, 220

Van Natta, Paul, 220

Van Ryn, Debra, 134

Vantrease, Teresa, 171

Varhola, Teresa, 146, 210

Veldt, loel, 146, 191, 201, 21

Vendrick, Rebecca, 171, 196

Vesilko, Bonnie, 146

Vest, Lori, 146

Vet, Dave, 157

Vickman, Jeffrey, 171, 205

Viguers, Jenniter, 32, 171, 196, 207

Vincent, Matthew, 54, 134, 196

Vinson, Barb, 30, 32, 56, 86, 146, 220

Vollmer, Paul, 146

Vonada, Susan, 13

Waddle, Marla, 157

Wagenschutz, Brenda, 171, 199, 201

Wagner, Dean, 171, 222

Wagner, Laurie, 17

Wagner, Rachel, 157, 195, 20 .

Wagner, Sandra, 146, 207

Wagoner, Susan, 157

Wainwright, Karen, 134, 137, 187, 196, 223

Waites, Kimberly, 134, 205

Waites, Darlene, 171, 209

Waites, Sue, 171

Waldo, Jeft, 146

Walker, Geoft, 72, 157

Walker, Letty, 43, 157

Walker, Vicki, 171

Wallace, Mary, 27, 44, 51, 146, 196

Waltenbaugh, Alan, 17

Ward, teff, 157, 198

Ward, Stephen, 171, 199, 201

Ward, Virginia, 134, 198, 199, 201, 216

Warix, Jeff, 134

Warner, David, 171

Warren, Mark, 106, 219

Waterman, Daryl, 146, 197, 20

Waterman, Vicki, 171, 194, 197, 20

Wates, Dennis, 26

Watts, Dennis, 171

Weaver, Carey, 51, 70, 146, 187, 190, 207, 217

Webb, Kenneth, 146, 203, 210

Webber, Bonny, 103, 146, 196

Weber, Joan, 47, 157, 207, 210

Webster, Karen, 134

Webster, Sally, 171, 194

\section{College Personnel}

Day, Jeannie, 187

Deichert, Steve, 38, 19

Depp. Pauline, 191

DiCuirci, Michael, 70, 103, 197, 201, 172, 180

Dieh, Pamela, 81, 181

Dillon, Dallas, 189

Dillon, Jeri, 189

Divan, Linda, 188

Dixon, Pat, 52, 106, 179, 196

Dixon, Paul, 174, 175

Dolph, Charles, 182

Durham, Cathleen, 218

Durham, Richard, 176, 218

Edlund, Kathy, 191

Ellington, Charles, 180, 222

Elmore, Austin, 182

Elmore, Marabeth, 188

Engelmann, George, 175

Fetzer, Lawrence, 175

Fisher, Jean, 176

Fissel, Nancy, 190

Frank, Dwayne, 178, 217

Frye, Bert

Gathany, Paul, 189

Gidley, David, 190

Gidley, Debbie, 186

Gidley, Irene, 186

Gifford, Paula, 191

Glanville, Ellen, 178

Green, Harold, 175, 207, 220

Green, Margaret, 186

Greenwood, Edward, 179

Greenwood, May, 186

Grier, James, 172, 17

Grifteths, Karen, 187

Grisham, Al, 189

Grisham, Betty, 189

Gromacki, Robert, 176

Grooms, Dewayne, 189

Grosh, lody, 179, 194

Grosh, Ronald, 179

Guenin, Roy, 175

Hall, Debbie, 187

Hall, Helen, 178, 219

Hall, Manda, 191

Halsey, loseph, 184

Hammell, , Debbie, 189

Harner, Becky, 189

Harner, Sandra

Hart, Cindy, 189

Hathaway, Mary, 191

Hawes, Betty, 191

Helmick, Larry, 183, 195

High, Charlie, 189

Howell, Agnes, 106, 187

Howell, Kathy, 186

Hunter, James, 190

lacobs, lack, 175

Jamison, Jim, 191
Wesld, Michael, 171

Weiss, Sharon, 134, 137

Wellinghoff, Deborah, 136, 146, 201, 221

Wells, Chris, 171

Wells, Mark, 26, 157, 187, 218

Welter, Lisa, 17

Wetzel, Dannette, 19, 134, 222

Wharton, Keith, 157

Whisler, Valerie, 54, 56, 85, 86

Whitaker, David, 157

Whitacre, David, 146, 219

Whitaker, Susan, 17

White Scott, 15

Whitten, Ted, 146, 199

Wickham, David, 146

Wickham, Michelle, 157, 216

Wicks, Cozette, 146, 201, 216

Wiele, Randy, 157

Wilcox, Mike, 171, 199, 207

Wilcox, Randy, 46, 146, 219

Wilkinson, Susan, 146, 210

Will, Miriam, 135, 199. 20 I

Will, Tamara, 171, 199, 201

Willetts, Jeff, 148, 157, 220

Willhite, Keith, 106, 135, 202, 207, 215, 220

Williams, Connie, 171, 210

Williams, Evelyn, 135, 187, 196, 216

Williams, Faith, 209

Williams, Jason, 171

Williams, Kathy, 146, 203

Williams, Linda, 171

Willms, Lori, 157

Wilson, Dale, 146
Wilson, Linda, 146, 187, 201, 215

Wilson, Randy, 79, 80, 157, 194, 201, 212, 21

Wilson, Rick, 45, 67, 87, 160, 17

Wilson, Tammy, 15?

Wind, Beth, 171, 216

Wing, Lois, 146, 201

Winters, Donna, 157, 202

Wiseman, Deidre, 54, 56, 17

Wiseman, Douglas, 79, 80

Wisnoski, Lisa, 147, 187

Wita, Debra, 171, 199, 201, 222

Witt, Debbie, 157, 198

Woltt, Ray, 135, 215

Womack, Mark, 57, 59, 91, 92, 157, 217, 222

Woods, Kenneth, 135, 201, 208, 222

Wozniak, Michele, 135

Wyse, Gene, , 97, 157, 210

Yager, Mindy, 171

Yater. Thomas, 27, 135, 187, 206, 207, 222

Yeager, Gary, 93, 206, 209

Yerkes, Joan, 171

Yoder, Chris, 27, 157, 198, 201

Yoder, Fran, 157

Yoder, Janice, 135

Yoder, Marlene, 135

Yoder, Vernon, 147

Young, Amy, 19, 62, 63, 135, 137, 197, 216

Yutzy, Elton, 17

Zehner. Carol, 157, 195, 208

Zickafoose, Robin, 147

Zimmerman, Anita, 157, 194, 210

Zimmerman, Dana, 147.
Jamison, Kary, 191

Jefferey, Joyce, 189

Jennings, I. Don, 175

Jeremiah, James, 174, 175

Johnson, Bob, 189

Johnson, Cliftord, 110, 173, 175, 218

Johnson, Eunice, 189

Johnson, Marilyn, 189

Kautman, Eileen, 190

Kearney, June, 33, 35, 86, 18

Killian, Lawrence, 183

King. Elvin, 27, 29, 93, 173, 181

Kisnet, David, 185, 207, 220

Kuhn, Gary, 188, 217

Kuhn, Rebecca, 31, 32

Larson, Mark, 179

Larson, Sue, 188

Lee, David, 189

Lee, Pat, 186

(ce. Serge, 189

Leightenheimer, Jim, 189

Loach, Barbara, 179

Long. Martha, 191

Maddox, Miriam, 185

Matson, Becky

Matson, David, 180

McClure, Philip, 180

McGillivray, John, 25, 26, 93, 18.

McGoldrick, James, 184

Mcintosh, Barbara, 18

Mcintosh, Richard, 176

Mclntosh, Teri 6, 190

Mick, Bernice, 187

Miller, Craig, 75

Miller, Mabel, 19

Mishler, loyce, 189

Mitchell, Mary, 187

Monroe, Allen, 92, 101, 184

Monroe, Beverty, 178

Moody, Deb, 190

Murdock, L. Murray, 79, 80, 184

Murphy, Dale, 175

Neely, Iim 189

O'Bryon, George, 175

Ouellette, Diane, 186

Ormsbee, Dave, 188

Overturt, Lisa, 191

Pagnard, Charies, 180, 197

Parvin, Donald, 176, 196

Parvin, Ir., Don, 189

Patterson, William, 175

Phillips, Ed, 189

Phillips, Geoftrey, 177

Phillips, Henry, 188

Phipps, Gerald, 189

Phipps, James, 172

Phipos, Terry, 183

Phipps, Terry, 183

Potter, Bill, 187

Printy, Beatrice, 106, 187, 196

Quinlan, Dora, 191

Rayburn, Ethel, 188

Rayburn, Marlin, 185

Rehn, Charlotte, 199

Rickard, Donald, 36, 175, 215

Rickard, Peq. 175

Riges, Jack, 176

Ring. lanice, 187

Riter, William, 177

Rock, David, 189

Ross, Charles, 175, 188

Ross, Molly, 137, 188

Rowe, Dan, 189

Saunders, Penny, 191

Schlappi, Sandra, 55, 56, 181

Seaman, lames, 177

Short, Mary, 188

Silvius, bon,

Smelser, Gerald, 175

Smith, Rick, 189

Smith, Susan, 188

Spencer, Dorathy, 190

Spencer, Edward, 52, 179

Stahl, Kari, 180

St. Clair, Na, 186

St. Calir, Jeft, 19

St. Clair, Kenneth, 2, 3, 175

Stephens, Debbie, 188

Stephens, Heien, 175

Street, Joan, 187

Strobridge, Lucia, 191 


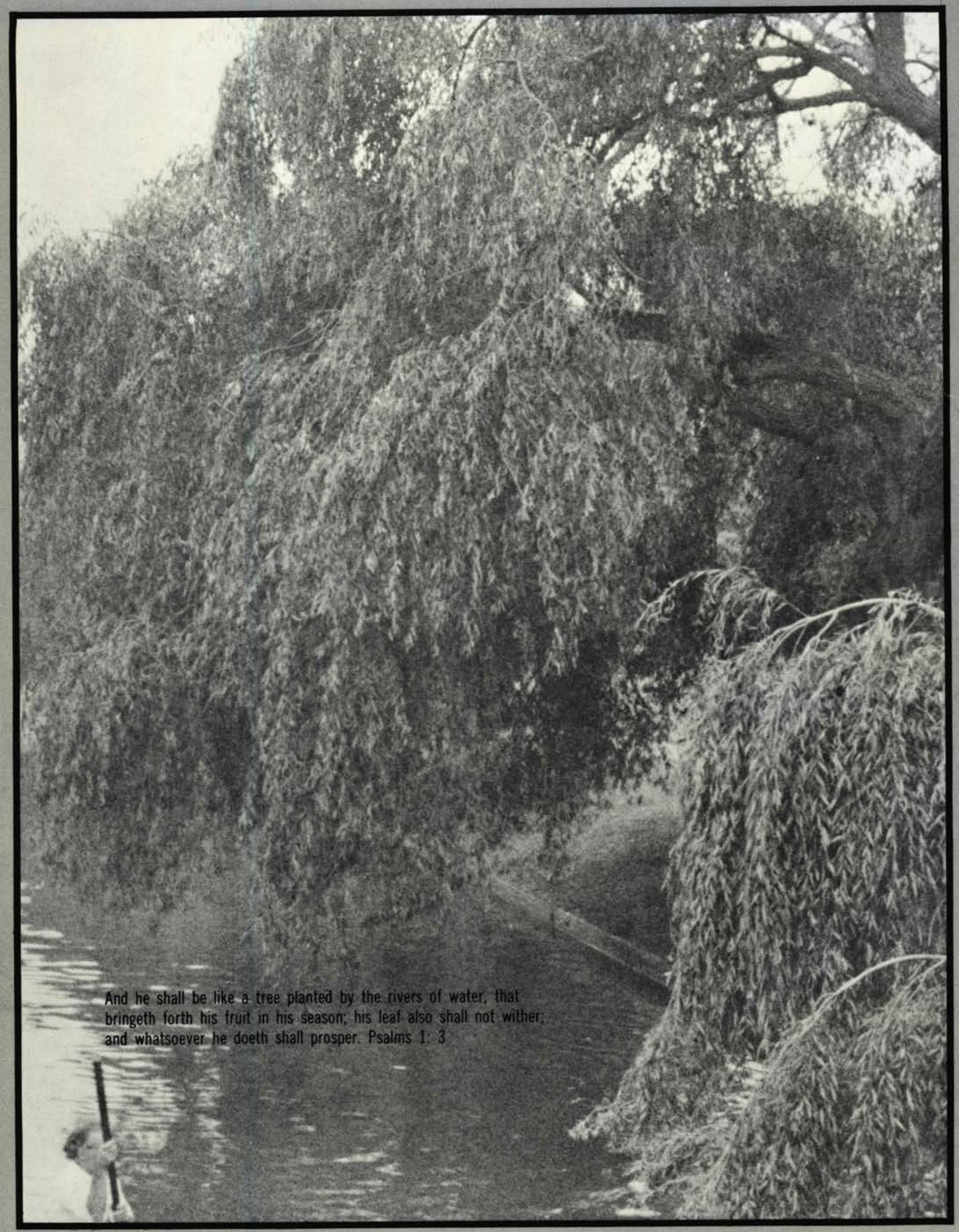







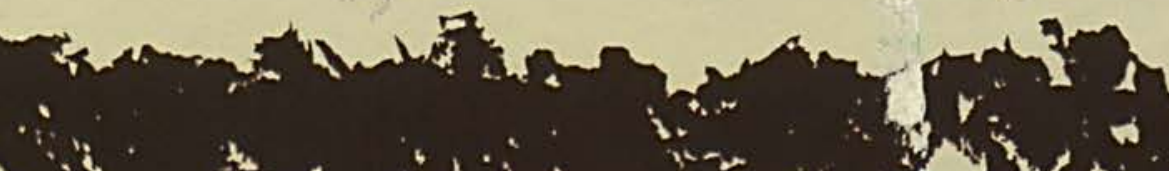

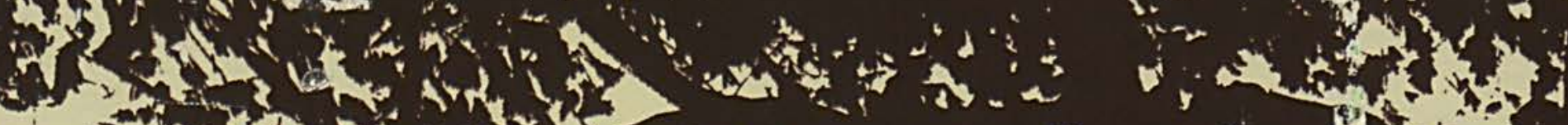

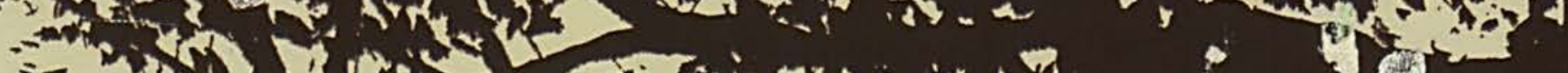

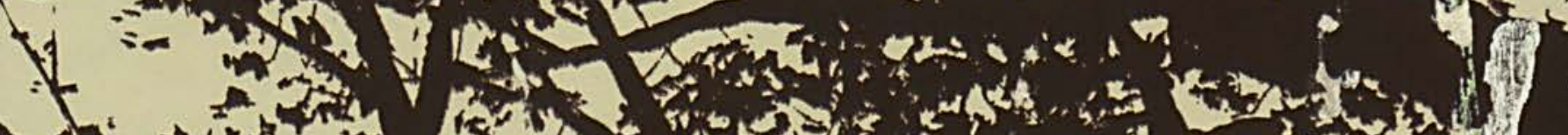

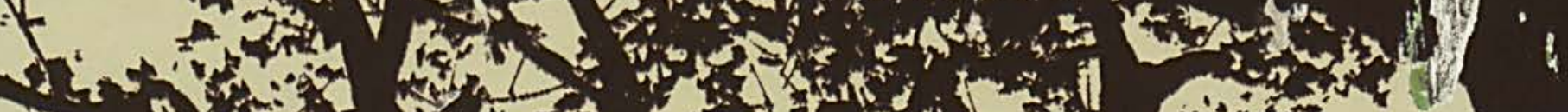

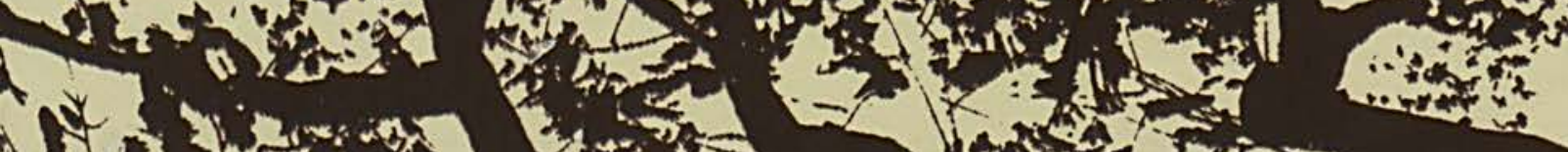

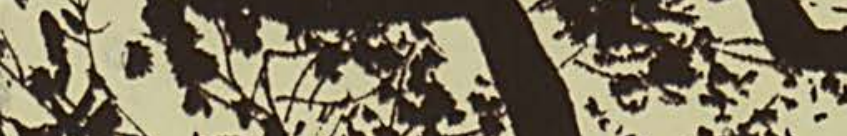
(1) abe Pin
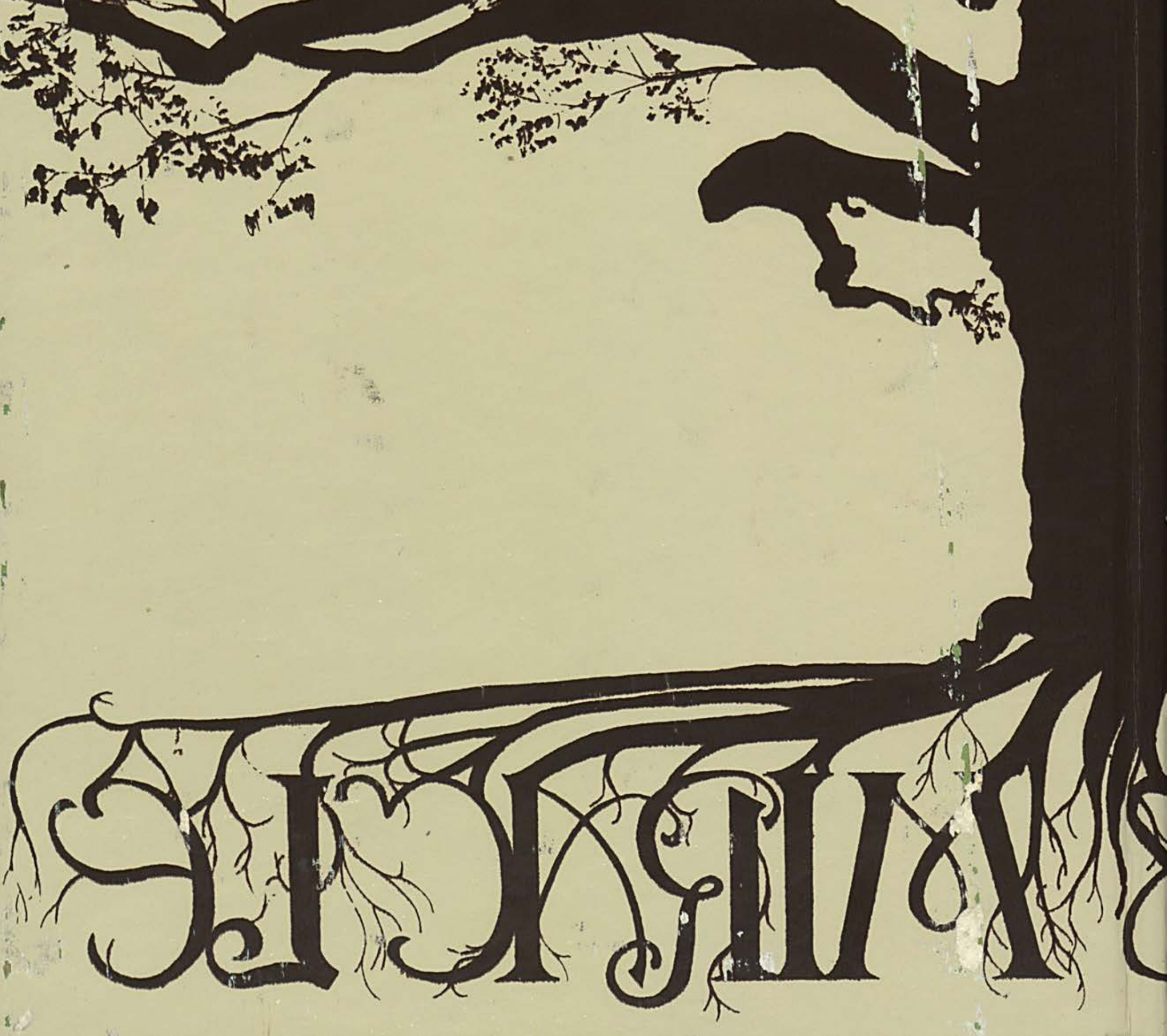